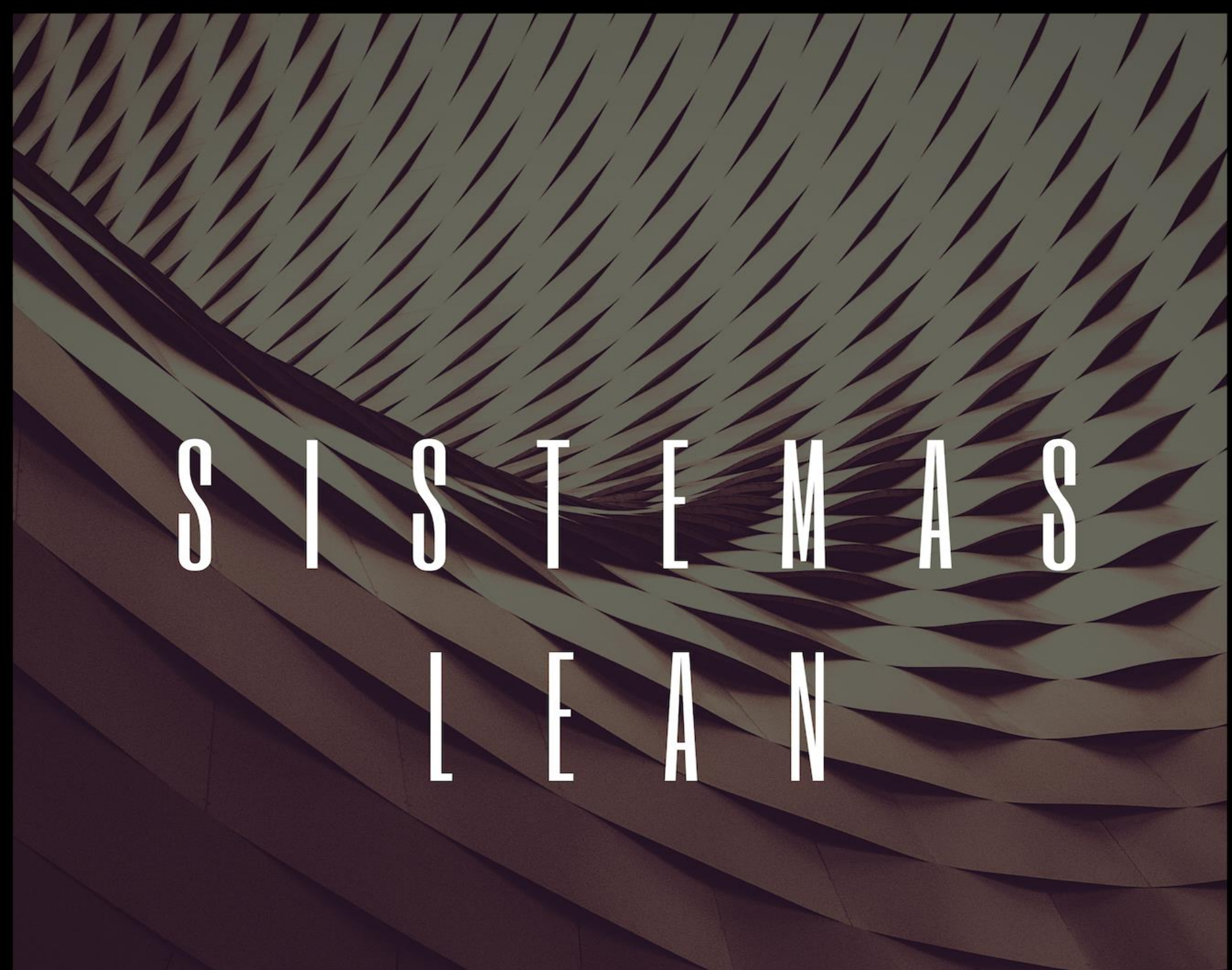

Renata Ferreira

Organizadora

Volume 1 
Renata Ferreira

(Organizadora)

\section{Sistemas Lean \\ Volume 1}

1a Edição

Belo Horizonte

Poisson

2018 
Editor Chefe: Dr. Darly Fernando Andrade

Conselho Editorial

Dr. Antônio Artur de Souza - Universidade Federal de Minas Gerais

Dra. Cacilda Nacur Lorentz - Universidade do Estado de Minas Gerais

Dr. José Eduardo Ferreira Lopes - Universidade Federal de Uberlândia

Dr. Otaviano Francisco Neves - Pontifícia Universidade Católica de Minas Gerais

Dr. Luiz Cláudio de Lima - Universidade FUMEC

Dr. Nelson Ferreira Filho - Faculdades Kennedy

Dados Internacionais de Catalogação na Publicação (CIP)

S623
Sistemas Lean - Volume 1/
Organização Renata Ferreira - Belo
Horizonte - MG: Poisson, 2018
318p
Formato: PDF
ISBN: 978-85-7042-020-6
DOI: 10.5935/978-85-7042-020-6.2018B001
Modo de acesso: World Wide Web
Inclui bibliografia
1. Lean 2. Produção. 3. Processos
I. Título
CDD-658

O conteúdo dos artigos e seus dados em sua forma, correção e confiabilidade são de responsabilidade exclusiva dos seus respectivos autores.

$\underline{\text { www.poisson.com.br }}$

contato@poisson.com.br 


\section{APRESENTAÇÃO}

Lean Manufacturing, também conhecido como sistema Toyota de produção, visa reduzir os desperdícios do processo produtivo, melhorando assim a qualidade e reduzindo o tempo e consequentemente o custo de produção. Lean na sua tradução, tem o significado de ser simples, enxuto e sua aplicabilidade visa reduzir ao máximo as complexidades do processo com foco na redução do tempo de realização de cada atividade, redução de desperdícios e ao final, aumentar a competitividade das organizações.

O Lean usa diversas ferramentas tais como: 5S, Análise de Gargalos, Kaizen (Melhoria Contínua), PDCA, Poka-Yoke, Análise de causa raiz, objetivos SMART, Just-in-time, Tempo Takt dentre outras. As ferramentas podem ser combinadas de acordo com o tipo do negócio, como é o caso do lean startup, lean healthcare e lean six sigma.

Para discorrer sobre o tema em questão, esse volume apresenta diversas formas de utilização dos conceitos lean em segmentos como manufatureiro, metalúrgico, têxtil, saúde, construção civil, dentre outros.

Ao longo dos seus vinte e quatro capítulos, conhecimentos importantes são passados, tornando esse livro uma ferramenta relevante para os interessados pelo tema.

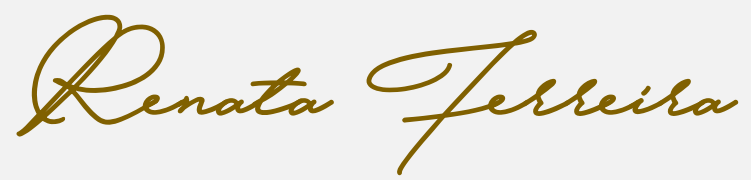




\section{Sumárīo}

Capítulo 1: Aplicação do MASP para reduzir o lead time do processo de garantia de uma metalúrgica

Layra Gabriela Gonçalves, Taís Oliveira da Silva Alfonso, Hiasmin Amaral Pinheiro, Simone Ferigolo Venturini

Capítulo 2: Emprego da metodologia lean seis sigma na melhoria de processos: Um estudo bibliométrico.

Amanda da Silva Xavier, Andersson Alves da Silva, Emerson Rodrigues Sabino, Amanda Duarte Feitosa, Taynara Siebra Ribeiro, Thays Lorranny da Silva Januário

Capítulo 3: Utilização do Seis Sigma em setores industriais do Rio Grande do Sul

Lucas Gonçalves Pagnossin, Ismael Cristofer Baierle, Cristiano Roos

Capítulo 4: Lean Healthcare: Estudo de caso sobre melhoria de processos e otimização de um estoque hospitalar

Fernando Cesar Brandão, Paula Camila Dias Portes

Capítulo 5: Estudo aplicado de Lean Healthcare em um hospital

Rosangela da Rosa da Silva, Ismael Cristofer Baierle, Cristiano Roos

Capítulo 6: Estruturação de controle operacional num ambiente fabril para implantação do código de barra bidimensional QR-code baseada nos conceitos de Lean Manufacturing

Jorge Okumura, Carlos Antônio Vinotti, Ismael Luiz dos Santos, Maria Lúcia Miyake Okumura, Osiris Canciglieri Junior

Capítulo 7: Aplicação de Ferramentas da Manufatura Enxuta em um setor de uma Fábrica de Doces.

Tiana Leal Vicente, Maria Aparecida Fernandes Almeida, Carolina dos Santos Nunan

Capítulo 8: Produção enxuta e ferramentas da qualidade: um estudo de caso em uma indústria de autopeças

Lorena Bittencourt Bastos, Gabriela da Rosa Witeck, José Wianey Adami , Jardel Santos de Oliveira, Edson Pacheco Paladini

Capítulo 9: Lean manufacturing: Uma abordagem da aplicação da ferramenta SMED em indústria rumo a manufatura 4.0. 


\section{Sumárīio}

Capítulo 10: Oportunidades de melhoria em um escritório de projetos de uma instituição de ensino superior.

Alice Rodrigues Almeida, Camila Farias Araújo, Fernanda Rolim Uepcoski, Simone Ferigolo Venturini, Taís Oliveira da Silva Alfonso

Capítulo 11: Proposta de modelo de Lean Startup para desenvolvimento de software B2C

André Eduardo Staedele, Diego Fettermann, Fernando Antônio Forcellini

Capítulo 12: Um estudo sobre a interação entre as ferramentas lean e os processos construtivos em uma obra em Florianópolis/SC

Taylana Piccinini Scolaro, Renata Mansuelo Alves Domingos

Capítulo 13: Gestão de estoque: iniciativas de uma organização brasileira rumo à indústria 4.0

Gabriela da Rosa Witeck, Guilherme Maranhão Barreto Pereira, Guilherme Luz Tortorella

Capítulo 14: Análise da situação atual do processo produtivo de uma pequena empresa: Aplicações do mapa de fluxo de valor e indicadores de desempenho

Paula Vasconcelos Stocco, Juliana Sayuri Kurumoto

Capítulo 15: Aplicação da técnica FAHP em processos Lean para avaliar o grau de tomada de decisão

Wagner Pietrobelli Bueno, Eduardo da Silva Fernandes, Guilherme Brittes Benitez, Bruna Dones Gayer, Arthur Marcon, Érico Marcon

Capítulo 16: Principais tecnologias da indústria 4.0 e práticas enxutas

Marcos Malinverni Pagliosa, Guilherme Luz Tortorella, João Carlos Espíndola Ferreira

Capítulo 17: Análise da filosofia lean manufacturing na comparação de uma máquina semiautomática com uma automática na produção de blocos de concreto e a viabilidade da utilização Poka Yoke na redução de desperdício: Estudo de caso.

Cleber Henrique Cota, Fábio Silva Abreu, Maicon Sulivan da Cruz, Rafaelle de Oliveira Almeida, Wilson Luigi Silva 


\section{Sumário}

Capítulo 18: Análise da aplicação da filosofia Lean Manufacturing em indústria de embalagens plásticas de pequeno porte

Luana Ferraz de Souza, Alessandra Lopes Carvalho, Danielle Brey-Gil Faria, César

Augusto Figueiredo Maciel

Capítulo 19: Conceitos do Sistema Toyota de Produção propostos por Shingo e Ohno e sua aplicabilidade atual nas organizações

Ismael Cristofer Baierle, Jones Luís Schaefer, Jaqueline de Moraes, Heloísa Pereira Burin, Johanna Dreher Thomas

Capítulo 20: Lean Six Sigma method and its application in the Industry 4.0

Amanda Duarte Feitosa, Laurent Muller, Francisca Jeanne Sidrim de Figueiredo,

Thais Cadete da Silva, Amanda da Silva Xavier, Taynara Siebra Ribeiro

Capítulo 21: Proposta de redução de tempo de setup em máquinas de testes de durabilidade em uma empresa fornecedora de autopeças com o uso de conceitos SMED e padronização

Lucas Verzenhassi Toledo, Matheus de Moraes, Ivan Correr

Capítulo 22: Aplicação de ferramentas da manufatura enxuta em uma fábrica de colchões: um estudo de caso

José Leodoro Sales Júnior, Mayanne Camara Serra, Ana Célia Silva Vieira, Alyson da Luz

Pereira Rodrigues, Eduardo Mendonça Pinheiro, Eduardo Carvalho Dourado

Capítulo 23: Lean construction - propostas de introdução da técnica em duas empresas construtoras na cidade de Manaus: case

Juliana Barbosa de Carvalho, Samantha Coelho Pinheiro

Capítulo 24: Princípios do lean aplicados na contratação pública 


\section{Gapítulo 1}

\section{APLICACÃO DO MASP PARA REDUZIR O LEAD TIME DO PROCESSO DE GARANTIA DE UMA METALURGICA}

\section{Layra Gabriela Gonçalves}

Taís Oliveira da Silva Alfonso

\section{Hiasmin Amaral Pinheiro}

\section{Simone Ferigolo Venturini}

Resumo: Cumprir prazos aceitáveis para equipamentos em garantia nem sempre é uma tarefa fácil, visto que as indústrias estão sob pressões cada vez maiores nos últimos anos. O objetivo deste trabalho foi registrar a solução implantada em uma metalúrgica da região metropolitana de Porto Alegre/RS. Esta solução reduziu o lead time do processo de garantia, sendo que seu registro possibilitará que o processo seja replicado com maiores chances de sucesso no futuro. A pesquisa seguiu o Método de Análise e Solução de Problemas (MASP), pontuando os aspectos que foram considerados quando a solução foi implantada. Além disso, construiu-se as etapas que não foram consideradas na época, como análise de causas raízes, por exemplo. Percebeu-se que os benefícios da solução foram além do esperado.

Palavras-chave: Método de Análise e Solução de Problemas; A3; lead time. 


\section{INTRODUÇÃO}

No atual cenário, progressivamente competitivo, oferecer um bom atendimento ao consumidor final não é mais uma opção e sim um dever. Nessas condições a satisfação do cliente é primordial, sendo tão importante quanto alcançar novos compradores, pois clientes satisfeitos tendem a realizar novos negócios com a empresa.

Quando um produto apresenta alguma falha, o cliente espera uma solução rápida e eficaz. Além disso, o Código de Defesa do Consumidor prevê que o atendimento de um produto em garantia deve ser concluído em, no máximo, 30 dias. O Método de Análise e Solução de Problemas proporciona que as soluções sejam mais duradouras e que os problemas não sejam recorrentes. Além disso, mais colaboradores são envolvidos nas decisões, o que gera mais engajamento (SOBEK; SMALLEY, 2010).

Desse modo, baseado no Método de Análise e Solução de Problemas (MASP), este trabalho tem por objetivo registrar a solução implantada em uma metalúrgica da região metropolitana de Porto Alegre/RS. Para isso, pretende-se: (i) levantar o contexto e o problema a ser analisado, (ii) analisar o problema a partir das etapas do MASP e (iii) registrar a solução para referências futuras.

Este trabalho está dividido nos seguintes capítulos: introdução; referencial teórico acerca da Método de Análise e Solução de Problemas (MASP), além da ferramenta A3; metodologia; resultados e conclusões.

\section{MÉTODO DE ANÁLISE E SOLUÇÃO DE PROBLEMAS (MASP)}

Devido a crescente busca por eficiência, para aumento de qualidade e redução de custos, para consequentemente oferecer um preço mais baixo nos produtos e serviços, as empresas estão cada vez mais cautelosas em relação aos problemas, para isso, é necessário um método de análise e solução destes, e isto faz parte de um pensamento que serve como a base do Modelo Toyota de Produção, o PDCA. Ao analisar qualquer sistema, se torna necessário, além da prevenção, a solução efetiva, que evite a recorrência do problema, e a qualificação e o aprendizado de quem o solucionou. Portanto, é fundamental o desenvolvimento dessas habilidades em todos os colaboradores, independente do cargo de ocupação (SOBEK; SMALLEY, 2010).

Antes de entender o método, é essencial entender a importância da resolução de problemas, e passar a enxergá-los como oportunidades de melhoria, crescimento organizacional e desenvolvimento de pessoal. Conforme Sobek e Smalley (2010), ao planejar sua resolução, é necessário o esclarecimento do problema, para identificação das causas, e consequentemente a definição de objetivos e metas, portanto se torna fundamental um bom planejamento, fazendo com que esta etapa seja a mais importante do ciclo PDCA.

O primeiro passo a ser seguido é o entendimento da situação atual em determinado contexto, de forma esclarecedora e detalhada. Conforme Sobek e Smalley (2010), "o contexto é crítico porque, com frequência, o segredo para resolver um problema está em um detalhe que ninguém notou ainda - pois, se alguém já tivesse notado, o problema teria sido prevenido" ( $p$. 42). Para que a situação seja descrita de forma ideal, é preciso ir até o local em que o problema ocorreu, ou seja, observar no local de ocorrência, além de falar com os envolvidos, não subestimar os operadores, pois seria uma perda intelectual. Para melhor entendimento, o problema tem origem de algo que deveria estar sendo feito, mas não está ocorrendo, ou seja, uma lacuna, entre o que se deseja e a situação presente.

Após o planejamento, basta executar o que foi planejado e acompanhar esta execução para verificar se está ocorrendo conforme o que foi definido na etapa P do PDCA. Após, define-se a necessidade de rodar o ciclo novamente, ou estabelecer o que foi feito como padrão. Pensa-se sempre no melhor para a empresa a longo prazo, evitando assim a recorrência do problema.

\subsection{FERRAMENTA A3}

A ferramenta A3 exige do solucionador de problemas um raciocínio lógico, ou seja a capacidade de percepção, para que a tomada de decisão ocorra de maneira bem pensada e analisada. Ou seja, é preciso ter disciplina para executar o que foi descrito no PDCA, de forma flexível, pois cada problema exige análises diferentes, não existindo um fórmula geral para a resolução.

A objetividade também é um importante elemento, pois a análise subjetiva impacta em 
diferentes entendimentos, considerando que há diversas perspectivas sob um mesmo problema, ou seja, é preciso transformá-lo em uma linguagem universal a toda empresa, para isso é necessário coleta de dados para comprovação do fato que está sendo descrito.

Para definir as ações que devem ser realizadas, a fim que os problemas sejam sanados, é necessário encontrar a causa raiz do problema. Primeiro, deve-se entender a situação atual e detalhar o problema, visto que antes desta etapa a percepção tende a ser superficial e necessita de análise. Em seguida deve-se através de ferramentas como Diagrama de Ishikawa e 5 Porquês, encontrar a causa raiz, e agir em cima desta. Esta etapa é fundamental, pois ela definirá as ações futuras (SOBEK; SMALLEY, 2010).

$\mathrm{Na}$ etapa de resultados, é preciso definir critérios a fim de alcançá-los. Conforme Sobek e Smalley (2010), "os maus resultados não apenas deixam de fazer a organização avançar, eles também refletem uma má compreensão, uma situação que precisa ser consertada" (p. 37). Ou seja, um mau planejamento gera resultados ruins, e isso faz com o que o ciclo PDCA fique em looping. Quando o entendimento da organização melhora, isso gera um melhor aprendizado e torna o solucionador cada vez mais apto para a resolução de problemas.

A ferramenta A3 tem a seguinte estrutura: Histórico; Condição Atual; Objetivo; Análise da Causa Fundamental; Contramedidas; Confirmação de Efeito e Ações de Acompanhamento (SOBEK; SMALLEY, 2010). É possível notar que o A3 conta a história da resolução de um problema, seguindo todo o ciclo PDCA, passando por planejamento, execução, análise e ajustes ou padronização.

Segundo Shook (2008): "completar e então discutir o material em um A3 força os indivíduos a observar a realidade, apresentar fatos, propor contramedidas de trabalho, visando atingir a meta definida, obter concordância e fazer o acompanhamento com um processo de verificação e ajuste, tendo em vista os resultados reais". Ou seja, o desenvolvimento do $A 3$ exige de quem o faz, o conhecimento do contexto em que o problema se inclui, e domínio das ferramentas da qualidade, para sua construção, de forma mais clara e objetiva.

A ferramenta auxilia na gestão, estimulando o aprendizado científico e conduz a tomada de decisões através do diálogo e da organização dos fatos, aperfeiçoando o processo e gerando resultados mais satisfatórios. Conforme Shook (2008), "O A3 é uma manifestação visual de um processo conceitual de resolução de problemas que envolve diálogo contínuo entre o responsável por um problema e outras pessoas em uma organização", ou seja, é essencial ir ao Gemba, para aprofundamento da análise.

\section{METODOLOGIA}

A partir das definições de Gerhardt e Silveira (2009), esta pesquisa é caracterizada como de abordagem qualitativa, pois analisa 0 objeto pesquisado de forma subjetiva. Temos também que a natureza da mesma é aplicada, pois gera conhecimentos para a solução de um problema. O caráter é exploratório, já que torna o problema explícito, e o procedimento é estudo de caso, uma vez que descreve um fenômeno específico.

A partir de dados colhidos na empresa objeto deste estudo, será construído o registro da solução empírica adotada por ela. Esse registro seguirá $O$ método de análise $e$ solução de problemas (MASP) e é relevante para resolução de futuros problemas na empresa estudada. A solução implantada se tratou da internalização do processo de garantia, que anteriormente era realizado por uma empresa terceirizada.

Assim, após a solução ter sido implantada, iniciou-se o levantamento de referencial teórico para o registro da mesma. Baseado na literatura, o registro seguiu as seguintes etapas: levantamento do histórico do problema; mapeamento da condição antes da solução, chamada de "condição atual"; definição do objetivo; análise da causa fundamental; indicação das contramedidas aplicadas na resolução o problema; confirmação de efeito das contramedidas e ações de acompanhamento.

\section{RESULTADOS}

O tema estabelecido para o A3 foi "reduzir o lead time no atendimento em garantia". Segundo o CDC (Código de Defesa do Consumidor) o atendimento em garantia deve ser realizado em, no máximo, 30 dias. Transcorrido esse tempo, a empresa deve, impreterivelmente, fornecer ao consumidor um 
novo equipamento ou realizar a devolução do dinheiro.

Para a construção do histórico, os dados foram extraídos de planilhas de registro anuais dos atendimentos em garantia. A coleta mostra que desde 2015 o lead time de atendimento de equipamentos em garantia é superior ao requerido pelo CDC. A média do lead time de atendimento foi de 28 dias, 34 dias e 38 dias nos anos de 2014, 2015 e 2016, respectivamente, sendo que, no ano de 2016, o atendimento mais elevado foi concluído em 68 dias. Os dados indicaram elevada tendência de o lead time permanecer afastado do requerido pelo Código de Defesa do Consumidor, já que no período de janeiro a maio do ano de 2017 nenhum mês teve a média de atendimentos em garantia realizados com lead time igual ou inferior a 30 dias.

A condição atual foi construída acentuando as principais etapas do macroprocesso. De forma detalhada, o atendimento em garantia iniciava com a reclamação do cliente, a qual era recebida pelo setor da qualidade por ligação ou e-mail. Então, o setor responsável analisava se o equipamento caracterizava garantia através da data de emissão nota fiscal de compra do consumidor final. Configurando garantia, era enviado ao cliente um informativo com orientações para a emissão da nota fiscal de remessa em garantia.

Após recebida a nota fiscal de remessa em garantia a qualidade deveria agendar a coleta com a transportadora e monitorar o andamento do frete. Quando o equipamento era recebido na empresa, a logística informava a qualidade a qual era responsável pela avaliação visual do equipamento (verificar se o equipamento estava nos padrões de fabricação) e identificação. O equipamento ficava na área denominada de GAR misturado aos demais equipamentos: os que estavam aguardando conserto, teste ou envio para o cliente.

A qualidade providenciava junto ao setor fiscal a nota de remessa em garantia para o envio do equipamento a uma assistência técnica terceirizada, a qual todos os equipamentos eram direcionados. Após 2 dias da solicitação a nota fiscal era emitida, possibilitando que fosse agendado o frete do equipamento da empresa até a assistência técnica. A assistência técnica recebia o equipamento, avaliava e solicitava as peças necessárias para realizar $\mathrm{O}$ atendimento. $\mathrm{O}$ setor da qualidade recebia a solicitação e requisitava via sistema as peças necessárias assim como o frete das peças da empresa até a assistência técnica terceira.

Após receber as peças a assistência técnica realizava o conserto do equipamento, caso não houvesse necessidade de peças, a assistência realizava o ajuste, não sendo necessário passar pelo processo de solicitação de peças. Era de responsabilidade da assistência técnica externa testar o equipamento após o conserto e devolvê-lo em boas condições e atendendo a todos os critérios de segurança. Posterior ao conserto a assistência preenchia um relatório de atendimento e emitia uma nota fiscal de retorno de conserto.

A nota fiscal era enviada à qualidade, que agendava $\mathrm{o}$ frete de coleta e, após o equipamento chegar na empresa ele era testado pela produção. Os testes ocorriam via agendamento e eram acompanhados pelo setor da qualidade. Caso o equipamento reprovasse no teste era enviado novamente para a assistência, se aprovado era enviado para o cliente.

O objetivo estabelecido foi encerrar o ano de 2017 com o lead time médio igual ou inferior a 30 dias. Para atingir a meta era necessário que a média do lead time mensal fosse de 25 dias.

As causas fundamentais foram encontradas através do Ishikawa e dos 5 porquês. Foram designadas como causas diretas as reprovações nos testes, a inexistência de identificação e o serviço externo. Foram elencadas como causas colaboradoras a falta de notas fiscais para envio, o processo de solicitação e envio de peças para realizar o conserto, a assistência externa não ter o peso padrão, a falta de interesse da assistência terceirizada, a imparcialidade para executar os testes e os numerosos fretes.

Ao executar os porquês foi percebido que a assistência técnica terceira não realizava os testes pois não havia solicitado o kit assistência. O kit era um elemento que toda assistência deveria adquirir ao ser credenciada, sendo composto por peças e pesos padrão para efetuar os testes.

A causa direta denominada como inexistência de identificação teve como causa raíz a falta de procedimento. Ao chegar na empresa, o setor responsável deveria notificar a 
qualidade que o equipamento chegou, entregando a nota fiscal de recebimento, mas frequentemente a entrega não ocorria ou a nota fiscal era entregue para outro setor da empresa que prestava serviço de conserto em equipamentos que não estavam em garantia.

Por fim, como causa raiz do serviço externo foi encontrada a falta de treinamento. Isso se deu já que havia mão de obra interna disponível para realizar os consertos, mas apenas um colaborador sabia como executálos.

Com embasamento nas causas raízes encontradas foi elaborado plano de ação. As principais condutas foram: a execução do $5 S$ na área da garantia visando a organização e identificação dos equipamentos, o mapeamento e treinamento dos colaboradores que seriam envolvidos, o piloto de como ocorreriam os consertos internos e a verificação do período de piloto.

Com a resolução dos 5 porquês notou-se a ausência de ações visando eliminar as causas de inexistência do kit assistência e do procedimento que determine como deve ocorrer a entrega de notas fiscais, possibilitando que a qualidade identifique os equipamentos. Porém, em relação ao procedimento, a aplicação do 5S apresentou efeito positivo, já que o novo layout (figura 1) da área possibilitou distinguir equipamentos recém recebidos dos demais.

Figura 1 - Layout após 5S

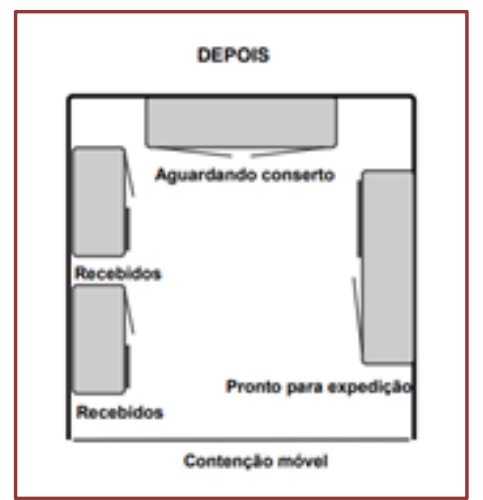

Fonte: Própria (2018)

A confirmação de efeito sucedeu do acompanhamento da média mensal do lead time de atendimento. O objetivo mensal foi alcançado, conforme indicado na Figura 2.

Figura 2 - Resultados mensais

\begin{tabular}{|c|c|}
\hline Mês & $\begin{array}{c}\text { Média de } \\
\text { atendimento (dias) }\end{array}$ \\
\hline Junho & 30 \\
\hline Julho & 25 \\
\hdashline Agosto & 23 \\
\hline Setembro & 25 \\
\hline Outubro & 20 \\
\hline Novembro & 20 \\
\hline Dezembro & 21 \\
\hline
\end{tabular}

Fonte: Própria (2018)

No primeiro mês ocorreram consertos internos e externos, enquanto o piloto de 15 dias era executado 3 equipamentos foram enviados para a assistência técnica terceirizada. No momento que os atendimentos foram feitos integralmente de forma interna o lead time diminuiu consideravelmente.

As ações de acompanhamento foram embasadas na padronização do processo através de procedimento e a divulgação do novo processo. 


\subsection{BENEFICIOS COMPLEMENTARES}

Afora alcançar o lead time desejado no atendimento em garantia, a internalização dos consertos ocasionou em ganhos mensuráveis e imensuráveis. Com os consertos realizados internamente houve a possibilidade de a qualidade acompanhar cada atendimento, sendo mais exigente no preenchimento dos relatórios. Isso proporcionou a compilação dos dados e a elaboração de um relatório mensal com as principais causas de defeito.
O relatório mensal era entregue para o gerente de produção em uma reunião, também mensal. A reunião era conduzida pelo setor da qualidade, mas contava com a engenharia e produção para discutir os dados do relatório visando entender e precautelar falhar recorrentes.

Houve também a redução de finanças com mão de obra, frete e peças, conforme mostra a Figura 3.

Figura 3 - Demonstrativo da redução de finanças

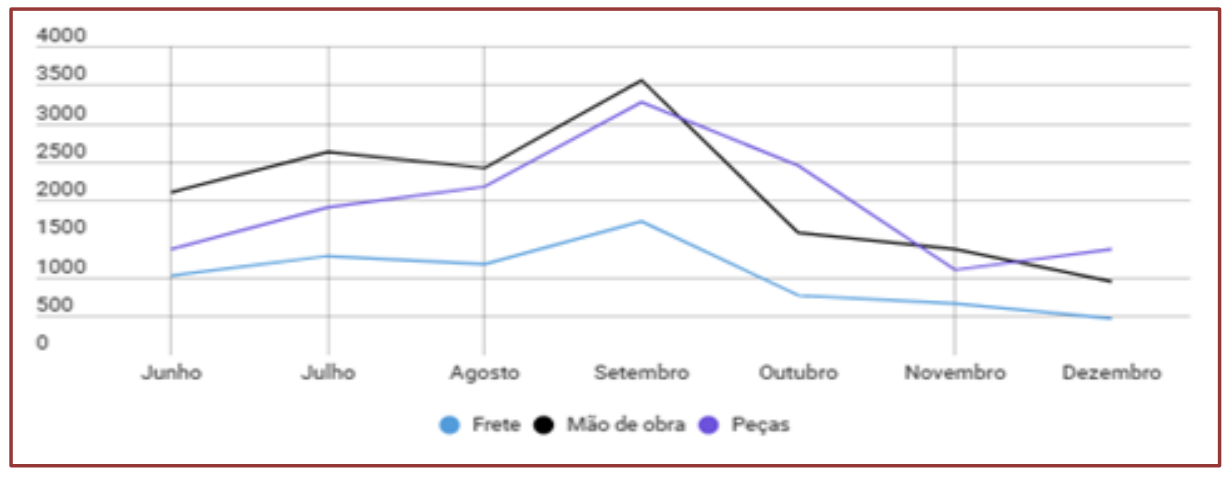

Fonte: própria (2018)

A economia foi de $\mathrm{R} \$ 7.089,00$ em frete, $R \$ 14.595,00$ em mão de obra e $R \$ 13.650,00$ em peças, totalizando uma contenção de $\mathrm{R} \$ 35.334,00$.

\section{CONCLUSÕES}

Este trabalho teve por objetivo registrar a solução implantada em uma metalúrgica da região metropolitana de Porto Alegre/RS. A solução encontrada pela empresa para reduzir o lead time do processo de garantia (internalizar as atividades) foi assertiva. Visando manter o sucesso em empreitadas futuras, buscou-se registrar por meio da ferramenta A3 o contexto e o histórico do problema.

\section{REFERÊNCIAS}

[1] GERHARDT, Tatiana Engel; SILVEIRA, Denise Tolfo. Métodos de pesquisa. Porto Alegre: Editora da UFRGS, 2009. 120p.

[2] SOBEK, Durward K.; SMALLEY, Art. Entendendo o pensamento A3: um componente
Após, o problema foi analisado e as causas diretas foram examinadas, chegando-se então nas causas raízes. Viu-se que as causas raízes foram parcialmente atendidas pelo plano de ação que a empresa executou na época em que a solução foi implantada. Essa análise também possibilitou localizar as lacunas entre o plano de ação executado e as ações necessárias para sanar as causas raízes do problema.

O registro da confirmação de efeito pode motivar os colaboradores a utilizarem o MASP em problemas futuros. Já as ações de divulgação disseminam a cultura do MASP para os demais. Para a empresa, utilizar o MASP promoverá uma cultura de resolver problemas de forma assertiva e estruturada, possibilitando resultados cada vez melhores.

crítico do PDCA da Toyota. Porto Alegre: Bookman, 2010. 192p.

[3] SHOOK, John. Gerenciando o aprendizado. São Paulo: Lean Institute Brasil, 2008, $138 p$. 


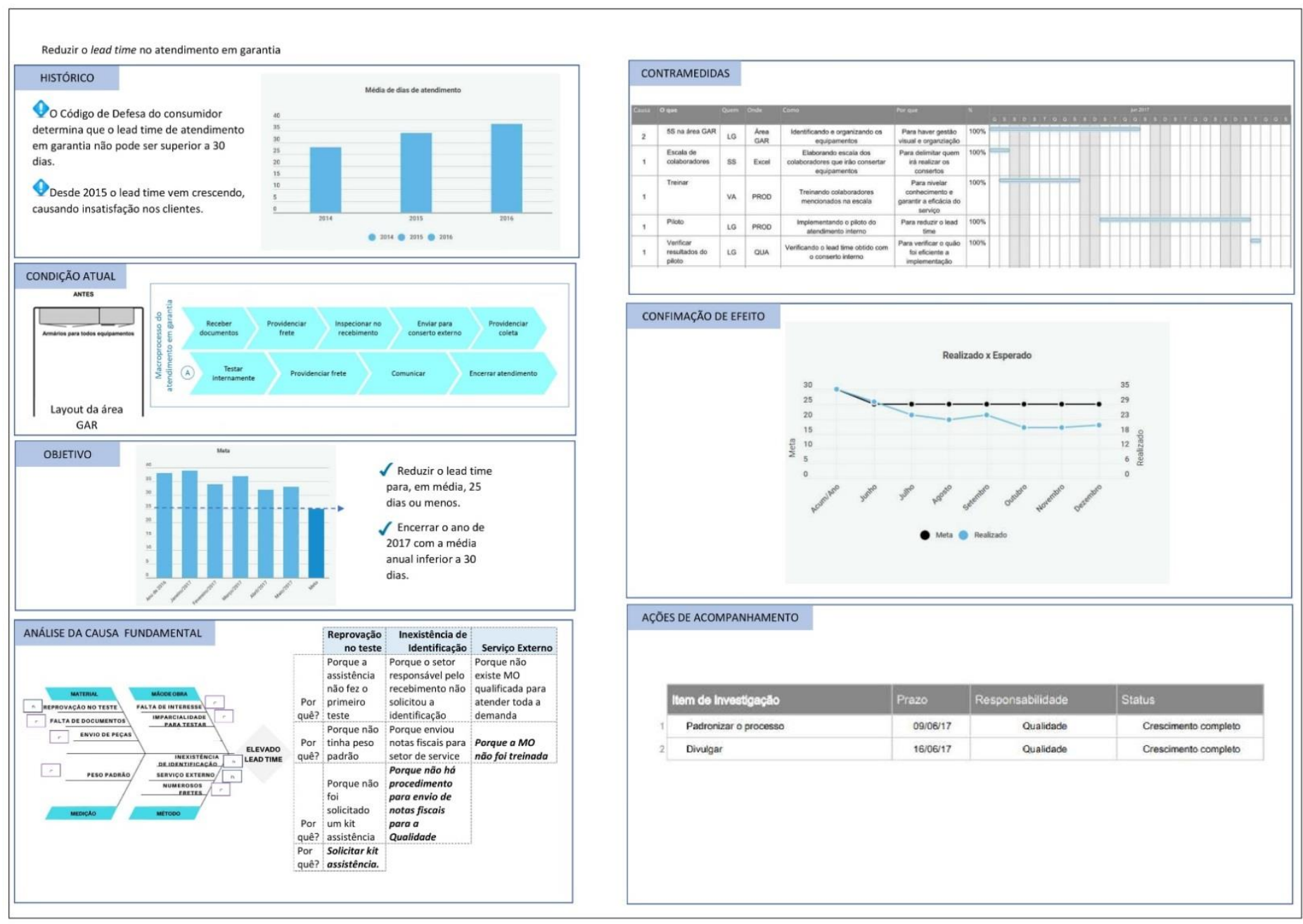




\title{
Bapítulo 2
}

\section{EMPREGO DA METODOLOGIA LEAN SEIS SIGMA NA MELHORIA DE PROCESSOS: \\ BIBLIOMETRICO}

\author{
Amanda da Silva Xavier \\ Andersson Alves da Silva \\ Emerson Rodrigues Sabino \\ Amanda Duarte Feitosa \\ Taynara Siebra Ribeiro \\ Thays Lorranny da Silva Januário
}

Resumo: A globalização ascendente força as empresas a estarem em constante alterações em seus processos com o intuito de permanecerem competitivas e atender as expectativas de seus clientes. O uso de metodologias de melhoria de processo contribui para que essas empresas alcancem tais objetivos. Uma dessas metodologias é a integração do Seis Sigma com o Lean Manufacturing, visto que essa união traz um grande impacto favorável aos desempenhos empresariais. $O$ Lean Manufacturing é uma metodologia iniciada pela Toyota, que almeja reduzir desperdícios e gerar valor ao produto fabricado. O Seis sigma teve seu início na Motorola e foca na melhoria dos processos por meio da eliminação de defeitos. Já o Lean Seis Sigma une as duas metodologias com o intuito de utilizar ferramentas estatísticas que contribuem para a tomada de decisão e as estratégias nos processos. O objetivo deste trabalho é analisar de forma quantitativa a produção científica acerca do Lean Seis Sigma nos últimos 10 anos em uma base de dados relevante a publicação de trabalhos nesta área de pesquisa, através de um estudo bibliométrico. Foi utilizado a base de dados dos anais do ENEGEP, visto sua importância para a produção nacional, com as palavras-chave "Lean Seis Sigma" e "Lean Six Sigma", em seguida utilizou-se filtros de inclusão e exclusão para seleção dos artigos encontrados. Foram encontrados na base de dados 26 artigos, sendo apenas 16 atuando em melhoria dos processos e, entre estes, 11 utilizaram a integração das metodologias. Destes 11 trabalhos, foram quantificadas 35 ferramentas diferentes utilizadas, destacando DMAIC, VSM, Histograma, Kaizen, Carta de Controle e Diagrama de Pareto. Dentre as áreas de publicação, apenas duas áreas foram computadas: Gestão da Produção e Gestão da Qualidade, comprovando o uso da metodologia na atuação em melhorias dos processos. Portanto, a pesquisa foi satisfatória, mesmo utilizando apenas uma base de dados.

Palavras-chave: Lean seis sigmas, Lean six sigma, Melhoria de processo, Estudo bibliométrico. 


\section{INTRODUÇÃO}

Devido a globalização as empresas estão sendo conduzidas a alterar suas sistemáticas na tentativa de permanecer nas negociações e atenderem às expectativas de um mercado dinâmico. Para isso, algumas delas recorrem a metodologias de melhoria de processos que possibilitam o contínuo aperfeiçoamento das empresas (ARIENTE, 2005; MARSHALL JUNIOR et al., 2012).

Dentre as várias metodologias de melhoria de processo destaca-se como mais utilizadas a Seis Sigma e a filosofia Lean Manufacturing. Alguns autores destacam que a integração dessas metodologias tem gerado às empresas impacto positivo no desempenho do negócio, sendo assim, altamente explorado pelas comunidades acadêmicas, devido a divulgação de ganhos financeiros atraentes, atendendo aos cinco critérios de desempenho da produção: qualidade, confiabilidade, velocidade, flexibilidade e custos (ENDLER et al., 2016; LUSTOSA et al., 2011).

$\mathrm{Na}$ literatura encontram-se diversos trabalhos acadêmicos abordando a temática do Lean Seis Sigma (LSS), onde sua atuação contribui tanto com ganhos quantitativos e qualitativos nas empresas, como também para a revisão teórica de artigos acadêmicos.

Em muitos trabalhos acadêmicos essa metodologia apresenta-se como fruto de investigações e interações entre pesquisadores ao longo do tempo, onde o avanço nessa área de estudo origina-se do know-how disponível sobre ele. Deste modo, o conhecimento acerca da evolução do LSS, bem como suas ferramentas, principais estudiosos e as pesquisas de maior relevância podem contribuir significativamente para compreensão do tema abordado e identificação de tendências sobre ele (ENDLER et al., 2016).

Destarte, busca-se analisar quantitativamente o perfil da produção científica sobre o Lean Seis Sigma destacando os temas mais relevantes e sua tendência nos últimos dez anos em uma base de dados que seja importante para a publicação de trabalhos nesta área de pesquisa, através de um estudo bibliométrico.

\section{EMBASAMENTO TEÓRICO}

\subsection{LEAN}

O Lean Manufacturing remete ao Sistema Toyota de Produção, um modelo gerencial Japonês pioneiro em atuar com estoques reduzidos e alta variabilidade. A escassez dos recursos ocorrida logo após a Segunda Guerra Mundial tornou-se desafio para as empresas japonesas produzirem com a mesma eficiência da Ford na época, a qual trabalhava com menor índice de desperdícios e menor custo. Este fato, posteriormente direcionou os empreendimentos das organizações para o alinhamento de ações que geram valor ao produto contextualizando os conceitos abordados pelo Lean Manufacturing (BARRETO, 2012; SAIA, 2009).

Assim, tem-se a filosofia Lean como o centralizador das atividades que agregam valor na concepção do cliente com ótica à eliminação de desperdícios. Deste modo, as organizações devem ter suas atividades bem definidas e sustentadas para evoluir no quesito qualidade e reduzir a velocidade de entrega dos produtos (DIAS, 2011).

Os desperdícios aqui citados, são nomeados e classificados pelo Lean Manufacturing em sete tipologias diferenciadas, onde após serem identificados checa-se qual metodologia melhor se adequa a exclusão deles, assim, algumas ferramentas são comumente utilizadas, tais como: 5S, Just-InTime (JIT), Jikota, TPM (Manutenção Produtiva Total), Kaizen, Kanban, VSM (Mapa de Fluxo de Valor), Poka Yoke e Estudo dos Métodos dos Tempos (BASTOS, 2012).

Mandujado (2016) sugere soluções por meio destas ferramentas ou outras metodologias simples que melhor de adeque a necessidade de cada um desses desperdícios, as quais estão representados no quadro 1 a seguir: 
Quadro 1: Os sete desperdícios

\begin{tabular}{|c|c|}
\hline Desperdício & Recomendações \\
\hline $\begin{array}{l}\text { Excesso de } \\
\text { Inventário }\end{array}$ & $\begin{array}{l}\text { Reunir pessoas e/ou processos para } \\
\text { mellhorar o fhxo de trabalho }\end{array}$ \\
\hline Espera & $\begin{array}{l}\text { Desenvolvimento de um plano de } \\
\text { commição }\end{array}$ \\
\hline Superprodução & $\begin{array}{l}\text { Utilizar o Vahue Stream } \\
\text { Mapeamento-VSM (Mapa de fluxo } \\
\text { de valor) }\end{array}$ \\
\hline $\begin{array}{l}\text { Processamento } \\
\text { Desnecessário }\end{array}$ & $\begin{array}{l}\text { Treinar fincionários e traballhar com } \\
\text { ficha de verificação para resultados }\end{array}$ \\
\hline $\begin{array}{l}\text { Transporte } \\
\text { excessivo }\end{array}$ & Desenvolver Plano 5s \\
\hline Defeito & $\begin{array}{l}\text { Use sugestões simples para eliminar } \\
\text { os desperdícios }\end{array}$ \\
\hline $\begin{array}{l}\text { Movimentação } \\
\text { desnecessária }\end{array}$ & $\begin{array}{l}\text { Desenvolver um processo ágil para } \\
\text { antecipar as necessidades dos } \\
\text { clientes }\end{array}$ \\
\hline
\end{tabular}

Fonte: Adaptado de Mandujano (2016)

A eliminação ou minimização destas ineficiências, melhora a produtividade, evita uso do recurso capital com peças defeituosas, reduz as áreas de estoques, desenvolve velocidade de resposta no processo com grande flexibilidade e reduz perdas de produtividade. Deste modo, entende-se que os desperdícios geram custos e tempos excessivos, daí a importância da eliminação dos mesmos (BATOS, 2012).

\subsection{SEIS SIGMA}

Trata-se de um conjunto de práticas desenvolvidas pela Motorola em meados da década de 80, com ótica à melhoria sistemática dos processos na eliminação dos defeitos. Um defeito é definido como a não conformidade de um produto ou serviço sobre as especificações do cliente (interno e externo). Essas especificações são determinadas a partir da voz do cliente (CHAHADE, 2009; DIAS 2011).

A letra grega sigma $(\sigma)$ é utilizada para indicar o desvio sobre a média de um processo, que quando aplicado permite gerar um menor custo de retrabalho e perdas. Deste modo é possível representar a capacidade de atender às especificações de um bem/serviço com 99,9997\% sem falhas, o que representa 3,4 defeitos por milhão de oportunidades (MANI; PÁDUA, 2008; CHAHADE, 2009).

$\mathrm{Na}$ tabela 1 está representado a conversão dos sigmas a nível mundial numa escala de 1 a 6 sigmas:

Tabela 1: Nivel de qualidade sigma

\begin{tabular}{|c|c|}
\hline $\begin{array}{c}\text { Nivel de } \\
\text { Qualidade }\end{array}$ & $\begin{array}{c}\text { Defeitos por } \\
\text { milhão }\end{array}$ \\
\hline 1,5 sigma & 500.000 \\
\hline 2 sigma & 308.537 \\
\hline 3 sigma & 66.804 \\
\hline 4 sigma & 6.210 \\
\hline 5 sigma & 233 \\
\hline 6 sigma & 3,4 \\
\hline
\end{tabular}

Fonte: Adaptado de Chahade (2009) 
Santana et al. (2004) afirma que em linguagem estatística o nível sigma consiste na dispersão dos dados em torno de uma média que visa centralizar os processos reduzindo a variabilidade. Os cálculos para encontrar o nível sigma estão representados no Quadro 2:

Quadro 2: Equações para cálculo do nível sigma

\begin{tabular}{|c|c|}
\hline Equações & Denominações \\
\hline TOP $=$ Unidade inspecionadas $* \frac{\text { oportunidade }}{\text { Unidades }}$ & $\begin{array}{c}\text { TOP }: \text { Total de } \\
\text { Oportunidade }\end{array}$ \\
\hline$D P O=\frac{\text { Defeitos encontrados }}{T O P}$ & $\begin{array}{c}D P O: \text { Defeitos por } \\
\text { Oportunidades }\end{array}$ \\
\hline$D P M O=D P O * 10^{6}$ & $\begin{array}{c}D P M O: \text { Defeitos } \\
\text { por Millaño de } \\
\text { Oportunidades }\end{array}$ \\
\hline
\end{tabular}

Fonte: Adaptado de Santana et al. (2004) e Pinto (2016)

Ter um nível sigma alto significa diminuir a variabilidade e aumentar a conformidade do processo, onde as consequências são verificadas nos retornos financeiros (PINTO, 2016). Segundo Werkema (2012) os retornos financeiros remetem as origens do Seis Sigma onde as empresas que adotaram essa metodologia apresentaram resultados de grande destaque para os stakeholders, de tal forma que a figura 1 apresenta as empresas e as contribuições conquistadas.

\section{Figura 1: Evolução dos ganhos financeiros com implantação do Seis Sigma}

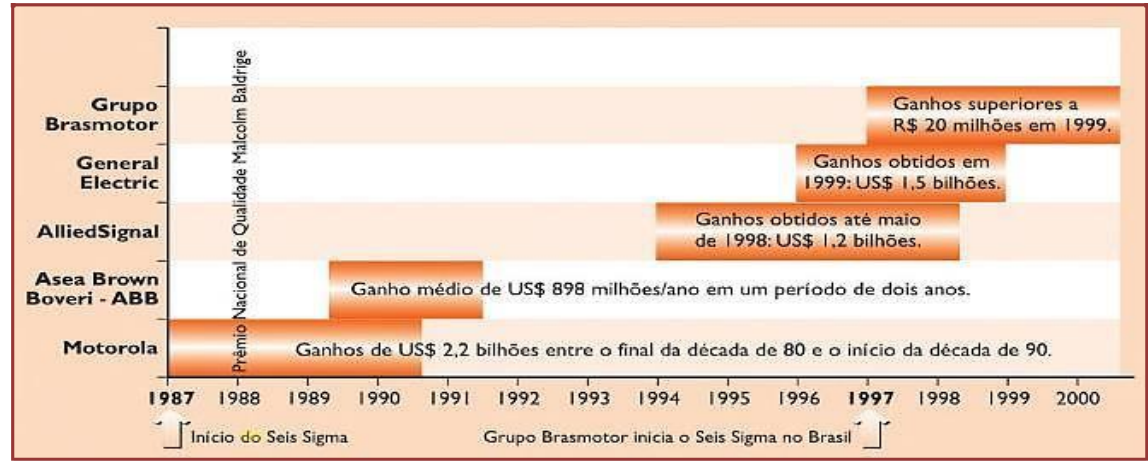

Fonte: Werkema (2012)

O Seis Sigma explora as oportunidades de ganhos e melhorias usando ferramentas estatísticas e um método estruturado designado DMAIC. As ferramentas estatísticas são usadas para a coleta e análise dos dados, onde os resultados sustentarão a tomada de decisão sobre as questões do processo investigado. O DMAIC refere-se a uma abordagem de ciclo de vida baseada em dados que garante a sequência ordenada, lógica, e eficaz do gerenciamento de projetos, objetivando identificação, quantificação e minimização das fontes de variações de um dado processo (SCATOLIN, 2005; SOKOVIC; PAVLETIC; PIPAN, 2010).
Esta metodologia é um acrônimo para cinco fases interconectadas: Definir, Medir, Analisar, Melhorar e Controlar. Na fase Definir deve-se identificar, priorizar e selecionar o projeto certo; a fase Medir é a característica-chave do processo, o escopo dos parâmetros e seus desempenhos; o Analisar identifica as principais causas determinantes do processo; o Implantar altera o processo e otimiza o desempenho e o Controle tem a função de sustentar o ciclo (SOKOVIC; PAVLETIC; PIPAN, 2010). 


\subsection{LEANSEIS SIGMA}

O termo Lean Seis Sigma descreve as duas áreas de melhoria operacional citadas anteriormente, que visa reduzir desperdícios, elevar desempenho bem como contribuir na satisfação do cliente. Independentemente do nível de atividade exercida dentro de uma organização, todos devem conhecer e implementar os conceitos desse método, que pode ser entendida como estratégia de negócio (ENDLER, 2016).

O Seis Sigma remete a uma estratégia gerencial disciplinada e quantitativa, apresentando mensuração direta dos benefícios, sendo um método estruturado para alcance das metas, necessitando de um elevado comprometimento da alta gerência. Enquanto que o Lean Manufacturing atua nos desperdícios existentes no processo produtivo visando a melhoria da velocidade de processos. Deste modo, o Lean identifica e elimina os problemas no fluxo e o Seis Sigma melhora a capacidade das etapas que agregam valor (WERKEMA, 2012).

A integração do Lean e do Seis Sigma é analisada, medida e controlada por um conjunto de ferramentas estatísticas ampliando a compreensão do problema e as decisões a serem tomadas, gerando um ganho financeiro para a empresa. O modelo deve ser estruturado sobre o tipo de problema ocorrido, sendo assim estratégico e focado em processos. Portanto, haverá um balanceamento entre as duas filosofias aproveitando as reconhecidas vantagens de ambas e equilibrando a complexidade e sustentabilidade (PACHECO, 2013).

A literatura retrata o Seis Sigma numa variação de dois a dez trabalhos publicados por ano nas bases de dados Web of Science e Scopus (SELEME et al., 2016). Já para o Lean Manufacturing, Rosa (2016) apresenta a variação de publicação variando entre 8 e 27 publicações por ano em quatro periódicos internacionais. Enquanto que na integração dessas duas metodologias, o número de publicações ainda é bastante recente podendo ser encontrada por Lean Seis Sigma ou Lean Six Sigma.

Para o caso do Lean Seis Sigma, Endler (2016) avaliou 84 artigos no período de 1999 a 2014 na base ISI Web of Knowledge e concluiu que as publicações começaram a evoluir a partir de 2008. Em relação ao Lean Six Sigma, Gonçalves Filho e Silva (2015) encontraram 54 trabalhos em uma análise de
2009 a 2014 enfatizando o maior número de publicações na base Scorpus (Elsevier), onde ocorreu um ascendente número de trabalhos entre 2011 e 2012.

\section{MÉTODO DA PESQUISA}

O trabalho foi realizado através de um estudo bibliométrico. Para Reis et al. (2017) a bibliometria é um método utilizado para se obter análise de pesquisas, capaz de identificar e quantificar uma produção científica a partir de um assunto específico. Vasconcelos (2014), destaca que a metodologia pode ser aplicada a partir da avaliação categórica de fontes bibliográficas e referências, das relações e padrões de organização, bem como pontos críticos, tendências e contrapontos, proporcionando também a revelação de reinvindicações atuais da área e as contribuições mais relevantes. Leite Filho (2006), enfatiza a importância da bibliometria para indicar rumos e estratégicas em pesquisas futuras a partir de indicadores de desempenho.

Foi utilizado para aplicação deste estudo, a base de dados dos anais do Encontro Nacional de Engenharia de Produção ENEGEP, evento este responsável pela grande propagação de trabalhos científicos e técnicos no campo da Engenharia de Produção no território nacional e precursor dos principais debates e discussões acerca dos assuntos relevantes da área, como o Lean Seis Sigma para melhoria dos processos.

A base de dados encontra-se no site http://www.abepro.org.br/publicacoes na categoria ENEGEP. O período da investigação são os artigos publicados entre 2006 e 2016, contemplando os últimos 10 anos do evento. Adotou-se como as palavras-chave de busca "Lean Seis Sigma" e "Lean Six Sigma", visto que existem publicações que consideram o nome na língua portuguesa do Brasil e outros que empregam o nome em inglês.

Com o intuito de filtrar e selecionar os artigos encontrados na pesquisa, partiu-se para a leitura do título e dos resumos de cada um, onde foram considerados incluídos na análise os trabalhos escritos em língua portuguesa, inglesa ou espanhola e que resultasse em algum tipo de melhoria de processo produtivo, seja como aplicação ou proposta. Os artigos que não abordavam aplicações da metodologia em empresas foram excluídos e 
foram desconsiderados os trabalhos cujo acesso estavam indisponíveis no banco de dados.

Utilizou-se o software Microsoft Office Excel 2013 para geração de gráficos de análises e tabelas com as principais informações encontradas no estudo bibliométrico.

\section{RESULTADOS E DISCUSSÕES}

\subsection{RESULTADOS DO ESTUDO} BIBLIOMÉTRICO

A pesquisa na base escolhida compreende 26 artigos que abordam sobre o assunto LSS, dentre os quais, 18 correspondem a palavrachave Lean Seis Sigma e 8 Lean Six Sigma sendo classificados segundo a figura 2 a seguir:

Figura 2: Classificação a partir das palavras-chaves pesquisadas

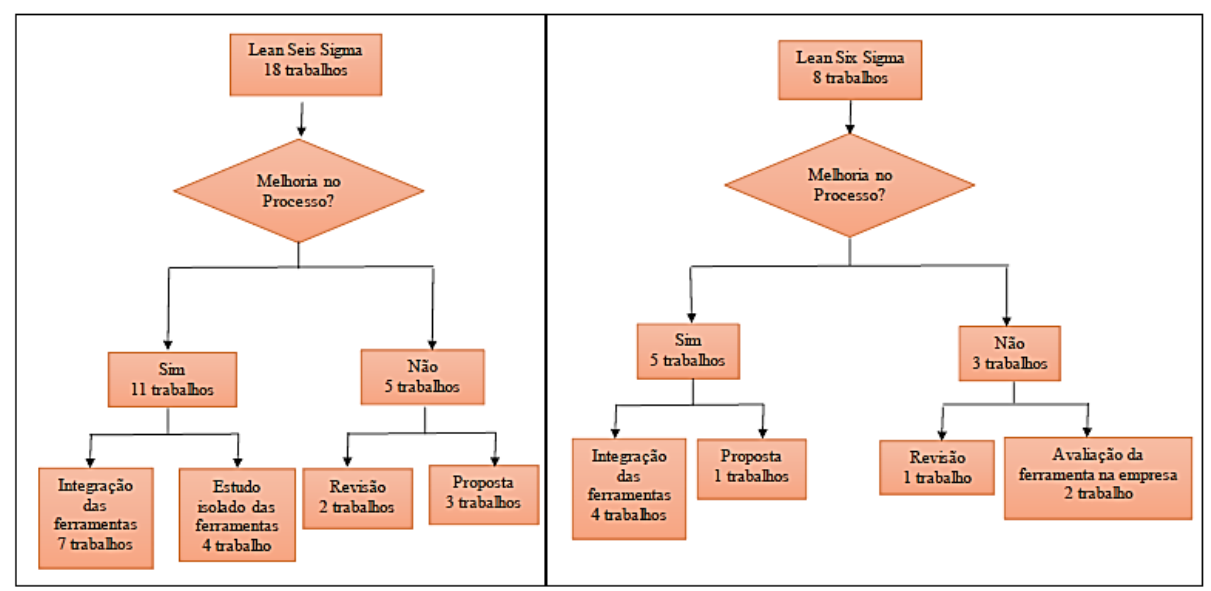

Fonte: Elaboração dos autores

A figura 2 mostra que em ambos os casos, a maior parte dos trabalhos publicados concentram-se na melhoria de processos com uso da integração, o que é ideal pelo fato de uma completar a outra, como visto no referencial teórico apresentado neste estudo, e que os trabalhos que não estão em melhoria de processos referem-se a revisão bibliográfica abordando a eficiência da ferramenta no meio organizacional.

Em uma análise descritiva dos trabalhos buscou-se identificar qual a tendência de crescimento ou declinação das publicações encontradas, como mostra a figura 3 a seguir:

Figura 3: Tendência de publicação LSS

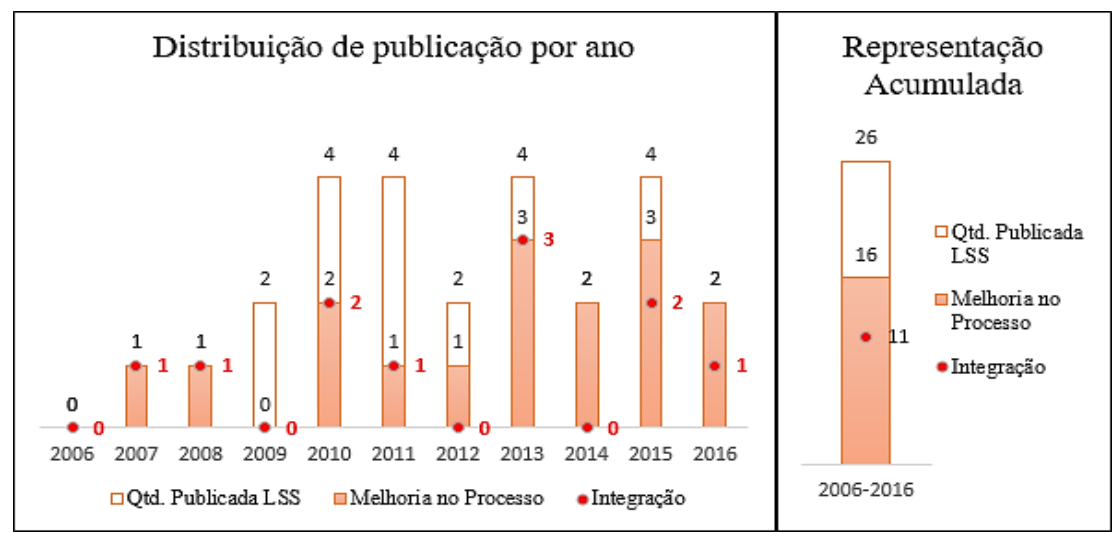

Fonte: Elaboração dos autores 
Na figura 3, verifica-se a pouca ocorrência de estudos entre 2006 e 2016 sobre a ferramenta Lean Seis Sigma resumindo em 26 trabalhos, dos quais apenas 16 foram aplicados em melhoria de processo, e dentre estes, apenas 11 utilizaram a integração das ferramentas totalizando o espaço amostral desse estudo.

No entanto, o maior número de publicações envolvidas no espaço amostral, concentramse no ano de 2013, dentre os quais destacase o trabalho de Dermachi, Souza e Alves que utilizaram a integração da metodologia em pequenos processos de uma Indústria Têxtil da Cocamar no Paraná, afim de gerar grande impacto no final da implantação de melhoria do processo, o objetivo deles era aumentar a produtividade de $83 \%$ para $93 \%$ chegando a eficácia global dos equipamentos, utilizando o maior número de ferramentas possíveis.

\subsection{FERRAMENTAS LSS UTILIZADAS NOS ESTUDOS}

Analisou-se a frequência de utilização das ferramentas que comtemplam o LSS, na busca por identificação das quais apresentaram-se com maior contribuição para as pesquisas, como está representado no gráfico 1:

Gráfico 1: Ferramentas LSS presente na amostra

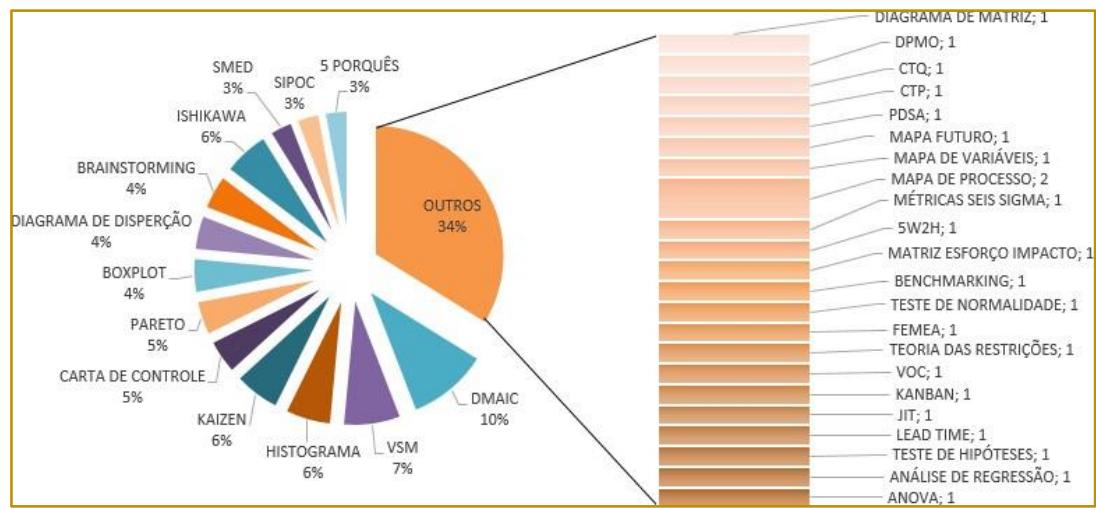

Fonte: Elaboração dos autores

Como visto no gráfico 1 , os 11 trabalhos da análise utilizaram em torno de 35 ferramentas para melhoria de processos dos quais 22 foram classificados como outros por serem usados apenas por um ou dois trabalhos, enquanto que as demais foram distribuídas em pizzas pela frequência de uso. No uso frequente destes instrumentos de melhorias destaca-se o trabalho de Leite e Montesco (2016) que usou em torno de 15 ferramentas em uma distribuidora de GLP, atuando na redução do tempo médio de saída do veículo e no aumento da margem líquida.

Dentre as ferramentas mais frequentes presentes no gráfico 1 pode-se salientar 6 delas como relevantes pelo maior número de aplicação: DMAIC, VSM (Mapa de Fluxo de Valor), Histograma, Kaizen, Carta de Controle e Pareto, as quais foram citadas entre 3 e 7 trabalhos, representados na tabela 2 a seguir:

Tabela 2: Ferramentas mais relevantes

\begin{tabular}{|l|c|}
\hline \multicolumn{1}{|c|}{ Ferramenta } & Frequencia de us o \\
\hline DMAIC & 7 \\
\hline VSM & 5 \\
\hline HISTOGRAMA & 4 \\
\hline KAIZEN & 4 \\
\hline CARTA DE CONTROLE & 3 \\
\hline PARETO & 3 \\
\hline
\end{tabular}

Fonte: Elaboração dos autores 
Sales (2006), Sokovic, Pavletic; Pipan (2010) e Bastos (2012), definem essas ferramentas como:

- O DMAIC: É um método estruturado que objetiva sequenciar logicamente as etapas da implantação de um projeto;

- VSM: Serve como principal fonte de informação onde é mostrado graficamente o processo em estudo como um todo, permitindo identificar os desperdícios existentes;

- Histograma: É uma ferramenta estatística onde pode ser representada a variabilidade do processo que alerta o dono do projeto, a necessidade de redução ou não avaliada em cada processo;

- Kaizen: É conhecido como melhoria contínua, onde todos os envolvidos podem estar sugerindo ideias para possíveis melhorias no processo afim de reduzir a complexidade produtiva;
- Carta de Controle: É uma ferramenta estatística onde fica ingressada a voz do cliente como especificações em que o projeto não pode ultrapassar;

- $\quad$ Pareto: Permite a priorização por meio da representação gráfica para evitar esforço desperdiçado com ações corretivas em atividades que não geram tanto impacto.

Estas ferramentas foram utilizadas em empresas do segmento industrial (5 trabalhos), comercial (2 trabalhos), ambos os segmentos (1 trabalho) e os outros dois não foram possíveis identificar 0 segmento atuante.

\section{2 ÁREAS DE PUBLICAÇÃO}

Para submissão de artigos no ENEGEP, é necessário que o trabalho seja alocado em uma das 11 áreas que o compõe, deste modo foram analisados e distribuídos os 11 trabalhos do estudo como segue a gráfico 2:

Gráfico 2: Distribuição de estudos por área de publicação na base ENEGEP

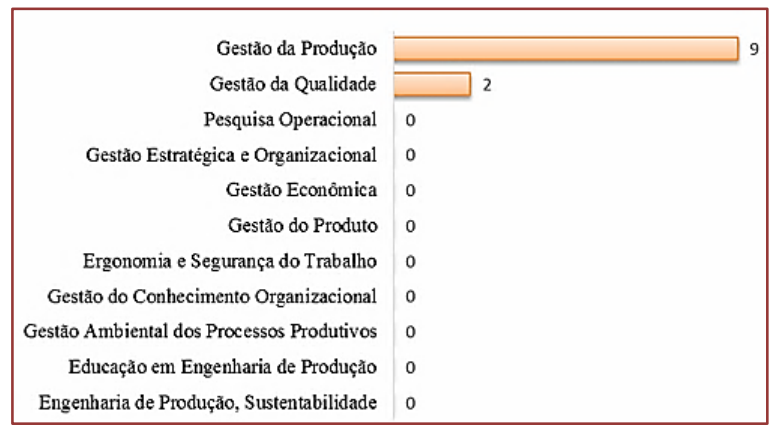

Fonte: Elaboração dos autores

O gráfico 2 mostra que existe um número considerável de publicações referente a temática, com ênfase dentro da área da gestão da produção reforçando, deste modo, a afirmativa de que o uso de técnicas do LSS empregadas ao gerenciamento da produção busca trazer melhorias de processo nas empresas reduzindo ineficiência e otimizando a capacidade das etapas que agregam valor.

Na área de Gestão de Produção as subáreas utilizadas foram: Gestão de Processos Produtivos (3 trabalhos); Gestão de Sistemas de Produção (4 trabalhos) e Logística e Gestão da Cadeia de Suprimentos (2 trabalhos). Contudo, a área de Gestão da Qualidade, apresentou trabalhos na subárea
Controle Estatístico da Qualidade (2 trabalhos).

\section{CONSIDERAÇÕES FINAIS}

A pesquisa analisou os principais estudos publicados na base artigos do evento Encontro Nacional de Engenharia de Produção - ENEGEP, onde a amostra dos artigos selecionados para o estudo bibliométrico revelaram que a maior número de pesquisas realizadas no período de 2006 a 2016 fizeram uso integrado das metodologias Seis Sigma e Lean Manufacturing para a melhoria de processos, onde as publicações tiveram início no ano de 2007 e atingiram os maiores números em 2013. 
Foi observado também que dos trabalhos que obtiveram resultados satisfatórios na melhoria de processo, todos fizeram uso de ferramentas como DMAIC, VSM, Histograma, Kaizen, Carta de Controle e gráfico de Pareto, caracterizando assim a eficiência das ferramentas em produtividade, eliminação de ineficiências, aumento na velocidade de respostas ao sistema e minimização das variações do processo, e consequentemente auxiliaram positivamente no processo decisório.

A pesquisas publicadas foram direcionadas principalmente para as áreas de gestão da produção e gestão da qualidade e

\section{REFERÊNCIAS}

[1] Ariente, Mariana; Casadei, Marco A.; Giuliani, Antonio Carlos; SPERS, Eduardo E.; PIZZANATTO, Nadia Kassouf. Processo de mudança organizacional: estudo de caso do Seis Sigma. Rev. FAE, Curitiba, v.8, n.1, p.81-92, jan./jun. 2005

[2] Barreto, André Renato. Sistema Toyota de produção: Lean manufacturing implantação e aplicação em uma indústria de peças automotivas. Tékhne \& Lógos, Botucatu, SP, v.3, n.2, Julho. 2012.

[3] Bastos, Bernardo Campbel. Aplicação do lean manufacturing em uma linha de produção de uma empresa do setor automotivo. Dissertação de Mestrado do curso de Pós-graduação em Engenharia Mecânica. Universidade de Taubaté. Taubaté/SP, 2012.

[4] Chahade, William Habib Lucas. Aplicação da metodologia seis sigma para incrementos da produtividade no envase de tintas decorativas. 2009. 160 p. Tese (Mestrado em Engenharia de Processos Químicos e Bioquímicos). Centro Universitário do Instituto Mauá de Tecnologia, São Caetano do Sul - SP, 2009

[5] Dias, Sérgio Matos. Implementação da metodologia Lean Seis Sigma - O caso do Serviço de Oftalmologia dos Hospitais da Universidade de Coimbra. Dissertação de Mestrado em Engenharia Biomédica. Faculdade de Ciência e Tecnologia da Universidade de Coimbra, 2011.

[6] Endler, Kellen Dayelle; Bourscheidt, Luiz Eduardo; Scarpin, Cassius Tadeu; Steiner, Maria Teresinha Arns; GARBUIO, Paula Andrea da Rosa. Rev. Produção Online, Florianópolis, SC, v. 16, n. 2, p. 575-605, abr./jun. 2016.

[7] Gonçalves Filho, Manoel; Silva, Reinado Gomes da. Análise bibliométrica sobre lean six sigma. Rev. Administração, Tânia Cristina Bassani Cecílio (org), v. 4, n.1 (2012), Nova Odessa, SP: Faculdades Network, 2015 enquadradas nas subáreas de gestão de sistemas de produção, gestão de processo produtivo, controle estatístico da qualidade e logística e gestão da cadeia de suprimentos.

Diante da delimitação do escopo do estudo, a pesquisa obteve sucesso por alcançar seus objetivos. A limitação da pesquisa deu-se principalmente por fazer uso de uma única base de dados. Dessa forma sugere-se para novas pesquisas fazer uso de bases de dados alternativas para explorar o uso da metodologia Lean Seis Sigma, além da possibilidade de ampliar as áreas de conhecimento do estudo.

[8] Leite Filho, G. A. Padrões de produtividade de autores em periódicos de congressos na área de contabilidade no Brasil: um estudo bibliométrico. In: Congresso USP Controladoria e Contabilidade. Congresso USP de Controladoria e Contabilidade, 2006.

[9] Lustosa, Leandro Junqueira; Mesquita, Marcos Aurélio; Quelhas, Osvaldo Luiz Gonçalves; Oliveira, Rodrigo Jorge. Planejamento e Controle da Produção. Rio de Janeiro: Elsevier: Abepro, 2011

[10] Mandujano, María G et al . Identifying waste in virtual design and construction practice from a Lean Thinking perspective: A meta-analysis of the literature. Rev. de la Construcción, Santiago, v. 15, n. 3, p. 107-118, 2016. Disponivel em: http://dx.doi.org/10.4067/S0718-

915X2016000300011. Acessado em: 07 de Abril de 2017

[11] Mani, Graziele Moro; Pádua, Fabiana Serralha Miranda de. Lean seis sigma. Interface tecnológica. v.5, n.1, 2008

[12] Marshall Junior, Isnard; Rocha, Alexandre Varanda; MOTA, Edmarson Barcelar; QUINTELLA, Odair Mesquita. Gestão da Qualidade e Processo. 1. Ed. Rio de Janeiro: FGV, 2012

[13] Pinto, Diogo Gonçalo Costa. Aplicação do Seis Sigma no Processo de Moldação da Indústria Corticeira. Dissertação de mestrado em Engenharia e Gestão Industrial, Faculdade de Ciência e tecnologia e Universidade nova de Lisboa, 2016.

[14] Pacheco, Diego Augusto de Jesus. Teoria das Restrições, Lean Manufacturing e Seis Sigma: limites e possibilidades de integração. Rev. Production, v. 24, n. 4, p. 940-956, oct./dec. 2014.

[15] Reis, Diego Araujo; Esperidião, Fernanda; JORGE, Marco Antônio; Ribeiro, Luiz Carlos de Santana; Mota, Talita de Souza; Santos, José Carlisson do Nascimento; Silva, Alessandra Tavares da. Estudo bibliométrico da produção científica nacional e internacional no setor de 
saneamento. Revista GEINTEC. vol.7, n.1, p.36693685, Aracaju, 2017.

[16] Saia, Rafael. O Lean Manufacturing aplicado em ambientes de Produção Engineer to order. Trabalho de Conclusão de Curso Engenheiro de Produção Mecânica. Universidade de São Paulo, São Carlos/São Paulo, 2009.

[17] Sales, Matías. Diagrama de Pareto. Recuperado el. Apr;15. 2006. Disponivel em: http://www.gestiopolis.com/recursos/documentos/fu Ildocs/eco/diagramapareto.htm. Acessado em: 01 de Abril de 2017.

[18] Santana, Claudio José de; Salles, Mara Telles; Quelhas, Osvaldo Luis Gonçalves; Pontes, Luís Antônio Longo. O Uso do Nível Sigma para Comparação de Processos Diferentes: Um Estudo de Caso. In: XXIV Encontro Nac. de Eng. de Produção, Florianópolis/SC, Brasil, 03 a 05 de nov de 2004.

[19] Scatolin, A. C. Aplicação da metodologia Seis Sigma na redução das perdas de um processo de manufatura. Dissertação de mestrado do programa de Pós-graduação em Engenharia
Mecânica, Universidade Estadual de Campinas, São Paulo, 2005

[20] Sokovic, M.; Pavletic, D.; Pipan, K. Kern. Quality Improvement Methodologies - PDCA Cycle, RADAR Matrix, DMAIC and DFSS. JAMME- Journal of achievements in materials and manufacturing Engineering. v. 43, ISSUE. 1. nov. 2010. Disponível em:<https://www.researchgate.net/profile/Mirko_Soko vic/publication/49600834_Quality_improvement_metho dolo gies__PDCA_cycle_Radar_matrix_DMAIC_and_DFSS/lin ks/0912f50ec1328b1a57000000/Qualityimprovement-methodologies-PDCA-cycle-RADARmatrix-DMAIC-and-DFSS.pdf>. Acessado em: 23 Fev. 2017

[21] Werkema, Cristina. Criando a cultura lean seis sigma. Rio de Janeiro: Elsevier, 2012.

[22] Rosa, Gimara Viana. Metodologia lean: um estudo bibliométrico a partir de uma análise de quatro periódicos internacionais 2006 - 2015. 2016. Monografia (Graduação em Engenharia de Produção) - Instituto de Ciências Exatas e Aplicadas, Universidade Federal de Ouro Preto, João Monlevade, 2016. 
ANEXO

Quadro 5: Lista de artigos selecionados para o estudo bibliométrico da literatura

\begin{tabular}{|c|c|c|}
\hline AUTOR(ES) & TíTULO & ANO \\
\hline BRITO, F. O; DACOL, S. & $\begin{array}{l}\text { A MANUFATURA ENXUTA E A METODOLOGIA SEIS SIGMA EM UMA INDUSTRIA DE } \\
\text { ALIMENTOS }\end{array}$ & 2008 \\
\hline BUSSO, C. M; MIIYAKE C. I & $\begin{array}{l}\text { ESTRATÉGIAS DE IMPLEMENTAÇÃO } \\
\text { LEAN SLX SIGMA }\end{array}$ & 2007 \\
\hline $\begin{array}{l}\text { CABEÇA, M G.; SILVA, I. B.; } \\
\text { BENEVIDES, G. }\end{array}$ & $\begin{array}{l}\text { ANÁLISE COMPARATIVA DO USO DAS FERRAMENTAS DE GESTÃO LEAN } \\
\text { MANUFACTURING E SEIS SIGMA: ESTUDO DE CASO }\end{array}$ & 2010 \\
\hline $\begin{array}{l}\text { CRUZ L. A. A. S.; } \\
\text { MONTEIRO, M. M }\end{array}$ & $\begin{array}{l}\text { APLICAÇÁO INTEGRADA DE LEAN, SEIS SIGMA E TEORIA DAS RESTRIÇÓES NO } \\
\text { RECEBIMENTO FISICO-FISCAL DE SUPRIMENTOS: O CASO DE UMA EMPRESA DO } \\
\text { SETOR EIÉTRICO BRASILFIRO }\end{array}$ & 2015 \\
\hline $\begin{array}{l}\text { DEMARCHI,V.; SOUZA, T. A.; } \\
\text { ALVES, P. D. }\end{array}$ & $\begin{array}{l}\text { APLICAÇÃO DO LEAN SEIS SIGMA PARA AUMENTO DE PRODUTIVIDADE DE } \\
\text { ATTVOS - UM ESTUDO DE CASO }\end{array}$ & 2013 \\
\hline $\begin{array}{l}\text { LEITE, D. G., MONTESCO, R } \\
\text { A. E. }\end{array}$ & $\begin{array}{l}\text { APLICAÇÃO DO LEAN SEIS SIGMA NA MELHORIA DE PROCESSO DE UMA } \\
\text { DISTRIBUIDORA DE G_P EM ARACAJU/SE }\end{array}$ & 2016 \\
\hline $\begin{array}{l}\text { LOURERO JUNIOR, M; } \\
\text { CALARGE, F. A. }\end{array}$ & $\begin{array}{l}\text { A ABORDAGEM DO LEAN SLX SIGMA NO DESENVOLVIMENTO DE FORNECEDORES: } \\
\text { UMA ANÁLISE NO SETOR DE ELETRODOMÉSTICOS }\end{array}$ & 2013 \\
\hline ROVETA, M C. & $\begin{array}{l}\text { O PROGRAMA LEAN SEIS SIGMA: UMA VISÃO PLENA DE UMA EMPRESA DO SETOR } \\
\text { DE MINERACÃO }\end{array}$ & 2013 \\
\hline $\begin{array}{l}\text { SANTOS, J. E. D.; OLIVEIRA, } \\
\text { O. J.; DONATO, I A.; } \\
\text { FIGUEIREDO, F. J. S. }\end{array}$ & $\begin{array}{l}\text { LEAN SIX SIGMA NA REDUÇÃO DO TEMPO SETUP EM UM DEPARTAMENTO DE } \\
\text { INJEÇÃO PLÁSTICA }\end{array}$ & 2015 \\
\hline $\begin{array}{l}\text { SGARBI JUNIOR, G.; } \\
\text { CARDOSO, A. A. }\end{array}$ & $\begin{array}{l}\text { LEAN SEIS SIGMA NA LOG'STICA - APLICAÇÃO NA GESTÃO DOS ESTOQUES EM } \\
\text { UMA EMPRESA DE AUTOPEÇAS }\end{array}$ & 2011 \\
\hline $\begin{array}{l}\text { VIEIRA FILHO, F. C.; ROSA, } \\
\text { G. O.; MORALES, D. }\end{array}$ & $\begin{array}{l}\text { APLICAÇÁO DA METODOLOGIA LEAN SLX SIGMA NA REDUÇÁO DA } \\
\text { VARIABIIDADE DO PROCESSO DE ENVASE EM UMA INDÚSTRIA DE ÓLEO } \\
\text { VEGETAL }\end{array}$ & 2010 \\
\hline
\end{tabular}




\section{Eapítulo 3}

\section{UTILIZACÃO DO SEIS SIGMA EM SETORES INDUSTRIAIS DO RIO GRANDE DO SUL}

\section{Lucas Gonçalves Pagnossin \\ Ismael Cristofer Baierle \\ Cristiano Roos}

Resumo: O objetivo neste trabalho de pesquisa é mapear dez setores industriais do Rio Grande do Sul quanto à utilização da iniciativa Seis Sigma. Os procedimentos metodológicos envolveram uma pesquisa exploratória, tendo sido adotada a pesquisa survey como procedimento técnico. A amostra intencional foi composta por 152 organizações de dez setores industriais. A taxa de retorno e aproveitamento da amostra foi de $76 \%$. A pesquisa foi aplicada por contato telefônico, estratégia que contribuiu para uma taxa consideravelmente alta de aproveitamento da amostra. O mapeamento nas organizações envolveu os percentuais de respondentes por setor industrial, os percentuais de empresas por faixa de funcionários, os percentuais de empresas por mesorregião, os percentuais de organizações que utilizam o Seis Sigma, os percentuais de organizações utilizam a Metodologia Seis Sigma por setor industrial, em qual ano a organização (ou unidade, ou filial) concluiu o primeiro projeto Seis Sigma, quantos projetos Seis Sigma são concluídos por ano, quantos projetos Seis Sigma são elaborados por ano, quais métodos de seleção de projetos Seis Sigma são utilizados, quais são as variáveis mais utilizadas na seleção de projetos Seis Sigma, entre outras questões. A conclusão central é que $17,55 \%$ das organizações industriais pesquisadas possuem o sistema de gestão da qualidade Seis Sigma implementado. Outro resultado relevante é que apenas $17 \%$ das organizações não utilizam um método matemático para selecionar projetos Seis Sigma e que 83\% das organizações utilizam sempre (ou na maioria das vezes) algum método matemático para selecionar projetos Seis Sigma. Dentre os levantamentos, foi possível verificar cinco dependências estatísticas entre as respostas das empresas e a caracterização das mesmas. Duas destas dependências foram entre as variáveis utilizadas para a seleção de projetos apontada neste estudo. Por fim, pode-se concluir que este trabalho cumpriu seus objetivos propostos, sendo relevante tanto para os profissionais da área acadêmica quanto para aqueles inseridos nas implementações da iniciativa Seis Sigma nos diferentes segmentos industriais. 


\section{INTRODUÇÃO}

Este trabalho aborda a utilização do sistema de gestão da qualidade Seis Sigma em organizações brasileiras. Apesar de ser cada vez mais divulgado e utilizado no cenário nacional, ainda são poucos os estudos disponíveis sobre como as organizações adotam este sistema. Descobrir em quantas indústrias utiliza-se o Seis Sigma, identificar quantos projetos são desenvolvidos por ano, bem como, entender como os projetos Seis Sigma são selecionados, são informações relevantes para os profissionais da aérea de ensino em Engenharia de Produção, que podem utilizar estes dados para planejar suas atividades de ensino-aprendizagem em Seis Sigma.

Neste contexto, o objetivo deste trabalho é mapear por meio de uma pesquisa survey dez setores industriais do Rio Grande do Sul quanto à utilização da iniciativa Seis Sigma. Para tanto, a segunda seção deste texto apresenta o referencial teórico sobre Seis Sigma. A terceira seção traz uma síntese do método de pesquisa utilizado. Na quarta seção estão os resultados obtidos e, logo na sequência, na quinta seção há as considerações finais e a conclusão deste trabalho.

\section{REFERENCIAL TEÓRICO}

A iniciativa Seis Sigma é uma estratégia de gestão bem conhecida utilizada para a melhoria da qualidade por meio de um conjunto de métodos estruturados e medidas estatísticas para avaliar e melhorar os processos das organizações (ANTONY et al., 2012). A iniciativa de gestão abrange ferramentas e técnicas com o objetivo de melhorar a qualidade tanto em processos de manufatura quanto administrativos (BUSCO; CAGLIO; SCAPENS, 2014).

O Seis Sigma é utilizado por organizações de classe mundial resultando em milhões de dólares de lucro (HILTON; SOHAL, 2012). $\mathrm{Na}$ maioria dos casos, uma organização utiliza a estratégia Seis Sigma para alcançar benefícios na lucratividade ou na satisfação do cliente (RAY; DAS; BHATTACHARYA, 2011; SOUZA et al., 2013; GlJO et al., 2014).

A iniciativa Seis Sigma se tornou conhecida em muitos países devido à sua capacidade em melhorar o desempenho de um processo, reduzir defeitos em produtos e serviços, minimizando a variabilidade em processos, bem como os custos operacionais (KUMAR; ANTONY; CHO, 2009). Esta estratégia resulta em maior satisfação dos clientes e afeta diretamente a lucratividade e a sobrevivência das organizações (ANTONY; KUMAR; MADU, 2005; ANTONY, 2007).

Buscando verificar o nível de conhecimento sobre a Metodologia Seis Sigma e identificar as características das empresas que adotaram a metodologia, Coneeição e Major (2011), realizaram uma pesquisa nas 500 maiores empresas de Portugal não financeiras. Com a abordagem de pesquisa escolhida obtiveram uma taxa de $64,2 \%$ de aproveitamento da amostra. Destas 17,9\% desconhecem o Seis Sigma. Foi verificado também que $64,2 \%$ das empresas respondentes possuíam 250 ou mais funcionários e que apenas 17,4\% dessas possuíam o Seis Sigma implementado.

Analogamente, Wiele, Iwaarden e Power (2010), verificaram que de 132 empresas localizadas na Irlanda que responderam sua pesquisa, $45 \%$ delas utilizavam a Metodologia Seis Sigma em uma ou mais partes de suas organizações. Também verificaram que $61 \%$ das empresas que utilizavam o Seis Sigma eram empresas de grande porte, enquanto apenas $29 \%$ eram pequenas e médias empresas. Já Ribeiro et al. (2015), abordaram organizações listadas como as maiores empresas brasileiras que utilizam programas da qualidade, pela Revista Exame, tendo sido abordadas 76 empresas. Foi apontando que $42,1 \%$ destas utilizam o Seis Sigma. Paralelamente, verificaram que o Seis Sigma está sendo adotado principalmente por organizações de grande porte dos setores de transformação.

Por outro lado, Carvalho, Ho e Pinto (2014) buscaram identificar os fatores críticos de sucesso para a implementação do Seis Sigma e as características principais da metodologia em empresas de manufatura e serviços no Brasil. Este estudo abordou 198 empresas, das quais apenas 46 aderiram ao Seis Sigma. O estudo ainda aponta que as empresas que utilizam o Seis Sigma possuíam programas da qualidade maduros.

A literatura qualificada sugere que o fator chave para o sucesso da estratégia Seis Sigma é a seleção de projetos (WANG; HSU; TZENG, 2014; MARQUES et al., 2013; MANVILLE et al., 2012; CHO et al., 2011; SHARMA; CHETIYA, 2010; KUMAR et al., 2007; BANUELAS et al., 2006). Seleção de 
projetos é o processo de avaliação de projetos individuais ou grupos de projetos, escolhendo-se pela implementação de um ou um conjunto de projetos, para que os objetivos da organização sejam alcançados (PADHY; SAHU, 2011).

$\mathrm{Na}$ literatura consultada para este trabalho foi possível verificar que alguns autores apresentam métodos de seleção de projetos Seis Sigma. Alguns métodos são de base quantitativa (métodos matemáticos) e outros de base qualitativa (utilizando informações).

Por exemplo, estudos listam alguns métodos para a seleção: 1. Analytic hierarchy process (AHP) e technique for order of preference by similarity to ideal solution (TOPSIS) (YOUSEFI; HADI-VENCHEH, 2016); 2. Decision-making trial and evaluation laboratory (DEMATEL), analytical network process (ANP) e technique for order of preference by similarity to ideal solution (TOPSIS) (VINODH; SWARNAKAR, 2015); 3. Simple additive weights (SAW), technique for order of preference by similarity to ideal solution (TOPSIS), VIKOR technique (FARSIJANI; SHAFIEI; AMIRIMOGHADAM, 2015); 4. Analytical hierarchy process (AHP) e project desirability matrix (PDM) (KUMAR; ANTONY; $\mathrm{CHO}, 2009$ ); 5. Pareto analysis (LARSON, 2003); 6. Analytic hierarchy process (AHP) (ADEBANJO et al., 2016).

Outro ponto evidenciado na literatura é que os principais critérios de entrada na seleção de projetos Seis Sigma são: custos do projeto, duração do projeto, número de Black e Green Belts; e dos critérios de saída são: satisfação do consumidor, impacto na estratégia organizacional, melhoria no nível sigma, impacto financeiro (impacto no custo da falta de qualidade - COPQ), crescimento da produtividade (KUMAR et al., 2007).

Com estes conceitos em mente, segue à próxima seção deste texto, onde cada um destes conceitos será envolvido em uma pesquisa survey com uma amostra de organizações industriais brasileiras.

\section{MÉTODO DE PESQUISA}

Adotando-se as definições teóricas de Miguel (2010), esta pesquisa é classificada: (i) quanto à natureza: aplicada, porque objetivase gerar conhecimentos para aplicação prática; (ii) quanto aos objetivos: pesquisa exploratória, pois trata-se de um tema contemporâneo e não consolidado na literatura (Seis Sigma) em um contexto real (em organizações brasileiras); (iii) quanto aos procedimentos técnicos: survey, (iv) quanto à abordagem de pesquisa: qualitativa, pois a pesquisa não pode ser representada matematicamente.

A pesquisa survey foi desenvolvida utilizando orientações do trabalho de Forza (2002). A survey abordou uma amostra de organizações (indústrias instaladas no Rio Grande do Sul) por meio da coleta de dados de forma individual, via questionário, aplicado por contato telefônico. A amostra desta pesquisa é não probabilística, não casual, pois a escolha dos elementos que compõem a amostra não foi aleatória. Trata-se de uma amostra intencional de dez setores de atividades industriais, considerando apenas organizações com 200 funcionários ou mais.

A amostra intencional foi composta por 152 organizações. As informações das empresas foram obtidas no banco de dados da Federação das Indústrias do Rio Grande do Sul. Essas 152 organizações são indústrias dos ramos de: Produtos de borracha e de material plástico; Máquinas, aparelhos e materiais elétricos; Máquinas e equipamentos para a agricultura e pecuária, exceto para irrigação; Produtos químicos; Produtos do fumo; Peças e acessórios para veículos automotores; Fabricação de artigos de cutelaria, de serralheria e ferramentas; Fabricação de produtos de minerais nãometálicos; Fundição; Fabricação de cabines, carrocerias e reboques para veículos automotores.

Neste trabalho foram encontradas dificuldades em relação ao banco de dados da Federação das Indústrias do Rio Grande do Sul. Não foi obtido sucesso em algumas tentativas de contatar as empresas em razão dos números de telefones desatualizados no banco de dados. Para contornar estas dificuldades, seguiu-se o protocolo de pesquisa estipulado, tendo sido feitas buscas na internet para tentar identificar os números de telefone das empresas. A empresa só foi descartada da amostra quando não foram encontradas informações necessárias na internet para realizar algum contato telefônico.

Outras dificuldades encontradas foram em relação aos responsáveis, pessoas que possuíssem conhecimento e autorização para informar a respeito do Seis Sigma. Dentre as maiores dificuldades estão: o responsável não se encontrava no estabelecimento; o responsável não poderia responder no 
momento; o responsável solicitava por e-mail; o responsável não era autorizado a responder devido a políticas internas. Para contornar estas dificuldades, também se seguiu o protocolo de pesquisa, onde se realizou um número máximo de cinco tentativas até que a empresa fosse descartada da amostra.

Depois de encerrada a coleta de dados, foi realizada a analise das respostas das empresas, bem como entre suas características, utilizando o teste QuiQuadrado. Este teste apresenta se há relações estatísticas de dependência entre variáveis nominais. Para isto, a significância do teste ( $p$ ) deve ser menor ou igual a 0,05.

Os resultados da pesquisa survey desenvolvida estão apresentados na próxima seção deste texto.

\section{RESULTADOS}

Primeiramente é caracterizada a amostragem, na Tabela 1 onde está a taxa de aproveitamento da amostra da pesquisa. Depois, na Tabela 2, está apresentado o percentual de respondentes por setor industrial, seguido da Tabela 3, onde está o percentual de organizações respondentes por número de funcionários. Na sequência, a Tabela 4 traz o percentual de organizações por mesorregião do estado do Rio Grande do Sul.

Tabela 1 - Aproveitamento da amostra da pesquisa

\begin{tabular}{|l|c|c|}
\hline \multicolumn{2}{|c|}{ Frequência } & $\%$ \\
\hline Responderam & 114 & $76 \%$ \\
\hline Não foi possível estabelecer contato & 8 & $5 \%$ \\
\hline Solicitaram por e-mail e não responderam & 6 & $4 \%$ \\
\hline Não puderam atender ou não estavam & 21 & $13 \%$ \\
\hline Não estavam autorizados a responder & 3 & $2 \%$ \\
\hline
\end{tabular}

Tabela 2 - Percentual de organizações respondentes por setor industrial

\begin{tabular}{|l|c|c|}
\hline & Frequência & $\%$ \\
\hline Produtos de borracha e de material plástico & 22 & $19 \%$ \\
\hline Máquinas, aparelhos e materiais elétricos & 12 & $11 \%$ \\
\hline $\begin{array}{l}\text { Máquinas e equipamentos para a agricultura e } \\
\text { pecuária, exceto para irrigação }\end{array}$ & 17 & $7 \%$ \\
\hline Produtos químicos & 8 & $6 \%$ \\
\hline Produtos do fumo & 7 & $18 \%$ \\
\hline Peças e acessórios para veículos automotores & 20 & $5 \%$ \\
\hline $\begin{array}{l}\text { Fabricação de artigos de cutelaria, de serralheria e } \\
\text { ferramentas }\end{array}$ & 6 & $8 \%$ \\
\hline Fabricação de produtos de minerais não-metálicos & 9 & $7 \%$ \\
\hline Fundição & 5 & $4 \%$ \\
\hline $\begin{array}{l}\text { Fabricação de cabines, carrocerias e reboques para } \\
\text { veículos automotores }\end{array}$ & & \\
\hline
\end{tabular}


Tabela 3 - Percentual de organizações respondentes por número de funcionários

\begin{tabular}{|l|c|c|}
\hline 200 a 350 & 52 & $\%$ \\
\hline 350 a 500 & 14 & $12 \%$ \\
\hline 500 a 850 & 20 & $18 \%$ \\
\hline 850 a 1200 & 8 & $7 \%$ \\
\hline 1200 a 1500 & 4 & $4 \%$ \\
\hline Mais de 1500 & 16 & $14 \%$ \\
\hline
\end{tabular}

Tabela 4 - Percentual de organizações respondentes por mesorregião do estado do Rio Grande do Sul

\begin{tabular}{|l|c|c|}
\hline \multicolumn{2}{|c|}{} & Frequência \\
\hline Região Central & 12 & $11 \%$ \\
\hline Região Sudeste & 4 & $4 \%$ \\
\hline Região Metropolitana & 38 & $33 \%$ \\
\hline Região Nordeste & 42 & $37 \%$ \\
\hline Região Noroeste & 18 & $16 \%$ \\
\hline
\end{tabular}

Cabe ressaltar que se obteve uma taxa de aproveitamento da amostra consideravelmente alta, $76 \%$. Este resultado, muito provavelmente está relacionado ao protocolo de pesquisa, onde o meio de aplicação dos questionários foi o contato telefônico. Também se pode verificar que há uma distribuição consideravelmente igualitária da amostra de respondentes entre os dez setores industriais pesquisados.

$\mathrm{Na}$ sequência, são apresentados resultados específicos sobre as questões em Seis Sigma.
$\mathrm{Na}$ Tabela 5 encontra-se o percentual de organizações que utilizam a Metodologia Seis Sigma e em sequência, na Tabela 6, é apresentado o percentual de organizações que utilizam a Metodologia Seis Sigma por setor industrial. Nesta tabela, pode-se verificar que três setores industriais juntos representam $60 \%$ do total de organizações que utilizam a iniciativa Seis Sigma (Produtos de borracha e de material plástico; Máquinas e equipamentos para a agricultura e pecuária, exceto para irrigação; Peças e acessórios para veículos automotores).

Tabela 5 - Percentual de organizações que utilizam o Seis Sigma

\begin{tabular}{|l|c|c|}
\hline & Frequência & $\%$ \\
\hline Não utiliza o Seis Sigma & 94 & $83 \%$ \\
\hline Utiliza o Seis Sigma & 20 & $18 \%$ \\
\hline
\end{tabular}

Tabela 6 - Percentual de organizações que utilizam o Seis Sigma por setor industrial

\begin{tabular}{|c|c|c|}
\hline & Frequência & $\%$ \\
\hline Produtos de borracha e de material plástico & 3 & $15 \%$ \\
\hline Máquinas, aparelhos e materiais elétricos & 2 & $10 \%$ \\
\hline $\begin{array}{l}\text { Máquinas e equipamentos para a agricultura e pecuária, } \\
\text { exceto para irrigação }\end{array}$ & 6 & $30 \%$ \\
\hline Produtos químicos & 1 & $5 \%$ \\
\hline Produtos do fumo & 1 & $5 \%$ \\
\hline Peças e acessórios para veículos automotores & 3 & $15 \%$ \\
\hline $\begin{array}{l}\text { Fabricação de artigos de cutelaria, de serralheria e } \\
\text { ferramentas }\end{array}$ & 0 & $0 \%$ \\
\hline Fabricação de produtos de minerais não-metálicos & 1 & $5 \%$ \\
\hline Fundição & 2 & $10 \%$ \\
\hline $\begin{array}{l}\text { Fabricação de cabines, carrocerias e reboques para } \\
\text { veículos a }\end{array}$ & 1 & $5 \%$ \\
\hline
\end{tabular}


Dando prosseguimento, a Tabela 7 mostra o ano em que a organização (ou unidade, ou filial) concluiu o primeiro projeto Seis Sigma.

Tabela 7 - Ano em que a organização (ou unidade, ou filial) concluiu o primeiro projeto Seis Sigma

\begin{tabular}{|l|c|c|}
\hline & Frequência & $\%$ \\
\hline anterior à ou em 2000 & 1 & $8 \%$ \\
\hline 2001 & 0 & $0 \%$ \\
\hline 2002 & 0 & $0 \%$ \\
\hline 2003 & 0 & $0 \%$ \\
\hline 2005 & 2 & $17 \%$ \\
\hline 2006 & 4 & $34 \%$ \\
\hline 2007 & 0 & $0 \%$ \\
\hline 2008 & 0 & $0 \%$ \\
\hline 2009 & 3 & $25 \%$ \\
\hline 2010 & 1 & $8 \%$ \\
\hline 2011 & 0 & $0 \%$ \\
\hline 2012 & 0 & $0 \%$ \\
\hline 2013 & 0 & $0 \%$ \\
\hline 2014 & 0 & $0 \%$ \\
\hline
\end{tabular}

A Tabela 8 apresenta o número de vezes que a organização (ou unidade, ou filial) descontinuou o programa Seis Sigma. A Tabela 9 mostra o número médio de projetos Seis Sigma concluídos por ano. Tem-se ainda a Tabela 10 que apresenta o número médio de projetos Seis Sigma que são elaborados por ano. Já na Tabela 11 tem-se a frequência das organizações que utilizam algum método de seleção de projetos. A Tabela 12 mostra se a organização utiliza algum método matemático para selecionar projetos Seis Sigma. A Tabela 13 mostra se a organização tem como necessidade algum novo método de seleção de projetos Seis Sigma. Por último, a Tabela 14 apresenta quais são as variáveis mais utilizadas na seleção de projetos Seis Sigma.

Tabela 8 - Número de vezes que a organização (ou unidade, ou filial) descontinuou o Seis Sigma

\begin{tabular}{|l|c|c|}
\hline \multicolumn{3}{|c|}{ Frequência } \\
\hline 0 & 6 & $50 \%$ \\
\hline 1 & 4 & $33 \%$ \\
\hline 2 & 2 & $17 \%$ \\
\hline 3 & 0 & $0 \%$ \\
\hline 4 ou mais & 0 & $0 \%$ \\
\hline
\end{tabular}

Tabela 9 - Número médio de projetos Seis Sigma concluídos por ano na organização

\begin{tabular}{|l|c|c|}
\hline & Frequência & $\%$ \\
\hline a 5 & 10 & $84 \%$ \\
\hline 11 a 15 & 1 & $8 \%$ \\
\hline 16 a 20 & 0 & $0 \%$ \\
\hline 21 a 25 & 0 & $0 \%$ \\
\hline 26 a 30 & 1 & $8 \%$ \\
\hline 31 a 35 & 0 & $0 \%$ \\
\hline 35 ou mais & 0 & $0 \%$ \\
\hline
\end{tabular}


Tabela 10 - Número médio de projetos Seis Sigma elaborados por ano na organização

\begin{tabular}{|c|c|c|}
\hline & Frequêr & $\%$ \\
\hline 0 a 5 & 6 & $50 \%$ \\
\hline 6 a 10 & 4 & $34 \%$ \\
\hline 11 a 15 & 1 & $8 \%$ \\
\hline 16 a 20 & 0 & $0 \%$ \\
\hline 21 a 25 & 0 & $0 \%$ \\
\hline 26 a 30 & 0 & $0 \%$ \\
\hline 31 a 35 & 1 & $8 \%$ \\
\hline 35 ou mais & 0 & $0 \%$ \\
\hline
\end{tabular}

Tabela 11 - Se a organização (ou unidade, ou filial) utiliza algum método de seleção de projetos Seis Sigma

\begin{tabular}{|l|c|c|}
\hline & Frequência & $\%$ \\
\hline Sim, todas às vezes & 4 & $34 \%$ \\
\hline Sim, na maioria das vezes & 6 & $50 \%$ \\
\hline Sim, na minoria das vezes & 1 & $8 \%$ \\
\hline Não & 1 & $8 \%$ \\
\hline
\end{tabular}

Tabela 12 - Se a organização (ou unidade, ou filial) utiliza algum método matemático de seleção de projetos Seis Sigma

\begin{tabular}{|l|c|c|}
\hline & Frequência & $\%$ \\
\hline Sim, todas as vezes & 3 & $25 \%$ \\
\hline Sim, na maioria das vezes & 7 & $58 \%$ \\
\hline Sim, na minoria das vezes & 0 & $0 \%$ \\
\hline Não & 2 & $17 \%$ \\
\hline
\end{tabular}

Tabela 13 - Se na organização (ou unidade, ou filial) tem como necessidade algum novo método de seleção de projetos Seis Sigma

\begin{tabular}{|l|c|c|}
\hline & Frequência & $\%$ \\
\hline Sim, para todos os casos & 4 & $34 \%$ \\
\hline Sim, para a maioria dos casos & 1 & $8 \%$ \\
\hline Sim, para a minoria dos casos & 1 & $8 \%$ \\
\hline Não & 6 & $50 \%$ \\
\hline
\end{tabular}


Tabela 14 - Variáveis mais utilizadas na seleção de projetos Seis Sigma na organização

\begin{tabular}{|l|c|c|}
\hline & Frequência & $\%$ \\
\hline Custos do projeto & 4 & 33 \\
\hline Duração do projeto & 1 & 8 \\
\hline Número de Black Belts & 2 & 17 \\
\hline Número de Green Belts & 1 & 8 \\
\hline Satisfação do consumidor & 4 & 33 \\
\hline Impacto na estratégia organizacional & 6 & 50 \\
\hline Melhoria no nível sigma & 2 & 17 \\
\hline Impacto financeiro (custo da má qualidade) & 8 & 67 \\
\hline Crescimento da produtividade & 5 & 42 \\
\hline Outras & 0 & 0 \\
\hline
\end{tabular}

Um ponto a destacar é a porcentagem de empresas do setor de máquinas e equipamentos para a agricultura e pecuária, exceto para irrigação. Representa $30 \%$ das empresas que possuem a Metodologia Seis Sigma implementada. Cabe destacar que não foi encontrada dependência estatística entre o setor industrial das empresas com as repostas sobre a utilização da Metodologia Seis Sigma (Apêndice A).

Das empresas que mantém a Metodologia Seis Sigma implementada, apenas cinco possuem menos de 300 colaboradores. Isto muito provavelmente porque a implementação do Seis Sigma ainda é pouco viável economicamente em micro e pequenas empresas, justamente por possuírem menos recursos financeiros disponíveis. Ao realizar o teste Qui-Quadrado, encontrou-se que há relações estatísticas entre a faixa de colaboradores das empresas e a utilização da Metodologia Seis Sigma (Apêndice B).

Considerando os anos em que as organizações obtiveram os primeiros resultados com a estratégia Seis Sigma, percebe-se que em 2004 e 2005 teve- se o maior número de organizações, $51 \%$ da amostra. Também cabe ressaltar que as organizações elaboram um número médio maior de projetos por ano do que o número médio de projetos concluídos por ano. Isto mostra que as organizações necessitam de algum modo, selecionar projetos de um portfólio. Ainda neste contexto, foi confirmado com outra questão a qual apontou que $84 \%$ da amostra utiliza algum método de seleção de projetos Seis Sigma em todas ou na maioria das vezes. Além disso, pode-se perceber que há dependência nas respostas do ano em que as organizações concluíram o primeiro projeto $e$ as respostas sobre a utilização de algum método de seleção de projetos Seis Sigma (Apêndice G). Também há dependência entre a média de projetos Seis Sigma concluídos e a média de projetos Seis Sigma elaborados (Apêndice O).

$\mathrm{Na}$ Tabela 15 são apresentados todos os resultados dos testes de dependência entre as variáveis abordadas por este trabalho. 0 procedimento foi realizado pelo teste QuiQuadrado.

No presente trabalho identificou-se que impacto financeiro (custo da má qualidade) (67\%), impacto na estratégia organizacional (50\%), crescimento da produtividade $(42 \%)$ e satisfação do cliente (33\%) são as variáveis críticas (mais utilizadas) no processo de seleção de projetos Seis Sigma por estas organizações. As demais variáveis colocadas como opções foram menos assinaladas pelos respondentes. Os cruzamentos das respostas mostraram duas dependências estatisticamente significativas. A primeira é representada pelo cruzamento entre a variável de duração do projeto Seis Sigma e o número de Black Belts (Apêndice A1) e a segunda pelo número de Black Belts e Green Belts (Apêndice B1). Ou seja, variável da duração do projeto Seis Sigma é igualmente utilizada ao número Black Belts, bem como, a variável do número de Black Belts é igualmente utilizada ao número de Green Belts. Assim, com base nestes resultados, pôde-se concluir este trabalho. 
Tabela 15 - Relação de cruzamentos realizados entre variáveis pelo teste Qui-Quadrado

\begin{tabular}{|c|c|c|c|c|}
\hline Cruzamento & Tabelas & Valor $\mathrm{p}$ & Dependência nas repostas & Apêndice \\
\hline 1 & 3 e 6 & 0,73137343390873 & Não são dependentes & $A$ \\
\hline 2 & 4 e 6 & 0,041 & São dependentes & $\mathrm{B}$ \\
\hline 3 & 5 e 6 & 0,40023943694670 & Não são dependentes & $\mathrm{C}$ \\
\hline 4 & 8 e 9 & 0,21450204259761 & Não são dependentes & $\mathrm{D}$ \\
\hline 5 & 8 e 10 & 0,70643844964128 & Não são dependentes & $E$ \\
\hline 6 & 8 e 11 & 0,78716677225790 & Não são dependentes & $\mathrm{F}$ \\
\hline 7 & 8 e 12 & 0,02375120727723 & São dependentes & $\mathrm{G}$ \\
\hline 8 & 8 e 13 & 0,16343984936890 & Não são dependentes & $\mathrm{H}$ \\
\hline 9 & 8 e 14 & 0,07408552704363 & Não são dependentes & I \\
\hline 10 & 9 e 10 & 0,54123233325820 & Não são dependentes & J \\
\hline 11 & 9 e 11 & 0,56970874665751 & Não são dependentes & K \\
\hline 12 & 9 e 12 & 0,23206146547753 & Não são dependentes & $\mathrm{L}$ \\
\hline 13 & 9 e 13 & 0,50742471081520 & Não são dependentes & M \\
\hline 14 & 9 e 14 & 0,22035389106523 & Não são dependentes & $\mathrm{N}$ \\
\hline 15 & 10 e 11 & 0,02853883895660 & São dependentes & $\mathrm{O}$ \\
\hline 16 & 10 e 12 & 0,79619521181757 & Não são dependentes & $P$ \\
\hline 17 & 10 e 13 & 0,78812099911434 & Não são dependentes & $Q$ \\
\hline 18 & 10 e 14 & 0,87948709878363 & Não são dependentes & $\mathrm{R}$ \\
\hline 19 & 11 e 12 & 0,61110847991070 & Não são dependentes & $S$ \\
\hline 20 & 11 e 13 & 0,58847660867745 & Não são dependentes & $\mathrm{T}$ \\
\hline 21 & 11 e 14 & 0,78078634817147 & Não são dependentes & $U$ \\
\hline 22 & 12 e 13 & 0,06523271362541 & Não são dependentes & V \\
\hline 23 & 12 e 14 & 0,78078634817147 & Não são dependentes & $x$ \\
\hline 24 & 13 e 14 & 0,64770299853148 & Não são dependentes & Z \\
\hline
\end{tabular}

\section{CONCLUSÃO}

A conclusão central é que $17,55 \%$ das organizações industriais pesquisadas possuem o sistema de gestão da qualidade Seis Sigma implementado. Destas, apenas $8 \%$ das organizações não utilizam um método matemático para selecionar projetos Seis Sigma. Este é um item relevante nos resultados, pois não utilizar métodos matemáticos torna a seleção de projetos subjetiva, o que segundo a literatura qualificada, é um dos maiores problemas encontrados nas práticas organizacionais. Ainda neste contexto, verificou-se que $50 \%$ da amostra respondeu que um novo método de seleção de projetos Seis Sigma é uma necessidade atual.

Ainda foi possível encontrar dependência no cruzamento entre algumas respostas e características da amostra. Estes são entre: o número de colaborados das empresas e a utilização do Seis Sigma; o ano em que as organizações concluíram o primeiro projeto e as respostas sobre a utilização de algum método de seleção de projetos Seis Sigma; a média de projetos Seis Sigma concluídos e a média de projetos Seis Sigma elaborados.

Por fim, pode-se concluir que o desempenho do protocolo de pesquisa e do questionário foi satisfatório por apresentar uma alta taxa de retorno, representando $76 \%$ de retornos positivos. De fato, a estratégia foi realizar uma pesquisa via contato telefônico, o que ajudou a acelerar o processo de investigação, bem como, eliminou a necessidade de espera pelo retorno do questionário. De todo modo, este trabalho cumpriu com seu objetivo proposto, mapeando setores industriais do Rio Grande do Sul quanto à utilização da iniciativa Seis Sigma. 


\section{REFERÊNCIAS}

[1] Adebanjo, D. et al. Prioritization of SixSigma project selection. Benchmarking: An International Journal, v.23, n.7, p.1983-2003, 2016.

[2] Antony, J. et al. Application of Six Sigma Dmaic methodology in a transactional environment. International Journal of Quality \& Reliability Management, v.29, n.1, p.31-53, 2012.

[3] Antony, J. Is six sigma a management fad or fact? Assembly Automation, v.27, n.1, p.17-19, 2007.

[4] Antony, J.; Kumar, M.; Madu, C. N. Six sigma in small- and medium-sized UK manufacturing enterprises: some empirical observations. International Journal of Quality \& Reliability Management, v.22, n.8, p.860-874, 2005.

[5] Banuelas, R. et al. Selection of six sigma projects in the UK. The TQM Magazine, v.18, n.5, p.514-527, 2006.

[6] Busco, C.; Caglio, A.; Scapens, R. W. Management and accounting innovations: reflecting on what they are and why they are adopted. Journal of Management and Governance, p.1-30, 2014.

Carvalho, M. M.; HO, L. L.; Pinto, S. H. B. The Six Sigma program: an empirical study of Brazilian companies. Journal of Manufacturing Technology Management, v. 25, n. 5, p. 602-630, 2014.

[8] Carvalho, M. M.; HO, L. L.; Pinto, S. H. B. The Six Sigma program: an empirical study of Brazilian companies. Journal of Manufacturing Technology Management, v. 25, n. 5, p. 602-630, 2014.

[9] Cho, J. H. et al. Selection of Six Sigma key ingredients (KIs) in Korean companies. The TQM Journal, v.23, n.6, p.611-628, 2011.

[10] Farsijani, H.; Shafiei Nikabadi, M.; Amirimoghadam, $\mathrm{H}$. Six sigma project selections using fuzzy network-analysis and fuzzy Madm. Decision Science Letters, v.4, n.1, p.87-96, 2015.

[11] Forza, C. Survey research in operations management: a process-besead perspective. International Jornal of Operations \& Production Management, v.22, n.2, p.152-194, 2002.

[12] Gijo, E. V. et al. An application of Six Sigma methodology for improving the first pass yield of a grinding process. Journal of Manufacturing Technology Management, v.25, n.1, p.125-135, 2014

[13] Hilton, R. J.; Sohal, A. A conceptual model for the successful deployment of Lean Six Sigma. International Journal of Quality \& Reliability Management, v.29, n.1, p.54-70, 2012.

[14] Kumar, M.; Antony, J.; Cho, B. R. Project selection and its impact on the successful deployment of Six Sigma. Business Process Management Journal, v.15, n.5, p.669-686, 2009.
[15] Kumar, U. D. et al. Six sigma project selection using data envelopment analysis. The TQM Magazine, v.19, n.5, p.419-441, 2007.

[16] Larson, A. Demystifying Six Sigma. New York: American Management Association, 2003.

[17] Manville, G. et al. Critical success factors for Lean Six Sigma programmes: a view from middle management. International Journal of Quality \& Reliability Management, v.29, n.1, p.7-20, 2012

[18] Marques, P. et al. Integrating Six Sigma with ISO 9001. International Journal of Lean Six Sigma, v.4, n.1, p.36-59, 2013.

[19] Miguel, P. A. C. (organizador). Metodologia de pesquisa em engenharia de produção e gestão de operações. Rio de Janeiro: Elsevier, 2010

[20] Padhy, R. K.; Sahu, S. A Real Option based Six Sigma project evaluation and selection model. International Journal of Project Management, v.29, n.8, p.1091-1102, 2011.

[21] Ray, S.; das, P.; Bhattacharya, B. K. Prevention of industrial accidents using Six Sigma approach. International Journal of Lean Six Sigma, v.2, n.3, p.196-214, 2011.

[22] Ribeiro, A. et al. Key observations from a survey about Six Sigma implementation in Brazil. International Journal of Productivity and Performance Management, v. 64, n. 1, p. 94-111, 2015 .

[23] Sharma, S.; Chetiya, A. R. Six Sigma project selection: an analysis of responsible factors. International Journal of Lean Six Sigma, v.1, n.4, p.280-292, 2010.

[24] Souza, R. P. et al. Implementation of a Six Sigma project in a $3 \mathrm{M}$ division of Brazil. International Journal of Quality and Reliability Management, v.30, p.129-141, 2013.

[25] Vinodh, S.; Swarnakar, V. Lean Six Sigma project selection using hybrid approach based on fuzzy DEMATEL-ANP-TOPSIS. International Journal of Lean Six Sigma, v.6, n.4, p.313, 2015.

[26] Wang, F.; Hsu, C.; Tzeng, G. Applying a hybrid mcdm model for six sigma project selection. Mathematical problems in engineering. v.2014, p. 13-13, 2014.

[27] Wiele, T. V. D.; Iwaarden, J. V.; Power, D. Six Sigma implementation in Ireland: the role of multinational firms. International Journal of Quality \& Reliability Management, v. 27, n. 9, p. 1054-1066, 2010 .

[28] Yousefi, A.; Hadi-Vencheh, A. Selecting Six Sigma projects: MCDM or DEA? Journal of Modelling in Management, v.11, n.1, p.309-325, 2016. 


\section{APÊNDICE}

Apêndice A - Cruzamento entre o número de funcionários com as repostas sobre a utilização do Seis Sigma

\begin{tabular}{|lccc|}
\hline Faixa de Funcionários & $\begin{array}{c}\text { Não utiliza a } \\
\text { metodologia Seis } \\
\text { Sigma }\end{array}$ & $\begin{array}{c}\text { Utiliza a } \\
\text { metodologia Seis } \\
\text { Sigma }\end{array}$ & $\begin{array}{c}\text { Total } \\
\text { Geral }\end{array}$ \\
\hline $\mathbf{2 0 0}$ a $\mathbf{3 5 0}$ & 46 & 6 & 52 \\
$\mathbf{3 5 0}$ a $\mathbf{5 0 0}$ & 14 & 0 & 14 \\
$\mathbf{5 0 0}$ a $\mathbf{8 5 0}$ & 14 & 6 & 20 \\
$\mathbf{8 5 0}$ a $\mathbf{1 2 0 0}$ & 5 & 3 & 8 \\
$\mathbf{1 2 0 0}$ a $\mathbf{1 5 0 0}$ & 4 & 0 & 4 \\
Mais de $\mathbf{1 5 0 0}$ & 11 & 5 & 16 \\
\hline Total Geral & 94 & 20 & 114 \\
\hline \multicolumn{4}{c}{} \\
\hline
\end{tabular}

Apêndice B - Cruzamento entre o setor industrial com as repostas sobre a utilização do Seis Sigma

\begin{tabular}{|lccc|}
\hline Setor Industrial & $\begin{array}{c}\text { Não utiliza a } \\
\text { metodologia Seis } \\
\text { Sigma }\end{array}$ & $\begin{array}{c}\text { Utiliza a } \\
\text { metodologia Seis } \\
\text { Sigma }\end{array}$ & $\begin{array}{c}\text { Total } \\
\text { Geral }\end{array}$ \\
\hline $\begin{array}{l}\text { Produtos de borracha e de material plástico } \\
\text { Fabricação de cabines, carrocerias e reboques para }\end{array}$ & 19 & 3 & 22 \\
veículos automotores & 4 & 1 & 5 \\
$\begin{array}{l}\text { Fabricação de artigos de cutelaria, de serralheria e } \\
\text { ferramentas }\end{array}$ & 6 & 0 & 6 \\
Produtos do fumo & 6 & 1 & 7 \\
Fundição & 6 & 2 & 8 \\
$\begin{array}{l}\text { Máquinas e equipamentos para a agricultura e pecuária, } \\
\text { exceto para irrigação }\end{array}$ & 11 & 6 & 17 \\
Máquinas, aparelhos e materiais elétricos & 10 & 2 & 12 \\
Fabricação de produtos de minerais não-metálicos & 8 & 1 & 9 \\
Peças e acessórios para veículos automotores & 17 & 3 & 20 \\
Produtos químicos & 7 & 1 & 8 \\
\hline Total Geral & $\mathbf{9 4}$ & $\mathbf{2 0}$ & $\mathbf{1 1 4}$ \\
\hline \multicolumn{1}{|c}{ Teste Qui-Quadrado $\mathbf{p}=\mathbf{0 , 7 3 1 3 7 3}$} \\
\hline
\end{tabular}

Apêndice C - Cruzamento entre a mesorregião do estado com as repostas sobre a utilização do Seis Sigma

\begin{tabular}{|lccc|}
\hline Mesorregião & $\begin{array}{c}\text { Não utiliza a } \\
\text { metodologia Seis } \\
\text { Sigma }\end{array}$ & $\begin{array}{c}\text { Utiliza a } \\
\text { metodologia Seis } \\
\text { Sigma }\end{array}$ & $\begin{array}{c}\text { Total } \\
\text { Geral }\end{array}$ \\
\hline Região central & 11 & 1 & 12 \\
Região metropolitana & 31 & 7 & 38 \\
Região nordeste & 36 & 6 & 42 \\
Região noroeste & 12 & 6 & 18 \\
Região sudeste & 4 & 0 & 4 \\
\hline Total Geral & 94 & 20 & 114 \\
\hline \multicolumn{5}{c}{ Teste Qui-Quadrado $\mathbf{p}=\mathbf{0 , 4 0 0 2 3 9 4 3 6 9 4 6 7 0}$} \\
\hline
\end{tabular}


Apêndice D - Cruzamento entre o ano em que a organização concluiu o primeiro projeto e o número de vezes que a organização descontinuou o programa

\begin{tabular}{|lcccc|}
\hline Ano & Nenhuma vez & Uma vez & Duas vezes & $\begin{array}{c}\text { Total } \\
\text { Geral }\end{array}$ \\
\hline anterior à ou em 2000 & 0 & 0 & 1 & 1 \\
$\mathbf{2 0 0 4}$ & 1 & 1 & 0 & 2 \\
$\mathbf{2 0 0 5}$ & 2 & 2 & 0 & 4 \\
$\mathbf{2 0 0 8}$ & 2 & 1 & 0 & 3 \\
$\mathbf{2 0 0 9}$ & 0 & 0 & 1 & 1 \\
$\mathbf{2 0 1 4}$ & 1 & 0 & 0 & 1 \\
\hline Total Geral & 6 & 4 & 2 & 12 \\
\hline \multicolumn{5}{l}{} \\
\hline
\end{tabular}

Apêndice E - Cruzamento entre o ano em que a organização concluiu o primeiro projeto e a média de projetos concluídos

\begin{tabular}{|lcccc|}
\hline Ano & $\mathbf{0}$ a $\mathbf{5}$ & $\mathbf{6}$ a $\mathbf{~ 1 0}$ & $\mathbf{2 1}$ a 25 & $\begin{array}{c}\text { Total } \\
\text { Geral }\end{array}$ \\
\hline anterior à ou em 2000 & 1 & 0 & 0 & 1 \\
$\mathbf{2 0 0 4}$ & 2 & 0 & 0 & 2 \\
$\mathbf{2 0 0 5}$ & 4 & 0 & 0 & 4 \\
$\mathbf{2 0 0 8}$ & 1 & 1 & 1 & 3 \\
$\mathbf{2 0 0 9}$ & 1 & 0 & 0 & 1 \\
$\mathbf{2 0 1 4}$ & 1 & 0 & 0 & 1 \\
\hline Total Geral & 10 & 1 & 1 \\
\hline \multicolumn{4}{l}{ Teste Qui-Quadrado $\mathbf{p}=\mathbf{0 , 7 0 6 4 3 8 4 4 9 6 4 1 2 8}$} \\
\hline
\end{tabular}

Apêndice F - Cruzamento entre o ano em que a organização concluiu o primeiro projeto e a média de projetos elaborados

\begin{tabular}{|lccccc|}
\hline Ano & $\mathbf{0}$ a $\mathbf{5}$ & $\mathbf{6}$ a $\mathbf{1 0}$ & $\mathbf{1 1}$ a $\mathbf{1 5}$ & $\mathbf{3 1}$ a 35 & $\begin{array}{c}\text { Total } \\
\text { Geral }\end{array}$ \\
\hline $\begin{array}{l}\text { anterior à ou em } \\
\mathbf{2 0 0 0}\end{array}$ & 1 & 0 & 0 & 1 & 1 \\
$\mathbf{2 0 0 4}$ & 1 & 1 & 0 & 2 & 2 \\
$\mathbf{2 0 0 5}$ & 2 & 2 & 0 & 4 & 4 \\
$\mathbf{2 0 0 8}$ & 0 & 1 & 1 & 3 & 3 \\
$\mathbf{2 0 0 9}$ & 1 & 0 & 0 & 1 & 1 \\
$\mathbf{2 0 1 4}$ & 1 & 0 & 0 & 1 & 1 \\
\hline Total Geral & 6 & 1 & 1 & 12 \\
\hline \multicolumn{7}{c}{ Teste Qui-Quadrado $\mathbf{p}=\mathbf{0 , 7 8 7 1 6 6 7 7 2 2 5 7 9 0}$} \\
\hline
\end{tabular}


Apêndice $\mathrm{G}$ - Cruzamento entre o ano em que a organização concluiu o primeiro projeto e as respostas sobre a utilização de algum método de seleção

\begin{tabular}{|lccccc|}
\hline Ano & Não & $\begin{array}{c}\text { Sim, na maioria } \\
\text { das vezes }\end{array}$ & $\begin{array}{c}\text { Sim, na minoria } \\
\text { das vezes }\end{array}$ & $\begin{array}{c}\text { Sim, todas as } \\
\text { vezes }\end{array}$ & $\begin{array}{c}\text { Total } \\
\text { Geral }\end{array}$ \\
\hline $\begin{array}{l}\text { anterior à ou em } \\
\mathbf{2 0 0 0}\end{array}$ & 0 & 1 & 0 & 0 & 1 \\
$\mathbf{2 0 0 4}$ & 0 & 2 & 0 & 0 & 2 \\
$\mathbf{2 0 0 5}$ & 0 & 2 & 0 & 2 & 4 \\
$\mathbf{2 0 0 8}$ & 0 & 1 & 0 & 2 & 3 \\
$\mathbf{2 0 0 9}$ & 1 & 0 & 0 & 0 & 1 \\
$\mathbf{2 0 1 4}$ & 0 & 0 & 1 & 0 & 1 \\
\hline Total Geral & 1 & 1 & 4 & 12 \\
\hline \multicolumn{5}{c}{ Teste Qui-Quadrado $\mathbf{p}=\mathbf{0 , 0 2 3 7 5 1 2 0 7 2 7 7 2 3}$} \\
\hline
\end{tabular}

Apêndice $\mathrm{H}$ - Cruzamento entre o ano em que a organização concluiu o primeiro projeto e as respostas sobre a utilização de algum método matemático de seleção

\begin{tabular}{|lcccc|}
\hline Ano & Não & $\begin{array}{c}\text { Sim, na maioria } \\
\text { das vezes }\end{array}$ & $\begin{array}{c}\text { Sim, todas as } \\
\text { vezes }\end{array}$ & $\begin{array}{c}\text { Total } \\
\text { Geral }\end{array}$ \\
\hline anterior à ou em 2000 & 0 & 1 & 0 & 1 \\
$\mathbf{2 0 0 4}$ & 0 & 2 & 0 & 2 \\
$\mathbf{2 0 0 5}$ & 1 & 1 & 2 & 4 \\
$\mathbf{2 0 0 8}$ & 0 & 3 & 0 & 3 \\
$\mathbf{2 0 0 9}$ & 1 & 0 & 0 & 1 \\
$\mathbf{2 0 1 4}$ & 0 & 0 & 1 & 1 \\
\hline Total Geral & 2 & 7 & 3 & 12 \\
\hline \multicolumn{5}{c}{ Teste Oui-Ouadrado $\mathbf{n}=\mathbf{0 . 1 6 3 4 3 9 8 4 9 3 6 8 9 0}$} \\
\hline
\end{tabular}

Apêndice I - Cruzamento entre o ano em que a organização concluiu o primeiro projeto e as respostas sobre a necessidade de um novo método de seleção de projetos

\begin{tabular}{|lccccc|}
\hline Ano & Não & $\begin{array}{c}\text { Sim, na maioria } \\
\text { das vezes }\end{array}$ & $\begin{array}{c}\text { Sim, na minoria } \\
\text { das vezes }\end{array}$ & $\begin{array}{c}\text { Sim, todas as } \\
\text { vezes }\end{array}$ & $\begin{array}{c}\text { Total } \\
\text { Geral }\end{array}$ \\
\hline $\begin{array}{l}\text { anterior à ou em } \\
\mathbf{2 0 0 0}\end{array}$ & 0 & 1 & 0 & 0 & 1 \\
$\mathbf{2 0 0 4}$ & 0 & 0 & 1 & 1 & 2 \\
$\mathbf{2 0 0 5}$ & 2 & 0 & 0 & 2 & 4 \\
$\mathbf{2 0 0 8}$ & 3 & 0 & 0 & 0 & 3 \\
$\mathbf{2 0 0 9}$ & 1 & 0 & 0 & 0 & 1 \\
$\mathbf{2 0 1 4}$ & 0 & 0 & 0 & 1 & 1 \\
\hline Total Geral & 6 & 1 & 4 & 12 \\
\hline \multicolumn{5}{c}{ Teste Qui-Quadrado $\mathbf{p}=\mathbf{0 , 0 7 4 0 8 5 5 2 7 0 4 3 6 3}$} \\
\hline
\end{tabular}


Apêndice $\mathrm{J}$ - Cruzamento entre o número de vezes que a organização descontinuou o programa e a média de projetos concluídos

\begin{tabular}{|lcccc|}
\hline $\begin{array}{l}\text { Descontinuou } \\
\text { o Seis Sigma }\end{array}$ & $\mathbf{0}$ a 5 & $\mathbf{6}$ a $\mathbf{1 0}$ & $\mathbf{2 1}$ a 25 & $\begin{array}{c}\text { Total } \\
\text { Geral }\end{array}$ \\
\hline Nenhuma vez & 5 & 0 & 1 & 6 \\
Uma vez & 3 & 1 & 0 & 4 \\
Duas vezes & 2 & 0 & 0 & 2 \\
\hline Total Geral & 10 & 1 & 1 & 12 \\
\hline \multicolumn{5}{l}{ Teste Qui-Quadrado $\mathbf{p}=\mathbf{0 , 5 4 1 2 3 2 3 3 3 2 5 8 2 0}$} \\
\hline
\end{tabular}

Apêndice $\mathrm{K}$ - Cruzamento entre o número de vezes que a organização descontinuou o programa e a média de projetos elaborados

\begin{tabular}{|lccccc|}
\hline $\begin{array}{l}\text { Descontinuou } \\
\text { o Seis Sigma }\end{array}$ & $\mathbf{0}$ a $\mathbf{5}$ & $\mathbf{6}$ a $\mathbf{1 0}$ & $\mathbf{1 1}$ a $\mathbf{1 5}$ & 31 a $\mathbf{3 5}$ & $\begin{array}{r}\text { Total } \\
\text { Geral }\end{array}$ \\
\hline Nenhuma vez & 2 & 2 & 1 & 1 & 6 \\
Uma vez & 2 & 2 & 0 & 0 & 4 \\
Duas vezes & 2 & 0 & 0 & 0 & 2 \\
\hline Total Geral & 6 & 4 & 1 & 12 \\
\hline \multicolumn{7}{r}{} \\
\hline
\end{tabular}

Apêndice $L$ - Cruzamento entre o número de vezes que a organização descontinuou o programa e as respostas sobre a utilização de algum método de seleção

\begin{tabular}{|lccccc|}
\hline $\begin{array}{l}\text { Descontinuou } \\
\text { o Seis Sigma }\end{array}$ & Não & $\begin{array}{c}\text { Sim, na maioria } \\
\text { das vezes }\end{array}$ & $\begin{array}{c}\text { Sim, na minoria } \\
\text { das vezes }\end{array}$ & $\begin{array}{c}\text { Sim, todas as } \\
\text { vezes }\end{array}$ & $\begin{array}{c}\text { Total } \\
\text { Geral }\end{array}$ \\
\hline Nenhuma vez & 0 & 2 & 1 & 3 & 6 \\
Uma vez & 0 & 3 & 0 & 1 & 4 \\
Duas vezes & 1 & 1 & 0 & 0 & 2 \\
\hline Total Geral & 1 & 6 & 1 & 4 & 12 \\
\hline \multicolumn{7}{r}{} \\
\hline
\end{tabular}

Apêndice M - Cruzamento entre o número de vezes que a organização descontinuou o programa e as respostas sobre a utilização de algum método matemático de seleção

\begin{tabular}{|lcccc|}
\hline $\begin{array}{l}\text { Descontinuou } \\
\text { o Seis Sigma }\end{array}$ & Não & $\begin{array}{c}\text { Sim, na maioria } \\
\text { das vezes }\end{array}$ & $\begin{array}{c}\text { Sim, todas as } \\
\text { vezes }\end{array}$ & $\begin{array}{c}\text { Total } \\
\text { Geral }\end{array}$ \\
\hline Nenhuma vez & 0 & 4 & 2 & 6 \\
Uma vez & 1 & 2 & 1 & 4 \\
Duas vezes & 1 & 1 & 0 & 2 \\
\hline Total Geral & 2 & 7 & 3 & 12 \\
\hline \multicolumn{2}{l}{ Teste Qui-Quadrado $\mathbf{p}=\mathbf{0 , 5 0 7 4 2 4 7 1 0 8 1 5 2 0}$} & & \\
\hline
\end{tabular}


Apêndice $\mathrm{N}$ - Cruzamento entre o número de vezes que a organização descontinuou o programa e as respostas sobre a necessidade de um novo método de seleção de projetos

\begin{tabular}{|lccccc|}
\hline $\begin{array}{l}\text { Descontinuou } \\
\text { o Seis Sigma }\end{array}$ & Não & $\begin{array}{c}\text { Sim, na maioria } \\
\text { das vezes }\end{array}$ & $\begin{array}{c}\text { Sim, na minoria } \\
\text { das vezes }\end{array}$ & $\begin{array}{c}\text { Sim, todas as } \\
\text { vezes }\end{array}$ & $\begin{array}{c}\text { Total } \\
\text { Geral }\end{array}$ \\
\hline Nenhuma vez & 3 & 0 & 0 & 3 & 6 \\
Uma vez & 2 & 0 & 1 & 1 & 4 \\
Duas vezes & 1 & 1 & 0 & 0 & 2 \\
\hline Total Geral & 6 & 1 & 1 & 4 & 12 \\
\hline \multicolumn{5}{r}{ Teste Qui-Quadrado $\mathbf{p}=\mathbf{0 , 2 2 0 3 5 3 8 9 1 0 6 5 2 3}$} \\
\hline
\end{tabular}

Apêndice O - Cruzamento entre a média de projetos concluídos e a média de projetos elaborados

\begin{tabular}{|lccccc|}
\hline $\begin{array}{l}\text { Projetos } \\
\text { concluídos }\end{array}$ & $\mathbf{0}$ a $\mathbf{5}$ & $\mathbf{6}$ a $\mathbf{1 0}$ & $\mathbf{1 1}$ a $\mathbf{~ 5 ~}$ & 31 a 35 & $\begin{array}{c}\text { Total } \\
\text { Geral }\end{array}$ \\
\hline $\mathbf{0}$ a $\mathbf{5}$ & 6 & 3 & 1 & 0 & 10 \\
$\mathbf{6}$ a $\mathbf{1 0}$ & 0 & 1 & 0 & 0 & 1 \\
$\mathbf{2 1}$ a $\mathbf{2 5}$ & 0 & 0 & 0 & 1 & 1 \\
\hline Total Geral & 6 & 4 & 1 & 1 & 12 \\
\hline \multicolumn{5}{c}{ Teste Qui-Quadrado $\mathbf{p}=\mathbf{0 , 0 2 8 5 3 8 8 3 8 9 5 6 6 0}$} \\
\hline
\end{tabular}

Apêndice P - Cruzamento entre média de projetos concluídos e as respostas sobre a utilização de algum método de seleção

\begin{tabular}{|lccccc|}
\hline $\begin{array}{l}\text { Projetos } \\
\text { concluídos }\end{array}$ & Não & $\begin{array}{c}\text { Sim, na maioria } \\
\text { das vezes }\end{array}$ & $\begin{array}{c}\text { Sim, na minoria } \\
\text { das vezes }\end{array}$ & $\begin{array}{c}\text { Sim, todas as } \\
\text { vezes }\end{array}$ & $\begin{array}{c}\text { Total } \\
\text { Geral }\end{array}$ \\
\hline $\mathbf{0}$ a $\mathbf{5}$ & 1 & 5 & 1 & 3 & 10 \\
$\mathbf{6}$ a $\mathbf{1 0}$ & 0 & 1 & 0 & 0 & 1 \\
$\mathbf{2 1}$ a 25 & 0 & 0 & 0 & 1 & 1 \\
\hline Total Geral & 1 & 6 & 1 & 4 & 12 \\
\hline \multicolumn{7}{r}{} \\
\hline
\end{tabular}

Apêndice Q - Cruzamento entre média de projetos concluídos e as respostas sobre a utilização de algum método matemático de seleção

\begin{tabular}{|lcccc|}
\hline $\begin{array}{l}\text { Projetos } \\
\text { concluídos }\end{array}$ & Não & $\begin{array}{c}\text { Sim, na maioria } \\
\text { das vezes }\end{array}$ & $\begin{array}{c}\text { Sim, todas as } \\
\text { vezes }\end{array}$ & $\begin{array}{c}\text { Total } \\
\text { Geral }\end{array}$ \\
\hline $\mathbf{0}$ a $\mathbf{5}$ & 2 & 5 & 3 & 10 \\
$\mathbf{6}$ a $\mathbf{1 0}$ & 0 & 1 & 0 & 1 \\
$\mathbf{2 1}$ a $\mathbf{2 5}$ & 0 & 1 & 0 & 1 \\
\hline Total Geral & 2 & 7 & 3 & 12 \\
\hline \multicolumn{5}{c}{$\mathbf{c}$} \\
\hline
\end{tabular}

Apêndice R - Cruzamento entre média de projetos concluídos e as respostas sobre a necessidade de um novo método de seleção de projetos

\begin{tabular}{|lccccc|}
\hline $\begin{array}{l}\text { Projetos } \\
\text { concluídos }\end{array}$ & Não & $\begin{array}{c}\text { Sim,na maioria } \\
\text { das vezes }\end{array}$ & $\begin{array}{c}\text { Sim, na minoria } \\
\text { das vezes }\end{array}$ & $\begin{array}{c}\text { Sim, todas as } \\
\text { vezes }\end{array}$ & $\begin{array}{c}\text { Total } \\
\text { Geral }\end{array}$ \\
\hline $\mathbf{0}$ a $\mathbf{5}$ & 4 & 1 & 1 & 4 & 10 \\
$\mathbf{6}$ a $\mathbf{1 0}$ & 1 & 0 & 0 & 0 & 1 \\
$\mathbf{2 1}$ a $\mathbf{2 5}$ & 1 & 0 & 0 & 0 & 1 \\
\hline Total Geral & 6 & 1 & 1 & 4 & 12 \\
\hline \multicolumn{5}{r}{} \\
\hline
\end{tabular}


Apêndice S - Cruzamento entre média de projetos elaborados e as respostas sobre a utilização de algum método de seleção

\begin{tabular}{|lccccc|}
\hline $\begin{array}{l}\text { Projetos } \\
\text { elaborados }\end{array}$ & Não & $\begin{array}{c}\text { Sim, na maioria } \\
\text { das vezes }\end{array}$ & $\begin{array}{c}\text { Sim, na minoria } \\
\text { das vezes }\end{array}$ & $\begin{array}{c}\text { Sim, todas as } \\
\text { vezes }\end{array}$ & $\begin{array}{c}\text { Total } \\
\text { Geral }\end{array}$ \\
\hline $\mathbf{0}$ a $\mathbf{5}$ & 1 & 3 & 1 & 1 & 6 \\
$\mathbf{6}$ a $\mathbf{1 0}$ & 0 & 3 & 0 & 1 & 4 \\
$\mathbf{1 1}$ a $\mathbf{1 5}$ & 0 & 0 & 0 & 1 & 1 \\
$\mathbf{3 1}$ a 35 & 0 & 0 & 0 & 1 & 1 \\
\hline Total Geral & 1 & 6 & 1 & 4 & 12 \\
\hline \multicolumn{7}{r}{ Teste Qui-Quadrado $\mathbf{p}=\mathbf{0 , 6 1 1 1 0 8 4 7 9 9 1 0 7 0}$} \\
\hline
\end{tabular}

Apêndice T - Cruzamento entre média de projetos elaborados e as respostas sobre a utilização de algum método matemático de seleção

\begin{tabular}{|lcccc|}
\hline $\begin{array}{l}\text { Projetos } \\
\text { elaborados }\end{array}$ & Não & $\begin{array}{c}\text { Sim, na maioria } \\
\text { das vezes }\end{array}$ & $\begin{array}{c}\text { Sim, todas as } \\
\text { vezes }\end{array}$ & $\begin{array}{c}\text { Total } \\
\text { Geral }\end{array}$ \\
\hline $\mathbf{0}$ a $\mathbf{5}$ & 2 & 2 & 2 & 6 \\
$\mathbf{6}$ a $\mathbf{1 0}$ & 0 & 1 & 0 & 4 \\
$\mathbf{1 1}$ a $\mathbf{1 5}$ & 0 & 1 & 0 & 1 \\
$\mathbf{3 1}$ a $\mathbf{3 5}$ & 0 & 3 & 1 & 1 \\
\hline Total Geral & 2 & 7 & 3 & 12 \\
\hline \multicolumn{5}{l}{} \\
\hline
\end{tabular}

Apêndice $U$ - Cruzamento entre média de projetos elaborados e as respostas sobre a necessidade de um novo método de seleção de projetos

\begin{tabular}{|lccccc|}
\hline $\begin{array}{l}\text { Projetos } \\
\text { elaborados }\end{array}$ & Não & $\begin{array}{c}\text { Sim, na maioria } \\
\text { das vezes }\end{array}$ & $\begin{array}{c}\text { Sim, na minoria } \\
\text { das vezes }\end{array}$ & $\begin{array}{c}\text { Sim, todas as } \\
\text { vezes }\end{array}$ & $\begin{array}{c}\text { Total } \\
\text { Geral }\end{array}$ \\
\hline $\mathbf{0}$ a $\mathbf{5}$ & 2 & 1 & 0 & 3 & 6 \\
$\mathbf{6}$ a $\mathbf{1 0}$ & 2 & 1 & 1 & 1 & 4 \\
$\mathbf{1 1}$ a $\mathbf{1 5}$ & 1 & 0 & 0 & 0 & 1 \\
$\mathbf{3 1}$ a $\mathbf{3 5}$ & 1 & 0 & 0 & 0 & 1 \\
\hline Total Geral & 6 & 1 & 1 & 4 \\
\hline \multicolumn{5}{r}{} \\
\hline
\end{tabular}

Apêndice V - Cruzamento entre as respostas sobre a utilização de algum método de seleção e as respostas sobre a utilização de algum método matemático de seleção

\begin{tabular}{|lcccc|}
\hline $\begin{array}{l}\text { Utiliza método } \\
\text { de seleção }\end{array}$ & Não & $\begin{array}{c}\text { Sim, na maioria } \\
\text { das vezes }\end{array}$ & $\begin{array}{c}\text { Sim, todas as } \\
\text { vezes }\end{array}$ & $\begin{array}{c}\text { Total } \\
\text { Geral }\end{array}$ \\
\hline Não & 1 & 0 & 0 & 1 \\
Sim, na maioria das vezes & 1 & 5 & 0 & 6 \\
Sim, na minoria das vezes & 0 & 0 & 1 & 1 \\
Sim, todas as vezes & 0 & 2 & 2 & 4 \\
\hline Total Geral & 2 & 7 & 3 & 12 \\
\hline
\end{tabular}

Apêndice X - Cruzamento entre as respostas sobre a utilização de algum método de seleção e as respostas sobre a necessidade de um novo método de seleção de projetos 


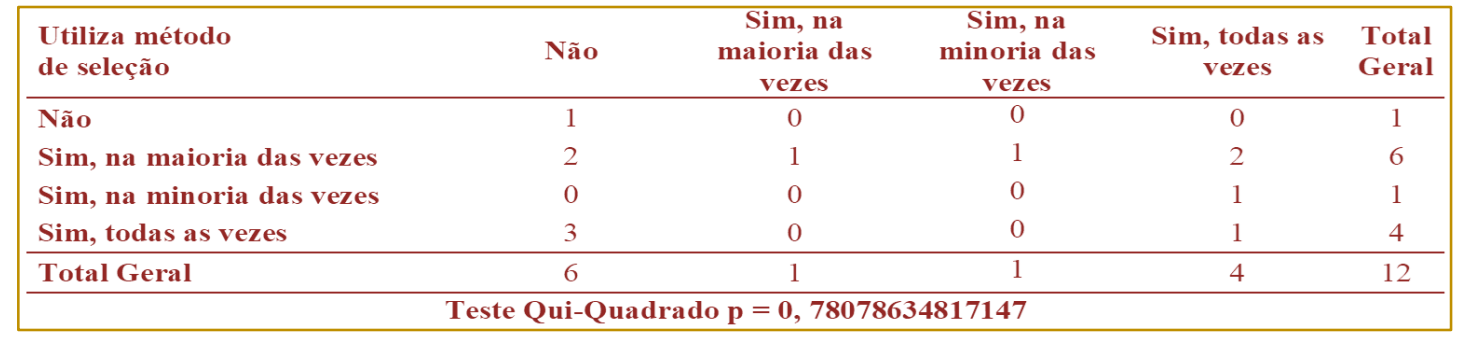

Apêndice Z - Cruzamento entre as respostas sobre a utilização de algum método de seleção e as respostas sobre a necessidade de um novo método de seleção de projetos

\begin{tabular}{|lccccc|}
\hline $\begin{array}{l}\text { Utiliza método } \\
\text { de seleção }\end{array}$ & Não & $\begin{array}{c}\text { Sim, na } \\
\text { maioria das } \\
\text { vezes }\end{array}$ & $\begin{array}{c}\text { Sim, na } \\
\text { minoria das } \\
\text { vezes }\end{array}$ & $\begin{array}{c}\text { Sim, todas as } \\
\text { vezes }\end{array}$ & $\begin{array}{c}\text { Total } \\
\text { Geral }\end{array}$ \\
\hline Não & 2 & 0 & 0 & 0 & 2 \\
Sim, na maioria das vezes & 3 & 1 & 1 & 2 & 7 \\
Sim, todas as vezes & 1 & 0 & 0 & 2 & 3 \\
\hline Total Geral & 6 & 1 & 1 & 4 & 12 \\
\hline \multicolumn{2}{l}{ Teste Qui-Quadrado $\mathbf{p}=\mathbf{0 , 6 4 7 7 0 2 9 9 8 5 3 1 4 8}$} & & \\
\hline
\end{tabular}

Apêndice A1 - Cruzamento entre as respostas das empresas que utilizam a duração de projetos e o número de Black Belts como variáveis para a seleção de projetos Seis Sigma

\begin{tabular}{|lccc|}
\hline Respostas & Não & Sim & $\begin{array}{c}\text { Total } \\
\text { Geral }\end{array}$ \\
\cline { 2 - 4 } Não & 10 & 1 & 11 \\
Sim & 0 & 1 & 1 \\
\cline { 2 - 4 } Total Geral & 10 & 2 & 12 \\
\hline \multicolumn{4}{r}{} \\
\hline
\end{tabular}

Apêndice B1 - Cruzamento entre as respostas das empresas que utilizam o número de Black Belts e Green Belts como variáveis para a seleção de projetos Seis Sigma

\begin{tabular}{|lccc|}
\hline Respostas & Não & Sim & $\begin{array}{c}\text { Total } \\
\text { Geral }\end{array}$ \\
\cline { 2 - 5 } Não & 10 & 0 & 10 \\
Sim & 1 & 1 & 2 \\
\cline { 2 - 4 } Total Geral & Teste Qui-Quadrado $\mathrm{p}=\mathbf{0 , 0 1 9 5 1 7 4 8 1}$ & 12 \\
\cline { 2 - 4 }
\end{tabular}




\section{Capítulo 4}

\section{LEAN HEALTHCARE: ESTUDO DE CASO SOBRE MELHORIA DE PROCESSOS E OTIMIZAÇÃO DE UM ESTOQUE HOSPITALAR}

\section{Fernando Cesar Brandão}

\section{Paula Camila Dias Portes}

Resumo: $O$ atual cenário macroeconômico e as crescentes exigências por qualidade e produtividade têm levado serviços públicos hospitalares, assim como os demais setores em prestação de serviços, a reavaliarem seus processos a fim de aprimorar seus desempenhos e atender melhor seu cliente. Para atender aos padrões da qualidade hospitalar requeridos, diversos hospitais vem se espelhando na filosofia Lean. Surge, então, o Lean Healthcare como um sistema de gerenciamento para redução de desperdícios, melhoria da qualidade de serviços para o paciente e aumento de eficiência nos resultados operacionais e financeiros da instituição de saúde. Este artigo tem como objetivo apresentar um estudo de caso realizado em um hospital público, tratando do processo de padronização de atividades de seu almoxarifado, bem como a otimização de seu estoque pelo uso de ferramentas da qualidade e da filosofia Lean Healthcare.

Palavras-Chave: lean healthcare, saúde, otimização de estoque, qualidade, padronização de processos 


\section{INTRODUÇÃO}

Os serviços públicos hospitalares, assim como os demais setores em prestação de serviços, vêm buscando melhorias em seus processos constantemente com o intuito de aprimorar o desempenho nos serviços prestados. No Brasil, como a remuneração em serviços de saúde é dada em volumes junto a uma inflação setorial consideravelmente superior a inflação média da economia (IPCA), nota-se um desafio em melhorar a qualidade de serviços para o paciente e ao mesmo tempo reduzir os custos para o setor da saúde (NETO et. al., 2016).

Segundo estudo realizado pela Fundação Oswaldo Cruz (2013), o índice de problemas que podem ser evitados dentro dos hospitais brasileiros está entre $66,7 \%$ a $73 \%$, quando comparados a $27 \%$ na França, por exemplo. Este índice engloba não somente erros médicos, mas também aqueles que se referem aos erros de diagnóstico, fornecimento de alimentação inapropriada e troca de medicamentos, por exemplo.

Para Neto et. Al (2016), as complexidades e desafios de produtividade encontradas nas operações hospitalares são diferentes dos outros setores de serviços, sugerindo a necessidade de padronizar processos e protocolos, bem como a personalização do atendimento ao cliente. Entende-se que a estabilidade financeira dar-se-á pela gestão da qualidade destas instituições.

Assim, procurando atender aos padrões da qualidade hospitalar, bem como a solução para problemas gerenciais e de processos, diversas empresas do ramo vem se espelhando no Lean Thinking aplicado à manufatura (ROSA et. al., 2016). Surge, aqui, - Lean Healthcare como um sistema de gerenciamento, que reduz desperdícios, melhora a qualidade de serviços para o paciente e aumenta a eficiência nos resultados operacionais e financeiros da instituição de saúde (EIRO; JUNIOR, 2013).

Deste modo, este artigo tem como objetivo apresentar um estudo de caso realizado em um hospital público, tratando do processo de padronização de atividades de seu almoxarifado, bem como a otimização de seu estoque pelo uso de ferramentas da qualidade e da filosofia Lean Healthcare.

\section{FUNDAMENTAÇÃO TEÓRICA}

A filosofia Lean Healthcare, aplicada à saúde, baseia-se nos conceitos do Lean Production (Produção Enxuta), para a melhoria organizacional e gerencial dos serviços de saúde (GRABAN, 2009). O termo "Produção Enxuta" foi criado pelo pesquisador John Krafcik por meados de 1980 e 1990. Este, é explicado pelos autores Womack, Jones e Roos (1992) como enxuta por utilizar menores quantidades de tudo em relação à produção em massa e ainda assim alcançar melhores resultados. Os subitens desta seção tem como trazem os princípios da produção enxuta e os sete desperdícios, temas usadas durante a metodologia deste artigo.

\subsection{OS CINCO PRINCÍPIOS DA PRODUÇÃO ENXUTA}

Para Womack e Jones (1996), a Produção Enxuta apresenta cinco princípios básicos para aumentar a flexibilidade e capacidade de resposta a real necessidade do cliente. Segundo o Lean Institute Brasil (2013), são eles:

a) Valor: identificar o que é valor para o cliente e não para a empresa, eliminando e/ou otimizando processos para que não se gaste recursos com etapas não valorizadas por ele;

b) Fluxo de valor: identificar e separar a cadeia produtiva em três tipos de processos aqueles que geram valor, aqueles que não geram valor, mas são importantes para a manutenção dos processos e da qualidade e por fim, os que não agregam valor e devem ser eliminados;

c) Fluxo contínuo: criar fluidez no processo, reduzindo tempos de fabricação, de processamento de pedidos e de estoques. Para Nazareno (2008) esta etapa exige uma mudança de mentalidade, sendo, portanto, uma tarefa difícil do processo;

d) Produção puxada: é a inversão do fluxo produtivo. As empresas não empurram mais seus produtos para os clientes (gerando grandes estoques), mas sim os deixam dizer o que querem comprar, no momento e quantidade correta;

e) Perfeição: é a quinta e última etapa, devendo ser tratada como meta de todos os envolvidos no fluxo de valor (fornecedores, fabricantes, distribuidores, revendedores) para a busca de melhoria continua (kaizen) em direção a um estado ideal. 


\subsection{OS SETE DESPERDÍCIOS}

Ao estabelecer o fluxo de valor, mencionado no item anterior, pode-se encaixar as atividades que não agregam valor para 0 cliente em sete tipos de desperdícios. Estes são apresentados por Shingo (1996) como:

a) Superprodução: Produzir mais ou mais cedo que o necessário para atender a demanda de certo período. É considerado o pior dos desperdícios, pois é causa geradora de outros;

b) Defeitos: Não atendimento as especificações do produto ou processamento de informações, da primeira vez em que ocorre, gerando retrabalho;

c) Espera: Longos períodos de ociosidade de tempo para bens, pessoas ou informações. Podendo ocorrer devido a falta de padronização e/ou organização de processos, por exemplo;

d) Processamento inapropriado: Executar 0 processo utilizando ferramentas ou procedimentos não adequados, causando prejuízo quanto à segurança dos operadores, à eficiência do processo, à qualidade do produto, entre outros;

e) Estoque desnecessário: Armazenamento excessivo de matéria-prima, insumos, processo ou produtos acabados; f) Movimentação excessiva: Excesso de movimentação dos operadores. Pode ser movendo, armazenando ou até mesmo procurando por peças, ferramentas ou outros insumos durante o processo. Isso pode ser causado por um layout que não favorece o processo, por falta de organização ou resultar de outros desperdícios:

g) Transporte excessivo: Transporte excessivo de bens e informações. Esse tipo de perda pode ocorrer quando o processo é desorganizado, descentralizado ou até mesmo muito burocrático, no caso de informações.

Para Liker (2005) ainda existe um oitavo desperdício: o de potencial humano. Este pode ser explicado pelo não aproveitamento de intelecto do colaborador, seja pela falta de reconhecimento de sugestões de melhoria vindas dos colaboradores ou a não consideração da vasta experiência que eles têm em suas funções.

\subsection{FERRAMENTAS DE GESTÃO DA QUALIDADE}

Atreladas ao Lean, existem as ferramentas de gestão da qualidade usadas para a melhoria de processos. Para este artigo, estão referenciadas no quadro 1 aquelas utilizadas durante o estudo.

\section{Quadro 1 - Ferramentas utilizadas}

\begin{tabular}{|l|l|}
\hline Ferramenta & \multicolumn{1}{c|}{ Descrição } \\
\hline $\begin{array}{l}\text { Voz do } \\
\text { Consumidor } \\
\text { (VOC) }\end{array}$ & $\begin{array}{l}\text { Segundo Carvalho (2001), captar a "voz do consumidor" - VOC (voice of } \\
\text { customer) é uma tarefa de monitoramento continuo para reconhecer quais } \\
\text { os atributos que influenciam a percepção do consumidor para a qualidade do } \\
\text { produto/serviço. }\end{array}$ \\
\hline SIPOC & $\begin{array}{l}\text { Segundo Jacobs e Chase (2012), é um modelo formalizado de entradas e } \\
\text { saidas, sendo essencial na etapa de definição do projeto. Tem o objetivo de } \\
\text { compreender as entradas de clientes, interfaces e interesses, utilizando suas } \\
\text { fontes e identificando seus destinos - saidas (GUPTA; SRI, 2012). }\end{array}$ \\
\hline $\begin{array}{l}\text { Diagrama } \\
\text { de Pareto }\end{array}$ & $\begin{array}{l}\text { É um gráfico de colunas, que mostra o impacto de cada um dos eventos que } \\
\text { estão sendo estudados. Os eventos com maior participação nos problemas } \\
\text { devem ser resolvidos em primeiro lugar. Isso porque, normalmente, uma ou } \\
\text { duas destas causas são responsáveis pela maior parte do problema. Por meio } \\
\text { dele se indica o quanto cada uma destes eventos representa, em termos } \\
\text { percentuais, do problema geral (PEINADO; GRAEML, 2007). }\end{array}$ \\
\hline Diagrama \\
de Ishikawa
\end{tabular} \begin{tabular}{l}
$\begin{array}{l}\text { Peinado e Graeml (2007) o definem como uma representação gráfica que } \\
\text { auxilia a identificação, exploração e apresentação das possiveis causas de } \\
\text { uma situação ou problema especifico. }\end{array}$ \\
\hline Fluxograma \\
$\begin{array}{l}\text { Os fluxogramas são formas de representar por meio de simbolos gráficos, a } \\
\text { sequência dos passos de um trabalho, para facilitar sua análise, sendo uma } \\
\text { ferramenta de rápida visualização e entendimento (PEINADO; GRAEML, } \\
\text { 2007). }\end{array}$ \\
\hline $\begin{array}{l}\text { A curva ABC baseia-se na classificação dos itens de estoque em três classes: } \\
\text { A, B e C, levando em consideração seus custos e quantidades. Na } \\
\text { composição da curva, os produtos relevantes são vistos em uma quantidade } \\
\text { pequena e com um alto valor, e devem ser administrados rigorosamente. } \\
\text { (POZO, 2010). }\end{array}$ \\
\hline
\end{tabular}

Fonte: Autor (2017) 


\section{MÉTODOS}

O estudo de caso apresentado foi realizado por um grupo de alunos de Engenharia de Produção em um hospital público localizado na região do Vale do Paraíba, interior de São Paulo.

O hospital em estudo é dividido em diversas macro áreas, como ambulatório, administração, maternidade, UTI, lavanderia, entre outras. A área abordada neste trabalho é a de estoque, responsável pelo recebimento, armazenagem e fornecimento dos insumos para as demais áreas do hospital.

O trabalho foi desenvolvido no decorrer de quatro meses, durante os quais foram feitas visitas técnicas diretamente no setor de Estoque, em média de 1 a 2 dias por semana. Durante o primeiro mês, tais visitas tiveram o intuito de conhecer o local de estudo e obter uma maior aproximação com a gestão e os funcionários da área, assim como suas funções, atividades, e visões particulares do setor.

A próxima fase do estudo de caso consistiu na construção de um SIPOC da área de estocagem, visando entender o funcionamento dos micro processos por um panorama geral. A partir de uma visão macro, verificou-se então a necessidade de detalhar passo a passo de cada etapa através do desenvolvimento de fluxogramas, possibilitando a identificação de possíveis falhas ou desperdícios no processo logo no início.

Com o entendimento do processo, conseguiuse compreender o que era esperado dos processos que do local, suas necessidades, falhas e pontos positivos, em resumo, distinguir o que poderia ser considerado anômalo. Com isso, realizou-se uma etapa de observação por um período de 2 semanas. Para isso, alternaram-se os observadores e os horários de visita, buscando coletar dados que realmente correspondessem à realidade. Nessa observação, todos os desperdícios e anomalias visíveis foram devidamente registrados.

Os desperdícios observados foram atrelados aos 7 desperdícios do Lean e contabilizados em um gráfico de Pareto, através do qual identificaram-se os problemas mais críticos observados.

Visando apontar possíveis causas raízes destes problemas, utilizou-se o Diagrama de Ishikawa, desenvolvido pelos alunos juntamente com os funcionários do local. Para cada possível causa raiz encontrada no diagrama, atribuiu-se uma ação, as quais receberam respectivos pesos levando em consideração a rapidez de implementação, o benefício da ação, e o custo atrelado. As ações que obtiveram a maior pontuação são as que trarão melhor custo benefício e, a partir delas, com o desenvolvimento de brainstormings frequentes e aplicações de ferramentas como a Curva $A B C$, sugestões para a implementação dessas ações foram apresentadas para a gestão do hospital.

Ao final do estudo, percebeu-se a necessidade de buscar indicadores confiáveis para melhor controle dos processos internos. Através da ferramenta Voz do cliente, definiram-se alguns indicadores chave, juntamente com as posições desses indicadores no período de execução do trabalho.

\section{RESULTADOS E DISCUSSÕES}

Nesta sessão, serão apresentados os resultados de cada ferramenta utilizada no desenvolvimento do projeto, assim como as propostas de melhorias.

\subsection{IDENTIFICAÇÃO DO PROBLEMA}

A primeira consistiu na elaboração de um SIPOC, possibilitando identificar os processos chave dentro do almoxarifado, como mostra a figura 1. 
Figura 1 - SIPOC do almoxarifado

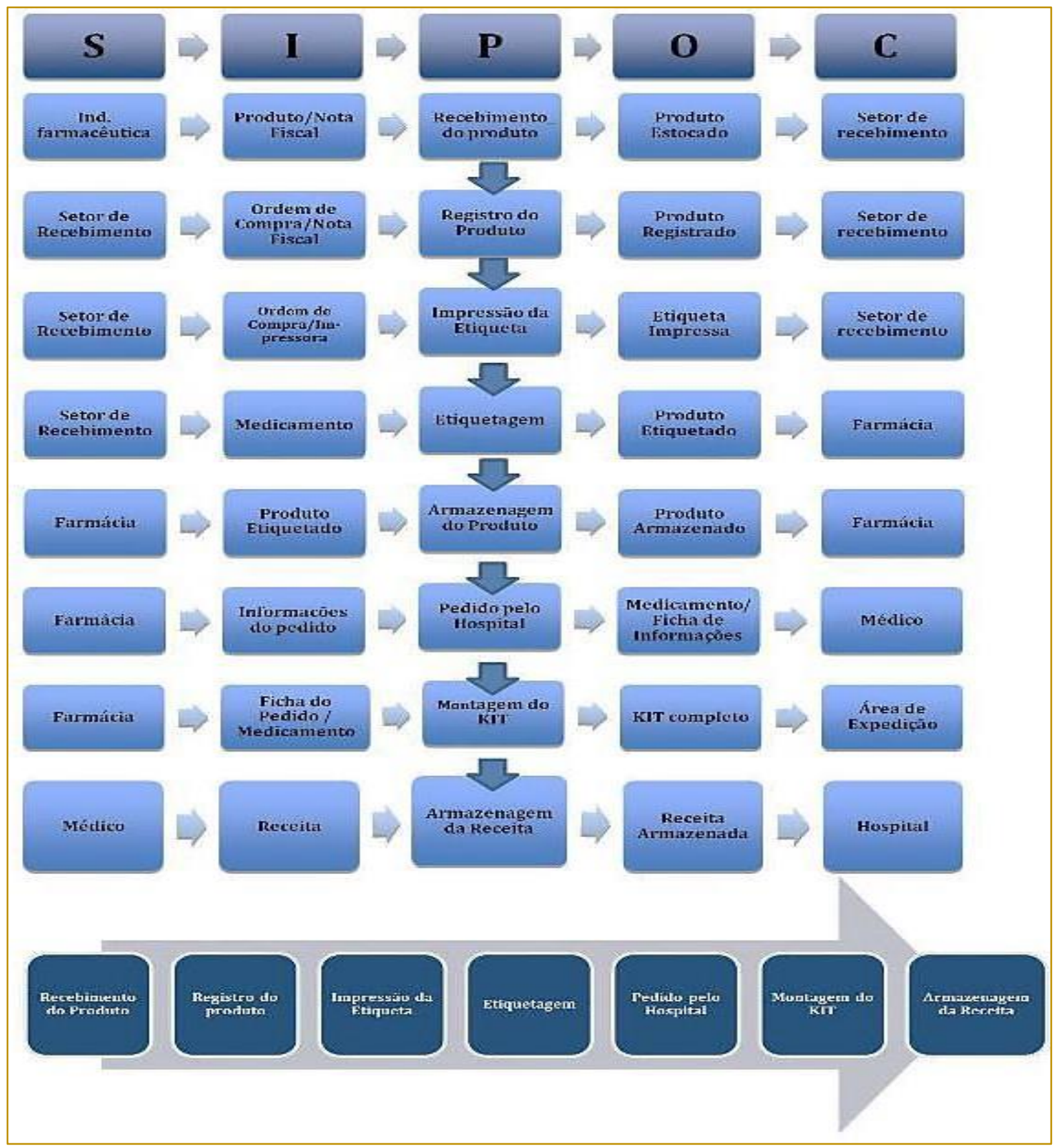

Fonte: Autor (2017)

Com a construção do SIPOC, foram visualizados os seguintes micro processos: recebimento e registro do produto, impressão da etiqueta, armazenagem do produto, pedido pelo hospital, montagem do kit e armazenagem da receita. Assim, pode-se obter uma visão macro dos processos internos, facilitando o desenvolvimento de fluxogramas, onde foram detalhadas a fundo cada atividade.
Foram montados dois fluxogramas: o primeiro refere-se ao processo de recebimentos de produtos até a estocagem dos mesmos. O segundo, à montagem dos kits para entrega às demais áreas do hospital (ver fluxogramas em anexo).

O quadro 2 apresenta alguns exemplos de problemas registrados durante o período de observações, atrelados aos 7 desperdícios conceituais do Lean. 
Quadro 2 - Os sete desperdícios no almoxarifado hospitalar

\begin{tabular}{|l|l|}
\hline \multicolumn{1}{|c|}{ Desperdício } & \multicolumn{1}{c|}{ Exemplos Observados no Almoxarifado hospitalar } \\
\hline 1. $\quad$ Defeitos & $\begin{array}{l}\text { Kits montados incorretamente (Sem etiquetagem/selagem ou com } \\
\text { medicamentos/materiais incorretos) e quebras de medicações; }\end{array}$ \\
\hline 2. $\quad$ Excesso de produção & $\begin{array}{l}\text { Supérfluos produzidos (Impressões, etiquetagens e Kits } \\
\text { duplicados, entre outros); }\end{array}$ \\
\hline 3. $\quad$ Espera & $\begin{array}{l}\text { Áreas à espera de pedidos devido à por falta de Materiais, } \\
\text { ociosidade de funcionários e falta de medicamentos no estoque; }\end{array}$ \\
\hline 4. $\quad$ Transporte & $\begin{array}{l}\text { Deslocamento de objetos, medicamentos e materiais de um lado } \\
\text { para o outro sem necessidade; }\end{array}$ \\
\hline 5. $\quad$ Movimentação & $\begin{array}{l}\text { Funcionários se movimentando excessivamente devido ao Layout } \\
\text { Inadequado, falha na divisão das atividades e falta de } \\
\text { padronização dos processos. }\end{array}$ \\
\hline 6. Processamento & $\begin{array}{l}\text { Atividades ou Etapas que não agregam valor (Atender } \\
\text { telefonemas, impressões desnecessárias, entre outras). }\end{array}$ \\
\hline Inadequado & $\begin{array}{l}\text { Excesso de Material ou Medicamento em Estoque que acabam } \\
\text { impactanto nos custos ou ainda atingindo a data de validade. }\end{array}$ \\
\hline 7. $\quad$ Estoque &
\end{tabular}

Fonte: Autor (2017)

Com os sete desperdícios bem definidos, foi possível uma abordagem quantitativa dos problemas encontrados no Almoxarifado, apresentado no gráfico de Pareto na figura 2.

Figura 2 - Gráfico de Pareto

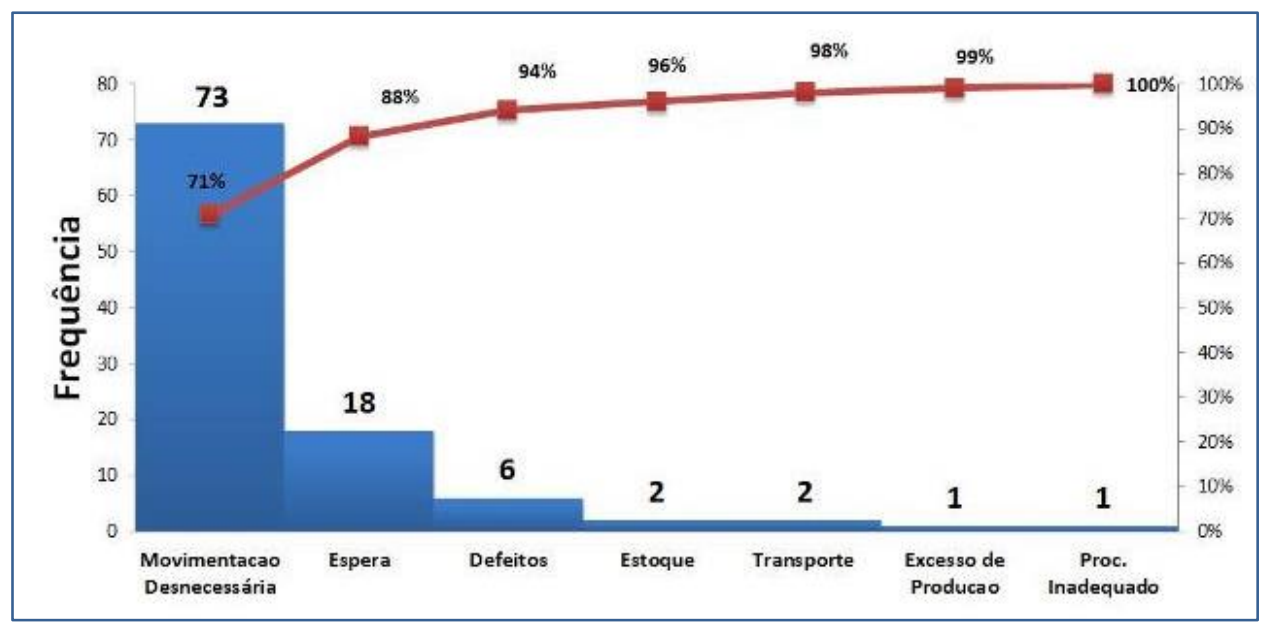

Fonte: Autor (2017)

Visto que apenas dois desperdícios representam $88 \%$ dos desperdícios observados na amostra em estudo, decidiu-se aprofundar a identificação das causas raízes de tais problemas utilizando um diagrama de Ishikawa, apresentado nas figuras 3 e 4. 


\section{9}

Figura 3 - Diagrama de Ishikawa para o desperdício Movimentação Excessiva

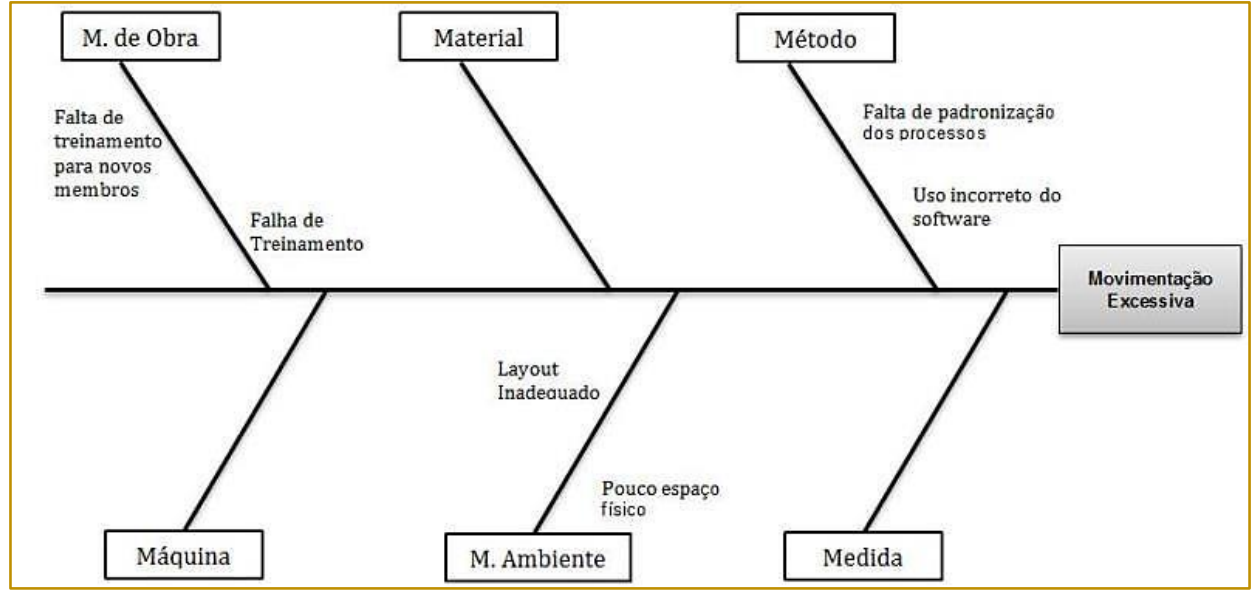

Fonte: Autor (2017)

Figura 4 - Diagrama de /shikawa para o desperdício Espera

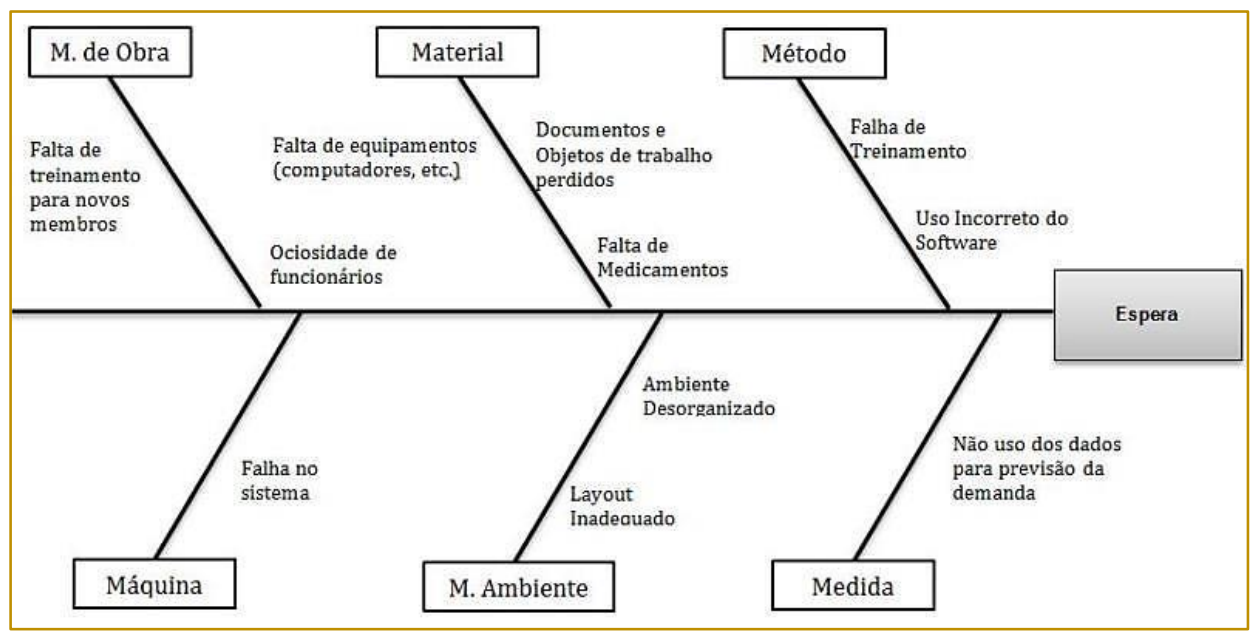

Fonte: Autor (2017)

\subsection{SUGESTÕES DE MELHORIA}

Através das causas raízes hipotéticas obtidas no diagrama de Ishikawa, analisou-se qual tipo de melhoria traria mais benefícios ao setor, visando o uso do mínimo possível de recursos. A matriz de priorização utilizada está apresentada no quadro 3.

Feita a análise da matriz de priorização, foram propostas as ações com potencial mais assertivo, sendo elas:
a) Execução da gestão do Estoque;
b) Realização da previsão da demanda;
c) Padronização dos processos;
d) Capacitação e treinamento adequados;
e) Divisão das tarefas de maneira correta;
f) Adequação do layout. 
Quadro 3 - Matriz de priorização

\begin{tabular}{|c|c|c|c|c|c|}
\hline Causa Raiz & Ação & Rapidez & Beneficio & Custo & Peso \\
\hline Falta de Medicamentos & Executar a gestão do estoque & 4 & 4 & 4 & 64 \\
\hline Layout Inadequado & Adequação do Layout & 3 & 3 & 4 & 36 \\
\hline $\begin{array}{c}\text { Não uso dos dados para } \\
\text { previsão da demanda }\end{array}$ & Realizar a previsão da demanda & 2 & 4 & 4 & 32 \\
\hline $\begin{array}{c}\text { Falta de padronização dos } \\
\text { processos }\end{array}$ & Padronização dos processos & 2 & 4 & 4 & 32 \\
\hline Ociosidade de Funcionários & Divisão correta de tarefas & 2 & 4 & 4 & 32 \\
\hline Falha ou falta de treinamento & $\begin{array}{c}\text { Capacitação e Treinamento } \\
\text { adequados }\end{array}$ & 3 & 3 & 3 & 27 \\
\hline Documentos e Objetos perdidos & Organização do ambiente - 5S & 3 & 2 & 4 & 24 \\
\hline Ambiente Desorganizado & $\begin{array}{c}\text { Organização do ambiente de } \\
\text { trabalho-5S }\end{array}$ & 3 & 2 & 4 & 24 \\
\hline Falhas no Sistema & $\begin{array}{c}\text { Manutenção preventiva nos } \\
\text { servidores }\end{array}$ & 2 & 2 & 2 & 8 \\
\hline Uso incorreto do software & $\begin{array}{c}\text { Treinamento para uso do } \\
\text { Software }\end{array}$ & 1 & 2 & 3 & 6 \\
\hline Falta de Equipamentos & $\begin{array}{c}\text { Aquisição de novos } \\
\text { Equipamentos }\end{array}$ & 3 & 1 & 1 & 3 \\
\hline Pouco espaço fisico & Ampliação do local & 1 & 2 & 1 & 2 \\
\hline
\end{tabular}

Fonte: Autor (2017)

\subsubsection{PRIMEIRAS OBSERVAÇÕES A PARTIR DOS FLUXOGRAMAS}

\subsubsection{FLUXOGRAMA 1: DO RECEBIMENTO ATÉ A ESTOCAGEM IDEAL (VER ANEXO 1)}

Com o novo mapa de processo para recebimento e estocagem, o setor de recebimento seria dividido em duas equipes: a de recebimento e a de etiquetagem. A primeira seria responsável por receber e conferir o produto, bem como a sua nota fiscal, contatar o setor de compras caso haja alguma irregularidade, lança-lo no sistema operacional, emitir etiquetas, elaborando um relatório de entrada de produto e nota fiscal, que devera ser encaminhado para a tesouraria e, por fim, realizar o encaminhamento de produtos para o setor de etiquetagem. A segunda realizaria não só o processo de etiquetagem propriamente dita, como de reposição e organização de materiais.

O bloco de anotações especifico de controle seria excluído para que todo produto seja registrado eletronicamente, visando o maior controle de produtos em estoque e evitando gastos com papel.

\subsubsection{FLUXOGRAMA 2: DO PEDIDO ATÉ A ENTREGA DO KIT (VER ANEXO 2)}

Deve-se priorizar a ordem de montagem dos kits pelo horário de chegada do pedido na impressora. Todo kit, sem exceção, deve ser selado para que não haja perigo de troca de medicamento ou perda, por quebra ou extravio. A falta de medicamento e/ou material deve ser registrada no sistema operacional a fim de ser contabilizada para posterior ajuste de estoque ou aderência na lista de produtos padrão.

\subsubsection{PREVISÃO DA DEMANDA E EXECUÇÃO DA GESTÃO DE ESTOQUE}

A previsão da demanda e execução da gestão de estoque estão diretamente interligadas e, portanto, serão abordadas de forma conjunta.

Com o auxílio da classificação ABC, mostrada no quadro 4, podemos observar que $17 \%$ da variedade dos produtos em estoque, são responsáveis por $75 \%$ do capital investido neste, ou seja, aproximadamente $R \$$ 210.000,00 em uma ínfima quantidade de produtos. 
Quadro 4 - Classificação ABC dos produtos no estoque hospitalar

\begin{tabular}{|c|c|c|rr|c|}
\hline Classificação & No de Produtos & $\begin{array}{c}\text { Percentual de } \\
\text { Produtos }\end{array}$ & $\begin{array}{c}\text { Capital } \\
\text { Representativo }\end{array}$ & $\begin{array}{c}\text { Percentual } \\
\text { do Capital }\end{array}$ \\
\hline A & 206 & $17 \%$ & R $\$$ & 210.827 & $75 \%$ \\
\hline B & 389 & $33 \%$ & RS & 56.434 & $20 \%$ \\
\hline C & 590 & $50 \%$ & R $\$$ & 14.066 & $5 \%$ \\
\hline Total & 1185 & $100 \%$ & RS & 281.328 & $100 \%$ \\
\hline
\end{tabular}

Fonte: Autor (2017)

Analisando o gráfico da figura 5, mostra-se de suma importância o foco na redução da quantidade destes produtos classe A. Para tais produtos serão definidos novos limites máximos e mínimos para suas respectivas quantidades no estoque com base em uma demanda histórica de 3 meses, levando em consideração um período padrão de compras.

Figura 5 - Gráfico da classificação ABC

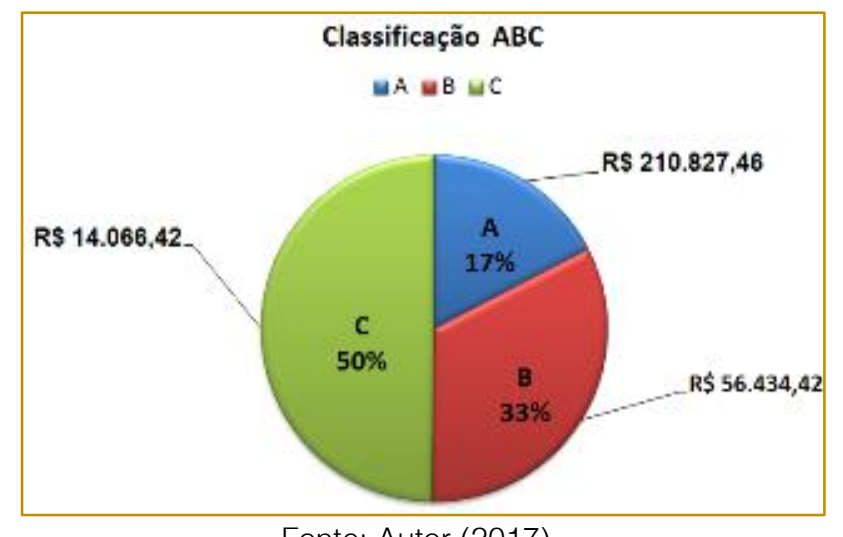

Fonte: Autor (2017)

A fim de eliminar as quantidades excessivas de produtos no estoque, sugere-se utilizem o sistema de gestão hospitalar para calcular ao menos 1 vez por mês as quantidades de estoque máximas e mínimas para os produtos da classe $A$, visto que a média mensal de consumo de produtos varia e, devido a isso, percebeu-se tal necessidade.

Para manter o estoque na quantidade ideal, deve atentar-se ao momento de realização da compra de cada produto. O relatório de Posição de Estoque irá ajudar o comprador a definir o que realmente precisa ser comprado e o que se julga desnecessário. Sugere-se que o mesmo será salvo em PDF, para se evitar gastos excessivos com impressão, além da facilidade da busca de algum medicamento no documento digital.

Alguns produtos considerados exceções, como produtos críticos ou com baixa rotatividade deverão ser avaliados pelo comprador, devido à incapacidade de padronização da compra de todos os insumos hospitalares.

\subsubsection{PADRONIZAÇÃO DOS PROCESSOS}

Padronizar todos os processos é inevitável para um melhor desempenho da equipe. Identificaram-se os seguintes processos com deficiências de padronização:
a) Montagem dos Kits;
b) Etiquetagem;
c) Recebimento de materiais/medicamentos;
d) Estocagem dos materiais/medicamentos.

Com a padronização destes processos, anomalias como tempos de espera, movimentos desnecessários e erros serão, em sua grande parte, evitados, impactando na satisfação dos clientes diretos e indiretos do almoxarifado. 
Toda a padronização deve ser documentada e executada conforme a descrição de instruções de trabalho.

\subsubsection{CAPACITAÇÃO E TREINAMENTO ADEQUADOS}

Para o tratamento desta anomalia, recomenda-se o uso da polivalência. Além de possibilitar uma flexibilidade produtiva e uma redução nas doenças do trabalho por esforços repetitivos, a polivalência possibilita um maior engajamento do time em relação aos objetivos globais.

O conhecimento da maior parte dos processos por toda equipe, ou parte dela, é de extrema importância para aperfeiçoar e qualificar as atividades.

A proposta é que equipes de treinamento se renovem e possam ser montadas e geridas por um líder responsável por passar o conhecimento aos outros integrantes, funcionários de diferentes áreas do hospital, promovendo uma troca de experiências e conhecimentos necessários para o entendimento dos processos.

O processo de treinamento deve-se seguir as seguintes etapas:

a) Analisar condições antes do treinamento (perfil dos treinados, motivação, précondições do ambiente);

b) Modelos e estratégias de treinamento (Ex.: aprendizagem específica, treinamento à distância, jogos, etc.);

c) Condições pós-treinamento (retenção e transferência do conhecimento).

\subsubsection{ADEQUAÇÃO DO LAYOUT}

O atual layout do almoxarifado não apresenta um fluxo contínuo fazendo com que os funcionários realizem movimentos desnecessários ao realizar as tarefas propostas. Segue na figura 6 uma representação do atual layout.

Figura 6 - Layout atual do almoxarifado

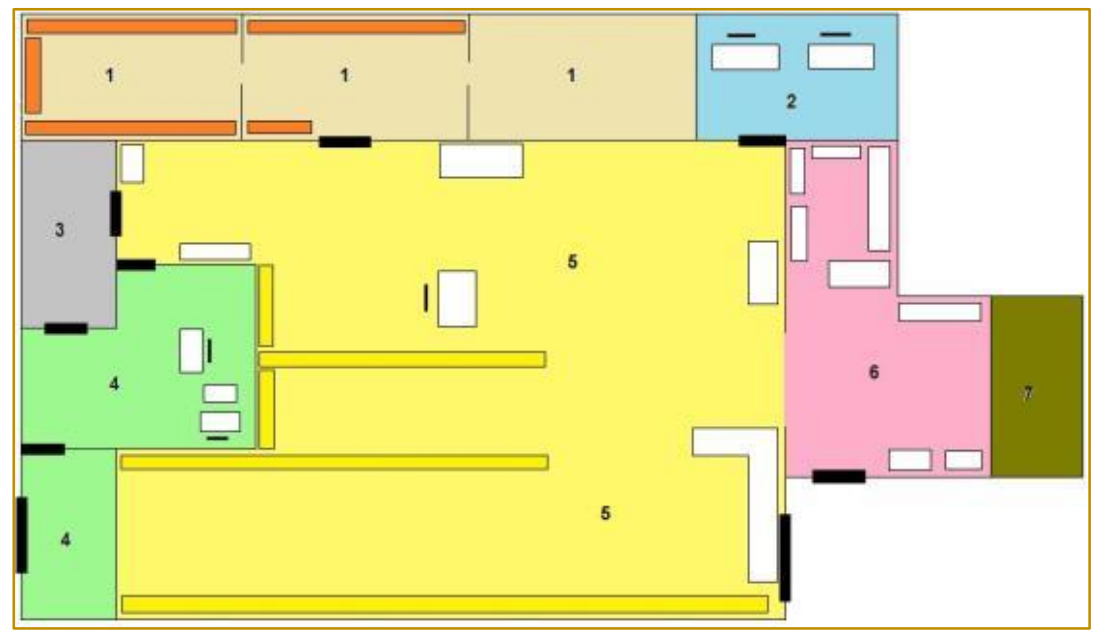

Fonte: Autor (2017) 
A farmácia foi dividida por áreas separadas por cores para que fique claro onde as alterações devem ser feitas. A área 1 se trata do almoxarifado, onde se encontram produtos de limpeza, materiais de escritório e que serve também de depósito para soro principalmente que é comprado em grande quantidade. A área 2 é o setor de compras, onde se encontram mesas e computadores que servem de instrumento de trabalho para os compradores. A área 3 soma os banheiros feminino e masculino. A área 4 é de recebimento das compras, nela ocorre a confecção das etiquetas e confirmação da conformidade do medicamento ou produto comprado. Na área 5 se encontram todos os medicamentos devidamente etiquetados, prontos para serem colocados nos kits e enviados aos pacientes. $\mathrm{Na}$ área 6 ocorre $\mathrm{O}$ processo de etiquetagem e na área 7 se encontra a sala de fracionamento. As figuras em branco na imagem se referem a armários, mesas e balcões e as fileiras em amarelo e laranja mais fortes representam as prateleiras.

De acordo com o fluxo citado anteriormente neste relatório e a análise do atual layout pode-se perceber a necessidade e viabilidade de levar o processo de etiquetagem para a área 4, uma vez que o produto é recebido nessa área e já sairia dela etiquetado e pronto para ser colocado em estoque na área 5 , sem a necessidade de ir para a área 6 e lá ficar parado. A área 6 seria destinada para deixar os kits montados separados pela divisão correspondente do hospital para que a entregadora tenha mais facilidade ao busca-los. Ela poderia também ser destinada para armazenamento em caso de muitos medicamentos chegando ao mesmo tempo.

A figura 7 representa o novo layout proposto, destacando as mudanças feitas acerca do processo de etiquetagem.

Figura 7 - Novo layout proposto para o almoxarifado

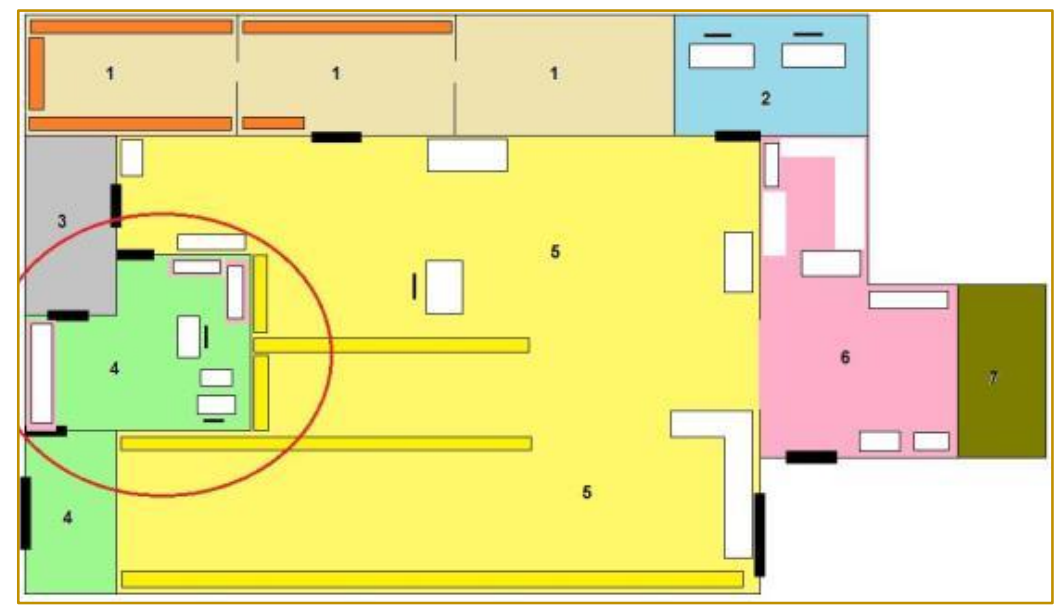

Fonte: Autor (2017)

O novo layout tem a proposta de melhor aproveitamento do ambiente além de não segmentar a tarefa de etiquetagem entre impressão e somente depois em outra área e por outra pessoa a colocação. Dessa forma a etiquetagem pode ser feita a qualquer momento sem atrapalhar as atividades de entrega dos kits.

\subsection{DEFINIÇÃO DE INDICADORES}

Através da ferramenta Voz do cliente apresentado na figura 8, levantaram-se alguns indicadores para observação de acordo com a necessidade do almoxarifado.

Os seguintes indicadores foram levantados:

a) Tempo médio de entrega do medicamento (em minutos)

b) Perda de medicamentos por quebra ou validade vencida em reais $(R \$)$

c) Capital parado em estoque em reais. 
Figura 8 - Voz do Cliente

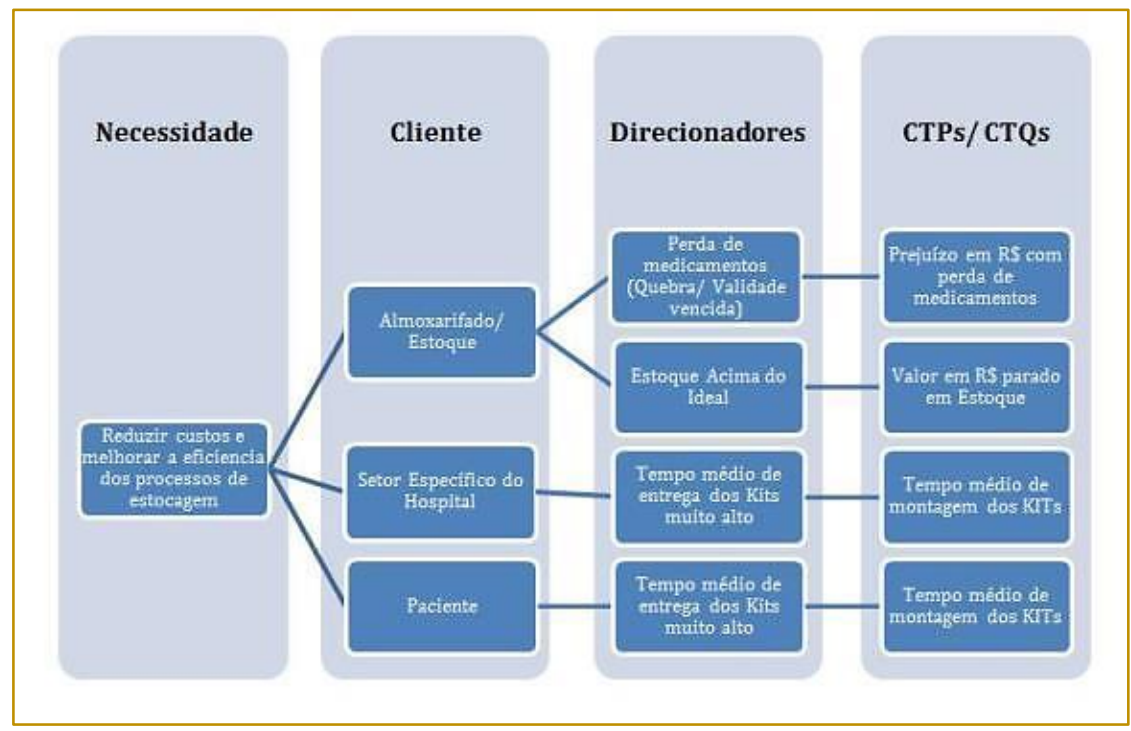

Fonte: Autor (2017)

\subsubsection{SITUAÇÃO DOS INDICADORES}

a) Perda com medicamentos no almoxarifado no último ano: $\mathrm{R} \$ 6.953,00$;

b) Tempo médio mensal de entrega dos Kits: 1 h10 min;

c) Capital em Estoque: $\mathrm{R} \$ 281.328,34$;
A proposta final seria um acompanhamento mês a mês destes indicadores, para verificação de uma evolução ou ainda identificação de anomalias do processo.

Vamos tomar como exemplo o acompanhamento mensal do prejuízo com a perda de medicamentos, apresentado na figura 9 .

Figura 9 - Gráfico representativo da perda de medicamentos

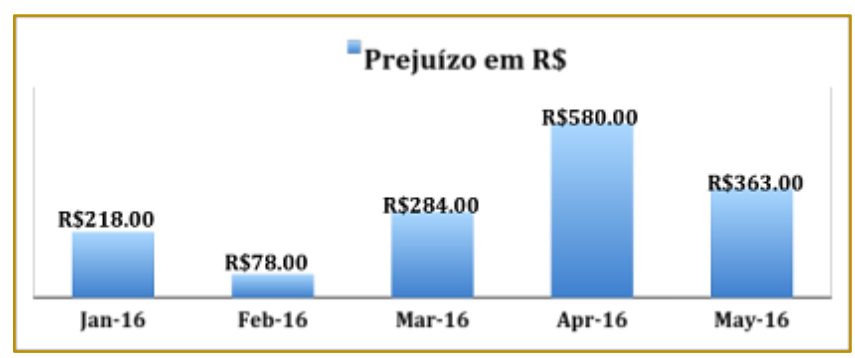

Fonte: Autor (2017)

Com esta análise, sugere-se, por exemplo, à gestão hospitalar estudar quais os fatores que levaram a um aumento do valor com perdas no mês de Abril (Motivos, tipos de medicamentos, datas específicas) e sanar tais problemas para reduções do valor no mês subsequente.

Da mesma maneira podem ser tratados os outros 2 indicadores relevantes, de forma a manter um processo eficiente e uma gestão saudável de todo o processo, dando 0 tratamento adequado à anomalias que surgirem.

\section{CONSIDERAÇÕES FINAIS}

O atual cenário macroeconômico e as crescentes exigências por qualidade e produtividade têm levado as organizações a repensarem seus processos em busca da redução de falhas e desperdícios. A aplicação do Lean Healthcare torna-se de 
suma importância para a indústria hospitalar, possibilitando a identificação e posteriormente eliminação de desperdícios.

A execução do planejamento para compra de insumos também se torna relevante, e exige o uso dos principais conceitos de gestão de estoques junto ao sistema de MRP instalado no local. O principal foco do planejamento de compras é atender a demanda e evitar o estoque excessivo (considerado um tipo de custo)

Assim sendo, o presente estudo de caso visou demonstrar como é possível o uso de ferramentas do Lean no setor hospitalar, a

\section{REFERÊNCIAS}

[1] Gupta, P., SRI, A., Seis sigma: Virtualmente sem Estatística, Porto: Vida Econômica, 2012.

[2] Eiro, N.Y.; Junior, A.S.T. Comparação entre modelos da qualidade total e Lean Production aplicados à área da saúde - Estudo de caso em serviço de medicina diagnóstica. SIMPOI, 2013. Disponível em: http://www.simpoi.fgvsp.br/arquivo/2013/artigos/E2 013_T00189_PCN11269.pdf> Acesso em: 05/05/2017

[3] Graban, M. Lean Hospitals - Improving Quality, Patient Safety, and Employee Satisfaction. Nova lorque: Taylor \& Francis Group, 2009.

[4] Lean Institute Brasil. Os 5 princípios do lean thinking (mentalidade enxuta). Disponivel em: $<$ http://www.lean.org.br/colunas/13/gilbertokosaka. aspx id=28\&c=13>. Acesso em: 01/05/17.

[5] Liker, J. K. O Modelo Toyota: 14 princípios de gestão do maior fabricante do mundo. Tradução de Lene Belon Ribeiro. Porto Alegre, Bookman, 2005.

[6] Fundaç̄ô Oswaldo Cruz. Erro em hospital é evitável em 73\% dos casos no Brasil. Folha de S. Paulo, 2013. Disponivel em: <http://www1.folha.uol.com.br/fsp/saudeciencia/12 1178-erro-em-hospital-e-evitavel-em-73-dos-casosno- brasil.shtml> Acesso em: 01/05/2017.

[7] Jacobs, F.R., Chase, R.B., Administração de operações e da cadeia de suprimentos, 13a Ed., Porto Alegre: AMGH Editora, 2012. partir do aporte teórico adotado para a pesquisa.

Observou-se que o almoxarifado hospitalar em estudo apresenta uma defasagem quanto aos processos gestão do estoque e previsão da demanda, padronização dos processos, capacitação e divisão de atividades entre os funcionários, além de algumas falhas no layout físico

Assim, vê-se que o objetivo deste estudo de caso foi atingido pelo uso do Lean Healthcare, uma vez que foram identificados diversos desperdícios e falhas de processo, sendo propostas sugestões de melhoria com base nesta filosofia.

[8] Nazareno, R. R. Desenvolvimento de sistemas híbridos de planejamento e programação da produção com foco na implantação de manufatura enxuta. Dissertação (Mestrado) Escola de Engenharia de São Carlos, Universidade de São Paulo. São Carlos, 2008.

[9] Neto, C.R.L.M.; Terra, J.C.; Klajner, S.; Lottenberg, C.L. Abordagem sistêmica para criar valor ao paciente. Harvard Business Review Brasil, 2016. Disponível em: < http://hbrbr.uol.com.br/abordagem-sistemica-paracriar-valor-ao-paciente/>. Acesso em: 08/05/2017.

[10] Peinado, J.; Graeml, A. R. Administração da produção: operações industriais e de serviços. Curitiba: UnicenP, 2007.

[11] Pozo,H. Administração de recursos

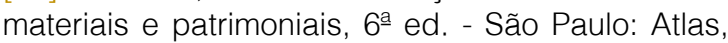
2010 .

[12] Rosa, B.H.; LUZ, T.B.S; DIAS, R.S.B.; Peralta, C.B.L. A abordagem Lean Healthcare: uma revisão bibliográfica sistemática. ENEGEP, 2016.

[13] Shingo, S. O Sistema Toyota de Produção do ponto de vista da engenharia de produção. Porto Alegre, Bookman, 1996

[14] Womack, J. P.; Jones, D. T. Lean Thinking - banish waste and create wealth in you corporation. New York, Simon \& Schuster, 1996.

[15] Womack, J. P.; Jones, D. T.; Roos, D. A Máquina que Mudou o Mundo. Campus, Rio de Janeiro, 1992. 


\section{6}

ANEXOS

Anexo1: Fluxograma 1: Do Recebimento Até A Estocagem Ideal

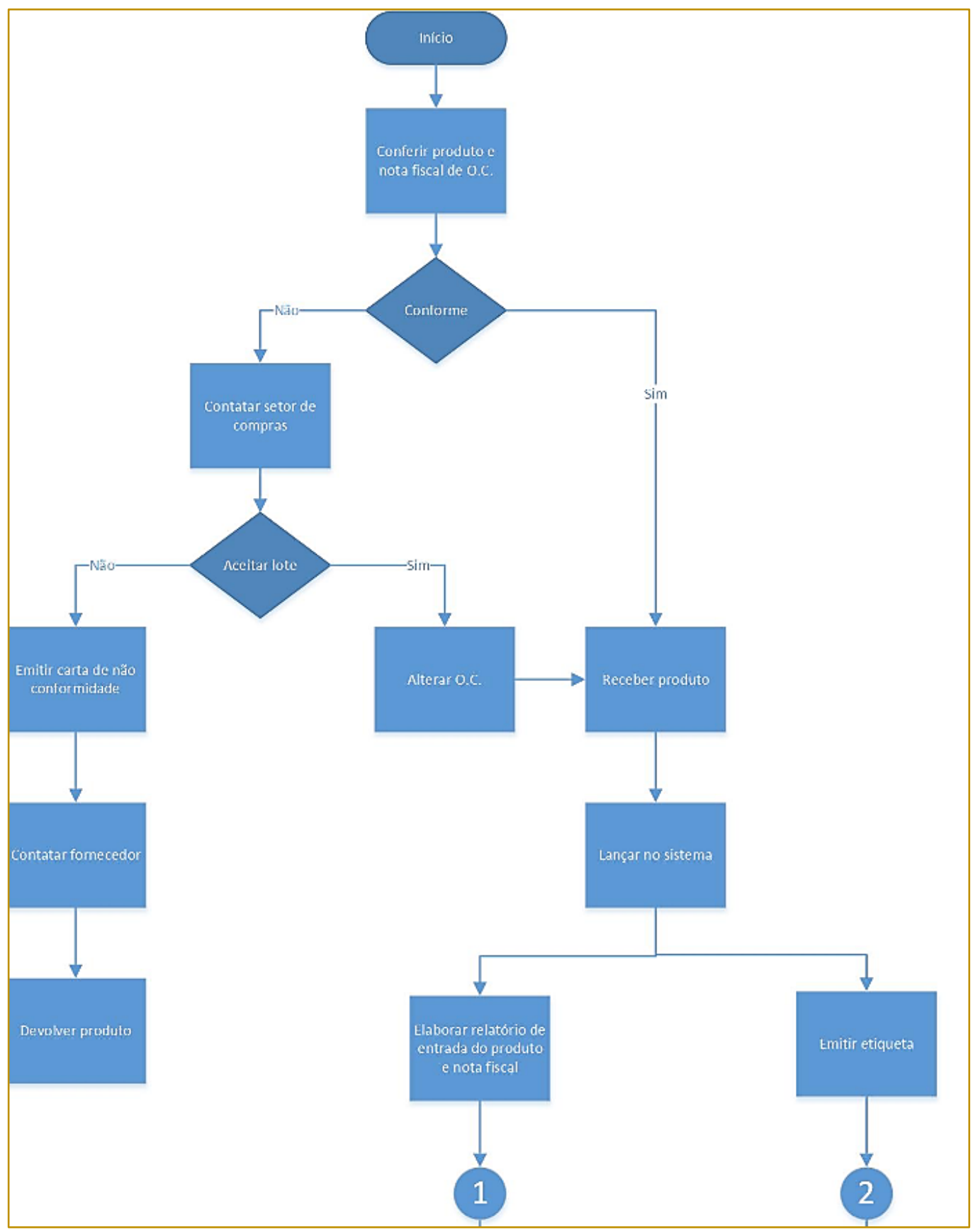

Fonte: Autor (2017) 


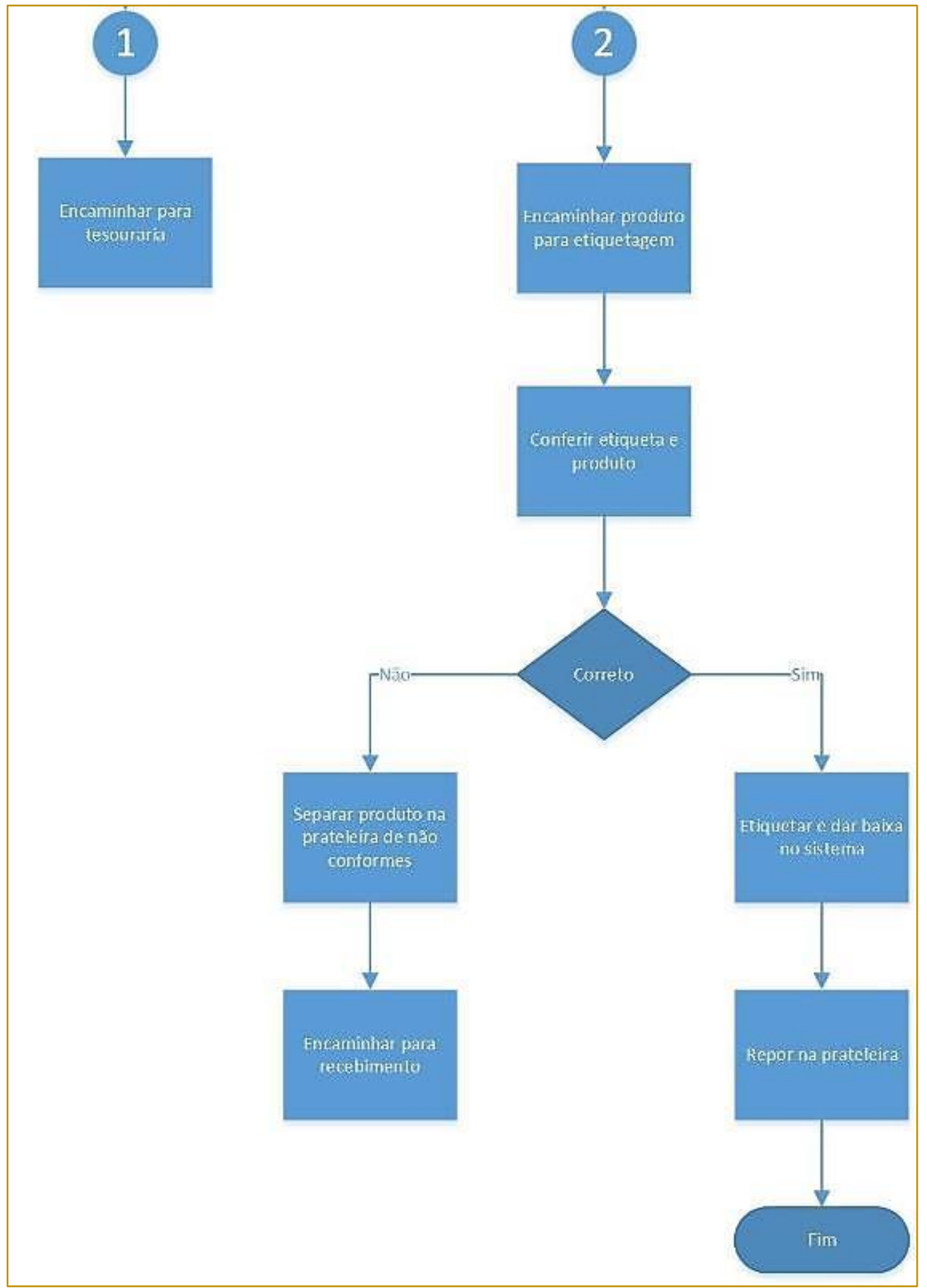

Fonte: Autor (2017) 
Anexo 2: Fluxograma 2: do pedido até a entrega do kit

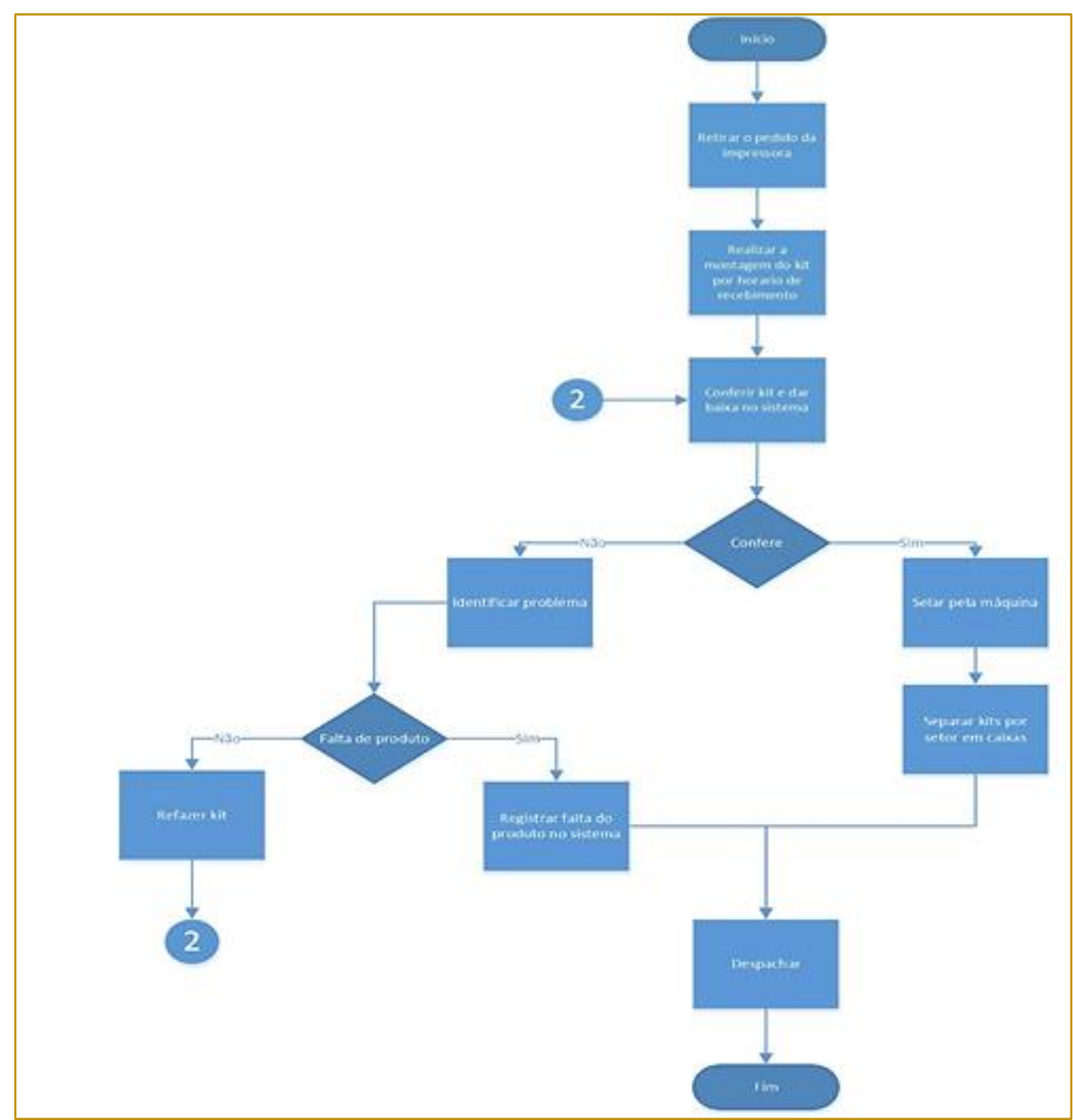

Fonte: Autor (2017) 


\section{Bapítulo 5}

\section{ESTUDO APLICADO DE LEAN HEALTHCARE EM UM HOSPITAL}

Rosangela da Rosa da Silva

Ismael Cristofer Baierle

Cristiano Roos

Resumo: O lean healthcare está continuamente se destacando como uma alternativa para a obtenção de uma melhor eficiência em processos de serviços ligados a saúde. De modo geral, isto ocorre por meio da redução de desperdícios e do aumento da qualidade em processos na área da saúde. Em vista disto, o objetivo deste trabalho é propor por meio do lean healthcare soluções relevantes para problemas detectados em um processo de dispensação de medicamentos em uma farmácia hospitalar. Os principais problemas práticos detectados foram atrasos na entrega de medicamentos, fatos que muitas vezes afetavam o atendimento ao paciente. Como procedimentos metodológicos tem-se uma pesquisa descritiva com abordagem qualitativa, tendo sido desenvolvida uma pesquisa-ação. A principal técnica da filosofia enxuta utilizada foi o mapeamento do fluxo de valor, a fim de avaliar o processo atual e propor melhorias com o mapa do estado futuro. Também foi utilizada a análise e otimização de leiaute para sustentar uma das proposições de melhoria mais significativas, que foi a mudança do arranjo físico dos locais de trabalho. Entre as melhorias propostas está a redução do lead time, da movimentação desnecessária e do estoque em processo, entre outras propostas que poderão reduzir desperdícios e proporcionar maior qualidade de trabalho, maior segurança e organização no atendimento aos pacientes. Assim, cabe destacar que este trabalho pode ser útil para profissionais que gerenciam farmácias hospitalares, bem como, para aqueles que buscam estudos aplicados em lean healthcare. De todo modo, esta pesquisa atingiu o objetivo inicialmente proposto. 


\section{INTRODUÇÃO}

O lean healthcare tem se mostrado cada vez mais como um meio prático e eficaz para alcançar processos de prestação de serviços em saúde mais eficientes. O lean healthcare pode ser definido como uma abordagem que minimiza riscos, acidentes e custos, possibilitando um aumento da qualidade do atendimento, da segurança e do bem-estar dos pacientes (LEAN INSTITUTE BRASIL, 2016).

O presente trabalho tem como tema o lean healthcare aplicado a processos de dispensação farmacêutica hospitalar. Esse tema está relacionado ao problema de pesquisa de ordem prática que originou este trabalho. Na prática foram detectados atrasos em um processo de dispensação de medicamentos dentro de uma farmácia de um hospital universitário. Este era um problema que interferia na rotina de trabalho, em consequência disso, algumas vezes, interferia no atendimento ao paciente.

Neste contexto, o objetivo geral deste trabalho é propor por meio do lean healthcare soluções relevantes para problemas detectados em um processo de dispensação de medicamentos em uma farmácia hospitalar. Os problemas serão novamente abordados na seção quatro deste artigo, onde se descreverá o estudo de campo realizado. A seção cinco trará as melhorias propostas e a seção seis apresentará as considerações finais da pesquisa. Antes disso, na seção dois apresentar-se-á o referencial teórico do trabalho e na seção três explicar-se-á o método de pesquisa utilizado.

\section{REFERENCIAL TEÓRICO}

Inicialmente nesta seção se fará uma contextualização do método lean healthcare e posteriormente se trará da literatura qualificada trabalhos que apresentam aplicações deste método.

\subsection{LEAN HEALTHCARE}

O pensamento e a prática lean na área da saúde proporcionam a criação de valor com menor desperdício de recursos e maior qualidade no atendimento aos pacientes (LEAN INSTITUTE BRASIL, 2016). Foi a partir dos anos 2000 que os primeiros hospitais dos Estados Unidos, da Europa e da Austrália começaram a explorar o lean (JONES, 2015).
Conceitos, técnicas e ferramentas, que por muito tempo inspiraram organizações de diversos setores, hoje se encontram metodologicamente adaptadas para o ambiente de saúde, o qual possui características distintas e requer atenção apropriada (LEAN INSTITUTE BRASIL, 2016).

Foi em 2007 que organizações pioneiras no uso do lean healthcare reuniram-se para compartilhar suas histórias no primeiro Global Lean Healthcare Summit, evento que visa à troca de conhecimentos e experiências sobre o tema, ocorrido no Reino Unido, que, por sua vez, deu início a muitos outros experimentos nesta área ao redor do mundo (JONES, 2015). Hoje em dia, princípios lean são conhecidos em todo o mundo e aplicações podem chegar muito além da produção de bens, serviços e entregas de cuidados médicos (SOUZA, 2009).

$\mathrm{Na}$ indústria, onde tradicionalmente se utiliza o lean manufacturing, o produto é um bem material, já no ambiente hospitalar, o produto é o serviço. Apesar do lean office ser uma adaptação das técnicas da produção enxuta ao setor terciário, na área de saúde, algumas ferramentas não são aplicadas da mesma forma (COSTA; MONTE; ESPOSTO, 2015). Os níveis de implementação de lean na área de saúde podem ser vistos como um único serviço ou um conjunto de ferramentas com o objetivo de remover os resíduos detectados (JORMA et al., 2016). Para complementar isto, na sequência são apresentados alguns trabalhos aplicados.

\subsection{TRABALHOS NA ÁREA DE LEAN HEALTHCARE}

O lean healthcare traz benefícios para organizações da área de saúde tanto no Brasil quanto em outros países do mundo. Possui um grande potencial de contribuição para o desempenho do setor de saúde. Faria (2013) comprova esta afirmação através de uma pesquisa aprofundada sobre o tema na literatura, onde verifica que a produção enxuta na área da saúde apresenta potencialidades claras de melhorias para o setor.

A fim de comprovar e analisar a eficiência de implementação da filosofia lean healthcare, alguns autores se propuseram a investigar na literatura casos de utilização da técnica. Bertani (2012) analisou alguns trabalhos e comprovou que a técnica lean healthcare é 
uma realidade para hospitais e que pode ser aplicada em várias áreas hospitalares, com ferramentas eficientes para melhorar os procedimentos e reduzir os custos. Andreamatteo et al. (2015) analisaram 243 artigos sobre o tema e mostraram que lean é um meio eficaz de aumentar a produtividade e que os Estados Unidos é o país líder em número de aplicações.

No Pronto Atendimento de lowa, nos Estados Unidos, o hospital reduziu em aproximadamente $50 \%$ (de 51 minutos para 25 minutos) o tempo médio de duração dos exames radiológicos, que era o principal "gargalo" detectado no processo, permitindo elevar a satisfação dos pacientes de $38 \%$ para 95\% (BATTAGLIA, 2010). Dávila e Gozález (2015) realizaram um estudo de três áreas hospitalares com o objetivo de avaliar se a aplicação da metodologia lean reduziria o desperdício e agregaria valor para o cliente. Um dos resultados obtidos foi que, após a implementação da ferramenta kanban, o custo do material armazenado caiu em $43 \%$ ao se comparar o custo total de 2012 com o de 2011.

O médico oncologista clínico Carlos Frederico Pinto, diretor da Sociedade Brasileira de Oncologia Clínica (SBOC), após participação no Global Lean Healthcare Summit afirmou que o conhecimento lean na área da saúde pode trazer benefícios imensos para instituições públicas e privadas no Brasil (BATTAGLIA, 2010).

Ainda, no estado de São Paulo, Oliveira (2014) desenvolveu uma proposta de aplicação de algumas ferramentas do lean healthcare, como mapeamento do estado atual e futuro, cinco porquês, kaizen e padronização do trabalho na gestão da logística hospitalar, em uma unidade de um laboratório público de ensino do interior do estado. Também em um hospital de São Paulo, Fabbri (2011) desenvolveu uma pesquisa para mostrar que é viável praticar lean healthcare em hospitais brasileiros e os resultados comprovaram que é benéfica e possível sua aplicação no país.

Uma das técnicas do sistema lean utilizadas por Costa, Ferreira e Leal (2015) foi o mapeamento de fluxo de valor em uma unidade hospitalar. O mapa do estado atual e do estado futuro, do fluxo do atendimento nos consultórios, permitiu identificar os processos que agregavam ou não valor, e assim, eliminar desperdícios e melhorar o atendimento aos pacientes. Costa, Monte e Esposto (2015) também utilizaram esta técnica em uma farmácia hospitalar do interior de São Paulo, para avaliar oportunidades de melhoria do fluxo atual, e propor soluções para o setor, obtendo resultados satisfatórios na pesquisa.

Valente, Esteve e Rosado (2012) identificaram através do lean, em uma farmácia hospitalar, medidas e formas para reduzir o desperdício, diminuindo os custos e formulando propostas para a estruturação de um modelo de custos que permita identificar fatores de racionalização e reajustamento. Abdelhadi e Shakoor (2014) obtiveram resultados satisfatórios na utilização do lean healthcare em uma farmácia hospitalar e ambulatorial de um grande hospital regional da Arábia Saudita, como um método para melhorar a qualidade do serviço e reduzir o tempo necessário para fornecer o medicamento.

Carvalho e Alves (2012) implementaram o pensamento lean para identificar desperdícios em um processo de dispensação de medicação hospitalar e propuseram melhorias para diminuir ou eliminar completamente os desperdícios identificados. Os autores concluíram que o processo de dispensação hospitalar é influenciado por diversos agentes que causam desperdício, principalmente tempos de espera, movimentos desnecessários e o processamento inapropriado.

Com este referencial teórico pode-se verificar que o lean healthcare demonstra ser uma importante técnica para a identificação e proposição de melhorias em uma dispensação farmacêutica hospitalar. Assim, pode-se afirmar a partir de outras pesquisas científicas que o lean healthcare mostra-se adequado para o problema de pesquisa que originou este trabalho e que há viabilidade de realização do objetivo proposto na introdução deste texto.

\section{PROCEDIMENTOS METODOLÓGICOS}

Nesta seção apresentar-se-á resumidamente o cenário, a classificação e as etapas da pesquisa.

\subsection{CENÁRIO DA PESQUISA}

Esta pesquisa prática e aplicada foi desenvolvida em uma farmácia de um hospital universitário federal localizado na região 
central do estado do Rio Grande do Sul. O setor específico em estudo neste trabalho é a dispensação de medicamentos. Trata-se da etapa final do processo dentro da farmácia hospitalar, onde o propósito é enviar medicamentos individualizados para os pacientes internados nas unidades assistenciais hospitalares.

\subsection{CLASSIFICAÇÃO DA PESQUISA}

Esta pesquisa é classificada quanto à natureza como aplicada, pois visa à aquisição de conhecimentos para realizar uma aplicação prática em processos farmacêuticos hospitalares. Quanto aos objetivos, é uma pesquisa descritiva, pois, de acordo com a definição de Gil (2009), é desenvolvida para proporcionar uma ampla descrição de um fenômeno em seu contexto e procura fornecer respostas a problemas do tipo "o que" e "como". Quanto aos procedimentos técnicos, uma pesquisa-ação, pois, envolverá a ação da autora, ou seja, seguindo a definição de Gil (2010), tem características situacionais, já que procura diagnosticar um problema específico numa situação específica, para alcançar um resultado prático.

Em relação à abordagem de pesquisa é classificada como qualitativa, pois as informações obtidas serão de acordo com perspectivas dos indivíduos, bem como interpretar o ambiente em que o problema acontece. Por fim, quanto ao método de pesquisa, é dedutivo, porque partirá de métodos genéricos para concluir questões particulares e específicas.

\subsection{ETAPAS DA PESQUISA}

Inicialmente foram realizadas as etapas com exigência teórica, ou seja, a introdução, o referencial teórico e os procedimentos metodológicos. As etapas seguintes foram mais práticas, isto é, a realização da coleta e da análise de dados, utilizando as técnicas científicas da pesquisa-ação para abordar o tema em estudo.

Seguindo o protocolo de coleta de dados elaborado, inicialmente foi mapeado o processo e na sequência foram realizadas observações e entrevistas informais com as funcionárias e as chefias do setor de dispensação de medicamentos. Isto foi realizado para se conhecer e identificar os problemas do processo, bem como as possíveis causas dos mesmos. Por conseguinte, foram definidas as ferramentas e os instrumentos de coleta de dados, baseada no produto principal da farmácia: os medicamentos. Estes são processados de acordo com uma prescrição, isto é, uma ficha nominal do paciente com a quantidade de medicamentos necessários para vinte e quatro horas.

Depois foi realizada uma coleta de dados piloto, a fim de definir quais melhorias poderiam ser realizadas na coleta oficial. Então foi coletada a demanda diária de prescrições do setor através de análise documental, isto é, foi analisada, para dezesseis dias a quantidade de prescrições diárias. Por fim foi feita a média dos dados. Para desenvolver o mapa do estado atual, foi realizada uma coleta não probabilística do lead time (tempo de atravessamento) e process time (tempo de processamento), através de planilha de coleta. Já a confiabilidade foi definida por estimativa, utilizando entrevista com as funcionárias e observações dos erros em cada etapa. Para a identificação das sete perdas foi utilizada a observação, análise documental e entrevistas.

Para o desenvolvimento do mapa do estado futuro, além da observação e análise documental, foi realizada uma entrevista com as funcionárias do setor, a fim de analisar a visão delas sobre o processo e quais as causas e melhorias que acreditavam ser viáveis. Também, a fim de identificar algumas causas dos problemas foi coletada a quantidade de vezes que tocava o telefone e que chegavam pessoas no balcão, visto que, de acordo com relatos, são fatores que interferem no processo. Ainda, foram realizadas reuniões com as chefias da farmácia para discutir as possíveis melhorias. Por último, as etapas da pesquisa foram concluídas com a proposição de melhorias para o processo de dispensação da farmácia do hospital universitário.

\section{ESTUDO DE CAMPO}

Com o intuito de realizar uma análise do processo e seus desperdícios foi utilizada uma ferramenta importante do lean healthcare, o mapeamento do fluxo de valor. $O$ resultado do mapeamento realizado no processo em estudo é apresentado na Figura 1. 
O processo inicia com a chegada da prescrição elaborada pelos médicos através do sistema AGHU (Aplicativo de Gestão para Hospitais Universitários). Todas as prescrições são codificadas, ou seja, é verificada a quantidade a ser liberada e se a solicitação está correta. Então, tira-se uma cópia dessa prescrição e realiza-se a separação dos medicamentos, onde são selecionados todos os medicamentos solicitados e embalados junto com a respectiva prescrição.

Após é realizada a etapa de baixa no estoque, onde, são registradas as saídas no sistema SIE (Sistema de Informações Educacionais) de cada medicamento identificado com um código de barras. Depois são colocados em uma mesma caixa os medicamentos das respectivas unidades de assistência hospitalar, em que os pacientes estão internados. Por fim, são dispensados os medicamentos.

Figura 1 - Mapa do estado atual

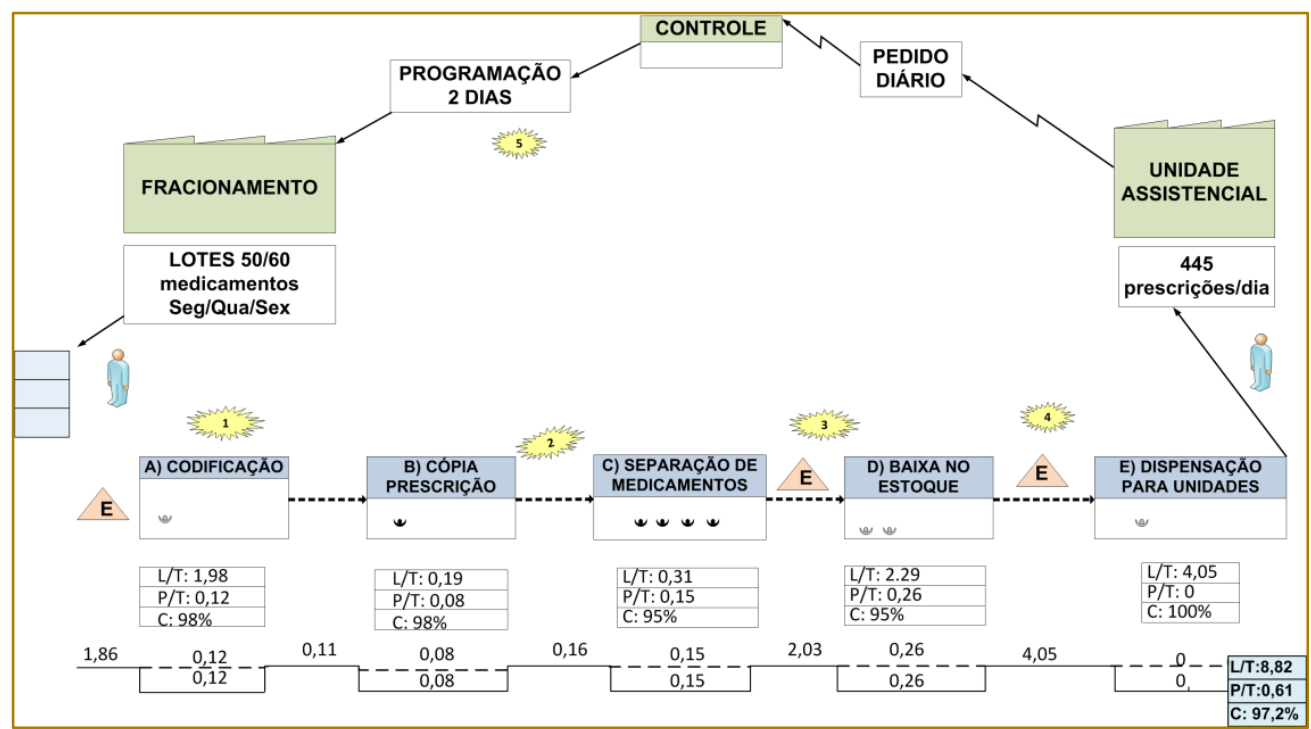

Percebe-se que o processo é puxado, pois inicia a partir da demanda das unidades assistenciais, com uma média de 445 prescrições por dia. O estoque de medicamentos na farmácia é programado para dois dias, e este é fornecido pelo setor de fracionamento em lotes de 50 e 60 unidades. Foram colocados balões kaizen em algumas etapas para demonstrar a possibilidade de melhorias pontuais, as quais são mais bem relatadas no mapa do estado futuro.

No mapa do estado atual pode-se visualizar o lead time $(\mathrm{L} / \mathrm{T})$ e o process time $(\mathrm{P} / \mathrm{T})$ dos medicamentos e a confiabilidade $(\mathrm{C})$ de cada etapa, bem como, os totais dos mesmos. Também, percebe-se que há estoque antes da codificação, entre os processos $C$ e $D$ e entre D e E.

Na sequência foram realizadas análises dos gargalos do processo e do takt time. Também se utilizou a técnica de análise das sete perdas. Por razões de limitação de palavras, supriram-se estes resultados neste texto.

De todo modo, após a realização do estudo de campo foi possível concluir que o processo é lento em um espaço físico pequeno e com necessidade de melhorias significativas em seu leiaute. A etapa de baixa no estoque e de codificação são os gargalos. Além disso, há um estoque em processo excessivo. As possíveis causas apontadas no estudo para os problemas relatados podem ser o espaço físico pequeno e os procedimentos operacionais obsoletos.

\section{PROPOSTAS DE MELHORIAS}

Atendendo o objetivo deste trabalho de pesquisa foram propostas melhorias para os problemas identificados no processo em estudo. Após analisar os dados coletados foi possível apresentar propostas de melhorias, conforme as subseções 5.1 e 5.2 deste texto. 


\subsection{PROPOSTAS RELACIONADAS À através do mapa do estado futuro, REORGANIZAÇÃO DO PROCESSO apresentado na Figura 2.}

Inicialmente foram propostas melhorias por meio do lean healthcare, em específico,

Figura 2 - Mapa do estado futuro

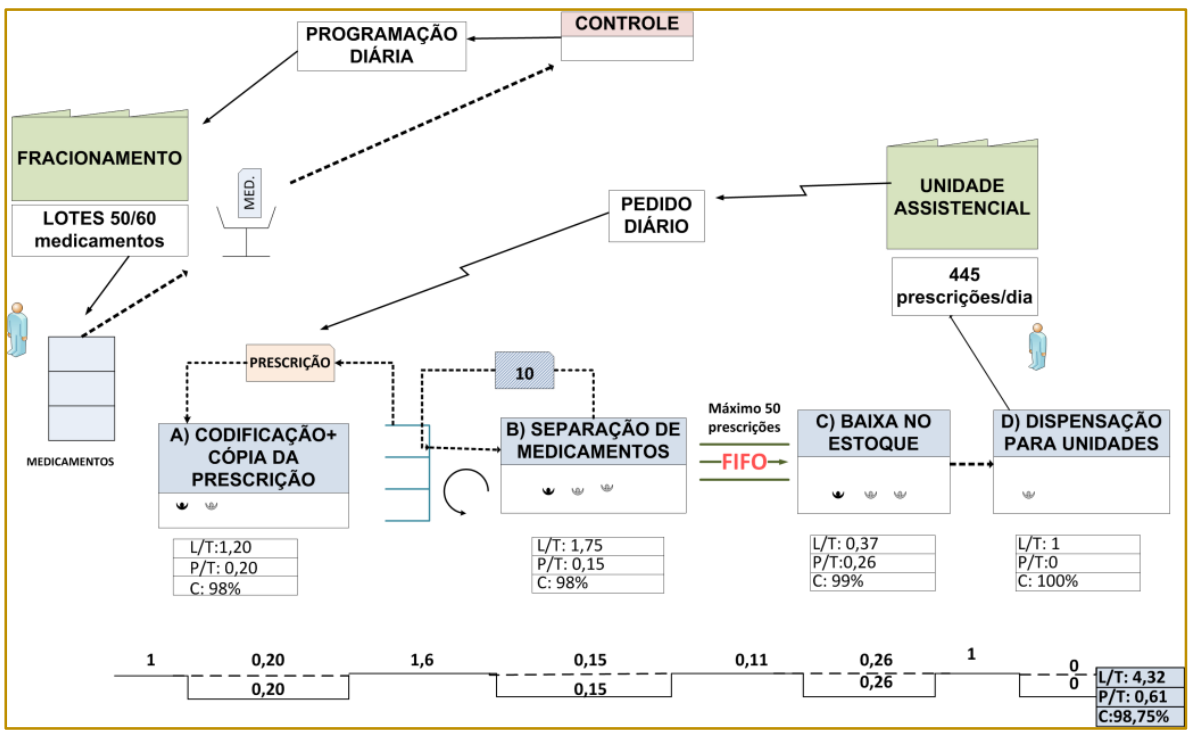

As propostas de melhorias no mapa do estado futuro são definidas através dos balões kaizen, apresentados no mapa do estado atual (Figura 1) e conceituadas na sequência.

- Kaizen 1: Redução do estoque em processo e do lead time na etapa de codificação e de movimentação entre as etapas de codificação e de cópia da prescrição, com a união de ambas, respeitando a ordem de precedência.

- Kaizen 2: Organização das prescrições codificadas através do uso de um supermercado entre as estações $A$ e B, isto é, ter uma sinalização, indicando que podem passar para a etapa de separação. Além disso, podem ser indicadas as prescrições da unidade que tem prioridade, ou seja, as unidades que precisam ser liberadas até uma hora determinada ou que possuem maior exigência de tempo. Este controle pode ser por Kanban, que é definido como uma prescrição com as informações do medicamento. Para a retirada sugeriu-se um controle através de um pitch, isto é, número de medicamentos de uma prescrição multiplicado pelo takt time.

- Kaizen 3: Redução potencial do estoque em processo entre as etapas de separação de medicamentos e baixa no estoque com a utilização de um FIFO (First In, First Out). Foram definidas no máximo 50 prescrições, pois é a média da demanda máxima da unidade que possui maior número de pedidos diários. Também, o lead time foi definido como a espera de apenas um medicamento.

- Kaizen 4: Redução do estoque em processo e consequentemente do lead time entre as etapas de baixa no estoque e dispensação para as unidades, através da padronização dos horários de retirada das prescrições prontas pelas unidades assistenciais, bem como, uma melhor comunicação entre as mesmas e a farmácia. O tempo de lead time proposto foi uma estimativa de um minuto por medicamento ou dez minutos por prescrição, pois se estima que é o tempo de deslocamento até a farmácia.

- Kaizen 5: Redução da utilização do espaço físico, através de controle de estoque de produtos fracionados, que poderá ser melhor entendido na proposta de melhoria de leiaute.

O número de operadores por estação de trabalho foi estabelecido por estimativa, respeitando o takt time. Sendo assim, sugeriu- 
se um operador permanente em cada etapa, com exceção da etapa de baixa no estoque que necessita de dois operadores, ambos com o suporte de funcionários auxiliares. Também, como sugestão, tem-se a possibilidade de um mesmo operador fixo realizar todas as tarefas, com ajuda de um operador piloto, o qual auxilia nas etapas.

\subsection{PROPOSTAS RELACIONADAS À MUDANÇA DE LEIAUTE}

Uma das propostas de melhoria mais pertinentes é a mudança do leiaute do setor. De acordo com Corrêa (2011), um bom projeto de arranjo físico pode eliminar atividades que não agregam valor, reduzir os tempos de ciclo, facilitar a movimentação, promover o acesso visual das operações, entre outras melhorias necessárias para 0 processo em estudo.

A fim de sustentar a viabilidade das propostas de melhoria foram analisadas as afinidades entre as etapas, sendo propostas três formas de leiaute, apresentadas nas Figuras 3, 4 e 5. Em cada proposta é apresentada a disposição das etapas.
$\mathrm{Na}$ proposta de leiaute 1 as atividades são dispostas em células de trabalho, onde as quatro primeiras etapas ficam juntas e a etapa de dispensação para as unidades separada. Esta disposição propõe que os medicamentos sejam estocados na célula de trabalho, podendo ser dispostos de acordo com a maior saída.

$\mathrm{Na}$ proposta de leiaute 2 também é apresentada uma disposição em células, porém, a etapa de cópia da prescrição seria compartilhada por duas células e a dispensação para as unidades ficaria separada, como na proposta anterior. O estoque de medicamentos seria por saída, isto é, ficariam próximos da célula somente os medicamentos que teriam maiores demandas, sendo que os demais seriam alocados em outras salas.

A proposta de leiaute 3 apresenta as etapas de codificação, cópia da prescrição e separação de medicamentos em uma célula. A etapa de baixa no estoque, considerada gargalo, seria dividida em quatro partes e a dispensação para as unidades ficaria separada. O estoque de medicamentos seria por demanda também, onde os que possuem maior saída ficariam próximos das células.

Figura 3 - Proposta de leiaute 1

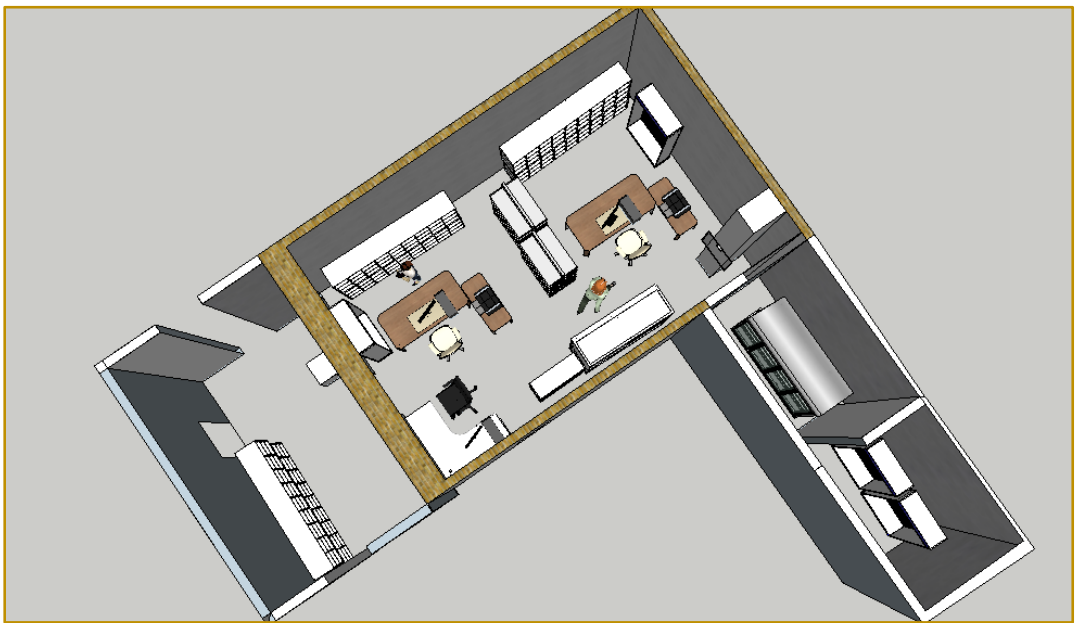


Figura 4 - Proposta de leiaute 2

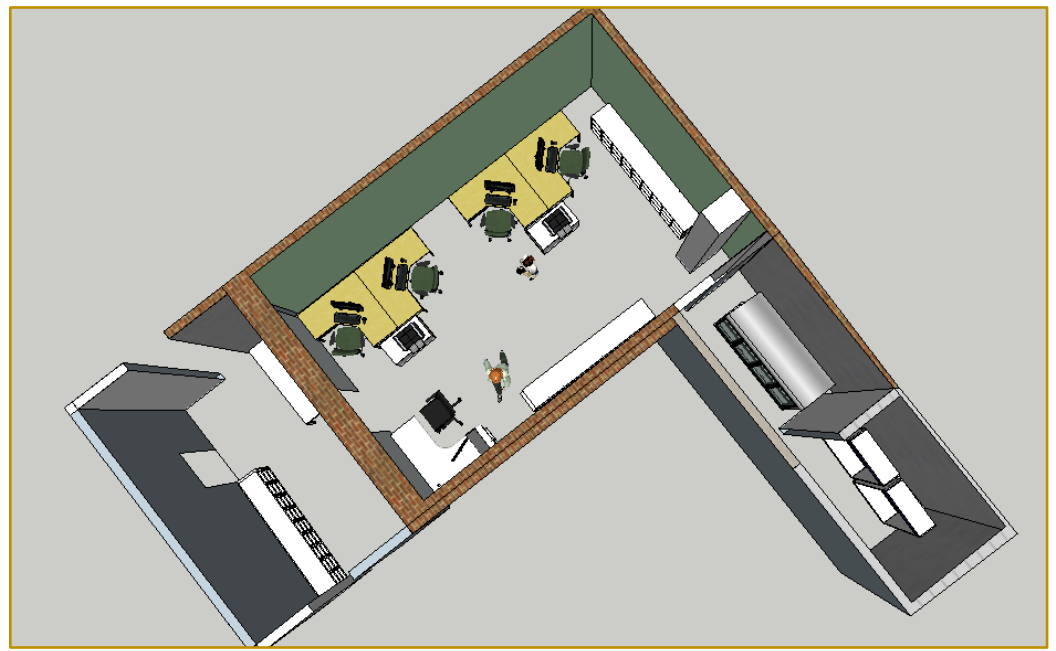

Figura 5 - Proposta de leiaute 3

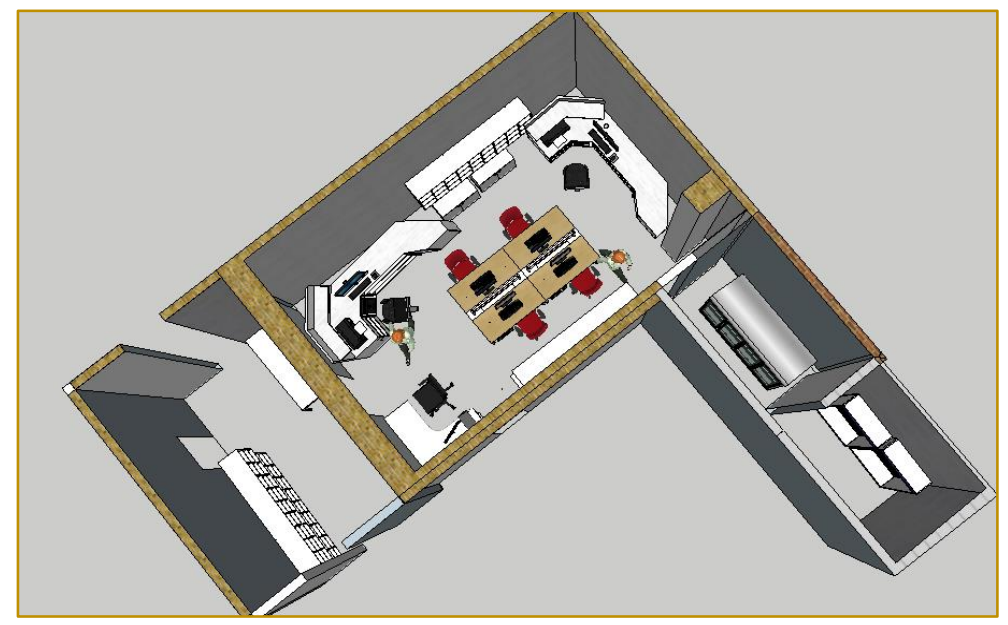

\subsection{DISCUSSÃO FINAL DAS PROPOSTAS DE MELHORIA}

Através das propostas de melhorias identificadas e apresentadas neste trabalho pretende-se solucionar o principal problema do processo em estudo, isto é, o atraso na entrega de medicamentos. Para isso, propuseram-se melhorias capazes de reduzir o lead time em 4,5 minutos, reduzir o estoque em processo da etapa de codificação, bem como eliminar a movimentação desnecessária entre as etapas de codificação e cópia da prescrição. Também, propôs-se a redução do estoque em processo antes da etapa de baixa no estoque, que é o principal gargalo do processo.

Ainda, com as propostas de melhorias pretende-se ter um processo mais organizado em relação ao leiaute e movimentação interna, bem como, espera-se um aumento na confiabilidade de $97,2 \%$ para $98,75 \%$. Sendo assim, a utilização das propostas mostra-se viável para solucionar o problema de pesquisa inicialmente identificado neste trabalho.

\section{CONSIDERAÇÕES FINAIS}

Este trabalho de pesquisa teve como objetivo geral propor melhorias relevantes para 0 processo de dispensação de medicamentos de uma farmácia hospitalar. Esse objetivo foi alcançado através da utilização da técnica lean healthcare. As melhorias concentraramse na otimização do processo e na mudança 
de leiaute. De fato, foram apresentadas propostas relevantes e plenamente aplicáveis na farmácia do hospital.

Com as propostas pretende-se melhorar o principal indicador de desempenho relacionado ao problema de pesquisa ascendente deste trabalho. Pretende-se reduzir o lead time de 8,82 minutos para 4,32 minutos. Também, através das propostas pretende-se reduzir os estoques em processo, bem como a movimentação desnecessária, que atualmente causa

\section{REFERÊNCIAS}

[1] Abdelhadi, A. e Shakoor, M. Studying the efficiency of inpatient and outpatient pharmacies using lean manufacturing. Leadership in Health Services. v. 27, n. 3, p. 255-267, 2014.

[2] Andreamatteo, A. et al. Lean in healthcare: a comprehensive review. Health Policy. v. 119, p. 1197-1209, 2015.

[3] Battaglia, F. Hospitais dos EUA melhoram indicadores de gestão com Sistema Lean. Em Pauta: LEAN Institute BRASIL. p. 1-2, 2010.

[4] Bertani, T. M. Lean heathcare: recomendações para implantações dos conceitos de produção enxuta em ambientes hospitalares. São Carlos. 2012. Originalmente apresentada como dissertação de mestrado, Universidade de São Paulo, 2012

[5] Carvalho, J. C.; Alves, A. Aplicação do Lean Thinking ao processo de distribuição da farmácia do Hospital da Luz. In. ISCTE-IUL. Lisboa, 2012. Anais eletrônicos...Lisboa, Instituto Universitário de Lisboa, 2012. Disponível em: $<$ http://hdl.handle.net/10071/4618>. Acesso em: maio 2016.

[6] Corrêa, H. L. Administração da produção: manufatura e serviços: uma abordagem estratégica. 2. ed. São Paulo: Atlas, 2011.

[7] Costa, A. R.; Ferreira, R.; Leal, F. Mapeamento de processos em uma unidade hospitalar: propostas de melhorias baseadas em conceitos lean. In. Encontro Nacional de Engenharia de Produção, 35. 2015, Fortaleza. Anais eletrônicos...Fortaleza: Abepro, 2015. p. 114, 2015. Disponível em: <http://www.abepro.org.br/biblioteca/TN_STO_206_ 227_27804.pdf>. Acesso em: 12 mar. 2016.

[8] Costa, L.; Monte, V.; Esposto, K. Mapeamento do Fluxo de Valor: Estudo de caso em uma farmácia hospitalar. In. Encontro Nacional de Engenharia de Produção, 35. 2015, Fortaleza. Anais eletrônicos... Fortaleza, ABEPRO, 2015. p. 112. 2015. Disponível em: <http://www.abepro.org.br/biblioteca/TN_STO_206_ 227_26939.pdf>. Acesso em: 12 mar. 2016.

[9] Dávila, S. P.; González, J. T. Mejora de la eficiencia de un servicio de rehabilitación mediante insatisfação no trabalho e atrasos no processo.

Por fim, pode-se concluir que este trabalho cumpriu com seu objetivo proposto, utilizando - lean healthcare que ainda é pouco explorado no Brasil. De fato, acredita-se que com o lean healthcare pode-se trazer oportunidades de melhorias significativas para os processos da área da saúde e, assim, contribuir com um benefício mútuo para o aprendizado e, principalmente, para a sociedade.

metodología Lean Healthcare. Revista de Calidad Asistencial. Barcelona, 2015. v. 30. n. 4, p. 162165, 2015

[10] Fabbri, B. P. F. Lean healthcare: um levantamento de oportunidades de ganho em um hospital brasileiro. São Carlos. 2011. Originalmente apresentada como dissertação de mestrado, Universidade de São Paulo, 2011.

[11] Faria, P. A. Lean healthcare: um estudo sobre a aplicação do pensamento enxuto em serviços de saúde. Rio de janeiro. 2013. Originalmente apresentada como dissertação de mestrado, Pontifica Universidade Católica do Rio de Janeiro, 2013.

[12] Gil, A. C. Como elaborar projetos de pesquisa. 5.ed. São Paulo: Atlas, 2010.

[13] Gil, A. C. Estudo de caso. 1.ed. São Paulo: Atlas, 2009.

[14] Jones, D. Lean Enterprise Institute. Lean Institute Brasil. 2015 p. 1-5, 2015. Disponível em: < http://www.lean.org.br/comunidade/artigos/pdf/artig o_314.pdf >. Acesso em: maio, 2016.

[15] Jorma, T. et al. Lean thinking in Finnish healthcare. Leadership in Health Services. v. 29, n. 1, 2016. p. 9-36.

[16] Lean Institute BRASIL. São Paulo, 2016. Disponível em: <http://www.lean.org.br>. Acesso em: maio 2016.

[17] Oliveira, T. S. Proposta de aplicação das ferramentas do lean healthcare à logística hospitalar. São Carlos. 2014. Originalmente apresentada como dissertação de mestrado, Universidade de São Paulo, 2014.

[18] Souza, L. B. Trends and approaches in lean healthcare. Leadership in Health Services. v. 22. n. 2, 2009. p. 121-139.

[19] Valente, R. P.; Esteves, M.I.; Rosado, J.M.Z.P. A metodologia Lean na área hospitalar, a Gestão da Qualidade enquanto fator de Melhoria Contínua e humanização do esforço de racionalização dos recursos. In. Seminário de I\&DT, 3. Porto Alegre, 2012. Anais eletrônicos...Centro Interdisciplinar de Investigação e Inovação do Instituto Politécnico de Porto Alegre, 2012. p. 1-16. Disponível em: <http://www.marco.eng.br/piepIII/Cases/LH-02.pdf>. Acesso em: maio 2016. 


\section{Bapítulo 6}

\section{ESTRUTURAÇÃO DE CONTROLE OPERACIONAL NUM AMBIENTE FABRIL PARA IMPLANTACÃO DO CÓDIGO DE BARRA BIDIMENSIONAL QR-CODE BASEADA NOS CONCEITOS DE LEAN MANUFACTURING}

\section{Jorge Okumura \\ Carlos Antônio Vinotti \\ Ismael Luiz dos Santos \\ Maria Lucia Miyake Okumura \\ Osiris Canciglieri Junior}

Resumo: As informações de identificação e rastreabilidade dos produtos com agilidade e confiabilidade são quesitos relevantes para atender um mercado competitivo e clientes exigentes. Diante das exigências elevadas, as informações do produto aumentam e incidem diretamente nos controles operacionais da cadeia de manufatura, pois os dados e controles inseridos sem planejamento na estrutura operacional podem resultar para ineficiência e queda de produtividade nas empresas. No entanto, abre a possibilidade de reversão desse quadro por meio de novas tecnologias e ferramentas, que foram surgindo e aplicados como instrumentos e métodos de trabalho, principalmente a partir da evolução da Tecnologia da Informação (TI) e em conjunto com o pensamento "Lean". O uso do código de barra iniciado nos anos setenta e aperfeiçoado nos últimos anos, tornou as informações mais precisas e conjugadas à melhoria da produtividade nos diversos segmentos da cadeia de produção. O presente artigo é um estudo de caso numa empresa de injeção de plástico sediada na região metropolitana de Curitiba - PR. O objetivo é abordar os conceitos do Lean Manufaturing aplicados na estruturação do controle operacional de um ambiente fabril para a implantação do Código de Barra bidimensional QR-Code. No resultado, apresenta a avaliação de desempenho do processo fabril nos primeiros 3 anos.

Palavras-chave: Tecnologia da Informação; Manufatura Enxuta; Sistema Toyota de Produção; Código de Barra Bidimensional QR-Code; Rastreabilidade. 


\section{INTRODUÇÃO}

O mercado globalizado e a concorrência acirrada nas relações econômicas e comerciais aceleraram para ressaltar a tecnologia de informação, que contribui para o acesso rápido e fácil de informações. As informações de identificação e rastreabilidade dos produtos com agilidade e confiabilidade são quesitos relevantes para atender um mercado competitivo e clientes exigentes. Desta forma, as empresas procuram atualizações tecnológicas para obter novos conhecimentos e principalmente para permanecer no mercado competitivo. Esta competitividade no mercado ao alinhar-se com conceito de manufatura enxuta, eliminam desperdícios no processo fabril e reduzem os custos de produção. Segundo Wiendahl (apud SELLITTO, 2005), um sistema de manufatura realimentado por informações pode detectar a tempo as mudanças ambientais que incidem nos resultados operacionais.

A competividade na manufatura está relacionada com a medição de resultados conforme um acompanhamento sistêmico no processo fabril. Deste modo, foi elaborado um plano de trabalho para elevar os resultados operacionais da unidade fabril, visando a estruturação do controle operacional e a implantação de controles informatizados em substituição aos utilizados manualmente. As necessidades de estruturação nos controles operacionais foram detectados nos levantamentos de dados preliminares, pois a forma de condução dos processos atuais e o nível de precisão da informação encontrada, impossibilitaria atingir a eficiência desejada com a implantação de nova tecnologia informatizada (OKUMURA et al.; 2018).

Neste contexto, o objetivo desta pesquisa é um estudo de caso de Lean Manufaturing aplicado na preparação do ambiente fabril de uma empresa de injeção de plástico sediada na região metropolitana de Curitiba - PR. Esta preparação consiste na estruturação do controle operacional para a implantação da ferramenta de Código de Barra bidimensional QR-Code.

O código de barra QR-Code apresenta maiores controles internos de segurança e consegue armazenar mais dados que 0 código de barra unidimensional. Assim, o uso do código de barra bidimensional permite aumentar a eficiência e a confiabilidade dos processos de controle por meio de redução ou eliminação da necessidade da digitação no sistema de banco de dados. A adoção desta ferramenta de trabalho requer-se a preparação e estruturação do controle operacional para sua implantação, como o caso de enxugamento dos processos alvos, levando em consideração que cada processo ou empresa, existem cada qual as suas particularidades nos controles internos, principalmente no processo fabril (OKUMURA et al.; 2018).

A pesquisa inicia-se com a revisão bibliográfica dos principais temas abordados seguido de procedimento técnico da metodologia de pesquisa e o estudo de caso. No resultado, apresenta a avaliação de desempenho do processo fabril nos primeiros 3 anos.

\section{REVISÃO BIBLIOGRÁFICA}

\subsection{CONCEITO LEAN MANUFACTURING}

O conceito de Lean Manufacturing ou manufatura enxuta é baseado no Sistema Toyota de Produção (STP) com principal foco de eliminação total do desperdício em todos os aspectos e níveis do processo produtivo e obter resultados em custos, produtividade, qualidade e no atendimento ao cliente (OHNO, 1997; SHINGO, 1996). Segundo Campos (2014), a necessidade do controle de qualidade do produto incide no custo final de manufatura, portanto o pensamento enxuto é uma forma de especificar valor e suas ações, que são alinhadas na melhor sequência criando o valor e realizar as atividades cada vez mais eficientes (WOMACK, 2004). Deste modo, o valor final é definido pelo cliente, que a empresa assume levando em conta as ações específicas de produção no produto, capacidade e preço (COSTA et al., 2008).

Ohno (1997) e Shingo (1996) identificaram os 7 grandes tipos de desperdícios no processo de manufatura, a seguir: a) por superprodução; b) por transporte excessivo; c) por processamento inadequados; d) por fabricar produtos defeituosos; e) por espera de período ocioso; f) por estoque desnecessário; g) por movimento dispensável. Segundo Ohno (1997), os resultados organizacionais provem do aumento da eficácia associada à redução de custos e a eficiência é notada na melhoria em cada estágio visto a fábrica como um todo. Desta forma, os objetivos do Lean Manufacturing são de operar o sistema da 
produção de forma descomplicado e aplicar redução contínua de desperdícios otimizando os processos e controles para alcançar qualidade e flexibilidade do processo, aumentando a capacidade de produção (COSTA et al., 2008).

A Autonomação e o Just-in-time formam os dois pilares do Sistema Toyota de Produção. $\mathrm{Na}$ Autonomação, o conceito é impedir a geração e a propagação de defeitos e eliminar qualquer anormalidade no processamento e fluxo de produção, Ghinato (1996). No Just-in-time, o conceito é de que "cada processo receba o item exato necessário, quando ele for necessário, na quantidade necessária" (OHNO, 1996). A parte mais visível do conceito está presente no uso do método "Kanban", que é uma ferramenta utilizada para o controle do estoque e a transmissão da informação sobre quando produzir ou adquirir determinado produto e estabelecer o lote de fabricação por fase no planejamento de controle de produção (OKUMURA et al., 2018).

Nas ferramentas do Sistema Lean encontra-se o 5S. Segundo Silva (1996), 5 S refere-se na realidade a cinco palavras japonesas iniciadas com a letra "S": Seiri, Seiton, Seiso, Seiketsu e Shitsuke, que identificam os cinco conceitos que são capazes de modificar e simplificar o ambiente de trabalho da organização, reduzir o desperdício, melhorando os aspectos de qualidade, produtividade e segurança nas empresas, tornando-o um "ambiente da qualidade" altamente estimulador para que as pessoas possam transformar os seus potenciais em realização.

O objetivo de um processo no Lean manufacturing é melhorar o desempenho, que pode estar relacionado com diversos fatores como: confiabilidade, crescimento, custo, flexibilidade, grau de inovação, grau de internacionalização, prazo, produtividade, qualidade, rentabilidade, velocidade, volume e outros. O resultado de desempenho é o retorno de avaliações do processo para aplicar ajustes ou mudanças, auxiliar na gestão, definir as responsabilidades, identificar as falhas e desperdícios (RODRIGUES, 2014).

\subsection{TECNOLOGIA DA INFORMAÇÃO}

As informações têm papel fundamental no fluxo de materiais, principalmente na gestão logística. Segundo Oliveira (2008), o sistema de informação para as empresas está no suporte aos processos e operações, no suporte à tomada de decisões e no suporte às estratégias em busca de vantagens competitivas.

O uso da Tecnologia da Informação (TI) tem influência relevante nas decisões para apoiar o sistema de manufatura das empresas, que direciona para ter impacto estratégico. Assim, a técnica do Just-in-time passa a ser ação para obtenção e manutenção de vantagens competitivas. A forma de operar na estratégia conduz para respostas rápidas, flexibilidade de mix de volume de produção, no atendimento às necessidades específicas dos clientes, que representa fatores relevantes de diferenciação (SLACK, 1993). Conforme Laurindo (2002) e Kaplan \& Norton (2001), o resultado de desempenho da empresa passa a ser avaliado de forma mais abrangente, não se restringindo apenas nos indicadores unicamente financeiros, como resultados no atendimento às expectativas dos clientes e nos processos de qualidade.

Além disso, a TI está cada vez mais presente nas atividades ligadas à produção, desde os antigos sistemas de controle inclusive nos sistemas ERP (Enterprise Resources Planning). O grande volume de recursos necessários para a implementação desses sistemas levantou dúvidas acerca da viabilidade da introdução. No entanto, uma das soluções para obter retornos favoráveis nos investimentos em TI são a coordenação e o alinhamento entre as estratégias de negócio e de $\mathrm{TI}$, adquiridos durante o processo dinâmico e contínuo ao longo do tempo. Essa perspectiva estratégica para a seleção de aplicações de Tl permite retorno nos resultados do negócio. Somente a capacidade da empresa em explorar a eficácia no uso da TI de forma contínua possibilita a manutenção de vantagens competitivas (OKUMURA et al. 2018). Cabe lembrar que a eficácia está associada à satisfação de metas, objetivos e requisitos de caráter mais amplo do negócio da empresa, enquanto eficiência está associada ao uso dos recursos (LAURINDO, 2002).

As aplicações de TI voltadas à produção são destacadas por operacionalizarem diferentes modelos usados no PCP. Neste sentido, os sistemas MRP (Materials Requirements Planning), permitiu equacionar o problema do cálculo de necessidades de materiais para produção de mix de produtos. Os sistemas 
MRP evoluíram para sistemas MRP II (Manufacturing Resources Planning), que passaram a ter maior abrangência, permitindo incluir no planejamento outros aspectos, como planejamento da capacidade (CRP - Capacity Requirements Planning), e permitindo a gestão de outros recursos como equipamentos, mão-de-obra e nos materiais (LAURINDO 2002).

Laurindo (2002) afirma que os sistemas MRP II foram, por algum tempo, o estado da arte em termos de instrumento de planejamento da produção, principalmente em sistemas de produção intermitente. A partir dos anos 80 , surgem outros modelos como Just-in-time (JIT) para controle de estoques na produção automobilística, que mais tarde foram introduzidos no MRP II e em áreas de gestão. Esta nova geração de sistemas foi denominada de "Sistemas ERP", chamados genericamente de Sistemas de Gestão Empresarial (Laurindo \& Mesquita, 2000). A próxima evolução consiste na TI integrando as diversas etapas da cadeia de suprimentos, inicialmente pelo EDI e atualmente via ecommerce B2B - business to business (MEDEIROS JUNIOR, 2002).

Segundo Stuber (apud Laurindo, 2002), o sistema ERP é mais procurado pelo ramo industrial, onde há a preocupação crescente de que haja um ambiente integrado de sistemas de informação que deem suporte aos objetivos da produção.

\subsection{CÓDIGO DE BARRA BIDIMENSIONAL}

O código de barra é utilizado amplamente devido a oferecer velocidade na leitura dos dados, precisão e alta manuseabilidade. À medida que a sua utilidade vem sendo reconhecida, as atribuições foram identificadas ao mercado, o fato de proporcionar maior capacidade de armazenagem, código com capacidade de expressar mais tipos de letras e capacidade de impressão em espaços menores. Para atender a essa demanda, foram testadas várias soluções, tais como, aumentar a quantidade de caracteres, "empilhar" vários códigos. Entretanto, esses esforços resultaram em problemas tais como: aumento da área de apresentação do código, dificuldade de leitura, elevação do custo de impressão (OKUMURA et al., 2018).

O código de barra bidimensional Quickly Response Code (QR-Code) foi desenvolvido em 1994 pela Denso-Wave Incorporated (2018) do grupo Toyota, com o objetivo de ter um código de fácil identificação pelas leitoras. Segundo a Denso-Wave Incorporated (2018), o QR-Code apresenta o melhor desempenho entre os outros modelos desenvolvidos no formato matriz, tendo como características principais: maior capacidade de armazenamento de caracteres em espaço reduzido além da alta velocidade de leitura. Assim, o Código bidimensional QR-Code armazena os dados na estrutura matriz em duas direções, na horizontal e vertical. Uma das características do QR-Code são os três elementos de posicionamento padrão no formato quadrado concêntrico e sobreposto na matriz que detecta a localização e orientação do símbolo em todas as direções e tem capacidade de armazenar dados numérico, alfanumérico, símbolos de pontuação, binário e símbolo da letra japonesa, conforme descrita na Figura 1. O uso do código de barra QR-Code atribui facilidade de uso e maior segurança das informações armazenadas (OKUMURA et al., 2012).

Figura 1 - Posicionamento Padrão e Capacidade de armazenamento de dados do QR-Code.

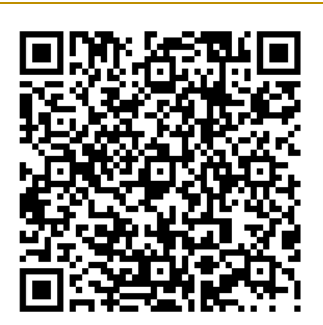

Posicionamento Padrão na matriz do QRCode: dois quadrados na parte superior e um quadrado do lado esquerdo.

\section{QR-Code - Capacidades de armazenamento de dados}

a) Somente numérico: até 7.089 caracteres

b) Alfanumérico: até 4.296 caracteres

c) Binário: até 2.953 bytes

d) Kanji, completo com kana (Símbolo da letra japonesa) até 1.817 caracteres.

Fonte: autores, adaptados de Denso-Wave (2018) e Okumura et al. (2012). 
A decisão do uso do QR-Code nesta pesquisa foi devido à facilidade oferecida no desenvolvimento do trabalho e atribuir os quesitos de agilidade e rastreabilidade do produto, pois, a empresa em estudo e o principal cliente adotaram o mesmo controle operacional reduzindo o tempo e o custo do desenvolvimento.

\section{METODOLOGIA DE PESQUISA}

O procedimento técnico da metodologia de pesquisa para conduzir este trabalho foi de acordo com o levantamento e conhecimento adquirido nos estudos realizados no chão de fábrica sobre as etapas dos processos de fabricação, bem como o conhecimento adquirido através das pesquisas realizadas sobre os sistemas de trabalho, com especial ênfase ao pensamento Lean baseado em Sistema Toyota de Produção - STP. Foram analisados detalhes dos processos tais como: o material e equipamento (máquina injetora), ferramental (molde) utilizados, o ciclo de fabricação, fluxo de movimentação das peças pela fábrica, a embalagem, entre outros itens.

O estudo de caso iniciou-se com levantamento bibliográfico dos temas pertinentes e na sequência foi realizada a com coleta de informações sobre os indicadores existentes para futuras comparações. Os indicadores utilizados são:

a) Nível de Atendimento ao Pedido do Cliente (\%) - para aferir a satisfação do cliente em relação ao fornecimento;

b) Nível do Estoque de Produto Acabado (dias) - para a garantia da continuidade do fornecimento ao cliente;

c) Tempo de Troca de Modelo (minutos) para aferir a capacidade de melhorias na manufatura;

d) Lead Time de Fabricação (minutos) - para aferir a capacidade de melhorias na manufatura;

e) Rejeição no Processo de Fabricação (\%) para aferir o nível da qualidade da manufatura;

f) Rejeição no Cliente (PPM) - para aferir o Sistema de Qualidade da empresa.

$\mathrm{Na}$ coleta dos dados iniciais houve a percepção clara sobre as necessidades de mudanças no controle operacional, tanto no plano comportamental quanto na forma de gerenciamento do trabalho. Iniciou-se com introdução dos conceitos do " 5 S" para suprir a falta de uma melhor organização e disciplina no chão de fábrica. $\mathrm{Na}$ etapa seguinte, foi introduzido o Kanban, ferramenta do STP de gerenciamento do estoque e da produção, buscando facilitar o planejamento da produção e o controle dos três pontos principais de fabricação - O Que, Quanto e Quando produzir.

\section{ESTUDO DE CASO}

\subsection{APRESENTAÇÃO DA EMPRESA}

A empresa é uma multinacional, fabricante de peças plásticas injetadas para a indústria de autopeças, estabelecida na cidade de Curitiba - Paraná. A fábrica opera com 10 equipamentos injetoras de plástico, sendo duas máquinas com capacidade de 850 toneladas de fechamento, três máquinas com 450 toneladas e outras entre 75 a 160 toneladas.

\subsection{FORMA DE TRABALHO ANTES DO KAIZEN}

Os indicadores antes de aplicar o Kaizen foram:

a) no requisito atendimento ao Cliente, a meta de Rejeição no Cliente era de 100ppm no máximo, e o resultado era de 312ppm.;

b) a meta do Nível de Atendimento ao Pedido do Cliente era de $100 \%$ de atendimento, com o resultado de $93,9 \%$;

c) nos resultados da área operacional a Rejeição no Processo de Fabricação tinha a meta de 2,5\% no máximo, com o resultado de $3,9 \%$;

d) o Tempo de Troca de Modelo com meta de 25 minutos, e o resultado de 45 minutos em média por troca;

e) outros indicadores considerados como reflexos desse baixo desempenho são: Lead Time de Fabricação de 957minutos, e o Nível do Estoque de Produto Acabado com 4,5 dias em média, monitorados sobre os grupos de produtos mais volumosos no sentido de ocupação do espaço e quantitativamente mais representativos. 
Conforme a Figura 2, demonstra o fluxo de fabricação antes do Kaizen, após receber a informação de previsão da demanda do cliente [1], o PCP elabora a Programação de Produção [2] para as injetoras - (frequência mensal). Com base na Programação de Produção e informações sobre o nível dos estoques, o PCP emite a Ordem de Produção [3], diariamente, indicando o que deve ser fabricado por máquina e por turno de trabalho. O setor da Produção fabrica os lotes de peças conforme a Ordem de Produção [4] e as submete ao acompanhamento do setor da Qualidade conforme definido no Plano de Inspeção [5]. A produção emite o Relatório de
Produção $[A]$ onde são registrados os dados de fabricação do lote e as submete ao setor de PCP [B] que transfere os dados para uma planilha eletrônica, confere e arquiva o registro. Os lotes produzidos são entregues para o Estoque de Produto Acabado [6] e são guardados nas respectivas posições de estocagem. Os materiais são retirados do estoque e entregues conforme as solicitações das linhas de produção do cliente [7]. Os materiais retirados do estoque são registrados no formulário romaneio (data, item, quantidade) [8] que serve como base dados para a emissão da Nota Fiscal de vendas [9].

Figura 2 - Fluxo de Fabricação antes do Kaizen.

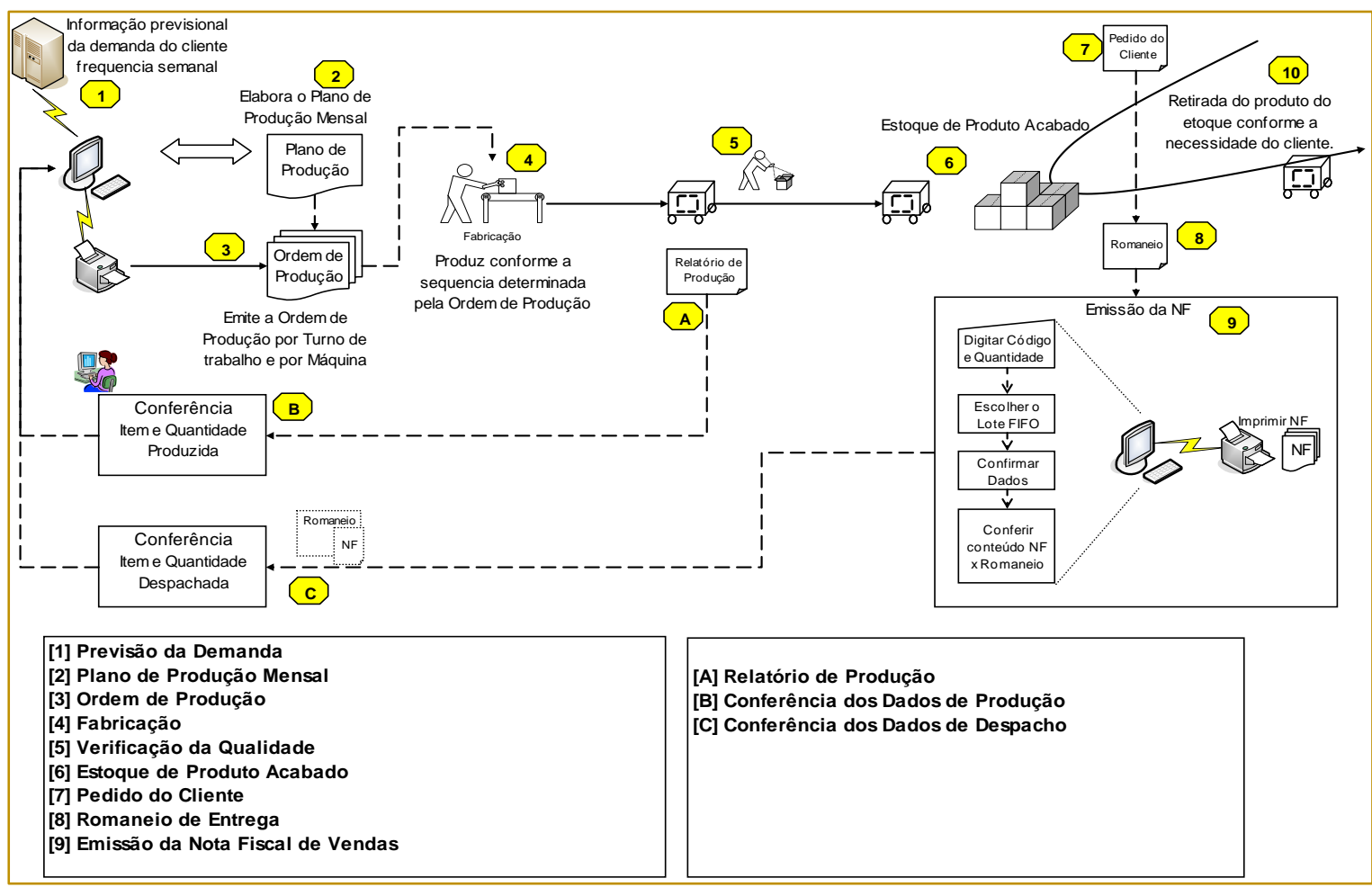

Figura 9 Demonstrativo do Fluxo de Fabricação antes do KaizenFtgrttee ? Auttorores.

O PCP recebe o romaneio e a via de arquivo da Nota Fiscal confere os dados e arquiva os registros e documentos [C]. A precisão dos dados registrados no romaneio ficava comprometido à medida que o estoque da empresa era considerado como uma extensão do estoque do cliente e a preocupação maior dos funcionários da empresa terceirizada consistiam em não deixar faltar materiais nas linhas de produção do cliente, deixando de anotar as retiradas dos itens, causando diferenças nos controles do estoque da empresa (OKUMURA et al., 2018).

\subsection{INTRODUÇÃO DO 5S}

O trabalho de estruturação do controle operacional da empresa iniciou-se com a aplicação do conceito do "5S" no chão de fábrica, com o intuito de organizar o fluxo dos materiais, facilitar a identificação das situações "em conformes", das "não conformes" e educar os funcionários no ponto de vista da disciplina. A gestão visual foi incorporada de forma simplificada nos locais de maior criticidade do ponto de vista do controle operacional de processo. 


\subsection{DESCRIÇÃO DO FLUXO DO} OPERACIONAL ESTRUTURADO

O fluxo operacional estruturado, conforme ilustrado na Figura 3, descreve-se o processo de despacho, que inicia com o pedido do cliente, representado pela apresentação do "Kanban transporte" [1] utilizado pelas linhas de produção do cliente. O responsável do almoxarife do cliente segue uma rota de abastecimento no horário para as linhas de produção (do cliente), entregando as peças solicitadas no ciclo de abastecimento anterior e recolhendo os pedidos de reposição de peças (embalagens vazias, Kanban de transporte ou de abastecimento). Ao receber - Kanban, o almoxarife da empresa anota o item e quantidade no romaneio de entrega [2]. Utilizando o Kanban do cliente como identificação, faz-se a coleta do material solicitado no estoque de produto acabado e transfere para a área de conferência. A forma de conferência consiste em retirar o Kanban de produção fixada na embalagem do produto acabado, substituindo-o pelo Kanban de transporte do cliente. Os lotes múltiplos do Kanban de transporte do cliente são os mesmos múltiplos para o Kanban de produção (empresa). A cada hora, o almoxarife lança os dados do romaneio no sistema informatizado para a emissão da nota fiscal de vendas [3]. No procedimento para a emissão da Nota Fiscal é acessado o sistema informatizado, que digita-se o código do item vendido e a quantidade. O sistema mostra os lotes do produto acabado disponíveis para o despacho, identificando o lote mais antigo e a quantidade em estoque de cada lote. O almoxarife deve observar se a quantidade do lote apontado pelo sistema será suficiente para atender o despacho em curso. Caso não o seja, após confirmar toda a quantidade do lote mais antigo ofertado pelo sistema, deverá repetir o processo no próximo lote mais antigo, até que a quantidade seja suficiente para completar o despacho em curso. Depois de confirmado o item e a quantidade, é dado o comando da emissão da nota fiscal de vendas [4]. O almoxarife leva o Kanban retirado do produto acabado para o portaKanban [5], localizado próximo às injetoras de plástico e, ao atingir a quantidade determinada de cartões, são colocadas em sequencia para iniciar um novo ciclo de fabricação [6].

Figura 3 - Fluxo de Fabricação com Kanban e com código bidimensional - QR-Code.

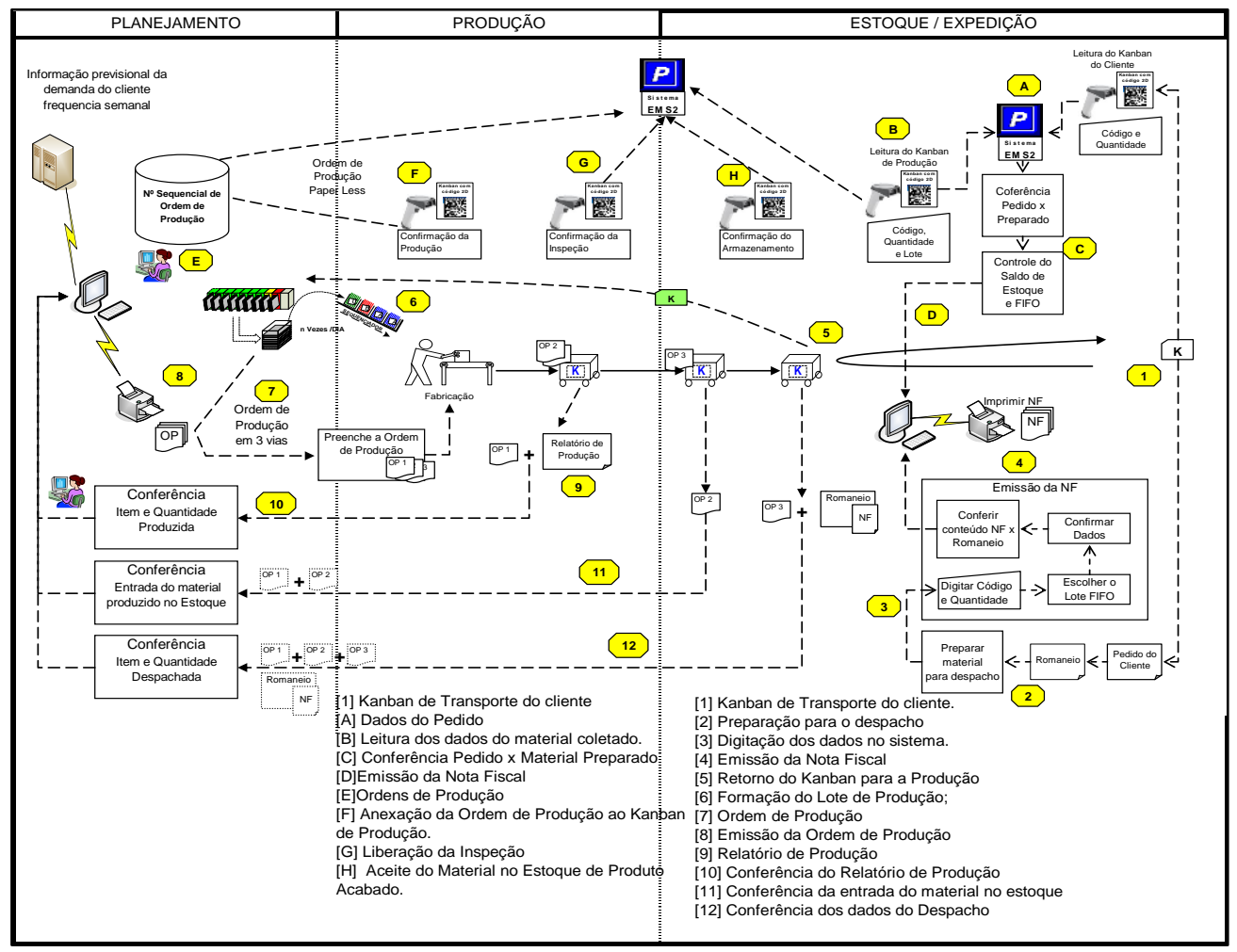

Fonte: Autores. 
Ao fabricar um novo lote de peças, cada fração da produção dividida em embalagem é identificada pelo respectivo "Kanban de produção" e cada embalagem de peças fabricadas recebe a ordem de produção em três vias [7] para sinalizar o status da peça em processo. A Ordem de Produção é gerada com antecedência pelo PCP no sistema informatizado, impresso e fica a disposição do setor de Produção [8]. Ao completar o lote de produção do item, a produção emite 0 Relatório de Produção [9] contendo todas as informações relativas ao lote fabricado, anexa à primeira via de todas as Ordens de Produção utilizadas e após a digitação dos dados no sistema informatizado, envia-as para o PCP para conferência e arquivamento [10]. Essas transferências de dados dos itens fabricados ocorrem pelo menos uma vez por turno de trabalho. Após passar pelo processo de verificação da qualidade, o material fabricado é enviado para o estoque de produto acabado. Ao ser aceito no estoque, retiram-se as segundas vias da Ordem de Produção [11] e são enviadas para O PCP para que sejam feitas as conferências e acompanhamentos dos itens fabricados. Depois de concluído o processo de despacho, as terceiras vias da Ordem de Produção são retiradas [12] e anexadas ao romaneio e a via da Nota Fiscal. Os três registros são encaminhados para o PCP para a conferência do processo, e ao juntarem-se as Ordens de Produção às demais vias encerram-se o ciclo da ordem de produção desse lote fabricado. Cada etapa do processo de controle operacional do produto, do nascimento até a sua expedição, é registrada através da digitação no sistema informático vigente (OKUMURA et al., 2018).

\subsection{PROCESSO COM A IMPLANTAÇÃO DO CÓDIGO DE BARRA BIDIMENSIONAL}

No processo de implantação, o código de barra bidimensional (2D) - QR-Code está impresso no Kanban tanto de produção quanto o de transporte do cliente e substitui a necessidade de digitação das informações no sistema. O código do item, a quantidade de peças a ser fabricado, o tipo de embalagem, a quantidade de peças por embalagem, a quantidade de Kanban por lote de produção estão parametrizados no sistema informações do TI. Os leitores de 2D estão vinculados aos processos conforme o fluxo de fabricação, com a segurança de que o sistema não aceita a leitura do mesmo Kanban no mesmo lote.
Ao receber o Pedido de fornecimento do cliente, representado pela apresentação do "Kanban Transporte" [1], o almoxarife faz a leitura do código QR-Code impresso no Kanban de Transporte do cliente [A]. Munido dessa informação, o almoxarife coleta os materiais no estoque e faz a leitura do $2 D$ no Kanban de Produção [B] de cada embalagem. O sistema confirma as informações do item solicitado com a do material coletado a ser despachado [C]. Se os dados estiverem corretos, o sistema libera a emissão da nota fiscal de vendas [D].

No processo de emissão da nota fiscal, a digitação do código da peça, a busca do lote e a confirmação da quantidade a ser despachada de cada lote passa a ser feito com simples ação de apontar a leitora no $Q R$ Code e ler as informações contidas no Kanban. $\mathrm{Na}$ posse dessa informação, o sistema consegue reconhecer o produto, a quantidade múltipla de despacho, o lote correto, ficando para o funcionário a ação de fazer a conferência dos itens na tela do computador e o comando para acionar a impressão da nota fiscal. O monitoramento do funcionamento do sistema pode ser feito online pelo funcionário autorizado, em qualquer computador ligado à da rede da empresa. As Ordens de Produção são previamente geradas e armazenadas dentro do banco de dados do sistema e ficam à disposição do setor da produção [E]. Ao completar a quantidade da primeira embalagem do lote, faz-se a leitura do QR-Code impresso no Kanban de Produção [F]. O sistema irá relacionar um número de ordem de produção que se repetirá nos demais Kanbans do mesmo item "lidos" pelo leitor até que se completem as quantidades de Kanban do lote de produção. Ao completar a verificação da qualidade das peças, o responsável pela inspeção fará a leitura do QR-Code do Kanban, sinalizando a liberação das peças dessa embalagem [G]. O Kanban da peça liberado pela leitora do setor da qualidade, passa em seguida pela leitora da entrada do estoque $[H]$, confirmando o aceite do material no estoque (OKUMURA et al., 2018).

\section{CONCLUSÕES}

No estudo inicial para implantação do código bidimensional QR-Code foi verificado a a necessidade de melhorar os processos de produção como um todo, pois, concluiu-se que eram altos os níveis de incertezas 
captadas desde a fase de planejamento até a expedição. As anotações nos registros de controle da produção à expedição eram imprecisas, creditadas às situações de falta de treinamento sobre a coleta de dados, a falta de controle e a falta de disciplina dos funcionários e encarregados.

Para alcançar o estado de controle operacional almejado pela empresa, havia a necessidade de promover uma mudança comportamental na organização, fazendo com que cada um cumprisse o seu papel no sistema de trabalho. Iniciou-se essa conscientização através do uso dos conceitos do "5S", dando ênfase na implantação do gerenciamento visual ou gestão a vista. Gradativamente foram introduzidas as demais ferramentas do Lean, que foram determinantes para o controle das incertezas ao longo dos processos de manufatura da empresa. O acompanhamento da estruturação do controle operacional pós Kaizen no ambiente fabril durante 3 anos alcançaram os resultados conforme a Tabela 1.

Tabela 1 - Resultados alcançados pós Kaizen.

\begin{tabular}{|l|c|c|c|}
\hline \multicolumn{1}{|c|}{$\begin{array}{c}\text { Indicadores } \\
\text { existentes }\end{array}$} & Metas & $\begin{array}{c}\text { Resultados } \\
\text { encontrados }\end{array}$ & $\begin{array}{c}\text { Resultados } \\
\text { alcançados }\end{array}$ \\
\hline 1-Rejeição no Cliente (PPM) & 100 & 312 & 12 \\
\hline 2-Atendimento ao pedido (\%) & 100 & 93,9 & 100 \\
\hline 3-Rejeição no Processo de Fabricação (\%) & 2,5 & 3,9 & 2,5 \\
\hline 4-Tempo de Troca de Modelo (minutos) & 25 & 45 & 17 \\
\hline 5-Lead Time de Fabricação (minutos) & - & 957 & 282 \\
\hline 6-Estoque de Produto Acabado (dias) & - & 4,5 & 2 \\
\hline
\end{tabular}

Fonte: autores

Deste modo, os resultados nos indicadores de desempenho foram a seguir:

a) Melhoria no desempenho de atendimento ao cliente, com a redução da Rejeição no Cliente da ordem de 96\% (312ppm para 12ppm);

b) Atendimento ao Pedido aumentou para 100\% (anterior estava com 93,9\%);

c) Melhoria no desempenho nos processos internos, como a Rejeição no Processo de Fabricação com redução de 36\% (3,9\% para $2,5 \%)$

d) Tempo de Troca de Modelo com redução de 55\% (45 minutos para menos de 20 minutos),

e) Lead Time de Fabricação com redução de 70\% (957 minutos para 282minutos);

f) Resultado do conjunto das ações, a redução do Estoque de Produto Acabado da ordem de 55\% (4,5 dias para 2 dias).

$\mathrm{Na}$ avaliação de desempenho demonstrou melhoria no sistema pós Kaizen com uso de ferramentas gerenciais e no controle operacional. Destaca-se a aplicação do "5S" que proporcionou a definição dos passos de cada fase do processo de operação, assim como resultou na base física e comportamental do TPM e, por conseguinte, proporcionou um ambiente funcional, limpo e organizado de trabalho.

Com aplicação do sistema do QR-Code, todos os processos ganham em confiabilidade e rastreabilidade, reduzindo no processo a necessidade e a possibilidade da falha por erro de digitação e evitando inclusive a falha por esquecimento da inserção dos dados, pois o próprio sistema controla a sequência de entrada dos dados do fluxo de fabricação.

$\mathrm{Na}$ produtividade também houve ganhos operacionais significativos, eliminando a necessidade de preparar os formulários com anotações de dados que posteriormente são inseridos no sistema para disponibilizar recursos. Assim, os dados são transferidos ao sistema de controle aproximando-se do estado de "informação em tempo real", que melhoram no suporte às tomadas de decisões estratégicas da empresa, dando uma significativa contribuição à manutenção da competitividade e do crescimento da organização. Este processo resultou na agilidade do controle operacional e no aumento de confiabilidade na documentação do produto para sua rastreabilidade. 


\section{AGRADECIMENTOS}

Os autores agradecem o apoio na pesquisa ao Instituto SENAI de Tecnologia em Logística de Produção (ISTLP SENAI/SC), Programa de

\section{REFERÊNCIAS}

[1] Campos, Vicente Falconi. TQC: Controle da Qualidade Total (no estilo japonês). 9.ed. Nova Lima: Editora Falconi, 2014.

[2] Costa, H. G.; Nanci, L. C.; Quelhas, O. L. G.; Carvalho, R. A.; Gutierrez, R. H.; Simão, V. G. Sistemas de produção. In. Lustosa, L.; Mesquita, M. A.; Quelhas, O.; Oliveira, R. Planejamento e controle da produção. Abepro. Rio de Janeiro: Elsevier, 2008.

[3] Denso-Wave Incorporated. History of QRCode. Disponível em: < http://www.qrcode.com/en/history/>. Acesso em: 16 mai. 2018.

[4] Ghinato, Paulo. Sistema Toyota de Produção: mais do que simplesmente Just-in-Time. Caxias do Sul: Universidade de Caxias do Sul, 1996.

[5] Kaplan, R.; Norton, D. P. Organização orientada para a estratégia. Rio de Janeiro: Campus, 2001.

[6] Laurindo, Fernando José Barbin; MESQUITA, Marco Aurélio. Material requirements planning: 25 anos de história; uma revisão do passado e prospecção do futuro. Gestão \& Produção, v. 7, n. 3, p. 320-337, São Carlos: dez de 2000. (Edição especial sobre Planejamento e Controle da Produção).

[7] Laurindo, Fernando José Barbin. Tecnologia da Informação: eficácia nas organizações. São Paulo: Editora Futura, 2002.

[8] Medeiros Junior, A. Análise de novas tecnologias de comunicação de dados utilizadas na gestão da cadeia de suprimentos. Dissertação de mestrado do Departamento de Engenharia de Produção, Escola Politécnica, Universidade de São Paulo. São Paulo: USP, 2002.

[9] Ohno, Taiichi. O Sistema Toyota de Produção: Além da produção em larga escala. Porto Alegre: Bookmann, 1997.
Pós-Graduação em Engenharia de Produção e Sistemas da Pontifícia Universidade Católica do Paraná (PPGEPS/PUCPR) e Conselho Nacional de Desenvolvimento Científico e Tecnológico (CNPq).

[10] Okumura, J.; Vinotti, C. A.; Santos, I. L.; Okumura, M. L. M.; Canciglieri Junior, O. Manufatura Lean aplicada no processo fabril para implantação do código de barra bidimensional QRCode no controle operacional. In. Anais do VIII Congresso de Sistemas Lean, p.48-60, Florianópolis (SC), Jun 2018.

[11] Okumura, M.L.M.; Canciclieri Junior, O.; Oliveira, C.V. A aplicação da tecnologia assistiva no processo de desenvolvimento integrado de produtos inclusivos: um estudo no acesso ao código QR pelo usuário com deficiência visual. Relatório Técnico (mestrado), Programa de Pósgraduação em Engenharia de Produção e Sistemas, Escola Politécnica, Pontifícia Universidade Católica do Paraná, 2012.

[12] Oliveira, R. J. Sistemas de informação. In. Lustosa, L.; Mesquita, M. A.; Quelhas, O.; Oliveira, R. Planejamento e controle da produção. Abepro. Rio de Janeiro: Elsevier, 2008.

[13] Rodrigues, M. V. Entendendo, aprendendo e desenvolvendo, Sistema de Produção Lean Manufacturing. Rio de Janeiro: Elsevier, 2014.

[14] Sellitto, Miguel Afonso. Medição e controle de desempenho estratégico em sistemas de manufatura. Tese de doutorado. Escola de Engenharia da UFRGS. Porto Alegre: UFRGS, 2005.

[15] Shingo, Shigeo. O Sistema Toyota de produção: do ponto de vista da engenharia de produção. Porto Alegre: Bookmann, 1996.

[16] Silva, J.M. O ambiente da qualidade na prática: 5S. Belo Horizonte: Fundação Christiano Ottoni, 1996.

[17] Slack, N. Vantagem competitiva em manufatura: atingindo competitividade nas operações industriais. São Paulo: Atlas, 1993.

[18] Womack, J. A mentalidade enxuta nas empresas: elimine o desperdício e crie riqueza. Trad. Ana Beatriz Rodrigues, Priscilla Martins Celeste. Rio de Janeiro: Elsevier, 2004. 


\section{Capítulo 7}

\section{APLICACÃO DE FERRAMENTAS DA MANUFATURA ENXUTA EM UM SETOR DE UMA FÁBRICA DE DOCES}

\section{Tiana Leal Vicente}

\section{Maria Aparecida Fernandes Almeida}

\section{Carolina dos Santos Nunan}

Resumo: A filosofia Lean Manufacturing pode ser aplicada a qualquer sistema produtivo com um padrão de repetição nas atividades. O objetivo deste trabalho é apresentar os resultados em produtividade obtidos no setor câmera fria, de uma família de produtos doces recheados de uma indústria de pequeno porte, fabricante de doces a base de leite. Para análise inicial da área da câmera fria utilizou-se o diagrama de espaguete para verificação, dimensões de equipamentos e distâncias percorridas para a produção dos doces e a cronoanálise para verificação os tempos das atividades e o valor de cada atividade. Após análise inicial aplicou-se a metodologia 5W2H para o planejamento das ações; a análise cronométrica para comparação dos tempos e valor das atividades; a alteração de layout em célula "U" para criação de fluxo contínuo e os cinco sensos (5S) para organização do setor. Essas ferramentas tornaram o layout mais eficiente e resultando em aumento de produtividade. O trabalho realizado foi classificado como estudo de caso baseado em pesquisa exploratória e descritiva, tendo como resultado melhorias tanto quantitativas como qualitativas no setor da câmera fria. Implicações práticas: Esse estudo deseja apresentar soluções de baixo custo na aplicação da filosofia Lean para melhoria de produtividade em uma empresa de pequeno porte.

Palavras-chave: Lean Manufaturing; Layout; Produtividade. 


\section{INTRODUÇÃO}

A necessidade em aumentar a produtividade das empresas de forma simples e com baixo custo é uma das premissas da filosofia do Sistema Toyota de Produção, também chamado de Lean Manufacturing, isso implica em mais resultado com menor custo. A forma tradicional de se organizar uma fábrica, com a hierarquia de cima para baixo, sem escutar os operadores, os problemas vivenciados dia a dia no chão de fábrica e falta de padrão, levam as empresas a geração de desperdícios industriais e um índice baixo de produtividade. Diante desse cenário de empresas de pequeno porte buscam melhorias nos seus processos produtivos para se manterem competitivas.

O presente estudo tem por o objetivo apresentar as mudanças feitas em um Layout de fábrica com a utilização de ferramentas e conceitos de Lean Manufaturing em uma pequena indústria de doces a base de leite aonde os empresários apontaram uma alta na demanda de um doce específico que tem como matéria prima principal: amendoim, melado e leite condensado. Foi relatado que o setor de fabricação deste passava por problemas produtivos e não explorava seu potencial satisfatoriamente. O setor continha atrasos e não produção do doce, que necessitava ser diária pela alta demanda dos clientes finais.

A trabalho foi realizado no setor de câmara fria da indústria com a família de doces recheados. Inicialmente realizou-se um estudo do funcionamento do setor, a rotina de trabalho dos operadores, após foi acompanhado o produto desde a solicitação da matéria prima, sua preparação, até chegar as mãos do consumidor final.

Neste artigo são apresentadas todas as etapas de análise, os desperdícios identificados na linha de produção da família em estudo, as ferramentas utilizadas para alterações no Layout e os resultados obtidos com as mudanças pelo pensamento Lean.

O presente trabalho está organizado como se segue. Na seção 1 é apresentada uma introdução sobre o trabalhos, sua justificativa e objetivos. A seção 2 apresenta o referencial teórico sobre os conceitos fundamentais de Lean Manufacturing $e$ as ferramentas utilizadas no estudo. $\mathrm{Na}$ seção 3 é apresentada a metodologia. A seção 4 apresenta a análise dos resultados e a seção 5 mostra a conclusão do trabalho.

\section{REVISÃO BIBLIOGRÁFICA}

Segundo Tubino (2015): "Manufatura Enxuta, é uma estratégia de produção focada na diferenciação, baseada em um conjunto de práticas, oriundas do Sistema Toyota de Produção, cujo objetivo é melhorar continuamente o sistema produtivo por meio da eliminação das atividades não agregadoras de valor ao cliente, chamadas hoje de desperdícios." Isso implica numa forma de gerenciar os recursos: pessoas, máquinas e materiais, tendo retorno em produtividade.

Fullmann (2009) relata que para um alcance efetivo de produtividade, é necessário melhorar a forma de trabalho, os recursos ou meios de produção. É necessário otimizar as condições do ambiente e a forma como o trabalho é exercido, os materiais utilizados para a realização das tarefas e a forma psicológica a qual os operadores são submetidos. Tais melhorias trazem como consequência redução no tempo de operação e/ou redução da carga horário da mão de obra e a redução de desperdícios industriais.

Os desperdícios na indústria, segundo Tubino (2015), é tudo aquilo que não agrega valor ao cliente, ou seja, são todas as atividades que no sistema produtivo dos fornecedores internos e externos transformam a matéria prima e/ou componentes em produto acabado. Os desperdícios mais comuns encontrados nas indústrias são:

a) Desperdícios de super produção: que pode ser quantitativa (ocorre quando se produz além do que é solicitado) e por antecipação (quando a empresa decide fabricar o produto antes de sua solicitação;

b) Desperdícios de Estoque: representam custo elevado, problemas de controle e gestão de estoques, grandes áreas ocupadas e grandes distâncias entre processos;

c) Desperdícios de Transporte: relacionam-se com a movimentação de materiais ao longo do processo gerando custos e que não agregam valor ao produto;

d) Desperdícios de Espera: ocorrem perdas por espera no processo, por espera do lote e por espera do operador;

e) Desperdícios de Processamento desnecessário: ocorre quando são realizadas ações desnecessárias para que o produto atinja as especificações do projeto;

f) Desperdícios de Movimentos improdutivos: correspondem as operações inúteis nas linhas de fabricação ou nas maquinas; 
g) Desperdícios na Fabricação de produtos defeituosos: são desperdícios decorrentes da fabricação de produtos que não atendem as especificações mínimas de qualidade e do projeto gerando retrabalhos, refugos ou itens suspeitos;

h) Desperdício Intelectual: é devido ao não aproveitamento das habilidades e competências na organização.

$\mathrm{Na}$ observação desses desperdícios e na redução deles, utilizaram-se neste estudo as ferramentas de Mapeamento de Processos, Diagrama de Espaguete, Cronoanálise, 5 W2H, Alteração de Layout, Fluxo Contínuo e $5 \mathrm{~S}$.

Slack (2007) apresenta mapeamento de processo como toda a técnica que identifica os diferentes tipos de atividades de um processo de produção, que mostra o fluxo de materiais, pessoas e/ou informações.

"O Diagrama de Espaguete é uma ferramenta que ajuda a estabelecer o layout a partir das observações das distâncias percorridas na realização de uma atividade ou processo." Freitas apud Deguirmendjian (2016, p.39).

A Cronoanálise é definida por Martins e Laugeni (2015) como um dos métodos mais empregados na indústria para medir o trabalho e tendo como resultado os tempos padrão de produção.

Para Lenzi, Kiesel e Zucco (2010) a metodologia de planejamento $5 \mathrm{~W} 2 \mathrm{H}$ como uma listagem de atividades específicas que devem ser desenvolvidas com o máximo de clareza e eficiência por todos os envolvidos em um projeto. Auxiliando no entendimento das atividades, não deixando dúvidas sobre o projeto. São elas:

- What (o que será feito?): coloca-se qual objetivo deseja-se alcançar;

- Why (por que será feito?): são colocados os motivos que justificam o que será feito;

- Where (onde será feito?): é detalhado

o local onde será executada a ação;

- When (quando?): é definido o tempo para execução da ação;

- Who (por quem será feito?): coloca-se o responsável por cada ação;

- How (como será feito?): define-se qual o processo que será feito para atingir o objetivo;

- How much (quanto vai custar?): é o cálculo dos recursos que deverão ser alocados para se atingir o objetivo.
Slack (2007) explica que um arranjo físico diz respeito ao posicionamento físico de máquinas, pessoas e recursos transformadores de um sistema produtivo. Slack (2007) ainda completa:

"O arranjo físico é geralmente aquilo que a maioria de nós nota primeiro ao entrar e uma unidade produtiva, porque ele determina a aparência da operação. Também determina a maneira segundo a qual os recursos transformadores - materiais, informação e clientes - fluem nessa operação." (SLACK, 2009, pág 181)

Slack et al (2008) apresenta o arranjo físico e o balanceamento de linha como as decisões mais importantes de um projeto. Para Rother e Shoock (2003), o fluxo contínuo representa o caminho percorrido por cada item em seu fluxo de fabricação, sem paradas, sem esperas, sem formação de estoques, superprodução e com menos movimentação e transporte. Isso ocorre quando as máquinas ficam mais próximas uma das outras, em um layout em forma de "U" (conhecido por célula de produção). Os autores caracterizam célula como um arranjo de pessoas, máquinas, materiais e métodos em que as etapas estejam próximas uma das outras.

A ferramenta $5 S$ segundo Fulmann (2009) é uma forma de organizar o local de trabalho como um local de qualidade. Cada S (em japonês) representa uma busca pela:

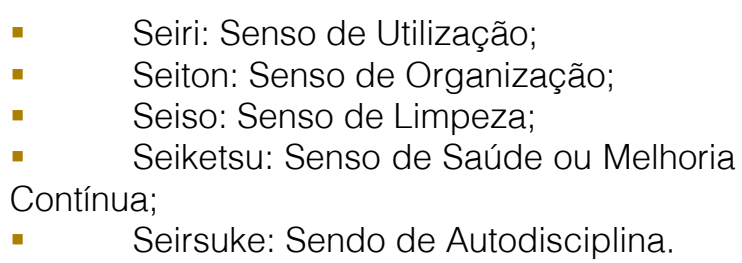

\section{MÉTODO PROPOSTO}

Essa pesquisa foi realizada em uma indústria de doces a base de leite, localizada no estado de Minas Gerais. A fábrica atende a clientes diretos no balcão ou indiretos que adquirem os produtos via telefone ou e-mail.

A produção é de uma batelada por dia de cada doce, se categorizando com uma produção empurrada, produzindo para estocar, o que implica em produção antecipada.

Mapeou-se todo o processo produtivo do doce, desde o pedido da matéria prima, a produção até sua expedição para o estoque e 
Figura 1 - Fluxograma da produção de doces com recheio.

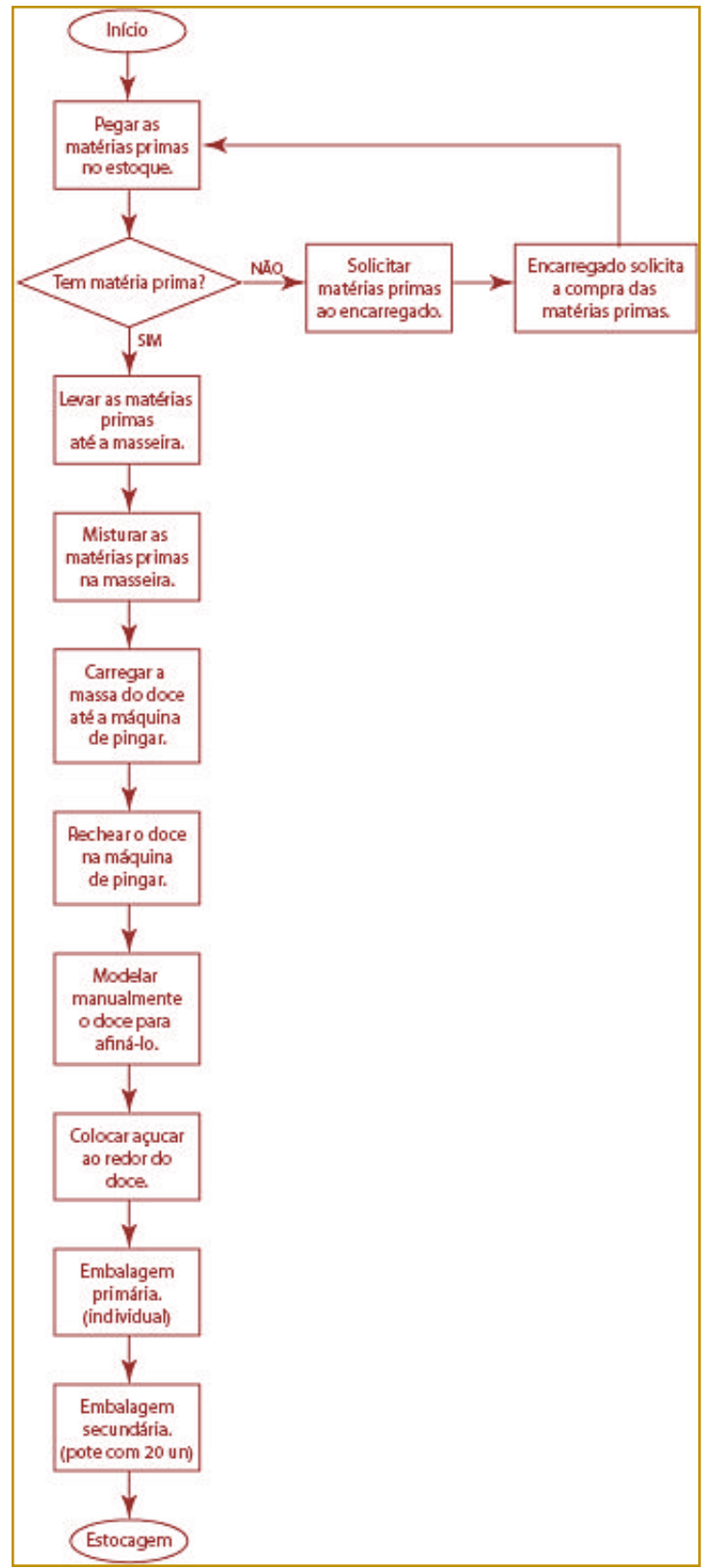

Fonte: Elaborado pelas autoras.

Para acompanhar a produção dos doces, primeiramente foi medida a área da câmera fria, seus equipamentos e mesas. Conforme é apresentado na Figura 2, a área comporta dois setores produtivos, ao lado direito do ambiente fica a produção dos doces com recheio, onde ficam as mesas 2 e 3, uma estante perto da mesa menor, uma mesa grande, a máquina que "pinga" e duas mesas pequenas. À esquerda o setor de corte manual composto pela máquina, mesa 1 , mesa 2 mais a esquerda perto das estantes de doces 1, 2 e dois lados, mesa lafayette e estante ao fundo. 
Figura 2 - Layout do setor câmara fria antes da aplicação das ferramentas lean. Fria

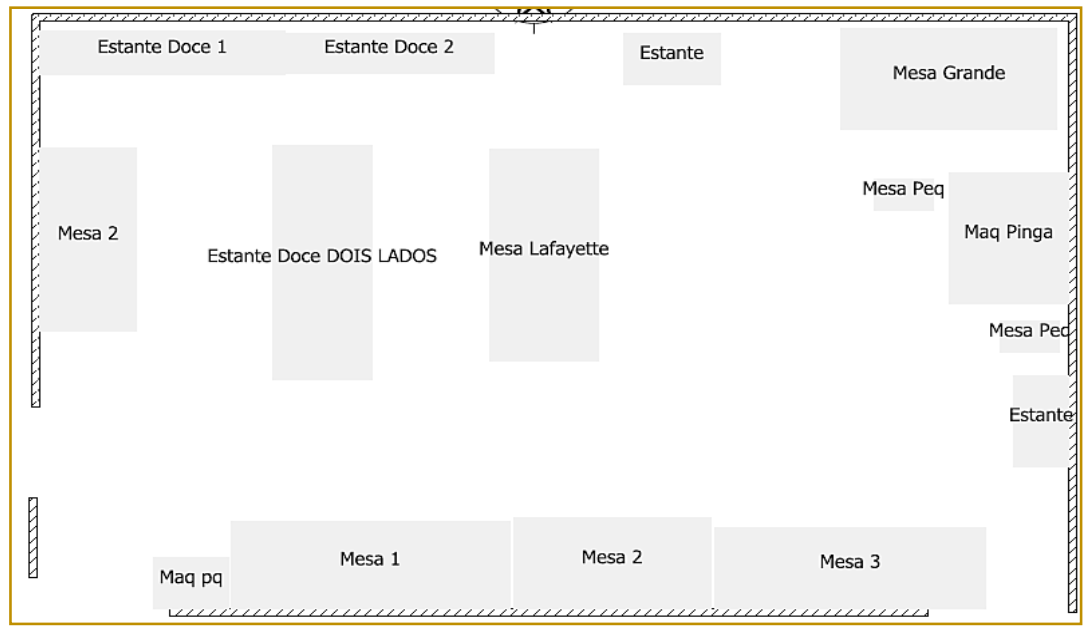

Fonte: Elaborado pelas autoras.

Conforme mostrado na Figura 3 foi utilizado para mapeamento do processo o Diagrama de Espaguete, para verificação das distâncias entre os equipamentos e a movimentação de pessoal.

Figura 3 - Diagrama de espaguete da produção do doce.

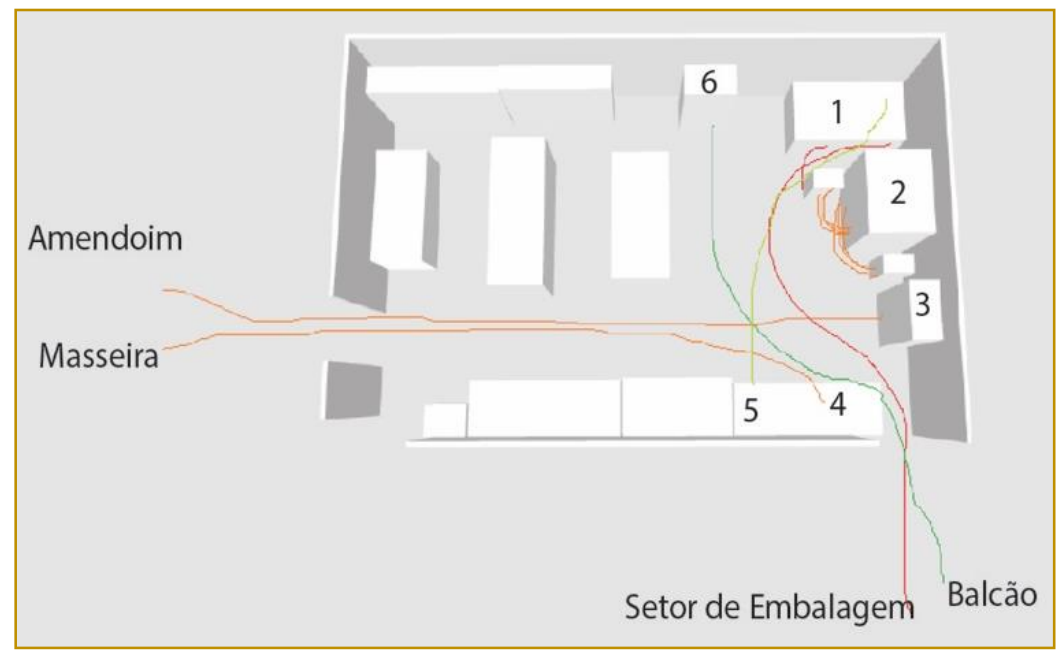

Fonte: Elaborado pelas autoras.

Conforme mostra a Figura 3, no deslocamento para produção da massa o operador pega o balde de melado que fica na marcação 4 e o leite condensado que fica na marcação 3 e caminha até a masseira e o amendoim para produzir a massa do doce. Após massa pronta ele retorna a câmera fria e entrega a massa para o operador da máquina que recheia e pinga $o$ doce no formato $e$ gramatura programada (2), dois operadores modelam manualmente os doces e passam açúcar (1). Estes operadores pegam o açúcar sempre que acaba em cima da mesa 5, e retornam para a mesa 1. Quando os doces estão acabados os operadores que modelam saem do local para que os operadores da embalagem retirem os produtos acabados e os levem ao setor de embalagem. As atendentes do balcão (como é chamado a recepção e atendimento ao cliente) por inúmeras vezes entram no setor até a estante para pegar produtos acabados pelo setor de corte (6).

Na medição inicial da produção dos doces, haviam 4 pessoas envolvidas. A primeira 
pessoa fazia a massa do doce em outro setor. Um segundo colaborador operava uma máquina de modelagem (que "pinga" e recheia o doce). As duas pessoas atuavam na modelagem manual (atividade necessária para afinar o doce para sua posterior passagem pela máquina de embalagem) e no acabamento com o açúcar.

O acompanhamento da produção do doce ocorreu entre 6:30 até 13:30 (7 horas de trabalho). Com o trabalho de 4 operadores foram produzidas 40 bandejas com 88 doces cada. Totalizando uma produção de 3.520 unidades por dia. Calculou-se então a quantidade de doces produzida por hora homem (3.520 doces/ 28 horas). Este valor representa um total de 125,7 unidades do doce produzidas por hora homem.

Foram produzidas planilhas de Cronoanálise com medições dos tempos e eles foram separados da seguinte forma:

- Atividade agregadora de valor: Atividade reconhecida como de valor ao produto.

- Atividade não agregadora de valor: Atividade não reconhecida como de valor ao produto.

- Atividade incidental: Atividade não reconhecida como de valor ao produto, mas necessária, por exemplo, satisfação de necessidades fisiológicas dos operadores.

Além das descritas anteriormente, foi aplicada na câmara fria a ferramenta dos Cinco Sensos (5S) com o envolvimento de todo pessoal do setor e demais indicados pelos gestores. Após a aplicação das ferramentas Lean selecionadas para este trabalho foi feita uma nova Cronoanálise para verificar os tempos e comparação de produtividade.

\section{RESULTADOS}

\subsection{FASE DIAGNÓSTICA}

O Diagrama de Espaguete, mostrado na Figura 3, indicou que a movimentação dos operadores é cruzada. Os atendentes do balcão entram no setor produtivo, atravessam o setor até chegarem à estante (marcação 6) para pegar doces acabados. O diagnóstico apontou que os carregamentos de peso em distâncias longas aconteciam simultaneamente. A distância do depósito de amendoim também era longe da masseira onde era feita a mistura da massa do doce. Uma pessoa passa no mesmo local que outra, cruzando e atrapalhando a passagem de outra. Este tipo de layout cria grandes paradas e fluxo cruzado.

O layout do setor da câmera fria apresentouse limitado para movimentação na área de finalização, com movimentos que comprometiam a ergonomia e saúde dos funcionários, com uma movimentação exagerada e sem orientação.

Observou-se também que os funcionários desperdiçavam tempo de produção aguardando a massa do doce que era feita em outro setor bem distante do setor deles. Inúmeras vezes os operadores necessitavam parar a produção por falta de bandejas (também chamadas tampas) para colocarem os doces ou por falta de matéria prima. O amendoim era a matéria prima que acabava com mais frequência, por falta de estoque. Nesta situação, a produção do doce cessava completamente. Foi identificado que não havia um controle visual nem administrativo sobre a quantidade utilizada entre um dia e outro. Esse procedimento ocasionava atrasos frequentes no pedido do material, resultando em produção ociosa por falta de matéria prima.

A Cronoanálise mostrou que em 420 minutos, que equivalem às 7 horas, um operador sem função definida, percorreu 4.230 metros. O operador percorreu vários pontos da indústria em busca de matéria prima, tampas, produção de massa para doce, levar doces prontos para o setor de embalagem e buscar informações com as atendentes de balcão.

O tempo aproximado de desperdício em movimentação pela fábrica do operador acompanhado foi de 2 horas e 27 minutos de um dia de trabalho de 8 horas.

Analisando o tempo de cada uma das atividades pela Cronoanálise, e agregando o valor de cada atividade, conforme legenda, gerou-se o gráfico mostrado na Figura 4. 
Figura 4 - Resultado da análise por tempo de operação, estado inicial.

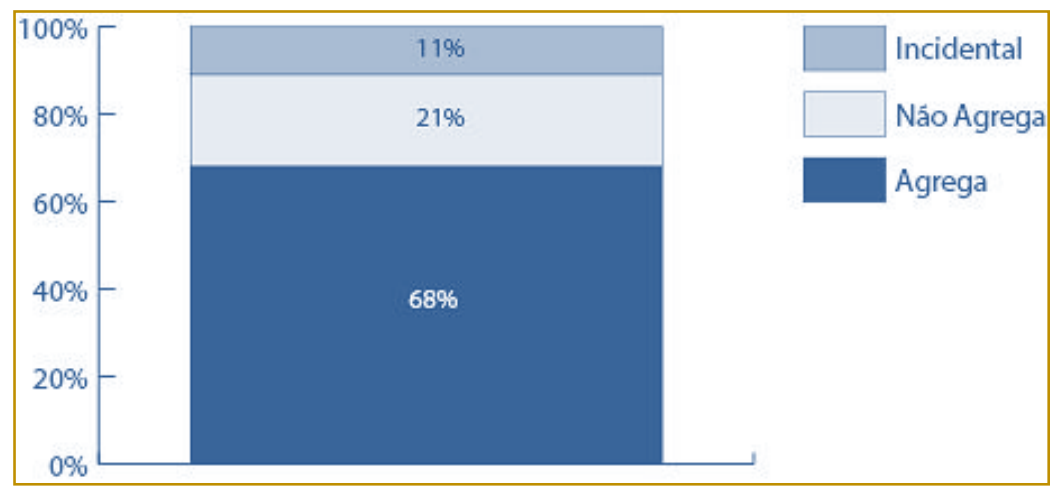

Fonte: Elaborado pelas autoras.

Durante a Cronoanálise verificou-se que não existia uma rotina sistemática de limpeza no setor, pois como a produção não atendia a demanda, os operadores dedicavam o horário integralmente para a produção, sem a parada para limpeza do ambiente. Também não havia procedimento padronizado para o manuseio dos doces. Outro ponto a considerar é que os operadores do setor não se sentiam com autonomia para tomar muitas decisões e tinham reclamações a respeito da forma como eram conduzidas a produção e as solicitações.

Compilando todos os dados obtidos na fase diagnóstica, os apontamentos mais evidentes foram:

a) Estoque não contabilizado, nem acompanhado;

b) Masseira e matérias primas ficam em locais afastados da produção;

c) Existência de máquina sem uso e outros objetos que precisam de destinação e organização;

d) A atividade modelagem manual ("enrolar") cria um gargalo na produção, cansaço e desgaste nos operadores. Tal atividade é realizada para deixar o doce mais fino para posterior entrada em uma máquina da embalagem.

\subsection{APLICAÇÃO DE FERRAMENTAS LEAN}

\subsubsection{PLANO DE AÇÃO DO 5W2H}

No diagnóstico a partir do Diagrama de Espaguete observou-se que a máquina de pingar doce não funcionava em seu total desempenho, sendo subutilizada, uma vez que havia muitas paradas, por falta da matéria prima, distâncias e manutenção. Criou-se um plano de ação $5 \mathrm{~W} 2 \mathrm{H}$ para listar todas as atividades necessárias para a melhoria da produtividade e redução de movimentação.

A criação de um Plano de Ação $5 \mathrm{~W} 2 \mathrm{H}$ foi utilizada para a definição de quais atividades e respectivos responsáveis, foi desenvolvida para a avaliação dos desempenhos antes e depois das mudanças sugeridas.

\subsubsection{CRONOANÁLISE}

As planilhas de Cronoanálise foram utilizadas para verificar os tempos das atividades e seus valores agregados e o Diagrama de Espaguete para identificar a movimentação. Observou-se que os operadores ficavam muito tempo em espera e o resultado apontou que o gargalo de produtividade estava na atividade modelar manualmente (enrolar), passar açúcar e colocar o doce na bandeja. A atividade modelar manualmente o doce não agrega valor ao produto, considerando-se um gargalo. A máquina de modelagem consegue modelar o doce mais fino, mas uma peça da mesma estava quebrada. Foi necessário substituir por uma nova peça. Com a máquina em total funcionamento, a atividade de modelar o doce manualmente não é mais necessária. $O$ doce sai da máquina com o diâmetro necessário para passar direto pela máquina de embalagem. $\mathrm{Na}$ figura 5, apresenta-se a atividades e seua valores de acordo com legenda sobre as atividades dos operadores após as ferramentas lean. 
Figura 5 - Resultado da análise por tempo de operação, estado após ferramentas lean.

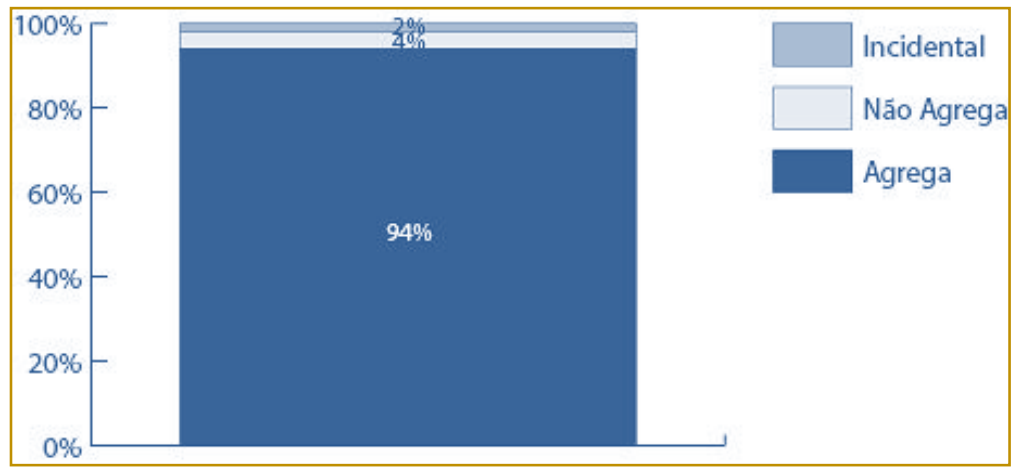

Fonte: Elaborado pelas autoras

\subsubsection{ALTERAÇÃO DE LAYOUT}

Estudou-se a melhor forma para criar um Layout em "U" para o setor do doce de caju, e que isolasse este do setor do corte. A Figura 6 mostra que a masseira foi colocada no setor do doce recheado, assim como a mesa do amendoim. Os melados foram colocados próximos e em cima de paletes de plástico, formando então um supermercado, com todas as matérias primas necessárias para a produção do doce. Foi designado um abastecedor, pessoa responsável por separar a matéria prima no final do turno para o outro dia.

Figura 6: Layout atual do setor câmara fria.

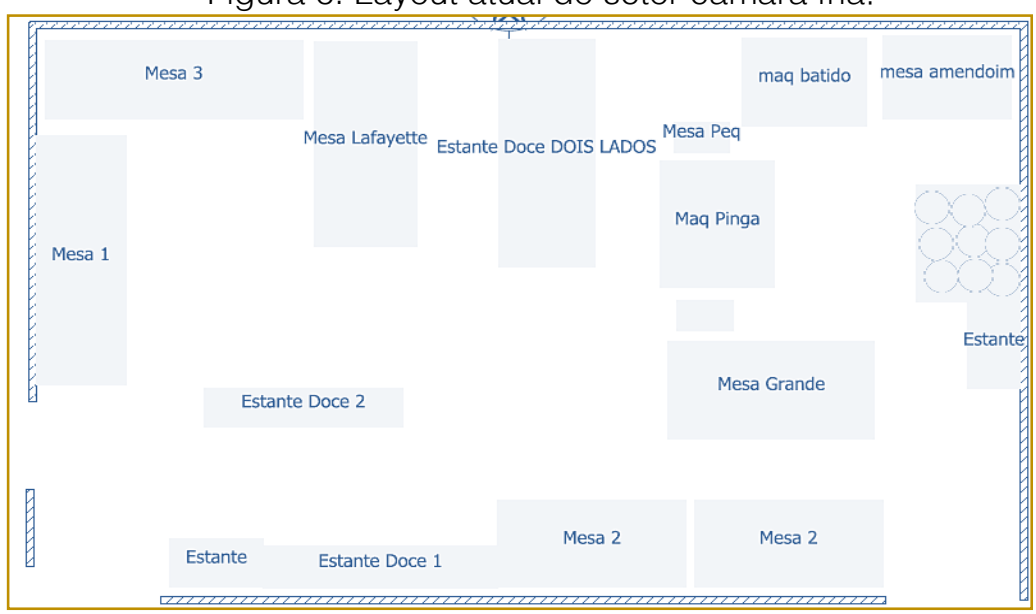

Fonte: Elaborado pelas autoras

\subsubsection{FLUXO CONTÍNUO DE OPERADORES E MATERIAIS}

A câmera fria é uma área onde ficam duas áreas de produção. Ao lado direito do ambiente fica a produção do caju e doces com recheio e a esquerda o setor de corte manual.

Para uma melhoria efetiva em relação ao deslocamento dos operadores, entrada e saída de material, foi estudado o Fluxo Contínuo. Para uma melhoria efetiva em relação ao deslocamento dos operadores, entrada e saída de material, foi estudado o Fluxo Contínuo conforme mostra a Figura 7. A estante onde as atendentes buscam os doces foi direcionada próxima a porta de saída. As mesas foram organizadas por tamanho e as alturas adaptadas para os operadores, abrindo espaço para a porta principal pudessem ser abertas em sua totalidade. Os setores foram mais bem distribuídos e com uma separação espacial. 
Figura 7 - Movimentação atual no Layout em "U” com fluxo contínuo.

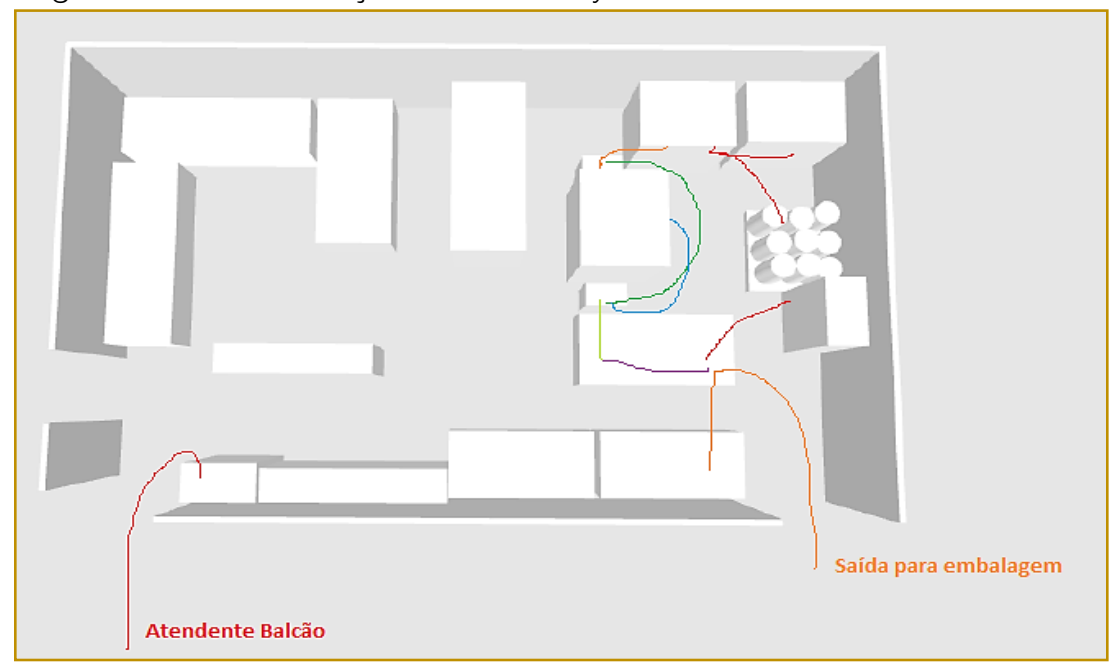

Fonte: Elaborado pelas autoras.

\subsubsection{APLICAÇÃO DE 5S}

Para um melhor entendimento do pensamento Lean e aplicação do 5S foram desenvolvidas as ações sumarizadas a seguir:

- Utilização: A máquina sem uso foi retirada do local e outros objetos que não faziam parte do ambiente de trabalho;

- $\quad$ Arrumação: Com a alteração do layout conforme fluxo contínuo etiquetou-se os locais de cada coisa;

- Limpeza: Foram limpos paredes, máquinas e instrumentos e locais dedetizados;

- Comprometimento: observou-se o empenho da equipe que aplicou o $5 \mathrm{~S}$ em outros setores da empresa entendendo os conceitos de melhoria contínua;

- Disciplina: Criou-se o hábito da limpeza ao final do turno. Assim não se perde tempo mais limpando a máquina com o doce seco.

Tabela 1 - Comparação de Produtividade

\begin{tabular}{|c|c|c|c|c|c|}
\hline \multicolumn{5}{|c|}{$\begin{array}{c}\text { Doces produzidos por } \\
\text { dia }\end{array}$} & \multicolumn{5}{c|}{$\begin{array}{c}\text { Número de } \\
\text { EP }\end{array}$} & 3520 & 7 & 4 & 28 & 125,7 \\
\hline EF & 9600 & 5,5 & 3 & 16,5 & 581,8 \\
\hline \multicolumn{5}{|c|}{ Cálculo de produtividade= (EF-EP)/EP $=(581,8-125,7) / 125,7$} \\
\hline \multicolumn{5}{|c|}{ Produtividade } \\
\hline
\end{tabular}

Fonte: Elaborada pelas autoras

\section{CONCLUSÕES}

O presente estudo possibilitou demosntrar o impacto das ferramentas de Lean Manufaturing no Layout da câmera fria de uma pequena indústria de doces,
Após a implantação das ferramentas lean, participação efetiva da equipe do setor, alcançou-se uma melhoria significativa de produtividade. Com a masseira próxima e supermercado para abastecimento eliminouse as grandes paradas. E fluxo contínuo facilitou a forma de produção. A máquina modeladora (pinga) recebeu a peça nova, o diâmetro do doce ficou ideal e padronizado eliminando a atividade modelagem manual, desocupando o operador para realocação em outro setor. Estas mudanças definiram um formato padrão de tamanho, cabendo 96 peças por bandeja. Esta modificação na modelagem permitiu uma saída em 5,5 horas (de 7:30 às 13:00) de 100 bandejas com 3 operadores. A Tabela 1 mostra o ganho de produtividade. A produção aumentou para 9.600 doces por dia em 16,5 horas homem, o que permite ao final do dia o aproveitamento de uma hora para limpeza. aumentando sua produtividade e reduzindo as distâncias de movimentação dos operadores.

Os ganhos de produtividade se deram na ordem do aumento de $363 \%$ de doces por 
homem/hora tendo sido utilizado das ferramentas de análise. Primeiramente utilizou-se mapeamento do processo, onde foram identificados a sequência operacional e os desperdícios no setor. O diagrama de espaguete apontou as grandes distâncias percorridas pelos operadores e a cronoanálise identificou os tempos das atividades e o valor agregado das mesmas.

Após a fase de mapeamento foi criado um plano de ação $5 \mathrm{w} 2 \mathrm{~h}$. As atividades verificadas como as possíveis soluções foram: Supermercado no setor, com todas as matérias primas necessárias para a produção. Controlar o estoque, uma pessoa responsável pelo abastecimento do supermercado ao final do turno de trabalho. Masseira no setor para redução de movimentação. Alteração do Layout em U. Compra da peça que deixa o doce mais fino, retirando a operação gargalo "enrolar", criando a redução de operadores de 4 para 3, liberando um operador para outro setor com maior necessidade. 5S no setor para organização, limpeza e marcações.

\section{REFERÊNCIAS}

[1] Deguirmendjian, Samira Candalaft. Lean Healthcare: Aplicação do Diagrama de Espaguete em uma Unidade de Emergência. DissSCD, 2016. Disponível em

<https://repositorio.ufscar.br/handle/ufscar/7405>. Acesso em: 20 de Maio 2018.

[2] Fullmann, Claudiney. O Trabalho: Mais Resultado com Menos Esforço - Passos para a Produtividade. São Paulo: Educator, 2009.

[3] Lenzi, Fernando César; Kiesel, Marcio Denie; Zucco, Fabrícia Durirux. Ação empreendedora: como desenvolver e administrar o seu negócio com excelência. São Paulo: Editora Gente, 2010.

[4] Martins, Petrônio G; Laugeni, Fernando Piero. Administração da Produção. 2. Ed. São Paulo: Saraiva, 2005.
A movimentação foi reduzida, pois as funções foram definidas e houve troca do layout, tendo como resultado melhoria no processo produtivo. O abastecedor traz todas as matérias primas necessárias para o dia e o deslocamento dos operadores se limita ao setor.

Os estudos, desde diagnóstico foram feitos com empenho dos operadores e percebeu-se que com ações simples e de baixo custo surtiram resultados muito altos. A tentativa de alterar o layout em $U$ foi a mais envolvente, foram feitos três testes de troca de layout para chegar ao layout que permitiu as melhorias vistas.

As ferramentas Lean utilizadas para alteração de layout mostraram-se eficazes, percebeu-se pelos gráficos que apresentam a mitigação de desperdícios, redução de tempo de deslocamento. A implementação do $5 S$ se mostrou efetiva, melhorando a oganização e limpeza do setor facilitando a transição dos operadores e mantendo uma rotina de higiene e saúde adequadas. Os ganhos na indústria foram tanto quantitativos como qualitativos.

[5] Rother, Mike; Shook, Jonh. Aprendendo a Enxergar: Mapeando o Fluxo de Valor para Agregar Valor e Eliminar o Desperdício. São Paulo: Lean Institute Brasil, 2003.

[6] Slack, Nigel; Chambers, Stuart; Jonhston, Robert. Administração da Produção. 2. ed. São Paulo: Atlas, 2007

[7] Slack, Nigel; Jones, Alistair; Jonhston, Robert. Princípios da Administração da Produção. São Paulo: Atlas, 2008.

[8] Tubino, Dalvio Ferrari. Manufatura Enxuta Como Estratégia De Produção: A Chave Para A Produtividade Industrial. São Paulo: Atlas, 2015. 


\section{Bapítulo 8}

\section{PRODUÇÃO ENXUTA E FERRAMENTAS DA QUALIDADE: UM ESTUDO DE CASO EM UMA INDÚSTRIA DE AUTOPEÇAS}

\section{Lorena Bittencourt Bastos}

Gabriela da Rosa Witeck

José Wianey Adami

Jardel Santos de Oliveira

Edson Pacheco Paladini

Resumo: Objetivo(s):Analisar o processo produtivo de uma indústria fornecedora de autopeças, localizada no estado de Santa Catarina, utilizando ferramentas de gestão e qualidade e propondo melhorias para o aumento da produtividade.

Metodologia/abordagem:No desenvolvimento do estudo de caso,utilizou-se as ferramentas 5W2H, Diagrama de Ishikawa, e histogramapara a determinação das causas do problema,onde foram identificados os problemas do processo, como o elevado tempo de setup e a necessidade de melhoria da performance. No plano de ação, para cada proposta sugerida foram analisadas as seguintes categorias: custo, facilidade e o impacto.

Resultados: Os resultados alcançados mostraram uma redução do tempo de setup de $38 \%$, a produtividade com um avanço em $15 \%$, após a proposta de melhorias. Os problemas apresentados neste trabalho, geram oportunidades de melhoria, desafia a situação atual e promove a solução dos mesmos.

Implicações práticas: $\mathrm{O}$ uso das ferramentas $5 \mathrm{~W} 2 \mathrm{H}$ Diagrama de Ishikawa e histograma, auxiliaram na identificação das causas raízes dos problemas envolvidos na produção. Este estudo mostrou a importância da utilização dessas ferramentas na gestão industrial, e como elas podem contribuir para o aumento da produtividade, redução do tempo de setup e otimização dos processos.

Palavras-chave: Tempo de setup; Melhoria de processos; Ferramentas da qualidade. 


\section{INTRODUÇÃO}

A filosofia da manufatura enxuta combina estratégias de flexibilidade nos processos, baixos custos da produção, e promove a lucratividade como resultado direto da redução de desperdícios. Enquanto aplicada em uma tríplice indissociável de pessoas, processos e operações, faz-se necessário um acompanhamento minucioso em todo o processo produtivo; no qual oportunidades de melhorias serão identificadas ao longo da cadeia produtiva, promovendo a eliminação sistemática de desperdícios, e de processos que não agreguem valor à cadeia e ao produto (OHNO, 1997; SILVA; ALVES, 2011).

As organizações recebem conhecimentos e informações do meio, adaptam-se e criam, de dentro para fora, novos conhecimentos e informações, recriando assim seu meio (NONAKA; TAKEUCHI, 1997). As primeiras ações à luz da filosofia enxuta demandam combinação e internalização de novos conhecimentos dentro da organização; seguido da implementação que envolve a mudança de aspectos técnicos e socioculturais (TORTORELLA; FOGLIATTO, 2014). Para tanto, é sinergético o uso de práticas lean, e outras ferramentas de qualidade, que apontem oportunidades de melhorias contínuas, para que a mentalidade enxuta possa fluir naturalmente dentro da organização e constituam melhores índices de produtividade.
Ao estabelecer foco em uma indústria de autopeças, esse estudo teve como objetivo adaptar os processos de fabricação à luz da mentalidade enxuta, fazendo uso da aplicação dos conceitos e ferramentas da qualidade, a fim de buscar melhores índices de produtividade e aumentar a capacidade de produção. Para tanto algumas etapas foram seguidas: coleta de dados, identificação dos problemas prioritários, análises, e por fim as propostas das ações.

\section{REVISÃO BIBLIOGRÁFICA}

\subsection{MANUFATURA ENXUTA FERRAMENTAS DA QUALIDADE}

As filosofias da qualidade e da manufatura enxuta são complementares. Juntas, as técnicas e ferramentas criam uma sinergia na eliminação de desperdícios, redução da variabilidade dos processos e aumento da capacidade de produção.

A manufatura enxuta é uma abordagem que envolve princípios e práticas de gestão, os quais possuem como objetivo reduzir o desperdício e melhorar a eficácia operacional ao longo de todo o fluxo de valor na melhoria contínua (TORTORELLA, 2015). O Quadro 1 apresenta uma sistematização das principais atividades e práticas associadas à manufatura enxuta.

Quadro 1 - Sistematização das principais ações e práticas que caracterizam a Manufatura Enxuta.

\begin{tabular}{|c|l|}
\hline Práticas e Características & \multicolumn{1}{|c|}{ Descrição } \\
\hline Melhoria Contínua & Busca contínua da melhoria em qualidade, custo, entrega e projeto; \\
\hline Just in Time (JT) & Busca o Fluxo Contínuo da Produção; \\
\hline Kanban & Sistemas de Cartões para criação de um Fluxo Puxado; \\
\hline Desenvolvimento de Fornecedor & Atividades para desenvolvimento de colaboração com o fornecedor; \\
\hline Manutenção Produtiva Total (TPM) & $\begin{array}{l}\text { Gestão visual para redução da desordem e ineficiência entre as } \\
\text { relaçôes administrativas e produtivas; }\end{array}$ \\
\hline Redução de Lote/Estoque & $\begin{array}{l}\text { Formação de capacidade pequenos lotes para disponibilidade dos equipamentir estoques e aumentar a pela } \\
\text { variedade; }\end{array}$ \\
\hline Funcionário Multifuncional & Desenvolvimento das habilidades dos funcionários por treinamentos; \\
\hline Círculo de Melhoria (Kaizen) & $\begin{array}{l}\text { Discussōes sistemáticas entre operacional e gestão visando a melhoria } \\
\text { contínua; }\end{array}$ \\
\hline Mapeamento do Fluxo de Valor & $\begin{array}{l}\text { Redução de desperdisicos através de um menor índice de defeitos, } \\
\text { diminuição do tempo de set-up, redução de residuos, diminuição do } \\
\text { consumo de energia, análise do lead-time e tempo de processo. }\end{array}$ \\
\hline
\end{tabular}

Fonte: Adaptado de Jabbouret al. (2013). 
As ferramentas de qualidade buscam reduzir itens defeituosos e custos. Tal resultado é viabilizado por meio da redução de variabilidade do processo, permitindo um aumento da competitividade e sustentabilidade da organização (SOUSA et al, 2017). Paladini (2011) ainda ressalta que os processos de implantação da gestão da qualidade decorrem de políticas, decisões e métodos patrocinados pela administração, mas que sejam de conhecimento e entendimento de quem vai realmente colocar em prática.

Neste trabalho serão utilizadas basicamente três ferramentas da qualidade: diagrama de causa e efeito, plano de ação $5 \mathrm{~W} 2 \mathrm{H}$ e histograma. O foco dessas ferramentas está na coleta de dados e análises dessas informações. O diagrama de Ishikawa, também conhecido como diagrama de Causa e Efeito, auxilia o processo de exploração das causas raízes do problema. De acordo com Slack, Chambers e Johnston (2009), os diagramas de Causa e Efeito são utilizados em programas de melhoramento, uma vez que fornecem um modelo de estrutura para gerações de idéias em grupo. Já a ferramenta 5W2H, de acordo com Campos (1992), é utilizada para nortear as atividades usando, apenas, as sete perguntas-chave: o que vai ser feito; por quem; onde; quando; porque; quanto vai custar; como será feito a resolução do problema. Por fim, a ferramenta da qualidade "histograma" ou "gráfico de barras", sinaliza a distribuição e frequência de determinada variável analisada. Neste caso, a ferramenta pode ser utilizada para verificação da freqüência em que ocorre a sobra de um determinado material dentro de um processo produtivo, permitindo assim, uma possível análise para redução nessa condição de sobra (CAMPOS, 1992).

\subsection{METODOLOGIA OEE}

Dentre os desperdícios abordados na manufatura enxuta, por Ohno (1997), o desperdício por equipamentos advém da espera no processamento em si, e na fabricação de produtos defeituosos. Para tanto, por meio da metodologia OEE é possível identificar e evitar as perdas no ambiente fabril, que envolvem índices de disponibilidade de equipamentos, de performance e de qualidade.

A OEE (Overall EquipmentEffectiveness) é um indicador especialmente útil em manufaturas de alto volume de produção, as quais priorizam o aumento de produtividade como fator de competição, tal como ocorre na indústria de processamento contínuo (RON e ROODA, 2005). Segundo Oliveira e Sangineto (2010) o cálculo de OEE é realizado a partir dos parâmetros de disponibilidade, performance e qualidade, como segue: disponibilidade é determinada pela fração de tempo que o processo está disponível em relação ao tempo total; a performance é a fração entre a quantidade de peças produzidas e a quantidade teórica máxima que deveria ser produzida; a qualidade é a fração de itens produzidos dentro das especificações, divididos pela quantidade total de itens produzidos.

\section{MÉTODO PROPOSTO}

O trabalho foi realizado em uma indústria fornecedora de autopeças para a linha automotiva, localizada na região sul do país. A pesquisa foi elaborada diante da necessidade do aumento da produtividade e performance dos gargalos produtivos da empresa.Em busca de melhores índices de eficácia, a empresa tomou a decisão em automatizar uma célula de trabalho, na qual eram fabricados diversos itens similares. Para tanto, uma máquina específica foi desenvolvida e entrou em operação com a proposta de substituir as atividades manuais.

Para o desenvolvimento deste trabalho foram utilizados ferramentas da qualidade, e conhecimentos aplicados na temática de Planejamento e Controle de Produção, como: capacidade produtiva; identificação de gargalos no processo; tempo de ciclo; cálculo do indicador OEE - onde é possível identificar a eficiência da disponibilidade - ; performance (queda de velocidade, pequenas paradas e ociosidades) ; qualidade (refugo e retrabalho).

Por meio de visitas in 10co, o processo foi observado e analisado, e por intermédio de dados históricos dos tempos de ciclo das operações foi possível uma demonstração da condição atual do gargalo produtivo. Com a compilação dos dados, foi viável a formulação das causas-raiz do problema, demonstradas no Diagrama de Ishikawa. E, por fim, realizado o plano de ação e proposta de melhorias do processo, de acordo com o nível de facilidade e impacto de cada proposta sugerida. 


\section{RESULTADOS}

\subsection{CARACTERIZAÇÃO DA EMPRESA}

O trabalho foi realizado em uma indústria fornecedora de autopeças para a linha automotiva. A empresa está localizada na região sul do país no estado de Santa Catarina, com mais de 40 anos de atuação no mercado de autopeças, contendo aproximadamente 1.000 funcionários em seu quadro de colaboradores.

A empresa possui em torno de 2.000 produtos em seu portfólio e atende praticamente à todas as montadoras no país. Atua tanto no mercado original, quanto ao de reposição. E produz anualmente 15 milhões de componentes.

\subsection{DISCUSSÃO DOS RESULTADOS}

O estudo foi realizado em uma máquina do fluxo 2, na célula 47 - situada na montagem automática impulsor -, com o objetivo de aumentar aproximadamente $75 \%$ da produção de suas peças fabricadas mensalmente.

Após tomar conhecimento dos processos, familiarização com a máquina - por meio da análise do fenômeno -, análise dados históricos, e tempo de ciclo de cada código executado naquele posto de trabalho, foi possível constatar que a máquina poderia produzir em 2 turnos cerca de 77.976 pçs/mês, e em 3 turnos 96.323 pçs/mês, conforme Tabela 1.

Tabela 1 - Tempo de ciclo na condição ideal

\begin{tabular}{|c|c|c|c|c|}
\hline Item & Qtde & $\begin{array}{l}\text { Tempo } \\
\text { de ciclo } \\
\text { (s) }\end{array}$ & $\%$ Prod. & $\begin{array}{c}\text { Tempo } \\
\text { Ponderado }\end{array}$ \\
\hline 1481 & 36.730 & 11,6 & \multirow[t]{2}{*}{$49 \%$} & \multirow[t]{2}{*}{5,69} \\
\hline 1750 & 5.293 & 11,6 & & \\
\hline 1663 & 13.240 & 21,18 & \multirow[t]{4}{*}{$51 \%$} & \multirow[t]{4}{*}{10,79} \\
\hline 1748 & 12.288 & 21,18 & & \\
\hline 1747 & 10.760 & 21,18 & & \\
\hline 1664 & 7.360 & 21,18 & & \\
\hline Total & 85.671 & - & $100 \%$ & 16,48 \\
\hline
\end{tabular}

2 TURNOS
2 tumos $=\frac{17 \mathrm{~h} \times 21 \mathrm{~d} \times 3.600}{16,48}=77.976 \mathrm{pçs} / \mathrm{mês}$
OEE $=\frac{85.671}{77.976}=110 \%$
$\beta$ TURNOS
3 tumos $=\frac{21 \mathrm{~h} \times 21 \mathrm{~d} \times 3.600}{16,48}=96.323 \mathrm{pçs} / \mathrm{mês}$
OEE $=\frac{85.671}{96.323}=89 \%$

Fonte: Autores (2018)

A condição atual no período de abril à agosto foi produzida uma média de 49.103 pçs/mês.
$\mathrm{Na}$ Figura 1, são representados os percentuais das produtividades mensais.

Figura 1 - Representação gráfica da produtividade mensal

\begin{tabular}{|c|c|c|c|c|c|c|}
\hline \multirow[t]{2}{*}{ 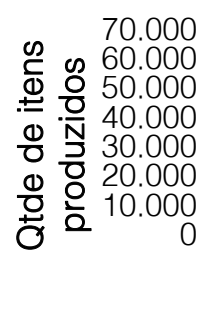 } & & & & & & \multirow[t]{4}{*}{$\begin{array}{l}30 \% \\
25 \% \\
20 \% \\
15 \% \text { ॰ } \\
10 \% \\
5 \% \\
0 \%\end{array}$} \\
\hline & Abril & Maio & Junho & Julho & $\begin{array}{c}\text { Agost } \\
0\end{array}$ & \\
\hline Qtde & 50.562 & 41.238 & 61.560 & 47.178 & 44.980 & \\
\hline$--\%$ & $21 \%$ & $17 \%$ & $25 \%$ & $19 \%$ & $18 \%$ & \\
\hline
\end{tabular}

Fonte: Autores (2018) 
Nas primeiras análises, para que a célula atendesse a fabricação de todos os códigos conforme a previsão da empresa foi previsto a necessidadede fabricar 85.671 peças. No entanto, para isto acontecer o OEE deveria melhorar de $69 \%$ para $89 \%$, conforme representado nos gráficos 2 e 3, da Figura 2.

Composição do OEE de agosto = 69\% (Disponibilidade $=86 \%$, Performance $=85 \%$, Qualidade = 95\%).

Figura 2 - Indicador OEE

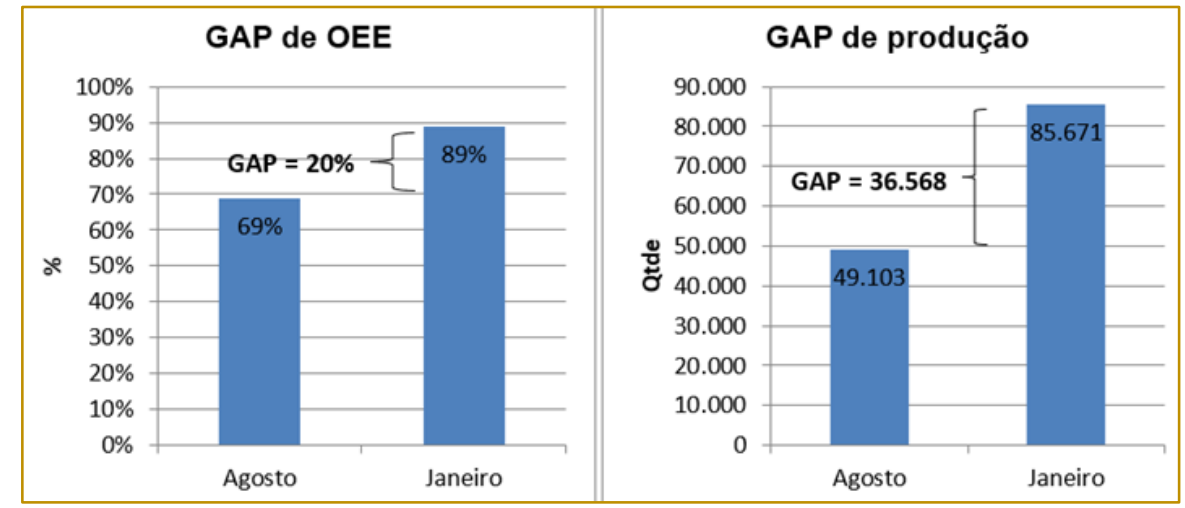

Fonte: Autores (2018)

Desta forma, para ser possível o aumento do OEE de 69\% para 89\% seria necessário aumentar a produção de 49.103 pçs/mês para 85.671 pçs/mês. No período em estudo, o tempo de ciclo real mensal da produção era de 16,4 s/pç e o tempo de ciclo teórico era de $13,91 \mathrm{~s} / \mathrm{pç}$. Desse modo, existia uma diferença em 2,4 s/pç, a qual gerava uma perda significativa na produção.

Foi verificado que os registros de paradas nos maquinários eram negligenciados, pois não havia precisão nos dados e os devidos cuidados nos apontamentos. Registravam-se apenas as grandes paradas, desprezando as demais. O apontamento de paradas era registrado pelo operador da máquina, em um sistema da empresa - específico para esta finalidade. As pequenas paradas, em muitas circunstâncias não eram registradas, afetando assim uma das características do indicador OEE: a disponibilidade.

Também foi observado que a máquina não registrava tempo de paradas, desta forma dependia do operador em anotar o horário correto de início e fim da parada, tanto para grandes e pequenas paradas. A Figura 3 ilustra os itens que mais contribuíram para a perda do item na disponibilidade, essas informações foram estratificadas pelo sistema da empresa.

Figura 3 - Perdas da disponibilidade

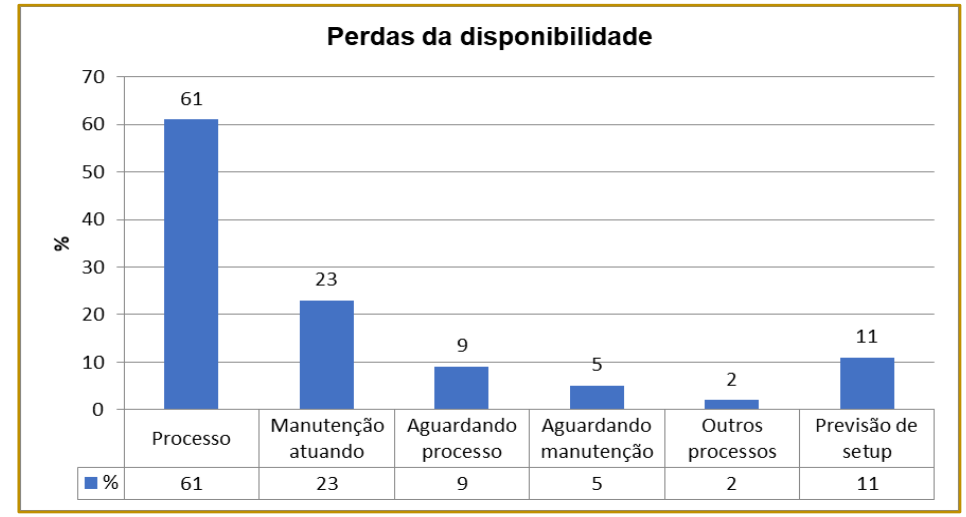

Fonte: Adaptado pelo sistema da empresa (2018) 
Foi identificado inconsistência dos dados referentes às perdas de processo, tais como refugos e produtos retrabalhados. Uma vez que alguns produtos considerados refugos, sem serem apontados no sistema, produtos que seriam retrabalhados, ou seja, peças que deveriam ser apontadas no item qualidade do indicador de OEE.

A figura 4 ilustra graficamente as perdas ocorridas em 13 dias de observações, nos quais apresentaram 6 peças defeituosas.

Figura 4 -Registro de perdas do processo

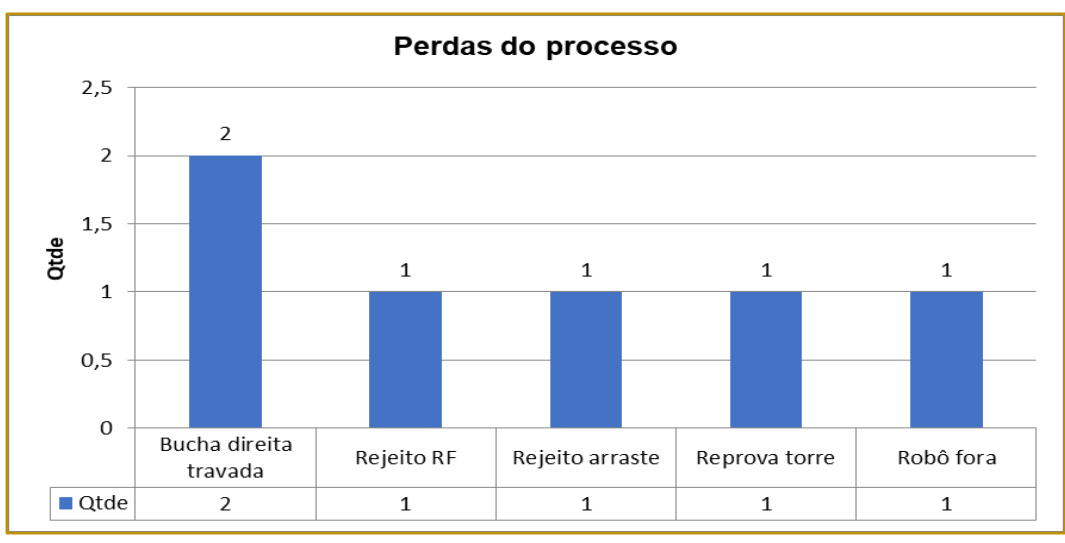

Fonte: Autores (2018)

A Figura 5 mostra graficamente o tempo total de máquina parada devido à manutenção. No período de 5 meses, houveram 63 horas de máquina parada para a área de manutenção.

Figura 5 - Tempo de setup

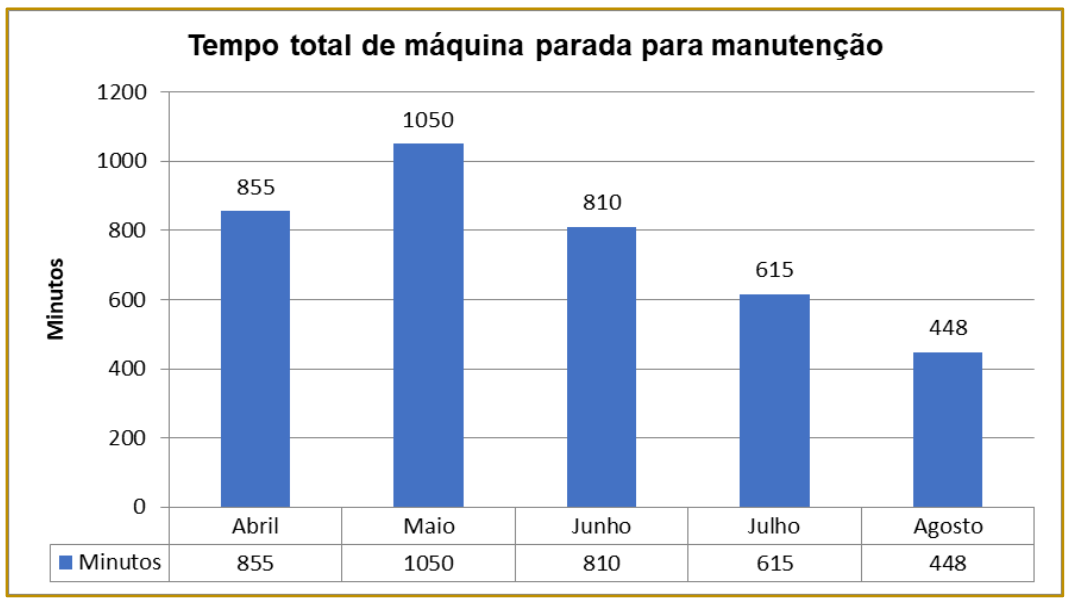

Fonte: Autores (2018)

Na Figura 6, mostra graficamente os defeitos estratificados do relatório da área de manutenção, onde o maior defeito constatado pela área de manutenção foi com 17 horas de máquina parada no período de 5 meses. $\mathrm{O}$ indicador MTTR (mean time torepair ou tempo médio para reparo) refere-se ao tempo médio que é aplicado para a realização de uma correção após um defeito. 
Figura 6 - Indicador MTTR

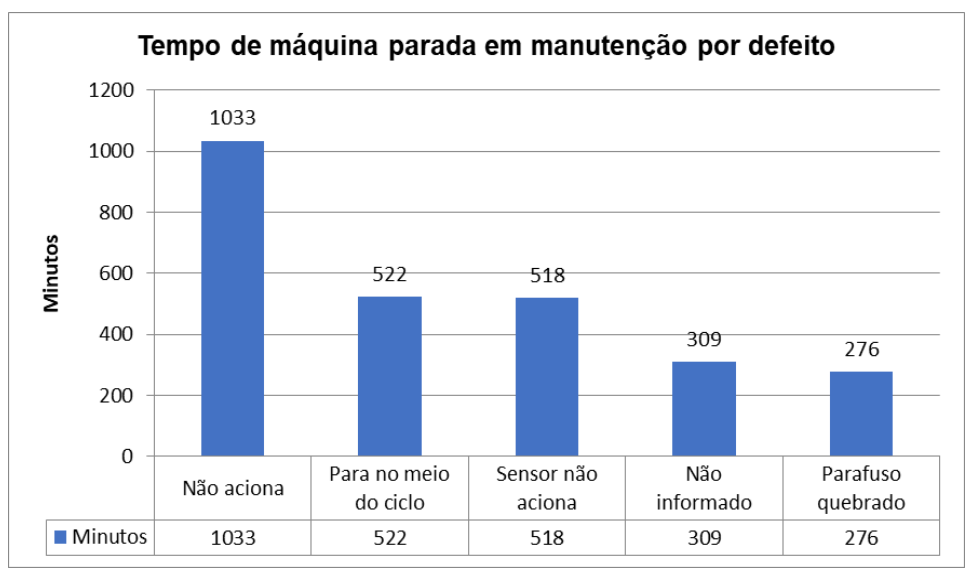

Fonte: Autores (2018)

No entanto, foi identificado que para alcançar os objetivos propostos deste trabalho, e consequentemente atingir o GAP de produção da empresa, seria necessário aumentar o OEE de $69 \%$ para $89 \%$, trabalhando principalmente no item disponibilidade e performance. Para o item disponibilidade foi sugerido melhorar de $86 \%$ para $95 \%$, e a performance melhorar de $85 \%$ para $95 \%$.

Utilizando a ferramenta $5 \mathrm{~W} 2 \mathrm{H}$, foi possível identificar as causas raízes para o problema. A pesquisa foi desenvolvida em duas linhas de raciocínios, a primeira representada por grandes paradas, assim afetando o item disponibilidade, e a segunda linha de raciocínio representada pelas pequenas paradas - apresentando queda de velocidade na produção, afetando assim o item performancedo indicador OEE.

Logo, a conclusão da causa raiz estão representadas na Figura 7 , com a primeira linha de raciocínio, onde foi concluso o problema raiz como o alto tempo de setup, e a Figura 8, com a segunda linha de raciocínio, onde foi concluso que o problema raiz é a necessidade de melhorar a performance.

Figura 7 -5W2H aplicado na primeira linha de raciocínio

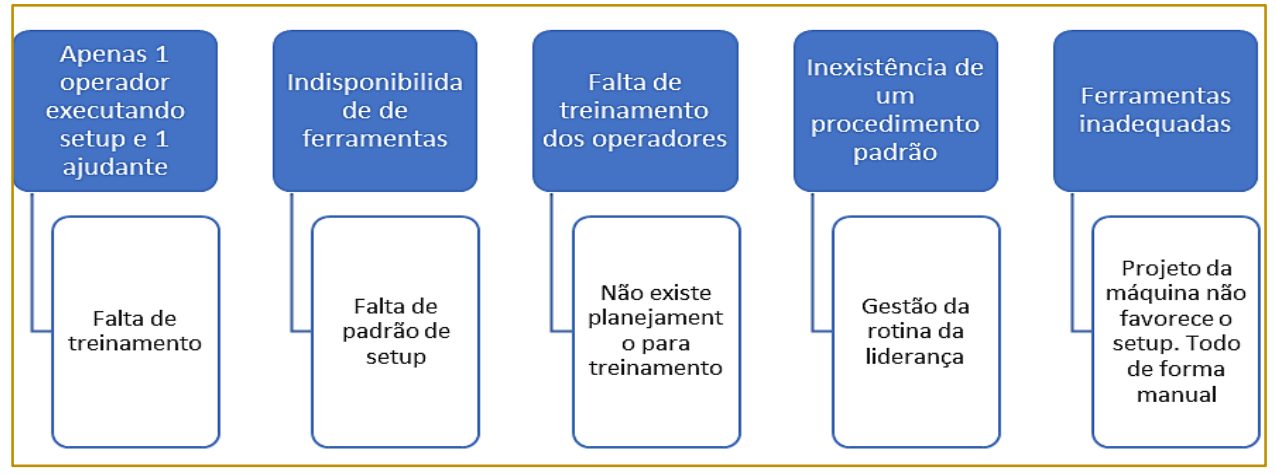

Fonte: Autores (2018) 
Figura 8 - 5W2H aplicado na segunda linha de raciocínio

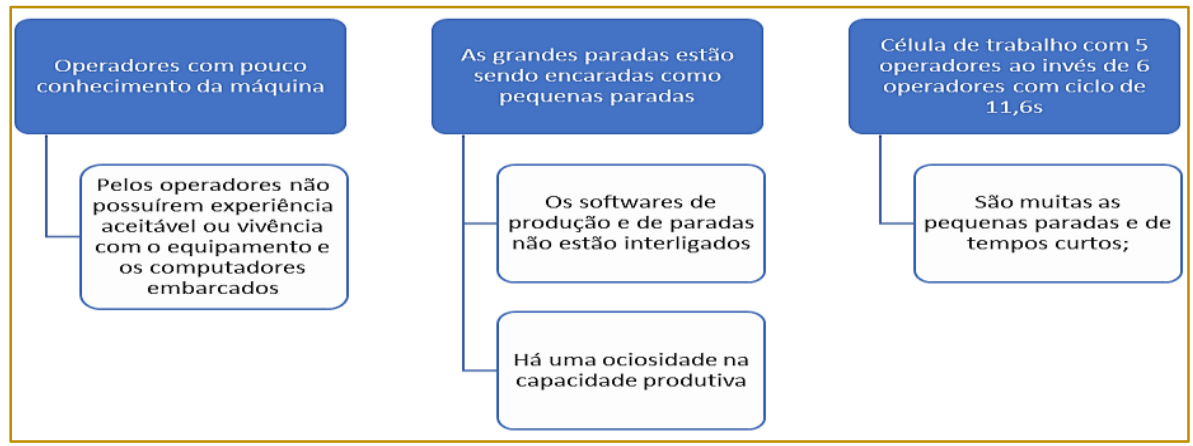

Fonte: Autores (2018)

$\mathrm{Na}$ construção do diagrama de Ishikawa, diagrama de causa e efeito, foi desenvolvido com duas linhas de raciocínios. Para o gráfico de causa e efeitona primeira linha de raciocínio, a definição do problema foi determinada como "alto tempo de setup", representados na Figura 9. E na segunda linha de raciocínio, foi definida como "melhorar a performance", como estão representados na Figura 10.
Analisamos as causas potenciais, passamos a examinar cada uma delas e definir se eram causas diretas ou não. E definimos que:

O - causa potencial investigada;

$X$ - causa potencial investigada e confirmada como causa contribuidora;

T - causa potencial investigada e confirmada como causa direta;

Figura 9 - Diagrama de Ishikawa para a primeira linha de raciocínio

MEIO AMBIENTE Falta de tempo padrão da atividade (O)

Fonte: Autores (2018)

Figura 10 - Diagrama de Ishikawa para a segunda linha de raciocínio

MEIO AMBIENTE

Fonte: Autores (2018) 
Após a definição das causas raízes do problema, foram avaliadas as soluções propostas aos itens disponibilidade e performance, onde os critérios de análise foram: custo, facilidade e o impacto. Conforme mostra o Quadro 2.

Quadro 2 -Avaliação das propostas sugeridas

\begin{tabular}{|c|c|c|c|c|c|}
\hline Ação & O quê & Custo & Facilidade & Impacto & $\mathrm{FCl}$ \\
\hline \multicolumn{6}{|c|}{ Análise para a disponibilidade } \\
\hline 1 & $\begin{array}{l}\text { Confeccionar procedimento de setup (observação: atentar em } \\
\text { coloc ar aviso que a panela está pronta para receber novas peças, } \\
\text { caso se for } 2 \text { operadores diferentes) }\end{array}$ & 3 & 3 & 3 & 9 \\
\hline 2 & $\begin{array}{l}\text { Confeccionar checklist de material nec essário para executar o } \\
\text { setup (trazer material completo no carrinho) }\end{array}$ & 3 & 3 & 2 & 8 \\
\hline 3 & $\begin{array}{l}\text { Verific ar a nec essidade de aplicação de produto desengordurante } \\
\text { em toda a troca }\end{array}$ & 3 & 3 & 1 & 7 \\
\hline 4 & $\begin{array}{l}\text { Determinar a quantidade nec essárias de caixas de armazenamento } \\
\text { no momento de trocas das arruelas para guardá-las no estoque }\end{array}$ & 3 & 3 & 1 & 7 \\
\hline 5 & Manter pinhão para teste no carrinho & 3 & 3 & 1 & 7 \\
\hline 6 & Guardar material em gabaritos & 3 & 2 & 1 & 6 \\
\hline 7 & Redimensionar carrinho de setup & 3 & 2 & 1 & 6 \\
\hline 8 & $\begin{array}{l}\text { Confeccionar gabarito de PU das peças que serão retiradas da } \\
\text { máquina (ajuda no } 5 \mathrm{~S} \text { ), conforme espec ificação do operador }\end{array}$ & 3 & 2 & 1 & 6 \\
\hline 9 & $\begin{array}{l}\text { Confeccionar tabuleiro de armazenamento para abastecer e } \\
\text { desabastecer a máquina }\end{array}$ & 1 & 2 & 3 & 6 \\
\hline 10 & $\begin{array}{l}\text { Comprar } 2 \text { parafusadeiras elétric a (com bateria) de tamanho } \\
\text { adequado ao posto de trabalho, para } 2 \text { operadores }\end{array}$ & 2 & 1 & 3 & 6 \\
\hline 11 & $\begin{array}{l}\text { Confeccionar gabarito de PU para guardar ferramental utilizado no } \\
\text { setup, para } 2 \text { operadores }\end{array}$ & 3 & 1,5 & 1 & 5,5 \\
\hline \multicolumn{6}{|c|}{ Análise para a performance } \\
\hline 1 & $\begin{array}{l}\text { Tomada de tempo do GBO para possivel revisão do balanceamento } \\
\text { da área }\end{array}$ & 3 & 3 & 3 & 9 \\
\hline 2 & Treinar os operadores & 3 & 1 & 3 & 7 \\
\hline 3 & $\begin{array}{l}\text { Melhorar o processo de apontamento das grandes paradas, nem } \\
\text { todas são apontadas }\end{array}$ & 2 & 1 & 3 & 6 \\
\hline 4 & Aumentar a exigência na função para operar o equipamento & 1 & 1 & 3 & 5 \\
\hline 5 & $\begin{array}{l}\text { Melhorar processo de coleta de informações de pequenas paradas } \\
\text { e grandes paradas e sua rotina }\end{array}$ & 1 & 1 & 3 & 5 \\
\hline 6 & Fazer o proc esso de desmagnetização na maquina & 1 & 1 & 3 & 5 \\
\hline 7 & $\begin{array}{l}\text { Implantar processo de apontamento das paradas através do } \\
\text { sistema do coletor }\end{array}$ & 1 & 1 & 3 & 5 \\
\hline 8 & $\begin{array}{l}\text { Implantar coleta de pequenas paradas e grandes paradas que seja } \\
\text { igual ao relatório de manutenção onde abre pelo defeito }\end{array}$ & 1 & 1 & 3 & 5 \\
\hline
\end{tabular}

Fonte: Autores (2018)

No entanto, foi elaborado um plano de ação com a finalidade de atingir os objetivos deste trabalho. Na elaboração deste plano de ação, o processo de setup foi filmado, cronometrado e discutido com os operadores. Como demonstrado no Quadro 3.

Foram feitas as análises internas e externas do setup e nos deparamos com questões simples, tais como:

- Buscar por peças e ferramentas em excesso;
- Procurar por ferramentas devido elas não estarem disponíveis no lugar adequado;

- Movimentação de peças e ferramentas desnecessárias ou em excesso;

- $\quad$ Ajuste dos parâmetros de máquina;

- Aperto de parafusos com equipamentos/ferramentas inadequadas;

- Retirada de material em

processamento;

- Caminhar ao redor da máquina;

- Posição do ferramental;

- Inspeção de peça para liberação, entre outros. 
Quadro 3 - Plano de ação

\begin{tabular}{|c|c|c|c|c|}
\hline \multicolumn{5}{|c|}{ Análise para a disponibilidade } \\
\hline \multicolumn{3}{|r|}{ Como } & Quando & Quem \\
\hline 1 & $\begin{array}{l}\text { Confeccionar } \\
\text { procedimento de setup }\end{array}$ & $\begin{array}{l}\text { Através de filmagem do setup, foi descriminadas as } \\
\text { atividades e foi aplicado o TRF (passo } 1 \text { ao 3). Em paralelo, } \\
\text { foram feitas entrevistas com os operadores para } \\
\text { alinhamento das atividades (setup interno do externo) }\end{array}$ & $24 /$ nov & UFSC \\
\hline 2 & $\begin{array}{l}\text { Confeccionar checklist } \\
\text { de material necessário } \\
\text { para executar o set up }\end{array}$ & $\begin{array}{l}\text { Através das filmagens e entrevistas foi identificado quais } \\
\text { materiais são necessários para cada etapa. }\end{array}$ & 24/nov & UFSC \\
\hline 3 & $\begin{array}{l}\text { Verificar a necessidade } \\
\text { de aplicação do } \\
\text { produto } \\
\text { desengordurante em } \\
\text { toda a troca }\end{array}$ & $\begin{array}{l}\text { Através de entrevista com os responsáveis da linha (Jean e } \\
\text { Fernando) }\end{array}$ & 24/nov & UFSC \\
\hline \multicolumn{5}{|c|}{ Análise para a performance } \\
\hline Item & $\mathrm{O}$ que & Como & Quando & Quem \\
\hline 1 & $\begin{array}{l}\text { Tomada de tempo do } \\
\text { GBO para possível } \\
\text { revisão do } \\
\text { balanceamento da área }\end{array}$ & $\begin{array}{l}\text { Através de filmagens dos processos, reavaliar os tempos e } \\
\text { realizar uma análise das operações }\end{array}$ & $17 /$ nov & UFSC \\
\hline 2 & Treinar os operadores & $\begin{array}{l}\text { Fazer um plano de treinamento para os operadores, com o } \\
\text { objetivo de criar conhecimento para identificação de } \\
\text { problemas }\end{array}$ & 15/jan & $\begin{array}{l}\text { Chefe } \\
\text { da } \\
\text { área }\end{array}$ \\
\hline 3 & $\begin{array}{l}\text { Melhorar o processo de } \\
\text { apontamento das GP, } \\
\text { nem todas são } \\
\text { apontadas }\end{array}$ & $\begin{array}{l}\text { Alinhar softwares para que a máquina informe de forma } \\
\text { sincronizada entre a produção e a paradas de máquinas, } \\
\text { envolver fabricante para a possibilidade de a própria } \\
\text { máquina apontar as paradas, como o objetivo de gerar } \\
\text { relatórios com a quantidade, tempo e motivos }\end{array}$ & 15/jan & $\begin{array}{l}\text { Chefe } \\
\text { da } \\
\text { área }\end{array}$ \\
\hline
\end{tabular}

Fonte: Autores (2018)

Figura 11 - Setup nas três situações analisadas

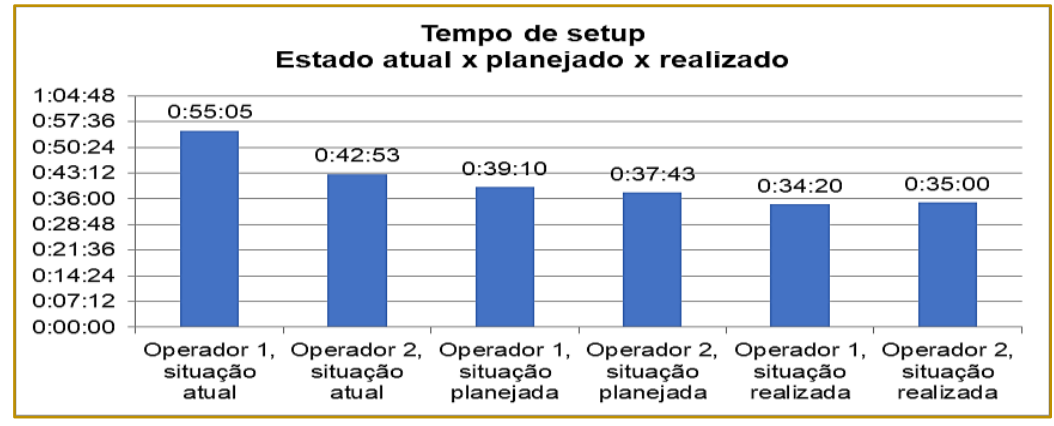

Fonte: Autores (2018)

Para o desenvolvimento deste trabalho, foram analisadas três situações: (i) situação atual; (ii) situação planejada e (iii) situação realizada, para a avaliação do tempo de setup, como representado na Figura 11.

Na situação atual, foi executado o setup pela primeira vez, filmamos, cronometramos e analisamos os pontos críticos do processo envolvido. Naquele momento identificamos que o setup executado por 2 operadores demorou 55:05 min, pelo operador 1 e 42:53 min pelo operador 2. Com estes dados traçamos as melhorias propostas e planejamos 39:10 min e 37:43 min para cada operador. No segundo setup realizado, na execuçãodo plano de ação planejado, atingimos 34:20 min e 35:00 min para cada operador, uma melhoria de $38 \%$ para o operador 1 e $17 \%$ para o operador 2 , obtendo uma redução de 21 min no tempo de setup para o operador 1 e 7 min para o operador 2 , comparando a situação atual com a realizada.

$\mathrm{Na}$ Figura 12, é possívelobservar a comparação do GBO da empresa com TC de $13,5 \mathrm{~s}$, o que ofertaria uma produção de 267pçs/h e o GBO proposto, com TC de 11,6 
s e uma produção de $307 \mathrm{pçs/h}$, isto

$15 \%$. representa uma melhoria na produtividade de

Figura 12 - Análise do GBO

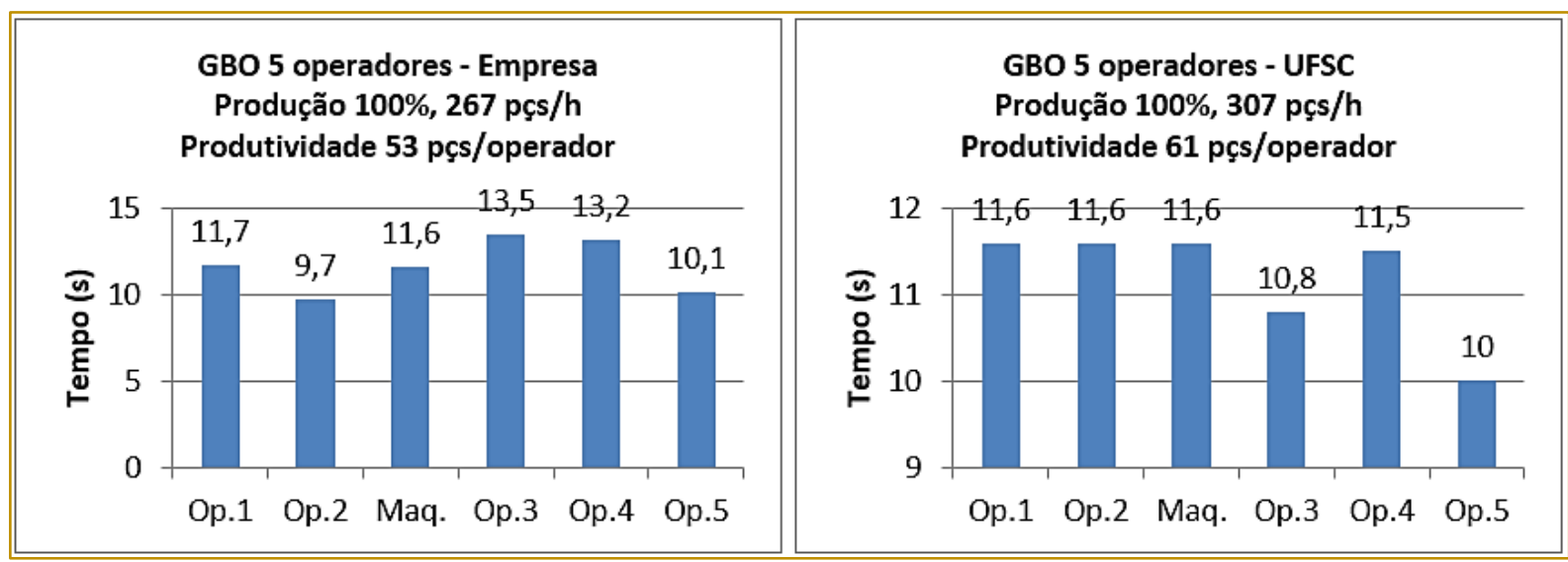

Fonte: Autores (2018)

A análise do GBO e análise de setup podem ser replicadas em outras células da empresa.Portanto, foi sugerido à empresa uma padronização e uma nova metodologia para a aplicação de setup nos maquinários, havendo um balanceamento com 5 operadores.

\section{CONCLUSÕES}

Este artigo relata uma pesquisa fundamentada em estudo de caso, que objetivou adaptar os processos de fabricação à luz da mentalidade enxuta, em uma indústria de autopeças, a fim de buscar melhores índices de produtividade e qualidade. Com o apoio dos operadores envolvidos, supervisão e a área de processo, foi possível desenvolver este estudo arquitetado com ferramentas da qualidade e metodologias da manufatura enxuta.

$\mathrm{O}$ uso das ferramentas $5 \mathrm{~W} 2 \mathrm{H}$, histograma e Diagrama de Ishikawa, auxiliaram na identificação das causas raízes dos problemas envolvidos na linha de produção. Este estudo mostrou a importância da utilização dessas ferramentas na gestão industrial, e como elas podem contribuir para REFERÊNCIAS

[1] Campos, V. F. Controle da qualidade total: no estilo japonês. Rio de Janeiro: Bloch, 1992

[2] Jabbour, A. B. L. S.; Teixeira, A. A.; Freitas, W. R. S.; Jabbour, C. J. C. Análise da relação entre manufaturaenxuta e desempenhooperacional de empresas do o aumento da produtividade, redução do tempo de setup e otimização dos processos.

Os resultados apresentados neste trabalho foram satisfatórios. O uso do indicador OEE evidenciou a possibilidade de aumento da produção de $69 \%$ para $89 \%$. No item de disponibilidade, mostrou-se possível otimizar os valores de $86 \%$ para $95 \%$, assim como a performance admite melhorias $85 \%$ para $95 \%$. Com tais resultados será possivel atingir aprodutividade mensal almejada pela organização.

As nossas conclusões suportam as teorias que a melhoria contínua é um fator desafiador para as organizações, e também factível. Uma vez confirmado a possibilidade da implementação de metodologias à luz da literatura, é necessário que seu meio seja adaptado tecnicamente e culturalmente para internalização de novos conhecimentos e conceitos dentro da organização. Fazendo-se, por fim, a melhoria contínua. O poder da prática de analisar e implementar propostas de melhorias para a solução de problemas, auxiliam as empresas a produzirem produtos/bens com maior qualidade, e manter-se competitiva no ambiente empresarial.

setorautomotivo no Brasil. RevistaAdministração, v. 48, n. 1, p. 843-856, 2013

[3] Oliveira, D.; Sangineto, M. Otimização do Processo de Envase de Lubrificantes por Meio da Aplicação do Indicador de Eficácia Global de Equipamentos e da Teoria das Restrições. In: ENEGEP, 30, 2010, São Carlos, SP, Brasil, Anais..., São Carlos: Abepro, 2010 
[4] Ohno, T. O Sistema Toyota de Produção, além da produção em largaescala. Porto Alegre: Bookman, 1997.

[5] Ron, A.; Rooda, J. Equipment effectiveness: OEE revisited. IEEE Transactions on Semiconductor Manufacturing, v.18, n.1, p.190196, 2005.

[6] Slack, N; Chambers, S; Johnston, R. Administração da Produção. São Paulo: Atlas, 2009.

[7] Silva, M. S. Q.; Alves, J. M. Aplicação do método de mapeamento do fluxo de valor nacadeia de suprimentos de eletrodomésticos. In: Simpósio de Administração da Produção, 14, 2011. Anais... SIMPOI, São Paulo, 2011.

[8] Sousa, S; Rodrigues, N; Nunes, E. Application of SPC and quality tools for process improvement. Procedia Manufacturing, v. 11, p. 1215-1222, 2017.

[9] Paladini, E.D. Gestão da qualidade: teoria e prática. (2a ed. 11.reimpr.). São Paulo: Atlas, 2011.

[10] Tortorella, G., Fogliatto, F. Method for assessing human resources management practices and organizational learning factors in a company under lean manufacturing implementation. International Journal of Production Research, v. 52, n. 15, p. 4623-4645, 2014.

[11] Tortorella, G.et al. The impact of contextual variables on learning organization in firms that are implementing lean: a study in Southern Brazil. The International Journal of Advanced Manufacturing Technology, v. 78, n. 9-12, p. 1879-1892, 2015. 


\section{Capítulo 9}

\section{LEAN MANUFACTURING: UMA ABORDAGEM DA APLICAÇÃO DA FERRAMENTA SMED EM INDÚSTRIA RUMO A MANUFATURA 4.0}

Anna Leticia Teixeira Rosa

Riana Auxiliadora Nunes Belarmino

Érika Cristina Ribeiro

Luciana Aparecida de Souza

Cleginaldo Pereira de Carvalho

Resumo: Atualmente, experimentamos a passagem pela quarta revolução industrial, em que a tecnologia, a digitalização e a otimização dos processos têm se tornado prioridade na busca pelas melhorias contínuas dos processos de produção e redução de custos. Entretanto, no Brasil, ainda evidencia-se um grande número de empresas que não se encontram alinhadas com as mudanças originadas por tal revolução. Na década de 50, no Japão, após a Segunda Guerra Mundial, houve o surgimento do Sistema Toyota de Produção (STP), o qual tinha por princípio a eliminação dos desperdícios existentes na manufatura. Posteriormente, definiu- se o sistema de manufatura denominado lean manufacturing (LM), o qual apresentava ferramentas que objetivavam a redução de perdas na produção. Uma das ferramentas do LM é o single minute exchange die (SMED), desenvolvido na década de 70 por Shingo. O SMED visa diminuir o tempo de setup das linhas de produção, para tempos de um dígito. O SMED se popularizou no Brasil como troca rápida de ferramenta (TRF) e tem sido empregado para aumento produtividade e da flexibilidade da manufatura. O objetivo deste trabalho é o estudo de caso da aplicabilidade da ferramenta SMED em uma empresa do segmento têxtil, cujo sistema de produção é contínuo. A justificativa para tal trabalho é a quase inexistência de pesquisa de aplicação da ferramenta SMED em sistemas contínuos de produção, principalmente no segmento mencionado.

Palavras-chave: SMED, lean manufacturing, têxtil, enxuta, indústria 4.0, STP 


\section{INTRODUÇÃO}

Com as mudanças do tempo e as revoluções industriais, a sociedade sofreu muitas transformações e muitas devido ao grande avanço tecnológico, fazendo assim com que as inúmeras empresas que compõe o mercado sintam a grande necessidade de estar sempre procurando inovações e aprimoramentos a fim de manterem-se firmes e competitivos no mercado atual. O novo padrão de mudanças, acaba trazendo grandes exigências para tais empresas, como o aumento do nível da qualidade, grande produtividade, flexibilidade, diminuição no custo de fabricação, diminuição no desperdício.

A indústria 4.0 traz esse conceito e foi proposto recentemente (2011). Para atender todas essas transformações o sistema produtivo fica em constante mudança. Foram realizados estudos que analisaram vários pontos que podem ser considerados obstáculos para a produção e um dos destaques para facilitar o modo operando sem aumentar os custos é diminuindo o seu tempo de setup, o tempo das trocas de ferramentas.

Para acompanhar o conceito de redução do tempo, é viável a implementação da ferramenta do lean, o SMED (Single Minute of Exchange Die), possui como objetivo criar maneiras que possam reduzir o tempo que é gasto nos processos de troca de linha, sem que haja o prejuízo no produto final.

O lean Manufacturing (LM) possui a filosofia que visa à produção enxuta, mesmo com o surgimento da empresa 4.0, ela não vai desaparecer e torna-se mais importante, pois a indústria 4.0 permite a visualização verdadeira de uma empresa enxuta, assim permitindo a compreensão mais rica da demanda do cliente, evitar os desperdícios, maior eficácia e menor rotatividade de empregos.

\section{FUNDAMENTAÇÃO TÉORICA}

\subsection{LEAN MANUFACTURING (LM)}

Com o fim da Segunda Guerra Mundial, muitas fábricas na Europa e no Japão estavam completamente destruídas e foi necessária a busca por um novo modelo de produção. Com isso surgiu, nas dependências da Toyota, o LM, modelo que possui como foco principal a produção enxuta. No entanto, esses conceitos só foram operacionalizados por Taiichi Ohno no final dos anos 40 (WOMACK e JONES, 1996).

De acordo com Ohno (1997), o objetivo do sistema é a eliminação de desperdício e elementos desnecessários na ordem de reduzir custos. Womack e Jones (1996) expande a abordagem e incorpora o conceito de lean thinking, que significa uma filosofia que requer menores prazos para realizar produtos e serviços com alta qualidade e seguindo custos, improvisando a produção através da eliminação do desperdício.

Ohno (1997) também identificou os principais tipos de desperdícios que foram categorizados como: sobre produção, espera, transporte, processamento inadequado, inventário desnecessário, movimento desnecessário e defeitos (JASTI e KODALI, 2014, BHAMU e SANGWAN, 2014). De acordo com Werkema (2011), um dos pontos importantes a observar é que a adopção da LM é um processo de mudança na cultura da organização e, portanto, não é algo fácil de ser alcançado. Logo, a utilização de uma ou mais ferramentas LM não garante que se obterá uma produção enxuta com sucesso.

Womack (2011) também compara o Lean ao sistema de produção em massa e mostra que praticamente é necessária apenas a metade de todos os fatores (humano, econômico e temporal) para se realizar a mesma fabricação, porém com mais qualidade.

A produção enxuta combina as vantagens da produção artesanal e em massa, evitando os altos custos da primeira e a rigidez desta última. Com essa finalidade, a produção enxuta emprega equipes de trabalhadores multi qualificados em todos os níveis de organização, além de máquinas altamente flexíveis e cada vez mais automatizadas, para produzir imensos volumes de ampla variedade (WORMACK; JONES; ROOS, 1900).

\subsection{LM TÊXTIL}

Apesar de a LM ser uma nova implantação no setor têxtil, o método de produção enxuta está sendo de grande valia, pois estão surgindo necessidades de redução de estoque, custo e desperdício, devido à grande disputa entre as indústrias no mercado e, como todos os outros setores industriais, a indústria têxtil também está à procura de métodos capazes de melhorar a fabricação através do método enxuto de produção. 
Segundo Gilsa (2016) as principais particularidades que precisam ser consideradas na implantação do lean no segmento Têxtil são:

a) Sazonalidade nas vendas (vendas não são niveladas durante $\mathrm{o}$ ano);

b) Grande necessidade de mão-de-obra direta;

c) Curto ciclo de vida dos produtos (moda);

d) Matéria-prima importada;

e) Concorrência direta com importados, entre outras.

Métodos de pesquisas realizadas já foram comprovados que o sistema diminui o desperdício e consequentemente gera lucro da indústria que queira implanta-la, como por exemplo, Cirino et al. (2013) realizaram um estudo em uma empresa têxtil brasileira empresa e com base em entrevistas e observações sistêmicas constatou que a adoção de práticas de LM proporcionou algumas vantagens à organização, tais como a redução tempo de espera. Karthi et al. (2013) relata o estudo de caso da implementação de Leansix sigma (LSS) e de Gestão da Qualidade Total (TQM) em uma fábrica têxtil e, assim, alcançando uma economia anual de 2 milhões de INR. Além disso, na literatura pode-se constatar com a pesquisa e propostas e modelos como o estudo feito por Kuniyoshi (2006) para mostrar como implementar o LSS em uma fábrica têxtil, destacando suas vantagens para resultados, incluindo um calendário para a sua aplicação.

Realizaram-se pesquisas para avaliar 0 estado da flexibilidade de recursos e ferramentas LM. Aplicação em fabricante de máquinas têxteis (CHAUHAN, 2016).

\subsection{MANUFATURA ENXUTA E SMED}

A manufatura enxuta pode ser definida como o conjunto de princípios, praticas ferramentas e técnicas criados para eliminar os desvios causadores da baixa produtividade operacional. De acordo com Womack e Jones a terminologia é uma abordagem que busca eliminar todas as fontes de desperdício do processo e beneficiar os clientes e a organização como um todo através de um desempenho otimização dos processos. Para que isso aconteça é necessário que haja a redução de desperdícios para que a organização produza produtos de qualidade, com um menor custo e um lead time reduzido.
O lead time é um fator diferencial no custeio dos processos de produção. A redução do mesmo resulta em menores custos de operação e agrega benefícios ao consumidor. Movimentações de materiais através de operações mais rápidas resultam num sistema mais enxuto e produtivo. (Garcia et al, 2001). A redução do lead time resulta numa aproximação entre os desejos do cliente e a resposta da empresa, proporcionando fidelização do cliente e menor complexidade nos negócios. Slack (1993) diz que o tempo ganho na redução do lead time é um investimento na satisfação do consumidor e na redução dos custos de manufatura.

De acordo com Martins e Laugeni (2005), o setup ou preparação trata-se de todo o trabalho que é feito a fim de colocar o equipamento em condições normais para produzir uma nova peça com qualidade. De acordo com Shingo os estágios conceituais de aplicação da ferramenta são os seguintes:

\subsubsection{ESTÁGIO INICIAL: COLETA DE INFORMAÇÕES}

No estágio inicial o que se destaca é a coleta de informações que serão estudadas, como a medição dos tempos reais de cada fase do setup, cronometragem de cada uma das tarefas, filmagens do processo. O feedback das informações é fornecido pelo operador que está executando a atividade no momento, pois apenas ele é capaz de identificar e apontar todos os problemas que interferem na operação e preparação dos equipamentos.

a) Estágio 1: Separando Setup interno e externo;

Essa fase consiste na separação as atividades entre Setup interno (atividades que são executadas com a máquina parada) e o Setup externo (atividades que são executadas com a máquina em operação)

b) Estágio 2: Convertendo setups internos em externos;

Nessa fase o objetivo é converter o máximo possível de estágio interno para externo, o operador deve encontrar ferramentas capazes de realizar tais atividades com o equipamento em funcionamento, o que faz com que se a máquina realmente precisar ser parada o tempo de parada seja muito menos.

c) Estágio 3: Melhoria permanente nas operações da máquina; 
Agora a busca é pela melhoria no processo como um todo, de maneira com que tudo que está relacionado à determinada operação seja realizado da melhor maneira possível e com o mínimo de interferências. Esse estágio caminha no sentido de que se muitos tempos de setup não são reduzidos num primeiro trabalho é necessário que se repita os estágios até que sejam alcançados melhores resultados.

\subsection{INDÚSTRIA 4.0}

Schwab (2016) indica que a indústria 4.0, ou Quarta Revolução Industrial, vai além de sistemas e máquinas conectadas. A diferença desta revolução em relação às anteriores é a fusão e interação de tecnologias de várias áreas do conhecimento, como físicas, digitais e biológicas.

O objetivo da Indústria 4.0 é explorar o potencial resultante do uso extensivo da internet, a integração de processos técnicos e processos de negócio, o mapeamento digital e a virtualização do mundo real, e também a oportunidade de criar produtos inteligentes (VDE,2013)

Segundo (RUSSWURM, 2014), a Indústria 4.0 possui três elementos principais: rede de produção, ciclo de vida do produto e da produção e os Sistemas Ciber-Físicos:

1) A cadeia de valor está desempenhando um papel cada vez maior. A interoperabilidade do ERP (Enterprise Resource Planning Planejamento dos Recursos Empresariais) entre fornecedores vai progredir para criar uma transparência total e uma ligação com a administração da empresa. Toda a informação necessária estará disponível em tempo real através das interfaces da empresa. 2) A fusão dos ciclos de vida do produto e da produção com base em um modelo de dados uniforme; somente então, os requisitos resultantes de ciclos de vida de produto cada vez mais curtos podem ser técnica e economicamente gerenciados.

3) Os sistemas Ciber-Físicos (SCF) são integrações da computação com os processos físicos, onde computadores e redes de monitoramento se incorporam para o controle de processos (LEE, 2006). São a base para uma maior flexibilidade e, por conseguintes tempos mais curtos para o mercado. Estas unidades de produção podem ser facilmente integradas nos processos de produção existentes

Segundo (MORAIS et a/ MONTEIRO, 2016) A Indústria 4.0 é caracterizada pela crescente digitalização e interconexão de produtos, cadeias de valor e de modelos de negócios, centra-se na produção inteligente de produtos, métodos e processos (Smart Production). Um elemento importante da Indústria 4.0 é a fábrica inteligente (Smart Factor). A Fábrica Inteligente domina a complexidade, é menos suscetível a interferências e aumenta a eficiência da produção. Na fábrica inteligente comunicar-se com as pessoas, máquinas e recursos será tão natural como em um contexto de rede social. A mudança de paradigma necessária para a indústria 4.0 é um projeto de longo prazo e está somente em um processo gradual. O recebimento de ações de valor dos sistemas de produção já instalados tem um papel central.

\section{METODOLOGIA}

O método de desenvolvimento deste trabalho foi o estudo de caso. De acordo com YIN (2001) o estudo de caso é um estudo de caráter empírico que investiga um fenômeno atual no contexto da vida real, geralmente considerando que as fronteiras entre 0 fenômeno e o contexto onde se insere não são claramente definidas.

Ao conduzir um estudo de caso, temos como benefícios, a possibilidade do desenvolvimento de novas teorias e de aumentar o entendimento sobre eventos reais e contemporâneos. (MIGUEL, 2012)

Este estudo foi construído na estrutura indicada por MIGUEL (2012), conforme figura 1. 
Figura 1: Condução de um estudo de caso.

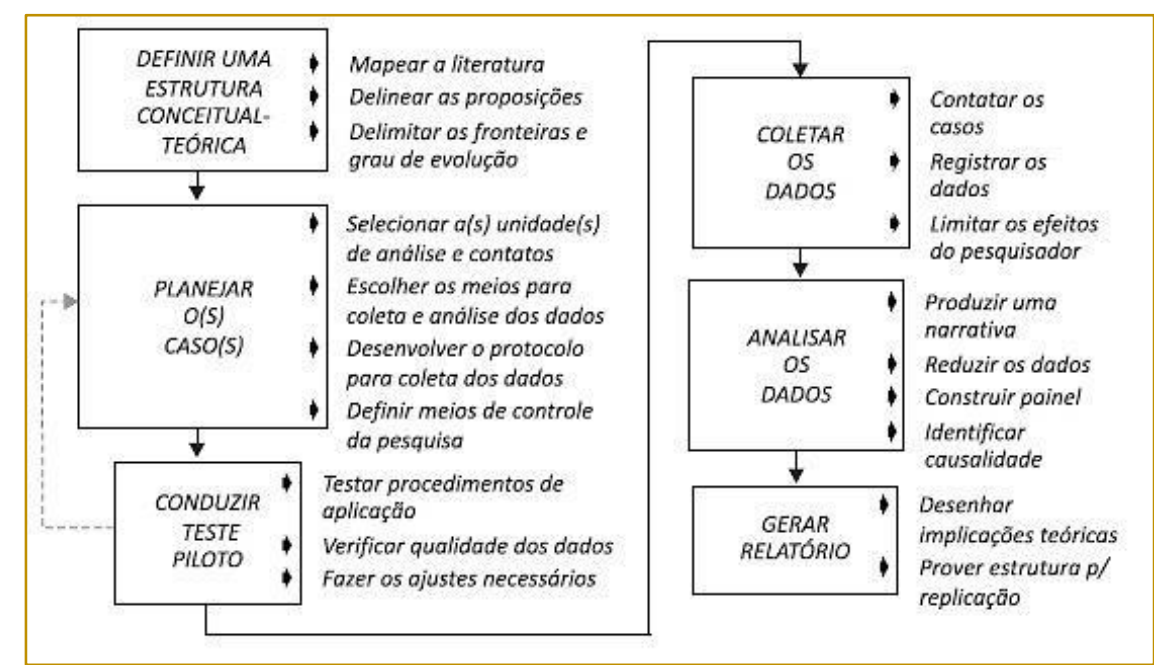

Fonte: Metodologia de pesquisa para engenharia de produção e gestão de operações. MIGUEL (2012)

Os dados da empresa que fundamentaram o estudo foram coletados e analisados durante quatro meses, este período equivale a 120 toneladas de produto foram produzidas.

Neste trabalho abordamos a aplicação do SMED em um sistema de produção contínua, com este tema definido, seguimos para a escolha do objeto de estudo, esta escolha acompanha as restrições do tema, afinal, o objeto de estudo precisava atender as especificações do tema. Escolhemos uma empresa do segmento têxtil que tem a sua produção contínua e um tempo de setup de dois dígitos, a partir dessas informações, foi gerado o foco para concentrar os esforços e recursos para o desenvolvimento da pesquisa.

Os métodos de pesquisa que foram empregados sobre o tema lean manufacturing nos proporcionou a constatação de as indústrias que utilizaram esse sistema, diminuíram os desperdícios e consequentemente geraram lucro com essas ações. Na pesquisa sobre a ferramenta SMED foi compreendido que a ferramenta atua sobre o tempo de setup de dois dígitos reduzindo-o para um dígito, essa redução acontece em três estágios, analisando o tempo de setup externo e interno, convertendo o setup interno em externo e por último realizando melhorias na máquina ou nas operações da máquina. Todas essas informações foram reunidas no formato de um referencial teórico.

As informações da empresa escolhida foram coletadas em um estudo anterior sobre aplicação da ferramenta LM no sistema de produção da mesma, no estudo foi possível identificar que a empresa tem um tempo médio de setup de 11 minutos e 50 segundos.

Essas gamas de informações foram reunidas em nosso referencial teórico delimitou as fronteiras do nosso estudo e proporcionou a fundamentação da nossa pesquisa. Em nosso referencial teórico inserimos múltiplas fontes de evidências, o que nos permitiu utilizar a técnica de triangulação, esta técnica compreende uma interação entre as diversas fontes de evidência para sustentar o desenvolvimento do estudo.

\section{DESENVOLVIMENTO PARA A APLICAÇÃO DA FERRAMENTA SMED}

Para realização da simulação do SMED na empresa escolhida, foi necessário coletar alguns dados fornecidos pelo pessoal da ACR durante as visitas à empresa têxtil. Segue abaixo os dados obtidos expostos nas tabelas 1, 2, e 3. 
Tabela 1: Tempos de paragem não programados do bordado (minutos)

\begin{tabular}{|c|c|c|}
\hline Data & Linha Quebrada & Troca de agulhas \\
\hline 23 de Agosto & 20 & - \\
\hline 24 de Agosto & 14 & 2 \\
\hline 25 de Agosto & 35 & 2 \\
\hline 26 de Agosto & 36 & 2 \\
\hline 12 de Setembro & 25 & - \\
\hline 13 de Setembro & 11 & 4 \\
\hline 14 de Setembro & 36 & 5 \\
\hline 15 de Setembro & 38 & 5 \\
\hline
\end{tabular}

Tabela 2: Tempo de configuração do bordado (minutos)

\begin{tabular}{|c|c|c|c|c|c|c|}
\hline $\begin{array}{l}\text { Linha } \\
\text { Superior }\end{array}$ & $\begin{array}{c}\text { Troca de linha } \\
\text { de fundo }\end{array}$ & Cola e cola & $\begin{array}{c}\text { Modificação } \\
\text { do design }\end{array}$ & $\begin{array}{c}\text { Linha de } \\
\text { corte/Mudança } \\
\text { de Lado }\end{array}$ & $\begin{array}{c}\text { Alterar linha e } \\
\text { lados }\end{array}$ & $\begin{array}{l}\text { Mudando } \\
\text { o quadro }\end{array}$ \\
\hline 4,5 & 10 & 51 & 12 & 72 & - & - \\
\hline 3 & 17 & 49 & - & 52 & 8 & - \\
\hline 1,5 & 32 & 28,5 & 6 & 39 & - & 6 \\
\hline 3 & 38 & 33 & 7 & 38 & - & - \\
\hline 5 & 10 & 45 & 15 & 60 & - & - \\
\hline 5 & 18 & 55 & - & 55 & 9 & - \\
\hline 2,5 & 35 & 30,5 & 8 & 45 & - & 8 \\
\hline 5 & 35 & 35 & 8 & 39 & - & - \\
\hline
\end{tabular}

Tabela 3: Tempo de configuração do bordado (minutos)

\begin{tabular}{|c|c|}
\hline $\begin{array}{c}\text { Tempo } \\
\text { Minutos }\end{array}$ & Pecas \\
\hline 15 & 150 \\
\hline 7 & 100 \\
\hline 10 & 200 \\
\hline 16 & 200 \\
\hline 22 & 300 \\
\hline 7 & 100 \\
\hline 8 & 100 \\
\hline 7 & 100 \\
\hline
\end{tabular}

Também foi necessária uma análise estatística com os dados coletados, exibidos nas tabelas
1,2, 3 acima, com a finalidade de obter o tempo de setup, como mostra a tabela a seguir.

Tabela 6 - produção abaixo análise de dados estatísticos de tempo

\begin{tabular}{|l|c|c|c|c|}
\multicolumn{1}{r}{ Tempo de inatividade } & \multicolumn{3}{c}{ Média (min) } & $\begin{array}{c}\text { Desvio } \\
\text { Padrão } \\
\text { (min) }\end{array}$ \\
Linha arrebentada (X1) & 26,88 & 10,86 & 40,39 & 0,134 \\
\hline Intercâmbio de linha superior (X2) & 3,69 & 1,361 & 36,91 & 0,128 \\
\hline Intercâmbio de linha botões (X3) & 24,38 & 11,82 & 48,49 & 0,103 \\
\hline Aplicação de cola pastel PET (X4) & 40,88 & 10,3 & 25,19 & 0,312 \\
\hline Corte de linha e troca lateral (X5) & 50,00 & 12,09 & 24,19 & 0,382 \\
\hline Mudança de linha e perfuração (X6) & 7,00 & 27,14 & 74,43 & 0,453 \\
\hline Troca de agulhas (X7) & 2,50 & 2,00 & 80,00 & 0,215 \\
\hline Mudança de linha e de lado (X8) & 2,13 & 3,94 & 185,59 & $<0,005$ \\
\hline Troca de suporte (X9) & 1,75 & 3,28 & 187,67 & $<0,005$ \\
\hline Tempo de configuração (X10) & 11,5 & 5,58 & 48,53 & 0,069 \\
\hline
\end{tabular}


Ao observar a Tabela 6, os coeficientes de variação são extremamente altos (em cima de

$20 \%$ ), resultando em um impacto negativo na produção que resulta em paradas. A não padronização dos processos causa altas variações nos valores de desvio padrão. As três principais causas prejudiciais a produção é a aplicação de cola pastel PET (X4) e o corte de linha e troca lateral $\left(X_{5}\right)$.

Para medir o impacto de uma redução possível destas variáveis, foi utilizado um modelo linear em (1) para calcular as quantidades de camisetas produzidas:

$$
\begin{aligned}
& T X_{i} \\
& Z \stackrel{i 1}{=} 2
\end{aligned}
$$

24

Onde:

$$
\begin{aligned}
& Z=\text { Número total de } t \text {-shirts } \\
& \text { produzidas } \\
& T=\text { Tempo de produção por turno } \\
& X i=\text { Parando a causa i (tabela 6) }
\end{aligned}
$$

A fim de determinar o ganho efetivo na produção com a redução do tempo, considerando as duas causas, foram realizadas a simulação de Monte Carlo usando o software Crystal Ball ${ }^{\circledR}$. As variáveis $X_{1}, X_{2}, X_{3}, X_{4}, X_{5}, X_{6}$, sete, e $X_{10}$, estão sendo considerados como uma distribuição gaussiana com teste realizado (tabela 5) para um nível de significância de 5\%. As variáveis $X_{8}$ e $X_{9}$ estão sendo consideradas como discretos.

Foi considerado um número de 1000 repetições do processo, com isso obteve-se o tempo de redução total do setup entre $5 \%$ e $30 \%$ do total de tempo atual para as variáveis de maior

impacto $X_{4}$ e $X_{5}$, como mostra a figura a seguir.

Figura 2 : Produção de t-shirts em função da redução do tempo de parada

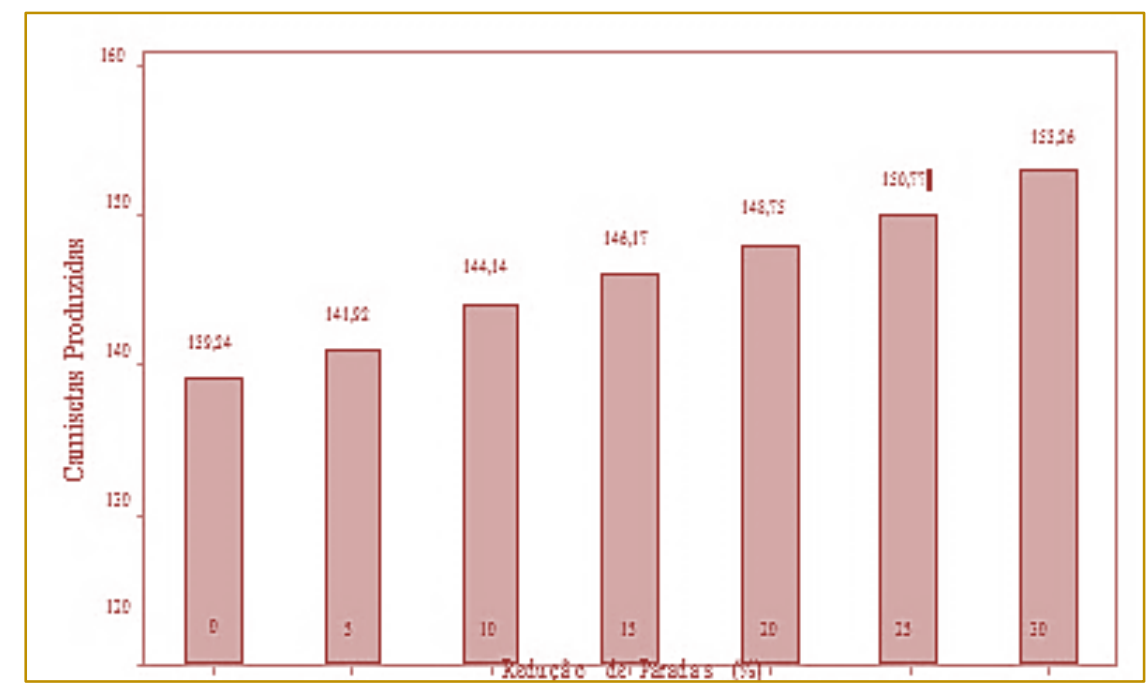

No caso da possibilidade de reduzir 30\% na média dos tempos de parada selecionada, haverá uma melhoria de $10 \%$ por dia do número total de camisetas produzidas, conforme ilustrado na figura anterior.

\section{CONCLUSÃO}

O presente artigo teve como objetivo analisar a aplicação dos conceitos SMED numa empresa do ramo têxtil e com sistema de produção contínuo.

Após a elaboração deste artigo conclui-se que a utilização da ferramenta SMED pode gerar uma grande redução de desperdícios de tempo dentro de uma organização. A implantação desse conceito pode ser observada na redução de tempos nas paradas para a troca de materiais utilizados na produção. Para implementar tal ferramenta 
deve ser realizada primeiramente uma análise dos setups, existe uma coleta de informações e tais informações são trabalhadas posteriormente, separando-os em setup externo e interno, convertendo o setup interno em externo e por último a realização de melhorias na máquina e/ou nas operações.

Por meio de um estudo de caso realizado na empresa foi possível perceber que existe uma grande perca com o desperdício de tempo nas paradas que interfere diretamente no resultado final, também é possível perceber que a implantação do método é de fácil aplicação e traz resultados muito compensatórios.

\section{REFERÊNCIAS}

[1]. Bastos, Bernardo Campbell. Aplicação de lean manufacturing em uma linha de produção de uma empresa do setor automotivo. Universidade de Taubaté, 2012.

[2]. Black, J.T. The Factory with a Future. Prentice Hall.p 1991.

[3]. Carvalho, Marly; Paladini, Edson. Gestão da qualidade: teorias e práticas. $2^{2}$ edição. Rio de Janeiro: Campus, 2012

[4]. Cerqueira, Vicente. Tecnologia em Design de Vidros Conformados: Uma Proposta Para Ganhos em Competitividade na Indústria 4.0. 2016.

[5]. Coelho, Pedro M Nogueira. Rumo à Indústria 4.0. 2016

[6]. Garcia, E.; Lacerda, L.; Arozo, R. Gerenciando incertezas no planejamento logístico: o papel. GILSA, Dietmar VON. Lean na Indústria Têxtil e de Confecção. 2016

[7]. Martins, P.; Laugeni, F. Administração da Produção. São Paulo. Editora Saraiva. 2005. 1990.

[8]. Miguel, Paulo Augusto Cauchik. Metodologia de Pesquisa para Engenharia de Produção e

[9]. Gestão de Operações. Rio de Janeiro: Elsevier: ABEPRO. 2012

[10]. Miguel, Paulo Augusto Cauchik. An investigation of qualitative research in an industrial engineering post graduate program. Anais do XI Simpep (Simpósio de Engenharia de Produção) Bauru, 2004.
A simulação realizada propôs uma diminuição dos tempos que gira em torno de 5\% e 30\% em todas as variáveis, caso seja possível à redução de $30 \%$ na média dos tempos de setup, haverá uma melhora bastante significativa de aproximadamente 10\% na produção diária da empresa, o que em longo prazo representa um avanço muito importante, havendo mais tempo disponível para aumentar a produção ou até mesmo elaborar e/ou diversificar os produtos.Apesar da diminuição bastante significativa, ainda é possivel reduzir ainda mais os tempos de parada, através de novos estudos e com a aplicação de novos conceitos de melhoria contínua para a empresa.

[11]. Morais, Roberto R; Monteiro, Rogério. A Indústria 4.0 e o Impacto na Área de Operações: Um Ensaio. 2016.

[12]. Nicholas, J. Competitive Manufacturing Management. Irwin/McGraw-Hill, 1998

[13]. Ohno, T. Sistema Toyota de produção Além da produção em larga escala. Porto Alegre: ED. Bookman, 1997.

[14]. Santos, H.A, Análise da aplicação do SMED em uma linha de produção de embalagem de líquidos de uma empresa da indústria farmacêutica. 48f. Trabalho de conclusão de curso (Graduação em Engenharia de Produção) Universidade Federal de São Carlos, São Carlos, 2013.

[15]. Santos, Paulo R. Indústria 4.0 - Sistemas Inteligentes para Manufatura do Futuro. 2016.

[16]. Sousa, R. Case research in operations management. EDEN Doctoral Seminar on Research Methodology in Operations Management. Bruxelas, 2005.

[17]. Shingo, Shigeo. O Sistema de troca rápida de ferramentas. Porto Alegre: Bookman Editora, 2000. Shingo, S. A revolution in manufacturing: the SMED system. Productivit Journal, V.50, p251, 2000

[18]. Womack, J.P.; Jones, D.T.; Roos, D. A máquina que mudou o mundo. Campus Rio de Janeiro, YIN, R.K. Estudo de caso - planejamento e método. 2. ed. São Paulo: Bookman, 2001. 


\section{Capítulo 10}

\section{OPORTUNIDADES DE MELHORIA EM UM ESCRITÓRIO DE PROJETOS DE UMA INSTITUIÇÃO DE ENSINO SUPERIOR}

\section{Alice Rodrigues Almeida}

\section{Camila Farias Araújo}

Fernanda Rolim Uepcoski

Simone Ferigolo Venturini

\section{Taís Oliveira da Silva Alfonso}

Resumo: Melhorar processos é essencial para que as corporações respondam imediatamente às mudanças que ocorrem no seu ambiente, bem como para manterem-se competitivas (PAIM et al., 2009). Neste estudo de caso, buscou-se analisar o fluxo atual de um dos processos do Escritório de Projetos de uma Instituição de Ensino Superior (IES). Essa análise foi realizada a partir do (i) acompanhamento de processos por meio do seu mapeamento, da (ii) identificação de pontos críticos - gaps ou lacunas - e do (iii) planejamento da situação futura. Foi escolhido, para análise, o processo de captação de projetos por meio de editais. Ao todo, foram encontradas 5 lacunas ao longo do processo. A situação futura foi construída e as sugestões de melhoria foram sistematizadas em um plano de ação. Esta pesquisa possibilitou que o referido Escritório repensasse suas práticas e revisse o modo como realizavam algumas tarefas.

Implicações práticas: Melhoria de processos.

Palavras-chave: Engenharia de Produção; Gestão de Processos; Escritório de Projetos. 


\section{INTRODUÇÃO}

A Gestão de Processos Administrativos, muitas vezes, é negligenciada na Engenharia de Produção por ter um viés de intangibilidade. Conforme Cruz (2013), diversas empresas acabam por não gerir adequadamente essa esfera por não saber lidar com tais demandas e como encaixá-las dentro da estratégia corporativa. Melhorar processos é essencial para que as corporações respondam imediatamente às mudanças que ocorrem ao seu redor, ou seja, no seu ambiente de atuação, e para manterem-se competitivas (PAIM et al., 2009).

O escritório de projetos (EP), cenário deste estudo, visa à objetividade, clareza e organização da captação, acompanhamento e finalização de projetos dentro da instituição. Um dos processos do referido escritório é a captação de recursos por meio de editais. Neste trabalho, buscou-se identificar formas de estruturação do escritório de projetos por meio da análise do fluxo atual de captação de editais e da proposição de melhorias a serem aplicadas no setor. A análise dos fluxos baseou-se nos preceitos do Business Process Management System (BPMS). O BPMS conecta pessoas e processos com o objetivo de melhorar o gerenciamento das informações e fluxos entre processos (CARRARA, 2011; VERNER, 2004).

Este trabalho está dividido nesta introdução; na fundamentação teórica, cujo foco foi a gestão de projetos e o BPMS; no método que foi utilizado e, posteriormente, os resultados encontrados com as análises e estudos. Após, o artigo encerra-se trazendo a conclusão do trabalho e as referências bibliográficas utilizadas para embasamento e fundamentação.

\section{REVISÃO BIBLIOGRÁFICA}

\subsection{GESTÃO DE PROJETOS}

Projeto pode ser descrito como um processo único, o qual necessita de várias atividades coordenadas e controladas para ser realizado. Essas devem ter suas datas para início e término fundamentadas para que se alcance algum objetivo conforme requisitos específicos. Os projetos também são limitados diante três esferas: tempo, custo e recursos (VALERIANO, 2007).
Para Verzuh (2000), um projeto só terá sucesso quando ele for entregue dentro do prazo estipulado, com o orçamento planejado e com alta qualidade. Isso reforça os requisitos citados pelo autor anterior, ou seja, os projetos são temporais, por mais diferenciados que possam ser, e devem ter seus custos planejados.

Conforme Harmon (2003), a gestão de projetos deve-se dividir em três grupos de tarefas macro: planejar, organizar e controlar. $\mathrm{O}$ autor ainda adiciona que medir e tornar o projeto mais eficiente depende de gestores responsáveis, que devem verificar se o trabalho foi realizado. Esse controle resulta em metas e indicadores que contribuem para o objetivo final da melhoria. A Engenharia de Produção tem como função a elaboração contínua de soluções de problemas e avaliação do desempenho organizacional. Para tanto, tem-se a gestão de projetos como uma de suas subáreas (ABEPRO, 2008).

\subsection{ESCRITÓRIO DE PROJETOS}

O escritório de projetos de uma Universidade é uma forma de cooperação entre a mesma e as empresas públicas ou privadas, ou seja, é uma forma de transferência de conhecimento, tecnologia e interação. Para Patah e Vimercati (2004), o PMO - Project Management Office (Escritório de Gerenciamento de Projetos) é uma entidade organizacional, cujo objetivo é apoiar os gerentes de projetos e os times da empresa, na fundamentação de princípios, práticas e metodologias de gestão de projetos.

Para Valeriano (2007), não se deve confundir escritório de projetos com escritório do projeto. Este último é apenas para o acompanhamento de um único projeto, possuindo caráter gerencial e administrativo. Já o primeiro é aquele que consegue gerir diversos projetos simultaneamente, podendo estes serem de várias naturezas. A evolução do Escritório de Projetos dentro da empresa pode trazer diversos benefícios como: maior alinhamento dos projetos com as estratégias e objetivos da organização; maior produtividade das equipes; maior racionalidade na distribuição de recursos; uniformidade de tratamento com as partes internas e externas, como clientes e patrocinadores; entre outros conforme demonstrado na Figura 1. 
Figura 1 - Alguns exemplos das interações proporcionadas pelo EP

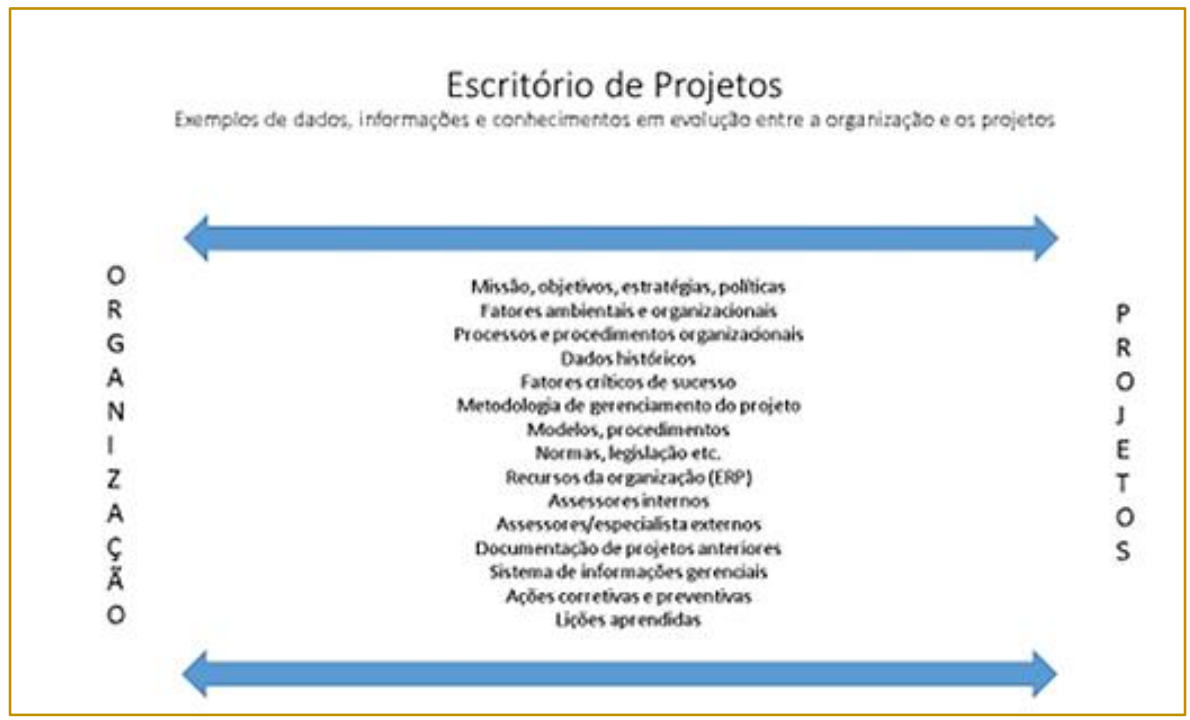

Fonte: Valeriano, 2007

\subsection{BUSINESS PROCESS MANAGEMENT SYSTEM - BPMS}

Um BPMS pode ser visto como um grupo de ferramentas ou instrumentos para atingir a melhoria do sistema de gestão (na ótica de processos). De acordo com Paim et al., (2009) estes sistemas possibilitam às organizações a modelagem, disponibilização e gerenciamento dos seus processos críticos para sua missão e que posteriormente podem ser distribuídos entre vários aplicativos da organização, departamentos corporativos e parceiros de negócios.

Em síntese, sistemas BPMS fazem a interconexão de pessoas e processos para que se atinja o gerenciamento de informações e se organize o fluxo de processos. (CARRARA, 2011; VERNER, 2004). Conforme Cruz (2013), para que se faça um desenho de um processo são necessários ao menos cinco itens:

a) Atividades: são as tarefas de um processo (manuais ou automáticas);

b) Rotas: é o fluxo das informações;

c) Operadores: são as bifurcações dos processos;

d) Dados do processo: status de execução, tempo de execução, entre outros;

e) Documentos: informações sobre o conteúdo do trabalho.
Neste trabalho foi utilizado um software para documentação, desenho, redesenho e modelagem de processos, o Bizagi ${ }^{\mathrm{B}}$. De acordo com Pavani Junior e Scucuglia (2011), é muito importante ter uma ferramenta que alcance uma visão holística das atividades desenvolvidas dentro da empresa, evitando ficar restrito a um único foco e certificando-se sobre a sinergia de todas as atividades. Para isso é necessário possuir uma ferramenta BPM que acompanhe inteiramente o processo e seja capaz de modelá-lo no formato mais próximo à realidade.

\section{MÉTODO PROPOSTO}

A pesquisa realizada neste trabalho é do tipo exploratória e descritiva. Exploratória devido ao levantamento de informações, tanto para o referencial teórico quanto para o mapeamento da situação atual. Também é descritiva, pois, além de explorar o setor e suas atividades, também foram descritas as características do ambiente e das atividades que englobam o setor (GERHARDT e SILVEIRA, 2009).

O Escritório de Projetos, objeto deste estudo, possui dentro do seu escopo a captação, o monitoramento da execução e a prestação de contas de projetos captados por meio de editais, leis de incentivo, emendas parlamentares, licitações e parcerias privadas e público privadas. O foco deste trabalho é o processo de captação por meio de editais. 
A fonte principal de informações foi 0 Escritório de Projetos. Contudo, além dos colaboradores desse setor, foram consultados outros departamentos da instituição como: professores pesquisadores, departamento jurídico e controladoria a fim de que, no momento do mapeamento dos processos, a visão de tais setores também fosse levada em conta. A Figura 2 demonstra o fluxo simplificado dos editais recebidos e tratados pelo EP.

Figura 2 - Fluxo simplificado dos editais no EP

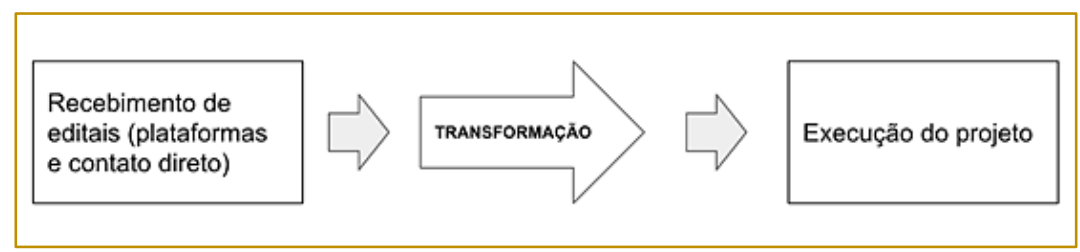

Fonte: Autoras

Vislumbrando os aspectos de: validez, confiabilidade e precisão, a seguir segue a relação das técnicas de coletas de dados utilizadas no presente trabalho (GERHARDT e SILVEIRA, 2009):

a) Pesquisa bibliográfica: os conceitos do referencial teórico foram obtidos na análise das fontes escolhidas. Foram: livros, artigos e Trabalhos de Conclusão de Curso;

b) Pesquisa documental: a fim de se apropriar dos processos do EP, foram analisados documentos e planilhas que estavam disponíveis nas pastas do escritório de projetos. Também se utilizou de documentos internos da Instituição, como o PDI - Plano de Desenvolvimento Institucional;

c) Entrevistas: estas foram realizadas com professores pesquisadores, departamento jurídico e controladoria, com a intenção de incorporar a visão dos mesmos ao mapeamento. Não foi utilizado formulário padrão ou diário de campo, mas foram anotadas todas informações pertinentes a este trabalho e principalmente para realizar o mapeamento da situação atual.

Para Gerhardt e Silveira (2009), a realidade dos estudos costuma ser mais complicada do que as hipóteses que pesquisamos e transcrevemos nos referenciais teóricos dos trabalhos. Por isso, muitas vezes, após a coleta de dados, temos alguns elementos não cogitados inicialmente. Para este trabalho também foram necessárias reuniões com os integrantes do setor para que se confirmassem as hipóteses e fossem propostas as reflexões e futuras melhorias. Por fim, o cronograma de trabalho seguiu a ordem da Figura 3.

Figura 3 - Cronograma de trabalho

\begin{tabular}{|c|c|c|c|c|c|}
\hline \multicolumn{6}{|c|}{$\begin{array}{c}\text { Cronograma de Trabalho } \\
\text { ojetivo: viabilizar melhorias no processo de captação }\end{array}$} \\
\hline Escopo: & Mês 1 & Mês 2 & Mês 3 & Mês 4 & Mês 5 \\
\hline 1. Descrição do status atual & & & & & \\
\hline a. Mapeamento dos tipos de captação & & & & & \\
\hline b. Mapeamento do processo & & & & & \\
\hline c. Identificação de indicadores & & & & & \\
\hline $\begin{array}{l}\text { d. Identificação dos pontos críticos/de } \\
\text { melhoria }\end{array}$ & & & & & \\
\hline 2. Desenvolvimento do status futuro & & & & & \\
\hline a. Mapeamento do processo futuro & & & & & \\
\hline $\begin{array}{l}\text { 3. Identificação de barreiras ou } \\
\text { dificuldades que afastam do status futuro }\end{array}$ & & & & & \\
\hline a. Quais são as barreiras? & & & & & \\
\hline b. Como diminuí-las? & & & & & \\
\hline 4. Elaboração do plano de ação & & & & & \\
\hline $\begin{array}{l}\text { 5. Identificação dos pontos positivos e } \\
\text { negativos do trabalho }\end{array}$ & & & & & \\
\hline
\end{tabular}




\section{RESULTADOS}

\subsection{SITUAÇÃO ATUAL DO EP}

O Escritório de Projetos objeto deste estudo surgiu em 2014 pela necessidade de ter um setor, dentro da instituição, que gerenciasse os projetos escritos por professores pesquisadores. Na época, não havia controle ou centralização dos trabalhos em andamento. Desde o seu início o Escritório tem como objetivo apoiar os escritores de projetos por meio da realização dos orçamentos necessários a cada projeto, escrita (construção da proposta, documentação exigida em cada edital e elaboração de declarações) e observar o alinhamento do edital pretendido com as estratégias da Universidade.

Atualmente, o escritório identifica oportunidades para captação de recursos, elabora propostas em conjunto com os proponentes ou professores convidados, monitora a execução dos projetos e presta contas dos mesmos. O setor possui quatro analistas que dividem entre si as atividades descritas.

\subsection{MAPEAMENTO DA SITUAÇÃO ATUAL}

O mapeamento das atividades e suas respectivas derivações têm um papel essencial para que ocorra a integração e interconexão das informações nas organizações. Neste trabalho foram mapeadas as atividades do EP no processo de captação de editais. Esse trabalho foi realizado utilizando 0 software $B i z a g i{ }^{\circledR}$ e estruturado através de conversas com colaboradores e análise documental. Após a construção do mapeamento, o mesmo foi validado em reunião com os colaboradores do setor, que realizaram contribuições em relação ao mesmo. A Figura 4 traz a versão do mapeamento da situação atual revisado pelos colaboradores.

Figura 4 - Mapeamento estado atual

Fonte: Autoras

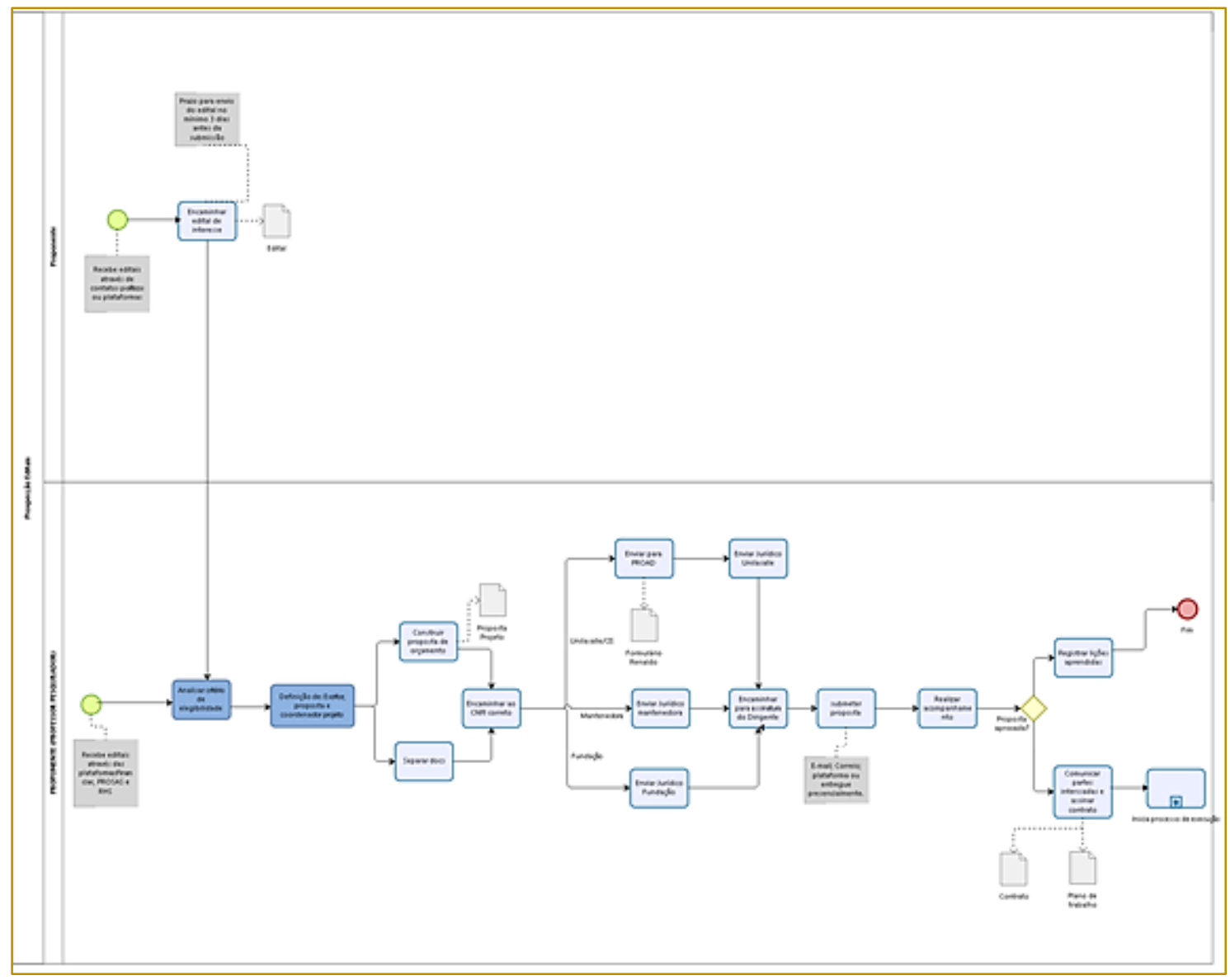


O mapeamento da prospecção de editais no escritório é composto por onze etapas. Primeiramente, ocorre o (1) o recebimento de editais, que pode ser por meio de plataformas específicas ou interações políticas. Caso o recebimento tenha sido pelo professor escritor, este deve manifestar o interesse de ser coordenador do projeto ao escritório. Após, é (2) avaliada a elegibilidade, ou seja, verifica-se a adequação do edital aos critérios e planejamento da Universidade. Após, são (3) definidos o escritor da proposta e o coordenador do projeto. O (4) orçamento e documentação solicitada no edital são juntados à proposta, de modo que a mesma está pronta para ser encaminhada (5) para (6) análise jurídica e (7) coleta de assinaturas. Após, a proposta é (8) submetida ao órgão de fomento e a equipe (9) monitora a sua aprovação. Caso a proposta seja aprovada, (10) as partes interessadas são comunicadas e o contrato é assinado. Do contrário, as partes são comunicadas e as lições aprendidas registradas. Por fim, com proposta aprovada, (11) inicia-se o processo de execução.

\subsection{GAPS}

Para Martins e Laugeni (2005), Gaps são lacunas existentes entre determinada situação e uma situação futura onde não devem haver desperdícios e divergências entre a expectativa do cliente e o que a empresa oferece. No caso do EP, gap é lacuna entre a situação atual e a situação futura desejada pela Universidade.

Para Cruz (2013), o redesenho de processos é resultado do estudo de melhorias implantadas de modo a continuar a padronização da organização, neste caso do EP. Melhorar processos é identificar tudo que afeta o desempenho do fluxo que está sendo analisado. A Tabela 1 apresenta os problemas identificados no fluxo do processo de captação de editais do EP.

Tabela 1 - Gaps identificados no processo de captação de editais

\begin{tabular}{|c|l|}
\hline Gap & \multicolumn{1}{c|}{ Tema } \\
\hline 1 & Critérios para seleção de projetos \\
\hline 2 & Seleção de escritores de projetos \\
\hline 3 & Padronização de formulários \\
\hline 4 & Elaboração de orçamento \\
\hline 5 & Cultura da IES \\
\hline \multicolumn{2}{c}{ Fonte: Autoras }
\end{tabular}

Observando-se a Figura 5, tem-se que o primeiro gap se refere à avaliação de critérios.

Figura 5 - GAP 1

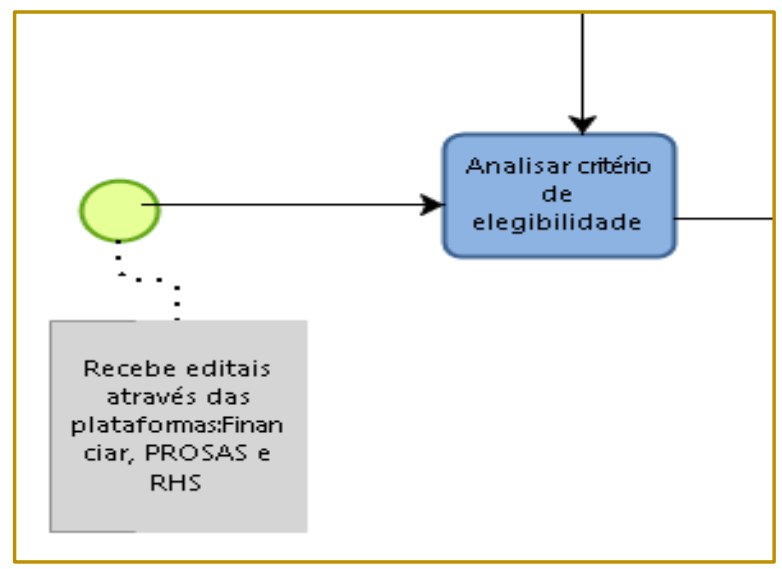

Fonte: Autoras

Atualmente, apenas avalia-se o critério de elegibilidade do edital, ou seja, o escritório analisa se a instituição pode ou não submeter uma proposta. Este critério inclui verificar se o 
edital é para empresas privadas sem fins lucrativos e se o objeto está dentro de ensino, pesquisa e extensão. Não é analisado se o edital é relacionado com as estratégias da Universidade e sua viabilidade. Como exemplo, observa-se a aquisição de alguns equipamentos que, após o projeto finalizado, estão ociosos na Universidade.

A Figura 6 apresenta o gap em relação aos escritores de propostas.

Figura 6 - GAP 2

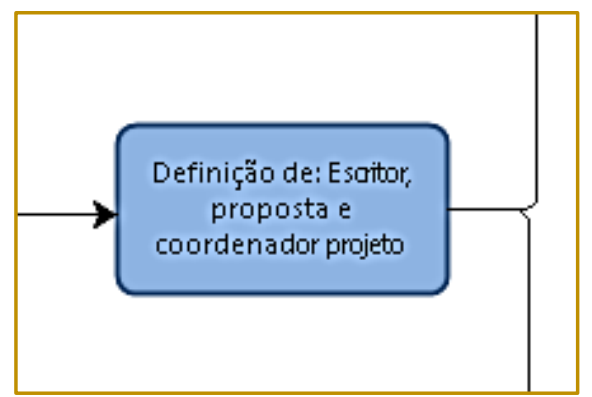

Fonte: Autoras

$\mathrm{Na}$ Universidade existem professores com parte das suas horas de trabalho designadas para escrever projetos, que é o corpo docente dos cursos de pós-graduação. Contudo, o mesmo não ocorre com outros professores. Assim, quando estes últimos manifestam interesse em escrever, muitas vezes acabam não cumprindo prazos de entrega. Dessa forma, a Universidade perde oportunidades de submeter projetos em algumas áreas.

A Figura 7 traz o gap relativo a falta de padronização dos formulários e à realização dos orçamentos dos projetos.

Figura 7 - GAP 3

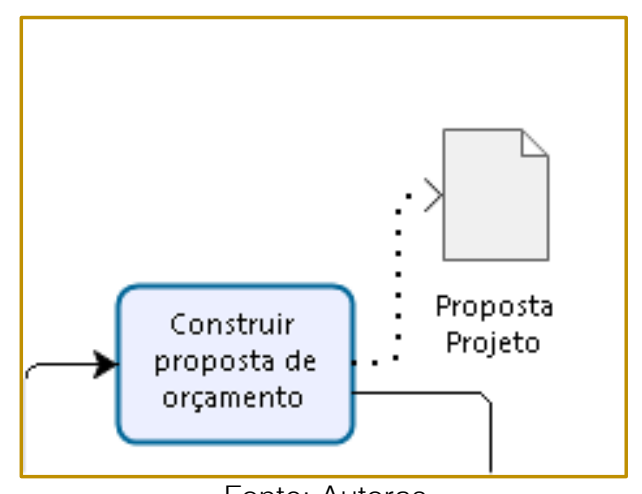

Fonte: Autoras

Em relação ao gap relacionado à falta de padronização dos formulários, atualmente o EP envia formulários aos professores interessados para a construção de orçamento dos editais, outras vezes o próprio professor constrói o orçamento. Nesta etapa foi identificado que não há um padrão de documento para todos os tipos de pesquisa. Isto dificulta o monitoramento e a análise da documentação quanto aos critérios que devem ser seguidos. Compreende-se que cada edital exige determinadas particularidades, mas a padronização facilitaria as próximas etapas do processo. Centralizar documentos de uso comum, como currículos, descrições de infraestrutura laboratorial, dados pessoais dos pesquisadores e outros, normalmente exigidos nos formulários dos editais, é um aspecto muito importante para a organização do EP e para que os projetos sejam bemsucedidos.

Em relação ao gap relacionado à realização dos orçamentos dos projetos, percebe-se que atualmente esta etapa é realizada tanto pelo professor pesquisador quanto pelo EP. Ocorre 
que, eventualmente, o EP não possui corpo técnico para orçar equipamentos e outros itens específicos à pesquisa relacionada ao edital, o que pode gerar uma fonte de erros na previsão dos recursos necessários para execução do projeto.

O gap de número 5 permeia todas as etapas do mapeamento e é relacionado à cultura de resistência. A cultura organizacional tem muita relação com o quanto uma organização pode progredir. Esta lacuna está alinhada com a percepção de que a visão de algumas pessoas é muito tradicional e consequentemente os objetivos ficam dispersos. A não compreensão da função do EP implica em dificuldades de relacionamento com alguns setores fundamentais no processo. Isto talvez seja reflexo do organograma atual da IES, pois há espaço para um redesenho nas funções do EP, de modo que ele atenda a objetivos mais estratégicos. Neste processo inclui-se a determinação de indicadores mais específicos e objetivos.

\subsection{W2H SITUAÇÃO FUTURA}

De acordo com Paim et al., (2009) ações de melhorias podem estar ligadas ao processo, à estrutura organizacional, à cultura organizacional e até mesmo ao modo de controle e mensuração do desempenho das diretrizes estratégicas. Para Godoy e Lisbôa (2012) o método 5W2H é constituído por uma série de perguntas que são direcionadas ao processo que está sendo analisado, essas permitem identificar as rotinas mais importantes, detectando as lacunas e demonstrando soluções. A Figura 8 apresenta o plano de ação construído para o EP.

Figura 8 - Plano de ação para o EP

\begin{tabular}{|c|c|c|c|c|c|c|}
\hline \multicolumn{7}{|c|}{ Plano 5w2h } \\
\hline $\begin{array}{l}\text { O que? } \\
\text { What? }\end{array}$ & $\begin{array}{l}\text { Quem? } \\
\text { Who? }\end{array}$ & $\begin{array}{l}\text { Onde? } \\
\text { Where? }\end{array}$ & $\begin{array}{l}\text { Quando? } \\
\text { When? }\end{array}$ & $\begin{array}{l}\text { Por que? } \\
\text { Why? }\end{array}$ & $\begin{array}{l}\text { Como? } \\
\text { How? }\end{array}$ & $\begin{array}{l}\text { Quanto? } \\
\text { How much? }\end{array}$ \\
\hline $\begin{array}{l}\text { Avaliar critérios } \\
\text { de viabilidade e } \\
\text { estratégia }\end{array}$ & $\begin{array}{l}\text { Equipe EP e } \\
\text { Pró-Reitoria }\end{array}$ & EP & $\begin{array}{l}\text { 16/10/2017 à } \\
\text { 20/12/2017 }\end{array}$ & $\begin{array}{l}\text { Garantir sustentabilidade } \\
\text { ao projeto e que o } \\
\text { mesmo é alinhado à } \\
\text { estratégia da empresa. }\end{array}$ & $\begin{array}{l}\text { Mapa estratégico, } \\
\text { reuniões entre Pró- } \\
\text { Reitores. }\end{array}$ & $\mathrm{R} \$ 0,00$ \\
\hline $\begin{array}{l}\text { Criar um banco } \\
\text { de professores } \\
\text { escritores }\end{array}$ & Equipe EP & EP & $\begin{array}{c}\text { 04/09/2017 à } \\
\text { 11/12/2017 }\end{array}$ & $\begin{array}{l}\text { Facilitar busca, } \\
\text { organização de dados, } \\
\text { otimização de tempo }\end{array}$ & $\begin{array}{l}\text { Buscar dados, } \\
\text { categorias, campos de } \\
\text { atuação. }\end{array}$ & $\mathrm{R} \$ 0,00$ \\
\hline $\begin{array}{l}\text { Padronização } \\
\text { de formulários } \\
\text { enviados aos } \\
\text { professores }\end{array}$ & Equipe EP & EP & $\begin{array}{l}\text { 02/10/2017 à } \\
\text { 11/10/2017 }\end{array}$ & $\begin{array}{l}\text { Padronizar, otimização } \\
\text { de tempo, }\end{array}$ & $\begin{array}{l}\text { Conferir por meio de } \\
\text { uma folha de verificação } \\
\text { quais as questões que } \\
\text { mais são necessárias e } \\
\text { se repetem nos projetos. }\end{array}$ & $\mathrm{R} \$ 0,00$ \\
\hline $\begin{array}{l}\text { Treinamentos } \\
\text { gestão de } \\
\text { projetos para } \\
\text { outros setores }\end{array}$ & Equipe EP & EP & $\begin{array}{c}\text { 20/11/2017 à } \\
\text { 15/12/2017 }\end{array}$ & $\begin{array}{l}\text { Esclarecer dúvidas dos } \\
\text { setores sobre a gestão } \\
\text { de projetos, mesmo que } \\
\text { superficiais, diminuição } \\
\text { de barreiras e ruídos de } \\
\text { comunicação. }\end{array}$ & $\begin{array}{l}\text { Agendar com as chefias, } \\
\text { organizar apresentação } \\
\text { e material para distribuir. }\end{array}$ & $\mathrm{R} \$ 0,00$ \\
\hline $\begin{array}{l}\text { Estimativa dos } \\
\text { recursos dos } \\
\text { projetos }\end{array}$ & $\begin{array}{l}\text { Equipe EP e } \\
\text { Pró-Reitoria }\end{array}$ & EP & A cada projeto & $\begin{array}{l}\text { A estimativa deve ser } \\
\text { feita com base nas } \\
\text { atividades definidas na } \\
\text { gestão do tempo }\end{array}$ & $\begin{array}{l}\text { Montar um plano de } \\
\text { gestão padrão com } \\
\text { perguntas a serem } \\
\text { respondidas pelo } \\
\text { professor. Matriz de } \\
\text { responsabilidade. }\end{array}$ & $\mathrm{R} \$ 0,00$ \\
\hline
\end{tabular}

Fonte: Autoras

\section{CONCLUSÕES}

Este trabalho teve por objetivo analisar o fluxo de um dos processos de um Escritório de Projetos de uma Instituição de Ensino Superior (IES). Para atingir esse propósito, o mapeamento do processo atual foi construído com auxílio do software Bizagi ${ }^{\mathbb{R}}$. Após, identificou-se 5 gaps ou lacunas no processo mapeado relacionados aos seguintes temas: critérios para seleção de projetos, seleção de escritores de projetos, padronização de formulários, elaboração de orçamento e cultura da IES. 
Esses gaps foram analisados e as sugestões de melhoria foram sistematizadas em um plano de ação, a ser executado pela equipe do EP objeto deste estudo. A equipe do EP se mostrou aberta ao compartilhamento das informações e a execução do plano de ação visando a implantação das sugestões de melhoria.

\section{REFERÊNCIAS}

[1] Abepro. Referências de conteúdos da Engenharia de Produção. Rio de Janeiro: ENEGEP, 2008. Disponível em: <http://www.abepro.org.br/arquivos/websites/1/\%C 3\%81reas\%20da\%20Engenharia\%20de\%20Produ \%С3\%A7\%С3\%A3o.pdf>. Acesso em: 03 abr. 2018.

[2] Carrara, André R. Implantação de sistema BPMS para a gestão por processos: uma análise crítica. Dissertação (Mestrado) - Escola Politécnica da Universidade de São Paulo. Departamento de Engenharia de Produção - São Paulo, 2011.

[3] Cruz, T. Sistemas Organização \& Métodos. 4. ed. São Paulo: Atlas, 2013.

[4] Gerhardt, Tatiana E.; Silveira, Denise, T. Métodos de pesquisa. 1 . ed. Porto Alegre: Editora da UFRGS, 2009.

[5] Godoy, Leoni Pentiado; Lisbôa, Maria da Graça Portela. Aplicação do Método 5W2H no Processo Produtivo do Produto: A Joia. Iberoamerican Journal of Industrial Engineering, Florianópolis, SC, Brasil, v. 4, n. 7, p. 32-47, 2012.

[6] Harmon, P. Business Process Change: a manager's quide to improving, redesigning and
Em trabalhos futuros, os demais processos do EP podem ser mapeados e analisados. Também é importante atentar para os procedimentos metodológicos a serem adotados, a fim de que os trabalhos possam ser replicados em contextos semelhantes.

automating processes. San Francisco: Morgan Kaufmann Publisshers, 2003.

[7] Martins, Petrônio G; Laugeni, Fernando P. Administração da Produção. 2 . ed., ver., aum. Atual. São Paulo: Saraiva, 2005.

[8] Paim, R.; Cardoso, V.; Caulliraux, H.; Clemente, R.. Gestão de processos: pensar, agir e aprender. 1 . ed. Porto Alegre: Bookman, 2009.

[9] Patah, L.A.; Vimercati, E. Implantação de escritório de projetos em instituição de ensino superior: estudo de caso em uma universidade privada. Revista de Gestão e Secretariado GeSec, São Paulo, v. 7, n.1, p.85-111, jan. labr.2016.

[10] Pavani Junior, O.; Scucuglia, R. Mapeamento e Gestão por Processos - BPM: Gestão orientada à entrega por meio de objetos. São Paulo: M.Books, 2011.

[11] Valeriano, Dalton. Moderno gerenciamento de projetos. 1 ed. 1a reimpressão. São Paulo: Pearson Prentice Hall, 2005.

[12] Verzuh, E. MBA compacto, gestão de projetos. 11 ed. Rio de Janeiro: Elsevier, 2000. 


\section{Bapítulo 11}

\section{PROPOSTA DE MODELO DE LEAN STARTUP PARA DESENVOLVIMENTO DE SOFTWARE B2C}

\section{André Eduardo Staedele}

\section{Diego Fettermann}

\section{Fernando Antônio Forcellini}

Resumo: Lean Startup Methodology (LSM) é uma metodologia para empreender negócios sustentáveis, focado no cliente, nos ciclos de aprendizado (buildmeasure-learn) e no mínimo produto viável. Inspirado nos princípios do Lean Thinking, LSM está direcionada a melhorar a taxa de sucessos de novos empreendimentos na área de tecnologia. Muitos novos empreendedores, por falta de conhecimento e experiência, assumem pressupostos de necessidades de clientes que não se sustentam no mercado. Esta taxa de insucesso pode ser explicada pela falta de aprendizado validado com o cliente potencial durante a definição do negócio e da oferta de produto e serviço no mercado. Ouvir o cliente para validar a proposta de negócio e construir a solução em um ciclo de interação ágil é fundamental para alcançar o sucesso. Atualmente, a literatura sobre o tema apresenta diversas iniciativas para auxiliar os novos empreendedores. Diante da falta de consolidação das propostas de $L S M$ presentes na literatura, este artigo tem por objetivo, a partir das diversas contribuições dos autores sobre o tema, propor um modelo de aplicação para um empreendedor que deseja iniciar um empreendimento de software B2C. Os resultados se apresentam na forma de um guia prático para a utilização do $\angle S M$ em novos empreendimentos.

Implicações práticas: Orientar novos empreendedores a desenvolver negócios de criação de software $\mathrm{B} 2 \mathrm{C}$ baseados nas melhores práticas do $L S M$, visando melhorar o seu desempenho e a sua taxa de sucesso na perenização do seu novo negócio.

Palavras-chave: lean startup; desenvolvimento ágil; mínimo produto viável; desenvolvimento de cliente. 


\section{INTRODUÇÃO}

Pesquisas atuais publicadas pela Harvard Business School apresentam uma taxa de insucessos de todos os tipos de Startups de cerca de 75\% (BLANK, 2013). Para auxiliar a reduzir os insucessos, foi desenvolvido o Lean Startup Methodology (LSM), uma metodologia de desenvolver negócio focando na experiência dos clientes e no aprendizado ágil.

O termo "Lean Startup" foi utilizado pela primeira vez em 2008 por Eric Ries em seu blog: "Startup Lesson Learned" (RIES, 2008). A metodologia foi popularizada no livro "The Lean Startup" (RIES, 2011), e enfatiza a importância de aprender com o cliente para produzir produtos baseados em soluções. Além do próprio Ries (2011), outros autores têm trabalhado para aprimorar o LSM. Ries (2011) afirma que muitos pequenos negócios vão à falência cedo, pois a visão do empreendedor esta desfocada da verdadeira necessidade do cliente. Isto se deve em função da falta de conhecimento e experiência em gestão de novos negócios. Conforme Ries (2011) define, empreender é gerenciar um novo negócio, e não se restringe somente a concepção do produto.

A partir do trabalho seminal de Ries (2011), foram desenvolvidos diversos aprimoramentos do LSM. Blank (2006) precursor do LSM em seu livro "The Four Steps of Epiphany" introduz o conceito de desenvolvimento de cliente e propõe um modelo de desenvolvimento para clientes. Ries (2011) em seu livro "The Lean Startup" introduz o assunto pela primeira vez como metodologia de desenvolvimento enxuto de novo empreendimento e contribui falando dos princípios que compõe o $L S M$. Ele conecta os conceitos e princípios as suas vivências como empreendedor de tecnologia. Ash Maurya (2012) complementa o trabalho de Ries em seu livro "Running Lean", propondo um modelo estruturado de desenvolvimento de negócio por meio da metodologia "Lean Canvas". Alistair Croll e Benjamin Yoskovits (2013) complementam os trabalhos anteriores com propostas de de indicadores chave de avaliação de desempenho para novos empreendimentos enxutos em seu livro "Lean Analytics". Ash Maurya (2016) propõe um modelo para dar escala ao novo negócio e torná-lo maior em seu livro "Scaling Lean". Outros autores também desenvolveram trabalhos sobre o tema, como reportado nos artigos de Mueller e Toring (2012), Moogk
(2012), Bosch et al (2013), o próprio Blank (2013), trazendo contribuições em conceitos como "Minimum Viable Product", "BuildMeasure-Learn Feedback Loop", "Pivoting", "Validated Learning", "Engine of Growth" e "Customer Development".

Em função do observado na literatura avaliada os autores deste artigo identificaram a oportunidade de propor um método detalhado abrangendo os conceitos e as práticas abordadas no portfólio bibliográfico coletado. Esta proposta visa melhorar a compreensão do $L S M$ para empreender na área de software $B 2 C$, cobrindo as etapas de desenvolvimento de um novo empreendimento, objetivando aumentar as possibilidades de sucesso para quem está iniciando um empreendimento nesta área.

\section{REVISÃO DA LITERATURA}

O LSM é inspirado nos princípios do Lean Thinking que foram definidos por Womack e Jones (1996) na década de 90. A metodologia foi popularizada por Ries (2011) com seu livro "The Lean Startup" enfatiza a importância de aprender com o cliente para produzir produtos baseados em soluções. Em seu livro, Ries (2011) fala das origens e dos princípios do $L S M$ através de sua vivência empresarial.

A fim de identificar os conceitos para a aplicação do LSM em empresas, são relacionados oito conceitos importantes e os principais autores que os fundamentaram.

\subsection{MINIMUM VIABLE PRODUCT (MVP)}

Ries (2011) define o termo MVP em seu livro "The Lean Startup", como uma versão do produto que pode iniciar o processo de aprendizagem utilizando o ciclo de aprendizado "Build-Measure-Learn Feedback Loop". Além disso, Ries (2011) afirma que o MVP permite que os empreendedores iniciem o processo de aprendizado o mais rápido possível com o objetivo de testar importantes hipóteses de negócio.

Maurya (2012) afirma que pode haver muito desperdício de recursos e demora quando se constrói a solução certa para o problema errado ou quando se possui um excesso de atributos indesejados. A solução é a construção de "apenas o suficiente" para se obter a resposta para os problemas dos clientes e o seu feedback. Ele ainda ressalta 
que o MVP deve ser "realizável, parecer real, rápido para fazer uma interação e minimizar o desperdício".

Bosch et al (2013 apud RIJSSENBEEK, 2015) se concentram na validação do $M V P$ e se preocupam com a questão de quais recursos são necessários para o $M V P$, afirmando que o $M V P$ tem um papel crítico na $\angle S M$ aplicado ao desenvolvimento de software.

Moogk (2012) afirma que "Startups podem se beneficiar do $\angle S M$, especialmente a partir das ideias e aprendizagem geradas como resultado do teste de um MVP, quando confrontadas contra as métricas relevantes."
Além disso, ela destaca potenciais benefícios do pioneirismo de tempo mais curto para o mercado.

\subsection{BUILD-MEASURE-LEARN FEEDBACK LOOP}

(BML)

Conforme Ries (2011), este ciclo pode ser considerado uma versão do método científico clássico que começa com a definição das hipóteses e da construção do MVP e termina com o teste de validação das hipóteses (Figura 1).

Figura 1 - Build-Measure-Learn Feedback Loop

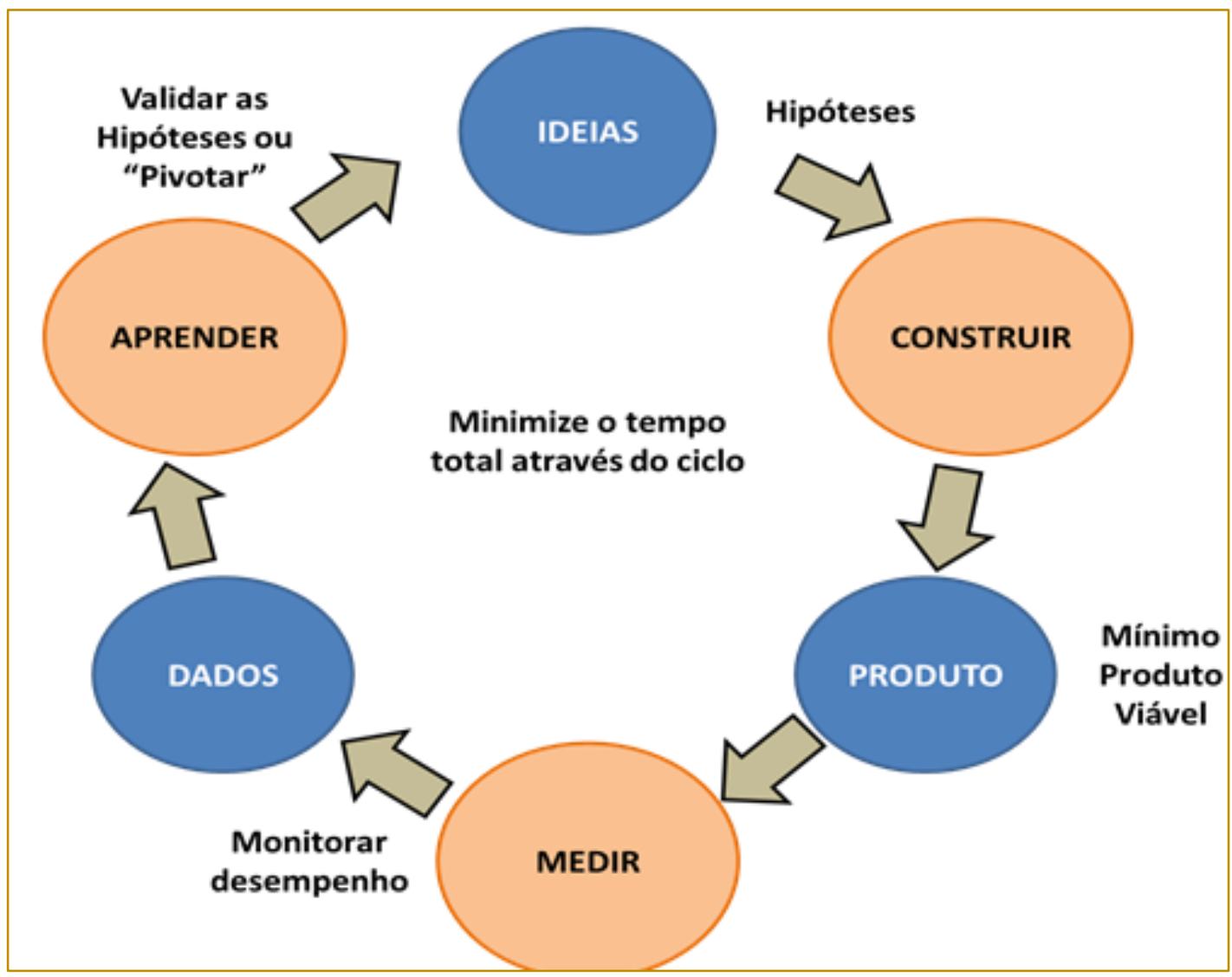

Fonte: Adaptado de Ries (2011)

Ries (2011) reforça que no começo a hipótese de valor e a hipótese de crescimento devem ser definidas, permitindo que o "motor de crescimento" seja controlado. Após esta etapa, deve-se entrar na fase de construção do MVP. Posteriormente, a fase da medição pode ser iniciada, onde uma avaliação será realizada para identificar se os esforços de desenvolvimento levarão ao desenvolvimento significativo do negócio. Na etapa final, "Aprender", a decisão mais importante tem que ser feita: se o empreendedor deve rejeitar ou manter a estratégia atual, um processo chamado de pivô, que será abordado na sequência.

Maurya (2012) descreve o ciclo BML como o feedback loop do cliente que é desenvolvido para verificar ou refutar as hipóteses de valor e de crescimento. 


\subsection{PLANO PIVÔ}

Ries (2011) define que um pivô é um plano de mudança controlada, preferivelmente utilizada para provar novas hipóteses sobre os produtos, estratégia e motores do crescimento, e eventualmente colocar o novo empreendimento em um caminho no sentido de desenvolver um negócio sustentável.

Maurya (2012) sustenta que a mudança pivô é sobre aprender a validar as hipóteses e descobrir uma proposta viável, também a chamando de correção de curso.

Mueller e Thoring (2012) afirmam que a mudança pivô de plano é central para um conceito chamado quickly failing, significando que quanto mais cedo uma hipótese é provada como errada, tanto mais cedo os ajustes para aquela hipótese podem ser feitos a fim de testá-la novamente.

Blank (2013) apoia o conceito afirmando que a mudança pivô é uma abordagem que é adotada por várias escolas de negócios. Ele faz uma clara distinção entre pequenos ajustes e os pivôs maiores que envolvem a formulação de novas hipóteses. Além disso, devido à suposição de que o fracasso é esperado, o pivô parece ter se tornado um conceito central para novos empreendimentos.

\subsection{APRENDIZADO VALIDADO}

Conforme mencionado por Ries (2011), novos empreendimentos não são somente desenvolver um produto ou serviço, mas aprender a desenvolver um negócio sustentável. Isto pode ser alcançado de um processo de aprendizagem validado, o que não é tanto uma ferramenta, mas uma filosofia no LSM. Aprendizagem validada, basicamente, responde à pergunta "era bom?" e pode ser subdividido em validação qualitativa e quantitativa.

\subsection{MOTOR DE CRESCIMENTO}

De acordo com Ries (2011) o motor de crescimento é o mecanismo que os novos empreendimentos utilizam para atingir o crescimento sustentável. Ele pode ser subdividido em três motores: motor pegajoso do crescimento, motor viral do crescimento e motor pago do crescimento.

Baseando-se nestes três motores, Maurya (2012) fornece algumas orientações que podem ser utilizadas para ajudar 0 empreendedor a escolher qual o motor ele precisa; começando com "validar as métricas de valor (1), a compreensão de como se comportar ao cliente com o produto (2), e escolher um motor para sintonizar (3)".

\subsection{DESENVOLVIMENTO DO CLIENTE}

Ries (2011) afirmou que a filosofia de desenvolvimento do cliente o guiou em seu trabalho como empreendedor para desenvolver a $\angle S M$.

Conforme Blank (2013), desenvolvimento de cliente é a busca de um novo empreendimento para um modelo de negócio viável. Começa com o simples princípio de aprender e descobrir quais clientes atrair e que mercados investir, requer um processo separado do desenvolvimento do produto. Blank (2006) propôs o modelo de desenvolvimento do cliente sob essa luz e este possui quatro estágios (Figura 2): Descoberta do cliente (I), Validação do cliente (II), Criação do cliente (III) e Construção da empresa (IV). 
Figura 2 - Customer Development Model

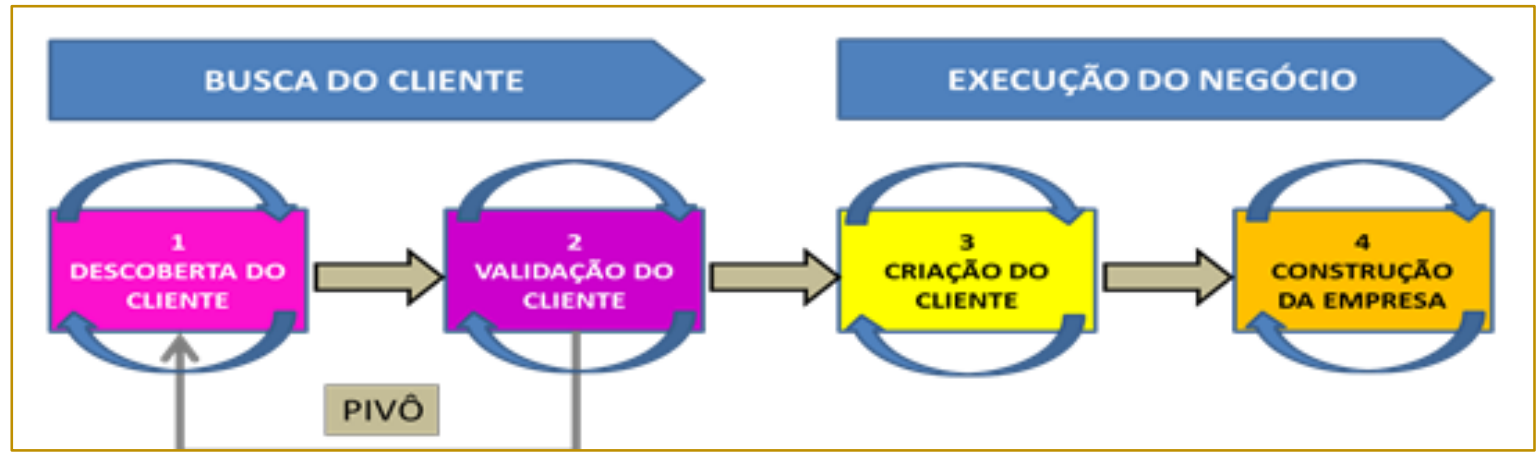

Fonte: Adaptado de Blank (2013)

Blank (2013) denomina a sua própria abordagem de "get-out-of-the-office", argumentando que ela seja uma alternativa superior para projetar antecipadamente qualquer coisa. Ele também afirma que o conceito se identifica em uma escala modesta com desenvolvimento ágil por não ter um ciclo desenvolvimento que leve um ano.

\subsection{LEAN CANVAS}

Conforme Maurya (2012), um lean canvas (Figura 3) é a versão de uma página com a representação do modelo de negócio. Sua utilização é recomendada em razão da rapidez com que pode ser realizado, pois é "rápido, conciso e portátil" (Maurya, 2012). Pelo seu poder de síntese, o lean canvas direciona o empreendedor a se focar somente nos aspectos críticos do modelo de negócio, a fim de dar ao seu novo negócio uma direção clara.

Blank (2013) complementa que o modelo de negócio baseado no lean canvas permite ao empreendedor olhar para os nove blocos de informações do seu negócio em uma página e que cada bloco contém uma série de hipóteses que o empreendedor deve testar.

Figura 3 - Lean canvas model

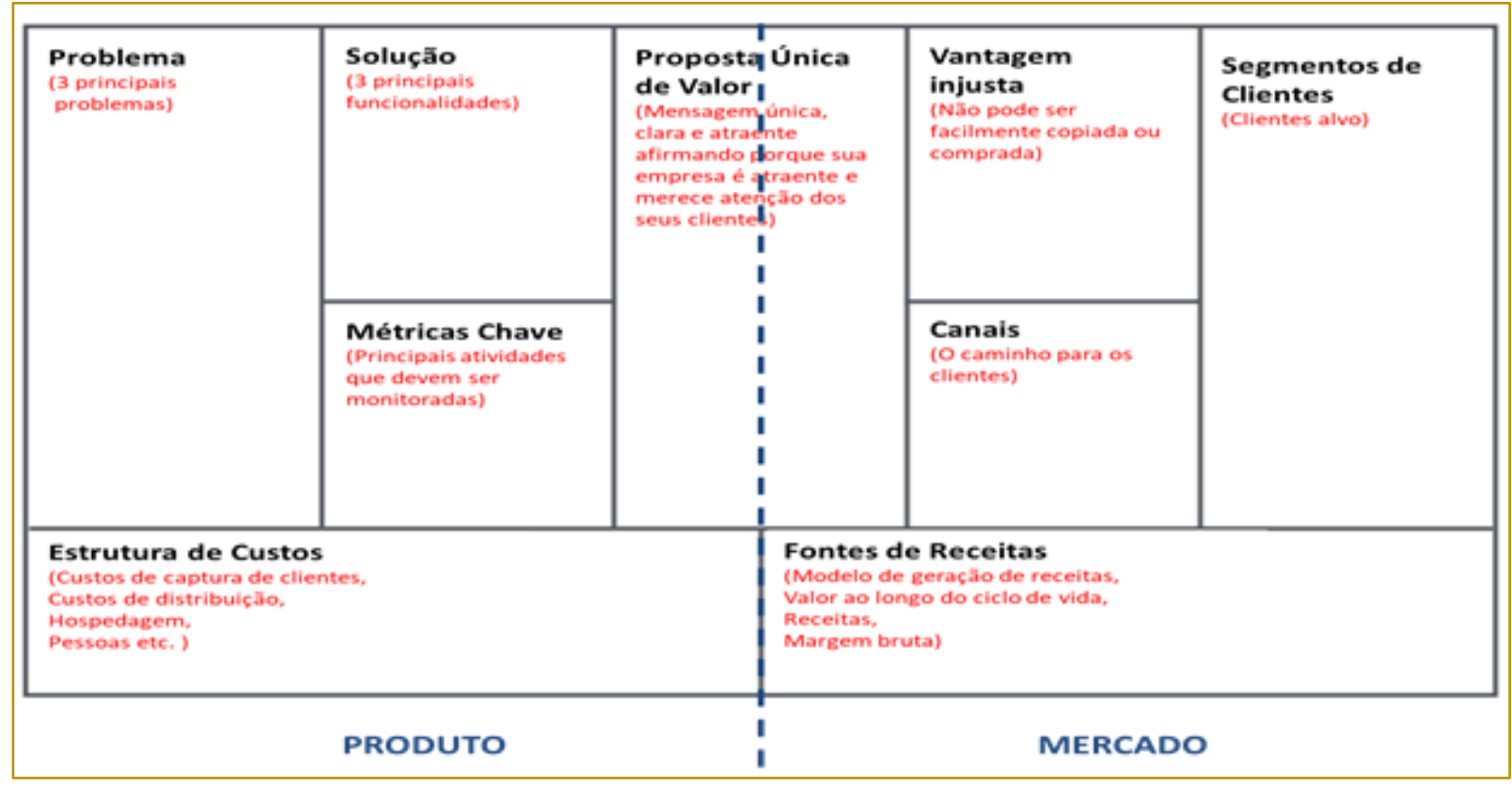

Fonte: Adaptado de Maurya (2012) 


\subsection{LEAN ANALYTICS}

Outra contribuição proporcionada ao LSM é o trabalho de Croll e Yoskovitz (2013). Em seu livro Lean Analytics, Croll e Yoskovitz (2013) propõem a construção de sistemas de avaliação de desempenho focados em novos negócios inovadores, orientando em cada fase do desenvolvimento do negócio a identificação das métricas que importam, além de apresentar modelos de medição de desempenho específicos para diversos tipos de Startups, objetivando que os novos empreendimentos estejam equipados com as métricas certas para obter a eficácia e a eficiência desejadas.

Maurya (2012) complementa que um modelo que é amplamente utilizado pelas empresas de software é o das métricas piratas (Figura 4). Este modelo de referência auxilia o empreendedor a definir as métricas adequadas para cobrir os aspectos relevantes que devem ser monitorados durante o desenvolvimento do novo negócio.

Figura 4 - Métricas Piratas

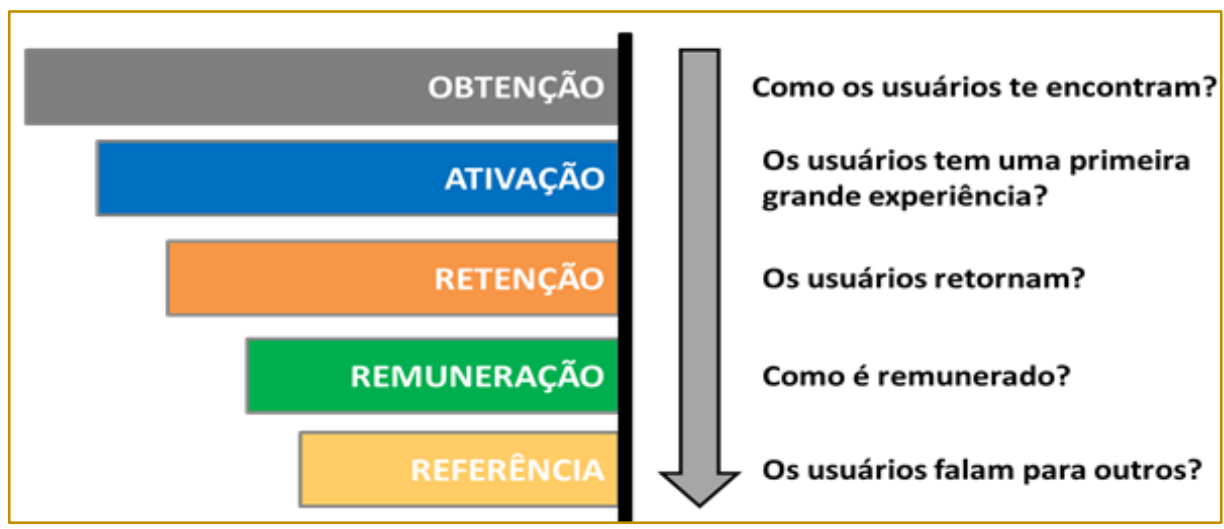

Fonte: Adaptado de Maurya (2012)

Croll e Yoskovitz (2013) também apresentam um sistema de avaliação de desempenho para negócios de aplicativos mobile, objeto de interesse deste artigo, recomendando que este tipo de empreendimento deve levar em conta as seguintes métricas: Downloads, Custo de aquisição do cliente, Índice de lançamento, Percentual de usuários ativos, Percentual de usuários que pagam, Tempo até a primeira compra, Rendimento médio mensal por usuário, \% de usuários que avaliaram o aplicativo, Viralidade, Desuso, Valor do tempo de vida do cliente.

\section{MÉTODO PROPOSTO}

A proposta do presente trabalho é desenvolver a partir dos conceitos apresentados no item 2, um modelo de aplicação para o novo empreendedor que deseja iniciar um empreendimento de software B2C. Para desenvolver este modelo é utilizada como referência uma versão adaptada da ferramenta da qualidade $5 \mathrm{~W} 2 \mathrm{H}$, usualmente aplicada para planejar e acompanhar o desenvolvimento de projetos de melhoria e padronizar as etapas de um processo. No modelo proposto são identificadas as etapas, os passos, as atividades, as ferramentas e técnicas utilizadas, os resultados esperados com a conclusão das atividades da etapa e os autores que conceberam os conceitos.

\section{RESULTADOS}

Como resultado é apresentado o guia prático para a utilização do $L S M$ em novos empreendimentos. 


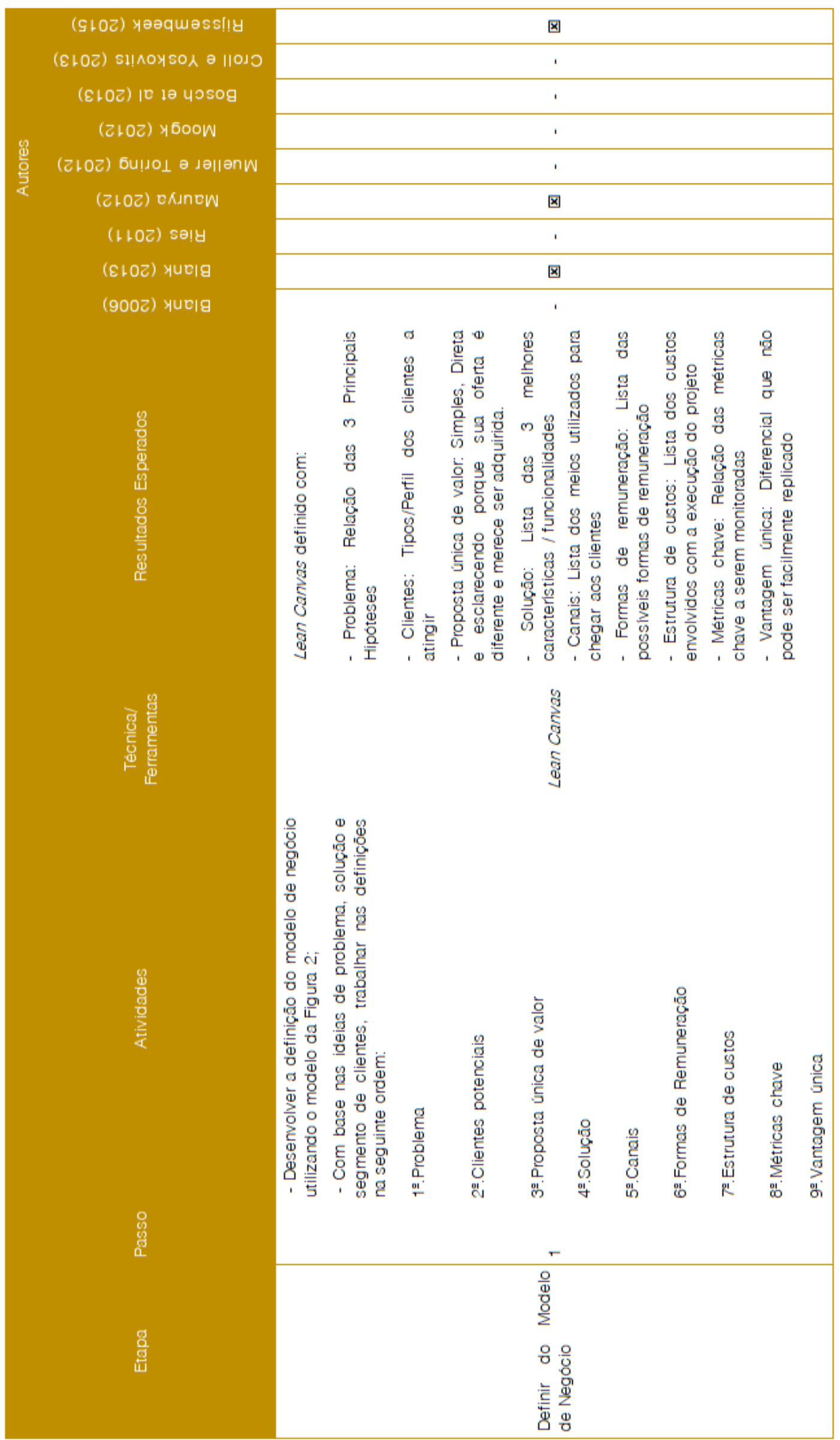




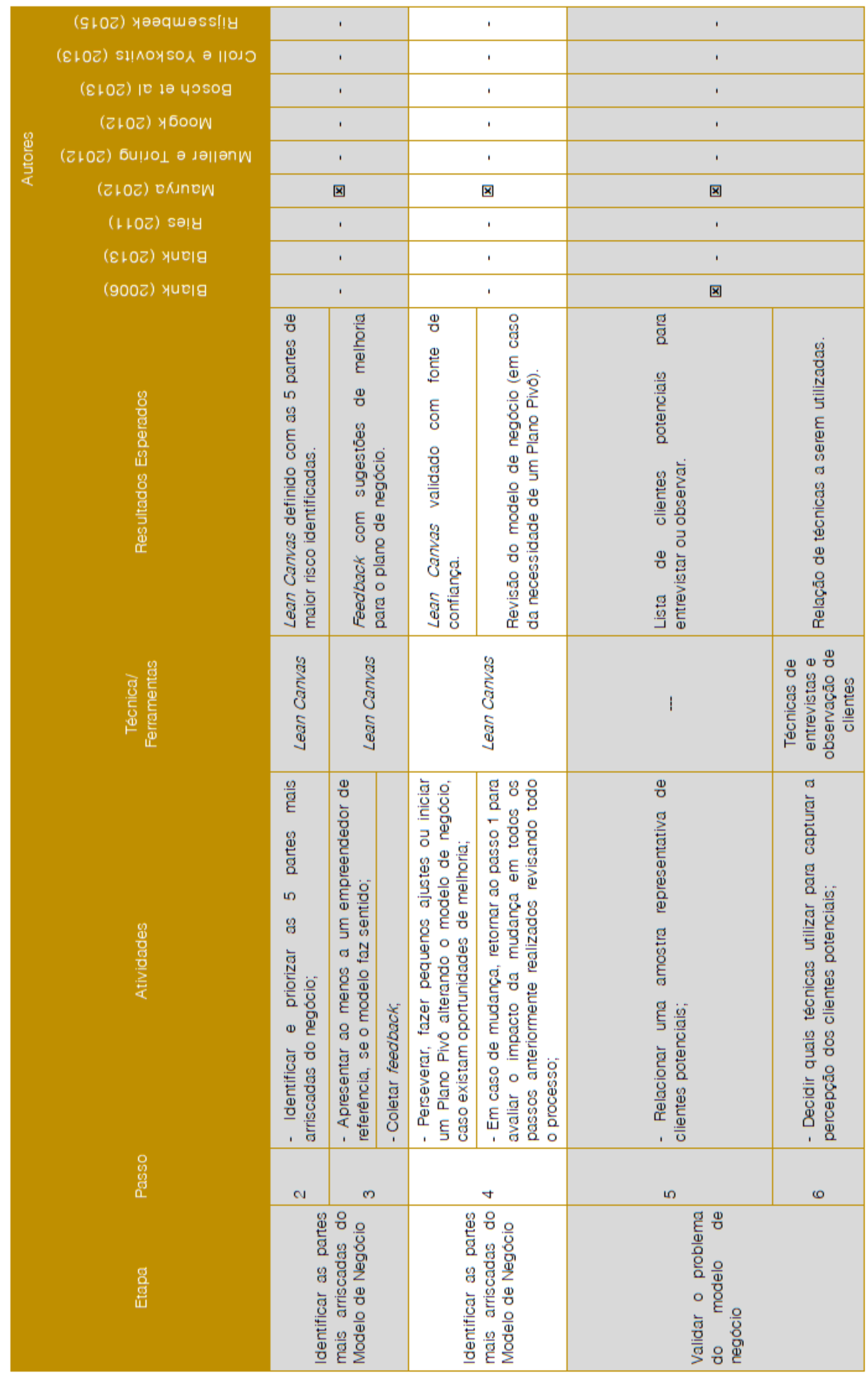




\begin{tabular}{|c|c|c|c|c|c|c|c|}
\hline (GเOZ) yәəquəss!!y & & & & \multicolumn{2}{|c|}{ 冈 } & \multicolumn{2}{|c|}{ 冈 } \\
\hline (EเOZ) s!n^oyso人 ə & & & & \multicolumn{2}{|c|}{ ' } & \multicolumn{2}{|c|}{ ' } \\
\hline$(\varepsilon+0 Z)$ |0 1ә บ०sog & & & & \multicolumn{2}{|c|}{ 凶 } & \multicolumn{2}{|c|}{ 冈 } \\
\hline$(z \vdash 0 z)$ y $600 \mathrm{~W}$ & & & & \multicolumn{2}{|c|}{ ' } & \multicolumn{2}{|c|}{ 冈 } \\
\hline 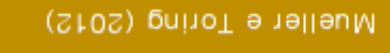 & & & & \multicolumn{2}{|c|}{ 冈 } & \multicolumn{2}{|c|}{ 冈 } \\
\hline$(z+O z)$ exunew & & & & \multicolumn{2}{|c|}{$凶$} & \multicolumn{2}{|c|}{$凶$} \\
\hline (troz) sə!y & & & & \multicolumn{2}{|c|}{ 冈 } & \multicolumn{2}{|c|}{ 冈 } \\
\hline 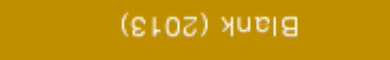 & & & & \multicolumn{2}{|c|}{ 凶 } & \multicolumn{2}{|c|}{ 冈 } \\
\hline (900乙) Үиㅣ & & & & \multicolumn{2}{|c|}{ ' } & \multicolumn{2}{|c|}{ ' } \\
\hline 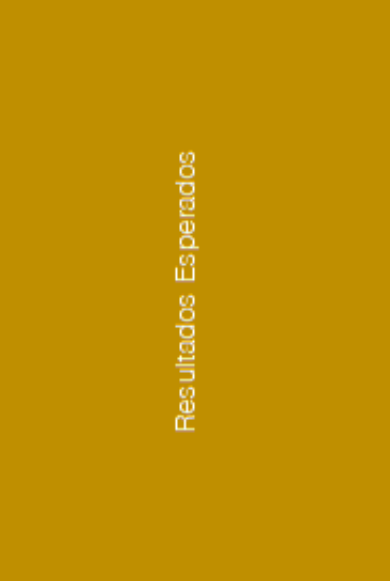 & 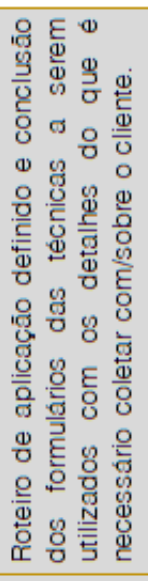 & \multicolumn{2}{|c|}{ 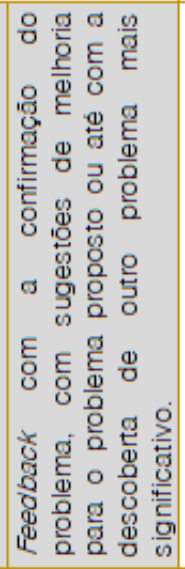 } & 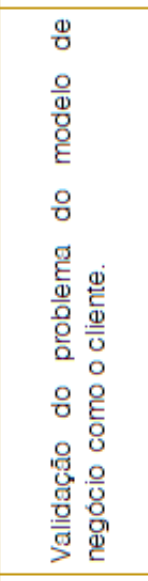 & 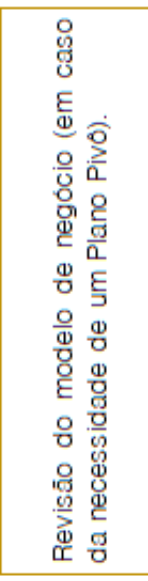 & 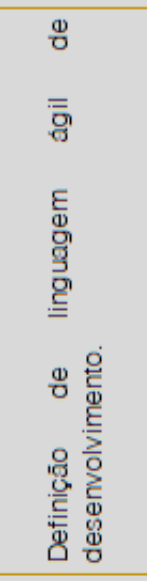 & 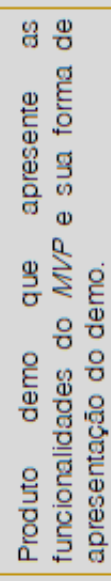 \\
\hline 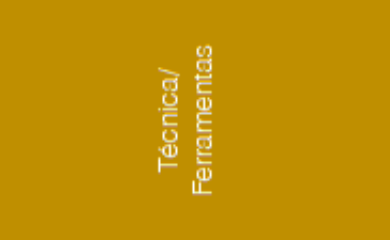 & 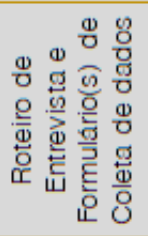 & \multicolumn{2}{|c|}{ 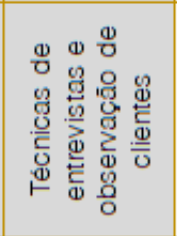 } & \multicolumn{2}{|c|}{ 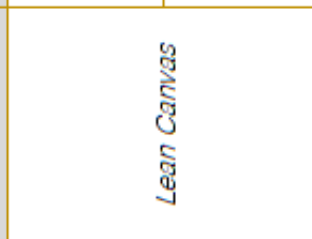 } & 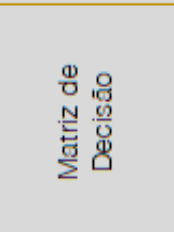 & 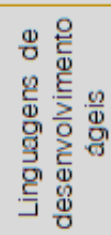 \\
\hline 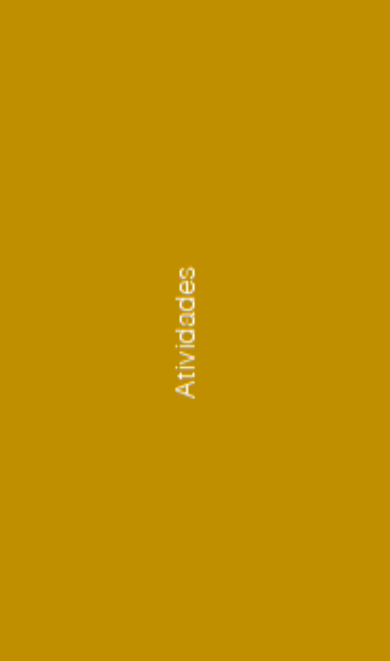 & 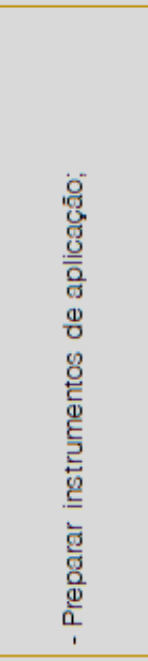 & 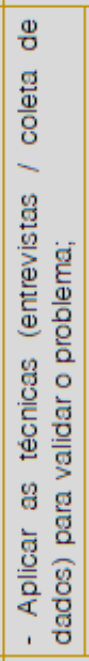 & 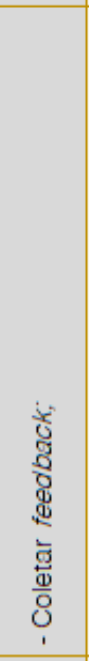 & 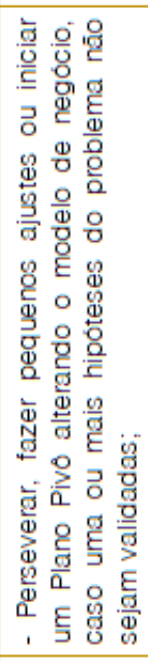 & 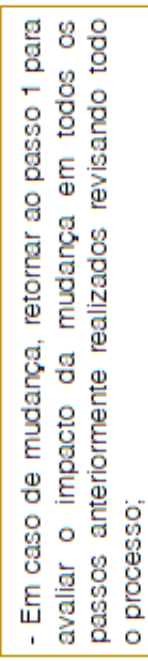 & 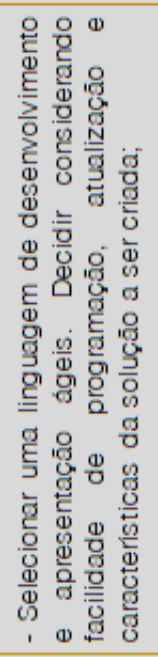 & 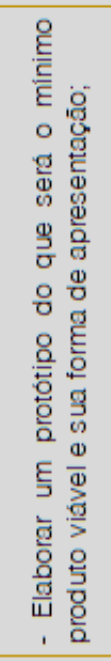 \\
\hline gू & n & \multicolumn{2}{|c|}{$\infty$} & \multicolumn{2}{|c|}{ a } & 우 & $\mp$ \\
\hline & & & & \multicolumn{2}{|c|}{ 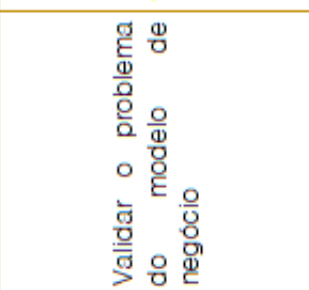 } & \multicolumn{2}{|c|}{ 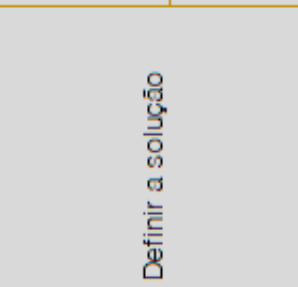 } \\
\hline
\end{tabular}




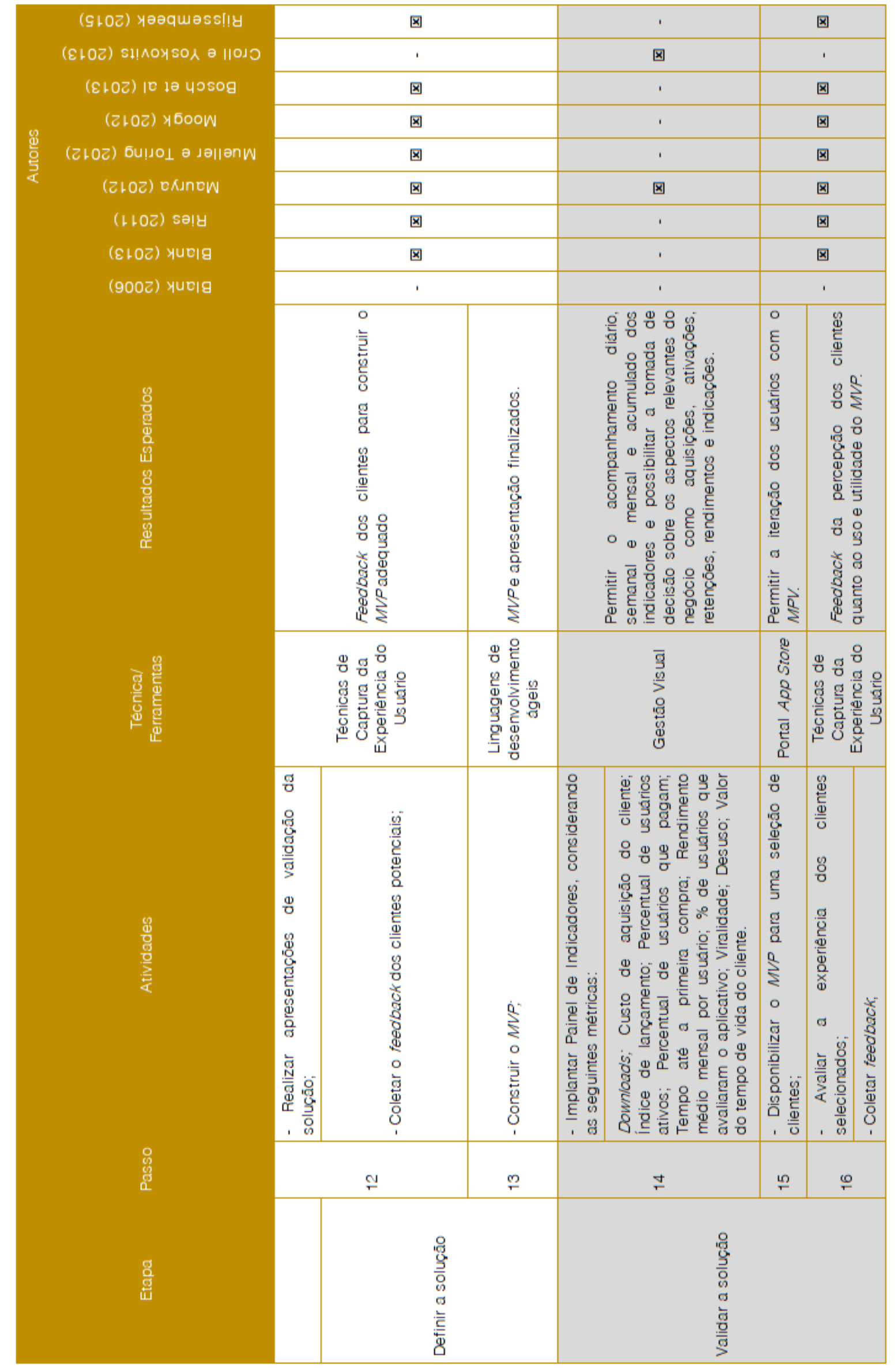




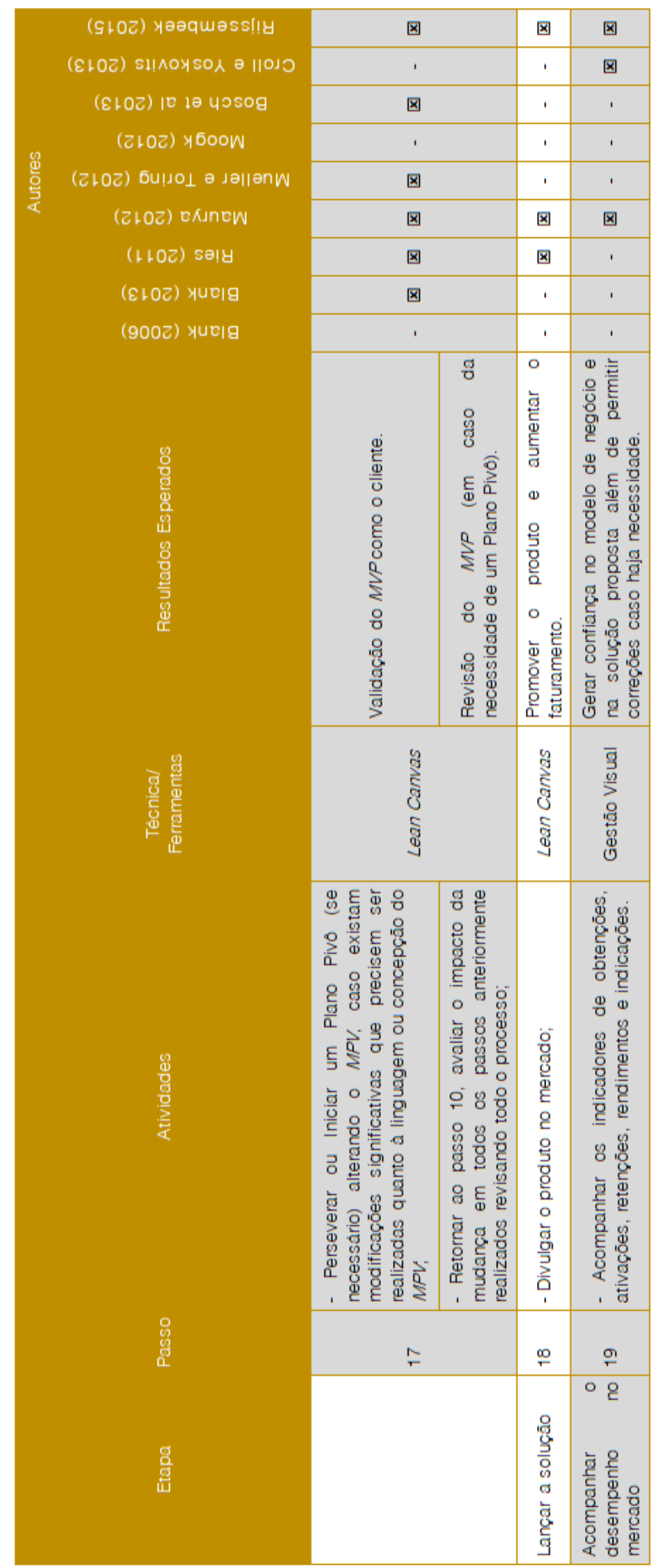




\section{CONCLUSÕES}

Durante o desenvolvimento desta pesquisa, foi observado na literatura utilizada, que cada um dos autores explorou diferentes aspectos e que estes se complementavam para o desenvolvimento do modelo. Cada um dos referenciais utilizados agrega com novas visões complementares e formas mais orientadas para o empreendedor que esta aprendendo a fazer. Os pesquisadores não identificaram na literatura utilizada durante a pesquisa, trabalhos que abrangessem todos os aspectos que foram reunidos no modelo proposto. Diante do observado, foi possível perceber que existem oportunidades para pesquisar sobre as abordagens dos diferentes pesquisadores e combiná-las para construir novos conhecimentos.

O modelo apresentado neste artigo pode contribuir com a comunidade empreendedora da área tecnológica, ao propor um modelo de aplicação do $\angle S M$ em um empreendimento de software B2C (Mobile Applications), consolidando conceitos, etapas, passos, técnicas e ferramentas explorados por diversos autores na literatura avaliada. Além disso, esta proposta pode ser utilizada como

\section{REFERÊNCIAS}

[1] Blank, S. The Four Steps to Epiphany. Lulu.com. 2006.

[2] Blank, S. Why the Lean Startup Changes Everything. Harvard Business Review. Pág. 63-72, 2013. Disponível em: <http://www.vto.at/wpcontent/uploads/2013/10/Why-the-Lean-Startup-

Changes-Everything_S.Plank_HBR -052013.pdf> Acesso em: 10.09.2016.

[3] Bosch, J.; Holmström Olsson, H.; Björk, J.; Ljungblad, J. The Early Stage Software Startup Development Model: A framework for Operationalizing Lean Principles in Software Startups. Springer-Verlag Berlin Heidelberg. Berlin, Germany, 2013.

[4] Crool, A. Yoskovitz, B. Lean Analytics. O'Reilly Media. California, USA, 2013.

[5] Maurya, A. Running Lean. O'Reilly Media. California, USA, 2012.

[6] Maurya, A. Scaling Lean. O'Reilly Media. California, USA, 2016.

[7] Moogk, D. R. Minimum Viable Product and the Importance of Experimentation in Technology Startups. Technology Innovation Management Review, Pág. 23-26. 2012. Disponível em: $<$ http://timreview.ca/article/535> Acesso em: 10.09.2016. material didático para disseminar o tema Lean Startup Methodology (LSM).

Como possibilidades de dar sequência a este trabalho, os autores visualizam as seguintes oportunidades futuras: Aplicação o modelo proposto através de uma pesquisa-ação para testar a sua aplicação e efetividade, pois em função das limitações de tempo, não foi possível validar a efetividade do mesmo pela sua prática. No modelo proposto não foram exploradas detalhadamente técnicas para coletar percepção e experiências de clientes assim como dar escala ao novo negócio após o mesmo se consolidar, o que também pode ser oportunidade de dar sequência ao trabalho iniciado; Trabalhar nas lacunas encontradas na literatura pesquisada como o desenvolvimento de método estruturado para identificar o motor de crescimento do negócio e desenvolvimento de método para definição de escopo e escolha de técnicas ágeis para sua construção do MPV são possibilidades adicionais; A sugestão proposta por Mueller \& Toring (2012) combinando LSM com Design Thinking também pode oportunizar um complemento interessante ao modelo detalhado proposto neste artigo.

[8] Mueller, R.M.; Thoring, K. Design thinking versus lean startup: a comparison of two user driven innovation strategies. Leading Innovation Through Design. Pág. 151-161. 2012. Boston, MA. USA. Disponível em: <https://www.researchgate.net/publication/2340660 97_Design_Thinking_VS_Lean_Startup_A_Compari son_OF_Two_User-Driven_Innovation_Strategies > Acesso em: 10.09.2016.

[9] RIES, E. The Lean Startup. Crown Business. New York, USA, 2011.

[10] Rijssenbeek, W.C.A. Applying lean startup methods in traditional manufacturing firms: a theoretical perspective. University of Twente, The Faculty of Behavioral, Management and Social Sciences, 2015. $\quad 6^{\text {TH }}$ IBA Bachelor Thesis Conference. Disponivel em: <http://essay.utwente.nl/68477/1/RIJSSENBEEK_B A_ManagementGovernance.pdf $>$. Acesso em: 02.08.2016.

[11] Startup Lessons Learned: The Lean Startup, 2008. Disponível em: <http://www.startuplessonslearned.com/2008/09/>. Acesso em: 13.05.2018.

[12] Womack, J.P.; Jones, D.T. Lean Thinking. Free Press, New York, USA, 1996. 


\section{Capítulo 12}

\section{UM ESTUDO SOBRE A INTERACÃO ENTRE AS FERRAMENTAS LEAN E OS PROCESSOS CONSTRUTIVOS EM UMA OBRA EM FLORIANOPOLIS/SC}

\section{Taylana Piccinini Scolaro}

\section{Renata Mansuelo Alves Domingos}

Resumo: O Lean Construction é eficaz para a gestão de processos na construção civil e para o alcance das metas do projeto, eliminando o desperdício. A implementação do Lean Construction depende, em sua maioria, da aprendizagem organizacional e da criação de conhecimento, que por sua vez é promovida por técnicas enxutas. No entanto, poucos estudos são encontrados acerca da gestão do conhecimento da construção enxuta, fato que é maximizado pela dificuldade de visualizar o fluxo de trabalho em um projeto de construção. A construção enxuta demonstrou ter um potencial significativo para impactar projetos de construção e está recebendo maior atenção em todo o mundo. A presente pesquisa, realizada a partir do acompanhamento da obra de um edifício residencial de múltiplos pavimentos no município de Florianópolis/SC, teve por objetivo avaliar a interação entre as ferramentas Lean e os processos construtivos aplicados no canteiro de obras, destacando aspectos com potencial de melhoria e propondo práticas de auxílio à implementação de ferramentas não observadas. Dessa forma, foram reunidas estratégias fundamentadas na bibliografia e na observação de processos na obra acompanhada, abordando questões relacionadas ao foco nas necessidades dos clientes, ao desperdício, à qualidade e ao fluxo de materiais e otimização de tempo. Os resultados encontrados permitem auxiliar gestores na utilização das ferramentas Lean na gestão e concepção dos canteiros de obras.

Palavras-chave: Construção enxuta; Racionalização; Qualidade. 


\section{INTRODUÇÃO}

Até em torno de 1980, grande parte das obras no Brasil eram públicas e com baixas exigências de qualidade. Os clientes eram acostumados a baixos padrões, o que proporcionava a não exigência de melhorias. Nos canteiros de obra, era recorrente o desperdício de materiais, mão de obra com baixa qualificação e grande rotatividade, sendo os altos custos facilmente repassados aos clientes. Nesse cenário, as construtoras obtinham lucros exorbitantes e, como a principal preocupação do setor eram os indicadores financeiros, o setor demorou para buscar mais eficácia e eficiência na sua forma de produção.

Com o avanço da tecnologia e com a globalização, as informações passaram a ser de fácil acesso e com rápidas mudanças. Isso fez com que os profissionais $e$ as organizações passassem a buscar melhorias em gestão e tecnologia. Nesse contexto, a construção enxuta (lean construction), trouxe uma filosofia que pode ser considerada um diferencial para a competitividade das empresas, uma vez que proporciona o desenvolvimento de um ambiente produtivo com a eliminação dos desperdícios e o aumento do valor agregado ao produto final da forma mais rápida e eficiente possível.

Ao longo dos anos 90 surgiram alternativas de modelos para gestão e a Lean Construction é uma delas. A pesquisa teve como base tal filosofia para a avaliação da qualidade da gestão de uma obra na cidade de Florianópolis, Santa Catarina. Para isso, o artigo apresentará as ferramentas utilizadas e como os conceitos foram e podem ser aplicados de forma prática em uma obra de construção civil.

\section{REVISÃO BIBLIOGRÁFICA}

A filosofia Lean Construction, baseada na Lean Production, a partir dos anos 90 surge como uma alternativa para realizar a gestão da produção na construção civil e eliminar desperdícios com materiais e mão de obra.

A Lean Production, quando comparada com a produção em massa, considera redução do esforço por parte dos operários, do espaço para a fabricação do produto, do investimento em ferramentas e das horas de planejamento. Além disso, emprega equipes de trabalho multiqualificadas e máquinas flexíveis de modo a produzir ampla variedade de produtos. O Lean Thinking consiste em um método racional de produção que busca eliminar elementos desnecessários, com o objetivo de reduzir desperdícios e criar valor (WOMACK et al., 1990).

O pensamento enxuto apresenta um modelo em que as ações são gerenciadas para produzir valor ao cliente, em que as melhorias resultam da redução do desperdício, do tempo de fluxo e do custo total do projeto. Dessa forma, a filosofia Lean considera que as atividades de fluxo que não agregam valor do ponto de vista do cliente - como retrabalhos, tempo de espera e movimentação dentro do canteiro - devem ser minimizadas ao máximo (HOWELL; BALLARD, 1998).

Koskela (1992) conceitua a Lean Construction de acordo com as seguintes ações:

- Redução de atividades que não agregam valor, permitindo maior eficiência dos processos e redução de perdas através da eliminação de atividades de fluxo;

- Redução da variabilidade da matériaprima fornecida, dos processos executados e da demanda de clientes;

- Redução do tempo de ciclo através da identificação de tempos improdutivos em etapas como transporte, espera, processamento e inspeção;

- Simplificação dos processos por meio da redução do número de passos ou partes e da padronização de elementos;

- $\quad$ Aumento do valor do produto com a consideração das necessidades dos clientes no projeto e na gestão da produção;

- Aumento da flexibilidade de saída através de alterações nas características finais do produto de acordo com as necessidades dos clientes;

$$
\begin{aligned}
& \text { - Aumento da transparência do } \\
& \text { processo. }
\end{aligned}
$$

Com o implemento da filosofia Lean, a partir do mapeamento das atividades e conhecimento de todos os processos envolvidos, tem-se a formação de uma construção transparente, em que se busca a redução de custos e prazos, a mitigação de desperdício de materiais e tempo de trabalho e, por consequência, o aumento da qualidade final do produto (RODRIGUES; PICCHI, 2010). 
As evidências empíricas de melhora nas reduções dos prazos e custos e no aumento da qualidade, faz com que o interesse das empresas em adotar as práticas Lean se tornem uma estratégia de competição (SANCHEZ; PÉRES, 2001). Porém isso pode não ocorrer de forma imediata, visto que fatores como o tipo da empresa, produto fornecido e o método adotado influenciam nos resultados (LEWIS, 2000).

É válido ressaltar que a aplicação da filosofia de produção enxuta é feita de forma a ser transferida e não replicada. Ou seja, deve-se estudar as práticas bem-sucedidas e as aprimorá-las durante a implementação (HIROTA; FORMOSO, 2000).

\section{METODOLOGIA}

A pesquisa desenvolvida com o intuito de reconhecer os potenciais de melhoria no âmbito dos Princípios Lean, contou com o acesso a uma edificação de 27.978,72 metros quadrados localizada no município de Florianópolis. A escolha da obra em estudo deu-se devido ao porte do empreendimento e da disponibilidade de coleta de informações.

A metodologia da presente pesquisa foi baseada principalmente nos artigos dos autores Oliveira et al. (2010) e Tonin e Schaefer (2013). Sendo desenvolvida uma própria a partir das leituras anteriores. Uma representação esquemática das etapas da pesquisa qualitativa é apresentada na Figura 1.

Figura 1 - Fluxograma da metodologia adotada

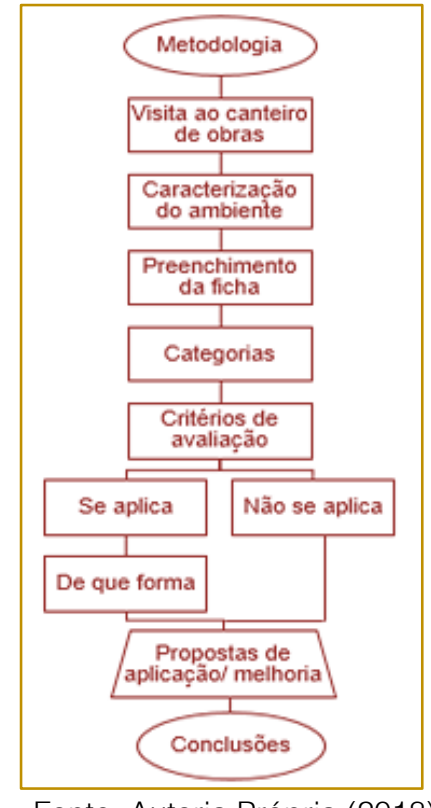

Fonte: Autoria Própria (2018)

Inicialmente, através de visitas ao canteiro de obras, foi realizada a caracterização do ambiente de trabalho e a coleta de informações acerca da estrutura organizacional da empresa. Em seguida, foi preenchida a ficha de avaliação elaborada com questionamentos referentes à aplicação dos Princípios do Lean Construction na obra, conforme mostra o Quadro 1. Para melhor visualização dos princípios no canteiro, os questionamentos foram separados por categorias e critérios e respondidos primeiramente com "Sim" ou "Não". Ainda, para questões respondidas com "Sim", foi verificado de que forma se dava a aplicação do critério na obra. 
Tabela 1 - Ficha de avaliação em categorias e critérios

\begin{tabular}{|c|c|}
\hline Categoria & Critério de avaliação \\
\hline \multirow{2}{*}{ Foco aos clientes } & $\begin{array}{l}\text { Existe algum tipo de flexibilização para eventuais mudanças requeridas pelos } \\
\text { clientes? }\end{array}$ \\
\hline & $\begin{array}{l}\text { Existe comunicação entre projetistas e o responsável pela construção para } \\
\text { alterações? }\end{array}$ \\
\hline \multirow{4}{*}{ Desperdícios } & $\begin{array}{l}\text { Existe um programa de gerenciamento de resíduos visando reciclagem e } \\
\text { separação dos entulhos? }\end{array}$ \\
\hline & $\begin{array}{l}\text { Há incentivos por meio da empresa para diminuir os resíduos no processo de } \\
\text { construção? }\end{array}$ \\
\hline & Os espaços são usados de forma eficiente? \\
\hline & Existem medidas para redução do desperdício de tempo (transporte, espera)? \\
\hline \multirow{7}{*}{ Qualidade } & Existe controle de qualidade dos materiais? \\
\hline & Existe medidas de segurança no canteiro de obras? \\
\hline & Há padronização nos processos? \\
\hline & A empresa possui alguma certificação de qualidade? \\
\hline & A empresa se preocupa com desempenho do edifício (térmico, acústico)? \\
\hline & Existe organização e limpeza no canteiro de obras? \\
\hline & $\begin{array}{l}\text { A empresa utiliza comunicação visual, indicando as informações através de } \\
\text { cartazes e placas? }\end{array}$ \\
\hline \multirow{5}{*}{$\begin{array}{l}\text { Fluxo de materiais e } \\
\text { otimização do tempo }\end{array}$} & Existe um controle para pedidos de reposição dos materiais? \\
\hline & Há um sistema para redução do tempo de transporte? \\
\hline & $\begin{array}{l}\text { A empresa faz uso de mão de obra reduzida trabalhando com equipes pequenas } \\
\text { para reduzir o tempo do ciclo? }\end{array}$ \\
\hline & $\begin{array}{l}\text { A empresa utiliza materiais feitos fora do canteiro (concreto usinado, argamassa } \\
\text { estabilizada, elementos pré-moldados)? }\end{array}$ \\
\hline & Existe um controle do cronograma da obra? \\
\hline
\end{tabular}

De modo a melhor descrever o diagnóstico atual da empresa, paralelamente ao preenchimento da ficha, as observações realizadas na obra em relação ao desempenho das operações e às atividades de fluxo foram registradas por meio de fotos.

Por fim, a partir do preenchimento do questionário, foi possível desenvolver um parecer técnico de auxílio à tomada de decisões por parte dos gestores, em cada categoria estabelecida, com base na filosofia Lean. Dessa forma, foram desenvolvidas propostas de aplicação para os critérios não implementados e sugestões de melhoria para aqueles já aplicados na obra.

\section{RESULTADOS}

A análise inicial se deu através das respostas aos questionários da ficha de avaliação. Mediante a isso, os resultados foram divididos em quatro grandes categorias: foco aos clientes, desperdícios gerados, qualidade da obra, otimização do tempo e fluxo dos materiais.
Para cada categoria, foi descrita uma visão geral da situação atual da empresa acerca do observado na obra e sugeridas possíveis melhorias a serem implementadas. Para os critérios não aplicados no canteiro, foram propostas medidas de implementação.

\subsection{FOCO NOS CLIENTES}

Womack e Jones (1996) abordam o conceito de produção puxada, em que a ideia se baseia em projetar e produzir aquilo que é necessidade do cliente e quando o cliente deseja, ou seja, deixa com que o cliente puxe o produto.

Percebeu-se de forma geral que existe uma comunicação regular com o cliente, criando assim uma flexibilização para mudanças no projeto e até mesmo em materiais de acabamento. Constatou-se durante as visitas um apartamento em específico que havia feito alterações no projeto arquitetônico e adquirido alguns materiais de forma privada como mostra a Figura 2. 
Figura 2 - Materiais adquiridos por apartamento para mudanças no acabamento

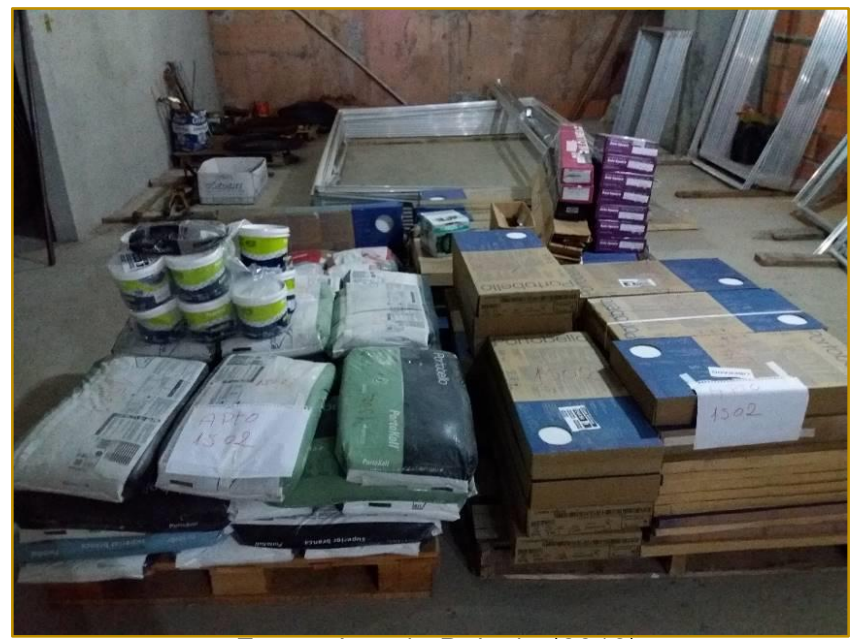

Fonte: Autoria Própria (2018)

As alterações de projeto por parte da construtora, incluindo mudanças de posição das paredes em alvenaria, são feitas durante a fase inicial de execução dos apartamentos de forma a evitar geração de resíduos e reduzir o retrabalho. Em obras em que não for verificada a necessidade por parte dos clientes em se executar paredes em alvenaria e que possam exigir mudanças mais constantes de alteração de layout, como escolas, sugere-se a utilização de divisórias leves.

\subsection{DESPERDÍCIOS GERADOS}

Em relação ao desperdício de material no canteiro, notou-se uma preocupação com a separação dos resíduos. As sobras de materiais são colocadas em carretões, transportadas por elevador e posteriormente armazenadas separadamente em baias sinalizadas, como ilustra a Figura 3. Três empresas fazem a destinação final dos resíduos, sendo uma responsável pelos metais, outra pelos plásticos e papelões e uma terceira pelos demais entulhos. Esta última, conta com um papa entulho localizado dentro da obra.

Figura 3 - Separação dos resíduos em baias sinalizadas

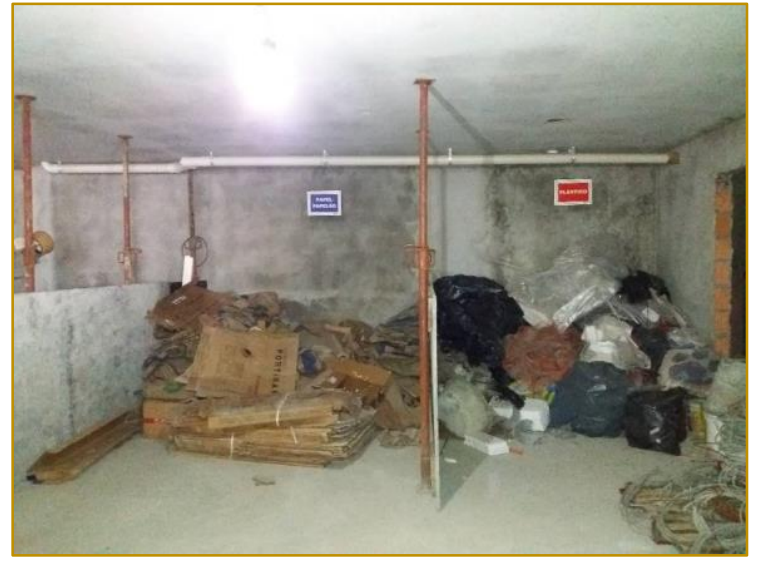

Fonte: Autoria Própria (2018) 
Uma alternativa de mitigação de geração de resíduos aplicada na obra é a utilização de argamassa estabilizada, que mantém a trabalhabilidade em longos períodos de tempo sem perder suas propriedades.

Entretanto, não foram observadas ações ou incentivos para a redução de desperdícios por parte dos funcionários. Sugere-se, então, que sejam realizados treinamentos com a equipe gestora e os operários, na admissão de funcionários e ao início de cada obra. Estes encontros teriam como finalidade incentivar um maior controle e planejamento das etapas da obra - por meio de ferramentas como o Gráfico de Gantt - de modo a estudar o reaproveitamento de sobras de material, e conscientizar os trabalhadores acerca dos impactos e das legislações ambientais.

Outra proposta seria 0 desenvolver o mapeamento do fluxo de valor com o intuito de identificar a ocorrência de desperdícios e buscar eliminá-los (RODRIGUES; PICCHI, 2010). Para isso, sugere-se a construção de um diagrama contendo todas as etapas de processos em que se identifiquem desperdícios, incluindo as atividades de fluxo.

\subsection{QUALIDADE DA OBRA}

A observação da qualidade na obra se deu com vistas à preocupação com a segurança no trabalho, com a limpeza e organização do canteiro e com a qualidade do serviço final, propriamente dita. A empresa possui selo de qualidade ISO 9001 e PBQP nível A.

Com relação à segurança, verificou-se o fornecimento de equipamentos de proteção individual (EPI's) à todos os funcionários por parte da construtora. O controle de aquisição dos EPI's é feito pelo almoxarife da obra por meio da assinatura do empregado no momento do recebimento, como mostra a Figura 4. Ainda, a fiscalização quanto a utilização dos EPI's é realizada por 2 técnicos de segurança da obra. Além disso, ao serem admitidos na construtora, todos os funcionários passam por um treinamento acerca das práticas de segurança e uso dos EPI's.

Figura 4 - Caderno de controle de aquisição de EPI

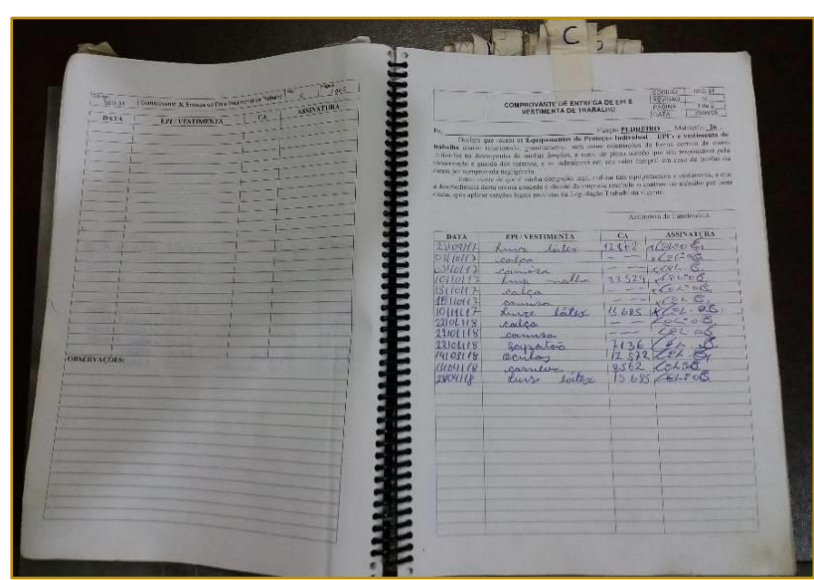

Fonte: Autoria Própria (2018)

Ainda, foram observadas práticas de limpeza e organização em diversos locais do canteiro de obras. Todas as áreas são devidamente sinalizadas por placas e separadas por telas quando necessário. As sinalizações vão desde avisos simples, como placas solicitando o não uso do celular ou informando acesso a banheiros e saídas, até proibições informando áreas restritas.
No pavimento térreo, foi fixada na parede uma placa indicando telefones úteis e de emergência, tanto da equipe da construtora quanto da rede pública, uma prática simples e transparente que permite o acesso a informação por parte de todos os funcionários. 
Figura 5 - Placa de acesso restrito (esquerda); Placa de acesso ao almoxarifado (direita).

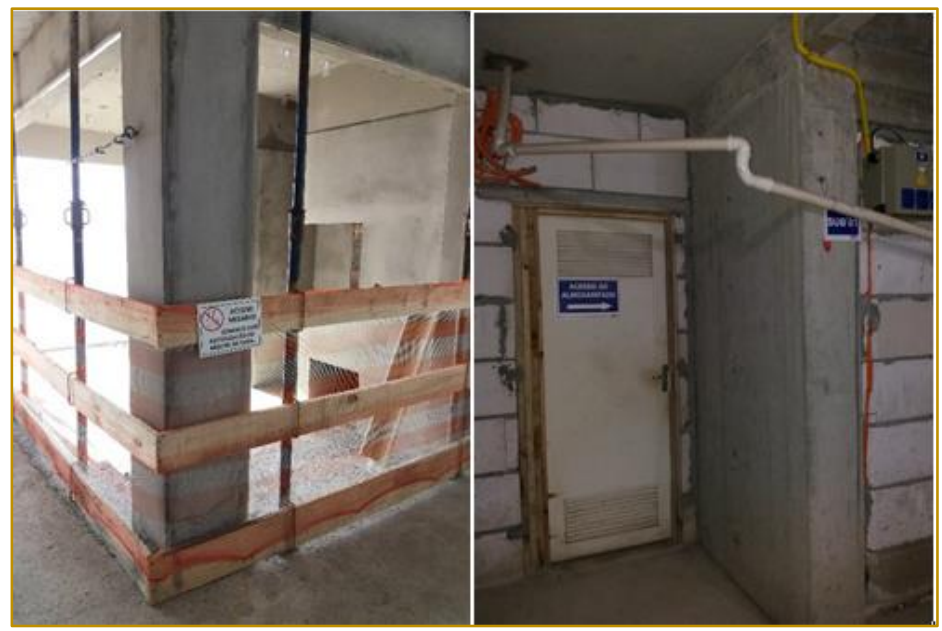

Fonte: Autoria Própria (2018)

O almoxarifado da obra também mostrou-se totalmente organizado. As prateleiras em estrutura metálica e de madeira utilizadas para o armazenamento do estoque de peças são reutilizadas de outras obras, transportadas e encaixadas no próprio canteiro, se mostrando uma prática eficiente, prática e sustentável.

Figura 6 - Prateleiras para armazenamento do estoque

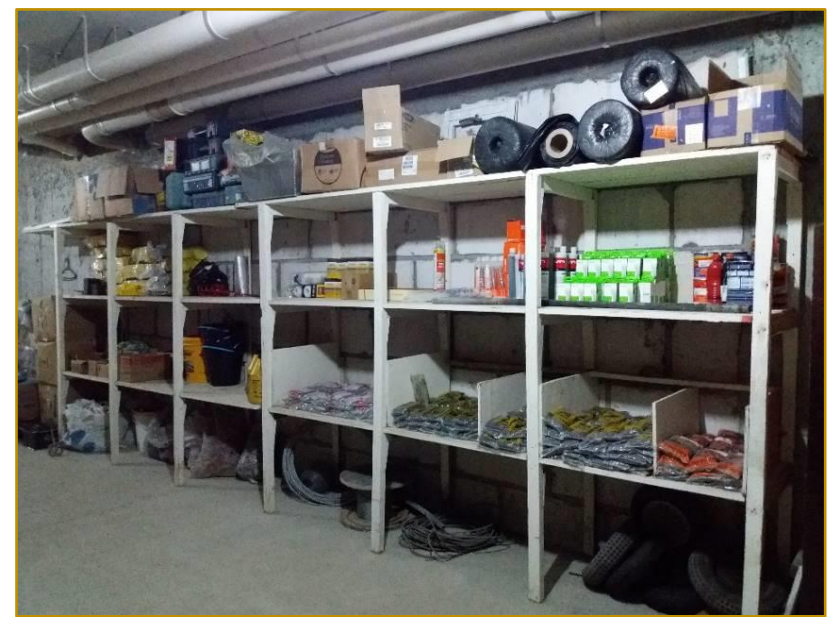

Fonte: Autoria Própria (2018)

Observaram-se também cuidados com isolamento térmico e acústico na execução de diversos serviços como utilização de mantas na laje, nas tubulações e lã de vidro entre as paredes de alvenaria que dividem apartamentos, demonstrando preocupação em manter certos padrões de qualidade compatíveis com as necessidades dos clientes alvo. 
Figura 7 - Isolamento acústico de tubulações

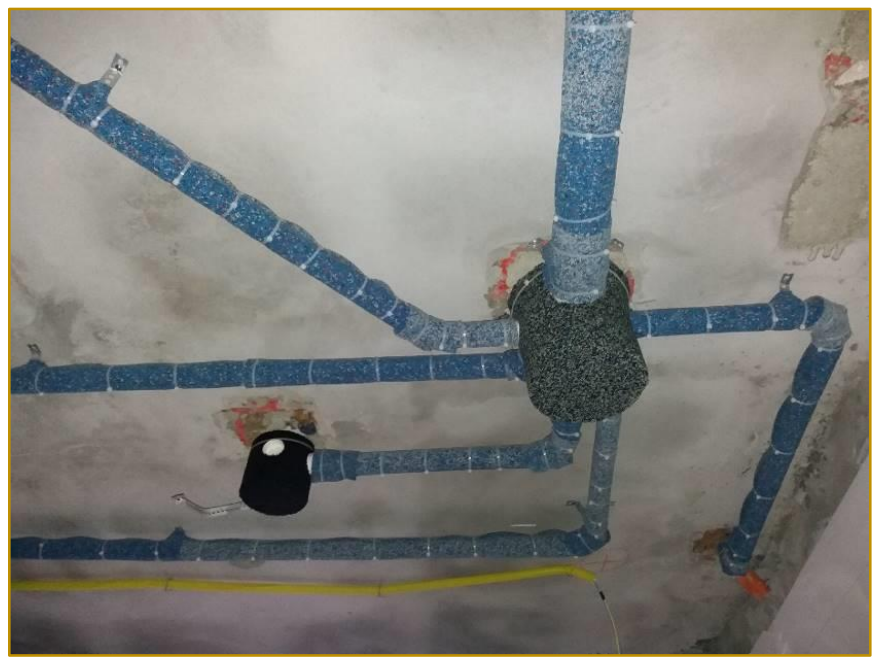

Fonte: Autoria Própria (2018)

A utilização de concreto usinado e argamassa estabilizada também são formas de se obter maior controle de qualidade do produto. Além disso, para ambos materiais, a construtora dispõe de uma ficha que permite registrar a data, o horário, o local e o responsável pela aplicação, conforme mostra a Figura 8 para o exemplo da argamassa estabilizada.

Figura 8 - Ficha de controle da argamassa estabilizada

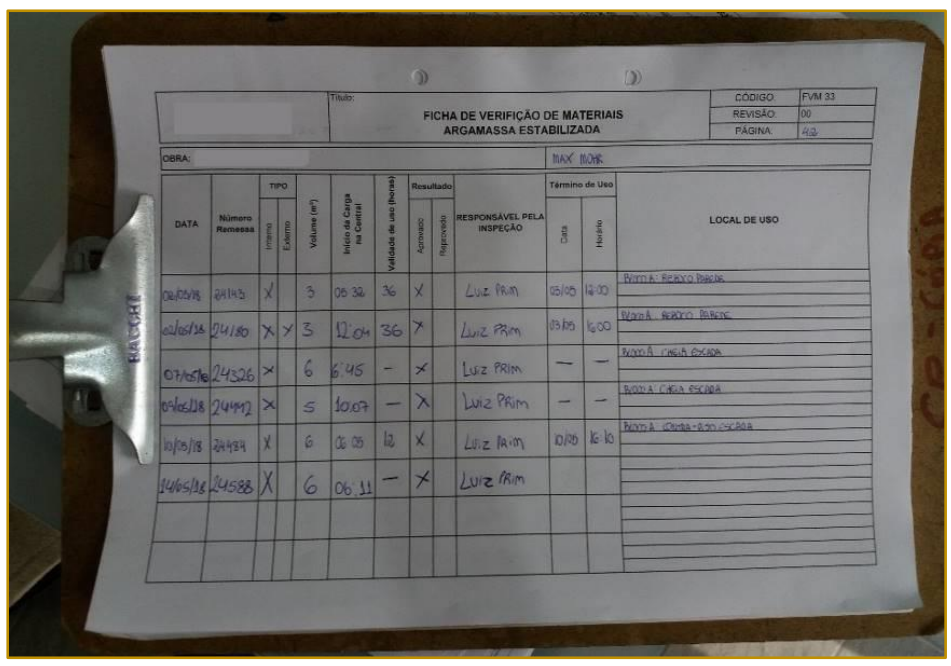

Fonte: Autoria Própria (2018)

\subsection{FLUXO DE MATERIAIS E OTIMIZAÇÃO DE TEMPO}

Algumas medidas para otimização de tempo são adotadas em canteiro como a utilização de concreto usinado e argamassa estabilizada. Além disso, a existência de mais de um local para armazenamento dos resíduos gerados apresenta-se como uma medida redutora no tempo de transporte.
A execução das etapas da obra é controlada por planilhas e plantas impressas no escritório da obra em que são preenchidos os serviços e andares já executados para controle de cronograma, conforme as Figuras 9 e 10. As impressões são em tamanho grande dando transparência e facilidade de observação dos processos. 
Figura 9 - Planilha de controle de serviços executados

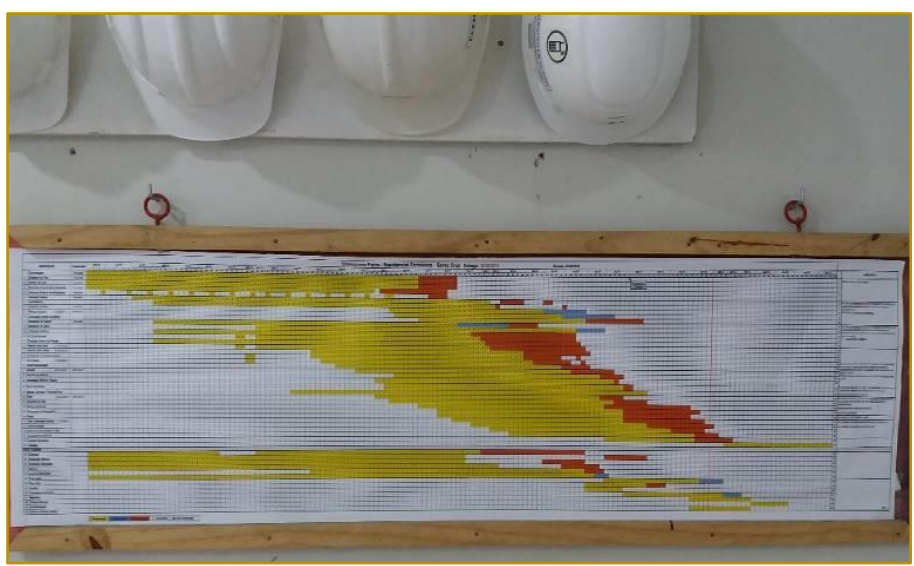

Fonte: Autoria Própria (2018)

Figura 10 - Planta de corte para controle de lajes executadas

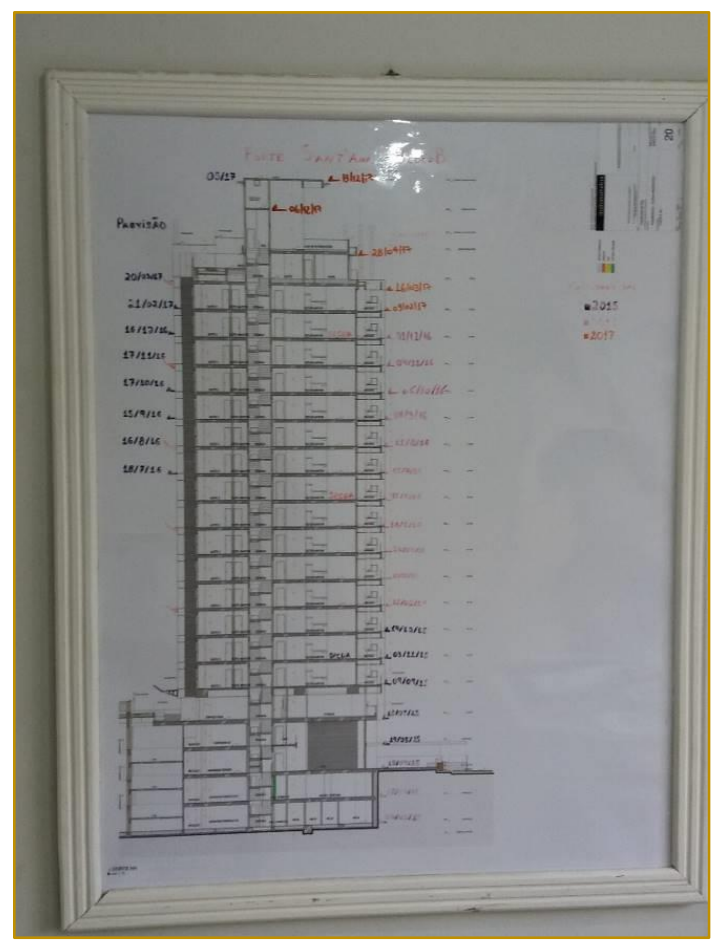

Fonte: Autoria Própria (2018)

Em relação ao controle de estoque, os próprios responsáveis pelas atividades, como encanadores e eletricistas, fazem 0 requerimento de materiais a serem comprados. O requerimento acontece de forma simples, através de anotações em blocos de papel que são entregues toda semana ao escritório sede da construtora. Os pedidos são feitos toda semana. Uma tentativa atual da empresa está sendo implementar um sistema de pedidos online, em que os funcionários façam os pedidos pela plataforma e ao mesmo tempo a construtora já tenha acesso aos mesmos.
Foi constatado também o uso de pequenos grupos de pessoas em diferentes frentes de trabalho. O que proporciona flexibilidade e redução do tempo de execução da obra.

O corte e dobra do aço é feito de forma manual, com o auxílio de tesouras e equipamentos de dobra. Para racionalização do processo e redução de sobras de aço, o material poderia ser encomendado previamente cortado e dobrado.

Além disso, por meio de uma das ferramenta do Lean Thinking, a linha de balanço, é possível verificar a movimentação das 
equipes de trabalho ao longo de atividades que serão executadas repetidamente em projetos lineares. Edifícios com múltiplos pavimentos, como é o caso da obra em estudo, são considerados projetos de construções lineares (SOUZA et al., 2014).

Ainda como forma de auxílio a produção enxuta, o kanban, outra ferramenta Lean Thinking já utilizada na construção civil, pode ser empregado para controle e gerenciamento do fluxo vertical de materiais. O sistema baseado na utilização de cartões se aplica tanto a produção de materiais como argamassas, quanto no transporte propriamente dito. Dessa forma, as equipes de trabalho solicitam diariamente os materiais necessários evitando estoques demasiados no pavimento (LEITE et al., 2004).

\section{CONCLUSÃO}

A identificação e definição das estratégias a serem aplicadas com base nos Princípios Lean deve considerar inicialmente o cenário atual da empresa, de forma a diagnosticar as estratégias já implementadas e aquelas ainda não consideradas no planejamento e na execução das etapas de serviço.

A partir do diagnóstico inicial, além de evidenciar aspectos com potencial de melhoria ou de aplicação, foi possível propor ferramentas de auxílio a implementação do Lean Construction por parte de uma

\section{REFERÊNCIAS}

[1] Hirota, E. H.; Formoso, C. T. O processo de aprendizagem na transferência dos conceitos e princípios da produção enxuta para a construção. In: Encontro Nacional Da Tecnologia Do Ambiente Construído - ENTAC, v. 7, 2000.

[2] Howell, G.; Ballard, G. Implementing lean construction: understanding and action. In: Proc. 6 th Ann. Conf. Intl. Group for Lean Constr. 1998.

[3] Koskela, L. Application of the new production philosophy to construction. Stanford, CA: EUA, Center for Integrated Facility Engineering - CIFE, Stanford University (Technical Report No 72). 1992.

[4] Lewis M. A. Lean production and sustainable competitive advantage. International Journal of Operations \& Production Management, Vol. 20 No. 8, pp. 959-978. 2000. construtora. Baseado nesta ideia, foram reunidas estratégias fundamentadas na bibliografia e na observação de processos na obra acompanhada.

Foram abordadas questões acerca da flexibilidade de projeto, relacionadas ao foco no atendimento das necessidades dos clientes; ao desperdício de materiais e geração de resíduos, considerando a importância da racionalização dos processos com vistas à sustentabilidade; à qualidade, no que diz respeito a segurança no trabalho, a limpeza e organização do canteiro e a qualidade do serviço final; e ao fluxo de materiais, buscando processos mais eficientes funcional e economicamente.

Esta pesquisa se deu com o objetivo de auxiliar gestores na identificação e implementação de ferramentas e práticas de Princípios Lean, com base na observação de processos já aplicados na obra acompanhada e em sugestões pontuais para melhoria de etapas específicas. Ainda, verificou-se que a estrutura do conceito Lean é sólida e bem estabelecida, no entanto, seu desenvolvimento deveria considerar as diferenças culturais, políticas e econômica entre os diferentes países.

Como sugestão para trabalhos futuros, indicase a ponderação de quais as ações sugeridas são mais efetivas para a promoção dos resultados esperados, de forma a estabelecer prioridade de estabelecimento das ações.

[5] Leite, M.O.; Pinho, I.B.; Pereira. P.E.; Heineck, L.F.M.; Rocha, F.E.M. Aplicação do sistema kanban no transporte de materiais na construção civil. Revista Produção Online, v. 4, n. 4, 2004.

[6] Rodrigues, M.R.; Picchi, F.A. Análise de experiências de aplicação do lean thinking na construção de edificações no Brasil. XIII Encontro Nacional de Tecnologia do Ambiente Construído, Canela, 2010

[7] Sanches, A.M.; Perez, M.P. Lean indicators and manufacturing strategies. International Journal of Operations \& Production Management, v. 21 no. 11, pp. 1433-1451, 2001.

[8] Souza, V.F.L.; Volta, C.B.; Magalhães, I.A. Aplicação do método da linha de balanço no planejamento e controle de obras com atividades repetitivas. XIII Seminário Estudantil de Produção Acadêmica, v. 13, 2014. 
[9] Womack, J.P.; Jones, D.T.; Roos, D. A máquina que mudou o mundo. Rio de Janeiro: Campus, 1990

[10] Womack, J. P.; Jones D. T. A Mentalidade Enxuta nas empresas: elimine o desperdício e crie riqueza. Tradução de Ana Beatriz Rodrigues e Priscila Martins Celeste. 5. ed. Rio de Janeiro: Campus, 1996 


\section{Gapítulo 13}

\section{GESTAOO DE ESTOQUE: INICIATIVAS DE UMA ORGANIZACAOO BRASILEIRA RUMO A INDUSTRIA 4.0}

\section{Gabriela da Rosa Witeck}

\section{Guilherme Maranhão Barreto Pereira}

Guilherme Luz Tortorella

Resumo: As prerrogativas que o uso da tecnologia voltada ao aumento de produtividade, qualidade e reduções de custos das operações fabris têm levado às empresas a investir em inovação e tecnologia. E dentro deste contexto surge no âmbito global a Indústria 4.0. Um coneito de indústria que abarca as principais inovações tecnológicas em automação, tecnologia da informação, internet das coisas e outras frentes tecnológicas aplicadas aos processos de manufatura. Associado à este novo conceito, este artigo tem como objetivo desenvolver uma política para a gestão de estoques de embalagens em uma fábrica de cimento da Votorantim Cimentos. O método de pesquisa proposto é composto por aspectos quantitativos, uma vez que combina a descrição do método atual de controle de estoques da empresa com o levantamento do histórico do consumo de embalagens. Os resultados sugerem uma nova política de gestão de estoques que possibilita a parametrização dos sistemas ERP da Votorantim Cimentos com o do fornecedor de embalagens para automatizar a geração de ordens de pedido com base nos estoques e consumo da planta.

Implicaçõespráticas: Definição depolítica de gestão de estoques para uma unidade Votorantim Cimentos.

Palavras-chave: Gestão de estoques; Manufatura; Indústria 4.0. 


\section{INTRODUÇÃO}

$\mathrm{Na}$ esfera onde a decisão empresarial é motivada por incumbências de lucratividade e responsabilidade social-ambiental, o uso inteligente de recursos mostra-se um critério seguro na definição de diretrizes. Estas exigências advêm de expectativas crescentes de produtividade, aumento do número de variantes de produtos e redução de tamanhos de lotes (CHENG et al., 2015). Para tanto, a ascensão de um novo modelo de indústria está sendo discutido mundialmente sob o tópico de Indústria 4.0 (HERMANN et al., 2016), o qual propõem a integração on-line de fornecedores, máquinas e clientes compondo uma rede de entidades.

Tais estruturas de produção, dotadas de dispositivos "inteligentes" ligados à rede, promovem alta capacidade de comunicação, constituindo as "Indústrias Inteligentes" que visam alargar o grau de flexibilidade em todos seus processos. No contexto de gestão de estoques, a Indústria 4.0 permite 0 planejamento e controle em tempo real. $O$ fluxo de informações e o planejamento operacional são os primeiros passos para a integração e execução dessa estratégia. Segundo Reddy et al. (2016), a predileção deve ser dada aos dados iniciais inseridos na rede. Uma vez que a informação é compartilhada online, o fornecedor e a fábrica podem equilibrar seus estoques, não havendo excessos em nenhuma das partes (BALLOU, 2006).

A Indústria 4.0 aborda ações de pesquisa e desenvolvimento em certas áreas para apoiar a adoção de seus princípios, e servir como base para alcançá-los (ZHOU, K.; ZHOU, F.; LIU, 2015; THOBEN; WIESNER; WUEST, 2017). Embora incorporado nas últimas tecnologias e a algoritmos inovadores, a fábrica inteligente se permite construir sobre os fundamentos do sistema Toyota de produção (BAUERNHANSL et al., 2014), manufatura enxuta.

A Votorantim Cimentos - empresa estudada passou a orientar seus próximos passos para investimentos em inovação e tecnologia, à luz da indústria 4.0. Alinhada à esta estratégia, a organização propõem alavancar a participação da tecnologia da informação, para tomar as melhores decisões na redução de custo, aumento da capacidade de produção e otimização do uso de recursos.

Este artigo visa desenvolver um estudo de caso, em uma organização cimenteira brasileira, que iniciou os primeiros passos de um grande projeto em direção à indústria 4.0. Ademais a pesquisa possui como objetivo geral desenvolver uma política para a gestão de estoque de matéria prima (embalagens) a fim de que, através dos dados estabelecidos e parametrizados, viabilize a integração online - via plataforma SAP - entre fornecedor e indústria, sendo capaz de processar grandes quantidades de dados para as aplicações "internet das coisas" em tempo real. Essa abordagem promete acelerar os processos de fabricação e logísticos, assim como aumentar a segurança e qualidade dos produtos e serviços.

\section{REVISÃO BIBLIOGRÁFICA}

\subsection{INDÚSTRIA 4.0.}

O conceito da Indústria 4.0 é conceituado como a resulta de esforços provindos de universidades, indústrias e do próprio governo Alemão, em busca do fortalecimento no setor de manufatura, através da convergência de tecnologias de informação e comunicação (BAENA et al., 2017). Kagermann, Wahlster e Helbig (2013) elucidam a Indústria 4.0 como um novo nível de organização e gerenciamento da cadeia de valor ao longo do ciclo de vida dos produtos. Thoben, Wiesner e Wuest (2017) corroboram ao afirmar que a disponibilidade de informações relevantes em tempo real permitirá que os sistemas de fabricação atendam aos requisitos do cliente através de processos dinâmicos de engenharia.

O uso da internet nas interações entre humanos e máquinas, possibilitará processos de fabricação mais inteligentes. À medida que o poder de computação e a capacidade de armazenamento de dispositivos móveis aumentam, os terminais e aplicativos móveis serão usados para projetar, fabricar e gerenciar o processo de industrialização (ZHOU, K.; LIU; ZHOU, L., 2015).

A Indústria 4.0 influencia significativamente o ambiente de produção com mudanças na execução de operações. A idéia básica deste conceito é a presença generalizada de uma variedade de coisas, como RFID, sensores, atuadores, celulares, entre outros que, através de esquemas de endereçamento exclusivos, são capazes de interagir uns com os outros e cooperar com seus vizinhos para atingir metas comuns e para troca de informação e comunicação, realizando identificação 
inteligente, localização, rastreamento, monitoramento e gerenciamento (HOZDIĆ, 2015; ZHOU, K.; LIU; ZHOU, L., 2015).

O avanço para a indústria 4.0 torna-se viável por meio da implantação de capacidades digitais (PwC, 2016), para tanto é demando comprometimento da alta direção e investimentos significativos. Baseado em cases de sucesso desta transformação, a consultoria PwC (2016) aponta seis etapas a serem seguidas, conforme Figura 1.

Figura 1 - Blueprint para a implantação da Indústria 4.0

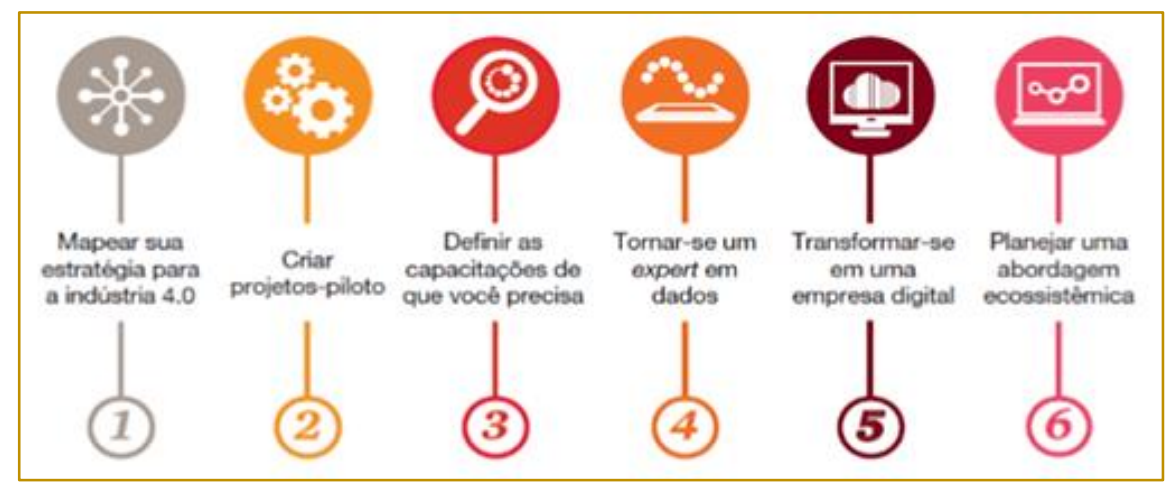

Fonte: PwC (2016, p. 29).

Etapa 1 - Mapear sua estratégia para Indústria 4.0: Segundo a PwC (2016), muitas empresas já começaram a digitalização de seus negócios, mas, com freqüência, o processo tem início em silos organizacionais e não segue uma abordagem holística. Nesta etapa é necessário ampliar o foco para além de detalhes técnicos e avaliar os impactos que novas aplicações teriam na cadeia de valor e nos relacionamentos com os clientes.

Etapa 2 - Criar projetos-piloto: Esta etapa consiste em utilizar projetos pilotos para estabelecer provas de conceito e demonstrar o valor gerado para o negócio

Etapa 3 - Definir as capacitações de que você precisa: Com base nos projetos-pilotos, podese mapear detalhadamente a arquitetura empresarial e as capacidades necessárias para permitir novos modelos de negócios digitais ou a digitalização interna.

Etapa 4 - Tornar-se um expert em dados: Organizar, analisar e aprender a extrair valor dos dados disponíveis criando vínculos diretos com a tomada de decisões e o desenho de sistemas inteligentes. Com isso, é possível melhorar os produtos e construir novas ofertas de serviços.

Etapa 5 - Transformar-se em uma empresa digital: Para poder capturar todo o potencial da Indústria 4.0 requer-se a transformação completa da empresa. O tom deve ser definido pelo topo, com liderança clara, comprometimento e visão dos executivos e stakeholders financeiros. Vale destacar, ainda, que a mudança não cessa ao implementar a Indústria 4.0, sendo necessário se reinventar diariamente de forma ágil para se manter à frente do jogo.

Etapa 6 - Planejar uma abordagem ecossistêmica: A Indústria 4.0 precisa se estender muito além da integração horizontal e vertical dentro da organização. Verdadeiros avanços no desempenho acontecem quando é possível entender o comportamento do consumidor e poder orquestrar o papel da empresa no futuro ecossistema de parceiros, fornecedores e clientes.

\subsection{GESTÃO DE ESTOQUES E MANUFATURA ENXUTA}

De acordo com Ohno (1997), a manufatura enxuta "é um sistema que visa à eliminação de perdas, entendendo-se perdas como a utilização de quaisquer recursos na quantidade acima da mínima necessária para obter a satisfação dos clientes". Slack, Chambers e Johnston (2009) observam que toda perda por estoque é um alvo que pode ser eliminado. Neste trabalho daremos ênfase para 0 desperdício de estoque, especificamente estoque de matérias primas aquele usado como ingredientes na linha de produção, e enquadrados entre os três tipos de estoque voltados à produção.

A gestão de estoques surge, portanto, para aperfeiçoar as reduções de custos e desperdícios, e ao mesmo tempo maximizar o 
nível de serviço a ser oferecido ao cliente. Dentre os modelos de estoque, Tubino (2000) divididos em dois grupos: os de emissão indireta e os de emissão direta. Os modelos de emissão indireta se encarregam de determinar o momento da reposição independentemente da demanda, já os de emissão direta que contemplam o sistema de reposição Material Requirement Planning (MRP), consiste em emitir pedidos de acordo com a demanda prevista.

O método do ponto de pedido, ou sistema de revisão contínua, é um modelo que exige acompanhamento ininterrupto durante sua implementação, e cujo processo de reabastecimento é totalmente baseado em pontos de reposição que indicam o momento em que o pedido deve ser feito (Ballou, 2006). Comumente é utilizado softwares nesse método, como por exemplo a plataforma SAP. A utilização de um ponto de ressuprimento exige recursos e esforço para sua gestão, devido ao constante monitoramento dos estoques, sendo também necessário se proteger das variações de lead time. As fórmulas abaixo advêm do autor Tubino (2000), e foram utilizadas nesse trabalho:

$$
\begin{gathered}
\text { Demanda o período } L \rightarrow \mu_{L}=L x \mu_{x} \\
\text { Desvio padrão no periodo } L \rightarrow \sigma_{L}=\sigma_{x} x L^{0,5} \\
\text { Estoque de segurança } \rightarrow \mathrm{ES}=Z x \sigma_{L} \\
\text { Ponto de ressuprimento } \rightarrow \mathrm{R}=\mu_{L}+E S
\end{gathered}
$$

Onde:

$L$ representa o lead time de ressuprimento;

$\mu_{x}$ representa a demanda média total;

$\sigma_{x}$ representa o desvio padrão;

$Z$ representa o valor $z$-score da distribuição normal

\section{MÉTODO PROPOSTO}

Para o desenvolvimento deste trabalho, optouse pela pesquisa exploratória de natureza quantitativa e fundamentada em um estudo de caso. A coleta dos dados - quantitativos - foi realizada durante o mês de abril de 2018, por meio de pesquisa documental. Foi utilizando como fonte-base o ERP da empresa (SAP) e planilhas de dados arquivadas, seguindo $O$ critério de delimitação temporal de 2012 até 2018. Através desse procedimento foi possível realizar o levantamento do consumo de embalagens de uma unidade fabril da Votorantim Cimentos.

Os dados coletados possuem natureza discreta, e foram clusterizados em 150 períodos de 15 dias (coincidindo com o lead time de entrega das embalagens). Alguns custos fixos logísticos foram fornecidos pela empresa, tais como: custo do produto, custo do pedido e custo de guarda. Importante salientar que para fins de preservação do sigilo das informações de mercado da empresa, os dados apresentados nesse estudo foram multiplicados por uma variável aleatória, entretanto procurou-se manter a ordem de grandeza das quantidades reais praticadas pela fábrica.

\section{RESULTADOS}

A Votorantim Cimentos é líder no mercado brasileiro de cimento e uma das maiores empresas globais do setor, com capacidade produtiva de cimento de 52,8 milhões de toneladas/ano. Com sede no Brasil, está presente em mais 11 países nas Américas, na Europa, na África e na Ásia. Possui 12 mil empregados e possui um parque industrial composto por 33 fábricas completas de cimento e 18 moagens.

O lócus desse estudo é a Unidade sediada no município de Imbituba, em Santa Catarina. Essa unidade foi escolhida como planta-piloto para o Projeto Indústria 4.0. Essa decisão foi baseada em alguns fatores, como: histórico de boa performance; confiabilidade das informações relacionadas ao consumo e estoques de embalagens; abertura da gestão para a incorporação de novas tecnologias digitais. 
A fábrica utiliza somente dois tipos de embalagens ( $\mathrm{A}$ e B), ambas as embalagens comportam $50 \mathrm{Kg} . \mathrm{O}$ presente estudo será realizado apenas com o SKU A, pois este corresponde a $90 \%$ no volume de consumo da fábrica. A Unidade estudada possui capacidade para armazenar 500.000 embalagens de cimento,e não há restrições de lote mínimo no fornecimento de embalagens.

\subsection{IDENTIFICAÇÃO DO COMPORTAMENTO DO CONSUMO DE EMBALAGENS}

A partir do ano de 2015, a economia do país iniciava os primeiros passos em uma recessão que se estende até os dias atuais. 0 consumo de embalagens que de 2012 a 2014 mantinha em uma média de 280 mil unidades, decaiu a partir de 2015, até se estabilizar nos patamares médios de 97 mil (janeiro de 2017 a março de 2018), como pode ser observado na Figura 2.

Figura 2 - Consumo de embalagens de $50 \mathrm{~kg}$ - 150 períodos

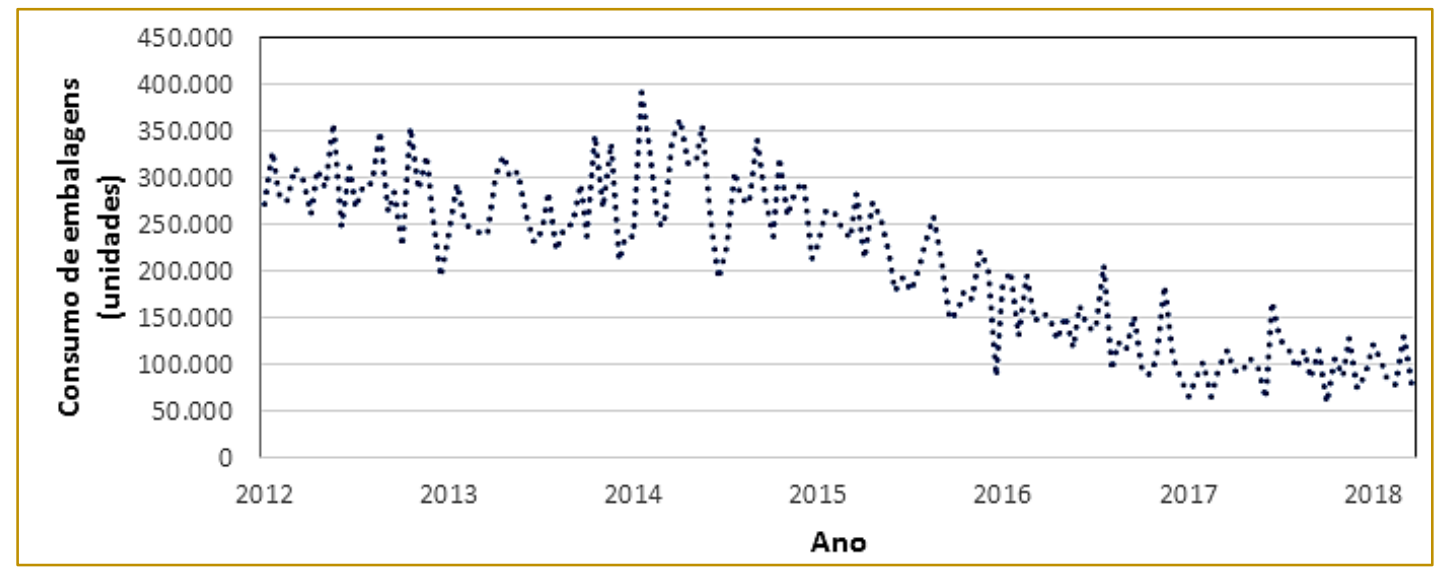

Fonte: Elaborado pelos autores

O consumo médio de embalagens calculado nos 150 períodos, entre 2012 a 2018, é de 210 mil unidades/período, com desvio padrão de 85 mil unidades e coeficiente de variação de $41 \%$. Foi realizada a mesma análise sobre os últimos trinta e seis períodos, observa-se menor variação no consumo de embalagens, cuja média foi calculada em 99,4mil unidades/período, e desvio padrão de 26 mil unidades com coeficiente de variação de $27 \%$. A Figura 3, a seguir, apresenta o gráfico do consumo de embalagens nos últimos 36 períodos.

Figura 3 - Consumo de embalagens de 50kg - Últimos 36 períodos

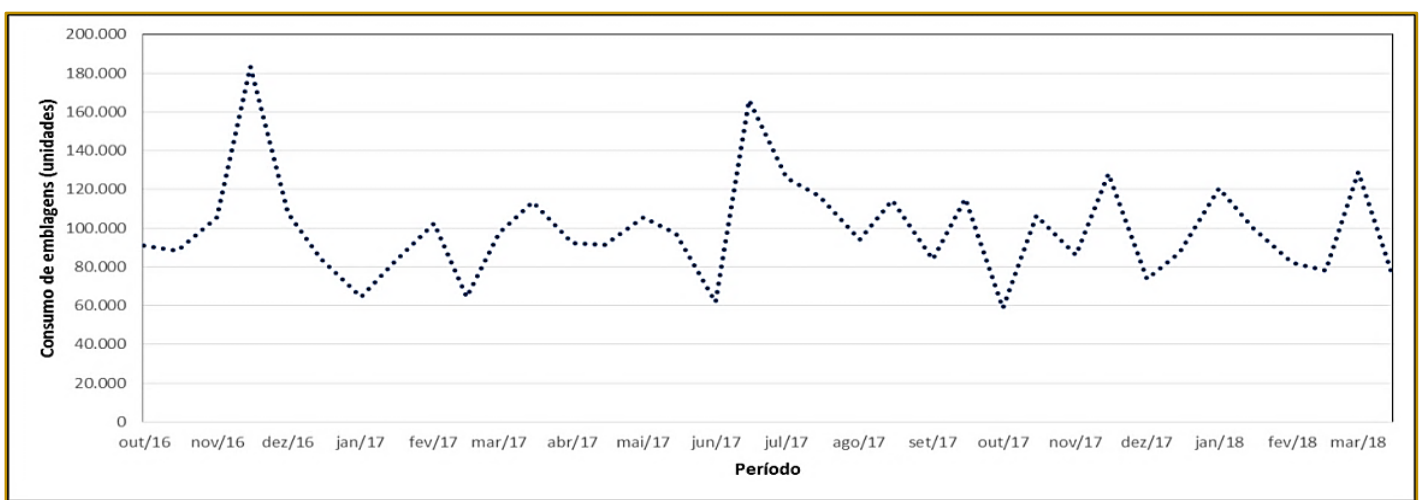

Fonte: Elaborado pelos autores 
A Figura 3 evidencia que, ainda que exista uma variabilidade acentuada com altos coeficientes de variação, o comportamento do consumo de embalagens não apresenta características ciclo-sazonais ou de tendências. Segundo os dados coletados, os picos de consumo dizem respeito contingências para atender mercados de outras unidades fabris da empresa.

A análise do comportamento do consumo de embalagens é um dos passos para alcançar os objetivos deste estudo, uma vez que o consumo de embalagens variável muito importante para a gestão dos estoques da empresa. A seção a seguir apresentará uma análise sobre o atual controle de estoques realizado pela empresa.

\subsection{ANÁLISE CRÍTICA DO CONTROLE DE ESTOQUE DE EMBALAGENS ATUAL}

A gestão do estoque de embalagens, atualmente, é realizada de forma empírica sem a definição de uma política de estoques definida. Não se tem definido um estoque de segurança ou ponto de ressuprimento. Diariamente, é realizado o inventário de estoque, e a partir desta informação, um profissional define se deve ou não realizar um novo pedido. O envio de pedido é feito através de e-mail, o lead time de recebimento do pedido é de 15 dias ( 1 período) com baixa variação observada no histórico do recebimento.

Com o objetivo de identificar qual o efeito da taxa de consumo de embalagens na quantidade de estoques de embalagens, foi elaborado um gráfico - Figura 4 -relacionando o estoque de embalagens com o consumo ao longo dos 150 períodos.

Figura 4 - Consumo versus estoque de embalagnes - 150 períodos

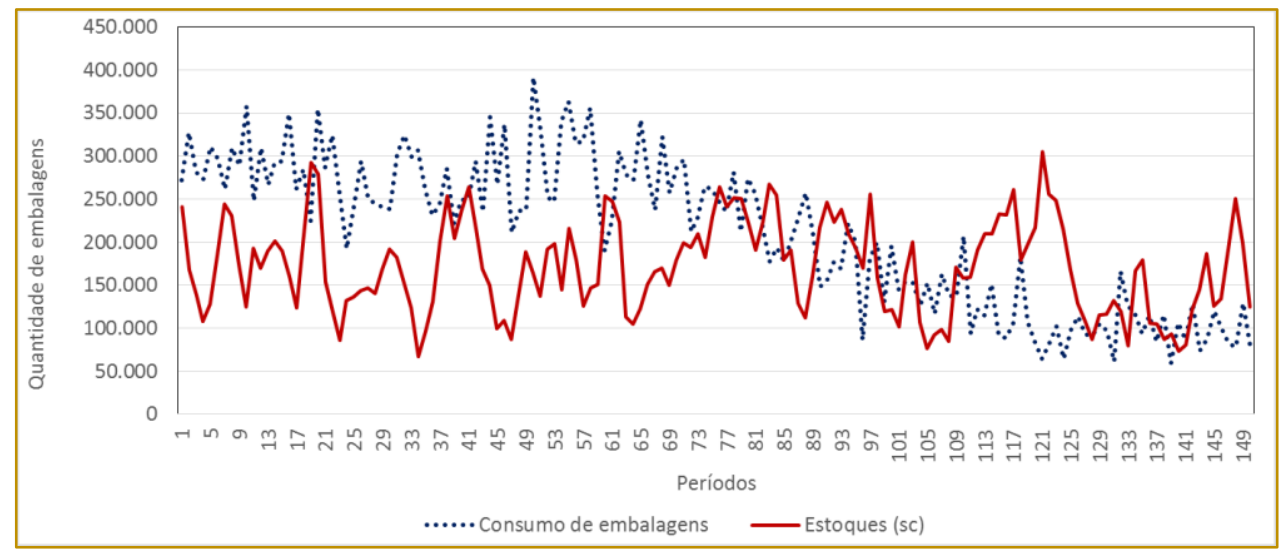

Fonte: Elaborado pelos autores

Observa-se que a redução do consumo de embalagens não impactou o estoque de embalagens, o que evidencia a ausência de uma política bem definida do controle de estoques de embalagens. Os valores de cobertura de estoque variam desde 0,2 até 4,7 períodos, com uma média de 1,6 períodos e desvio padrão de 1,0 período. A Figura 5 apresenta 0 estoque no período e 0 respectivo valor da cobertura de estoque. 
Figura 5 - Consumo de embalagens versus estoque de cobertura - 150 períodos

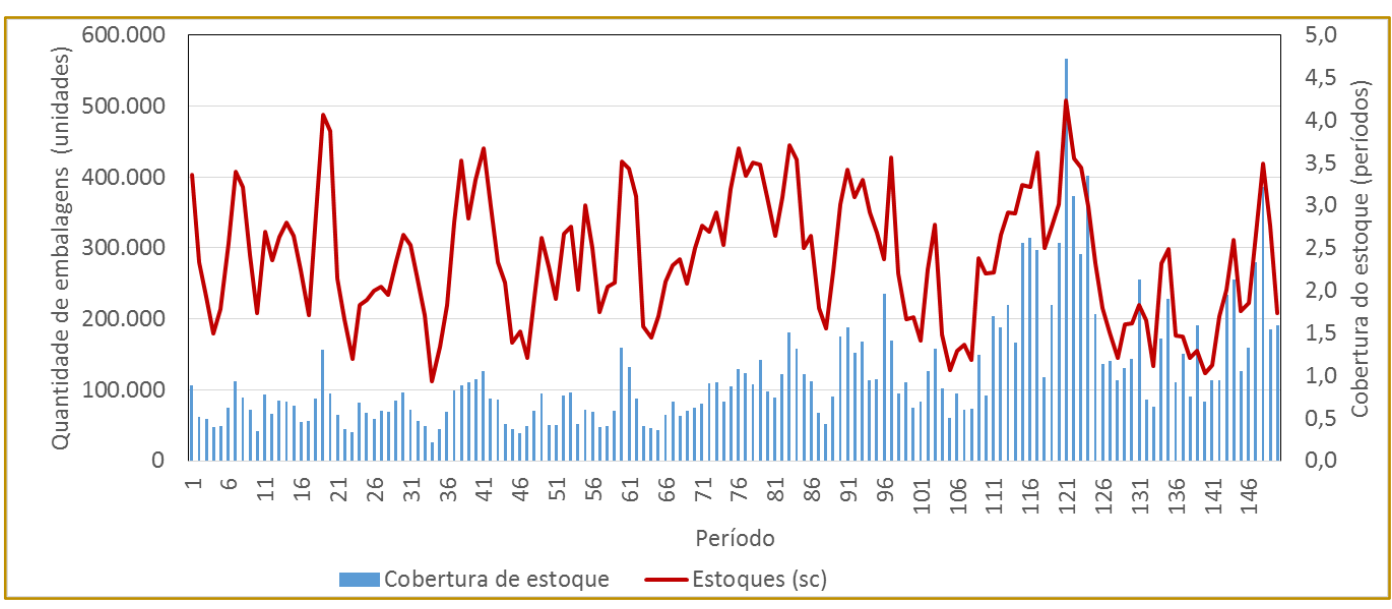

Fonte: Elaborado pelos autores

Observa-se na Figura 5 o incremento médio da cobertura de estoques a partir do período de redução do consumo. Conseqüência da falta de uma política de controles de estoques, a cobertura de estoque de planta oscila praticamente descontrolada incorrendo em riscos de escassez, quando há um incremento do consumo e causando um excesso de estoque de embalagens, quando há uma redução do consumo.

A estratégia voltada para o uso da tecnologia como apoio à operação, somada às elevadas quantidades observadas no histórico do consumo de embalagens, associados, ainda, ao alto nível de serviço definido pela empresa foram os motivadores da escolha do modelo de revisão contínua para definição da política de estoques, como será apresentado na seção a seguir.

\subsection{PROPOSTA DE POLÍTICA DE GESTÃO DE ESTOQUES DE EMBALAGENS}

Com o objetivo de desenvolver uma política para a gestão de estoque de matéria prima, este estudo propôs estabelecer dados parametrizados, por meio de um sistema de Revisão Contínua $(Q)$, ponto de reposição $(R)$ e estoque de segurança (ES).Para tanto, foi utilizado a fonte-base dos últimos 36 meses de consumo da embalagem SKU A, cuja média é de 99.442 unidades/período, com desvio padrão de 26.374 unidades, correspondendo, como supracitado, à um coeficiente de variação de $27 \%$.

Os custos fixos logísticos foram fornecidos pela empresa, como segue: custo do SKU A $(R \$ 0,33)$; custo do pedido ( $R \$ 31,82)$ e custo de guarda ( $R \$ 0,0015)$. O nível de serviço desejado é de $98 \%$. E o lead time de recebimento das embalagens é de 1 período. Com base nestas informações, foi possível calcular a lote ideal de compra $Q^{*}$, o ponto de ressuprimento $R$ e o estoque de segurança ES, apresentados na Tabela 1.

Tabela 1 - Parâmetros de estoques calculados

\begin{tabular}{|c|c|}
\hline \multicolumn{1}{|c|}{ Item } & Quantidade (embalagens) \\
\hline Lote ideal de compra $\left(\mathrm{Q}^{\star}\right)$ & 112.810 \\
\hline Estoque de segurança $(\mathrm{ES})$ & 54.165 \\
\hline Ponto de ressuprimento $(\mathrm{R})$ & 153.608 \\
\hline
\end{tabular}

Fonte: Elaborado pelos autores

De acordo com os dados calculados e apresentados na Tabela 1, o sistema de estoques ao alcançar a quantidade de 153.608 unidades, deverá emitir ao fornecedor de embalagens um pedido de 112.810 unidades.

Para validar o modelo proposto, a política de estoques foi simulada na demanda dos 
últimos 24 períodos. Os parâmetros de lote ideal de compra $\left(Q^{*}\right)$, estoque de segurança (ES) e ponto de ressuprimento (R) foram aplicados no consumo dos últimos 24 períodos e o resultado da simulação é apresentado no gráfico a seguir.

Figura 6 - Simulação da aplicação da política de estoques - 150 períodos

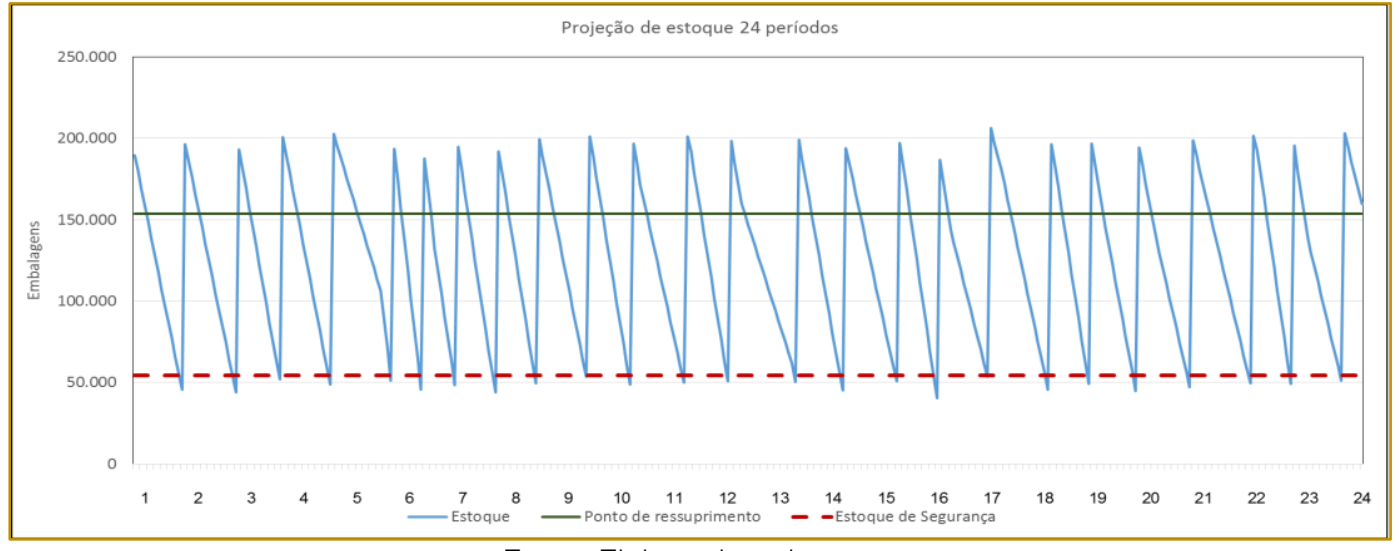

Fonte: Elaborado pelos autores

Observa-se que a política aplicada nos últimos 24 períodos regula o estoque de embalagens da fábrica, eliminando os riscos de escassez e as perdas causadas por excesso de estoque. Cabe ressaltar que o resultado da política está atrelado à baixa variabilidade do lead time de entrega das embalagens, observado no histórico de recebimento das embalagens na fábrica.

\section{CONCLUSÃO}

Enquanto a Indústria 4.0 permite $\mathrm{O}$ planejamento e controle em tempo real, o fluxo de informações e dados inseridos em rede demandam alta confiabilidade. $O$ presente estudo realizou uma proposta de política de estoques de embalagens, idealizando os primeiros passos para a

\section{REFERÊNCIAS}

[1] Ballou, Ronald H. - Gerenciamento da Cadeia de Suprimentos / Logística Empresarial / Ronald H. Ballou; Tradução Raul Rubenich. - 5aㅡ. Ed. - Porto Alegre: Bookman, 2006.

[2] Baena, Felipe et al. Learning Factory: The Path to Industry 4.0. Procedia Manufacturing, v. 9, p. 73-80, 2017

[3] Bauernhansl, Thomas; TEN Hompel, Michael; Vogel-Heuser, Birgit (Ed.). Industrie 4.0 in Produktion, Automatisierung und Logistik: Anwendung, Technologien und Migration. Wiesbaden: Springer Vieweg, 2014. integração e execução da nova estratégia de tecnologia visada pela empresa.

Com as definições claras do lote ideal de compra, estoque de segurança e do ponto de ressuprimento encontrados à luz da literatura, a proposta aporta as prerrogativas da redução da variabilidade da cobertura de estoques, assim como a redução do risco de escassez e desperdícios causados por excessos de estoques. Para este estudo no qual a empresa estuda apresenta-se em fase de transição para a Indústria 4.0, o uso da tecnologia na gestão dos estoques da empresa via plataforma SAP, assim como a segurança de baixa variação no lead time do fornecimento de embalagens, corroboram na decisão de optar pelo sistema de revisão contínua como política de gestão de estoques.

[4] Cheng C.; Guelfirat, T.; Messinger, C.; Schmitt, J.; Schnelte, M.; Weber, P. Semantic degrees for industrie 4.0 engineering: deciding on the degree of semantic formalization to select appropriate technologies. In: European Software Engineering Conference And The Acm Sigsoft

[5] Kagermann, Henning; Wahlster, Wolfgang; Helbig, Johannes. Recommendations for implementing the strategic initiative Industrie 4.0: Final report of the Industrie 4.0 Working Group. Frankfurt, Alemanha, 2013, 82p.

[6] Symposium On The Foundations Of Software Engineering, 10., 2015, Bergamo. Proceedings... Nova York: ACM New York, 2015. p.1010-1013. 
[7] Confederação Nacional da Indústria (CNI). Desafios para a indústria 4.0 no Brasil. Distrito Federal: Brasília, 2016.

[8] Hermann, M.; Pentek, T.; Otto, B. Design principles for industrie 4.0 scenarios: a literature review. In: Annual Hawaii International Conference on System Sciences, 49., 2016, Estados Unidos. Proceedings... Washington, DC: IEEE Computer Society, 2016. p. 3928-3937.

[9] Ohno, Taiichi. O sistema Toyota de produção além da produção. Bookman, 1997.

[10] PwC. Indústria 4.0: Digitização como vantagem competitiva no Brasil. 2016. Disponível em:

$<$ https://www.pwc.com.br/pt/publicacoes/servicos/ assets/consultorianegocios/2016/pwc-industry-4survey-16.pdf>. Acesso em: 21 mai. 2018

[11] Reddy, Guduru R. K.; Singh, Harpreet; Hariharan, S. Supply Chain Wide Transformation of
Traditional Industry to Industry 4.0. Journal of Engineering and Applied Sciences - Asian Research Publishing Network (ARPN). vol. 11, n. 18. Phagwara, India: 2016.

[12] Slack, Nigel et al. Administração da Produção. Atlas, São Paulo, 2009.

[13] Thoben, Klaus-Dieter; Wiesner, Stefan Alexander; Wuest, Thorsten. "Industrie 4.0" and Smart Manufacturing - a review of research issues and application examples. International Journal of Automation Technology, v. 11, n. 1, p. 4-17, 2017.

[14] Tubino, D. F. Planejamento e controle da produção: teoria e prática . Editora Atlas SA, 2000.

[15] Zhou, Keliang; LIU, Taigang; Zhou, Lifeng. Industry 4.0: Towards future industrial opportunities and challenges. In: 12th International Conference on Fuzzy Systems and Knowledge Discovery, 2015, Zhangjiajie, China. Anais... Zhangjiajie: IEEE Xplore, 2016. Disponível em: <http://ieeexplore.ieee.org/document/7382284>. Acesso em: 21 mai. 2018. 


\section{Capítulo 14}

\section{ANÁLISE DA SITUAÇ̃̃O ATUAL DO PROCESSO PRODUTIVO DE UMA PEQUENA EMPRESA: APLICAÇÕES DO MAPA DE FLUXO DE VALOR E INDICADORES DE DESEMPENHO}

\section{Paula Vasconcelos Stocco}

\section{Juliana Sayuri Kurumoto}

Resumo: O objetivo desta pesquisa é apresentar uma análise da situação atual do processo produtivo de uma pequena empresa metalúrgica que produz autoclaves, uma vez que a empresa busca melhorar a qualidade dos seus processos, diminuir a quantidade de retrabalhos externos e internos, além de minimizar os atrasos de entrega. O objetivo desta análise é identificar os principais pontos críticos do processo. Para isso foi utilizado o mapa de fluxo de valor e os indicadores de desempenho como ferramentas. Os conceitos de mapa de fluxo de valor e indicadores de desempenho foram esclarecidos em uma inicial revisão bibliográfica, seguida pela construção do mapa de fluxo de valor e da apresentação dos indicadores de desempenho relevantes neste contexto. Como principais resultados da análise do processo produtivo explicitou-se a necessidade de melhoria do lead time, da redução dos estoques intermediários e do tempo de troca de ferramentas. Notou-se também a efetividade da utilização das duas ferramentas, que mostraram, a princípio, ser complementares entre si.

Palavras-chave: Mapa de Fluxo de Valor; Indicadores; Produção Enxuta 


\section{INTRODUÇÃO}

$\mathrm{Na}$ década de 70, as empresas japonesas passaram a apresentar produtos de qualidade e confiabilidade superiores aos produtos americanos, iniciando um processo de evolução do controle da qualidade nos países do ocidente. Esta evolução ocorreu devido à preocupação em atender as expectativas do cliente mais do que buscar atender a especificações de produtos (CARPINETTI, 2012, p. 20).

A gestão da qualidade apresentou uma crescente importância desde então. O mercado passou a exigir produtos de maior qualidade, sem defeitos e com o preço baixo, o que impulsionou a procura por programas de qualidade, tais como a produção enxuta (CARPINETTI, 2012).

A produção enxuta tem como prioridade a eliminação de atividades no processo produtivo que não agregam valor ao produto (RAHANI; AL-ASHRAF, 2012). Uma das ferramentas utilizadas para esta análise é o mapa de fluxo de valor, que é aplicado para a visualização dos desperdícios no fluxo produtivo. O mapa permite ainda a criação de um processo no "estado futuro", que seria o obtido após melhorias serem aplicadas (ROTHER, SHOOK; 2003).

Utilizar o mapa de fluxo de valor é uma forma de mensurar os resultados organizacionais e diagnosticá-los. Para Popova e Sharpanskykh (2010), esta mensuração é importante para que a empresa seja capaz de tornar seus objetivos em realidade, e explica que uma forma comumente utilizada é por meio de indicadores de desempenho, que são um conjunto de medidas que medem aspectos atuais e que são importantes para o futuro da empresa (PARMENTER, 2007).

Tanto os indicadores quanto o mapa de fluxo de valor são ferramentas utilizadas para análise, e, nesta pesquisa, serão utilizadas em conjunto para análise do processo produtivo de uma empresa de pequeno porte do setor metalmecânico, que está buscando aumentar sua vantagem competitiva ao melhorar sua qualidade. Atualmente, a empresa apresenta valores de seus indicadores abaixo do esperado. Objetiva-se, com a utilização das duas ferramentas, o entendimento das falhas que ocorrem no processo produtivo e a visualização do reflexo das mesmas nos resultados da empresa.

\section{REVISÃO BIBLIOGRÁFICA}

\subsection{PRODUÇÃO ENXUTA}

Taiichi onhno, engenheiro da Toyota motor company, delineou completamente a produção enxuta em 1960, ao desenvolver um conjunto de práticas moldadas que são chamadas atualmente de filosofia enxuta. Esta filosofia pode ser entendida como a que visa eliminar desperdícios, tornando a produção mais rápida, com maior confiabilidade e que produz seus produtos com muita qualidade (slack; chambers; Johnston, 2009). Ohno (1997, p.17) afirma que a eliminação de desperdícios na produção pode levar ao aumento da eficiência produtiva, e, se observarmos o ambiente de trabalho e seus processos é possível notar muitos desperdícios envolvidos. Shingo (1996) determina que existem sete tipos de desperdícios, ou perdas, que podem ocorrer no processo. Estas são explicadas por slack, chambers e Johnston (2009, p. 456):

a) Superprodução, que consiste na produção de mais produtos do que o requerido pela demanda.

b) Tempo de espera, que pode ser medido pelo tempo e eficiência de máquina e mão de obra;

c) Transporte, representado pela movimentação de materiais pela fábrica;

d) Processamento, que são os processos produtivos que podem conter algumas operações que não agregam valor; entendidos como desperdícios da qualidade;

e) Estoque, que é entendido como algo que deve ser eliminado. Shingo (1996) explica também o estoque intermediário, que pode ser o lote completo que se mantém aguardando 0 lote precedente ser processado, inspecionado ou transportado. Outro caso ocorre quando peças de um mesmo lote se mantém aguardando outras serem processadas na linha de produção;

f) Movimentação, entendida como os movimentos desnecessários de um operador;

g) Produtos defeituosos, considerado um desperdício da qualidade.

A produção enxuta se tornou uma estratégia para muitas organizações, tornando-se um tema em ascensão, e passou a ser entendida como uma forma de obter melhores resultados nos processos de manufatura (GONCALES FILHO; CAMPOS, ASSUMPCAO, 
2016). De Abrantes (2012) otimizou a linha de produção de uma empresa a partir da aplicação da filosofia de manufatura enxuta e como resultado obteve redução do lead time, do estoque intermediário e melhorou a produtividade dos funcionários. Em números, Singh e Singh (2013) também aplicaram ferramentas lean e puderam obter $51,87 \%$ de redução no tempo de ciclo, $21,51 \%$ de redução no estoque intermediário e $25,88 \%$ de redução no lead time.

\subsection{MAPEAMENTO DE FLUXO DE VALOR}

O mapa de fluxo de valor é utilizado na filosofia enxuta para retratar o estado atual dos processos produtivos e visualizar o estado que se deseja alcançar, que seria o ideal. Este mapeamento permite englobar dois tipos de fluxos da manufatura, que são o fluxo de informações e de materiais (rother; shook, 2003).os autores ainda explicam que o mapa de fluxo de valor (mfv) é uma ferramenta essencial por permitir enxergar 0 fluxo produtivo, identificar e mapear as fontes de desperdício, formar a base de um plano de implementação, entre outros. Martin e osterling (2014) reforçam ao afirmar que o mfv permite a visualização de redundâncias, intervalos e uma visão abrangente de como o trabalho é realizado no fluxo.muitas aplicações da ferramenta (de queiroz; rentes; araújo, 2004; salgado et. Al 2009; bonatto et. Al 2014) têm se mostrado eficientes para melhorar processos. Bonatto et. Al (2014) analisaram o fluxo de valor de uma pequena empresa do setor moveleiro e, após propor melhorias, obteve redução de estoques intermediários, redução de custos com retrabalho e diminuiu o lead time do processo em 40,6\%. De Queiroz, rentes e Araújo (2004) conseguiram obter uma melhora de $77 \%$ no lead time após o mapa. Já salgado et. Al (2009) aplicou o mfv na área de serviços, para identificar desperdícios no processo de desenvolvimento de produtos. Após a utilização da ferramenta, os autores puderam identificar variados tipos de perdas, tais como retrabalho, tarefas interrompidas, pobre reutilização do conhecimento, entre outros.

Para a aplicação do mapa de fluxo de valor, os autores rother e shook (2003) definem as etapas conforme figura 1 :

Figura 1 - Passos do MFV

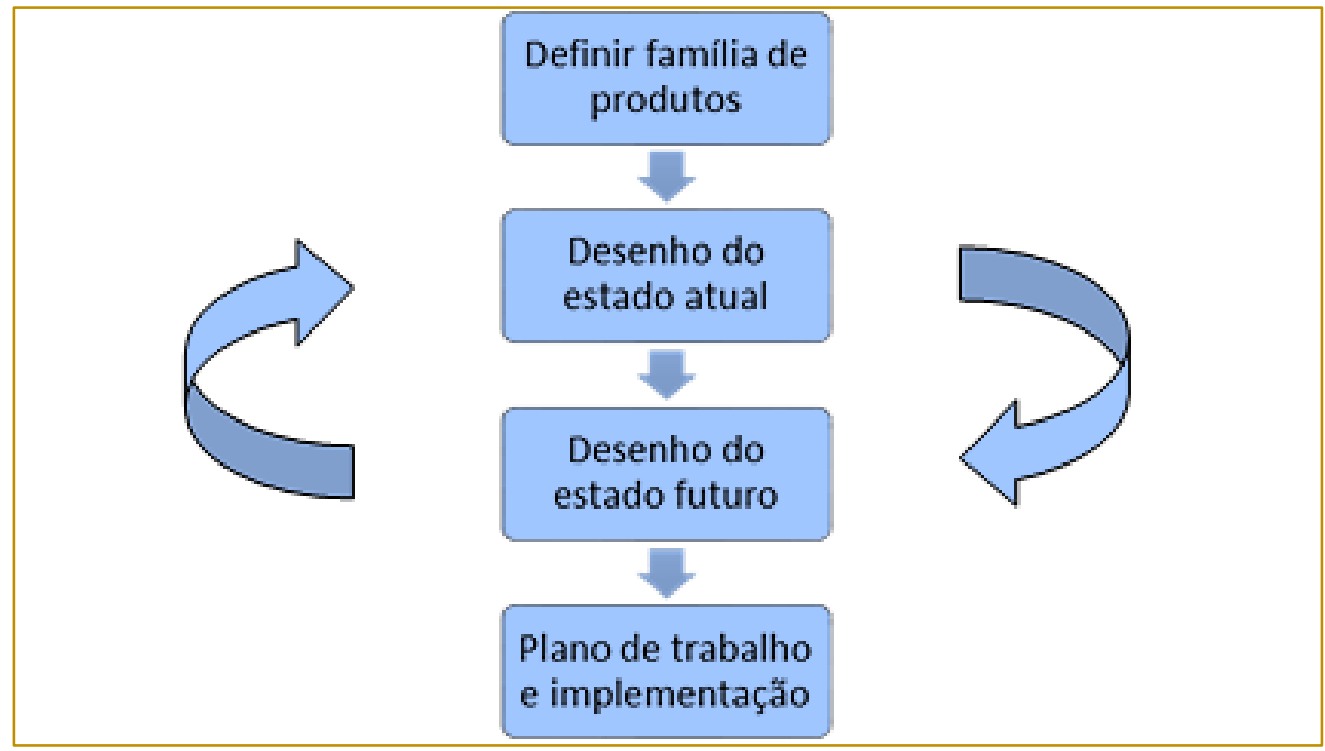

Fonte: Adaptado de Rother e Shook (2003)

Santos, Gohr e Dos Santos (2011) afirmam que o MFV é capaz de facilitar a implementação dos princípios da filosofia enxuta, como explicado também por Rother e Shook (2003), que concordam sobre a simbologia própria e procedimentos prédefinido do MFV. 


\subsection{CONCEITOS UTILIZADOS NO MAPA DE FLUXO DE VALOR}

Para elaborar o mapa do fluxo de valor é necessário compreender alguns conceitos como:

\section{a) Tempo de Ciclo}

Para Alvarez e Antunes Junior (2001), o tempo de ciclo é o tempo necessário para execução do trabalho em uma peça. Raj et.al (2016) define o tempo de ciclo como o tempo requerido para finalizar um produto, ou $\mathrm{O}$ tempo entre uma peça sair de um posto de trabalho para outro.

\section{b) Lead Time}

Marodin e Zawislak (2005) definem lead time como o tempo que uma peça leva para passar por todo o processo produtivo, de matéria-prima à entrega final ao cliente. Rother e Shook (2003) complementam ao afirmar que o Lead Time é o tempo que uma peça leva para se movimentar por todo um fluxo de valor.

\section{c) Takt-time}

Alvarez e Antunes Junior (2001) buscaram esclarecer o conceito de takt-time, minimizando as diferenças de definições da literatura. Os autores então propõem que takttime é "(...) tempo que rege o fluxo dos materiais em uma linha ou célula". Este tempo determina a frequência de produção de acordo com o volume de vendas, e produzir de acordo com o tempo takt requer eliminação de paradas de máquina não planejadas, eliminação de tempos de troca e resposta rápida para problemas (ROTHER; SHOOK, 2003).

\subsection{INDICADORES DE DESEMPENHO}

A gestão de uma organização, isto é, o conjunto de ações que ocorrem para direção e controle de uma empresa (MARANHÃO; MACIEIRA, 2015), acontece a partir da avaliação e medição de resultados, obtidos a partir da utilização de indicadores. Tung, Baird e Schoch (2011) explicam que um sistema para mensurar a performance, como os indicadores, garante que organizações possam clarear seus objetivos e operar de forma mais eficiente. Para Fernandes (2004, p.4), o resultado do indicador favorece a quantificação de um processo e permite a análise de desempenho.

Pesquisas apontam para a importância da análise de desempenho nas organizações e a necessidade de um sistema de medição de desempenho (MEYBODI, 2009; FULLERTON; WEMPE, 2009; TUNG; BAIRD; SCHOCH, 2011; NASCIMENTO et. al 2011). Para Meybodi (2009), as empresas que possuem sistemas produtivos baseados em Just-InTime, método inserido no contexto da produção enxuta, utilizam um mix balanceado de indicadores, que abordam tanto objetivos financeiros como também a inovação da empresa e agilidade.

Tung, Baird e Schoch (2011) elucidam que no âmbito de empresas que utilizam a produção enxuta, alguns exemplos de indicadores são: distância percorrida pelos operadores, porcentagem de eficiência do processo, porcentagem de atividades que agregam valor dentro de um processo, dentre outros.

\section{MÉTODO DE PESQUISA}

Do ponto de vista dos objetivos, a pesquisa é classificada como exploratória que tem o intuito de obter informações sobre os assuntos aqui tratados: mapa de fluxo de valor e indicadores de desempenho (PRODANOV; FREITAS, 2013). Quanto aos procedimentos técnicos foi utilizado a pesquisa bibliográfica e o estudo de caso. Este último foi realizado em uma empresa do setor metalmecânico do estado do Paraná.

A pesquisa seguiu os passos descritos da Figura 2, uma adaptação da orientação de Rother e Shook (2003): 
Figura 2 - Passos para a construção do MFV

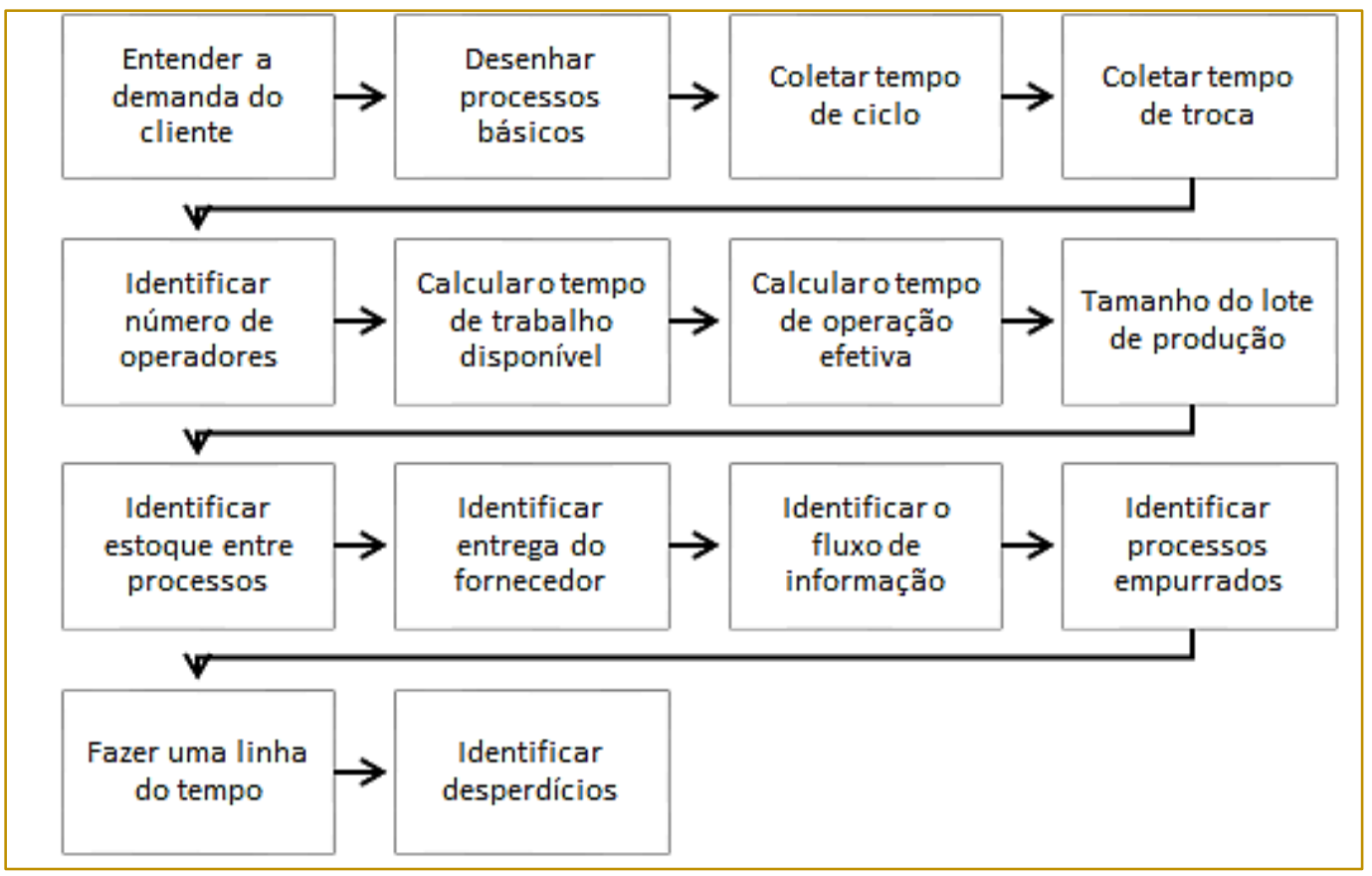

Fonte: Adaptado de Rother e Shook (2003)

Para a coleta de dados foi utilizada a observação, a cronoanálise e o sistema de indicadores da empresa. Após a construção do MFV foi realizada uma comparação entre as perdas percebidas por meio da interpretação do mesmo e os resultados insatisfatórios dos indicadores de desempenho em busca de uma conexão entre ambos e como a melhoria nos pontos indicados como críticos do processo podem refletir no desempenho dos indicadores.

\section{RESULTADOS}

\subsection{EMPRESA}

A empresa estudada atua no setor metalmecânico desde 1983, produzindo equipamentos em aço inox para os seguintes segmentos: cozinhas industriais, laboratórios, hospitais, entre outros. Trata-se de uma indústria de pequeno porte localizada no estado do Paraná, que fabrica principalmente autoclaves, aparelhos utilizados para esterilização.

A empresa apresenta preocupação com a qualidade dos processos, e a política de qualidade visa atender os requisitos e as normas, promovendo a melhoria contínua dos processos. Sua meta atualmente é reduzir os índices de defeitos e retrabalho, que vem afetando seu desempenho no mercado.

\subsection{MAPA DE ESTADO ATUAL}

Segundo os passos propostos por Rother e Shook (2003), que foram esclarecidos na Figura 2, para a criação do mapa de fluxo de valor, o primeiro passo é definir qual a família de produtos focada no mapa. As autoclaves produzidas pela empresa são constituídas de três partes principais: cuba tampa e base, que são unidas ao final do processo. A cuba é o item que mantém seu percentual de retrabalho mais alto, isto é, do total de itens retrabalhados por mês, as cubas possuem uma média de $56 \%$ de retrabalho em relação aos outros itens.

Durante os meses de fevereiro a junho de 2016, foram coletados os dados das demandas mensais de cubas, concluindo uma demanda média mensal de 1021 cubas. Foi realizado um mapeamento completo da cadeia produtiva, seguido pela medição do tempo de ciclo, coletado por meio da observação dos processos individuais. $\mathrm{Na}$ Figura 3 apresenta-se os tempos de ciclo finais determinados para cada setor. 
Figura 3 - Tempos de ciclo dos processos

\begin{tabular}{|c|c|}
\hline Setor & $\begin{array}{c}\text { Tempo de } \\
\text { ciclo (s) }\end{array}$ \\
\hline \hline Calandra & 80 \\
\hline Solda & 334 \\
\hline Estampa & 97 \\
\hline Solda & 497 \\
\hline Acabamento & 996 \\
\hline Inspeção & 114 \\
\hline Expedição & 900 \\
\hline Takt - Time & 3018 \\
\hline
\end{tabular}

Fonte: Autoras

Outro tempo aferido foi o tempo de troca de ferramentas, no entanto, a maioria das operações não realiza troca de ferramentas entre os processos, ou há máquinas que possuem duas unidades de tamanhos diferentes, para cubas maiores ou menores.
Assim, muitos tempos de troca se mantiveram zerados.

Sobre o número de operadores, a Figura 4 esclarece os envolvidos nas operações de cada setor.

Figura 4 - Número de operadores envolvidos nos processos

\begin{tabular}{|c|c|}
\hline Setor & $\begin{array}{c}\mathbf{N}^{\mathbf{0}} \text { de } \\
\text { operadores }\end{array}$ \\
\hline \hline Calandra & 1 \\
\hline Solda & 3 \\
\hline Estampa & 1 \\
\hline Solda & 2 \\
\hline Acabamento & 8 \\
\hline Inspeção & 1 \\
\hline
\end{tabular}

Fonte: Autoras

Depois, calculou-se o tempo total disponível por dia, que totaliza 8 horas $(28800$ segundos). Com isso, verificou-se o tempo de operação efetiva, considerando todos os tempos que envolvem atividades que não são diretamente ligadas à produção, mas que acontecem diariamente. Por exemplo, a manutenção preventiva, que nem todos os processos possuem, mas muitos apresentam intervalos diários para realizá-la. A Figura 5 apresenta todo o cálculo realizado para definição do tempo de operação efetiva dos processos. 
Figura 5 - Cálculo do tempo de operação efetiva

\begin{tabular}{|c|c|c|c|c|c|c|c|}
\hline Setor & Ope rações & $\begin{array}{c}\text { Tempo Total } \\
\text { (s) }\end{array}$ & $\begin{array}{l}\text { Tempo de Troca de } \\
\text { Ferramentas (s) }\end{array}$ & $\begin{array}{c}\text { Tempo de } \\
\text { Manutenção } \\
\text { Preventiva (s) }\end{array}$ & Total (s) & Disponibilida de \% & $\begin{array}{l}\text { Disponibilidade } \\
\text { média (\%) }\end{array}$ \\
\hline \multirow{3}{*}{ Calandra } & Limpar Blank & 28800 & 0 & 0 & 28800 & $100 \%$ & \multirow{3}{*}{$100 \%$} \\
\hline & Virar borda do Blank & 28800 & 180 & 0 & 28620 & $99 \%$ & \\
\hline & Calandrar Blank & 28800 & 180 & 0 & 28620 & $99 \%$ & \\
\hline \multirow{5}{*}{ Solda } & Pontear Blank & 28800 & 0 & 300 & 28500 & $99 \%$ & \multirow{5}{*}{$100 \%$} \\
\hline & Limpar interior do cilindro & 28800 & 0 & 0 & 28800 & $100 \%$ & \\
\hline & Cordear cilindro & 28800 & 0 & 300 & 28500 & $99 \%$ & \\
\hline & Lixar solda & 28800 & 0 & 0 & 28800 & $100 \%$ & \\
\hline & Aplicar gel decapante & 28800 & 0 & 0 & 28800 & $100 \%$ & \\
\hline Estampa & Prensar borda & 28800 & 2400 & 3600 & 22800 & $79 \%$ & $79 \%$ \\
\hline \multirow{2}{*}{ Solda } & Soldar fiundo no cilindro & 28800 & 0 & 2400 & 26400 & $92 \%$ & \multirow{2}{*}{$95 \%$} \\
\hline & Soldar porcas na Cuba & 28800 & 0 & 300 & 28500 & $99 \%$ & \\
\hline \multirow{8}{*}{ Acabamento } & Testar Cuba & 28800 & 0 & 0 & 28800 & $100 \%$ & \multirow{8}{*}{$98 \%$} \\
\hline & Lixar borda da Cuba & 28800 & 0 & 900 & 27900 & $97 \%$ & \\
\hline & Polir borda da Cuba & 28800 & 0 & 900 & 27900 & $97 \%$ & \\
\hline & Lixar cordão interior da Cuba & 28800 & 0 & 900 & 27900 & $97 \%$ & \\
\hline & Polir cordão interior da Cuba & 28800 & 0 & 900 & 27900 & $97 \%$ & \\
\hline & Polir interior da Cuba & 28800 & 0 & 900 & 27900 & $97 \%$ & \\
\hline & Lustrar interior da Cuba & 28800 & 0 & 900 & 27900 & $97 \%$ & \\
\hline & Lavar Cuba & 28800 & 0 & 0 & 28800 & $100 \%$ & \\
\hline Inspeção & Inspeção da Cuba & 28800 & 0 & 0 & 28800 & $100 \%$ & $100 \%$ \\
\hline
\end{tabular}

Fonte: Autoras

O tamanho do lote de produção foi definido como de uma semana, que é o tempo que as cubas demoram para completar todo seu ciclo produtivo até a inspeção. Entre os processos, identificou-se estoques intermediários, dentre eles: matéria-prima no almoxarifado, entre a solda e a estampa e na inspeção. Por fim, as cubas à espera da expedição ficam estocadas por cerca de quinze dias, aguardando o final da produção do restante das cubas requisitadas pelo pedido do cliente.

A entrega do fornecedor foi identificada, assim como o fluxo de informação nos processos desde o pedido do cliente. Os processos empurrados e os desperdícios foram visualizados, e então, com todos os dados aferidos e identificados, foi desenvolvida uma linha do tempo com as informações. Como resultado, obteve-se um Lead Time de 25 dias, em comparação com
2118 segundos, isto é, aproximadamente 35 horas de processamento. Após todos os passos de criação do mapa de fluxo de valor serem concluídos, o mapa pode ser visualizado no Anexo 1.

\subsection{INDICADORES DE DESEMPENHO}

A empresa conta com alguns indicadores de desempenho relevantes para a avaliação da qualidade da prestação de serviços, sendo, por exemplo, o indicador de retrabalho e mensuração do índice de atraso de entrega.

a) Indicador de retrabalho mensal

Este indicador, visto na Figura 6, quantifica a quantidade de cubas que foram retrabalhadas em relação ao número total de cubas que foram produzidas em determinado mês. 
Figura 6 - Indicador de retrabalho das cubas

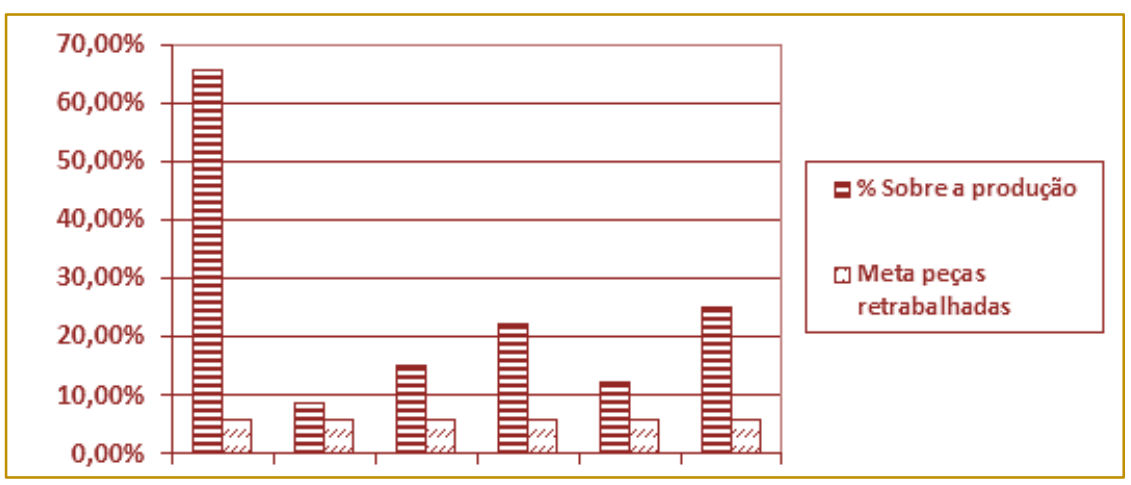

Fonte: Autoras

É possível notar que a meta de $6 \%$ de retrabalho da produção total não foi atingida em nenhum dos meses, mantendo uma média de $25 \%$ de retrabalho sob a quantidade de cubas produzidas.

a) Indicador de atraso de entrega
A fim de mensurar o atraso de entrega das cubas para o cliente, este indicador mensura a quantidade de peças pendentes para entrega em relação à demanda total do mês, como visto na Figura 7.

Figura 7 - Indicador de atraso de entrega

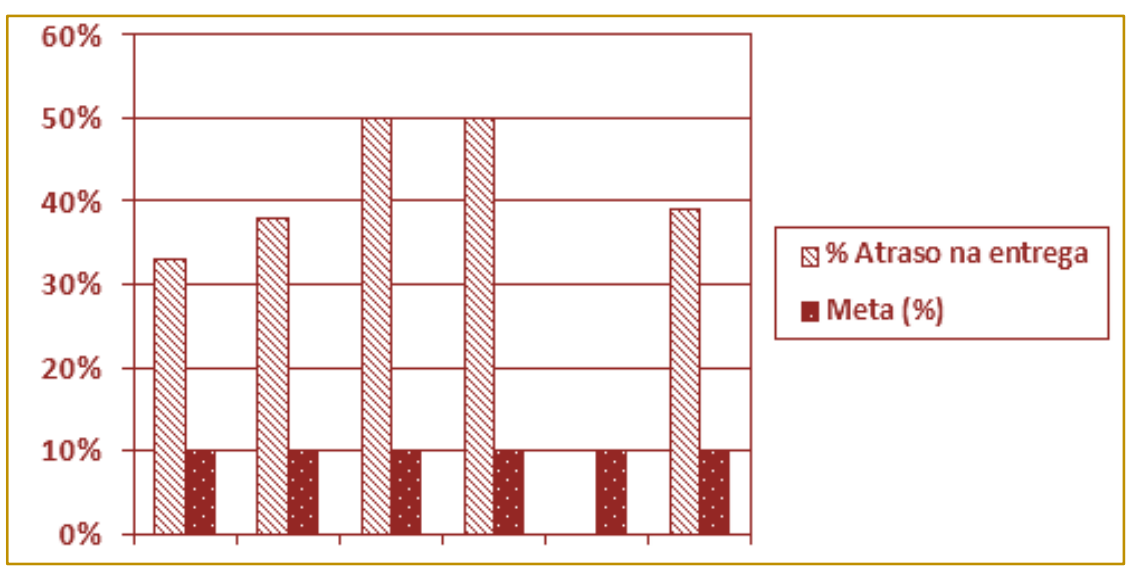

Fonte: Autoras

Nota-se que na maioria dos meses apresentados houve atraso de ao menos 30\% da quantidade total que deveria ser entregue ao cliente. Em maio houve cumprimento da demanda, pois também houve uma diminuição da mesma.

b) Indicador de riscos nas cubas

Quando as cubas chegam ao final do processo, é realizada uma inspeção para certificar-se que não há nenhuma falha na peça, requerendo retrabalho. Quando há algo não conforme com o produto, ou algum defeito, a cuba retorna para o processo produtivo para conserto e a causa é contabilizada. De todas as cubas retrabalhadas, a maior causa incide nas cubas riscadas, como é possível visualizar no indicador mostrado na Figura 8. 
Figura 8 - Indicador de risco nas cubas

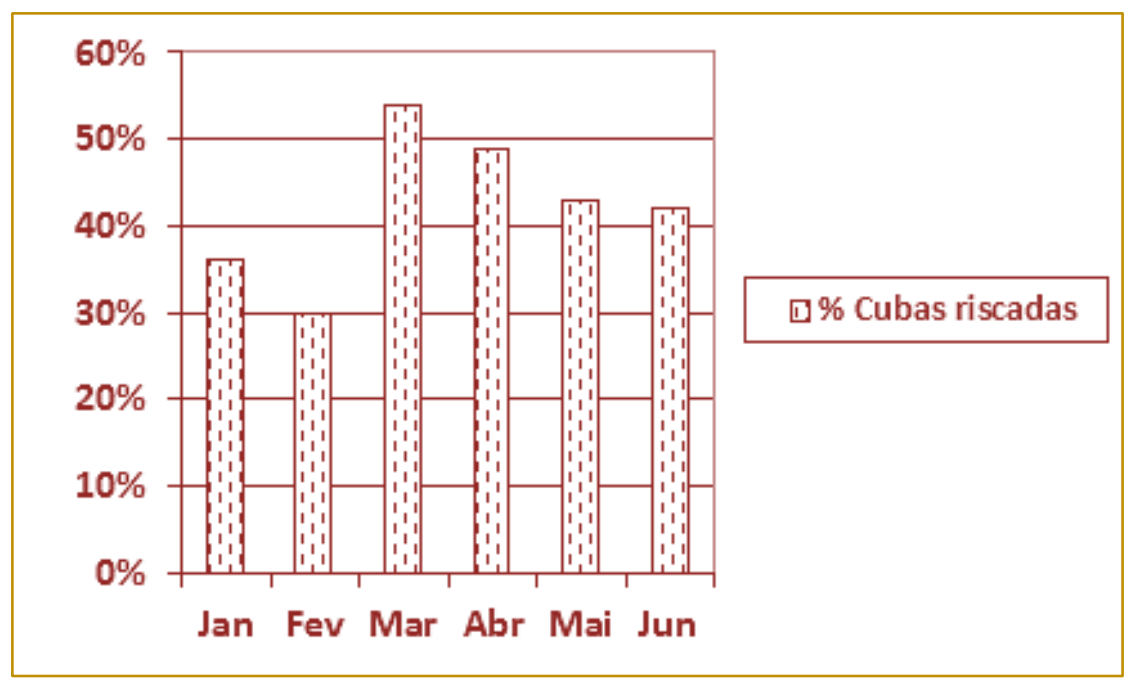

Fonte: Autoras

Os riscos nas cubas mostram-se uma causa comum do retrabalho interno, representando uma média mensal de $42 \%$ entre janeiro a junho de 2016.

\section{CONCLUSÕ̃S}

O objetivo da pesquisa foi analisar a situação atual do processo produtivo de uma pequena empresa, que precisa melhorar a qualidade dos seus produtos e satisfação dos clientes. Para tanto, utilizou-se o mapa de fluxo de valor e os indicadores de desempenho como ferramentas de análise.

O Mapa de Fluxo de Valor apresentou-se como uma ferramenta capaz de obter informações de todos os processos envolvidos na produção do produto, inclusive desde o setor administrativo. Com ele, foi possível visualizar de forma clara e quantitativa as condições atuais do processo e as falhas que eram passíveis de ocorrer.

O resultado do mapa, assim como o processo de criação do mesmo levam à percepção de várias oportunidades de melhoria. Refletindo acerca da coleta de tempos de ciclo, nota-se que há um desbalanceamento da produção, isto é, existe significativa variação no tempo dos processos e os mesmos não possuem proximidade entre si. Isto pode ser o principal motivo para a formação de estoques intermediários, visto que o desalinhamento dos processos faz com que os mesmos trabalhem em velocidades diferentes, produzindo em quantidades diferentes por determinado tempo, como por exemplo o tempo de ciclo de 334s no processo de solda para 97s no processo de estampa.

A formação de estoques intermediários pode estar relacionada à média de $25 \%$ de cubas retrabalhadas ao mês do indicador de retrabalho mensal. As cubas são produtos delicados e podem ser riscadas e amassadas com muita facilidade. Um armazenamento inadequado das mesmas nestes estoques intermediários, assim como no estoque final, pode refletir em falhas e defeitos que requerem retrabalho.

Os indicadores, por sua vez, ao serem analisados de forma isolada, apresentavam resultados negativos em relação à atrasos e retrabalho, sendo notável a necessidade da aplicação de melhorias nos processos. O MFV unido aos indicadores serviu como uma ferramenta de análise de causas, em que apresentou as possíveis razões para que os resultados dos indicadores ocorressem. Os indicadores contribuem para o MFV ao serem capazes de priorizar os pontos de melhoria, uma vez que o mapa proporciona a visualização de muitas falhas, e os indicadores registram aqueles que são mais urgentes para receberem atenção.

Por meio dos dados obtidos das duas ferramentas, conclui-se que o processo apresenta ao menos três dos sete desperdícios definidos por Shingo (1996), sendo eles: tempo de espera, estoque e produtos defeituosos. O MFV pôde mostrar o desbalanceamento da produção, e o takt time, que se mostra muito além do que 
deveria ser para atender a demanda, refletindo no indicador de atraso de entrega.

Os próximos passos desta pesquisa seriam a criação do mapa de fluxo de valor futuro e aplicação de melhorias no processo

\section{REFERÊNCIAS}

[1] Alvarez, Roberto dos Reis; Antunes Junior, José Antonio Valle. Takt-Time: Conceitos E Contextualização Dentro Do Sistema Toyota De Produção. Gestão e Produção, São Carlos, v. 8, n. 1, p.1-18, abr. 2001

[2] Bonatto, Franciele et al. Mapeamento do fluxo de valor: Um estudo de caso em uma indústria moveleira. Revista Espacios, v. 35, n. 7 , p.1-16, jun. 2014

[3] Carpinetti, Luiz Cesar Ribeiro. Gestão da Qualidade: Conceitos e Técnicas. São Paulo: Atlas, 2012. 239 p.

[4] DE Abrantes, Rafael Santiago. Optimização de uma linha de produção aplicando a metodologia Lean. 2012. Dissertação de Mestrado. Universidade de Aveiro.

[5] DE Queiroz, José Antonio; Rentes, Antonio Freitas; de Araujo, Cesar Augusto Campos. Transformação enxuta: aplicação do mapeamento do fluxo de valor em uma situação real. 2004. Disponível em:

http://www.hominiss.com.br/es/img/usr/tesesartigos/Transformacao_enxuta_aplicacao_do_mape amento.pdf. Acesso em: 8 jul. 2017

[6] Fernandes, Djair Roberto. Uma contribuição sobre a construção de indicadores e sua importância para a gestão empresarial. Revista FAE, Curitiba, v. 7, n. 1, p.1-18, jan. 2004.

[7] Fullerton, Rosemary R.; WEMPE, William F. Lean manufacturing, non-financial performance measures, and financial performance. International Journal of Operations \& Production Management, v. 29, n. 3, p. 214-240, 2009.

[8] Goncales Filho, Manoel; Campos, Fernando Celso de; Assumpcao, Maria Rita Pontes. Revisão sistemática da literatura com análise bibliométrica sobre estratégia e Manufatura Enxuta em segmentos da indústria. Gest. Prod., São Carlos, v. 23, n. 2, p. 408-418, June 2016.

[9] Maranhão, Mauriti; Macieira, Maria Elisa Bastos. Os Indicadores Nossos de Cada Dia: Avaliação Quantitativa do Desempenho Organizacional. São Paulo: Editora Baraúna, 2015.

[10] Marodin, Giuliano; Zawislak, Paulo. Mapeamento do fluxo de valor em empresa madeireira. XII Simpósio de Engenharia de Produção (SIMPEP). Bauru, São Paulo, Brasil, v. 7, 2005 produtivo. Após as melhorias aplicadas seria possível confirmar a relação do MFV como ferramenta de causa para os indicadores de desempenho do processo (retrabalho e atraso de entrega), caso as melhorias refletissem positivamente nos resultados dos indicadores.

[11] Martin, Karen; Osterling, Mike. Value Stream Mapping: How to Visualize Work and Align Leadership for Organizational Transformation. United States: McGraw-Hill, 2014.

[12] Meybodi, Mohammad Z. Benchmarking performance measures in traditional and just-intime companies. Benchmarking: An International Journal, v. 16, n. 1, p. 88-102, 2009.

[13] OHNO, Taiichi. O Sistema Toyota de Produção: além da produção em larga escala. Porto Alegre: Bookman, 1997. $131 \mathrm{p}$

[14] Parmenter, David. Key performance indicators: developing, implementing and using winning KPIs. New Jersey: John Wiley \& Sons,2007. $236 \mathrm{p}$.

[15] Popova, Viara; Sharpanskykh, Alexei. Modeling organizational performance indicators. Information systems, v. 35, n. 4, p. 505-527, 2010.

[16] Prodanov, Cleber Cristiano; Freitas, Ernani Cesar de. Metodologia do Trabalho Científico: Métodos e Técnicas de Pesquisa e do Trabalho Acadêmico. 2. ed. Novo Hamburgo: Universidade Feevale, 2013.

[17] Rahani, A. R.; AL-Ashraf, Muhammad. Production flow analysis through value stream mapping: a lean manufacturing process case study. Procedia Engineering, v. 41, p. 1727-1734, 2012.

[18] RAJ, AS Vishnu et al. Optimization of Cycle Time in an Assembly Line Balancing Problem. Procedia Technology, v. 25, p. 1146-1153, 2016.

[19] Rother, Mike; Shook, John. Aprendendo a enxergar: mapeando o fluxo de valor para agregar valor e eliminar o desperdício. São Paulo: Lean Institute Brasil, 2003. 102 p.

[20] Salgado, Eduardo Gomes et al. Análise da aplicação do mapeamento do fluxo de valor na identificação de desperdícios do processo de desenvolvimento de produtos. Gestão \& Produção, v. 16, n. 3, p. 344-356, 2009.

[21] Santos, Luciano Costa; Gohr, Cláudia Fabiana; dos Santos, Eder Jonis. Aplicação do mapeamento do fluxo de valor para a implantação da produção enxuta na fabricação de fios de cobre. Revista Gestão Industrial, v. 7, n. 4, 2011.

[22] SHINGO, Shingeo. O Sistema Toyota de Produção: Do Ponto de Vista da Engenharia de Produção.Porto Alegre: Bookman, 1996. 
[23] SINGH, Harwinder; SINGH, Amandeep. Application of lean manufacturing using value stream mapping in an auto-parts manufacturing unit. Journal of Advances in Management Research, v. 10, n. 1, p. 72-84, 2013.

[24] Slack, Nigel; Chambers, Stuart; Johnston, Robert. Administração da Produção. São Paulo: Atlas, 2009. $703 \mathrm{p}$.
[25] Tung, Amy; Baird, Kevin; Schoch, Herbert $P$. Factors influencing the effectiveness of performance measurement systems. International Journal of Operations \& Production Management, v. 31, n. 12, p. 1287-1310, 2011. 
ANEXO

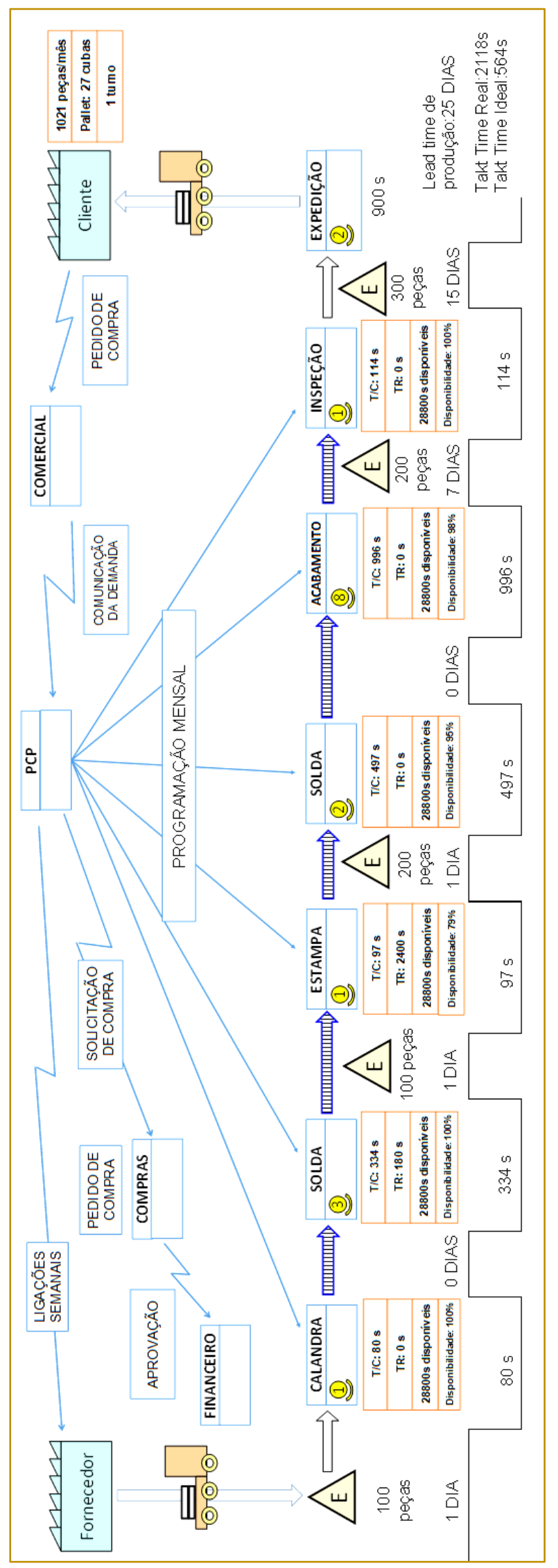




\section{Capítulo 15}

\section{APLICAÇÃO DA TÉCNICA FAHP EM PROCESSOS LEAN PARA AVALIAR O GRAU DE TOMADA DE DECISÃO}

Wagner Pietrobelli Bueno

Eduardo da Silva Fernandes

Guilherme Benitez.

Bruna Dones Gayer

Arthur Marcon

Érico Marcon

Resumo: O objetivo da pesquisa centralizou as atenções no setor manufatureiro, no qual se buscou estruturar hierarquicamente uma abordagem sobre o grau em tomada de decisão no âmbito organizacional, facilitando assim, a aplicabilidade enxuta Lean. Assim, a proposta transcorreu com o auxilio analítico da ferramenta matemática Fuzzy - Analytic Hierarchy Process (FAHP). Como entrada de dados utilizou-se das matrizes paritárias e individuais entre três gestores (nível estratégico) e nove supervisores especialistas (nível operacional) em produção utilizando técnicas de aplicação de questionário individual e grupo focal respectivamente. As respostas foram coletadas por meio da aplicação categórica, no qual o papel de moderador foi realizado pelo próprio pesquisador, com seis constructos e 33 subconstructos em três empresas de ramos diferentes, mas com características do setor manufatureiras fortemente relacionadas. Dessa forma, como metodologia de pesquisa a abordagem utilizada foi multicaso, considerando-a de formato qualitativa e quantitativa. Como respostas sobre as operações e processos das indústrias no âmbito atual, após realizar a deffuzificação de análise FAHP os valores que obtiveram maior grau de importância foram o constructo gestão (23\%); capacidade (22\%) e custos (20\%). Conclui-se que, para filosofias Lean, estes três fatores engajados impactam em um grau de 65\% nas decisões geradas nas três organizações estudadas neste modelo.

Palavras chave: FAHP, Lean, Processos, Produção. 


\section{INTRODUÇÃO}

A interação entre produção limpa e consumos ambientalmente sustentáveis é um campo fértil de pesquisa que tem avançado constantemente no meio empresarial. Ser sustentável economicamente por meio de uma produção mais limpa é um conceito que muitos gestores buscam para suas organizações atualmente (MANZINI; VEZZOLI, 2011; YONG et al., 2016). Assim, considerar a matéria prima como desenvolvimento sustentável deixou de ser um viés único nos sistemas produtivos. Muitas organizações caminham para combinações no qual, práticas de serviços sustentáveis, ou seja, as sistemáticas dos processos são tão significativas quanto ao produto em transformação (SILVESTRE; SILVA NETO, 2014; VAN HOOF; LYON, 2013; YONG et al., 2016).

Nesse contexto, a intensificação da industrialização global, a magnitude como a população consome matéria-prima, faz com que especialistas relacionados a teorias e práticas sustentáveis reflitam em como melhorar um ambiente que tem uma forte demanda em produtos e serviços com fatores ambientais e sociais propensos a serem mais rentáveis de maneira econômica (TSENG; LIN; CHIU, 2009).

É nesse sentido, que métodos relacionados à produção mais limpa (PmaisL) e práticas de gestão ambiental (PGA), são considerados eficientes para redução e eficiência dos processos especificamente na geração de resíduos industriais. Estes termos PmaisL e PGA contribuem significativamente para inovações sustentáveis de processos, produtos e serviços, correspondente a usos de recursos naturais e minimização de resíduos gerados (GUIMARÃES; SEVERO; VASCONCELOS, 2017).

Compreende-se que, há muitos trabalhos relacionados à PmaisL e $P G A$ na literatura com distintas abordagens e técnicas consolidadas. Sendo assim, a principal contribuição científica deste artigo tem como base a replicação e melhoria do método utilizado pelos autores Tseng, Lin e Chiu (2009) intitulado "fuzzy ahp-based of cleaner production implementation in Taiwan PWB manufacturer" que utilizou critérios para avaliar a tomada de decisão de PmaisL no setor manufatureiro como um estudo de caso. As questões que motivaram a realizar este artigo provêm da interpretação identificar a percepção de especialistas (teóricos e práticos) quanto aos critérios e conceitos de prioridade em produção mais limpa no caráter industrial.

Outra questão que será avaliada no artigo é o modelo que melhor define a construção destes conceitos na produção mais limpa. É nesse sentido, que o objetivo do artigo, em suma, é propor um framework de PmaisL e PGA aos gestores por meio de metodologias multicriteriais.

Partindo disso, o presente artigo possui uma metodologia baseada em cálculos multicriteriais Fuzzy-Analytic Hierarchy Process (FAHP) com o propósito de sugerir 3 modelos com critérios sustentáveis para produção mais limpa. Avaliar obtendo assim, modelo A, modelo, B e modelo C. Para identificar qual melhor alternativa entre os modelos, foi aplicado o método de Fuzzy Sets. Com o auxílio desse método, pode-se o obter por meio de simulações e comparações de cenários, definindo qual o modelo que resultaria em uma melhor tomada de decisão para aplicação de estágios em gestão ambiental condizente com as respostas de especialistas teóricos e com know-how utilizando as técnicas ambientais de modo prático.

Desse modo, a projeção dos resultados esperados é fazer com que os modelos encontrados sejam praticáveis, resultando em indicadores capaz de ajudar as equipes e responsáveis na construção e desenvolvimento de produção mais limpa nas organizações. $\bigcirc$ modelo proposto final poderá oferecer de modo multicriterial quais decisões deverão ser tomadas para fornecer um padrão adequado aos gestores na implementação de PmaisL e PGA.

\section{REFERENCIAL}

\subsection{ORGANIZAÇÕES E SUSTENTABILIDADE}

As questões ambientais passaram a ser um dever e uma preocupação da sociedade, empresas e pessoas que são afetadas pelas atividades industriais no meio ambiente. No caso em especial das empresas, um dos motivos que faz com que estas adotem políticas ambientais em suas operações e estratégias é uma possível melhora de imagem para assim gerar mais oportunidades de negócios (TANNURI; BELLEN, 2014). 
No entanto, fazer mudanças de hábitos em organizações em atividade é complexo, pois muitas vezes esbarra em questões culturais (BRITO; BRUNSTEIN; AMARO, 2014). Cabe à direção da empresa, propor e rever fatores que possam envolver toda a equipe e, trazer retornos à empresa e cliente com base em melhorias de gestão ambiental (MOURA 2011).

Assim, partindo do conceito de sustentabilidade, a norma ISO 14001, que atualmente é fundamental para que as empresas brasileiras almejem o mercado internacional (POMBO e MAGRINI, 2008), define que uma organização precisa estabelecer fundamentações capazes de identificar suas atividades ambientais, quanto a processos, produtos e serviços prestados (Zhang et al., 2016). Assim, tais aspectos contribuem para ações socioambientais, sendo que de algum modo, se tenha influência no que está sendo produzido (NASCIMENTO; TOMETICH, 2013; SVENSSON, 2015).

Tais adaptações de processos e produtos, incentivados pela ISO 14001, acabam sendo um diferencial importante para as organizações obterem vantagem competitiva. No entanto, o custo de implantação da ISO 14001 é elevado (sendo muitas vezes inacessível a pequenas empresas) e também requer mudanças significativas na cultura e estrutura de uma organização (POMBO e MAGRINI, 2008).

Desse modo, aspectos ambientais são compostos por diversos elementos provindos de produtos ou serviços gerados por uma organização de qualquer tamanho, que podem ser interagidos com o meio ambiente (MOURA, 2011). Dar-se então, a relevância em identificar estes critérios para avaliações de indicadores de desempenho sustentáveis, que normalmente são evidenciados nos relatórios de sustentabilidade emitidos pelas organizações para demonstrar um desempenho ambiental positivo a grupos de interesses. (BELLEN, 2014).

\subsection{EXTENSÃO CHANG FUZZY-ANALYTIC HIERARCHY PROCESS (FAHP)}

Harmonizando as teorias FAHP forma-se uma estrutura que propõe uma pré-qualificação e escolha de quais critérios será considerada de maior importância. Para isso, criou-se a necessidade em elaborar seis etapas que direcionam os cálculos para identificar os pesos dos critérios conforme demonstradas na Figura 1 (CHOU; YU, 2013).

Figura 1 - Estrutura para escolha de critérios

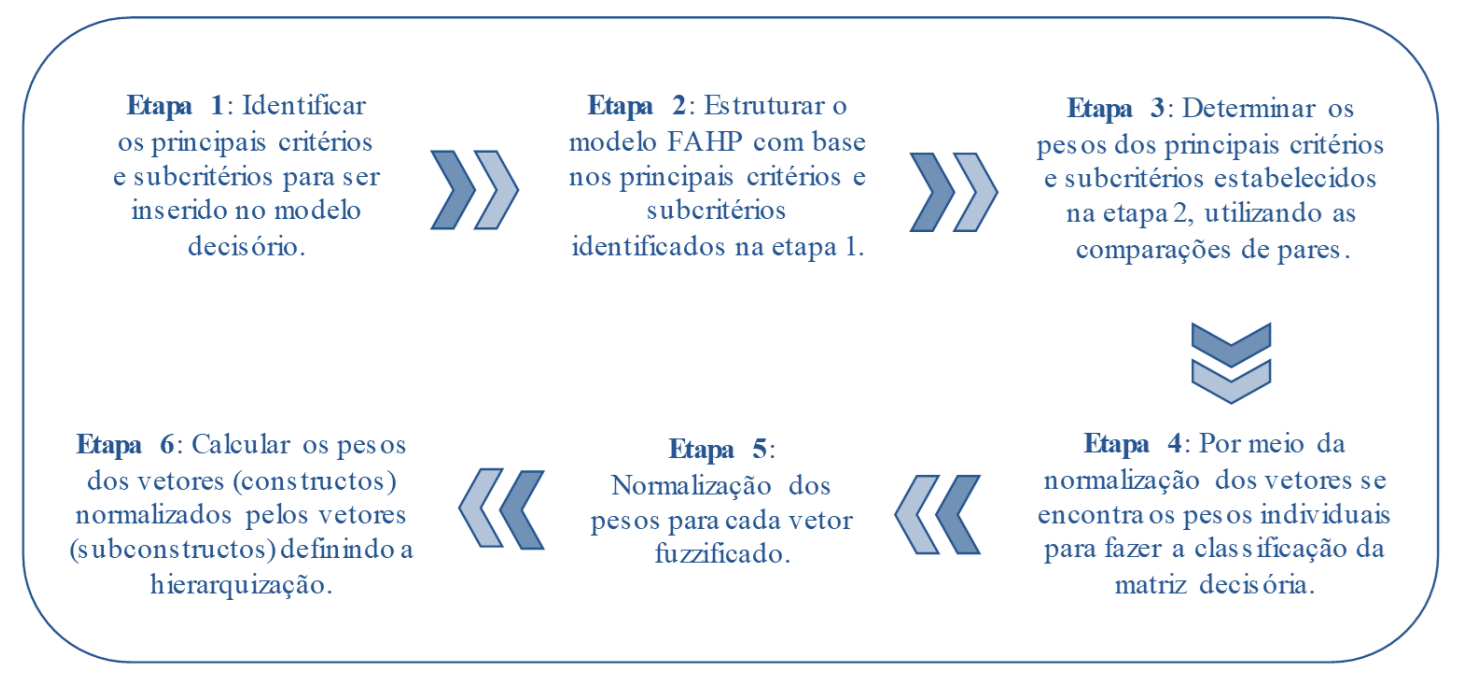

Fonte: Autores

Seguindo estas seis etapas é possível se chegar a uma padronização para processos decisórios, fornecendo soluções que reduzam as falhas na proposta de pesquisa, ante as incertezas e imprecisões não encontradas (RASHID; HUSNINE, 2014; WU et al., 2014;
WANG, 2015; FALAT; MARCEK; DURISOVA, 2016; ZARE et al., 2016).

Neste viés, a finalidade dos estudos realizados pela metodologia Analytic Hierarchy Process (AHP) é a hierarquização 
das ações que se encontram em primeiro plano e as de segundo plano para escolha da ordem de tomada de decisão. Ressalva que, essas ações devem estar de acordo ao IC -

$$
I C=\frac{|\lambda \max -N|}{N-1}
$$

Posteriormente, a Razão de Consistência, RC é realizada, permitindo considerar a inconsistência, em função dos julgamentos
Índice de Consistência que avalia o grau de inconsistência da matriz realizada par a par, pela Equação 1 (ZARE et al., 2016).

$$
R C=\frac{I C}{I R}
$$

As teorias FAHP aperfeiçoam estruturas, que qualificam os processos decisórios para problemas ou sugestões, escolhidas através de critérios que são considerados de maior importância. Portanto, Van Laarhovem \& Pedrycz (1983) sugerem que para fundamentação aplicativa de FAHP elaboremse quatro etapas sequenciais. realizados, por meio da Equação 2, que deve ser $<0,10$.

\begin{tabular}{|c|c|c|c|c|}
\hline Escala & $\begin{array}{c}\text { Avaliação- } \\
\text { AHP }\end{array}$ & $\begin{array}{c}\text { Inversa- } \\
\text { AHP }\end{array}$ & Avalia & Inversa-Fuzzy \\
\hline Extremamente preferido & 1 & 1 & $(1 ; 1 ; 3)$ & $(1 / 3 ; 1 ; 1)$ \\
\hline Muito fortemente preferido & 3 & $1 / 3$ & $(1 ; 3 ; 5)$ & $(1 / 5 ; 1 / 3 ; 1)$ \\
\hline Fortemente preferido & 5 & $1 / 5$ & $(3 ; 5 ; 7)$ & $(1 / 7 ; 1 / 5 ; 1 / 3)$ \\
\hline Moderadamente preferido & 7 & $1 / 7$ & $(5 ; 7 ; 9)$ & $(1 / 9 ; 1 / 7 ; 1 / 5)$ \\
\hline Igualmente preferido & 9 & $1 / 9$ & $(7 ; 9 ; 9)$ & $(1 / 9 ; 1 / 9 ; 1 / 7)$ \\
\hline
\end{tabular}

Tabela 1 - Escala de conversões

Fonte: SAATY e SHIH (2009); KAHRAMAN, (2008); Chang (1996).

Utilizando o método da extensão de Chang (1996) são calculadas conforme as etapas consideradas na sequência, que são:

Etapa 1: Transformação dos valores originais (crisp) do modelo AHP original em números
Antes de iniciar as seis etapas propostas mencionados no parágrafo anterior são necessárias que se organize o processo de transformação de escalas. Primeiro organizase as escalas de AHP (valores ímpares) e posteriormente transformados para escala fuzzy, como apresentado na Tabela 1.

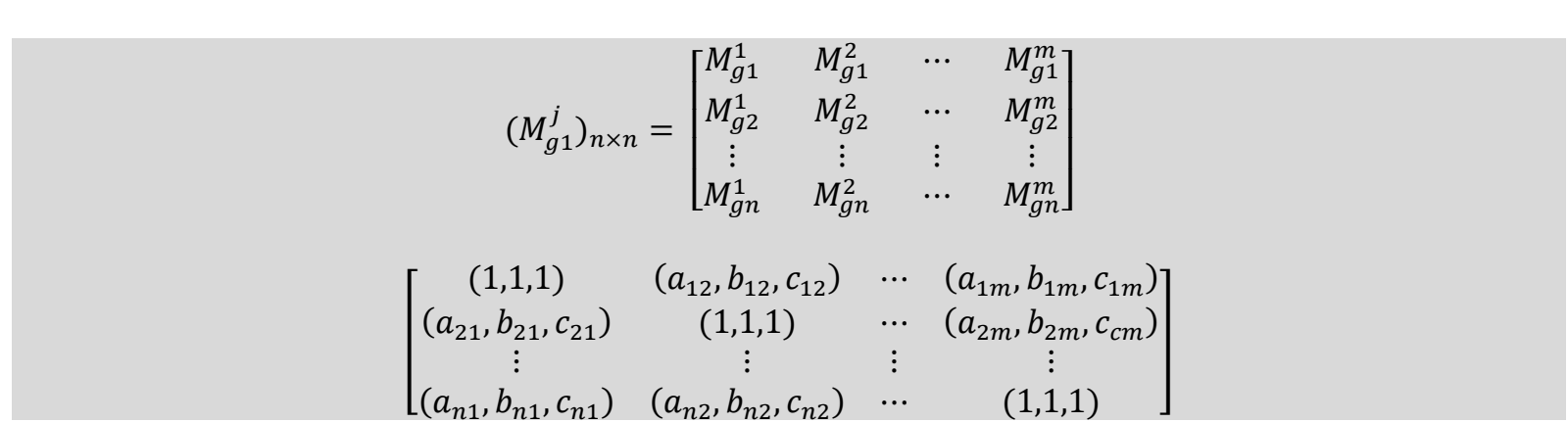

fuzzy e a comparação pareada de cada critério e subcritério em uma matriz. Esta operação pode ser visualizada pela seguinte expressão matemática: 
Etapa 2: O valor da medida sintética fuzzy em relação ao $i^{\text {th }}$ objeto é definida pelas Equações 3, 4, 5 e 6.

$$
\begin{aligned}
& S_{i}=\sum_{j=1}^{m} M_{g i}^{j} \otimes\left[\sum_{i=1}^{n} \sum_{j=1}^{m} M_{g i}^{j}\right]^{-1} \\
& \sum_{j=1}^{n} M_{i j}=\left(\sum_{j=1}^{n} l_{i j}, \sum_{j=1}^{n} m_{i j}, \sum_{j=1}^{n} u_{i j}\right), i=1,2,3, \ldots, \\
& \sum_{i=1}^{m} \sum_{j=1}^{n} M_{g i}^{j}=\left(\sum_{i=1}^{m} \sum_{j=1}^{n} l_{i j}, \sum_{i=1}^{m} \sum_{j=1}^{n} m_{i j}, \sum_{i=1}^{m} \sum_{j=1}^{n} u_{i j}\right) \\
& {\left[\sum_{i=1}^{m} \sum_{j=1}^{n} M_{i j}\right]^{-1}=\left(\frac{1}{\sum_{i=1}^{m} \sum_{j=1}^{n} u_{i j}}, \frac{1}{\sum_{i=1}^{m} \sum_{j=1}^{n} m_{i j}}, \frac{1}{\sum_{i=1}^{m} \sum_{j=1}^{n} l_{i j}}\right)}
\end{aligned}
$$

Etapa 3: O grau de possibilidade de $M_{2}=$ $\left(l_{2}, m_{2}, u_{2}\right) \geq M_{1}=\left(l_{1}, m_{1}, u_{1}\right)$ é definido pela Equação 7.

$$
V\left(M_{2} \geq M_{1}\right)=\sup _{y \geq x}\left[\min \left(\mu_{M_{2}}(x), \mu_{M_{2}}(y)\right)\right]
$$

Equação (8):

$E$, pode ser equivalentemente a

$$
\begin{gathered}
V\left(M_{2} \geq M_{1}\right)=h g t\left(M_{1} \cap M_{2}\right)=\mu_{M_{2}}(d)= \\
\left\{\begin{array}{c}
1, \text { se } m_{2} \geq m_{1} \\
0, \text { se } l_{1} \geq l_{2} \\
\frac{l_{1}-u_{2}}{\left(m_{2}-u_{2}\right)-\left(m_{1}-l_{1}\right)}, c c
\end{array}\right.
\end{gathered}
$$

A formulação deste trabalho seguiu o método original de Chang (1996), portanto utilizou-se a primeira e a terceira condição da Equação (8).
Etapa 4: O grau de possibilidade para um número fuzzy convexo ser maior do que $k$ números fuzzy convexos $M_{i}(i=1,2,3, \ldots, k)$ pode ser definido pela Equação 9.

$$
\begin{gathered}
V\left(M \geq M_{1}, M_{2}, \ldots, M_{k}\right)=V\left[\left(M \geq M_{1}\right)\right] e\left(M \geq M_{2}\right) e \ldots e\left(M \geq M_{k}\right)= \\
\min V\left(M \geq M_{i}\right), i=1,2,3, \ldots, k
\end{gathered}
$$

A Equação (9) assume a forma da Equação

(10) avaliando o mínimo das possibilidades:

$$
d^{\prime\left(A_{i}\right)}=\min V\left(S_{j} \geq S_{i}\right)
$$

Etapa 5: Por meio da normalização, os vetores de peso são obtidos pela Equação (11) onde $W$ é um número não fuzzy.

$$
W_{i}=\frac{w_{i}^{\prime}}{\sum_{i=1}^{n} w_{i}^{\prime}}
$$


Etapa 6: Cálculo dos pesos globais para os subcritérios. Os pesos globais dos subcritérios são calculados pela multiplicação do peso local de cada subcritério pelo peso do critério a que pertence. Este último procedimento define a hierarquização final de todos os subcritérios por meio dos seus pesos obtidos.

\subsection{LOGICA FUZZY SETS}

A teoria do Fuzzy Sets foi introduzida por Zadeh (1965) com a finalidade de fornecer uma ferramenta para se trabalhar com uma enorme gama de problemas onde há uma indefinição que surge principalmente a partir de uma ambiguidade intrínseca do que de uma variação estatística (DE LUCA; TERMINI, 1973).

A lógica fuzzy envolve valores complexos de sistema não lineares. Em relação a regra que direciona os dados para que possam variar entre os extremos 0 e 1 , tornando-se uma lógica multivalorada, conforme as Equações 12 e 13. Na lógica fuzzy o caso de expressão correto é a Equação 13, onde se considera um conjunto $A$, em um elemento $x$ com relação ao conjunto (KAHRAMAN, 2008; MASSA et al., 2015).

$$
f(x)=\left\{\begin{array}{l}
1 \text { se, } e \text { somente se, } x \in a \\
0 \text { se, } e \text { somente se, } x \notin a
\end{array}\right.
$$

$$
\mu(x)=\left\{\begin{array}{c}
1 \text { se, e somente se, } x \in a \\
0 \text { se, } \text { e somente se, } x \notin a \\
0 \leq \mu(x) \leq 1 \text { se } x \text { pertence parcialmente a }
\end{array}\right.
$$

Assim que, o conceito é trabalhar com maior número de informações possíveis, de bivalência ou multivalência, por meio de métodos de incertezas, sendo explicado, com expressões linguísticas.

A fuzzificação é composta por fuzzy triangular e trapezoidal. A proposição entre esses dois métodos de busca de resultados é o relacionamento entre as variáveis do modelo e regiões fuzzy. As Equações 14 e 15 representam respectivamente os dois métodos de fuzzificação. Um valor fuzzy triangular é composto se sua função de pertinência é de acordo com a Equação 14:

$$
\varphi A(x)=\left\{\begin{array}{c}
0, \text { se } x \leq a \\
\frac{x-a}{u-a}, \text { se } a<x \leq u \\
\frac{x-b}{u-b}, \text { se } u \leq x<b \\
0, \text { se } x \geq b
\end{array}\right.
$$

É um valor trapezoidal e dito e sua função de pertinência é apresentada conforme a Equação 15.

$$
\varphi \mathrm{A}(\mathrm{x})=\left\{\begin{array}{c}
\frac{\mathrm{x}-\mathrm{a}}{\mathrm{b}-\mathrm{a}}, \text { se } \quad \mathrm{a} \leq \mathrm{x}<b \\
1, \text { se } \mathrm{b} \leq \mathrm{x} \leq \mathrm{c} \\
\frac{\mathrm{d}-\mathrm{x}}{\mathrm{d}-\mathrm{c}}, \text { se } \quad \mathrm{c}<x \leq d \\
0, \text { caso contrário }
\end{array}\right.
$$

A equação que corresponde a defuzzificação é o centro de gravidade. Pois, este apresenta a média das áreas de todas as figuras correspondentes do conjunto fuzzy. Para 


$$
\begin{aligned}
G(B) & =\frac{\sum_{n}^{i=0} u i \varphi B(u i)}{\sum_{n}^{i=0} \varphi B(u i)} \\
G(B) & =\frac{\int \mathbb{R} u \varphi B(u) d u}{\int \mathbb{R} \varphi B(u) d u}
\end{aligned}
$$

Assim, qualquer número real, que de certa forma possa representar o conjunto fuzzy $B$ (citado nas equações) pode ser considerado uma defuzzificação de $B$.

\section{METODOLOGIA}

Do ponto de vista de abordagem do problema, este artigo pode ser classificado como sendo qualitativo pelo modo de busca de coleta de dados e quantitativo pela utilização de cálculos matemáticos. De acordo com os objetivos e procedimentos técnicos, partindo de uma extensão do trabalho de Tseng, Lin e Chiu (2009) o artigo tem como foco um estudo de caso múltiplo holístico de modo exploratório-descritivo.

Ao total, 20 empresas participaram da coleta de dados, sendo estas dos seguintes setores: calçadista; confecções de painéis plásticos; gráficas; pré-moldados; madeireira; estruturas metálicas; materiais em pvc e laticínios. Foram entrevistados a partir de um questionário escalar, um gestor de cada empresa, com cargos de gerência ou sócios.

Também, foi aplicado o mesmo questionário de modo paritário a três especialistas na linha de pesquisa em sustentabilidade, sendo dois da UFRGS (um professor de doutorado e um aluno de mestrado) e um aluno de doutorado da UNISINOS. Estas entrevistas contêm quatro constructos chaves sendo: organização; sistemas e tecnologia; avaliação de desempenho; treinamentos e pessoas. Com base em cada um desses constructos obtêm-se subcategorias conforme descritas no artigo de Tseng; Lin e Chiu (2009). A elaboração e aplicação dos questionários foram oriundas do método Analytic Hieranchy Process (AHP). Os cálculos foram compostos pelos métodos FAHPe Fuzzy Sets.

\subsection{CRITÉRIOS DE SIMULAÇÃO FAHP PARA FUZZY SETS}

A Figura 2 tem como objetivo apresentar o framework que deverá ser contemplado na projeção do artigo. Desse modo, mediante a aplicação dos questionários $A H P$ e, simulação Fuzzy Sets, as siglas utilizadas foram: NACnão atende parcialmente; NAT-não atende; APA- atende parcialmente; ATE- atende; APLatende plenamente, para atender respectivamente as escalas da Tabela I, utilizando o software DecisorGUI.

Para simulação é importante ressaltar que, os termos linguísticos foram determinados de acordo com a perspectiva dos pesquisadores, porém, os graus de pertinência (ponderação de valores) foram adotados conforme os resultados finais das alternativas (A: B: C) do FAHP e, sofreram alterações que foram empregadas matematicamente de acordo com a Operação Algébrica por Multiplicação Escalar (OAME) proposta pela lógica fuzzy sets.

$\mathrm{Na}$ Figura 2 as cores em escala de cinza representam as os inputs realizados pelos cálculos em Fuzzy-AHP, em escala de verde, são realizados os cálculos em Fuzzy Sets e a caixa em cor laranja são os outputs possíveis encontrados na pesquisa. 
Figura 2 - Framework da pesquisa

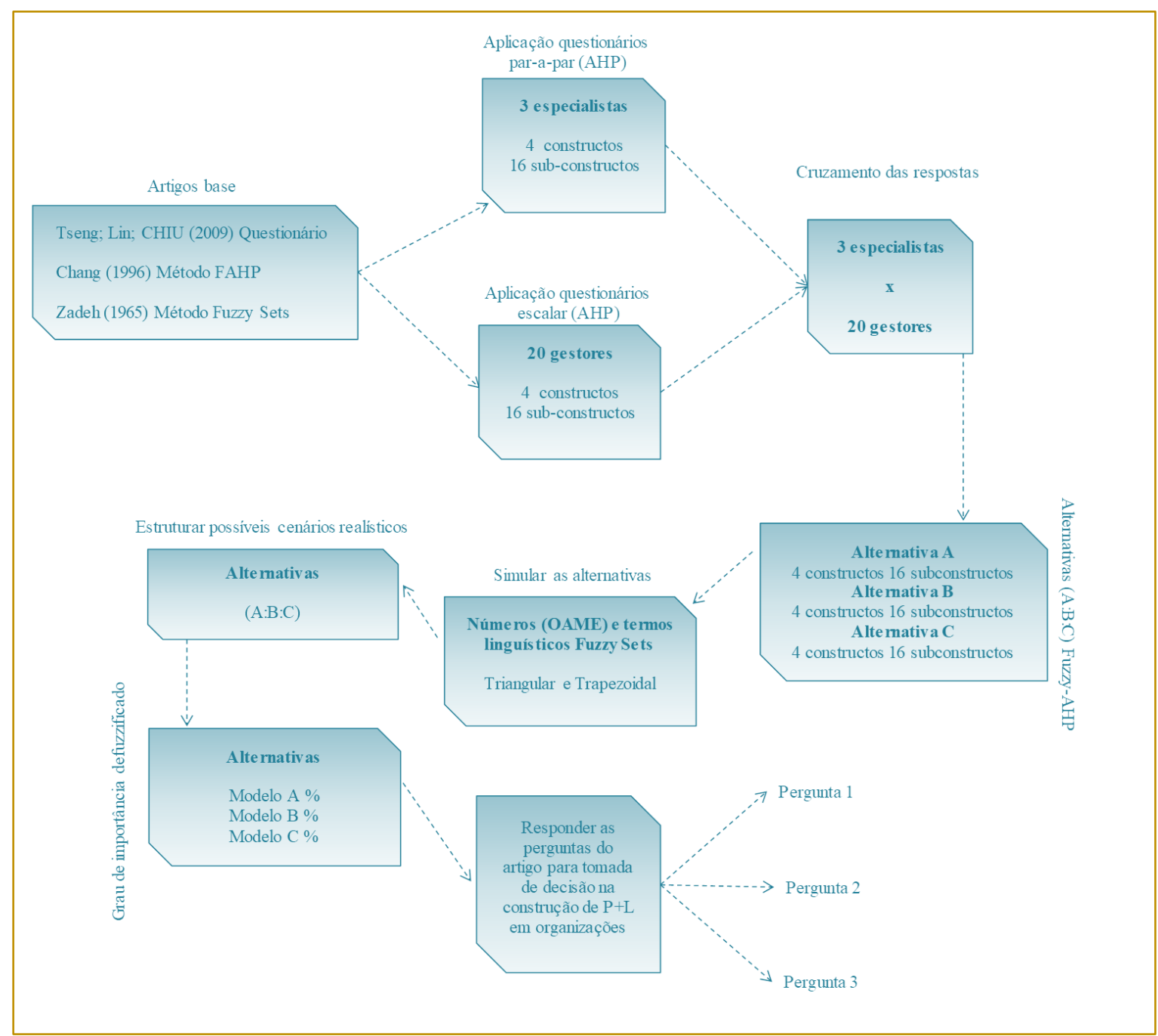

Fonte: Autores

Após realizar múltiplos cenários projetando como se comportaria um sistema produtivo real baseado em normas e regulamentos em produção mais limpa, são inseridas as alternativas (A; B; C) do FAHP na simulação, para então, encontrar 0 grau de confiabilidade (entre 0 e 100\%) sobre qual modelo condiz com uma melhor perspectiva de aplicação na tomada de decisão gerencial. Necessariamente, são realizadas diversas simulações para encontrar um melhor resultado e então responder às questões de pesquisa, utilizando o software InFuzzy.

\section{RESULTADOS}

Os resultados apresentados nesta pesquisa procuram auxiliar a tomada de decisão dos gestores quanto a quais indicadores devem ser utilizados primeiro e qual o percentual para que possa ter ganho na aplicação de um sistema produtivo com produção mais limpa.

\subsection{ANÁLISE FAHPENTRE OS MODELOS}

A análise $F A H P$ serve para apresentar de forma mais próxima possível o pensamento humano quanto a tomada de decisão. Para tanto, a construção das matrizes par-a-par obteve razão de consistência abaixo do estipulado por Saaty $<0,10$. Para o modelo $(A)$ os constructos ficaram com $(0,06)$ modelo $(B)$ $(0,06)$ e modelo $(C)(0,05)$. O Quadro 1 apresenta o RC para os subconstructos. A importância em apresentar a razão de consistência é informar o quanto as questões envolvidas foram compreendidas pelos respondentes e o grau de veracidade sobre as mesmas conforme destacados por Saaty. 
Nesse sentido, todas as matrizes permaneceram abaixo de 0,10.

Quadro 1 - Razão de Consistência Saaty das matrizes dos subconstructos

\begin{tabular}{|c|c|c|c|}
\hline & Modelo A & Modelo B & Modelo C \\
\hline Organização & $R C-0,10<0,04$ & $R C-0,10<0,07$ & $R C-0,10<0,06$ \\
\hline Sistemas e Tecnologia & $R C-0,10<0,09$ & $R C-0,10<0,10$ & $R C-0,10<0,06$ \\
\hline Avaliação de Desempenho & $R C-0,10<0,08$ & $R C-0,10<0,10$ & $R C-0,10<0,06$ \\
\hline Treinamentos e Pessoas & $R C-0,10<0,10$ & $R C-0,10<0,06$ & $R C-0,10<0,01$ \\
\hline
\end{tabular}

Fonte: Autores.

Utilizando as mesmas regras para os três modelos $(\mathrm{A}: \mathrm{B}: \mathrm{C})$ e partindo dos resultados de FAHP conforme os questionários, a lógica construída a partir de valores originados entre (0 e 1) obtiveram os resultados defuzzificados com a capacidade combinatória dos constructos, conforme mostra o gráfico da Figura 3. Primeiramente, os cálculos realizados no FAHP quanto aos modelos obtiveram os seguintes aspectos confirmatórios: no modelo (A) a capacidade combinatória dos constructos $(22 ; 32 ; 22 ; 34)$ resultou em uma probabilidade de $17,21 \%$ de ganho e uma confiabilidade de 50\%. Para o Modelo (B) a capacidade combinatória dos constructos $(32 ; 42 ; 11 ; 15)$ resultou em uma probabilidade de $22,21 \%$ e a confiabilidade $52,09 \%$ e o Modelo (C) a capacidade combinatória dos constructos $(33 ; 22 ; 20 ; 25)$ resultou em uma probabilidade de 17,60\% com a confiabilidade de $48,12 \%$.

O gráfico da Figura 3 apresenta alguns pontos distintos entres os analistas teóricos e práticos. Dois dos três modelos propostos seguem um raciocínio lógico semelhante. Pode-se dizer que o modelo $(A)$ e $(C)$ estão mais próximos em linha de pensamento quanto a processos decisórios em PmaisL. Os constructos organização e sistemas e tecnologia, para os modelos (A) e (C) obtiveram apenas $54 \%$ não sendo considerados muito relevantes pelos especialistas. Ou seja, para os modelos (A) e (C), os valores dos indicadores nos constructos permaneceram próximos e estáveis, nenhum constructo teve um destaque considerável. Percebe-se também, que no modelo B a partir da Figura 3, sistemas e tecnologia e, organização, em conjunto, representaram $75 \%$ dos indicadores com uma superioridade bastante significativa com o foco em sistemas e tecnologia. Fato este, que pode ter remetido a inserção da alta tecnologia desenvolvida nas industrias como sendo revolução da 14.0.

Figura 3 - Fuzzificação dos respondentes Teoria x Prática

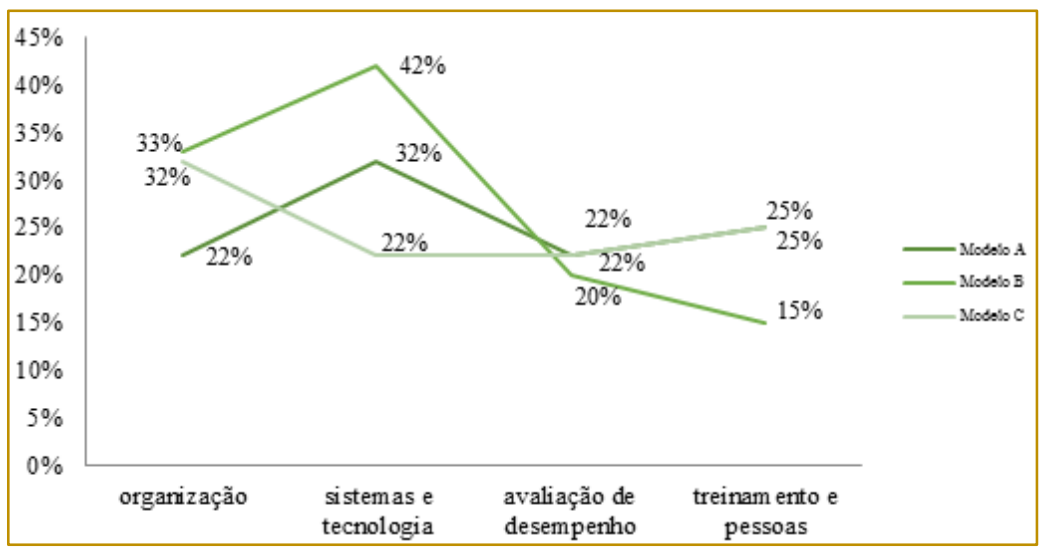

Fonte: Autores

Considera-se que entre a teoria e a prática existe uma lacuna de pensamento evolutivo quanto a aplicação de produção mais limpa no setor industrial. Para tanto, a pesquisa buscou melhorar os modelos utilizando a lógica fuzzy. Este controlador/simulador tem como proposição elencar o quanto o modelo é robusto para aplicação nas indústrias, se aproximando do raciocínio lógico humano em tomada decisão entre teóricos e práticos. Neste sentido, partindo dos resultados do FAHP para cada modelo $(\mathrm{A} ; \mathrm{B} ; \mathrm{C})$ os 
resultados combinatórios dos constructos simulados obtiveram melhorias que serão apresentadas a seguir, no item 4.2.

\subsection{ANÁLISE DEFUZZIFICADO ENTRE OS MODELOS}

Para o Modelo (A) os constructos resultaram em $57,71 \%$ de confiabilidade utilizando como melhor combinação resultante no sistema de (40; $17 ; 13 ; 30)$ e a probabilidade de ganho em $22,12 \%$. No Modelo (B) a probabilidade de ganho resultou em $22,90 \%$ e $57,61 \%$ de confiabilidade com os constructos (45; $25 ; 10$; 20) e, no Modelo (C) a probabilidade de ganho gerou em torno de $19,01 \%$ e $57,79 \%$ de confiabilidade de acordo com os constructos $(38 ; 20 ; 10 ; 32)$.
Ao contrário dos resultados $F A H P$ onde 0 destaque estava entre organização e sistemas e tecnologia, após defuzzificar os modelos a ênfase ficou entre organização e treinamentos e pessoas. O que pode ser bastante significativo, pois se o gestor credita energia da empresa para ser competitiva mercadologicamente o fator treinar pessoas é fundamental para que consiga então, após, aplicar em tecnologia. Ou seja, após a simulação ficou bastante evidente que desenvolver na gestão e liderança, planos estratégicos, mudanças de cultura e treinamentos e desenvolvimentos é fundamental pensando em evoluir a empresa no sentido de realizar produção mais limpa.

Figura 4: similaridade entre os modelos após construção dos cenários probabilísticos

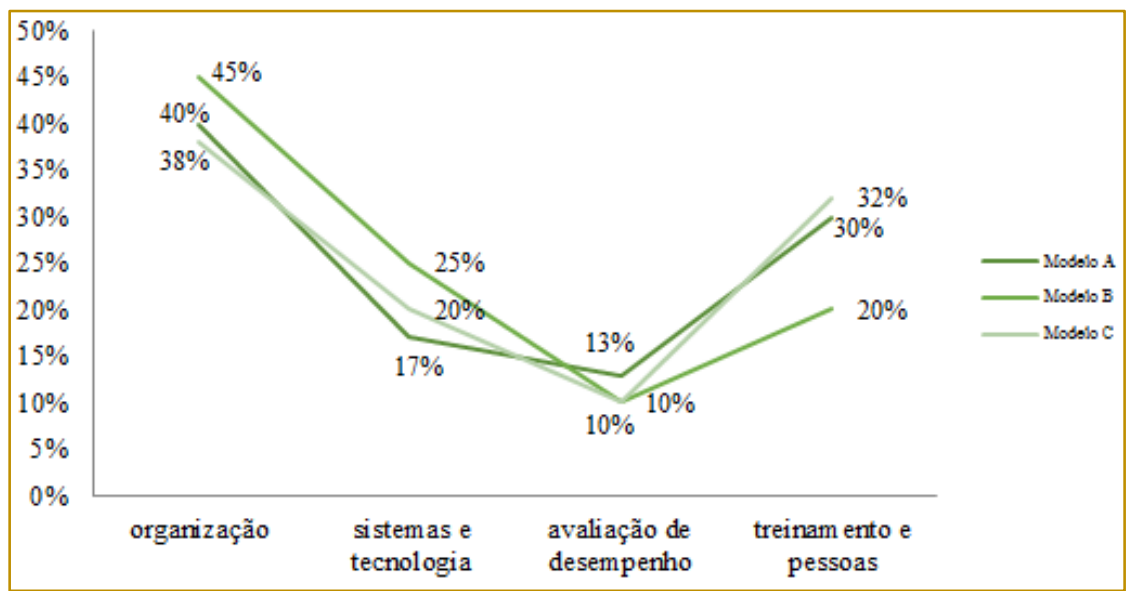

Fonte: Autores

A defuzzificação serve para que possa ser analisado qual a probabilidade em confiabilidade para se tomar determinada decisão. Nesse sentido, foram construídos 50 possíveis cenários e 115 simulações para tomada decisão no software InFuzzy. Sendo assim, em comparação mediana entre os resultados obtidos, na Figura 3 condiz que, a relação teoria e prática se resume em iniciar os processos de aplicação em produção mais limpa por meio da organização e sistemas e tecnologia, enquanto que, na Figura 4 indica que uma decisão eficiente deve ser iniciada com base na organização e treinamento dos colaboradores, comentado anteriormente. Corroborando, não se pode afirmar uma tomada de decisão padroniza de pesquisa, entre qual modelo estaria mais eficiente ao inserir na indústria (FERREIRA et al. 2017). São variáveis que depende muito da estrutura e cultura organizacional da empresa atualmente e, como a mesma deseja inserir estes indicadores.

Conforme a literatura apresenta (PIMENTA; GOUVINHAS, 2012), enaltecem a justificativa que para se chegar a um resultado mais sistêmico, para que se possa obter êxito na implementação de PmaisL, as variáveis devem ser percebidas pelo gestor com base nas políticas, metas e objetivos bastante concisos organizacionalmente e, então, realizar treinamento dos colaboradores para que todos os níveis organizacionais tanto quanto (estratégico, tático e operacional) possam estar cientes sobre aplicabilidade e desenvolvimento do PmaisL na empresa, no qual o principal fator para melhorias a ser adotada em organizações é o desenvolvimento cultural (FERREIRA et al. 2017). 
Dentre os destaques encontrados no gráfico da Figura 4, questões tecnológicas, segundo a literatura, (FERREIRA et al. 2017) são fatores relativamente importantes para qualquer estrutura organizacional. A evolução para Industria 4.0 conhecida como um dos passos mais importantes para progressão humana já traz pontos fortes sobre sua aplicabilidade, porém, todo e qualquer processo tecnológico a ser implementado precisa primeiramente organizar e treinar a empresa.

\subsection{ANÁLISE DE SENSIBILIDADE HIERÁRQUICA ENTRE OS MODELOS ANTES E APÓS SIMULAÇÃO}

Após a defuzzificação, ficou consumado que os três modelos são considerados adequados para aplicação devido sua verossimilhança entre os valores nos constructos. O ranking do FAHP é uma importante fonte de informação para adequar aos indicadores na empresa que deseja construir. Para isso, no estudo, foi importante apresentar o comportamento dos critérios e subcritérios quanto à aplicação dos mesmos para indicadores antes e após a simulação.

No Quadro 2, observa-se que entre as subcategorias o indicador de maior relevância após a simulação ficou gestão e liderança. Esta afirmação se dá, porque muitas empresas que desejam tornar-se competitivas devem iniciar por uma gestão consistente para então fazer abrangências em outros pontos na empresa. Somente com uma melhoria na gestão e liderança é que se consegue passar a todos os envolvidos na empresa o que realmente se almeja.

Quadro 2- critérios de prioridades para indicadores

\begin{tabular}{|c|c|c|c|c|c|c|c|}
\hline Critérios & Conceitos & $\begin{array}{l}\text { Antes } \\
\text { Sim. } \\
\text { MA }\end{array}$ & $\begin{array}{l}\text { Após } \\
\text { Sim. } \\
\text { MA }\end{array}$ & $\begin{array}{c}\text { Antes } \\
\text { Sim. } \\
\text { MB }\end{array}$ & $\begin{array}{l}\text { Após } \\
\text { Sim. } \\
\text { MB }\end{array}$ & $\begin{array}{l}\text { Antes } \\
\text { Sim. } \\
\text { MC }\end{array}$ & $\begin{array}{l}\text { Após } \\
\text { Sim. } \\
\text { MC }\end{array}$ \\
\hline \multirow{4}{*}{$\begin{array}{l}\text { Organização } \\
\text { Antes Sim- } 2^{\circ} \\
\text { Após Sim - } 1^{\circ}\end{array}$} & Gestão e liderança & $2^{\circ}$ & $2^{\circ}$ & $1^{\circ}$ & 10 & 10 & 10 \\
\hline & Plano estratégico & $5^{\circ}$ & $3^{\circ}$ & $4^{\circ}$ & $2^{\circ}$ & $2^{\circ}$ & $2^{\circ}$ \\
\hline & Foco no cliente & $1^{\circ}$ 은 & 1 은 & $8^{\circ}$ & $8^{\circ}$ & $7^{\circ} \underline{-}$ & $7^{\circ} \underline{-}$ \\
\hline & Compromisso de gestão & $8^{\circ}$ & $8^{\circ}$ & $5^{\circ}$ & $3^{\circ}$ & $3^{\circ}$ & $3^{\circ}$ \\
\hline \multirow{4}{*}{$\begin{array}{l}\text { Sistemas } \\
\text { tecnologia } \\
\text { Antes Sim - } 1^{\circ} \\
\text { Após Sim - } 3^{\circ}\end{array}$} & Ferramentas e tecnologia & $7^{\circ} \underline{-}$ & $7^{\circ} \underline{-}$ & $3^{\circ}$ & $5^{\circ}$ & $5^{\circ}$ & $5^{\circ}$ \\
\hline & Análise e melhoria de processos & $3^{\circ}$ & $4^{\circ}$ & $2^{\circ}$ & $4^{\circ}$ & $4^{\circ}$ & $4^{\circ}$ \\
\hline & Análise da cadeia de fornecedores & $4^{\circ}$ & $5^{\circ}$ & $7^{\circ} \underline{-}$ & $7^{0} \underline{0}$ & $6^{0}$ & $6^{0}$ \\
\hline & Avaliação do ciclo de vida & $6^{\circ}$ & $6^{\circ}$ & $6^{\circ}$ & $6^{\circ}$ & $8^{\circ}$ & $8^{\circ}$ \\
\hline \multirow{4}{*}{$\begin{array}{l}\text { Avaliação de } \\
\text { desempenho } \\
\text { Antes Sim - } 4^{\circ} \\
\text { Após Sim - } 4^{\circ}\end{array}$} & Medição de desempenho interno & 9음 & $12^{\circ}$ & $11^{\circ}$ & $15^{\circ}$ & $10^{\circ}$ & $12^{\circ}$ \\
\hline & Medição de desempenho externo & $10^{\circ}$ & $13^{\circ}$ & $12^{-}$ & $16^{\circ}$ & $12^{\circ}$ & $13^{\circ}$ \\
\hline & Melhoria contínua & $12^{\circ}$ & $14^{\circ}$ & $13^{\circ}$ & $14^{\circ}$ & $16^{\circ}$ & $16^{\circ}$ \\
\hline & Critérios de medição & $16^{\circ}$ & $15^{\circ}$ & $14^{\circ}$ & $11^{\circ}$ & $11^{\circ}$ & $14^{\circ}$ \\
\hline \multirow{4}{*}{$\begin{array}{l}\text { Treinamentos } \\
\text { e pessoas } \\
\text { Antes Sim - } 3^{\circ} \text { - } \\
\text { Após Sim - 2ํ}\end{array}$} & Treinamento de colaborador & $13^{\circ}$ & $11^{\circ}$ & 9은 & 9은 & 9은 & 9음 \\
\hline & Mudança de cultura & $14^{\circ}$ & $15^{\circ}$ & $10^{\circ}$ & $10^{\circ}$ & $13^{\circ}$ & $10^{\circ}$ \\
\hline & Envolvimento do empregado & $11^{\circ}$ & 9은 & $15^{\circ}$ & $12^{\circ}$ & $14^{\circ}$ & $15^{\circ}$ \\
\hline & Existência da cultura organizacional & $15^{\circ}$ & $10^{\circ}$ & $16^{\circ}$ & $13^{\circ}$ & $15^{\circ}$ & $11^{\circ}$ \\
\hline
\end{tabular}

Fonte: autores.

Neste mesmo sentido outros subconstructos se destacaram hierarquicamente na pesquisa como, planos estratégicos ficando entre os três mais relevantes, no qual o plano ambiental deve coincidir com as orientações estratégicas da organização, otimizar o uso de recursos e assegurar a disponibilidade de funcionários treinados para implementação da produção mais limpa. Para compromisso de gestão, a intenção é promover a criação de valores claros e visíveis de qualidade, juntamente com um sistema de gestão para orientar todas as atividades da empresa para a excelência da qualidade.
Para ferramenta e tecnologia, a sua utilização é no sentido de evitar uso de produtos químicos, fazer reciclagem e reutilização para aperfeiçoar eficiência ambiental. Em análises e melhorias de processos para empresa, devem ser desenvolvidas filosofias de qualidade, política ambiental, procedimentos e objetivos, adquirindo informações de funcionários, clientes, fornecedores e concorrentes. E, quanto ao foco no cliente, considera-se atenções quanto a exigências e expectativas dos clientes, visando sua satisfação. 


\section{DISCUSSÃO DOS INDICADORES}

Pergunta 1: qual a percepção dos especialistas (teóricos e práticos) quanto ao uso dos critérios e conceitos de prioridade em $P+L$ no caráter industrial?

No viés dos especialistas, ficou bastante claro, conforme o gráfico da Figura 3 que o nível de compreensão e aplicabilidade entre teoria e prática ainda tem algumas barreiras que necessitam ser analisadas, ou seja, o que a teoria apresenta não está sendo percebida pelos gestores no momento da prática e qual a importância de cada critério. Introduzir produção mais limpa exige não somente responsabilidade iniciais dos gestores, como culturalmente dos colaboradores. O que a teoria explica é que, por meio dos subconstructos analisados necessita de maiores conhecimentos sobre o real conceito em aplicar questões de sustentabilidade nas organizações, é quebrar culturas. Implementar sem conhecer a real necessidade da empresa é ter custos altos e muitas vezes desnecessários.

Desse modo, percebeu-se que os especialistas práticos necessitam de mais abordagens sobre como trabalhar com produção mais limpa nas organizações, ou seja, como seria a estruturação hierárquica destes indicadores para aplicar nas empresas. A perspectiva dos resultados na pesquisa era de que os três modelos estivessem verossimilhança, porém, não foi este resultado apresentado pelo método multicriterial AHP, somente após aplicar simulações que a lógica do pensar me modo igual é que foi apresentada no modelo.

Pergunta 2: qual o modelo que define a melhor construção dos conceitos na PmaisL?

Em métodos multicriteriais probabilísticos, são muito utilizados para fazer afirmações sobre qual modelo poderá ser utilizado em determinada empresa (FERREIRA et. al. 2017). E, com simulações e construção de cenários é possível se chegar a uma tomada de decisão bastante segura em se tratando de sustentabilidade abordada nesta pesquisa.

Para cenários envolvendo FAHP com respostas dos especialistas o melhor modelo a ser considerado como indicadores é o modelo B, conforme Quadro 3. porque sua confiabilidade correspondeu a 52,09\%. Em termos literários, essa porcentagem é considerada baixa (FERREIRA et. al. 2017) visto que, alguns autores trazem como sendo um modelo aplicável acima de $70 \%$.

Quadro 3 - FAHP real e Fuzzy Sets

\begin{tabular}{|c|c|c|}
\hline \multicolumn{3}{|c|}{ FAHP - REAL } \\
\hline $\begin{array}{c}\text { Indicador Modelo A } \\
(22 \% ; 32 \% ; 22 \% ; 34 \%)\end{array}$ & $\begin{array}{c}\text { Capacidade do Modelo A } \\
\qquad 17,21 \%\end{array}$ & $\begin{array}{l}\text { Confiabilidade do Modelo A } \\
50 \%\end{array}$ \\
\hline $\begin{array}{c}\text { Indicador Modelo B } \\
(32 \% ; 42 \% ; 11 \% ; 15 \%)\end{array}$ & $\begin{array}{l}\text { Capacidade do Modelo B } \\
22,21 \%\end{array}$ & $\begin{array}{l}\text { Confiabilidade do Modelo B } \\
52,09 \%\end{array}$ \\
\hline $\begin{array}{c}\text { Indicador Modelo C } \\
(33 \% ; 22 \% ; 20 \% ; 25 \%)\end{array}$ & $\begin{array}{c}\text { Capacidade do Modelo C } \\
\qquad 17,60 \%\end{array}$ & $\begin{array}{c}\text { Confiabilidade do Modelo C } \\
48,12 \%\end{array}$ \\
\hline \multicolumn{3}{|c|}{ FUZZY SETS - SIMULADO } \\
\hline $\begin{array}{l}\text { Indicador Modelo A } \\
(40 \% ; 17 \% ; 13 \% ; 30)\end{array}$ & $\begin{array}{c}\text { Capacidade do Modelo A } \\
22,12 \%\end{array}$ & $\begin{array}{c}\text { Confiabilidade do Modelo A } \\
57,71 \%\end{array}$ \\
\hline $\begin{array}{c}\text { Indicador Modelo B } \\
(45 \% ; 25 \% ; 10 \% ; 20 \%)\end{array}$ & $\begin{array}{l}\text { Capacidade do Modelo B } \\
\qquad 22,90 \%\end{array}$ & $\begin{array}{l}\text { Confiabilidade do Modelo B } \\
\qquad 57,61 \%\end{array}$ \\
\hline $\begin{array}{c}\text { Indicador Modelo C } \\
(38 \% ; 20 \% ; 10 \% ; 32 \%)\end{array}$ & $\begin{array}{c}\text { Capacidade do Modelo C } \\
\qquad 19,01 \%\end{array}$ & $\begin{array}{l}\text { Confiabilidade do Modelo C } \\
57,79 \%\end{array}$ \\
\hline
\end{tabular}

Fonte: autores.

Porém, após fazer 115 simulações com 50 cenários, uma melhora foi apresentada pelo Fuzzy Sets nos modelos (A; B; C). Pode se dizer então, que os três modelos são considerados relevantes após a simulação, pois índice de porcentagem não sofreu altas variações. Sendo assim, compreende-se que no Fuzzy Sets foi encontrado um padrão de tomada de decisão no qual se tem similaridade quanto a confiabilidade e aplicabilidade do modelo em pensamento de produção mais limpa. Estes dados podem ser percebidos na Figura 4.

Quanto a melhor tomada de decisão sobre qual modelo de indicadores utilizar é uma questão que tem como principal ação compreender junto as necessidades da empresa. Algumas organizações podem optar por utilizar indicadores que obtenham maiores êxitos em organização e treinamento e 
pessoas, nesse sentido a melhor escolha seria o modelo $(\mathrm{C})$. Caso o empreendedor queira optar por organização e sistemas e tecnologia encontraria a solução de melhorias no modelo (B). Neste estudo a principal contribuição para os resultados foi apresentar a confiabilidade de cada modelo no método FAHP e no método Fuzzy Sets contemplando indicadores.

\section{CONCLUSÃO}

A proposição do artigo é buscar que uma verossimilhança entre os três modelos no qual as constantes possam ser justificadas por apenas um valor. $\mathrm{Na}$ comparação dos modelos simulados o ( $\mathrm{B}$ B e C) estão com similaridades próximas o que significa que apesar de os teóricos serem de instituições distintas o pensamento quanto a melhor forma de aplicar as práticas de produção mais limpa estão consideravelmente próximas, utilizando a construção de cenários Fuzzy Sets.

Esse fato deixa claro perante a literatura que, a teoria e a prática precisa de mais estudos em sinergia. Existe uma lacuna de pesquisa para identificar o porquê estes dois campos entre teóricos e práticos ainda mantêm-se com pensamentos literalmente distante para aplicação como apresentado na Figura 3 do gráfico.

Quando trata-se de estudos de métodos FAHP e Lógica Fuzzy para os modelos não existe uma forma certa ou errada de aplicação. Este fator depende muito da complexidade do ambiente organizacional em

\section{REFERÊNCIAS}

[1] Brito, M. D.; Brunstein, J.; Amaro, R. A. Sustentabilidade, incubadoras de empresas e universidades: um olhar para a nova geração de empreendedores. 38ํㅡㄹ Encontro ANPAD. 2014.

[2] Chang, Da-Yong. Applications of the extent analysis method on fuzzy AHP. European journal of operational research, v. 95, n. 3, p. 649655, 1996.

[3] Chou, Chien-Chang; Yu, Ker-Wei. Application of a new hybrid fuzzy AHP model to the location choice. Mathematical Problems in Engineering, v. 2013, 2013.

[4] De Luca, Aldo; Termini, Settimo. A definition of a nonprobabilistic entropy in the setting of fuzzy sets theory. In: Readings in Fuzzy Sets for Intelligent Systems. 1993. p. 197-202. que está por ser aplicado. Porém, projetos com porcentagens abaixo de $70 \%$ podem sofrer baixas ao aplicar os indicadores fuzzy. Neste artigo o pressuposto foi de compreender o quão está próximo o pensamento sobre aplicações de técnicas ambientais em sistemas organizacionais.

E na pesquisa após realizar várias técnicas, as porcentagens apresentadas pelo gráfico quanto aos modelos $(A ; B ; C)$ afirmam que a capacidade de evolução para melhorar os modelos ainda depende de outros fatores neste artigo não abordados. Os gestores respondentes ainda consideram a aplicabilidade das técnicas de PmaisL complexas no sistema industrial, por fatores como, quebra de cultura organizacional, infraestrutura, desenvolvimento de pessoal, Tempo de Resposta Rápida para melhorias (TRRM), custos altos.

Para os teóricos consideram que há necessidades de as organizações serem mais agressivas quanto a abordagem sustentável devido as projeções oferecidas pelo mercado. A saída, segundo os teóricos, seria o desenvolvimento primeiramente do nível estratégico em querer fazer as coisas, o tático em buscar estas melhorias contínuas e os operadores por acreditarem em um TRRM capaz de gerir bons resultados para todos. Para tanto, uma lacuna, não estudada no artigo é identificar: quais as barreiras que explicam a pouca similaridade entre teoria e prática quando relacionado com questões ambientais?

[5] Falat, Lukas; Marcek, Dusan; Durisova, Maria. Intelligent soft computing on forex: exchange rates forecasting with hybrid radial basis neural network. The Scientific World Journal, v. 2016, 2016

[6] Ferreira, Alexandre Rodrigues et al. Priorização dos requisitos de sustentabilidade em incubadoras tecnológicas: Um estudo de caso na região central do Rio Grande do Sul, Brasil. Interciencia, v. 42, n. 2, p. 108, 2017.

[7] Guimaraes, J. C. F.; Severo, E. A.; Vasconcelos, C. R. M. Sustainable Competitive Advantage: A Survey of Companies in Southern Brazil. V.14. N.3, 2017.

[8] Kahraman, Cengiz (Ed.). Fuzzy multicriteria decision making: theory and applications with recent developments. Springer Science \& Business Media, 2008. 
[9] Manzini, Ezio; Vezzoli, Carlo. O desenvolvimento de produtos sustentáveis. Os requisitos ambientais dos produtos industriais. Edusp, 2002.

[10] Massa, F. et al. Finite element analysis of frictionless contact problems using fuzzy control approach. Engineering Computations, v. 32, n. 3, p. 585-606, 2015.

[11] Moreira, José Carlos Teixeira. Foco do cliente: O cliente como real investidor para o futuro da sua empresa. São Paulo: Gente, 2009.

[12] Nascimento, Luís Felipe; Tometich, Patrícia. Sustentabilidade: Resultados De Pesquisa Do Ppga/ea/ufrgs. Porto Alegre: Sul, 2013.

[13] Neto, S. M.; Pires, IRS. Medição de desempenho em cadeias de suprimentos: um estudo na indústria automobilística. Gestão \& Produção, São Carlos, v. 19, n. 4, p. 733-746, 2012.

[14] Pimenta, Handson Claudio Dias; Gouvinhas, Reidson Pereira. A produção mais limpa como ferramenta da sustentabilidade empresarial: um estudo no estado do Rio Grande do Norte. Production, v. 22, n. 3, p. 462-476, 2012.

[15] Pombo, Felipe Ramalho; Magrini, Alessandra. Panorama de aplicação da norma ISO 14001 no Brasil. Gestão \& Produção, v. 15, n. 1, p. 1-10, 2008.

[16] Rashid, Tabasam; Husnine, Syed Muhammad. Multicriteria group decision making by using trapezoidal valued hesitant fuzzy sets. The Scientific World Journal, v. 2014, 2014.

[17] Saaty, Thomas L.; Shih, Hsu-Shih. Structures in decision making: On the subjective geometry of hierarchies and networks. European Journal of Operational Research, v. 199, n. 3, p. 867-872, 2009.

[18] Silvestre, B. S. Silva Neto, R. E. Are cleaner production innovations the solution for small mining operations in poor regions? The case of Padua in Brazil. Journal of cleaner production, v. 84, p. 809-817, 2014.

[19] Svensson, G. Sustainable quality management: a strategic perspective. TQM Magaz. v. 18, p. 22-29, 2015.

[20] Tannuri, G.; Bellen, H. M. V. Indicadores de desempenho ambiental evidenciados nos relatórios de sustentabilidade: uma análise à luz de atributos de qualidade. Revista de Gestão Social e Ambiental, v. 8, n. 1, p. 2-19, 2014

[21] Tseng, Ming-Lang; LIN, Yuan-Hsu; CHIU, Anthony SF. Fuzzy AHP-based study of cleaner production implementation in Taiwan PWB manufacturer. Journal of Cleaner Production, v. 17, n. 14, p. 1249-1256, 2009.

[22] Van Hoof, Bart; Lyon, Thomas P. Cleaner production in small firms taking part in Mexico's Sustainable Supplier Program. Journal of Cleaner Production, v. 41, p. 270-282, 2013.

[23] Van Laarhoven, P. J. M.; Pedrycz, Witold. A fuzzy extension of Saaty's priority theory. Fuzzy sets and Systems, v. 11, n. 1-3, p. 229-241, 1983.

[24] Wang, Ming-Tang. Use of a combination of AHP and ism for making an innovative rescue caring design in landslide area. Mathematical Problems in Engineering, v. 2015, 2015.

[25] Wu, J. T, Wang, J. Q. Wang, J. Zhang, H. Y. Chen, X. H. Hesitant fuzzy linguistic multicriteria decision-making method based on generalized prioritized aggregation operator. The Scientific World Journal, v. 2014, 2014.

[26] Yong, J. Y. Klemes, J. J. Varbanov, P. S. Huisingh, D. Cleaner energy for cleaner production: modelling, simulation, optimisation and waste management. Journal of Cleaner Production, $v$. 111, p. 1-16, 2016.

[27] Zadeh, Lotfi A. Fuzzy sets. Information and control, v. 8, n. 3, p. 338-353, 1965.

[28] Zare, R. Nouri, J. Abdoli, M. A. Arabi, F.Atavi, M. The integrated fuzzy AHP and goal programing model based on LCA results for industrial waste management by using the nearest weighted approximation of $\mathrm{FN}$ : aluminum industry in Arak, Iran. Advances in Materials Science and Engineering, v. 2016, 2016. 


\section{Gapítulo 16}

\section{PRINCIPAIS TECNOLOGIAS DA PRÁTICAS ENXUTAS}

\section{Marcos Malinverni Pagliosa}

Guilherme Luz Tortorella

João Carlos Espíndola Ferreira

Resumo: A Indústria 4.0 (14.0) trouxe mudanças disruptivas em relação ao modo de como os processos produtivos atuais são determinados. Diante da intensa competição existente no contexto das empresas de manufatura as organizações precisam ficar atentas para o surgimento de novos conceitos e tecnologias capazes de alterar significativamente o modo de como estas empresas operam. Até o momento, muitas empresas tem adotado a manufatura enxuta (ME) como uma forma eficiente de se alcançar melhores resultados e tornarem-se mais competitivas. Porém, com o surgimento das tecnologias da 14.0 muitas dúvidas referentes a compatibilidades entre estas duas abordagens foram levantadas. $\mathrm{O}$ objetivo deste trabalho é realizar uma revisão sistemática da literatura com o objetivo de identificar as principais tecnologias da 14.0 e práticas de ME. Para isso, foi empregado uma metodologia de revisão sistemática onde foram analisados 85 artigos que resultou na identificação de 9 tecnologias da 14.0 e 14 práticas de ME. Este artigo busca contribuir com o campo de construção da teoria relacionada a 14.0 e a ME proporcionando um maior conhecimento da literatura existente, bem como apontar lacunas de pesquisas para fomentar futuros trabalhos

Palavras-chave: Indústria 4.0; Tecnologias da Indústria 4.0; Práticas Enxutas 


\section{INTRODUÇÃO}

As empresas manufatureiras estão inseridas em um ambiente altamente competitivo e constantemente expostas a desafios como o surgimento de conceitos e tecnologias disruptivas (GLIGOR; HOLCOMB, 2012; SCHUMACHER et al., 2016). Nesse contexto, as organizações precisam operar com altos padrões de qualidade, produtividade e baixos custos para garantir a própria sobrevivência. Sendo assim, inúmeras abordagens foram desenvolvidas para apoiar as organizações a alcançarem tais objetivos. Dentre as quais, pode-se destacar a já consolidada Manufatura Enxuta (ME) e a recente Indústria $4.0(14.0)$

A partir da adoção de tecnologias oriundas da 14.0, um novo modelo de gestão está se configurando. Segundo Schumacher et al. (2016), a 14.0 representa uma nova fase para a indústria, oferecendo significativos avanços tecnológicos que permitem a integração em tempo real entre todos os participantes da cadeia de valor tornando-a mais produtiva, inteligente e ágil. As tecnologias da 14 . 0 permitem que o sistema de produção seja modular e variável capacitando-o a produzir em massa produtos altamente customizados (KAGERMANN et al., 2013). A 14.0 adota o conceito de produção inteligente (smart industry), o qual é capaz de atender novos requisitos de mercado (KOLBERG et al., 2016). A 14.0 se apresenta como uma alternativa de solução para sistemas produtivos que visam alto nível de flexibilidade, agilidade, baixo custo de produção e rapidez de resolução perante os problemas (RADZIWONA et al., 2014).

A ME por sua vez, vem sendo amplamente usada e disseminada entre os diversos tipos de indústria tendo como seus principais objetivos eliminar os desperdícios presentes no fluxo de valor, melhoria da qualidade e produtividade e produzir de acordo com a visão do cliente (WOMACK; JONES, 2004; JASTI; KODALI, 2015). De acordo com Burch e Smith (2017), a

ME capacita a empresa a reduzir o uso de recursos e maximizar as receitas gerando impactos positivos aos stakeholdders. A ME é um conjunto de práticas que tem como objetivo gerar um sistema eficiente, organizado e dedicado nas ações de melhoria contínua e eliminação de desperdícios (SIMPSON; POWER, 2005). ambas as abordagens apresentam pontos convergentes, visto que tanto a ME como a 14.0 buscam melhorias em produtividade, qualidade, focam na eliminação dos desperdícios e estão orientadas para o cliente.

No entanto, a ME, usualmente considerada como uma abordagem low-tech que prima pela simplicidade de aplicação (DICKMANN, 2008), pode apresentar pontos conflitantes com as modernas tecnologias da 14.0. Além disso, Grobner (2007) enfatiza que a ME é caracterizada por uma intensa integração humana com foco na eficiência, o que pode contrapor a aplicação de tais tecnologias fundamentalmente orientadas à digitalização e flexibilidade dos sistemas produtivos. A necessidade de investimentos para o acesso às novas tecnologias e a carência de profissionais qualificados são obstáculos que preocupam as organizações (PWC, 2016); podendo, inclusive, tornarem-se em um fator impeditivo para a adoção das novas tecnologias por parte de algumas empresas.

Baseado na relevância das questões levantadas acima, constata-se a existência de uma escassez de trabalhos relacionados à adoção das tecnologias da $14.0 \mathrm{em}$ empresas em implementação da ME (GJELDUM et al., 2016; KOLBERG et al., 2016; LANDSCHEIDT; KANS, 2016). Nesse sentido, pode-se formular a seguinte questão de pesquisa: "quais as principais tecnologias da Indústria 4.0 e práticas enxutas adotadas em empresas manufatureiras?". Assim, esse trabalho busca responder a essa questão, tendo por objetivo identificar quais são as principais tecnologias da Indústria 4.0 e PE existentes em empresas manufatureiras a partir de uma revisão sistemática de literatura.

Além dessa seção introdutória, este trabalho está dividido da seguinte forma. A seção 2 trata de um breve descrição sobre os conceitos e princípios relacionados à 14.0 e ME. A seção 3 descreve o método de revisão de literatura empregado, cujo análise bibliométrica e discussão dos resultados estão apresentados na seção 4. A seção 5 finaliza o artigo trazendo as conclusões e direcionamentos futuros de pesquisa.

\section{REVISÃO BIBLIOGRÁFICA \\ 2.1 INDÚSTRIA 4.0}

A 14.0 pode ser definida como um grupo de

Nesse sentido, pode-se constatar que 
tecnologias e conceitos aplicáveis na cadeia de valor de organizações, estabelecendo a interconexão e comunicação em tempo real entre pessoas, equipamentos e produtos (HERMANN et al., 2016, PWC, 2016). Considerada como a quarta revolução industrial, as tecnologias da 14.0 permitem um alto nível de comunicação e interação entre os participantes do fluxo de valor, capacitando os sistemas produtivos para a customização em massa (LASI et al., 2014; POSADA et al., 2015). A adoção das tecnologias da 14.0 possibilita integrar benefícios oriundos da produção customizada e intermitente com a alta produtividade e custos reduzidos do sistema de produção em massa (TAMAS et al., 2016; CNI, 2016; XU; CHEN, 2016).

Conforme observado na Figura 1, a terceira revolução industrial data da década de 70 e teve seu foco na automação de máquinas e processos individuais. Já a 14.0 se concentra na digitalização e integração do "end to end" de todos os ativos físicos e na maciça integração dos participantes da cadeia de valor (PWC, 2016).

Figura 1- Evolução histórica da Indústria

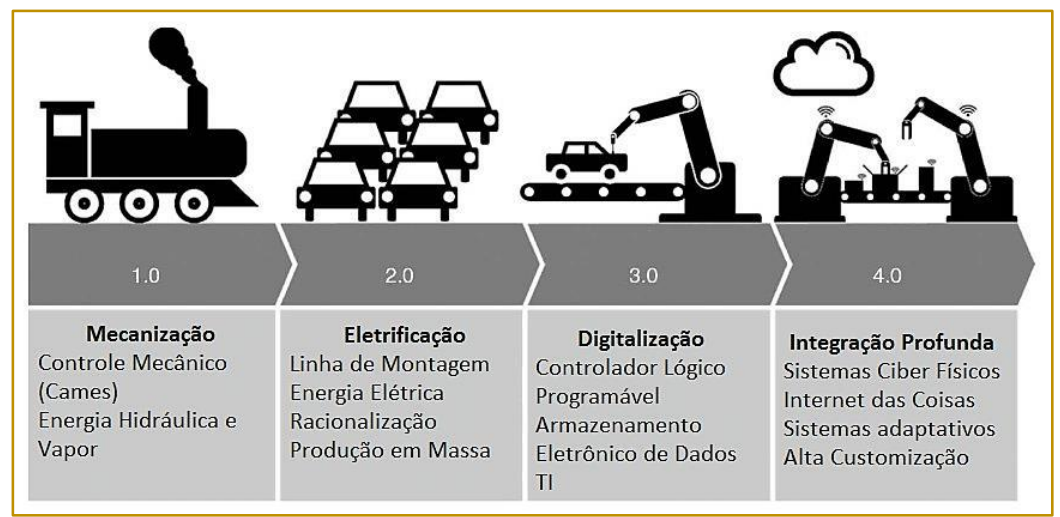

Fonte: Adaptado de Feuber e Park (2017)

A 14.0 é a mais recente tendência quando se trata de automação e troca de dados no sistema produtivo (CNI, 2016; I-SCOOP, 2017). Uma de suas principais vantagens frente aos sistemas produtivos atuais está na capacidade de se adaptar rapidamente a cenários com demanda volátil e produtos com ciclo de vida curto (Sanders et al., 2017). De acordo com Tamas et al. (2016), a 14.0 tem gerado importantes alterações no sistema produtivo e criado demanda para novos trabalhos. Nesse sentido, pesquisas recentes abordando o tema evidenciam que existe uma escassez de pesquisas tratando do impacto de suas associações no ambiente da manufatura (Gjeldum et al., 2016; Kolberg et al., 2016; Landscheidt; Kans, 2016;

Martinez et al., 2016; Sanders et al., 2016; Xu; Chen, 2016; Sanders et al., 2017; Santorella, 2017).

\subsection{MANUFATURA ENXUTA}

A ME pode ser descrita como uma abordagem produtiva que abrange uma variedade de práticas produtivas, direcionadas para a redução das variações nos processos (Shah; Ward 2003), identificação e eliminação de desperdícios ao longo do fluxo de valor (Womack; Jones, 1997; Ohno, 1998; Schonberger, 2007; Liker; Franz, 2011). Os benefícios observados e a simplicidade de aplicação da ME são alguns dos motivos pelos quais a mesma vem sendo amplamente adotada em um vasto número de empresas (Fullerton; Watters, 2001; Simpson; Power, 2005; Dennis, 2008; Burch; Smith 2017), de diferentes segmentos tais como manufatura (Herlyn, 2011; Conger; Miller, 2013; Kanigolla et al., 2014), saúde (Holm; Ahlstrom, 2010;) e construção civil (Ballard, 2002; Gao; Low, 2014).

A ME está baseada no aumento real de produtividade e qualidade e na minimização dos desperdícios presentes ao longo da cadeia de valor (Womack; Jones, 2004; Shah; Ward, 2007). Diversos estudos evidenciaram que a implementação de seus princípios e práticas está positivamente associada a melhoria do desempenho operacional (Liker; Franz, 2011; Conger; Miller, 2013; KANIGOLLA et al., 2014; REZENDE et al., 
2016)

Cabe destacar que a ME é uma abordagem sócio técnica que considera o ser humano como um fator fundamental de sustentação da melhoria contínua (SCHEIN, 2004; LEONARD; PAKDIL, 2016). Sua implementação resulta em uma abordagem sistemática de vários princípios e práticas de gestão que influenciam os indivíduos e a qualidade do trabalho executado (GETTY, 1999).

\section{MÉTODO}

A identificação das tecnologias da 14.0 e PE foi realizada a partir de um levantamento sistemático da literatura. Para tal foi utilizado o método Systematic Search Flow (SSF) ou Fluxo de Busca Sistemática, proposto por Ferenhof e Fernandes (2016), devido a sua consistência e confiabilidade. O método é composto por quatro fases divididas em oito atividades, conforme mostra a Figura 2.

Figura 2 - Fases e atividades do SSF

\begin{tabular}{|c|c|c|c|c|c|c|c|c|}
\hline Fase & \multicolumn{4}{|c|}{ 1- Protocolo de pesquisa } & \multicolumn{2}{|c|}{ 2- Análise } & \multirow{2}{*}{$\begin{array}{r}\text { 3- Síntese } \\
\text { (3.1) }\end{array}$} & \multirow{2}{*}{$\begin{array}{c}\text { 4- Escrever } \\
(4.1)\end{array}$} \\
\hline & $(1.1)$ & $(1.2)$ & $(1.3)$ & $(1.4)$ & (1.5) & (2.1) & & \\
\hline Atividade & $\begin{array}{l}\text { Estratégia } \\
\text { de busca }\end{array}$ & $\begin{array}{l}\text { Consulta } \\
\text { em base } \\
\text { de dados }\end{array}$ & $\begin{array}{l}\text { Gestão dos } \\
\text { documentos }\end{array}$ & $\begin{array}{c}\text { Padronização } \\
\text { e seleção dos } \\
\text { documentos }\end{array}$ & $\begin{array}{c}\text { Composição } \\
\text { do portifólio } \\
\text { de } \\
\text { documentos }\end{array}$ & $\begin{array}{c}\text { Consolidação } \\
\text { dos dados }\end{array}$ & $\begin{array}{c}\text { Elaboração } \\
\text { de } \\
\text { relatórios }\end{array}$ & Escrever \\
\hline
\end{tabular}

Fonte: Adaptado de Ferenhof e Fernandes (2016)

\subsection{PROTOCOLO DE PESQUISA PARA A SELEÇÃO DA LITERATURA SOBRE AS TECNOLOGIAS DA I4. O E AS PE - FASE 1}

A primeira fase da metodologia SSF tem como objetivo definir o protocolo de pesquisa e é dividida em 5 atividades a saber: (i) estratégia de busca; (ii) consulta em banco de dados;

(iii) gestão dos documentos; (iv) padronização e seleção dos documentos; e (V) composição do portfólio de documentos.

Durante esta fase foram executados vários filtros visando selecionar apenas os artigos que estejam alinhados com o tema de pesquisa. Os artigos selecionados são provenientes de quatro diferentes base de dados. Além dos filtros de busca relacionados a palavras-chave, foram usados outros tipos de filtros tais como: ( $/$ ) tipo de documento, (journal article e conferece article) e idioma (inglês); (ii) artigos não duplicados; (iii) títulos, palavras-chave e resumo alinhados com o tema; (iv) documentos disponíveis, e por fim, ( $v$ leitura integral do documento. Ao final deste processo obteve-se o total de 85 artigos que formaram o portfólio bibliográfico (PB) desta pesquisa conforme mostra o Quadro 1. A relação dos artigos que constituem O PB final pode ser vista no Apêndice 1.

Quadro 1 - Levantamento da literatura

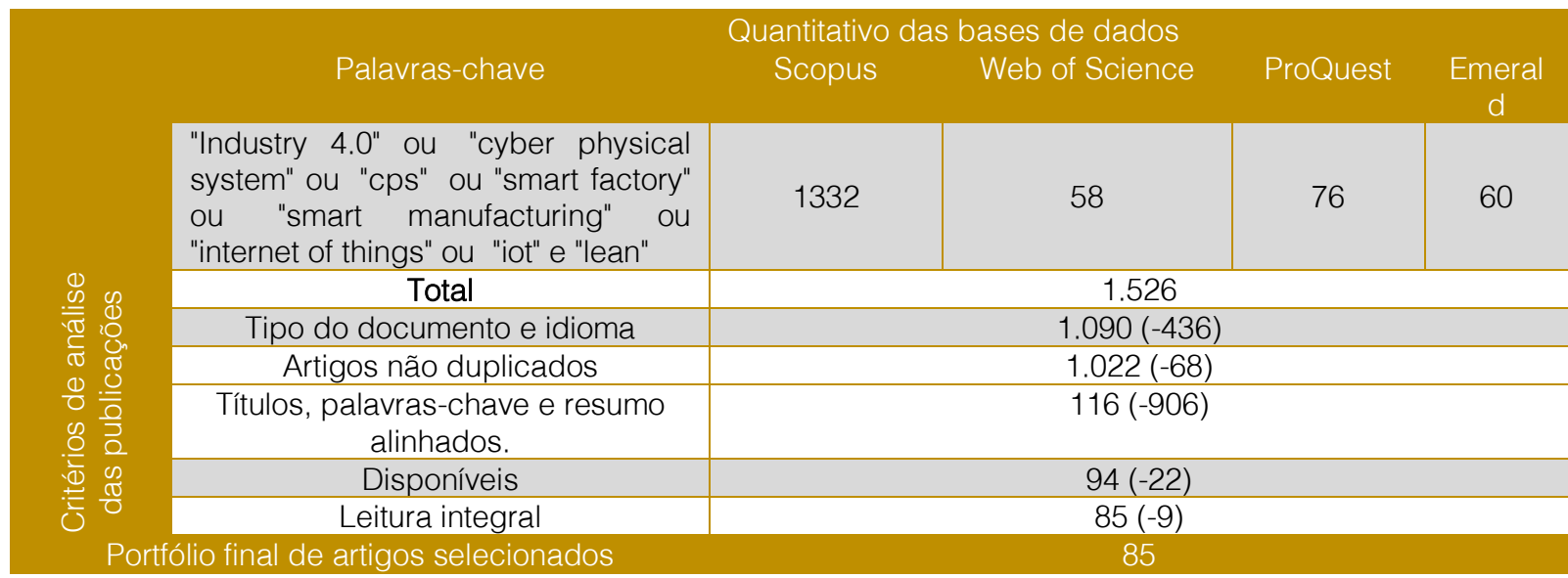




\subsection{ANÁLISE DOS DADOS - FASE 2}

A segunda fase tem como objetivo consolidar os dados (atividade 2.1). Nesta fase o pesquisador dedica-se a análise e interpretação dos dados bibliométricos que ajudam a estabelecer relações de significância e a evidenciar fatores relevantes à pesquisa (FERENHOF; FERNANDES, 2016). Desse modo, a análise das variáveis foi dividida em duas categorias sendo elas variáveis básicas e avançadas. As variáveis básicas analisadas foram: (i) número de publicações por periódicos, (ii) evolução da pesquisa ao longo dos anos, (iii) países onde as pesquisas ocorreram e (iv) tipo de estudo realizado sendo os mesmos classificados como estudos teóricos ou práticos. Quanto a análise das variáveis avançadas, buscou-se identificar:

(I) quais são as principais tecnologias da 14.0 empregadas na manufatura e (ii) quais são as principais PE empregadas na manufatura.

\subsection{SÍNTESE - FASE 3}

Nesta fase (atividade 3.1), as deduções sobre o tema são construídas sendo posteriormente agrupadas e condensadas em relatórios, tabelas e gráficos. Segundo Ferenhof e Fernandes (2016), o processo de síntese dos dados permite a geração de novos conhecimentos.

Por fim, cabe destacar que nesta fase levantam-se as lacunas de conhecimento existentes para sugestão de temas para futuras pesquisas.

\subsection{ESCREVER - FASE 4}

A última fase tem como objetivo a consolidação e registro dos resultados da pesquisa através da escrita científica. Nesta atividade (atividade 4.1) é preciso resgatar o objetivo da revisão de literatura, assim como os resultados obtidos nas fases de análise e síntese. Por fim com o auxílio de relatórios o pesquisador passa a fundamentar a escrita dos resultados (FERENHOF; FERNANDES, 2016).

\section{RESULTADOS}

Com base no PB de 85 publicações utilizadas para esta pesquisa, identificou-se que as mesmas estão distribuídas em 37 periódicos e 48 eventos científicos. Referente aos eventos cabe destacar duas conferências, a saber: Changeable, Agile, Reconfigurable \& Virtual Production Conference e International Federation of Automatic Control, com 4 publicações cada. Quanto aos periódicos, pode-se destacar o Advances in Manufacturing e o International Journal of Production Research, também com 4 publicações cada. A Tabela 1 mostra a distribuição de publicações por periódico/evento contidos no PB.

Tabela 1 - Número de artigos publicados em periódicos/eventos

\begin{tabular}{|c|c|c|c|}
\hline $\begin{array}{l}\text { Evento } \\
\text { científico }\end{array}$ & Peniódico & Descrição & $\begin{array}{c}\text { Total de } \\
\text { publicaçőes }\end{array}$ \\
\hline & $\mathrm{x}$ & Advances in Manufacturing & 4 \\
\hline $\mathrm{x}$ & & $\begin{array}{l}\text { Changeable, Agile, Reconfigurable \& Virtuall } \\
\text { Production Conference }\end{array}$ & 4 \\
\hline $\mathrm{x}$ & & Intemational Federation of Automatic Control & 4 \\
\hline & $\mathrm{x}$ & Intemational Joumal of Production Research & 4 \\
\hline $\mathrm{x}$ & & 50th Conference on Marufacturing Systems & 3 \\
\hline $\mathrm{x}$ & & $\begin{array}{l}\text { 9th Intemational Conference on Digital Enterprise } \\
\text { Technology }\end{array}$ & 2 \\
\hline $\mathrm{x}$ & & 6th Conference on Leaming Factories & 2 \\
\hline $\mathrm{x}$ & & $\begin{array}{l}\text { 27th Intemational Conference on Fexible } \\
\text { Automation and Intelligent Manufacturing }\end{array}$ & 2 \\
\hline $\mathrm{x}$ & & 49th Conference on Marmfacturing Systems & 2 \\
\hline & $\mathrm{x}$ & Intemational Federation for Information Processing & 2 \\
\hline & $\mathrm{x}$ & Intemational Joumal of Immovation Management & 2 \\
\hline $\mathrm{x}$ & & $\begin{array}{l}\text { Intemational Symposium on Intelligent } \\
\text { Manufacturing and Automation }\end{array}$ & 2 \\
\hline $\mathrm{x}$ & & Outros 27 exentos & 27 \\
\hline & $\mathrm{x}$ & Outros 26 periódicos & 26 \\
\hline
\end{tabular}


Após a análise dos periódicos, verificou-se a evolução do número de publicações durante os anos. Apesar de não ter ocorrido delimitação temporal na etapa de seleção dos documentos do PB, observa-se que todas as publicações estão concentradas no período compreendido entre os anos de 2010 e 2017 como mostra a Figura 3. Tal feito pode ser explicado em virtude do tema 14.0 ser considerado um tema novo, e também devido a pesquisa estar contemplando somente trabalhos que correlacionam os temas "Lean" com "Ind. 4.0". Assim, identificou-se que $72,7 \%$ das publicações do PB correspondem aos dois últimos anos. Além disso, as publicações apresentam um pico de 33 artigos no ano de 2016, permanecendo uma tendência semelhante em 2017.

Figura 3 - Evolução temporal das publicações

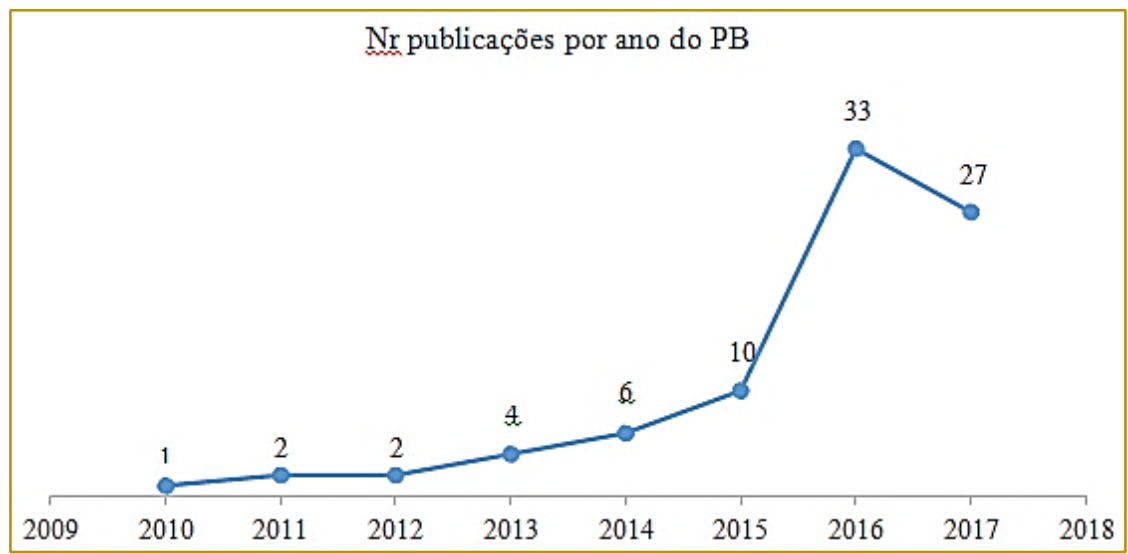

Quanto aos países onde os estudos foram realizados, pode-se destacar a Alemanha com 28 publicações, correspondendo a 31\% de todo o PB. Em seguida China, EUA e Inglaterra apresentam 5 publicações cada um, conforme mostra a Tabela 2. Ao total, as pesquisas foram realizadas por 31 países diferentes, sendo que $85 \%$ das pesquisas ocorreram em países desenvolvidos e 15\% em países emergentes, como mostra a Figura 4. Tal fato denota que o presente tema tem recebido maior atenção pelo grupo dos países desenvolvidos, dado que tais países são amplamente industrializados e possuem melhores recursos para desenvolvimento de pesquisa e tecnologia.

Tabela 2 - Número de publicações por país

\begin{tabular}{|l|c|}
\hline \multicolumn{1}{|c|}{ País } & Total de Publicações \\
\hline Alemanha & 28 \\
\hline China & 5 \\
\hline Estados Unidos & 5 \\
\hline Inglaterra & 5 \\
\hline Áustria & 4 \\
\hline Brasil & 4 \\
\hline Noruega & 4 \\
\hline Hungria & 3 \\
\hline Itália & 3 \\
\hline Árrica do Sul & 3 \\
\hline Croácia & 2 \\
\hline Malásia & 2 \\
\hline Polônia & 2 \\
\hline República Checa & 2 \\
\hline Suécia & 2 \\
\hline Taiwan & 2 \\
\hline Outros 15 países & 15 \\
\hline
\end{tabular}


Figura 4 - Países pesquisadores e tipo de Pesquisa

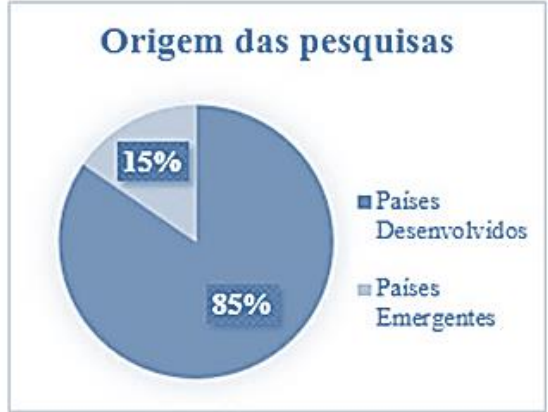

Outro aspecto analisado diz respeito ao tipo do estudo realizado, sendo os mesmos classificados nas categorias estudos teóricos ou estudos práticos. Segundo Demo (2009), o estudo teórico promove a discussão e possíveis revisões sobre o tema abordado visando a aprimorar os fundamentos teóricos. Já o estudo prático, busca a comprovação empírica de algo, através de experimentos ou pela observação de determinado contexto servindo para embasar e comprovar aquilo que foi apresentado conceitualmente. Dessa forma, Identificou-se que o maior número de estudos são de natureza teórica $(80 \%$ das publicações) e que somente $20 \%$ são estudos práticos conforme pode ser visto na Figura 4.

\subsection{PRINCIPAIS TECNOLOGIAS DA I4.0}

Conforme mencionado anteriormente a análise das variáveis avançadas desta pesquisa aborda a identificação das principais tecnologias da 14.0 e PE existentes em empresas manufatureiras. Nesse sentido, - Quadro 2 apresenta as principais tecnologias da 14.0 elencadas na literatura de acordo com sua frequência de citação.

Dentre as 9 tecnologias identificadas, podese notar que a frequência de citação das mesmas varia significativamente. Tal fato pode ser explicado devido as mesmas possuírem características, aplicações e objetivos diferentes. A tecnologia identificada com maior frequência de citação foi a loT (47 citações). Sua alta frequência de citação pode ser explicada devido a sua grande versatilidade, podendo ser aplicada de inúmeras formas e em diversos ambientes (ISLAM et al., 2015; ALMADALOBO, 2016; SANTOS et al., 2016;

SHARIATZADEH et al., 2016). Os avanços

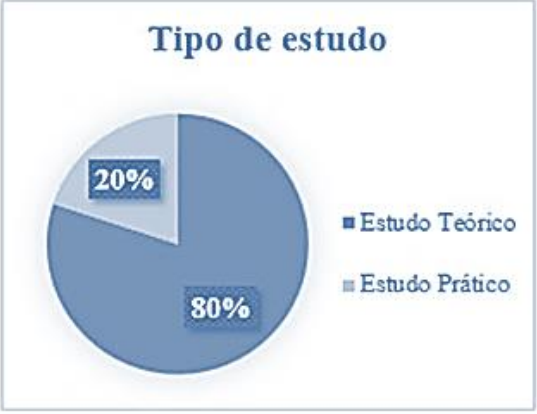

tecnológicos conquistados, a facilidade de acesso e a redução no custo para se adquirir a internet são alguns dos fatores que colaboraram positivamente para a loT estar sendo amplamente disseminada. Além disso, por se tratar de uma tecnologia que serve muitas vezes como base para outras tecnologias da 14.0 (p.ex.: CPS, computação em nuvem e simulação), a loT é vista como uma porta de a entrada para 14.0 (CNI, 2016; TAMAS et al., 2016; XU; CHEN, 2016).

Dentre as tecnologias com menor número de citações identificadas na pesquisa têm-se a Additive Manufacturing ou manufatura aditiva com 9 citações. A manufatura aditiva compreende tecnologias tais como impressora 3D em níveis industriais (RUBMANN et al., 2015). Além disso, referese a processos controlados por um sistema computadorizado, nos quais o material é unido e solidificado camada por camada formando objetos de formas variadas baseadas em um modelo digital (TAUFIK; JAIN, 2013). Esta apresenta um bom potencial de aplicação para a produção de pequenos lotes de produtos customizados, complexos e leves. Nesse sentido, existem iniciativas de aplicação em indústrias renomadas como a aeroespacial (turbinas de aviões), na qual houve ganhos com redução de matérias-primas, diminuição do peso dos componentes e do tempo de produção (MIT TECHNOLOGY REVIEW, 2018).

A baixa frequência de citação dessa tecnologia pode ser explicada devido ao fato de a mesma ainda não estar plenamente desenvolvida. Dessa forma, apenas um número limitado de empresas adotaram seu uso até o momento e sua aplicação ainda se restringe a contextos mais específicos quando comparadas a outras tecnologias da 14.0. Além disso, o nível de virtualização de processos onde a manufatura aditiva estão inseridas depende do porte da empresa, 
uma vez que pequenas e médias empresas muitas vezes não possuem recursos destinados a este fim (BRETTEL et al., 2014).

Quadro 2 - Principais tecnologias da 14.0

\begin{tabular}{|c|c|c|c|c|c|}
\hline Código & Tecnologia 14.0 & Definição / objetivos & $\begin{array}{l}\text { Estudo } \\
\text { teórico }\end{array}$ & $\begin{array}{l}\text { Estudo } \\
\text { prático }\end{array}$ & Frequência \\
\hline $\mathrm{T} 1$ & $\begin{array}{l}\text { Internet of Things (IOT) } \\
\text { Internet das coisas }\end{array}$ & $\begin{array}{l}\text { Possibilita a interatividade entre } \\
\text { pessoas e objetos para a troca de } \\
\text { dados e informações entre todos os } \\
\text { objetos conectados à internet }\end{array}$ & 39 & 8 & 47 \\
\hline & $\begin{array}{l}\text { Cyber phisical system } \\
\text { (CPS) }\end{array}$ & \multirow{2}{*}{$\begin{array}{l}\text { Permite alta integração entre as } \\
\text { pessoas e os sistemas físicos em } \\
\text { tempo real através do uso de } \\
\text { avançadas tecnologias de sistemas } \\
\text { de computação, comunicação e } \\
\text { controle (espaço cibernético). }\end{array}$} & \multirow[b]{2}{*}{33} & \multirow[b]{2}{*}{7} & \multirow[b]{2}{*}{40} \\
\hline T2 & Sistemas cyber físicos & & & & \\
\hline T3 & Big data & $\begin{array}{l}\text { A vasta utilização de sensores e } \\
\text { sistemas de controle utilizados na } \\
\text { indústria resulta na geração de uma } \\
\text { enorme quantidade de dados. Big } \\
\text { data é o termo que descreve o } \\
\text { imenso volume de dados } \\
\text { estruturados ou não e o seu } \\
\text { gerenciamento. }\end{array}$ & 18 & 3 & 21 \\
\hline T4 & $\begin{array}{l}\text { Horizontal/vertical } \\
\text { integration Integração } \\
\text { horizontal /e vertical }\end{array}$ & $\begin{array}{l}\text { Uso da tecnologia para integrar os } \\
\text { sistemas de informação de toda a } \\
\text { cadeia de valor que estará } \\
\text { conectada e automatizada pela } \\
\text { digitalização de dados. }\end{array}$ & 17 & 3 & 20 \\
\hline T5 & $\begin{array}{l}\text { Cloud computing } \\
\text { Computação em nuvem }\end{array}$ & $\begin{array}{l}\text { Os CPSs irão gerar grandes volumes } \\
\text { de dados (Big data), a computação } \\
\text { em nuvem servirá para armazenar } \\
\text { esses dados que poderão ser } \\
\text { acessados de qualquer lugar. }\end{array}$ & 23 & 4 & 27 \\
\hline T6 & $\begin{array}{l}\text { Advanced robots } \\
\text { Robotização avançada }\end{array}$ & $\begin{array}{l}\text { Robôs que utilizam inteligência } \\
\text { artificial e conceitos como "machine } \\
\text { learning" capazes de executar } \\
\text { tarefas com alto nível de } \\
\text { complexidade com o mínimo de } \\
\text { interação humana. }\end{array}$ & 14 & 1 & 15 \\
\hline T7 & $\begin{array}{l}\text { Augmented reality } \\
\text { Realidade aumentada }\end{array}$ & $\begin{array}{l}\text { Usa a tecnologia para tornar a } \\
\text { informação interativa ao adicionar } \\
\text { uma sobreposição de conteúdo } \\
\text { digital e informações relevantes no } \\
\text { mundo em torno do usuário. }\end{array}$ & 9 & 2 & 11 \\
\hline T8 & $\begin{array}{l}\text { Additive manufacturing } \\
\text { Manufatura aditiva }\end{array}$ & $\begin{array}{l}\text { É um processo aditivo de construção } \\
\text { de objetos, camada sobre camada a } \\
\text { partir de dados e modelos 3D. }\end{array}$ & 9 & 1 & 10 \\
\hline T9 & Simulation Simulação & $\begin{array}{l}\text { Simula de modo virtual conceitos, } \\
\text { aplicação e construção de protótipos } \\
\text { e processos através de recursos } \\
\text { computacionais. }\end{array}$ & 12 & 2 & 14 \\
\hline
\end{tabular}

\subsection{PRINCIPAIS PE}

Em relação a identificação das principais $\mathrm{PE}$ existentes em empresas manufatureiras, 0 Quadro 3 apresenta as 14 PE identificadas no PB de acordo com sua frequência de citação.

A PE que obteve a maior frequência de citação foi o kanban (10 citações). Segundo
Kumar e Panneerselvam (2007), kanban é basicamente um cartão que contém as informações necessárias para a produção de um produto em todas as etapas de sua produção. A alta frequência de citação do kanban é justificada pela sua grande importância dentro dos sistemas produtivos. Além disso, indica que o mesmo é uma PE 
altamente associada ao contexto de smart factory proposto pela 14.0 (vide KOTANI, 2007; KOURI, 2008; LAGE JUNIOR; GODINHO FILHO, 2010; KOLBERG; ZUHLKE, 2015; SANDERS et al., 2016; SANDERS et al., 2017). Estes trabalhos sugerem aplicações do kanban com novas tecnologias visando obter melhorias e maximizar seus benefícios.

Com relação à $\mathrm{PE}$ com menor número de citação, Total Productive Maintenance (TPM) ou Manutenção Produtiva Total obtive apenas 3 citações, o que de certa forma é um resultado contrário ao esperado. A 14.0 possui condições de fornecer um vasto número de dados e informações que podem ser utilizados no aprimoramento do desempenho de equipamentos, convergindo para os objetivos almejados a partir da implementação do TPM. Os poucos trabalhos relacionados ao tema, tais como Yoon (2012) e Geng et al. (2014), sugerem a aplicação das tecnologias da 14.0 para o aperfeiçoamento da manutenção preditiva. Já Zhu et al. (2012) e Zhang (2015) propõem o uso das tecnologias relacionadas à 14.0 para auxiliar na manutenção, reparo e operação (MRO) de equipamentos complexos, tais como os empregados em fundição na indústria siderúrgica.

Apesar da prática 'TPM' apresentar um potencial alinhamento com as tecnologias da 14.0 conforme evidências apresentadas, até o momento existe uma carência de trabalhos relacionando esses aspectos e suas possíveis sinergias. Nesse sentido, vale ressaltar que a baixa frequência de citação pode não estar ligada à falta de alinhamento entre estas, mas, sim, resultante de outros fatores. O TPM, por exemplo, se caracteriza por ser um conjunto de atividades conectadas que visa atender a um objetivo comum. No entanto, até o momento as aplicações da 14.0 apresentam um enfoque centrado em soluções pontuais, nas quais as tecnologias estão sendo aplicadas sem necessariamente estarem relacionadas com a implementação de processos de suporte ao TPM.

Quadro 3 - Principais tecnologias da 14.0

\begin{tabular}{|c|c|c|c|}
\hline Práticas Enxutas & $\begin{array}{l}\text { Estudo } \\
\text { teórico }\end{array}$ & $\begin{array}{l}\text { Estudo } \\
\text { prático }\end{array}$ & Frequência \\
\hline Kanban & 11 & & 11 \\
\hline $\begin{array}{l}\text { Value-stream mapping (VSM) } \\
\text { Mapeamento do fluxo de valor }\end{array}$ & 7 & 1 & 8 \\
\hline Kaizen & 7 & & 7 \\
\hline $\begin{array}{l}\text { Poka yoke } \\
\text { Sistemas a prova de erros }\end{array}$ & 6 & 1 & 7 \\
\hline Andon & 6 & & 6 \\
\hline $\begin{array}{l}\text { Pull production } \\
\text { Produção puxada }\end{array}$ & 6 & & 6 \\
\hline $\begin{array}{l}\text { SMED } \\
\text { Troca rápida de ferramentas (TRF) }\end{array}$ & 6 & & 6 \\
\hline $\begin{array}{l}\text { Heijunka } \\
\text { Nivelamento da produção }\end{array}$ & 4 & & 4 \\
\hline $\begin{array}{l}\text { Standardization } \\
\text { Padronização }\end{array}$ & 4 & & 4 \\
\hline $\begin{array}{l}\text { Total quality management (TQM) } \\
\text { Gestão da qualidade total }\end{array}$ & 4 & & 4 \\
\hline $\begin{array}{l}\text { Takt time } \\
\text { Tempo takt }\end{array}$ & 3 & 1 & 4 \\
\hline $5 S$ & 4 & & 4 \\
\hline $\begin{array}{l}\text { Jidoka } \\
\text { Autonomação }\end{array}$ & 3 & & 3 \\
\hline $\begin{array}{l}\text { Total productive maintenance (TPM) } \\
\text { Manutenção produtiva total }\end{array}$ & 3 & & 3 \\
\hline
\end{tabular}




\section{CONCLUSÕES E LACUNAS DE PESQUISA}

O presente trabalho procurou identificar as principais tecnologias da 14.0 e PE existentes em empresas de ME. Para alcançar tal objetivo, foi feito um levantamento sistemático da literatura identificando-se um portfólio com 85 artigos, de modo a apresentar um panorama sobre o presente tema. Cabe destacar que a pesquisa contemplou somente trabalhos que abordavam concomitantemente os temas tecnologias da 14.0 e Lean. Nesse sentido, de fato percebe-se que apenas uma parcela dos trabalhos consolidados na literatura foi considerada. Contudo, sabe-se da existência de trabalhos exclusivamente voltados para as PE e 14.0 onde a gama de PE e tecnologias da 14.0 é maior do que as relacionadas por este trabalho. Além disso, conforme mencionado anteriormente constata-se uma carência de trabalhos relacionados os dois temas. Nesse sentido, este estudo contribui para o fortalecimento do corpo de conhecimento sobre as tecnologias da $14.0 \mathrm{e}$

\section{REFERÊNCIAS}

[1] Albani, H.; Antunes, C.; Senna, P.; de Souza, L. A.; Monteiro, A. Determinação de métricas e mapeamento de riscos para a análise de cadeias de suprimentos enxutas. Journal of Lean Systems, v.1, n. 1, p. 31-50, 2016.

[2] Almada-Lobo, F. The Industry 4.0 revolution and the future of manufacturing execution systems (MES). Journal of Innovation Management, v. 3, n. 4, p. 16-21, 2016.

[3] Ballard, G., Tommelein, I., koskela, L. And Howell, G. Lean construction tools and techniques. In Design and Construction: Building in Value, $\mathrm{p}$. 227-255. Oxford: Butterworth-Heinemann, 2002.

[4] Cni, Brazil's National Confederation of Industry, Industry 4.0: a new challenge for Brazilian industry, CNI Indicators, v. 17, n. 2, 2016.

[5] Brettel, M.; Friederichsen, N.; Keller, M.; Rosenberg, M. How virtualization, decentralization and network building change the manufacturing landscape: An Industry 4.0 Perspective. International Journal of Mechanical, Industrial Science and Engineering, v. 8, n. 1, p. 37-44, 2014.

[6] Burch, V. R. F.; Smith, B. Using simulation to teach lean methodologies and the benefits for millennials. Total Quality Management \& Business Excellence, p. 1-15, 2017.

[7] Conger, S.; Miller, R. Problem-based learning for a lean six sigma course. University of Dallas, USA. Sprouts: Working Papers on Information Systems, v. 13, n. 1, 2013.
Lean pontuando suas características e aplicações em diferentes níveis do fluxo de valor.

No tocante as lacunas de pesquisa identificadas pela pesquisa, observou-se que até o momento a associação das tecnologias da 14.0 com PE estão focadas na solução de problemas pontuais da manufatura. Assim sendo, existem poucos estudos abordando aplicações das tecnologias da 14.0 e PE de uma forma mais completa, onde várias tecnologias e PE poderiam ser aplicadas em conjunto. Esse modelo de abordagem pode oferecer maiores benefícios e resultados aos sistemas produtivos. Além disso, uma visão mais holística tende a ser mais consistente visto que a aplicação de certas tecnologias oferece suporte à novas aplicações. Nesse sentido, propõe-se o desenvolvimento de trabalhos direcionados a este tipo de abordagem visando analisar o impacto das tecnologias e PE aplicadas em conjunto na manufatura.

[8] DEMO, P. Pesquisa e construção de conhecimento: metodologia científica no caminho de Habermas. Tempo Brasileiro, Rio de Janeiro, 2009.

[9] Dennis, Pascal. Produção Lean simplificada: Um guia para entender o sistema de produção mais poderoso do mundo. São Paulo: Bookman, 2008.

[10] Dickmann, P. Schlanker Materialfluss: mit Lean Production, Kanban und Innovationen. Springer- Verlag, 2008.

[11] Erlach, K. Value stream design: The way towards a lean factory, Berlin, New York, Springer, 2013. FERENHOF, H. A.; R.F. Fernandes. Desmistificando a revisão de literatura como base para redação científica: método SSF. Revista ACB: Biblioteconomia em Santa Catarina, v. 21, n. 3, p. 550-563, 2016.

[12] Fullerton, R. R.; Watters, M .C. The production performance benefits from JIT Implementation. A Journal of Operations Management, v. 19, p. 81-86, 2001.

[13] Gao, S.; Low, S. P. The Toyota Way model: an alternative framework for lean construction. Total Quality Management \& Business Excellence, v. 25, n. 5-6, p. 664-682, 2014.

[14] Getty, L. Ergonomics and the customer satisfaction model: ergonomics in the language of business. Proc HumFactors Ergon Soc Meet v. 43, n. 14, p. 815-819, 1999.

[15] Gjeldum, N.; Mladineo, M.; Veza, ।. Transfer of model of innovative smart factory to 
Croatian economy using lean learning factory, Procedia CIRP, v. 54, p. 158-163, 2016.

[16] Gligor, D. M.; Holcomb, M. C. Understanding the Role of Logistics Apabilities in Achieving Supply Chain Agility: A Systematic Literature Review, Supply Chain Management, v. 17, 2012.

[17] Grobner, M. Gemeinsamkeiten und Unterschiede von Just-in time-, Just-in-sequenceund One-piece- flow-Fertigungskonzepten. Schlanker Materialfluss mit Lean Production, Kanban und Innovationen, p. 14-17, 2007.

[18] Herlyn, W. J. PPS in der Automobilindustrie: Produktionsprogrammplanung von Fahrzeugen und Aggregaten. München, Carl Hanser, 2011.

[19] Hermann, M.; Pentek, T.; Otto, B. Design principles for Industrie 4.0 scenarios: A literature review. Conference Proceedings of 49th Hawaii International Conference on System Sciences, p. 3928-3937, 2016.

[20] Holm, M.; Ahlstrom, P. Lean Service - a literature review. Center for Innovation and Operations Management, p. 1-10, 2010.

[21] I-SCOOP. Industry 4.0: the fouth industrial revolution guide to Industrie 4.0. Disponível em:<https://www.i-scoop.eu/industry-4-0/> Acessado em 20/06/2017.

[22] Islam, S. R.; Kwak, D.; Kabir, M. H.; Hossain, M.; Kwak, K. S. The internet of things for health care: a comprehensive survey. IEEE Access, v. 3, p. 678-708, 2015.

[23] Jasti, N.; Kodali, R. Lean production: Literature review and trends. International Journal of Production Research, v. 53, n. 3, p. 867-885, 2015.

[24] KAGERMANN, H.; HELBIG, J.; HELLINGER, A.; WAHLSTER, W. Recommendations for implementing the strategic initiative INDUSTRIE 4.0: Securing the future of German manufacturing industry; final report of the Industrie 4.0 Working Group. Forschungsunion, 2013

[25] Kanigolla, D., Cudney, E., Corns, S. Enhancing engineering education using projectbased learning for lean and six sigma. International Journal of Lean Six Sigma, v. 5, n. 1, p. 45-61, 2014.

[26] Kolberg, D.; Zühlke, D. Lean automation enabled by industry 4.0 technologies. IFACPapersOnLine, v. 48, n. 3, p. 1870-1875, 2015.

[27] Kolberg, D.; Knobloch, J.; Zühlke, D. Towards a lean automation interface for workstations.

[28] International Journal of Production Research, v. 55, n. 10, p. 2845-2856, 2016
[29] KOTANI, S. Optimal method for changing the number of kanbans in the e-Kanban system and its applications. International Journal of Production Research, v. 45, n. 24, p. 5789-5809, 2007.

[30] KOURI, I. A.; SALMIMAA, T. J.; VILPOLA, I. $H$. The principles and planning process of an electronic kanban system. Novel algorithms and techniques in telecommunications, automation and industrial electronics. p. 99-104, 2008.

[31] Kumar, C. S.; Panneerselvam, R. Literature review of JIT-KANBAN system. The International Journal of Advanced Manufacturing Technology, v. 32, n. 3-4, p. 393-408, 2007.

[32] Lage Junior. M.; Godinho Filho, M. Variations of the kanban system: Literature review and classification. International Journal of Production Economics, v. 125, n. 1, p. 13-21, 2010.

[33] Landscheidt, S.; Kans, M. Automation practices in Wood product industries: lessons learned, current practices and future perspectives. Proceedings of the 7th Swedish Production Symposium SPS, p. 25-27, 2016.

[34] Lasi, H.; Fettke, P.; Kemper, H.G.; Feld, T.; Hoffmann, M. Industry 4.0. Business \& Information Systems Engineering, v. 6, 2014.

[35] Leonard, K. M.; Pakdil, F. Performance Leadership TM. Business Expert Press, 2016.

[36] Liker, J. K.; Franz, J. K. The Toyota way to continuous improvement: Linking strategy and operational excellence to achieve superior performance, v. 1, New York: McGraw-Hill, 2011.

[37] Martinez, F.; Jirsak, P.; LORENC, M. Industry 4.0. The end lean management? The 10th international Days of Statistics and Economics, p. 8-10, 2016.

[38] Mit Technology Review. Additive manufacturing GE, the world's largest manufacturer, is on the verge of using 3-D printing to make jet parts. Disponível em:

[39] <https://www.technologyreview.com/s/513 716/additive-manufacturing/> Acessado em 20/03/2018

[40] Ohno, T. O Sistema Toyota de Produção. Porto Alegre: Bookman, 1997.

[41] Posada, J.; Toro, C.; Barandiaran, I.; Oyarzun, D.; Stricker, D.; amicis, R.D. Visual

[42] Computing as a Key Enabling Technology for Industrie 4.0 and Industrial Internet. Computer Graphics and Applications, v. 35, 2015.

[43] PWC. 2016 Global industry 4.0 Survey: Building the Digital Enterprise, 2016. Disponivel em: <https:// www.pwc.com/industry40/> Acessado em 12/06/2017

[44] Radziwon, A.; Bilberga, A.; Bogersa, M.; Madsen, E.S. The Smart Factory: Exploring Adaptive and Flexible Manufacturing Solutions. 
International Symposium on Intelligent Manufacturing and Automation, v. 69, p. 11841190, 2014.

[45] Rother, M.; Shook, J. Learning to see: value stream mapping to add value and eliminate muda. Lean Enterprise Institute, 2003.

[46] Rubmann, M.; Lorenz, M.; Gerbert, P.; Waldner, M.; Justus, J.; Engel, P.; Harnisch, M.

[47] Industry 4.0: The future of productivity and growth in manufacturing industries. Boston Consulting Group, v. 9, 2015.

[48] Sanders, A.; Elangeswaran, C.; Wulfsberg, J. Industry 4.0 implies lean manufacturing: research activities in industry 4.0 function as enablers for lean manufacturing. Journal of Industrial Engineering and Management, v. 9, n. 3, p. 811833, 2016.

[49] Sanders, A.; Subramanian, K. R.; Redlich, T.; Wulfsberg, J. P. Industry 4.0 and Lean

[50] Management-Synergy or Contradiction?. International Conference on Advances in Production Management Systems, p. 341-349, 2017.

[51] Santorella, G. Lean culture for the construction industry: Building responsible and committed project teams. Taylor \& Francis, 2017.

[52] Santos, B. P.; Silva, L. A.; Celes, C. S.; Borges, J. B.; Neto, B. S. P.; Vieira, M. A. M.;

[53] Loureiro, A. A. Internet das coisas: da teoria a prática. Minicursos SBRC-Simpósio Brasileiro de Redes de Computadores e Sistemas Distribuídos, 2016

[54] Schein, E. H. Organizational Culture and Leadership (Jossey-Bass business \& management series). Jossey Bass Incorporated, 2004.

[55] Schonberger, R. J. Japanese production management: An evolution with mixed success. Journal of Operations Management, v. 25, n. 2, p. 403-419, 2007.

[56] Schumacher, A.; Erol, S.; Sinn, W. A maturity model for assessing Industry 4.0 readiness and maturity of manufacturing enterprises. Procedia CIRP, 52, 161-166, 2016.

[57] SHAH, R.; WARD, P. T. Lean manufacturing: context, practice bundles, and performance. Journal of operations management, $v$. 21, n. 2, p. 129-149, 2003
[58] Shah, R.; Ward, P.T. Defining and Developing Measures of Lean Production. Journal of operations management, v.25, p. 785-805, 2007.

[59] Shariatzadeh, N.; Lundholm, T.; Lindberg, L.; Sivard, G. Integration of digital factory with smart factory based on Internet of Things. Proceedings of 26th Design Conference, v. 50, p. 512-517, 2016.

[60] Simpson, D.F.; Power, D.J. Use the Supply Relationship to Develop Lean and Green Suppliers. Supply Chain Management, v. 10, n.1, p.60-68, 2005

[61] Tamas, P.; Illes, B.; Dobos, P. Waste reduction possibilities for manufacturing systems in the industry 4.0 .

[62] IOP Conference Series: Materials Science and Engineering, v. 161, n. 1, p. 12074, 2016.

[63] Taufik, M.; Jain, P. K. Role of build orientation in layered manufacturing: a review. International Journal of Manufacturing Technology and Management, v. 27, n. 1-3, p. 47-73, 2013.

[64] Womack, J. P.; Jones, D. T. Lean thinking banish waste and create wealth in your corporation. Journal of the Operational Research Society, v. 48, n. 11, p. 1148-1148, 1997.

[65] Womack, J. P.; Jones, D. T. A máquina que mudou o mundo. Rio de Janeiro: Campus, 2004.

[66] Xu, Y.; Chen, M. Improving Just-in-Time manufacturing operations by using Internet of Things based solutions. Proceedings of the 9th International Conference on Digital Enterprise Technology, v. 56, p. 326- 331, 2016.

[67] Yoon, J. S.; Shin, S. J.; Suh, S. H. A conceptual framework for the ubiquitous factory. International Journal of Production Research, v. 50, n. 8, p. 2174-2189, 2012.

[68] Zhang, Z.; Liu, G.; Jiang, Z.; Chen, Y. A cloud-based framework for lean maintenance, repair, and overhaul of complex equipment. Journal of Manufacturing Science and Engineering, v. 137 , n. 4, p. 040908, 2015

[69] Zhu, H.; Gao, J.; LI, D.; Tang, D. A Webbased Product Service System for aerospace maintenance, repair and overhaul services. Computers in Industry, v. 63, n. 4, p. 338-348, 2012 . 
APÊNDICE 1 - PB FINAL

\begin{tabular}{|c|c|}
\hline \multicolumn{2}{|r|}{ Artigo Do Pb } \\
\hline 1 & $\begin{array}{l}\text { Adeyeri, M. K.; Mpofu, K.; Olukorede, T. A. Integration of agent technology into manufacturing } \\
\text { enterprise: A review and platform for industry 4.O. In Industrial Engineering and Operations } \\
\text { Management (IEOM), } 2015 \text { International Conference, p. 1-10, } 2015 .\end{array}$ \\
\hline 2 & $\begin{array}{l}\text { Alias C.; Salewski, U.; Ruiz, V. E. O.; Olalla, F. E. A.; Reymão, J. D. E. N.; Noche, B. } \\
\text { Adapting Warehouse Management Systems to the Requirements of the Evolving Era of Industry 4.O. } \\
\text { Proceedings } 12 \text { th International Manufacturing Science and Engineering Conference, p. V003T04A051- } \\
\text { V003T04A051,2017. }\end{array}$ \\
\hline 3 & $\begin{array}{l}\text { Almada-Lobo, F. The Industry } 4.0 \text { revolution and the future of manufacturing execution systems (MES). } \\
\text { Journal of Innovation Management, v. } 3, \text { n. } 4, \text { p. } 16-21,2016 \text {. }\end{array}$ \\
\hline 4 & $\begin{array}{l}\text { Ang, J. H.; Goh, C.; LI, Y. Smart design for ships in a smart product through-life and industry } 4.0 \\
\text { environment. Evolutionary Computation (CEC), } 2016 \text { IEEE Congress on, p. 5301-5308, } 2016 .\end{array}$ \\
\hline 5 & $\begin{array}{l}\text { Arnold, C.; Kiel, D.; Voigt, K. I. How the industrial internet of things changes business models in different } \\
\text { Manufacturing industries. International Journal of Innovation Management, v. 20, n. 8, p. 1640015, } \\
2016 \text {. }\end{array}$ \\
\hline 6 & $\begin{array}{l}\text { Aydos, T. F.; Ferreira, J. C. Rfid-based system for lean manufacturing in the context of internet of things. } \\
\text { Automation Science and Engineering International Conference, p. 1140-1145, } 2016 .\end{array}$ \\
\hline 7 & $\begin{array}{l}\text { Bagheri, B.; YANG, S.; KAO, H. A.; LEE, J. Cyber-physical systems architecture for self-aware } \\
\text { machines in industry } 4.0 \text { environment. IFAC-Papers OnLine, v. 48, n. 3, p. 1622-1627, } 2015 .\end{array}$ \\
\hline 8 & $\begin{array}{l}\text { Bassi, L. Industry 4.0: Hope, hype or revolution?. Research and Technologies for Society and Industry, } \\
\text { p. 1-6, } 2017 .\end{array}$ \\
\hline 9 & $\begin{array}{l}\text { Bhamu J.; Singhk. Lean manufacturing: literature review and research issues. International Journal of } \\
\text { Operations Product Management, v. 34, n. } 7, \text { p. 876-940, } 2014 \text {. }\end{array}$ \\
\hline 10 & $\begin{array}{l}\text { Brettel, M.; Friederichsen, N.; Keller, M.; Rosenberg, M. How virtualization, } \\
\text { decentralization and network building change the manufacturing landscape: An Industry } 4.0 \\
\text { Perspective. } \\
\text { Internatinnal. Inırnal nf Merhaniral Indı ıctrial Srience and Fnnineering v } 8 \text { n } 1 \text { n } 37-44 \text { 2n14 }\end{array}$ \\
\hline 11 & $\begin{array}{l}\text { Brettel, M.; Klein, M.; Friederichsen, N. The relevance of manufacturing flexibility in the context of } \\
\text { Industrie 4.0. Procedia CIRP, v. 41, p. 105-110, } 2016 \text {. }\end{array}$ \\
\hline 12 & $\begin{array}{l}\text { Broy, M.; Cengarle, M. V.; Geisberger, E. Cyber-physical systems: imminent challenges. In Monterey } \\
\text { workshop, p. 1-28, 2012. }\end{array}$ \\
\hline 13 & $\begin{array}{l}\text { Butzer, S.; Kemp, D.; Steinhilper, R.; Schotz, S. Identification of approaches for remanufacturing 4.0. In } \\
\text { European Technology and Engineering Management Summit, p. 1-6, } 2016 .\end{array}$ \\
\hline 14 & $\begin{array}{l}\text { Chen, J. Y.; TAl, K. C.; CHEN, G. C. Application of Programmable Logic Controller to Build-up an } \\
\text { Intelligent Industry 4.0 Platform. Procedia CIRP, v. 63, p. 150-155, } 2017 .\end{array}$ \\
\hline 15 & $\begin{array}{l}\text { Chiang, Y.; Lee, D. Smart manufacturing with the Internet of makers. Journal of the Chinese Institute of } \\
\text { Engineers, v. 40, n. } 7, \text { p. 585-592, } 2017 \text {. }\end{array}$ \\
\hline 16 & $\begin{array}{l}\text { Chromjaková, F.; BOBÁK, R.; HRUSECKA, D. Production process stability-core assumption of industry } \\
4.0 \text { concept. IOP Conference Series: Materials Science and Engineering, v. 215, n. 1, p. 012024, } 2017 .\end{array}$ \\
\hline 17 & $\begin{array}{l}\text { DAVE, B.; KUBLER, S.; FRÄMLING, K.; KOSKELA, L. Opportunities for enhanced lean construction } \\
\text { management using Internet of Things standards. Automation in construction, v. 61, p. 86-97, } 2016 .\end{array}$ \\
\hline 18 & $\begin{array}{l}\text { Doh, S. W.; Deschamps, F.; de Lima, E. P. Systems integration in the lean manufacturing systems value } \\
\text { chain to meet industry } 4.0 \text { requirements. In ISPE TE, p. 642-650, } 2016 .\end{array}$ \\
\hline 19 & $\begin{array}{l}\text { Dombrowski, U.; Richter, T.; Krenkel, P. Interdependencies of industrie } 4.0 \text { \& lean production systems: } \\
\text { A use cases analysis. Proceedings of } 27 \text { th International Conference on Flexible Automation and } \\
\text { Intelligent Manufacturing, v. 11, p. 1061-1068, } 2017 .\end{array}$ \\
\hline 20 & $\begin{array}{l}\text { Edwards, P.; Ramirez, P. When should workers embrace or resist new technology?. New technology, } \\
\text { work and employment, v. 31, v. 2, p. 99-113, } 2016 \text {. }\end{array}$ \\
\hline 21 & $\begin{array}{l}\text { Eleftheriadis, M. S. R. J.; Myklebust, O. A guideline of quality steps towards zero defect manufacturing } \\
\text { in Industry. In } 2016 \text { International Conference on Industrial Engineering and Operations Management, } \\
2016 .\end{array}$ \\
\hline
\end{tabular}


(continuação...)

Erol, S.; Jager, A.; Hold, P.; OTT, K; Sihn, W. Tangible industry 4.0: a scenario-based approach to

22 learning for the future of production. Proceedings of 6th Conference on Learning Factories, v. 54, p. 13-18, 2016.

23

Esmaeilian, B.; Behdad, S.; WANG, B. The evolution and future of manufacturing: A review. Journal of Manufacturing Systems, v. 39, p. 79-100, 2016.

Fera, M.; Macchiaroli, R.; Fruggiero, F.; Lambiase, A.; Miranda, S. Application of a

24 business process model (BPM) method for a warehouse RFId system implementation. International Journal of RF Technologies, v. 8, n. 1-2, p. 57-77, 2017.

25 Gao, Q.; SHI, R.; Wang, G. Construction of intelligent manufacturing workshop based on lean management. Procedia CIRP, v. 56, p. 599-603, 2016.

Giaimo, F.; Yin, H.; Berger, C.; Crnkovic, I. Continuous experimentation on cyber-physical systems:

26 challenges and opportunities. Proceedings of the Scientific Workshop Proceedings of XP 2016, p. 14, 2016.

Gronau, N. Determinants of an appropriate degree of autonomy in a cyber-physical production

27 system.Proceedings of 52th Changeable, Agile, Reconfigurable \& Virtual Production, v. 52, p. 1-5, 2016.

28 Karakose, M.; Yetis, H. A Cyberphysical System Based Mass-Customization Approach with Integration of Industry 4.0 and Smart City. Wireless Communications and Mobile Computing, 2017.

KERN, W.; RUSITSCHKA, F.; KOPYTYNSKI, W.; KECKL, S.; BAUERNHANSL, T. Alternatives to

29 Assembly line production In the Automotive Industry. In The 23rd International Conference on Production Research, p. 1-9, 2015.

30 Kibira, D.; Morris, K.; Kumaraguru, S. Methods and tools for performance assurance of smart manufacturing systems. National Institute of Standards and Technology, v. 121, p. 281-313, 2015.

Kiel, D.; Muller, J. M.; Arnold, C.; Voigt, K. I. Sustainable industrial value creation: benefits and

31 challenges of idustry 4.0. International Journal of Innovation Management, v. 21, n. 8, p. 17400152017

32

Kirazli, A.; Hormann, R. A conceptual approach for identifying Industrie 4.0 application scenarios. In IIE Annual Conference. Proceedings, p. 862, 2015.

Kolberg, D.; Berger, C.; Pirvu, B. C.; Franke, M.; Michniewicz, J. Insights from a

33 Framework for designing cyber-physical systems in production environments. Proceedings of the 49th Conference on Manufacturing Systems, v. 57, p. 32-37, 2016b.

KOLBERG, D.; KNOBLOCH, J.; ZÜHLKE, D. Towards a lean automation interface for workstations. International Journal of Production Research, v. 55, n. 10, p. 2845-2856, $2016 \mathrm{a}$.

35 Kolberg, D.; Zühlke, D. Lean automation enabled by industry 4.0 technologies. IFAC-Papers OnLine, v. 48, n. 3, p. 1870-1875, 2015.

36 KUSTERS, D., PRAB, N.; GLOY, Y. S. Textile learning factory 4.0-preparing Germany's textile industry for the digital future. Procedia Manufacturing, v. 9, p. 214-221, 2017.

37 Lee, C. K. M.; Zhang, S. Z.; NG, K. K. H. Development of an industrial Internet of things suite for smart factory towards re-industrialization. Advances in Manufacturing, v. 5, n. 4, p. 335-343, 2017.

38 Lee, J.; Bagheri, B.; Kao, H. A. A cyber-physical systems architecture for industry 4.0-based manufacturing systems. Manufacturing Letters, v. 3, p. 18-23, 2015.

39 Lee, J.; Bagheri, B.; Kao, H. A. A cyber-physical systems architecture for industry 4.0-based manufacturing systems. Manufacturing Letters, v. 3, p. 18-23, 2015.

40 Lee, M. X.; Lee, Y. C.; Chou, C. J. Essential implications of the digital transformation in industry 4.0. Journal of Scientific \& Industrial Research, v. 76, p. 465-467, 2017.

Liao, Y.; Deschamps, F.; Loures, E. D. F. R.; Ramos, L. F. P. Past, present and future of Industry 4.0-a

41 systematic literature review and research agenda proposal. International Journal of Production Research, v. 55, n. 12, p. 3609-3629, 2017.

Marjani, M.; Nasaruddin, F.; Gani, A.; Karim, A.; Hashem, I. A. T.; Siddiqa, A.;

42 Yaqoob, I. Big loT data analytics: Architecture, opportunities, and open research challenges. IEEE Access, v. 5, p. 5247-5261, 2017. 
(continuação...)

43 Martinez, F.; Jirsak, P.; Lorenc, M. Industry 4.0. the end lean management? The 10th international Days 43 of statistics and Economics, p. 8-10, 2016.

44 Micieta, B.; Hercko, J.; Botka, M.; Zrnic, N. Concept of intelligent logistic for automotive industry. Journa of Applied Engineering Science, v. 14, n. 2, p. 233-238, 2016

Mora, E.; Gaiardelli, P.; Resta, B.; Powell, D. Exploiting lean benefits through smart manufacturing: a

45 comprehensive perspective. In IFIP International Conference on Advances in Production Management Systems, p. 127-134, 2017

46

Mourtzis, D.; Zogopoulos, V.; Vlachou, E. Augmented reality application to support remote maintenance as a service in the Robotics industry. Procedia CIRP, v. 63, p. 46-51, 2017.

Mrugalska, B.; Wyrwicka, M. K. Towards lean production in industry 4.0. Proceedings of the 7th

47 International Conference on Engineering, Project, and Production Management, v. 182, p. 466- 473, 2017.

48

Neugebauer, R.; Hippmann, S.; LEIS, M.; LANDHERR, M. Industrie 4.0-From the perspective of applied research, Proceedings of the 49th Conference on Manufacturing Systems, v. 57, p. 2-7, 2016.

49 Nunes, M. L.; Pereira, A. C.; Alves, A. C. Smart products development approaches for industry 4.0. Procedia Manufacturing, v. 13, p. 1215-1222, 2017.

50 Prinz, C.; Morlock, F.; Freith, S.; Kreggenfeld, N.; Kreimeier, D.; Kuhlenkotter,

50 B. Learning Factory modules for smart factories in Industrie 4.0. Procedia CIRP, v. 54, p. 113-118, 2016.

Radziwon, A.; Bilberga, A.; Bogersa, M.; MADSEN, E.S. The smart factory: exploring adaptive and

51 flexible manufacturing solutions. International Symposium on Intelligent Manufacturing and Automation, Ranz, F.; Schuhmacher, J.; Hummel, V. Competence development for collaborative work systems in

52 learning factories. In IIE Annual Conference. Proceedings Institute of Industrial and Systems Engineers, REN, L.; ZHANG, L.; TAO, F.; ZHAO, C.; CHAI, X.; ZHAO, X. CLoud manufacturing: from concept to

53 practice. Enterprise Information Systems, v. 9, n. 2, p. 186-209, 2015.

54 Rodseth, H.; Schjolberg, P.; Marhaug, A. Deep digital maintenance. Advances in Manufacturing, v. 5, n. 4, p. 299-310, 2017.

55 Rong, W.; Vanan, G. T.; Phillips, M. The internet of things (IoT) and transformation of the smart factory. In Electronics Symposium (IES) 2016 International, p. 399-402, 2016.

56 Rubmann, M.; Lorenz, M.; Gerbert, P.; Waldner, M.; Justus, J.; Engel, P.; Harnisch,

56 M. Industry 4.0: The future of productivity and growth in manufacturing industries. Boston Consulting Sackey, S. M.; Bester, A.; Adams, D. Industry 4.0 learning factory didactic design parameters for

57 industrial engineering education in South Africa. South African Journal of Industrial Engineering, v. 28, Sanders, A.; ELANGA 1 ESWARAN, C.; Wulfsberg, J. Industry 4.0 implies lean manufacturing: research

58 activities in industry 4.0 function as enablers for lean manufacturing. Journal of Industrial Engineering Sanders, A.; Subramanian, K. R.; Redlich, T.; Wulfsberg, J. P. Industry 4.0 and lean

59 management-synergy or contradiction?. International Conference on Advances in Production Saniuk, S.; Saniuk, A. Decision support system for rapid production order planning in production

60 network. In International Conference on Intelligent Systems in Production Engineering and Maintenance, Schuh, G.; Potente, T.; Wesch-Potente, C.; Weber, A. R.; Prote, J. P. Collaboration

61 mechanisms to increase productivity in the context of industrie 4.0. Procedia CIRP, v. 19, p. 51-56, Schumacher, A.; Erol, S.; Sihn, W. A maturity model for assessing industry 4.0 readiness and maturity of 62 manufacturing enterprises. Procedia CIRP, v. 52, p. 161-166, 2016.

63

Schumacher, A.; Erol, S.; Sinn, W. A maturity model for assessing Industry 4.0 readiness and maturity of manufacturing enterprises. Procedia CIRP, v. 52, p. 161-166, 2016.

64

Schumacher, A.; Erol, S.; Sinn, W. A maturity model for assessing Industry 4.0 readiness and maturity of manufacturing enterprises. Procedia CIRP, v. 52, p. 161-166, 2016.

Shariatzadeh, N.; Lundholm, T.; Lindberg, L.; Sivard, G. Integration of digital factory with smart factory based on Internet of Things. Proceedings of 26th Design Conference, v. 50, p. 512- 517, 2016. 
(continuação...)

\begin{tabular}{|c|c|}
\hline 66 & $\begin{array}{l}\text { Shih, L. H.; Lee, Y. T.; Huarng, F. Creating customer value for product service systems by incorporating } \\
\text { internet of things technology. Sustainability, v. } 8, n \text {. } 12, \text { p. } 1217,2016 \text {. }\end{array}$ \\
\hline 67 & $\begin{array}{l}\text { Spath, D.; Gerlach, S.; Hammerle, M.; Schlund, S.; Strolin, T. Cyber-physical system for } \\
\text { self-organised and flexible labour utilisation. Proceedings of the 22nd International Conference on } \\
\text { Production Research, v. 50, n. 22, } 2013 \text {. }\end{array}$ \\
\hline 68 & $\begin{array}{l}\text { Stojkic, Z.; VEZA, I.; BOSNJAK, I. Concept of information system implementation (crm and erp) within } \\
\text { industry 4.0. In 26th DAAAM International Symposium on Intelligent Manufacturing and Automation, p. } \\
912-919,2016 \text {. }\end{array}$ \\
\hline 69 & $\begin{array}{l}\text { Strandhagen, J. W.; Alfnes, E.; Strandhagen, J. O.; Vallandingham, L. R. The fit of } \\
\text { industry } 4.0 \text { applications in manufacturing logistics: a multiple case study. Advances in Manufacturing, } \\
\text { v.5, n. 4, p. 344-358, } 2017 \text {. }\end{array}$ \\
\hline 70 & $\begin{array}{l}\text { Strueker, J.; Weppner, H. A Cloud-based Messaging Service for Cross-Enterprise Data Exchange with } \\
\text { Smart Objects. Proceedings in Association for Information Systems, } 2012 .\end{array}$ \\
\hline 71 & $\begin{array}{l}\text { TAMÁS, P. Decision support simulation method for process improvement of intermittent production } \\
\text { systems. Applied Sciences, v.7, n. 9, p. 950, } 2017 \text {. }\end{array}$ \\
\hline 72 & $\begin{array}{l}\text { Tamás, P.; ILLÉS, B. Process improvement trends for manufacturing systems in industry 4.0. Academic } \\
\text { Journal of Manufacturing Engineering, v. 14, n. 4, } 2016 .\end{array}$ \\
\hline 73 & $\begin{array}{l}\text { Tamás, P.; Illés, B.; Dobos, P. Waste reduction possibilities for manufacturing systems in the industry } \\
\text { 4.0. In IOP Conference Series: Materials Science and Engineering, v. 161, n. 1, p. 012074, } 2016 .\end{array}$ \\
\hline 74 & $\begin{array}{l}\text { Tao, F.; ZHANG, L.; Venkatesh, V. C.; LUO, Y.; CHENG, Y. Cloud manufacturing: a computing and } \\
\text { service-oriented manufacturing model. Proceedings of the Institution of Mechanical Engineers, Part B: } \\
\text { Journal of Engineering Manufacture, v. 225, n. 10, p. 1969-1976, } 2001 .\end{array}$ \\
\hline 75 & $\begin{array}{l}\text { Trstenjak, M.; Cosic, P. Process planning in Industry } 4.0 \text { environment. Procedia Manufacturing, v. 11, p. } \\
\text { 1744-1750, } 2017 .\end{array}$ \\
\hline 76 & $\begin{array}{l}\text { VALMOHAMMADI, C. Examining the perception of Iranian organizations on internet of things solutions } \\
\text { and applications. Industrial and Commercial Training, v. } 48, \text { n. 2, p. 104-108, } 2016 \text {. }\end{array}$ \\
\hline 77 & $\begin{array}{l}\text { Villalba. D. J.; Ordieres, M. J. B.; Nuber, G. The Hoshin Kanri Tree. cross-plant lean shopfloor } \\
\text { management. Proceedings of the 5th Conference on Learning Factories, v. 32, p. 150-155, } 2015 .\end{array}$ \\
\hline 78 & $\begin{array}{l}\text { Wagner, T.; Herrmann, C.; Thiede, S. Industry } 4.0 \text { impacts on lean production systems. } \\
\text { Proceedings of the 50th Conference on Manufacturing Systems, v. 63, p. 125-131, } 2017 .\end{array}$ \\
\hline 79 & $\begin{array}{l}\text { WEYER, S.; SCHMITT, M.; OHMER, M.; GORECKY, D. Towards industry } 4.0 \text {-standardization as the } \\
\text { crucial challenge for highly modular, multi-vendor production systems. Ifac-Papersonline, v. } 48, \text { n. 3, p. } \\
579-584,2015 \text {. }\end{array}$ \\
\hline 80 & $\begin{array}{l}\text { Wiech, M.; Bollhoff, J.; Metternich, J. Development of an optical object detection solution for defect } \\
\text { prevention in a Learning Factory. Procedia Manufacturing, v. 9, p. 190-197, } 2017 .\end{array}$ \\
\hline 81 & $\begin{array}{l}\text { XU, R.; Yang, L.; Yang, S. H. Architecture design of internet of things in logistics management for } \\
\text { emergency response. In Green Computing and Communications (GreenCom), IEEE and Internet of } \\
\text { Things (iThings/CPSCom), IEEE International Conference on e IEEE Cyber, Physical and Social } \\
\text { rnmmiting } n \text { 205 }\end{array}$ \\
\hline 82 & $\begin{array}{l}\text { XU, Y.; Chen, M. Improving just-in-time manufacturing operations by using internet of things based } \\
\text { solutions. Proceedings of the 9th International Conference on Digital Enterprise Technology, v. 56, p. } \\
326-331,2016 \text {. }\end{array}$ \\
\hline 83 & $\begin{array}{l}\text { Yoon, J. S.; Shin, S. J.; Suh, S. H. A conceptual framework for the ubiquitous factory. International } \\
\text { Journal of Production Research, v. 50, n. 8, p. 2174-2189, } 2012 \text {. }\end{array}$ \\
\hline
\end{tabular}


(continuação...)

Zhang, Z.; Liu, G.; Jiang, Z.; Chen, Y. A cloud-based framework for lean maintenance, repair, and 84 overhaul of complex equipment. Journal of Manufacturing Science and Engineering, v. 137, n. 4, p 040908, 2015. 138, 2010. 


\section{Bapítulo 17}

\section{ANÁLISE DA FILOSOFIA LEAN MANUFACTURING NA COMPARACÃO DE UMA MÁQUINA SEMIAUTOMÁTICA COM UMA AUTOMATICA NA PRODUCCÃO DE BLOCOS DE CONCRETO E A VIABILIDADE DA UTILIZACÃO POKA YOKE NA REDUÇÃO DE DESPERDICIO: ESTUDO DE CASO}

\section{Cleber Henrique Cota}

Fábio Silva Abreu

Maicon Sulivan da Cruz

\section{Rafaelle de Oliveira Almeida}

Wilson Luigi Silva

Resumo: A automação de processos é um modo que muitas empresas encontraram de melhorar fabricação de seus produtos. Os benefícios são significativos para atingir o aumento da produtividade através de ciclos de produção mais rápidos, com eficiência e com uma qualidade superior. São capacitados para fornecer respostas consistentes eliminando os problemas de controle de qualidade envolvidos com o erro humano e os processos podem ser cautelosamente regulados e controlados. Esta pesquisa trata da análise através do Lean Manufacturing de comparação entre duas máquinas sendo uma semiautomática e outra automática em uma das maiores empresas de blocos de concreto da região metropolitana de Belo Horizonte e como o poka yoke pode reduzir possíveis desperdícios na produção do bloco. Ao final deste estudo, observou-se que os resultados mostram como a máquina automática aumenta a produtividade de blocos em um menor tempo de fabricação e melhora na qualidade do bloco. Metodologias e ferramentas como poka yoke, kaizen, 8S auxiliaram na identificação dos pontos na empresa.

Palavras-chave: Automação. Blocos. Comparação. Lean Manufacturing. Poka Yoke. 


\section{INTRODUÇ̃̃O}

A alvenaria estrutural é um material de construção tradicional que tem sido usado há milhares de anos (DUARTE, 1999) e com o tempo ela foi se modernizando. A utilização dos blocos de concreto aumenta a durabilidade da construção, reduz custos, aumenta a produtividade, além de ser considerada menos agressiva ao meio ambiente por não necessitar da queima no seu processo produtivo.

O aumento da produtividade com máquinas já acontece há muito tempo, desde a época da Revolução Industrial, em que máquinas substituíram o trabalho humano. Com o passar do tempo, houve a inovação em vários setores, inclusive na fabricação de blocos de concreto, na qual o processo produtivo, através de máquinas automáticas, mudou completamente o cenário de empresas. Houve melhoras na qualidade do produto, otimização do produto e redução do desperdício. Com isso, as empresas de fabricação de bloco de concreto puderam ter maior competitividade no mercado, melhorar os preços dos produtos a fim de aumentar os lucros e, consequentemente, a satisfação de seus clientes internos e externos.

A gestão de desperdício tem sido grande preocupação de gerentes, engenheiros, administradores e de todas as pessoas envolvidas direta ou indiretamente às áreas produtivas, pelo simples fato do produto final ter um poder aquisitivo mais em conta.

Há muito tempo, o Lean Manufacturing é uma iniciativa que busca eliminar desperdícios, isto é, excluir o que não tem valor para o cliente e alavancar a velocidade da produtividade com resultados melhores para a empresa que possui um sistema automatizado. Afinal o que de fato é o Lean Manufacturing?

A origem de o Lean Manufacturing nasceu da necessidade das empresas japonesas no setor automobilístico, no Sistema Toyota de Produção, de inovar técnicas na produção de veículos diferentemente do que já existia na época. Taiichi Ohno foi um executivo que, iniciou na década dos anos 1950, a criação e implantação de um sistema de produção em que $\mathrm{o}$ foco era identificar e eliminar os desperdícios, obtendo a redução de custos e aumentando a qualidade dos produtos. Empresas automatizadas e com produção contínua têm resultados melhores com a implantação desse sistema.
Dentro do Lean Manufacturing, Taiichi Ohno identificou sete tipos de desperdícios, sendo eles: irregularidade nos produtos, quantidade excessiva de produção, estoques de mercadorias, transporte desnecessários, processamento inapropriado, movimento irrelevante de pessoas e espera de funcionários para finalizar o trabalho ou atividade anterior.

Este Trabalho de Conclusão de Curso pretende apresentar um estudo de caso sobre como a automatização alavancou o processo produtivo de uma empresa de produção de blocos de concreto, com o objetivo de realizar estudos por meio da filosofia Lean Manufacturing, comparar 0 processo semiautomático com o automático, e, possivelmente, identificar os desperdícios por meio do poka yoke.

\subsection{CONTEXTO DO PROBLEMA}

Segundo Andrade (2015) nos últimos tempos, "o Brasil está vivendo um momento crítico, isso não é novidade para ninguém, o dólar disparou e o mercado interno perdeu competitividade. Por isso que o governo está equivocado em adotar medidas que estão promovendo o estrangulamento da nossa economia nacional, o que vem prejudicando, gravemente nosso setor industrial, que é uma das locomotivas para o desenvolvimento brasileiro, gerando empregos de qualidade e impulsionando, positivamente, outros setores da economia". Devido ao que Andrade (2015) relatou, muitas empresas estão recorrendo a várias ferramentas ou filosofias para que continuem no mercado. E uma dessas filosofias, que vem aumentando a implantação em todos os setores industriais e de serviços é o Lean Manufacturing. Vale lembrar que a implantação dessa filosofia atua em um processo de oscilação na cultura da própria empresa e, desta forma, não é algo simples de ser aplicado.

Nos últimos meses de 2015, o mercado está cada vez mais difícil de sobreviver. Empresas estão deixando de existir, muitas vezes por não inovar no seu processo produtivo. Então para melhorar o escoamento da produção, grande parte das empresas do setor da construção civil está investindo em tecnologia, para acompanhar o mercado e principalmente seu concorrente.

Para a empresa tornar-se competitiva e reduzir ao máximo o seu custo no produto 
final, deve-se buscar meios que reduzam o tempo de movimentação, os custos de produção, resíduos e o retrabalho com perda de matéria-prima em seu processo, sem perder a eficácia no atendimento do mercado. De acordo com o Sindicato das Indústrias de Produtos de Cimento do Estado de Minas Gerais (SIPROCIMG) existem aproximadamente 155 empresas que produzem blocos de concreto, localizado na grande Belo Horizonte.

Empresa que atua na fabricação de blocos de concreto que, no caso, é o objeto de pesquisa, apresenta dificuldades em reduzir o desperdício de matéria-prima gerado na produção dos blocos de concreto manual ou semiautomático, que muitas vezes são pelos motivos: arranjo físico inadequado, matriz para fabricação do bloco desgastada, tábua do bloco danificada.

Com isso, existem filosofias e ferramentas que, se empregadas, podem auxiliar no fluxo para que se atinja um resultado satisfatório, como por exemplo: o desenvolvimento de um estudo através da filosofia Lean Manufacturing na empresa de fabricação de blocos juntamente com a comparação de uma máquina semiautomática com uma totalmente automática. Tudo isso como forma de comparar como a automatização melhorou o processo de fabricação de blocos e como o poka yoke pode reduzir ou eliminar possíveis desperdícios gerados durante $\mathrm{o}$ processo produtivo.

\subsection{PROBLEMA DE PESQUISA}

Como estudos por meio da filosofia Lean Manufacturing contribuíram na comparação de duas máquinas sendo uma semiautomática e outra automática, com identificação de possíveis pontos de desperdícios através do poka yoke?

\subsection{OBJETIVOS}

\subsubsection{OBJETIVO GERAL}

Realizar estudos por meio da filosofia Lean Manufacturing e mapear processo da máquina semiautomática e automática identificando possíveis pontos de desperdícios através do poka yoke.

\subsubsection{OBJETIVOS ESPECÍFICOS}

a) Mapear o processo de produção nas máquinas semiautomática e automática;

b) Comparar a máquina semiautomática com a automática por meio do Lean Manufacturing;

c) Identificar os pontos de melhoria e ganho de produtividade;

d) Identificar possíveis desperdícios produtivos através do poka yoke.

\subsection{JUSTIFICATIVA}

A metodologia operacional de uma determinada empresa é fundamental na decisão para o controle de qualidade, custo do produto e quantidade a ser produzido, procurar obter o máximo da eficiência dos equipamentos, a eficácia e efetividade da produção e procurar o diferencial no mercado cada vez mais competitivo.

Para acompanhar o mercado, é importante para as empresas desenvolver métodos inovadores na produção e implantar novas gestões para continuar no mercado, e uma delas é o Lean Manufacturing. Espera-se aplicar este estudo na comparação de um processo semiautomático e outro automático, diminuir os custos na fabricação do bloco de concreto e reduzir ou eliminar possíveis desperdícios por meio do poka yoke.

Equipamentos, máquinas e tecnologias envolvidas no processo produtivo são de responsabilidade de um determinado setor da empresa, no qual esses são reparados e modificados, quando necessário, a fim de garantir seu melhor aproveitamento. É de importância salientar que as participações dos colaboradores fazem toda a diferença nessa nova gestão, uma vez que, a necessidade de novas ideias parte dos colaboradores, que estão continuamente, observando o que pode ser melhorado no processo produtivo.

Este estudo é importante também para a sociedade pelo fato de mostrar como a tecnologia poderá obter resultados significativos na área da construção civil, sendo beneficiada com melhores preços na aquisição do bloco e, consequentemente, na redução do valor do produto final.

O estudo de caso proporciona uma ampla visão de aplicação de ferramentas e técnicas de gestão na prática, criando a oportunidade para o Engenheiro de Produção inserir os 
conhecimentos acadêmicos, qualificando-se para atuar com responsabilidade em qualquer das áreas do curso.

\section{REFERENCIAL TEÓRICO}

A evolução dos sistemas de produção iniciouse no século $X X$, em que estabeleceu as primeiras especializações da produção e do trabalho. As empresas começaram a racionalizar as máquinas, reduzir a força de trabalho e, consequentemente, aumentar o volume de produção. Durante anos, houve a evolução dos sistemas de produção, buscando, cada vez mais, aumentar a produtividade e reduzir o custo. Hoje, no século XXI, as empresas melhoram gradativamente seu processo produtivo através das mais variadas ferramentas e filosofias já existentes.

Nesta parte do estudo, será explicado como surgiram os sistemas de produção, quem foram os autores consagrados, quais as principais ferramentas utilizadas, como o processo produtivo evoluiu e os problemas, como, desperdício, que as empresas devem ficar atentas.

\subsection{EVOLUÇÃO DO SISTEMA DE PRODUÇÃO}

Primeiramente, é preciso definir o que é produção, e segundo Shingo (1989) é uma rede de processos e operações, no qual tudo que entra (input) se transforma e saí (output) um produto ou serviço.

Por volta de 1780, os sistemas de produção eram artesanais, ou seja, a produção em todos os estágios era realizada, na maioria das vezes, por uma pessoa, no caso, o artesão. Como a demanda aumentou, os artesãos não conseguiam atender a toda sua clientela, surgindo assim a manufatura, no qual cada artesão trabalhava em uma etapa do processo produtivo do produto/serviço. Tempos depois, ocorreu a Revolução Industrial, em que houve o aumento da produção e reduziu a mão de obra. Com isso, máquinas dos diferentes tipos surgirão, evoluindo os processos de produção. Assim começou a aparecer especialistas que inovaram a produção, começando por Frederick Taylor.

Em torno de 1901, coube a Frederick Taylor, o pioneiro no desenvolvimento de técnicas efetivas, sistematizar o estudo e a análise do trabalho. Taylor propôs o uso de Scientific Management.

De acordo com Motta (2000), Scientific management significa administração científica e sua principal característica é a organização e divisão de tarefas dentro de uma empresa com o objetivo de obter o máximo de rendimento e eficiência com o mínimo de tempo e atividade.

Taylor (1990) dividiu suas ideias em fases. Em uma primeira fase, projetou três princípios básicos, que apontou a obtenção de uma mão de obra mais ágil, mas estimulou-se o operário com salários mais altos:

a) Atribuir a cada operário a atividade mais elevada que permitisse mais disposição;

b) Buscar o máximo de produção que cada operário conseguisse e esperar de um operário proficiente de sua categoria;

c) Para cada operário, que fornecesse uma soma alta de trabalho, haveria um pagamento 30 a 50\% superior à média dos colaboradores de sua categoria.

A segunda fase desenvolveu outras ideias/objetivos, mais gerais:

a) Desenvolver uma ciência que houvesse uma divisão de trabalho, lugar dos métodos frequentes;

b) Selecionar o melhor operador para cada categoria e, em seguida, prepará-lo, ensiná-lo e formá-lo, em posição à prática normal de deixar para ele a função que preferir se formar;

c) Destacar as funções de preparar e planejar a realização do trabalho, explicando-as aos trabalhadores nas funções adequadas;

d) Especificar os trabalhadores nas funções adequadas:

e) Preestabelecer tarefas individuais do trabalhador e oferecer prêmios quando executado;

f) Monitorar o andamento do trabalho.

Através dessas fases, é que Taylor propôs a proposta de tempos e movimentos, a qual era verificar com a máxima precisão possível os tempos fundamentais para realizar algum movimento feito pelos trabalhadores a cada processo produtivo.

Outro especialista foi Ford, que segundo Maximiano (2007), Henry Ford começou quando ainda era jovem. Aos 12 anos, já ocupava grande parte do seu tempo livre em uma pequena loja de máquinas equipada por 
ele próprio. Foi nessa loja que, em 1878 e com 15 anos, construiu o seu primeiro motor a vapor.

Em 1908, enquanto a indústria automobilística americana produzia apenas 65.000 automóveis por ano, Durant já previa uma produção de 1 milhão de carros por ano e Ford já tinha encontrado um meio de tornar realidade aquela visão: "seu Modelo T" (SLOAN Jr., 1999, p.31)

Construirei um carro para as grandes massas, feito com os melhores materiais, pelos melhores homens que puderem ser contratados e seguindo os projetos mais simples que a moderna engenharia puder conceber [...] de preço tão baixo que qualquer homem que ganhe um bom salário seria capaz de possuir - e de desfrutar com sua família a bênção das horas de prazer nos grandes espaços abertos da natureza (Declaração de Henry Ford no início da carreira como produtor de carros) (TEDLOW, 2002, p.31).

Segundo Luiz (2005), Ford encontrou um meio de aumentar a produção, através do "Modelo T". Em 1908, produziu 65 mil unidades de carros. Quase vinte anos depois, em 1927, Ford vendeu mais de 15 milhões de carros, sendo que no Brasil essa quantidade de produção chegou ao ano de 2005, observa-se que esse avanço na produção já vem de muito tempo.

Com o avanço da produção, Ford acrescentou a padronização dos produtos, além de fazer com que os mesmos se movam enquanto estações de trabalho ficam paralisadas (linha de montagem móvel), com isso houve um grande aumento de produtividade, por meio dos princípios da administração científica de Taylor.

Outro sistema de produção existente é o SPE (sistema de produção enxuta) que se define Produção Enxuta como sendo uma forma de otimizar a produção através de vários fatores que, quando alinhados, acabam por possibilitar um melhor desempenho do sistema produtivo como um todo. Entre estes fatores estão itens como redução dos tempos de fabricação e dos estoques, flexibilização, trabalhadores multifuncionais, diminuição das perdas e produção puxada pela demanda e a busca constante para eliminar qualquer perda que não gere valor agregado aos produtos (WOMACK; JONES, 2004; GHINATO, 2000; MOREIRA, 2008).
$\mathrm{Na}$ década de 1980, surge a produção impulsionada no qual os clientes é que determinam as linhas de produção. Não são as empresas que determinam os produtos para o mercado, mas os clientes que determinam a qualidade, custo e tempo (FRANCIO, 2008, p.2)

Foi observado que de tempos em tempos está havendo uma melhoria na produção, seja na linha de montagem, na preocupação com estoques ou, até mesmo, na qualidade do produto.

Na década de 1990, as empresas começam a se preocupar com a economia de escopo, a flexibilidade, variabilidade, simplicidade e melhoria contínua (FRANCIO, 2008, p.2).

Um tipo de sistema que auxilia a produção é o Just in case, no qual mesmo que não tenha demanda, há produção.

\subsubsection{JUST IN CASE.}

Henry Ford foi um dos idealizadores do sistema de produção de automóveis que empurrou, como embasamento para as linhas de montagem, uma filosofia de produção em grande escala e com ampla propulsão para superprodução. Diante deste fato histórico, em 1907, Henry Ford lançou seu primeiro automóvel modelo T, e após seis anos já havia mais de quinhentos mil veículos do modelo em questão circulando pelas ruas, chegando a quase 20 anos de fabricação (1908 a 1927), atingir a marca de 15 milhões de carros produzidos. A forma de produção era em massa, pois o importante era produzir e fazer encher seus estoques de produtos. Desta forma, se houvesse algum cliente que solicitasse seu produto, ele já teria em mãos para pronta entrega, mas que segue os padrões e características predefinidos e que não alteravam caso aparecesse qualquer necessidade extra ao que era feito, conforme exposto por Corrêa; Corrêa (2007).

Para Santos (2003), o que Ford realizou foi agrupar um conjunto de recursos e conceitos já disponíveis naquele tempo:

A produção estandardizada de espingardas já se fazia nos finais do Séc. XVIII; Os matadouros de Chicago já usavam as movinglines por volta de 1860; A produção em série de carros já era conhecida no princípio do Séc. XX (por ex., era praticada pela Oldsmobile, um dos quatro construtores que deram origem à General Motors, em 
1908); Taylor já tinha teorizado e posto em prática os seus princípios do scientific management (SANTOS, 2003, p.29).

Com isso, Ford teve um embasamento dos conceitos aplicados por Taylor e outros idealizadores da época, tendo como premissa agregar as ideias instituídas pelos mesmos, através da sua visão sistemática e holística. Isso gera uma produção de grande escala, a qual esta metodologia ficou conhecida em Just in case.

Segundo Gusmão (1998), Just in case é uma metodologia que se utiliza de seus recursos de produção, levando a capacidade máxima de se produzir, adiantando a demanda futura perante a forma de estoques. Este conceito não desenvolve esforços nem para eliminar as variabilidades nem para balancear as capacidades produtivas, pois o objetivo é operar e produzir o tempo todo na sua máxima capacidade, em que sua cadência de produção é ditada pela capacidade acumulada do primeiro processo, que "empurra" a produção no sentido aos processos consecutivos, resultando estoques consecutivamente mais alto do que necessário.

No Just in case é comum instituir estoques entre os estágios do processo, pois se observou que dentro de uma das etapas do processo produtivo poderá ocorrer paradas produtivas e gerar, nas demais partes do processo de produção, continuidade de produzir em demasia. Com isso, acabam criando estoques intermediários dentro da cadeia de produtiva, conforme Gusmão (1998).

Para Corrêa; Corrêa (2007) com o passar dos anos, esse sistema passou a ter alterações consideráveis pelo fato de ter acontecido alguns eventos na época (crise da bolsa de valores de Nova York e segunda Guerra Mundial), que impactaram diretamente nas grandes empresas.

Devido a esses eventos, as empresas sofreram muito, pois seus estoques eram altos e não havia muita procura pelos seus produtos, logo acabavam comprometendo a qualidade e, consequentemente, comprometendo a obsolescência dos produtos fabricados.

Um sistema de produção que surgiu foi Sistema Toyota de Produção, no qual a priorizava a melhoria contínua, como mostra o tópico a seguir.

\subsection{SISTEMA TOYOTA DE PRODUÇÃO}

Durante a década de 70, ocorreu a crise do petróleo, que gerou um grande impacto sobre a capacidade competitiva das empresas. Houve a necessidade de encontrar formas de "levantar" as empresas, mesmo com um cenário conturbado com situações desfavoráveis. E foi no meio dessa dificuldade que a Toyota Motor Company apresentou maneiras de se erguer novamente.

O Sistema Toyota de Produção surgiu de um estudo executado por Eiji Toyoda em companhia de seu principal engenheiro de produção Taiichi Ohno sobre outro modelo existente executado na fábrica da Ford, até então a unidade mais apropriada e completa do mundo. O modelo de produção em massa, elaborado por Henry Ford em 1930, refere-se ao antigo modelo de produção que construía centenas de carros por ano, todos eles produzidos pelo exemplar sistema artesanal. Nesse período, a quantidade de produção era muito baixa, no qual comparado aos dias atuais. Fabricava cerca de mil carros por ano e, raramente, seriam encontrados dois carros iguais (WOMACK; JONES; ROOS, 1992).

Durante as visitas as fábricas da Ford para estudar o modelo de produção em massa, Toyoda e Ohno perceberam que o pequeno mercado e com demandas fragmentadas não iria suportar altos volumes de produção. Portanto, para sobreviver, os gerentes perceberam que era necessário fazer uma adaptação ao mercado japonês, isto é, um contraste a filosofia Ford da época, eram necessários baixos volumes e com diferentes modelos usando a mesma linha de montagem. A necessidade do mercado japonês exigia qualidade, custo baixo, leadtime curto e flexibilidade (OHNO, 1997, p.52).

Ainda nas visitas de estudo as fabricas americanas, em 1950, os gerentes da Toyota observaram muitos equipamentos produzindo grandes quantidades e formando estoques que seriam transferidos para outro processo e assim por diante. Esse tipo de processo causava o acumulo de estoques intermediários decorrente do excesso de produção e defeitos escondidos em grandes lotes acumulados por semanas (OHNO, 1997, p.52).

Ainda Ohno (1997) concluiu que o sistema Ford não seria capaz funcionar na Toyota, que era aproximadamente menor e precisava de respostas mais eficientes e menos caras. A Toyota realizou um Benchmarking (BM), na 
Ford, que segundo Spendolini (1992) é um processo contínuo e sistemático para avaliar produtos e processos de trabalho de organizações que são reconhecidas como representantes das melhores práticas, com a finalidade de melhoria organizacional.

Nesse Benchmarking ${ }^{1}$, a Toyota aproveitou a linha de montagem móvel de Ford e implementou a melhoria na redução de desperdícios. Estabeleceu também a produção puxada, no qual o conceito será visto no tópico 2.3.2. Desenvolveu outros métodos para solucionar os problemas. Alguns desses métodos serão vistos no decorrer desse estudo.

Atualmente, o legado e a filosofia da Toyota é sempre cogitar em ensinar e reforçar o conjunto de valores que os fundadores autorizaram, tais como o colocar a mão na massa, inovação e trabalhar na causa raiz das questões fundamentadas em fatos.

Atualmente se usa o termo Lean Manufacturing que significa Manufatura Enxuta - ME, o qual foi cunhado no livro 'A Máquina que Mudou o Mundo' que trata de um amplo estudo sobre o TPS. O Lean tem sido o modelo de gestão escolhido pelas empresas que tentam implantar em suas fábricas as mesmas práticas diferenciadas do TPS, a fim de atingir os mesmos níveis de desempenho da Toyota (WOMACK, 1992, p. 63).

O sistema ME tem como motivo principal coordenar os sistemas padronizados de produção a um método enxuto com base de melhoria de processos e redução de perdas.

Vários especialistas definiram 0 Lean Manufacturing ou Manufatura Enxuta (ME):

ME como uma abordagem que busca uma forma melhor de organizar e gerenciar os relacionamentos de uma empresa com seus clientes, cadeia de fornecedores, desenvolvimento de produtos e operações de produção, segundo a qual é possível fazer cada vez mais com menos (menos equipamento, menos esforço humano, menos tempo, etc.) (WOMACK; JONES, ROOS, 1998, p. 71).

Abordagem da ME engloba ampla variedade de práticas gerenciais, incluindo Just in Time,

\footnotetext{
1 Benchmarking (BM), que retrata um processo de conferência como forma de encontrar "o melhor na classe", por meio de análise, por estudo de caso, das condutas de outras empresas (SILVA 2010)
}

sistemas de qualidade, manufatura celular, entre outros. Ainda de acordo com esse autor, o ponto fundamental da ME é que essas práticas devem trabalhar de maneira sinérgica para criar um sistema de alta qualidade que fabrica produtos no ritmo que $\mathrm{O}$ cliente deseja, sem desperdícios (SHAH; WARD, 2003, p. 39).

A filosofia Just in Time é integrada de práticas que intensificam o aproveitamento de seus recursos materiais, com a intenção de eliminar perdas e desperdícios durante o processo produtivo, em conjunto com o Lean Manufacturing, permite reduzir estoques e eliminar o que há de desnecessário na empresa.

Vários autores citam a ME com as diversas características e com o objetivo de oferecer uma definição mais exata e recente. Segundo Godinho (2004), o Lean Manufacturing define a Manufatura Enxuta como uma referência estratégica e composto de gestão, concentrado a certas situações de negócio, que propõem ajudar a empresa a atingir determinados objetivos de qualidade e produtividade, parâmetros constituídos por uma série de ideias, fundamentos, regras que conduzem a empresa, além de ferramentas, tecnologias e metodologias empregadas.

Essa filosofia Lean pode ser a solução para a eliminação ou, pelo menos, a redução de desperdício e ajudará no processo automático de uma empresa.

\subsubsection{ELIMINAÇÃO DO DESPERDÍCIO}

Segundo Ohno (1988), ser "enxuto" virou um jargão dentro das empresas. Um empresário, ao ouvir sobre seus concorrentes que estão fazendo sucessos no mercado com um programa enxuto, poderá dizer aos subordinados: "temos de ser enxutos para e sobreviver no mercado cada vez mais competitivo". Esse tal subordinado corre atrás de qualificações e certificados nesse negócio enxuto e põe em prática.

Às vezes, uma ferramenta usada pela Toyota da forma que as empresas utilizam pode nem mesmo fazer sentido em seu ambiente, levando em conta que muitas pessoas podem chegar a uma conclusão que "o sistema enxuto não funciona aqui".

Tudo o que estamos fazendo é olhar para linha de tempo desde o momento em que o cliente nos faz um pedido até o ponto quando 
coletamos o pagamento. E estamos reduzindo essa linha de tempo, removendo as perdas sem valor agregado (TAIICHI OHNO, 1988, p. 34).

Para Ohno (1988), o sistema Toyota de produção reduz o tempo entre o pedido do cliente e a entrega eliminando a perda, no qual não há valor agregado. Assim, proporciona aos seus clientes alta qualidade, a um baixo custo, dentro do prazo e que permite que uns dos objetivos da Toyota seja estoque zero, padronizado e volume de estoque em transformação. O sistema enxuto está ligado não apenas com ferramentas e técnicas, mas também com filosofia. Por exemplo, eliminar perdas com uso de ferramentas enxutas trará retorno financeiros imediatos.

Ainda segundo Ohno (1988), nos processos como linha de produção, há tempo de cada atividade, materiais, fluxo de informações e o mapeamento do início ao fim, pois existem várias perdas.

Baseado em um método cíclico de melhoria contínua, a Toyota usufrui desses benefícios de melhoria por todo sistema. Toda mudança gera uma porção de desconforto. Se uma empresa quer realmente ser enxuta, infelizmente terá de passar certos sacrifícios para produzir um resultado satisfatório. $\mathrm{Na}$ verdade, o sucesso é o resultado de um processo de melhoria ao qual identifica as perdas, entende a raiz do problema e coloca em prática ações para solucionar as causas. Sendo que, isso não será tão simples como instalação de um software. Para ter sucesso, segundo Ohno (1988), depende de três coisas:

a) Focar na compreensão dos conceitos da sustentação da filosofia do sistema enxuto, ao invés de focar na aplicação descuidada das ferramentas;

b) Aceitar os aspectos dos processos enxutos, mesmo aqueles que geram resultados indesejáveis de curto prazo;

c) Planos de implementação que contenham a sistemática, a cíclica e a contínua das perdas. Segundo Shingo (2007), uma autoridade do JIT e engenheiro da Toyota Motor Company, no Japão, eliminar desperdícios significa analisar todas as atividades realizadas dentro da fábrica e minimizar as que não agregam valor à produção.

Atividades as quais podem ser aplicadas ao desenvolvimento de produtos, à tomada de pedidos e ao escritório, e não somente à linha de produção são sete principais sem valor agregado, ainda foi criada uma oitava atividade (LIKER, 2007, p. 38).

Atividades que não estão associadas ao valor final produto, devem ser monitoradas constantemente a fim de diminuir e/ou eliminar todo e quaisquer desperdícios.

De acordo com Corrêa; Corrêa (2007), apenas o tempo de processamento agrega valor no produto. Eliminar desperdício na produção nada mais é que acreditar que outra tarefa não poderá se iniciar sem que uma antecessora termine.

a) Superprodução: Produzir pensando no futuro, baseado em pedidos anteriores dos clientes, produz mais do que o necessário no pedido, esse hábito já é considerado um grande desperdício. De maneira geral, essa estratégia gera problemas e restrições do processo produtivo, como por exemplo, estoque excessivo, podendo ser esse físico ou em informações, custo com excesso de pessoal, armazenagem, transporte, tempo de preparações de maquinas e equipamentos, grandes distancia a percorrer com o material devido ao arranjo físico inadequado. Dessa forma, a filosofia JIT, sugere que seja produzido somente o necessário que irá consumir no momento, para que isso ocorra seja diminuído o tempo de setup ${ }^{2}$, sincroniza a produção com a demanda, que compacta o layout da fábrica;

b) Espera: Todo material a ser processado que fica na espera, formando filas que exijam altas taxas de utilização dos equipamentos. $\mathrm{Na}$ filosofia JIT, o fluxo de material é essencial, e não as taxas de utilização dos equipamentos. Para eliminar esse desperdício é muito importante o balanceamento da linha de produção com o fluxo de trabalho. É importante salientar também que os trabalhadores estando como "vigias" desses equipamentos e/ou máquinas, estando tendo que esperar pela etapa do processamento ou próxima ferramenta, peça, suprimentos, insumos, ou ainda, não tendo trabalho por falta de estoque, paralisação do equipamento e gargalo de capacidade;

\footnotetext{
${ }^{2}$ Setup é o método de alteração da produção de um item para outro em um mesmo equipamento que requer troca de ferramenta e/ou dispositivo. (LEAN INSTITUTE BRASIL. [2008])
} 
Estes dois tipos de desperdícios superprodução e espera, ocorrem, respectivamente, quando é fabricado mais que o necessário, ocasionando uma quantidade de produtos maior que a demanda e tempo perdido por máquinas, pessoas não se apresentar prontos para a próxima atividade, causando assim uma espera.

Ainda de acordo com Corrêa; Corrêa (2007), outros quatro tipos de desperdícios são:

c) Transporte ou transferência: Toda movimentação de material ou trabalho em processo de determinado local para outro, que seja a mínima distância. Todo material, peça, produto acabado que for movimentado durante o processo, que seja para estocá-lo ou retira-lo do estoque. Esse desperdício não acrescenta valor ao produto acabado, por isso é necessário ter uma devida restrição do processo e das instalações, que impõe grande distancias a serem percorridas ao longo do processamento. Essas movimentações devem ser retiradas ou diminuídas ao máximo, através de planejamento de arranjo físico adequado. Depois de eliminar as necessidades de armazenamento, reduzindo os estoques, e a necessidade de movimentação, através da redução de movimentação, dessa forma, poderemos pensar na racionalização do transporte e movimentação de materiais os quais não foram eliminados;

d) Processamento Incorreto: Toda e qualquer atividades e tarefas realizadas desnecessariamente para processar as peças. Ferramentas defeituosas, projeto mal elaborado, geram produtos com erros. Por outro lado, uma perda pode ser gerada por quando um produto é oferecido com maior qualidade, isto é, além do necessário especificado no projeto. Deve-se se perguntar, "porque determinado item ou componente faz parte do produto", ou "deve ser fabricado", "porque fazer essa atividade ou etapa do processo". Por isso, a importância da aplicação das metodologias de engenharia e analise de valor, que basicamente está ligada à redução do número de componentes ou operações necessárias para produzir peça, produto, ou simplesmente uma etapa do processo. Todo e qualquer elemento que implica em custo no produto e não agrega valor se torna passível de futura analise de custos diretos e indiretos; e) Excesso de estoque: Além de ocultar outros tipos de desperdícios, os estoques também geram desperdícios de investimentos e espaço. Como excesso de materiais prima, estoque em processo, produtos acabados, causa lead time mais longo, obsolescência, artefatos danificados, custos com transporte, armazenagem e atrasos. A redução desse desperdício pode ser conseguida através da redução do tempo de preparação das máquinas, reduzindo $o$ lead time de produção, sincronizando o fluxo de trabalho, diminuindo as flutuações de demanda, aumentando a confiabilidade das máquinas e garantindo a qualidade dos processos. A filosofia JIT não aceita a situação vigente ou mesmo de padrão de desempenho. As metas colocadas pelo JIT costumam ser estáticas e funcionam como padrão, com base nos quais são exercidas a atividade de controle minimizando desvios desses padrões. O controle mantém o processo estável e os resultados dentro das tolerâncias aceitáveis. Conforme Corrêa; Corrêa (2007), as metas para uma melhoria contínua colocadas pelo JIT são:

a) Zero defeito;

b)Tempo zero de preparação;

c) Estoques zero;

d) Movimentação zero;

e) Quebras zero;

f) Lead Time zero;

g) Lote unitário.

Esses objetivos podem dar certo em várias empresas, garante melhoria contínua do processo e caso a empresa não de certo com esses objetivos é pelo fato de que são vistas como metas ambiciosas e inatingíveis comparadas aos métodos tradicionais;

f) Movimentação: Esses desperdícios estão presentes dentro das fabricas nas mais variadas situações. Qualquer movimento exigido pelos funcionários durante seu trabalho que não agregam valor ao produto, como localizar, procurar, empilhar peças, ferramentas, etc. caminhar dentro da fábrica já é uma perda. Economizar nos movimentos aumenta a produtividade e reduz os tempos associados aos processos produtivos. As técnicas de estudo dos tempos e movimentos é justificada, pois o JIT tem enfoque na baixa tecnologia, procurando soluções simples e de baixos custos. Deve-se tomar o cuidado com a automatização do processo, primeiramente 
aprimoramos os movimentos, para então mecanizar e automatizar; senão corre-se o risco de automatizar os desperdícios;

O desperdício relacionado ao transporte ocorre quando um produto é transportado para outro ponto em que não seja o local final dele. Já o processamento incorreto é quando há algum processo dentro da produção que poderia ser descartado e não afetaria na qualidade do produto final. Outro desperdício é o excesso de estoque que nada mais é do que possuir uma quantidade maior que o necessário. E o último desperdício citado acima é o de movimentação que ocorre quando funcionários devem se deslocar dentro da empresa. Muitas vezes, isso acontece por um layout com um planejamento incorreto.

Por fim Corrêa; Corrêa (2007) cita mais dois tipos de desperdícios:

g) Defeitos: Produzir peças defeituosas, fazer um retrabalho, produzir para substituir, em geral peças com problemas de qualidade, significam desperdiçar materiais, mão-deobra, disponibilidade de equipamentos, movimentação de materiais defeituosos, armazenagem destes, inspeção, entre outros. De uma maneira geral, os defeitos não podem ser aceitos e nem gerados, o processo produtivo deve ser planejado de forma que seja prevenido os defeitos para que se possa eliminar a inspeção. E comum nas fábricas encontrar diversas maneiras e formas de várias etapas do processo produtivo de evitar esses defeitos que na maioria das vezes são gerados por uma falha humana. A utilização desses dispositivos às provas de falhas é conhecida como Poka Yoke, adotado na filosofia do JIT;

h) Não aplicação da criatividade dos funcionários: Melhoria contínua dos processos produtivos, ideias, habilidades, perda de tempo e oportunidades por não envolver seus funcionários ou muito menos escutá-los.

O defeito é ocasionado por alguma falha durante o processo de fabricação, sendo na maioria das vezes responsabilidade do colaborador ou equipamento.

Segundo Ohno (1988), os sete primeiros tipos de perdas são tão críticos e impactam no que se chama de oitava perda. Devidos aos problemas estarem ocultos, os funcionários das equipes não são obrigados a pensarem. A redução de perdas expõe os problemas forçando toda equipe a usar suas criatividades.

E para reduzir ou até mesmo eliminar os desperdícios, há uma filosofia que poderá auxiliar na solução desse problema. Esta nova filosofia deu início após o Japão ter sofrido com a guerra e pelo fato de não ter recurso disponível para impulsionar consideravelmente a reconstrução da produção industrial daquele país, onde será explicado como esta nova filosofia Just in time mudou totalmente o rumo do Japão, transformando em referência para os demais países (CORRÊA; CORRÊA, 2007).

\subsubsection{SISTEMA JUST IN TIME}

O Just in Time (JIT) apresenta inúmeros conceitos, independentemente do segmento que ele for inserido. Contudo, podem-se explanar alguns conceitos como, por exemplo, a de Motta (1993) que cita:

O Just in time é, única e exclusivamente, uma técnica que se utiliza de várias normas e regras para modificar o ambiente produtivo, isto é, uma técnica de gerenciamento, podendo ser aplicada tanto na área de produção como em outras da empresa (MOTTA, 1993, p.46).

De acordo com a ideia de Motta (1993), Just in time era buscar um sistema de administração que conseguisse coordenar a produção com a demanda especial de variados modelos e cores de veículos com o mínimo de atraso. Foi lançado como uma filosofia, ao qual engloba tópicos de gerenciamento de materiais e da qualidade, arranjo físico, projeto do produto, organização do trabalho e recursos humanos.

Para Shingo (1996), em japonês, Just in time tem o significado de estar "no momento certo", "oportuno", entretanto, o termo direciona a uma ideia de larga escala e de padronização, se for analisado apenas o momento de entrega, pois noToyota Production System, o pensamento é desenhado em ter itens necessários, no número necessário e no tempo necessário, sem a formação de estoques.

JIT significa que em um processo de fluxo, as partes corretas necessárias à montagem alcançam a linha de montagem no momento em que são necessários e somente na quantidade necessária. Uma empresa que 
estabeleça esse fluxo integralmente pode chegar ao estoque zero (ONHO, 1997, p.26).

O objetivo do JIT acontece através de um mecanismo que reduz estoques, os quais tende a ocultar problemas e trabalha com melhoria contínua no processo produtivo. Por outro lado, tem sido utilizado para evitar a descontinuidade do processo. O sistema de "puxar" a produção é feito sob demanda, produzindo em cada etapa simplesmente os itens, nas quantidades e no momento necessário para não haver estoque.

Para Slack; Chambers; Johnston (2007), configurando como um dos alicerces de sustentação do Sistema Toyota de Produção, o Just in time define-se várias formas: na eliminação de desperdícios, no processo, na gestão de produção e, o mais importante, que fique decidido onde e como necessita ser aplicado, sendo que, pelas formas atuais que se conhece, acrescenta quanto à figura de mobilidade de atendimento do produto finalizado.

[... tenta atender à demanda instantaneamente, com qualidade perfeita e nenhum desperdício - enfatiza a eliminação de desperdícios e tempo de atravessamento rápido, ambos os quais contribuem para estoques baixos - promove um impacto significativo na habilidade da operação em aprimorar sua eficiência intrínseca (SLACK; CHAMBERS; JOHNSTON, 2007, p.506-507).

A filosofia JIT é reduzir estoques, de forma que os problemas sejam visíveis e consiga ser eliminados ou reduzidos por meio de estímulos centralizados e priorizados. Produz e entrega conforme demanda e com qualidade, garante que a implementação do sistema de administração JIT foi feita com sucesso.

Ohno (1997) recomenda que, para o Just in time funcionar adequadamente, necessita ser fundamentado como se fosse um supermercado, ou seja, apenas é reposto o estoque conforme a necessidade. Outra forma de notar um supermercado constituiria de que, quando é imprescindível qualquer produto, ela tem de estar disponível para o cliente no tempo que ele precisar.

O Just in time para o Toyota Production System é uma ferramenta de importância fundamental no seu planejamento, a aplicação do JIT necessita ser de modo que não sobrevenha em produção de estoques pontuais devido a rejeições por qualquer causa em algum item do fluxo. Isso acaba acontecendo quando não há devida comunicação entre as áreas, criando inconvenientes decorrentes do início de que todo produto acabado deve estar finalizado. Para que isso chegue ao produto acabado e sem desperdícios, Ohno (1997) diz que um produto que se encontrar imperfeito é a causa de um problema no começo. Deste modo, a consequência final da empresa ficará comprometida, sendo que, toda vez que acontecer qualquer reprocesso ou qualquer produto for desaprovado, existirá uma nova aquisição da empresa em recursos materiais e humanos, todavia, não possuirá valor agregado ao produto acabado.

Outra metodologia que fortalece o STP no dia a dia é o Kaizen. No próximo tópico, será explicado que Kaizen é um processo de executar melhorias e obter o propósito enxuta de cortar todos os desperdícios que inseri custos e não integrar valores ao produto.

\subsubsection{METODOLOGIA KAIZEN}

Kaizen é um termo origem japonesa que significa "melhoria contínua", sendo que Kai significa "mudar" e zen "para melhor", mas antes de tudo é uma filosofia de trabalho e de vida. Para o Kaizen, é sempre possível fazer melhor, nenhum dia deve finalizar sem que alguma melhoria tenha sido implantada, relata Shingo (1996).

Para Monden (1999), a finalidade principal do Kaizen é a procura devotada da diminuição de custos em todas as fases da metodologia eliminando qualquer desperdício.

Com o Kaizen, elimina-se ou reduz tudo aquilo que não agrega valor ao produto ou serviço e não contribui para o desempenho competitivo da empresa. Quando se utiliza essa filosofia em um empreendimento, ele se torna forte, dinâmico, competitivo, flexível e lucrativo, em qualquer oscilação do mercado (OLIVEIRA NETTO; TAVARES, 2006).

O Kaizen tem como objetivo buscar soluções (melhorias ou correções) para combater o desperdício e as perdas concretas (material) ou abstratas (ações sem valor) e mão de obra, com muito empenho e método, sendo necessário que todos os colaboradores de uma empresa estejam empenhados com esta filosofia, desde o colaborador de piso de fábrica até o gerente geral da empresa. Com isso, o Kaizen exige o envolvimento de todos 
independentemente do nível hierárquico da organização (IMAI, 2005).

O kaizen requer uma mudança na percepção - uma mudança da cultura - de todos na organização. Todos devem, constantemente, identificar todos os tipos diferentes de desperdício no trabalho para poder eliminálos. O mais importante é que isso requer apoio dos superiores. Sempre que o KAIZEN não é executado com sucesso, 99\% do tempo é porque a administração superior não o compreendeu ou não teve o compromisso necessário para executá-lo corretamente (IMAI, 2005, [s.p]).

Essa prática propõe o bem não apenas da organização como a do colaborador, partindo do pressuposto de que o tempo é um excelente indicador de competitividade, além de identificar e eliminar os desperdícios que existem na empresa seja na produção, produto final, manutenção de equipamentos ou ainda, processos administrativos.

Segundo Oliveira Netto; Tavares (2006) relatam que o Kaizen é um acessório aos métodos de reengenharia, requerendo e aprimorando por meio de inovações, ou seja, supre os processos empregados na empresa pelo Kaizen, através disso, promove o progresso por meios da eliminação de problemas identificados nos processos.

IMAI (1994) faz uma analogia entre os atributos do Kaizen e as distinções da inovação, que estão representadas no quadro 1.

Quadro 1 - Qualidades do kaizen e da inovação

\begin{tabular}{|c|c|c|}
\hline & Kaizen & Inovação \\
\hline 1. Efeito & $\begin{array}{l}\text { A longo prazo é duradouro, porém } \\
\text { monótono. }\end{array}$ & A curto prazo, porém empolgante. \\
\hline 2. Ritmo & Pequenos progressos. & Grandes progressos. \\
\hline 3. Estrutura de tempo & Contínua e incremental. & Intermitente e não incremental. \\
\hline 4. Mudança & Gradual e constante. & Repentina e passageira. \\
\hline 5. Envolvimento & Todos. & Poucos "defensores" selecionados. \\
\hline 6. Enfoque & $\begin{array}{l}\text { Coletivismo, esforços em grupo, } \\
\text { enfoque sistêmico. }\end{array}$ & $\begin{array}{l}\text { Forte individualismo ideias e } \\
\text { esforços individuais. }\end{array}$ \\
\hline 7. Método & Manutenção e melhoramento. & Refugo e retrabalho. \\
\hline 8. Estímulo & $\begin{array}{l}\text { "Know-how" e atualizações } \\
\text { convencionais. }\end{array}$ & $\begin{array}{l}\text { Avanços tecnológicos, novas } \\
\text { inovações novas teorias. }\end{array}$ \\
\hline 9. Exigências práticas & $\begin{array}{l}\text { Exige pouco investimento, porém } \\
\text { grandes esforços para mantê-lo. }\end{array}$ & $\begin{array}{l}\text { Exige grande investimento, porém } \\
\text { poucos esforços para mantê-lo. }\end{array}$ \\
\hline 10. Orientação do esforço & Pessoas. & Tecnologia. \\
\hline 11. Critérios de avaliação & $\begin{array}{l}\text { Processo e esforços por melhores } \\
\text { resultados. }\end{array}$ & Resultados por lucro. \\
\hline 12. Vantagem & $\begin{array}{l}\text { É útil na economia de crescimento } \\
\text { lento. }\end{array}$ & $\begin{array}{l}\text { Adapta-se melhor à economia de } \\
\text { crescimento rápido. }\end{array}$ \\
\hline
\end{tabular}

Fonte: Adaptado de IMAI, 1994, p. 21.

O quadro1 demonstra as particularidades e diferenças do Kaizen e inovação, no qual cada conceito aplica-se sua metodologia, com isso o Kaizen apresenta técnicas e/ou ferramentas de qualidade mais simples de aplicação, mas, em alguns momentos, o bom senso acaba sendo a melhor forma técnica e, por outro lado, existe a inovação, em que sua aplicabilidade é mais complexa, exigindo maior e alta tecnologia sofisticada e com elevado custo de investimento.

Uma das coisas maravilhosas do KAIZEN é que ele não exige, necessariamente, técnicas sofisticadas, nem tecnologia avançada. Para implementar o kaizen, você precisa apenas de técnicas simples e convencionais, como as sete ferramentas do controle de qualidade (diagrama de Pareto, diagramas de causa e efeito, histogramas, cartas de controle, diagramas de dispersão, gráficos e folhas de verificação). Muitas vezes, tudo o que é necessário é bom senso. Por outro lado, a inovação geralmente exige tecnologias altamente sofisticadas, bem como enormes investimentos (IMAI, 2005, p.20).

Fazer melhor é sempre possível, todos os dias devem ser implantados algumas melhorias quaisquer que sejam na estrutura da empresa ou no próprio indivíduo. As mudanças feitas devem ser graduais e nunca bruscas, para que a estrutura da empresa não seja comprometida. 
De acordo com Monden (1999), localizam-se as atividades Kaizen, em que são delineadas as operações e tratados, os inconvenientes para levantar a ética da zona de trabalho e, consequentemente, acrescentam a qualidade dos processos, nos quais os eventos e falhas acontecem.

Desde modo, o Kaizen tem seus 10 mandamentos que devem seguir conforme IMAI (2005), tais como:

1) O desperdício é o inimigo n⒈ Para eliminálo, é preciso sujar as mãos.

2) Melhorias graduais continuadamente; não é ruptura pontal.

3) Todos na empresa têm de estar envolvidos, desde os gestores do topo e intermédios, até o pessoal de base; a metodologia não é elitista.

4) A estratégia deve ser barata. O aumento de produtividade deve ser feito sem investimentos significativos. Não se deve aplicar somas astronômicas em tecnologia e consultorias.

5) Aplica-se e qualquer lugar, não serve só para japoneses.

6) Apoia-se numa gestão visual, numa total transparência de procedimentos, processos e valores; torna os problemas e desperdícios visíveis aos olhos de todos.

7) Focaliza a atenção no local onde se cria realmente o valor ('gemba' em japonês).

8) Orienta-se para os processos.

9) Dá prioridade às pessoas, ao humanwar ${ }^{3}$; acredita-se em que o esforço principal de melhoria deve vir de uma nova mentalidade e estilo de trabalho das pessoas (orientação pessoal para a qualidade, trabalho em equipe, cultivo da sabedoria, elevação da moral, autodisciplina, círculos de qualidade e prática de sugestões individuais ou em grupo).

10) O lema essencial da aprendizagem organizacional é aprender fazendo. (IMAI, 2005).

Para Ortiz (2006), desenvolver um programa de Kaizen preparado é um desafio que visa desenvolver a melhoria contínua, pois é mais

\footnotetext{
3 Humanware é um modelo de gerenciamento do fator humano, descrito para apresentar ferramentas de prevenção, análise e manuseio de conflitos prolongado ao ciclo de vida de um projeto (GENEXUS, 2007).
}

transitável ampliar um programa que tenha implicação real e de extensa duração. Ortiz (2006) ainda diz que todo sucesso só poderá vir se todas as pessoas de uma organização venham participar de treinamentos e inclusive sobre as políticas e padrões. Agora caso os gestores e colaboradores ficarem com dúvidas, as chances para obter êxito serão baixas. A alta diretoria tem que criar a visão e continuar destinada para conseguir o sucesso desejado.

O Kaizen então é uma ferramenta de melhoria contínua e estratégica que inicia e finaliza pelos colaboradores de todo o sistema hierárquico da empresa. Ele proporciona um norte, levando os colaboradores para uma melhora de suas capacidades, fazendo com que descubram perspectivas de alta qualidade, pequeno custo e entrega em tempo hábil do produto e/ou serviço.

Levando em conta que o Kaizen busca melhorias para combater a perda de desperdício e mão de obra, outra ferramenta que pode auxiliar o Kaizen é o Poka Yoke. É um mecanismo a prova de erros, evitando o acontecimento de defeitos.

\subsubsection{POKA YOKE}

"Poka Yoke é uma palavra japonesa que significa "prevenção de defeitos". Surgiu no contexto da filosofia ZQC (Controle de qualidade zero), tendo sido desenvolvido e implementado por Shingo, em 1961, na Toyota Motor Corporation" (JOSÉ, L., 2010).

O Poka Yoke é um método direcionado na identificação dos possíveis erros que podem ser encontrados durante $\mathrm{o}$ processo de fabricação ou, até mesmo, no desenvolvimento de projetos, tendo como intuito extinguir os potenciais de erros. A eliminação dos erros deve-se focar nas causas, através de implantações de dispositivos à prova de erro nas máquinas e nos equipamentos, com objetivo de detectar os prováveis erros instantaneamente, com o foco em corrigi-los, não prejudicando o processo produtivo. Esta ferramenta tem como principal característica a utilização de dispositivos menos complexos e de pouco custo, a fim de acertar e controlar o processo com a finalidade de evitar ou minimizar a ocorrência de erros (CORRÊA; CORRÊA, 2007).

Conforme Shingo (1996), Poka Yoke é uma ferramenta de inspeção sucessiva, auto 
supervisão e inspeção que opera na origem do problema, sendo que propicia a inspeção $100 \%$ através do controle mecânico ou físico. Partindo deste princípio, o Poka Yoke apresenta pontos de advertência e controle, em que o Poka Yoke de controle é o mais eficaz, tendo como finalidade parar todo o processo até que a situação causadora do problema seja resolvido ou reparado. O Poka Yoke de advertência sinaliza que há um problema, mas o processo continua funcionando, mesmo que os colaboradores não atendam o aviso. Desta forma Shingo (1996), conceituou estes dois métodos da seguinte forma:

a) Método de Controle - quando o Poka Yoke está ativo, a máquina ou linha de processamento é interrompida, de forma que o problema pode ser reparado;

b) Método de Advertência - quando o Poka Yoke é ativado, um sinal soa ou uma luz indicadora, pretendendo alertar o trabalhador.

Ainda Poka Yoke apresenta três tipos de método de controle, em que cada um apresenta sua funcionalidade conforme citado por Shingo (1996).

a) O método de contato indica os defeitos em mérito da existência ou não de contato entre o dispositivo e alguma característica funcional à forma ou ao tamanho do produto (algumas vezes são introduzidas deliberadamente pequenas mudanças na dimensão ou forma do produto, de forma que os defeitos sejam mais facilmente identificáveis). São também utilizadas diferenças de cor e técnicas nelas baseadas são consideradas extensões do método de contato;

b) O método de conjunto determina se um dado número de atividades previstas é executado;

c) O método das etapas estabelece se são seguidas as etapas ou operações determinadas por um dado procedimento.

Shingo (1996) também garante que o dispositivo Poka Yoke em si não é um sistema de inspecionamento, mas sim um método de determinar erros ou defeitos que pode ser empregado para atender uma determinada função de inspeção, sabendo que a inspeção é um objetivo e o Poka Yoke é um método, em que a inspeção somente detecta defeitos depois que o mesmo ocorre, pois não é uma maneira capaz de eliminar os defeitos naquele processo exclusivo. Portanto, o primeiro passo é definir qual método Poka
Yoke (controle ou advertência), que seja capaz de realizar a função de inspeção desejada, para depois se aplicar no tipo de processo de forma apropriada analisando o dispositivo Poka Yoke, sendo de contato, conjunto ou de etapas.

Portanto é preciso saber identificar as atividades de uma produção, ficar atento quanto às restrições estabelecidas e até os problemas que poderão ocorrer no meio da fabricação de algum produto. Tudo isso pode ser identificado por meio de um mapeamento de processos.

\subsection{MAPEAMENTO DE PROCESSOS}

Mapeamento de processo é uma das ferramentas essenciais do Lean Manufacturing, proposto por Rother\&Shook (1998), que se baseou em uma técnica de modelagem proveniente de metodologia da linha de valor. Cada empresa utiliza diferentes técnicas de mapeamento que mostra diferentes enfoques, sendo que a correta interpretação desta técnica é fundamental durante este processo. Tais técnicas podem ser utilizadas individualmente ou em conjunto dependendo do que se vai mapear.

A escolha do mapeamento como ferramenta de melhoria se baseia em seus conceitos e técnicas que quando empregadas de forma correta, permite documentar todos os elementos que compõem um processo e corrigir qualquer um desses elementos que esteja com problemas sendo uma ferramenta que auxilia na detecção das atividades não agregadoras de valor (MELLO, 2008, p. 27).

Em um mapa de processos consideram-se atividades, informações e restrições de interface de forma simultânea. A sua representação inicia-se do sistema inteiro de processos como uma única unidade modular, que será expandida em diversas outras unidades mais detalhadas, que, conectadas por setas e linhas, serão decompostas em maiores detalhes de forma sucessiva (VILLELA, 2000 apud HUNT, 1996).

Uma das ferramentas utilizadas para a visualização do processo é o diagrama de fluxo de processo ou fluxograma de processo, como mostra a Figura 1, no qual se representa os diversos passos ou eventos que ocorrem durante a execução de uma tarefa específica, ou durante uma série de ações através de alguns dos símbolos padronizados pela Sociedade Norte Americana de 
Engenheiros Mecânicos (ASME), conforme apresentado em Barnes (1982):

Figura 1 - Símbolos padronizados para o gráfico de fluxo de processo

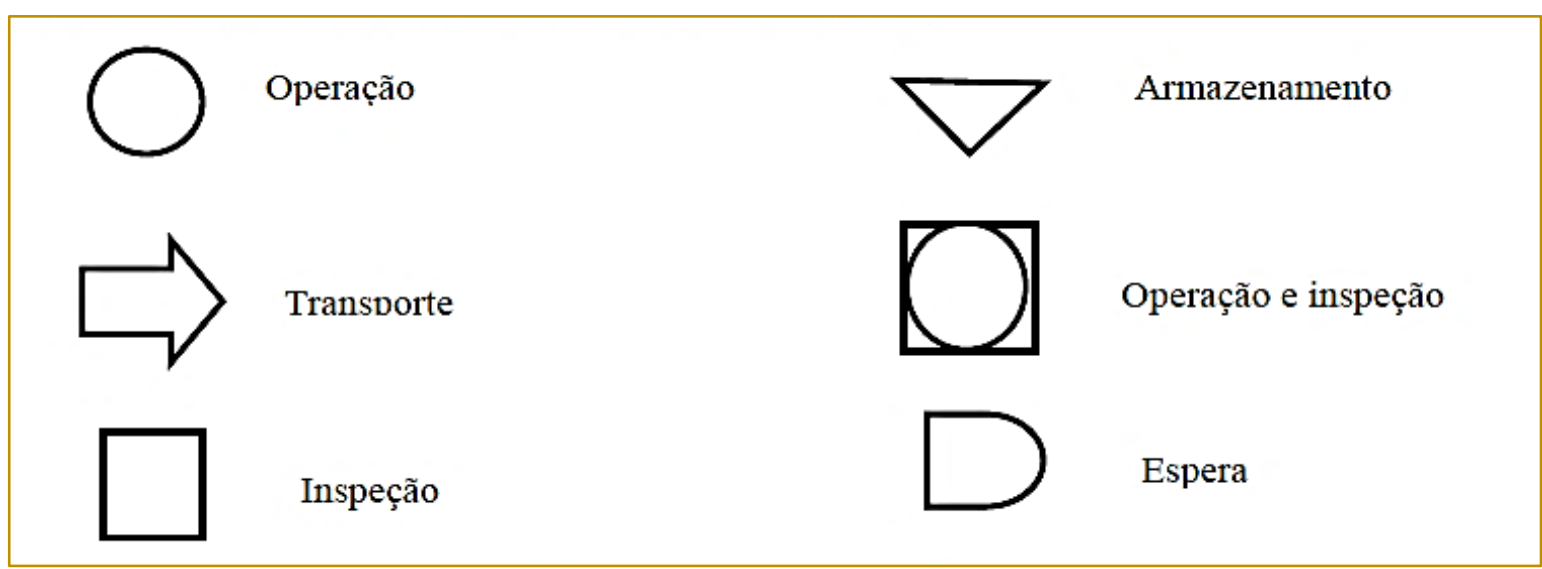

Fonte: BARNES, 1982

Cada mapeamento de processos é de um jeito, mas todos têm símbolos que significam alguma atividade, além de deixar melhor a visualização do processo e para quem está verificando entender melhor como funciona cada atividade.

Segundo Villela (2000), o mapeamento de processo é uma ferramenta gerencial, analítica e de intercomunicação que tem finalidade de ajudar a aprimorar os processos existentes ou introduzir uma nova estrutura focada para o processo. Para comparar as situações atual e desejada, de forma a gerar tensão estrutural que impulsionará a mudança na organização, torna-se necessário mapear a empresa como ela é.

Segundo Tachizawa; Scaico (1997, p.128) processo é "o conjunto de tarefas com um ou mais itens de controle" e tarefa é "conjunto de atividades que produzem um resultado/produto com item de controle". Os processos têm a função de atender aos objetivos. E para alcançar esses objetivos pode-se utilizar um fluxograma básico, em que tudo que entra se transforma e sai um produto/serviço acabado, no qual mostra um fluxo de um processo produtivo básico de cadeira, na figura 2.

A partir da figura 2, identifica-se qual é o problema do processo para modelar como ela deverá ser e apresentar um mapa de como o problema será resolvido ou implantação do novo processo. A análise permite a redução de custo no desenvolvimento de produto e serviço, a redução nas falhas de integração entre sistema e melhora do funcionamento da organização, além de ser mais adequado a uma ferramenta, proporcionando entendimento do processo atual e eliminar ou facilitar aqueles que necessitam de mudanças. 
Figura 2 - Fluxograma do processo produtivo de cadeira

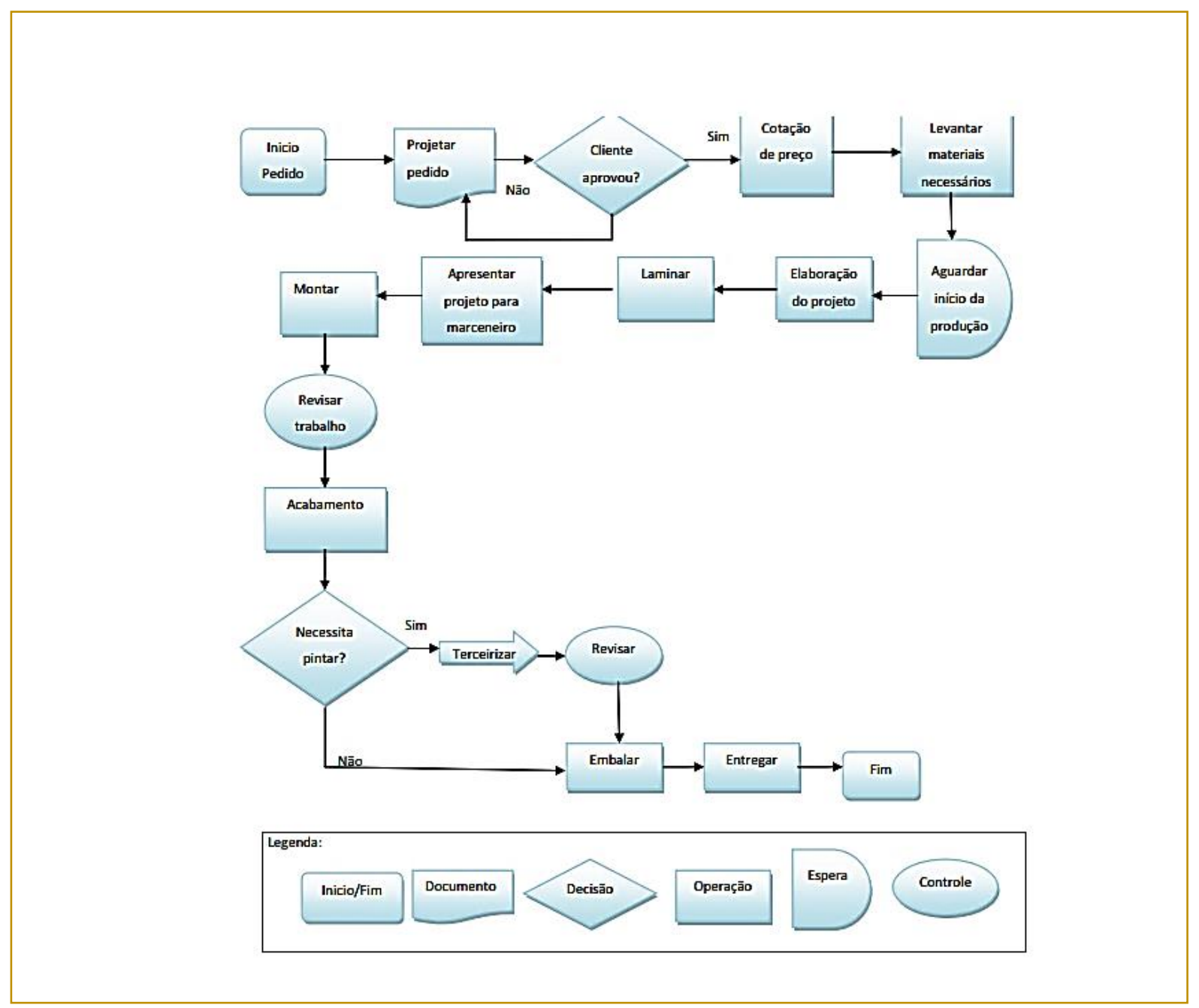

Fonte: ADAPTADO DE X SEPROSUL, 2010

O mapa do processo consiste na identificação de todas as atividades especificas que ocorre ao longo do fluxo de valor referente ao produto. Entende-se fluxo de valor o conjunto de todas as atividades que ocorre desde a colocação do pedido até a entrega ao consumidor final. É um processo de observação e compreensão do estado atual e o desenho de um mapa dos processos que se tornará na sua base para o Lean Manufacturing, ou seja, uma representação visual de cada processo e informação real que se reformulam um conjunto de etapas chaves e desenham um mapa do estado futuro de como a produção deveria fluir (ROTHER; SHOOK, 1998).

Como mostra a figura 3 , tem-se uma demonstração visual da sequência de materiais e de informações para um grupo de produtos. Mapear é a etapa principal de um processo, pois é a parte do mapeamento que se distende a utilização das técnicas lean.

A figura 3 ilustra um exemplo de um modelo de processo usando a técnica de mapeamento do fluxo de valor. Neste mapa, observa-se todo o fluxo de produtos e informações desde o fornecedor de peças até o consumidor final.

Cada empresa tem seu próprio mapeamento de processos, seja básico ou até os mais complexos, mas sempre identificando as atividades do processo produtivo por meio da técnica de mapear. E como os fluxogramas estão sempre sendo melhorados, os modelos de produção não ficam atrás. E para deixar o sistema ainda mais completo, há várias ferramentas de qualidade que ajudam a eliminar o desnecessário na empresa, em especial será explicado no próximo tópico, a Filosofia 8S. 
Figura 3 - Mapa do fluxo de valor

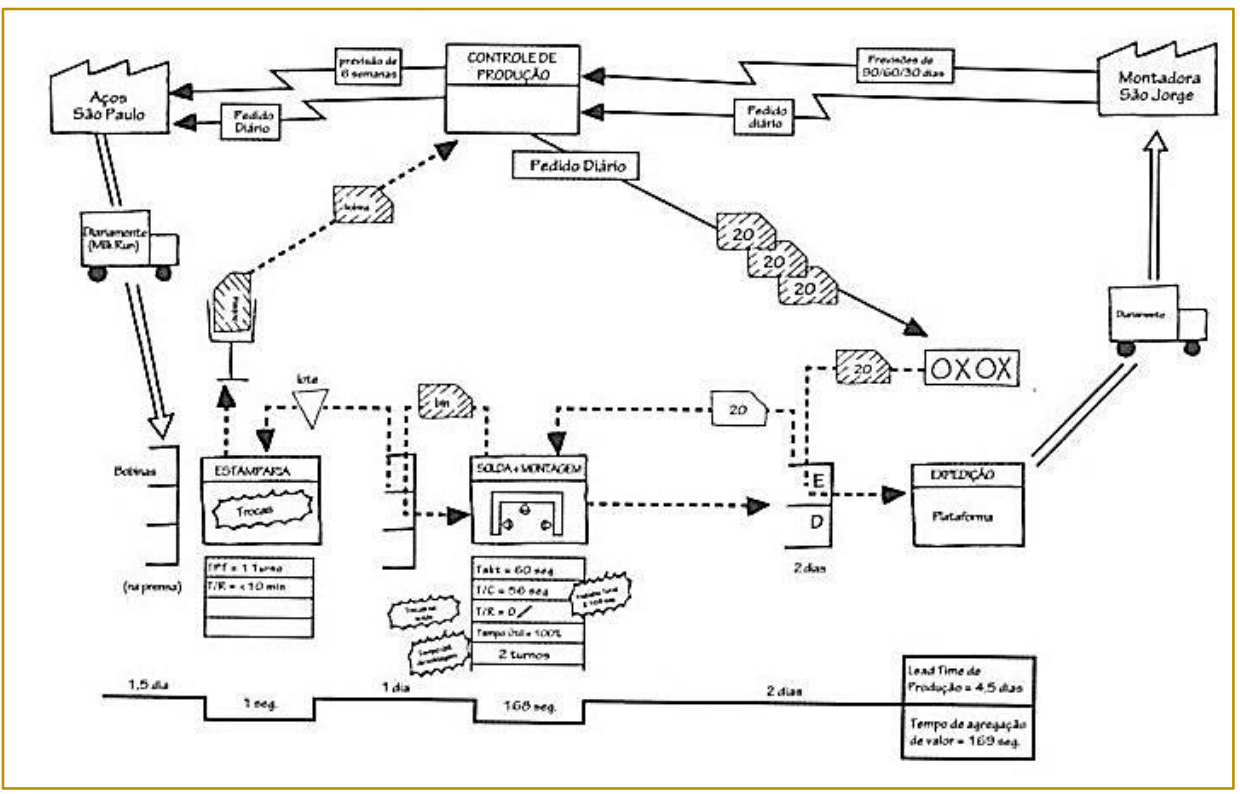

Fonte: ROTHER; SHOOK, 1998, p.96.

\subsection{FERRAMENTAS DA QUALIDADE}

Segundo Juran (1993), qualidade é adequação ao uso. Quando um cliente usar um produto/serviço obteve a satisfação, pois desempenhou sua função determinada para seu fim. Em tempo algum a qualidade de produtos e serviços foi tão abordada, estudada e praticada como no século XXI. Especialista, como Kaoru Ishikawa, propagou ou ajudou a espalhar alguns dos métodos conhecidos como "ferramentas da qualidade" que proporciona o completo controle dos processos ou melhorias na tomada de decisões.

\subsubsection{FILOSOFIA 8S}

O programa 8S é uma filosofia que prepara um ambiente de trabalho com base na educação, devendo ter uma estrutura geral e uma introdução baseada nas características internas de cada organização, de acordo com Abrantes (1998). Mas para isso é necessário explicar primeiramente a filosofia 5S. O 5S, os "Cinco Sensos", é uma ferramenta dentro do Lean Manufacturing, tendo seu surgimento no Japão, por volta 1950, pelo professor Kaoru Ishikawa. Os $5 S$ são cinco palavras, que quando falada em japonês, iniciam pela letra S, finalizando em si as premissas: Utilização (Seiri), Ordenação (Seiton), Limpeza (Seiso), Higiene (Seiketsu) e Autodisciplina (Shitsuke), conforme Campos (1992).
Para Campos (1992), esta ferramenta foi, e prossegue sendo, a base da qualidade total que modificou em menos de 20 anos um país arrasado pela guerra e sem recursos materiais, numa discussão industrial poupada. É obvio que não são apenas cinco palavras que irão mudar uma empresa e um país. Para que esta mudança ocorra, depende necessariamente do engajamento e do interesse de todos os envolvidos, fazendo e seguindo as metodologias com um processo contínuo de aprendizagem educacional.

"O programa $5 \mathrm{~S}$ em alguns momentos acaba sendo confundido como um surto febril de limpeza, na realidade é uma nova forma de conduzir a organização com proventos de produtividade" (CAMPOS, 1992, p. 52).

A prática dos $5 \mathrm{~s}$ se torna importante e valorizada a partir do momento em que ela faz parte do dia a dia dos funcionários. Ela se incorpora dentro de cada um, cada vez mais à medida que se vai praticando. Na verdade, não significa somente limpeza e organização que está por trás dessa filosofia. Envolve muito mais, como por exemplo, a qualidade de vida dos funcionários, ganho no aumento de produtividade, satisfação dos clientes e outros.

Segundo o conceito de Campos (1992), o objetivo do $5 S$ é melhorar a qualidade dos serviços/ produtos; melhorar a qualidade de vida dos colaboradores; educar para a simplicidade de atos e ações, maximizar o 
aproveitamento dos recursos disponíveis; reduzir desperdícios; melhorar o ambiente de trabalho e de atendimento ao usuário; reduzir e prevenir acidentes; melhorar as relações humanas; aumentar a autoestima do colaborador/ residentes. Pode-se observar que estas premissas estão bem direcionadas, onde cada "S" tem sua importância, que são eles:

Quadro 2 - 5S nas áreas administrativas e de produção

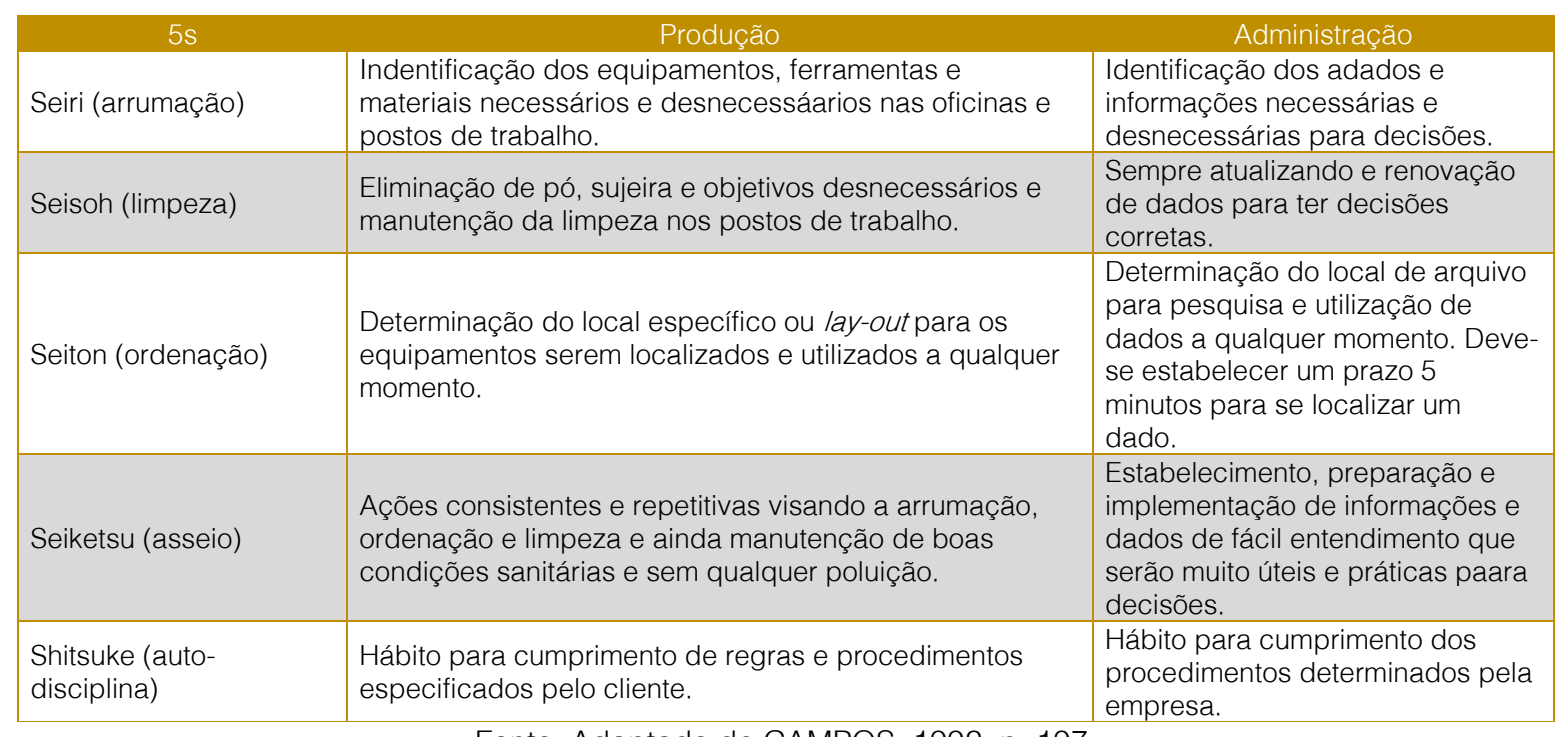

Fonte: Adaptado de CAMPOS, 1992, p. 197.

Referente ao quadro 2, 5S engloba os conceitos adquiridos pela indústria japonesa após a guerra, pois cada conceito citado no quadro tem como objetivo direcionar um senso de espírito disciplinar estruturando e direcionando o colaborador a manter seu ambiente organizacional limpo, organizado, arrumado, identificados e mantendo a autodisciplina na aplicação do 5S.

Segundo Abrantes (1998), com o objetivo de fortalecer a filosofia da ferramenta, foram recomendados mais três sensos (Shikari, Shido e Setsuyaku), com isso surgiu o $8 \mathrm{com}$ a responsabilidade de torná-lo um êxito e de uso contínuo. Vale lembrar que o grande proveito do programa $8 S$ é a extensão para aperfeiçoamento de continuidade do 5S.

O 8S é uma forma simples de combate ao desperdício, à captação, à conservação de recursos e ao aumento de capital, em que sua aplicabilidade poderá ser em qualquer tipo de empresa ou instituição, independente do porte de cada uma. Outro ponto vantajoso do 8S, é que o seu foco não contempla investimentos em máquinas, em equipamentos e em sistemas automáticos, mas sim tratando de uma metodologia de gestão humana e materiais, tendo como parâmetro a capacidade intelectual e criativa dos colaboradores, conforme Abrantes (1998).

A princípio, o investimento é nos seres humanos, com educação, treinamento qualificação profissional. O método oferece a modificação no comportamento de gestores e colaboradores, que por sua vez passam a criar times unidos com o objetivo, com visão de sobrevivência e com continuidade dos negócios, principalmente, através da economia e do combate aos desperdícios.

Diante disso, os três "S" acrescentados têm sua importância e particularidade, tais como: 
Quadro 3 - Introdução de mais 3S

\begin{tabular}{|c|c|c|}
\hline $3 S$ & PRODUÇÃO & ADMINISTRAÇÃO \\
\hline $\begin{array}{l}\text { SHIKARI } \\
\text { (determinação e } \\
\text { união). }\end{array}$ & $\begin{array}{l}\text { Prega a participação determinada da } \\
\text { alta administração em parceria com a } \\
\text { união de todos os funcionários. }\end{array}$ & $\begin{array}{l}\text { O exemplo vem de cima. Motivação. Liderança } \\
\text { e comunicação são as chaves deste Senso. }\end{array}$ \\
\hline $\begin{array}{l}\text { SHIDO (senso de } \\
\text { treinamento). }\end{array}$ & $\begin{array}{l}\text { Prega o treinamento do profissional e a } \\
\text { educação do ser humano. }\end{array}$ & $\begin{array}{l}\text { Estas ações qualificam o profissional e } \\
\text { engrandecem o ser humano que, passa a ter } \\
\text { melhor empregabilidade, essencial nos tempos } \\
\text { modernos, onde o desemprego está } \\
\text { aumentando e os novos postos de trabalho } \\
\text { exigem profissionais educados e treinados. }\end{array}$ \\
\hline $\begin{array}{l}\text { SETSUYAKU } \\
\text { (senso de } \\
\text { economia e } \\
\text { combate aos } \\
\text { disperdícios). }\end{array}$ & $\begin{array}{l}\text { Prega o combatedos desperdícios } \\
\text { reduzindo os custos e aumentando a } \\
\text { produtividade. }\end{array}$ & $\begin{array}{l}\text { Capacidade de raciocínio e criatividade das } \\
\text { pessoas, especialmente muitas de baixo nível } \\
\text { hierárquico e escolar. Estas devem ser bem } \\
\text { recompensadas, elogiadas e deve-se investir } \\
\text { com atenção especial no seu desenvolvimento } \\
\text { escolar e profissional. }\end{array}$ \\
\hline
\end{tabular}

Fonte: Adaptado de ABRANTES, 1998, p. 5.

O quadro 3 acima apresenta mais três "S", tendo como objetivo trabalhar o lado humano, em que cada senso tem sua particularidade. O Setsuyaku tem como função buscar combater o desperdício, reduzindo custos e aumentando a produtividade, o Shindo pregase a questão da qualificação dos colaboradores através de treinamentos e da melhoria do lado humano e, por fim, o Shikari que é o envolvimento da alta gestão administrativa com os demais setores, levando todos a terem uma visão e aplicação conjunta, trabalhando em equipe.

A partir desta ideia, sabe-se que aplicação desta ferramenta é de uso diário em todos os conceitos, pois com o passar do tempo, as pessoas acabam diminuindo seu envolvimento, caindo no esquecimento as premissas a serem seguidas no 8S. Portanto é importante $\mathrm{O}$ engajamento de todos envolvidos para que isso não aconteça. Levando em conta a aplicação já adquirida com o programa 5S, pode-se dizer que, como o 8S reúne ações de educação, treinamento, mudanças físicas e comportamentais, além de agraciar e valorizar os colaboradores com sugestões de acordo com Abrantes (1998).

O 8S é uma ferramenta de grande eficácia na economia de recursos de combate aos desperdícios, o que geram resultados positivos na qualidade e produtividade das empresas, além que concede um ganho na renda, crescimento do montante agregado e novos funcionários a ser contratado.

\subsection{BLOCOS DE CONCRETO}

No Brasil, os blocos de concreto começaram a ser difundidos por volta de 1940, com uma construção de um conjunto residencial no Rio de Janeiro.

Segundo Barbosa (2004), os primeiros equipamentos indicados à produção dos blocos de concreto no Brasil foram comprados dos Estados Unidos na década de 50 , determinando a abertura da história desse segmento no país.

Outro fato importante, ocorrido também nessa época foi a utilização de blocos de concreto na construção de núcleos habitacionais próximos às hidrelétricas, sendo utilizados como matéria prima, o resíduo originado na britagem dos agregados que eram utilizados nas construções das barragens (MEDEIROS, 1993, p.83).

O que pode observar pelo que Medeiros (1993) relata é que a utilização desse tipo de produto era muito baixa em muitas regiões do país e quando utilizado era para a produção de residências e construção de barragens.

Dentre os elementos de produção de residências e construção de barragens, sobressai a ausência de conhecimento profissional a respeito do assunto, desde a produção dos blocos nas centrais de processos produtivos até o crescimento dos potenciais atribuídos à sua utilização (TANGO, 1984; ALVES, 2004). Este episódio se intensifica com o elevado número de fabricantes de blocos de concreto, os quais possuem pouca informação, na grande maioria, ligada à normatização determinada pela Associação Brasileira de Normas 
Técnicas (ABNT), além de infraestrutura não ser conforme à produção a esse tipo de produto.

Os blocos de concreto são empregados na construção das alvenarias possibilitando o emprego de técnica de arranjo modular e oferecendo para a construção mais razoável. Porém os blocos de concreto devem estar assegurados às conformidades estabelecidas pela ABNT, com relação às demissões e à resistência.

\subsubsection{PROCESSO PRODUTIVO DO BLOCO DE CONCRETO}

Em 1824, o construtor inglês Joseph Aspdin queimou conjuntamente pedras calcárias e argila, transformando-as num pó fino. Percebeu que obtinha uma mistura que, após secar, tornava-se tão dura quanto às pedras empregadas nas construções. A mistura não se dissolvia em água e foi patenteada pelo construtor no mesmo ano, com o nome de cimento Portland, que recebeu esse nome por apresentar cor e propriedades de durabilidade e solidez semelhantes às rochas da ilha britânica. (FORTI, 2009).

A utilização de blocos de concreto na alvenaria iniciou-se após o surgimento do cimento Portland, quando começou a produzir produtos grandes e maciços de concreto. Foi a partir daí que surgiram esforços para a modernização na produção do bloco.

Por volta de 1866, iniciaram-se os primeiros esforços para o desenvolvimento de técnicas de moldar blocos vazados (BESSER, 2004). No final do século XIX, vários equipamentos para produzir o bloco foram desenvolvidos nos Estados Unidos, um deles se encontra na Figura 4.

Figura 4- Máquina de bloco do século XIX

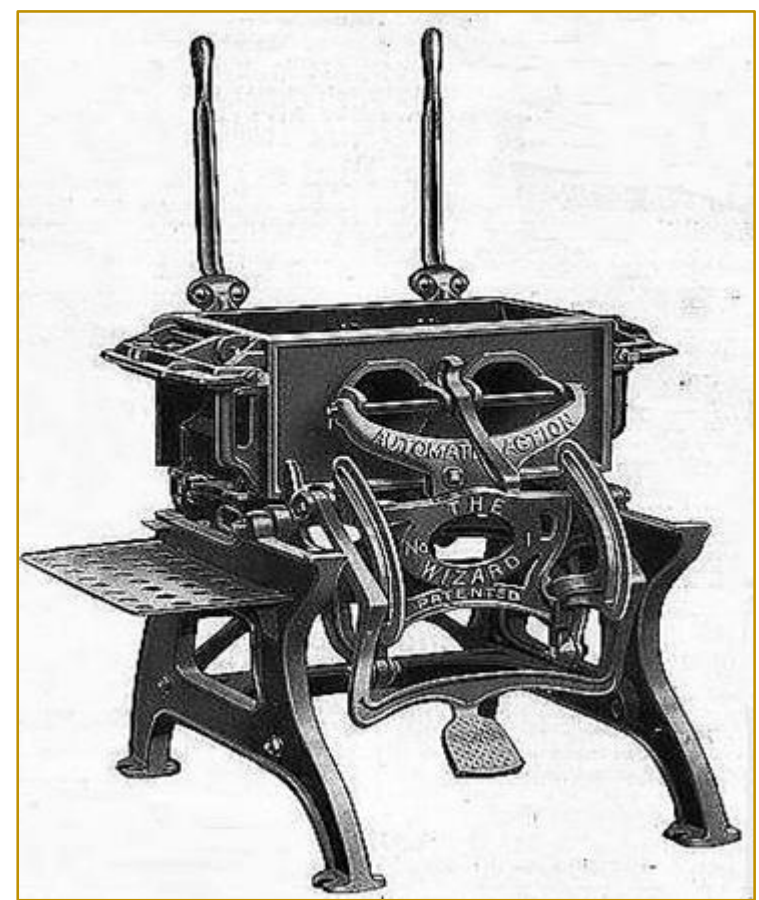

Fonte: http://www.parks.ca.gov/pages/789/images/block\%20mach.jpg,2015. apud, besser, 2004

A partir de então, houve melhorias nos processos produtivos, na qualidade dos produtos, nos resultados obtidos, por meio das máquinas automatizadas, como mostra a Figura 5. 
Figura 5 - Vibro e prensa moderna

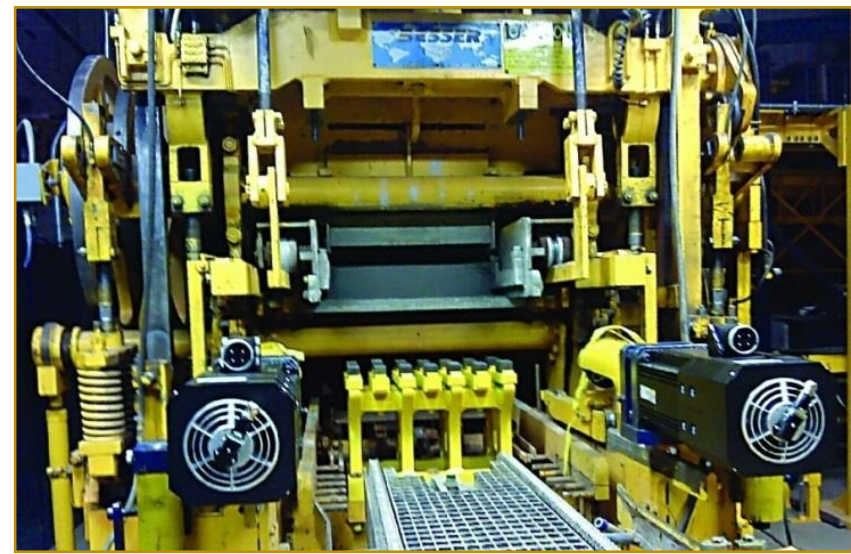

Fonte: http://besser.com/concrete-products-equipment/advanced-servo-vibration, 2015.apud, Besser, 2004

A fabricação industrial de blocos de concreto no Brasil ocorreu com 30 anos de defasagem em relação aos países europeus (HOFFMANN, 1941). Atualmente, em 2015, as fábricas de blocos no país diferem muito em termos de sofisticação e condições de organização. Em muitas fábricas de blocos, alguns estágios do processo produtivo são automatizados. Esses estágios de produção podem ser visualizados abaixo.

Figura 6 - Fluxograma do processo de fabricação de blocos de concreto

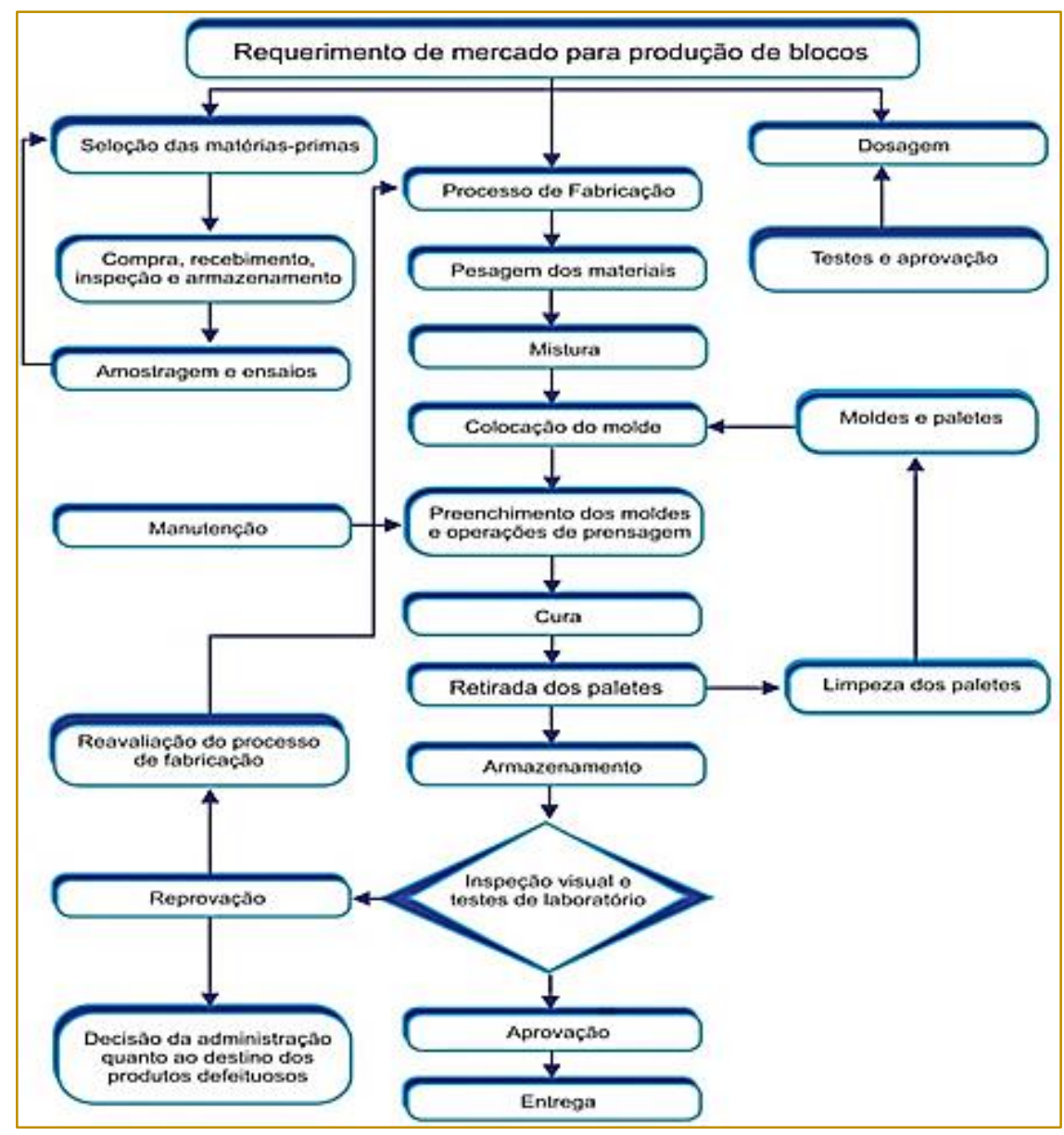

Fonte: Adaptado de SALVADOR FILHO, 2007. 
O fluxograma da figura 6 , mostra como é a fabricação de blocos de concreto no geral nas empresas. As primeiras etapas são a seleção, compras, recebimento e armazenamento em baías e silo da matériaprima. Em seguida, é feita a pesagem dos materiais de acordo com o tipo de bloco. A próxima atividade é o misturador, nos quais todos os materiais e água são misturados até obter um concreto adequado. Em seguida, o concreto é colocado em moldes, que possuem a dimensão correta do bloco a ser produzido no momento. Depois de moldado, é feito a cura dos blocos produzidos, ou seja, é a parte do processo em que o bloco irá secar. Depois de seco, é paletizado e armazenado à espera do cliente final e retirado algumas peças de blocos para fazer o ensaio de compressão no laboratório.

Entendendo-se todo o processo produtivo da fabricação do bloco de concreto, pode-se chegar à causa raiz de desperdício no momento da produção. E pode verificar como a automatização das máquinas revolucionou o processo produtivo dos blocos de concreto.

\section{METODOLOGIA DE PESQUISA}

Pesquisa tem um caráter positivo, "é um processo formal e sistemático de desenvolvimento do método científico, o objetivo fundamental da pesquisa é descobrir respostas para problemas mediante 0 emprego de procedimentos científicos" (GIL, 1999, p. 42).

Neste tópico do estudo, foram apresentados os tipos de pesquisa que se encaixam no tema proposto, como será realizado, e as ferramentas que serão utilizados para fazer a pesquisa, ou seja, buscar possibilidades de responder os problemas propostos nos objetivos desse estudo, através de dados que serão coletados, conceitos e outros.

\subsection{TIPOS DE PESQUISA}

Segundo Gil (2010), pesquisa é um procedimento racional e sistemático que tem como objetivo proporcionar respostas aos problemas que são propostos. A partir do momento que não se possui informação considerável para atender ao problema, ou quando a informação não esteja bem clara e definida, a pesquisa é requerida para que se possa relacioná-la ao problema. Para Gil
(2006), existem dois tipos de pesquisas: básica e aplicada.

"O conceito de aplicação tem sido muito utilizado na literatura mais antiga, no sentido de atividade cientifica socialmente relevante" (APPOLINÁRIO, 2006apud DEITZ, 1983).

De acordo com Appolinário (2006), para referências a pesquisas cujas conclusões conduzem à solução de problemas de interesses imediatos para a sociedade em detrimento da sua relevância teórica.

Dessa forma o termo, está mais ligado à questão da finalidade comercial. Já a pesquisa básica (ou fundamental) estaria ligada ao incremento do conhecimento científico sem quaisquer objetivos comerciais, da mesma forma que a pesquisa aplicada poderia ser suscitada por objetivos comerciais, ou seja, estaria focada para o crescimento de novos processos ou produtos orientados para as necessidades de mercado.

Verificou-se a forma de pesquisa aplicada no presente trabalho procurando desenvolver novas práticas de produção com a automatização e, consequentemente, reduzir os desperdícios. Com vistas nos processos produtivos dos blocos de concreto, utilizamse várias matrizes com formas, modelos e tamanhos diferentes, dessa forma, foi comparado todo o processo da semiautomática e automática e o quão grandemente atingiu a produtividade e como o poka yoke ajudou na redução de desperdício.

\subsection{NATUREZA DA PESQUISA}

Segundo Appolinário (2006), é muito difícil que haja alguma pesquisa totalmente qualitativa ou somente quantitativa. Isso ocorre devido ao fato de qualquer pesquisa possuir elementos tanto qualitativos e quantitativos, ou seja, ao invés de duas categorias dicotômicas e isoladas, há uma dimensão contínua com duas polaridades extremas, e as pesquisas se encontrarão em algum ponto desse contínuo, com tendência para um lado ou mais para o outro.

Existe uma distinção interessante, que antes de definir se uma pesquisa é qualitativa ou quantitativa, deve-se esclarecer a diferença entre outros dois termos fundamentais: os conceitos de "fato" e de "fenômeno", sendo que esse primeiro refere-se a qualquer evento 
que possa ser considerado objetivo, mensurável e passível de ser investigado cientificamente. Já o fenômeno pode ser entendido como interpretação subjetiva que se faz dos fatos (APPOLINÁRIO, 2006 apud MARTINS; BICUDO, 1989).

Segundo Appolinário (2006):

a) Pesquisas quantitativas: seriam aquelas que lidariam com os fatos de comuns nas ciências naturais, enquanto as pesquisas qualitativas lidariam com os fenômenos típicos das ciências sociais;

b) Pesquisa qualitativa: prevê a mensuração de variáveis predeterminadas, buscando verificar e explicar sua influência sobre outras variáveis nos processos. Centralizando sua busca em informações matematizáveis, não se preocupando com determinadas exceções, mas com generalizações.

Realizou-se o meio de pesquisa tanto quantitativa quanto qualitativa a fim de identificar os desvios no processo de fabricação dos blocos do processo semiautomático, que influenciou nos desperdícios. Como neste processo utilizou somente um tipo de produto com um tipo de mistura, pode ser obtida cientificamente uma análise qualitativa desse produto utilizado na produção dos blocos de concreto. Uma vez que se conhecem os elementos necessários para produzir os blocos, tanto quanto à matéria-prima, quanto os parâmetros de regulagem nas prensas, pode ser mensurada todos os desvios encontrados. Com todas as informações coletadas e processadas, pode ser quantificada a forma de como os elementos mensurados durante o processo produtivo 0 quanto eles afetaram nos possíveis problemas de desperdícios no processo semiautomático e automático. Desde início do recebimento da matéria prima, estocagem, "blendagem", concepção da construção das matrizes, regulagens de operação da prensa e até na saída do produto final, todos esses elementos podem ser mensurados antes, durante e depois do processo produtivo.

\subsection{PESQUISA QUANTO AOS FINS}

Quanto aos fins, conforme descrito por Gil (2006, p. 27), podem ser utilizados três tipos de pesquisas, sendo que cada tipo pesquisa tem sua particularidade, direcionando 0 estudo para possíveis métodos dos conceitos a serem aplicados, são elas: a) Pesquisa Exploratória: tem como finalidade realizar descoberta de práticas ou diretrizes que precisam ser modificadas e obtenção de alternativas ao conhecimento científico existente, tendo como objetivo principal a descoberta de novos princípios para substituírem as atuais teorias e leis cientificas, com isso a pesquisa exploratória passa-se executar coletas de dados e informações em grande teorização sobre o assunto, inspirando ou sugerindo uma hipótese explicativa;

b) Pesquisa Explicativa: tem por objetivo ampliar generalizações, definir leis mais amplas, estruturar sistemas e modelos teóricos, relacionar hipóteses numa visão mais unitária do universo e gerar novas hipóteses por força de dedução lógica, onde exige uma síntese e reflexão para que vise identificar os fatores que contribuem para a ocorrência dos fenômenos, explica o "porque das coisas". Nas ciências naturais exige a utilização de métodos experimentais e nas ciências sociais o método observacional;

c) Pesquisa Descritiva: é realizada através de observação, registros e analises dos fenômenos, sem que entre no mérito do seu conteúdo. É um método que não há interferência do pesquisador, onde apenas procura descobrir a frequência de como este fenômeno acontece. Também visa descrever determinadas características de populações ou fenômenos ou o estabelecimento de relações entre variáveis, com isso basicamente consiste na coleta de dados através de um levantamento (GIL, 2006, p. 27).

Para expandir o conhecimento sobre o tema apresentado, coletar dados que visam buscar responder os objetivos dessa pesquisa, tendo por classificá-la como pesquisa exploratória, no qual teve o propósito de analisar as práticas ou instruções que precisam ser alterado e aquisição de alternativas nas duas máquinas existentes, em busca de comparar dois processos e agregar e/ou melhorar os métodos utilizados, através de uma coleta de dados e acrescentando conhecimento sobre um evento de interesse sem ampla teorização sobre o assunto, motivando ou propondo alguma melhoria.

\subsection{PESQUISA QUANTO AOS MEIOS}

De acordo com Gil (2006, p.204), para a aquisição de uma boa pesquisa, seus dados e resultados devem ter muita clareza nos 
métodos de obtenção. Os campos de atuações das pesquisas são bastantes diversificados e vários métodos e técnicas são usados para coletar e interpretar dados. Segundo Gil (2006, p. 204), os meios usados para expressar um desenho de pesquisa científica são:

a) Pesquisa documental: neste tipo de pesquisa a natureza das fontes vale de materiais que não recebem ainda um tratamento analítico, ou que podem ser reelaborados de acordo com os objetos da pesquisa;

b) Pesquisa experimental: de modo geral, o experimento representa o melhor exemplo de pesquisa científica. Essencialmente, a pesquisa experimental consiste em determinar um objeto de estudo, selecionar as variáveis que seriam capazes de influenciá-lo, definir as formas de controle e de observação dos efeitos que a variável produz no objeto;

c) Pesquisa Ex post facto: neste tipo de pesquisa o estudo é realizado após a ocorrência de variações na variável dependente no curso natural dos acontecimentos;

d) Pesquisa levantamento: caracteriza-se pela interrogação direta das pessoas cujo comportamento se deseja conhecer. Basicamente, procede-se à solicitação de informações a um grupo significativo de pessoas acerca do problema estudado para, em seguida, mediante análise quantitativa, obterem-se as conclusões correspondentes aos dados coletados;

e) Pesquisa estudo de campo: Apresenta muitas semelhanças com o levantamento. Distingue-se, porém, em diversos aspectos. De modo geral, pode-se dizer que o levantamento tem maior alcance e o estudo de campo, maior profundidade;

f) Pesquisa estudo de caso: Esta pesquisa consiste no estudo profundo e exaustivo de um ou poucos objetos, de maneira que permita seu amplo e detalhado conhecimento, tarefa praticamente impossível mediante outros delineamentos já considerados;

g) Pesquisa-ação: Com base empírica que é concebida e realizada em estreita associação com uma ação ou com a resolução de um problema coletivo e no qual os pesquisadores e participantes representativos da situação ou problema estão envolvidos de modo cooperativo ou participativo; h) Pesquisa participante: Assim como a pesquisa-ação, caracteriza-se pela interação entre pesquisadores e membros das situações investigadas e ciência dominante (GIL, 2006, p. 204).

Seguindo as classificações citadas acima, esta pesquisa se caracteriza como estudo de caso, que Yin (2001, p.102) define como uma pesquisa empírica que "investiga um fenômeno contemporâneo dentro de seu contexto vida real; especialmente quando os limites entre o fenômeno e o contexto não são claramente definidos". Principalmente por haver caráter investigativo com profundidade e detalhamento, procurando compreender como a automatização aumentou a produtividade do processo produtivo.

\subsection{UNIVERSO E AMOSTRA}

Entende-se por universo de pesquisa um grupo de pessoas, objetos ou eventos com conjunto comum de característica definidora (GRESSLER, 2004). Neste caso, o universo da pesquisa é a empresa como um todo.

Já a amostra consiste em um subconjunto de sujeitos extraídos de um universo por meio de alguma técnica de amostragem (GRESSLER, 2004). A amostra da pesquisa consiste, em uma representação do universo, de forma que para este estudo são os setores em que fica as máquinas semiautomática e automática.

\subsection{COLETA E ANÁLISE DE DADOS}

A coleta de dados é o processo pelo qual são investigados os objetos que se pretende conhecer, como exemplo: documentação, entrevistas (Estruturadas; Semiestruturada; Não Estruturada), observação direta, entre outros. A análise de dados é nada mais do que a sintetização do resultado da investigação dos seus objetos, conforme GRESSLER, (2004).

Seguindo os conceitos GRESSLER, (2004), as metodologias, na coleta de dados, apresentam três métodos mais usuais que são utilizados para realização das análises, sendo denominadas como entrevistas. Este modelo apresenta três tipos de entrevistas, tendo como finalidade direcionar e/ou auxiliar o pesquisador na busca de coletar dados contundentes para sua análise aos pontos observados. Com isso, Gressler (2004) define os três tipos de entrevistas como: 
a) Entrevista não estruturada: Segundo Isaac e Michael (1975) apout Gressler (2004), a entrevista não estruturada, aberta ou informal dá ao respondente ampla liberdade e flexibilidade para que este se expresse em seu próprio modo e ritmo. O entrevistador tem um objetivo específico, que procura atingir sem impor uma estrutura ao respondente. Este d entrevista é o mais sujeito a vieses ou erros resultantes da inexperiência. A entrevista não estruturada é usada com frequência em estudos de caso, psicologia clínica, orientação educacional, autobiografias. É também usada para levantar as variáveis que devem ser inseridas em um estudo.

b) Entrevista semi-estruturada ou focalizada: É construída em torno de um corpo de questões do qual o entrevistador parte para uma exploração em profundidade. Requer mais treinamento e habilidades do investigador para manter o foco, reconhecendo pontos significativos e evidenciando elementos tendenciosos.

c) Entrevista estruturada ou padronizada: Uma entrevista é considerada estruturada quando segue uma padronização de questões, cujos parâmetros são préestabelecidos. Esta modalidade de entrevista segue uma estrutura bem definida, permitindo esclarecimentos, dentro de limites. Os entrevistados respondem às mesmas perguntas, na mesma ordem e formuladas com as mesmas palavras. A entrevista padronizada busca informações específicas e concisas. Seu uso é adequado quando a investigação visa obter informações completas e acuradas de todos os respondentes. As vantagens da entrevista estruturada estão ligadas à padronização das questões e, consequentemente, à grande facilidade em classificá-las. As restrições em relação à flexibilidade concorrem, em grande parte, para maior confiabilidade do instrumento, mas, por outro lado, este perde muito na profundidade das questões. (GRESSLER, 2003, p.164-165).

A partir desta explanação, propuseram a realização deste estudo com objetivo de verificar o histórico mensal, tendo início em janeiro de 2016, analisando todas as atividades desenvolvidas dentro dos dois processos produtivos, através de relatórios de controle de produção, planilhas relacionadas ao desenvolvimento do processo, gráficos quantitativos e qualitativos ligados à produção fornecidos pela empresa, controle de produção. Para melhor entendimento, houve a necessidade de realizar visitas diárias por um período de 20 dias, com o responsável pela produção de blocos da área para coletar informações de tempo, visando comparar o tempo de cada processo produtivo semiautomático e automático no qual foi utilizado um cronômetro para saber o tempo de cada processo e feito uma filmagem para melhor entendimento do processo.

Além de buscar o entendimento, observação e acompanhamento do processo, foram coletadas informações da quantidade de blocos produzidos, quantidade de agregados utilizados, com o objetivo de programar a sequência de horas e fluxo das atividades. Foi realizada entrevista não estruturada com os responsáveis pela produção e gerenciamento do processo, para buscar melhor engajamento do processo, podendo chegar à comparação dos dois processos.

\subsection{ORGANIZAÇÃO EM ESTUDO}

A pesquisa em estudo foi desenvolvida na empresa Alpha Ltda, situada na cidade de Contagem/MG, sendo uma empresa de porte médio, que possui um quadro de 95 funcionários. É a maior produtora de blocos de concreto do mercado mineiro. Suas atividades começaram em 1995, com a fabricação de lajes pré-moldadas, blocos de concretos estruturais e vedação e mourões de concreto. A empresa tem como principal atividade a fabricação de blocos de concreto estrutural e de vedação. Constitui uma cartela diversificada de clientes. Em 2012, a Alpha mudou todo o processo produtivo, investindo em automatização para aumentar sua produtividade. Com o investimento em novos modernos equipamentos, a capacidade de produção supera quase vinte vezes os números de 2003 (no qual era 160.000 blocos de concreto por mês), com capacidade de produção de cerca de 2,8 milhões de blocos de concreto por mês.

\subsection{LIMITAÇÕES DA PESQUISA}

De acordo com Meirelles (2007, p. 530) limitação de pesquisa é a "limitação é toda imposição geral, gratuita, unilateral e de ordem pública, condicionadora do exercício de direitos ou de atividades particulares às exigências do bem-estar social". 
A falta de dados precisos, controles gerados no processo de fabricação foi uma limitação de pesquisa para este estudo. Teve-se que esperar os dias que iria produzir o mesmo tipo de bloco nas duas máquinas, semiautomático e automático, também sendo uma limitação na pesquisa. A dificuldade para entrevistar o encarregado de produção, pelo fato do mesmo ser uma pessoa responsável por outros setores e ser muito ocupado. Outro fato é que a empresa não autorizou a divulgação de alguns gráficos da produção das máquinas.

\section{APRESENTAÇÃO E DISCUSSÕES DOS RESULTADOS}

"Os resultados se referem à descrição dos fatos verificados no corpus estudado, então a discussão gira em torno de pontos a serem interpretados sobre esses fatos." (SWALES E FEAK, 2004, p.269).

\subsection{MAPEAMENTO DO PROCESSO DE PRODUÇÃO DE BLOCOS DE CONCRETO NA MÁQUINA SEMIAUTOMÁTICA E AUTOMÁTICA}

$\mathrm{Na}$ figura 6 do tópico 2.5.1 mostra de uma forma geral como é um processo produtivo de bloco de concreto. Já na figura 7 , mostra um mapeamento de todo o processo da empresa em estudo e como a produção das máquinas semiautomática e automática é a mesma, foi feito somente um fluxograma para os dois modos, como mostra abaixo.

Figura 7 - Fluxograma do processo produtivo de bloco de concreto

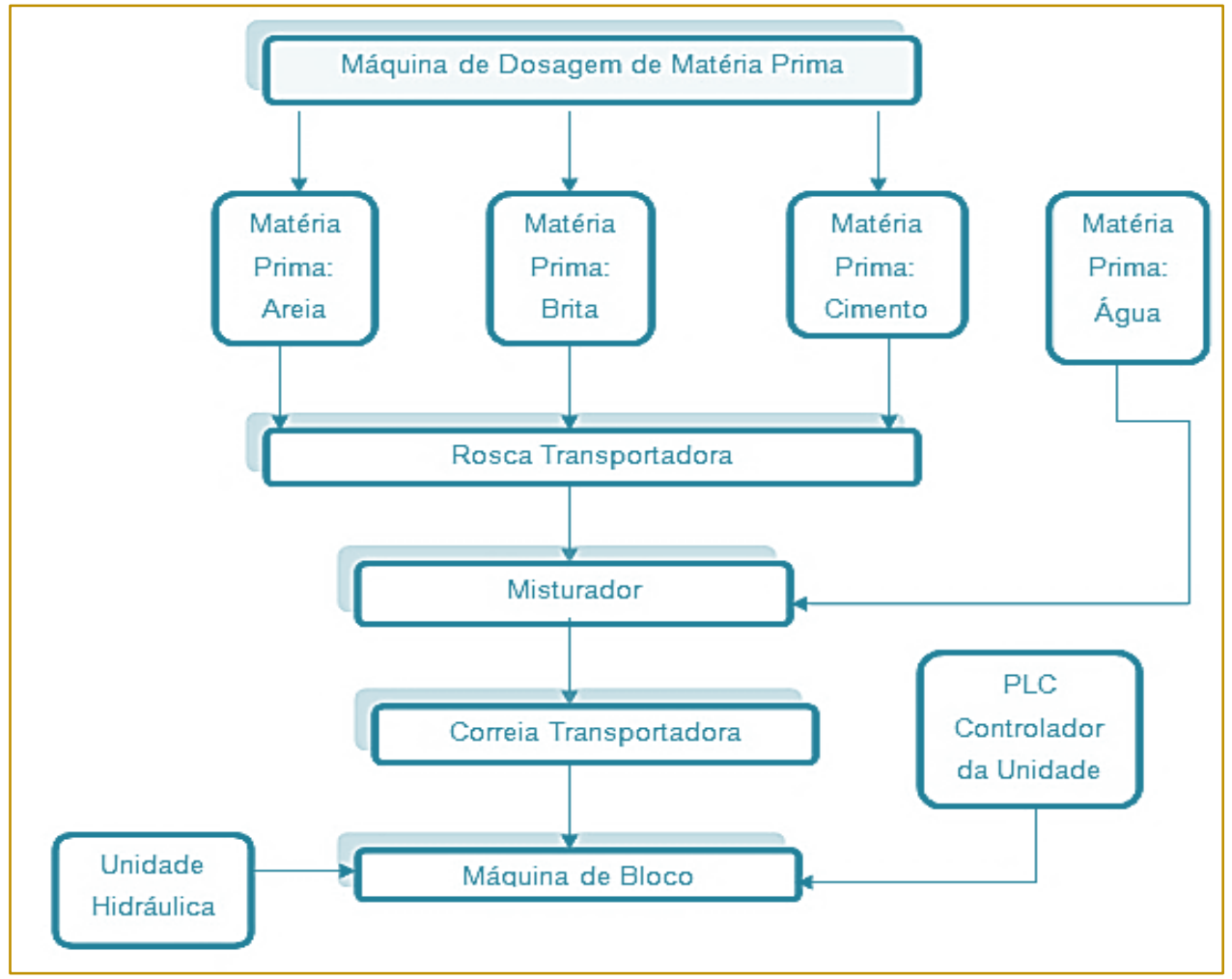

Fonte: Autoria dos Pesquisadores, 2016.

Durante um período de 20 dias, foi analisado, na empresa em estudo, o bloco BC $14 \times 19 \times 34 \mathrm{~cm}$ de $4,0 \mathrm{Mpa}$, no qual foi observada a produção do bloco nas máquinas semiautomática e automática em respectivas figuras 8 e 9 
Figura 8 - Máquina semiautomática

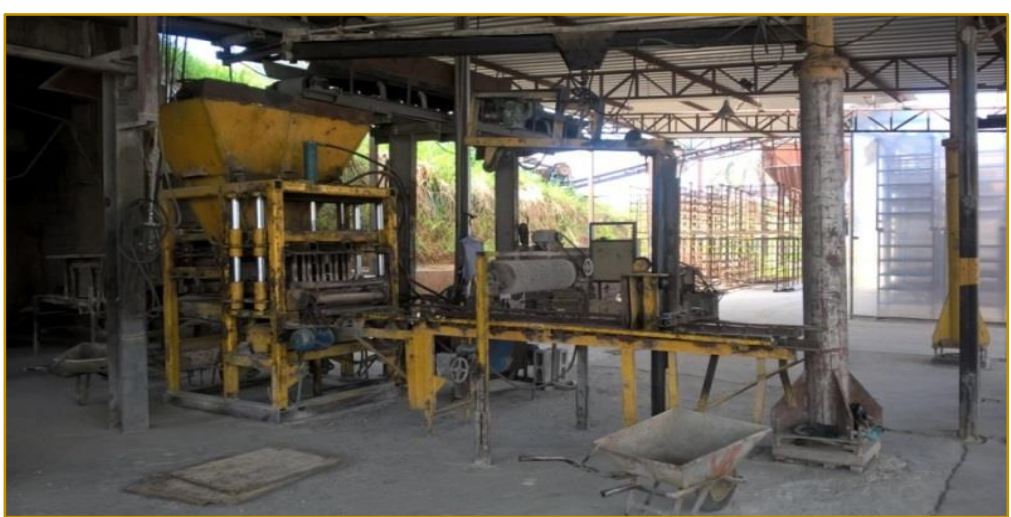

Fonte: Autoria dos pesquisadores, 2016.

Figura 9 - Máquina automática

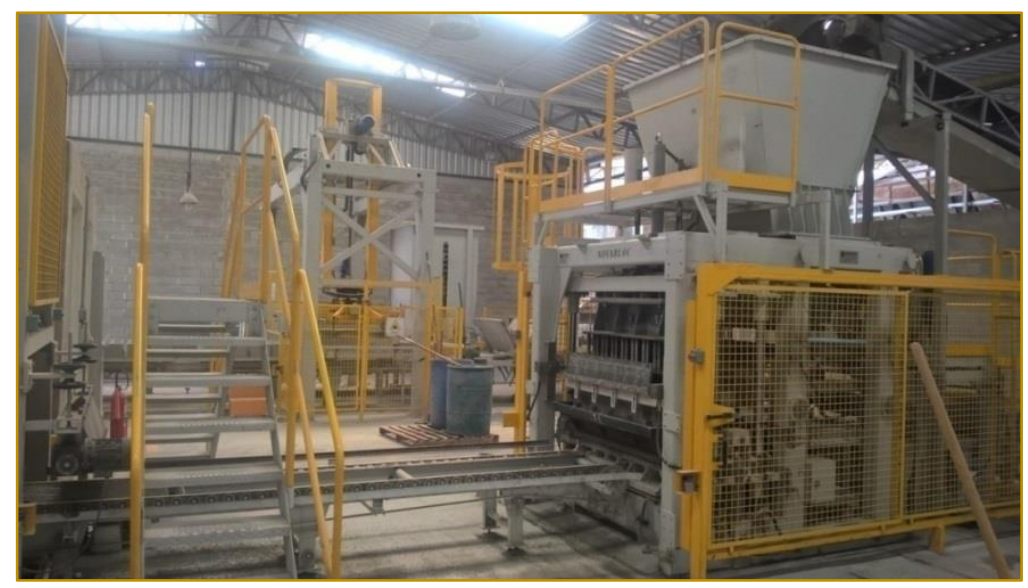

Fonte: Autoria dos pesquisadores, 2016.

Em qualquer uma das máquinas, os processos praticamente são os mesmos, o que diversifica é somente o modo como feito. $\mathrm{Na}$ automática, o processo de cura vai direto, não precisa ser feito como na semiautomática que necessita do transporte com a pinça e a empilhadeira, como mostra o quadro seguinte.

Quadro 4- Nome dos processos das máquinas

\begin{tabular}{|l|c|c|}
\multicolumn{1}{|c|}{ Processo } & Semiautomática & Automática \\
\hline Pesagem & $\sqrt{ }$ & $\sqrt{ }$ \\
\hline Misturador & $\sqrt{ }$ & $\sqrt{ }$ \\
\hline Esteira Alimentadora & $\sqrt{ }$ & $\sqrt{ }$ \\
\hline Moldagem/Vibração & $\sqrt{ }$ & $\mathrm{x}$ \\
\hline Transporte (Pinça) & $\sqrt{ }$ & $\sqrt{ }$ \\
\hline Empilhadeira (Cura) & $\sqrt{ }$ & $\mathrm{x}$ \\
\hline Direto para cura & $\mathrm{x}$ & \\
\hline
\end{tabular}

Fonte: Autoria dos Pesquisadores, 2016.

Analisando o quadro acima, foi identificado que o transporte dos blocos para a cura é feito diretamente na própria esteira que se segue após a prensagem. Mantendo-se um movimento constante e sincronizado da esteira com os equipamentos envolvidos, sendo que os paletes contendo os blocos de concreto são transportados para o interior do elevador, no qual se desloca verticalmente para cima nas prateleiras, liberando a próxima 
vaga para a chegada de um novo palete com os blocos, assim eliminar o trabalho da pinça que há na máquina semiautomática.

Ao completar a carga no elevador que suporta 10 prateleiras, é acionado o veículo de transporte conhecido como multiforca das prateleiras, que faz apenas o movimento retilíneo e uniforme exclusivamente de transportar os blocos diretamente para a estufa, para executar o processo de cura dos

blocos que em média dura 24 horas. Após esse processo é retirado os blocos para a "paletização", eliminando o trabalho da empilhadeira, pelo fato das movimentações de paletes de bloco tornou-se automatizada, com isso, todo e qualquer oportunidade qualitativa apresentada sobre o bloco e falhas operacionais foram mitigadas após a esta mudança.

\subsection{COMPARANDO A PRODUÇÃO NA MÁQUINA SEMIAUTOMÁTICA COM A AUTOMÁTICA POR MEIO DO LEAN MANUFACTURING}

Durante as visitas na Alpha, foi calculado com a ajuda de um cronômetro, o tempo que cada tipo de processo leva para fazer um traço, ou seja, relação entre as quantidades de materiais constituintes de uma mistura, da

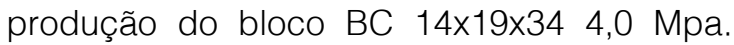
Como mostra o quadro 5.

Quadro 5- Tempo de cada processo na semiautomática e automática

\begin{tabular}{|c|c|c|}
\hline & Semiautomática & Automática \\
\hline & \multicolumn{2}{|c|}{ Tempo (segundos) } \\
\hline Pesagem & 17 & 62 \\
\hline Misturador & 97 & 85 \\
\hline Esteira Alimentadora & 75 & 22 \\
\hline Moldagem/Vibração & 20 & 11 \\
\hline Transporte (Pinça) & 20 & \\
\hline Empilhadeira (Cura) & 112 & 60 \\
\hline Total & 341 & 240 \\
\hline
\end{tabular}

Fonte: Autoria dos Pesquisadores, 2016.

Com base nos tempos de pesagem, foi constatado um tempo maior no sistema automático devido ao volume de material a ser processado relativamente superior em relação à semiautomática. Por outro lado, nos demais processos têm-se o ganho de tempo no processamento automatizado, resultando em um número maior de fabricação de blocos de concreto em menor tempo de produção.

Com o investimento da máquina automatizada, o Lean Manufacturing foi uma forma de melhorar a organização de todo o processo produtivo, gerenciar a máquina automática com todos os processos da empresa, além de alcançar os objetivos da empresa, como aumento da produtividade de blocos com uma qualidade superior.

\subsection{IDENTIFICANDO OS PONTOS DE MELHORIA E GANHO DE PRODUTIVIDADE}

No quadro 6, mostra a quantidade de blocos que foram produzidas nas referidas máquinas, tendo como comparativo entre as duas máquinas, a fim de apresentar os resultados de cada ponto mensurado como: quantidade de colaboradores, quantidade de matéria-prima, número de traços, total de horas produzidas e quantidade de blocos produzidos por hora.

Quadro 6- Dados da produção semiautomático e automático

\begin{tabular}{|l|c|c|}
\hline Quantidade de Colaborador (pessoas) & Semiautomática & Automática \\
\hline Quantidade Total de matéria prima/hora $(\mathrm{Kg})$ & 7.252 & 15.070 \\
\hline Número de Traços/hora & 7 & 11 \\
\hline Peças Produzidas/hora & 726 & 2.676 \\
\hline
\end{tabular}

Fonte: Autoria dos pesquisadores, 2016. 
Pode-se observar que o número de colaboradores é menor na máquina automática em relação a semiautomática, pelo fato das operações serem interligadas em linha por esteira rolante. Isso permite um fluxo de processos constante, eliminando certas estações de trabalhos.

Outro ponto a ser citado é o consumo de matéria-prima e os traços, no qual se têm um maior consumo de matéria-prima e número de traços, mas por sua vez tem a maior capacidade produtiva/hora em relação à semiautomática. Contudo, a empresa consegue produzir mais com menos tempo.

\subsection{IDENTIFICANDO POSSÍVEIS DESPERDÍCIOS PRODUTIVOS ATRAVÉS DO POKA YOKE}

Durante a coleta de dados na empresa em estudo, foram observados três pontos de possíveis desperdícios nas duas máquinas semiautomática e automática. Esses pontos estão descritos no quadro 7.

Quadro 7- Levantamento de possíveis desperdícios

\begin{tabular}{|c|c|c|}
\multicolumn{2}{|c|}{ Semiautomática } & Automática \\
\hline Superprodução & $x$ & $\checkmark$ \\
\hline Excesso de Estoque & $x$ & $\checkmark$ \\
\hline Tempo & $\checkmark$ & $x$ \\
\hline
\end{tabular}

Fonte: Autoria dos pesquisadores, 2016.

Nós últimos tempos, o mercado da construção resulta com a instabilidade econômica do país, coagindo as empresas a se adequarem ao cenário atual. Devido à esta situação, a empresa Alpha teve que reestruturar sua demanda produtiva, com isso alguns investimentos feitos nos últimos tempos, como a máquina automática, havendo um ganho em relação à quantidade de blocos produzidos, mas em contrapartida, por causa desta estabilidade econômica, a máquina semiautomática proporciona uma demanda menor na produção de blocos pelo fato da mesma não produzir em grande volume de blocos/hora, ao contrário a automática produz em alta escala independentemente da quantidade solicitada.

Outro ponto de possível desperdício observado é o excesso de estoque, pelo fato da automática não ter opção de produzir em pequenas escalas, com isso gera alto estoque. Por outro lado, a semiautomática proporciona uma produção mais cadenciada, conseguindo atender os pequenos pedidos.

Já referente ao tempo, a possibilidade de desperdício na semiautomática é maior que a automática, por causa do número de setups que é realizado em cada estação na fabricação do bloco.

Todo este sistema é composto com poka yoke, a fim de garantir que todo o processo seja factível contra falhas, que por sua vez, caso ocorra alguma falha em um determinado ponto do processo, todo sistema é paralisado automaticamente. O mesmo pode-se dizer com os desperdícios analisados, o poka yoke, pode controlar com mais eficácia os pontos mencionados, através de sensores, para não haver nenhuma falha e posteriormente a decorrência dos desperdícios.

\section{CONCLUSÃO}

Esta pesquisa visou identificar o tipo de processo de fabricação de blocos de concreto mais viável do ponto de vista empresarial. Através da aplicação do lean manufacturing, utilizou-se algumas ferramentas da qualidade para melhor compreensão desse estudo de caso, o qual foi realizado na empresa Alpha. Atualmente, existem dois processos de fabricação distintos na empresa, sendo um semiautomático e outro totalmente automatizado. No decorrer deste estudo, foi relatado sobre o poka yoke, no qual é uma ferramenta imprescindível em processos automatizados, a qual visa prevenir erros durante a produção, evitando assim, desperdícios de matéria-prima e tempo, os quais são uns dos itens mais importantes nessa produção.

Em um contexto geral, mostrou-se a importância de conhecer o processo e utilizar as ferramentas para levantamento dos dados para indicar os pontos de ganho sobre a produção de blocos e também as fragilidades nas duas máquinas de trabalho. 
Foi observado que após a mudança para a máquina automática, a empresa trabalha em sistema Just in case, tendo uma produção empurrada, ou seja, fabricada em alta escala sem que haja uma demanda uniforme para produção de blocos, com isso acaba gerando estoques intermediários no processo e, consequentemente, um volume elevado do produto acabado. Isso se deve a necessidade de atender a todos os tipos de clientes, aqueles que solicitam pequenas quantidades de blocos em regime de pronta-entrega e, também, a grandes pedidos do produto que há uma necessidade maior de tempo de produção, a fim de atender a todos, portanto não consegue trabalhar em sistema Just in time (produção puxada), fabricando somente a quantidade que foi solicitada.

Tratando-se da metodologia Kaizen, esse critério foi utilizado para analisar os parâmetros de produção de cada processo, tendo em vista que o estudo foi feito através de comparação de capacidade produtiva, assim toma-se os tempos de produção de cada máquina, quantidade de traços realizados e quantidade de matéria-prima, logo os dados foram estratificados de cada máquina de modo a obter os resultados e notado que houve uma melhora significativa na aplicação de máquina automatizada.

Outra ferramenta a ser citado foi a filosofia 8S, tendo uma aplicação considerável no processo. Foi observado que a empresa já adotava a filosofia 5S SEIRI (arrumação), SELTON (ordenação), SEISOH (limpeza), SEIKETSU (asseio), SHITSUKE (autodisciplina), mas com a mudança do equipamento de semiautomática para

\section{REFERÊNCIAS}

[1] Abrantes, José. Como o Programa dos Oito Sensos (8S) pode ajudar na educação e qualificação profissional, reduzindo custos, aumentando a produtividade e combatendo o desemprego. Tese (Doutorado em engenharia de produção. Área APIT) - Universidade Federal do Rio de Janeiro - COPPE/UFRJ. 1998. Disponível em:

<http://www.abepro.org.br/biblioteca/ENEGEP1998 _ART106.pdf>. Acesso em: 12 set. 2015.

[2] Alves, Dagoberto; Samora, Kwami. Aplicação da técnica de mapeamento de fluxo de processo no diagnóstico do fluxo de informações de cadeia cliente - fornecedor. 2002. Disponível em: automática, foram aplicados mais três conceitos no processo que foram utilizados no estudo de caso, sendo elas: SHIKARI (determinação e união), SHIDO (senso de treinamento) e SETSUYAKU (senso de economia e combate ao desperdício). Portanto, a empresa ganhou em força e determinação do grupo de trabalho, mantendo o espírito de trabalho em equipe, são realizados treinamentos com os colaboradores envolvidos no processo e transformando-os em agentes multiplicadores na área e no combate aos desperdícios, tendo um ganho considerável nas ações em cada etapa do processo de fabricação de blocos.

Através dos resultados obtidos nessa pesquisa, é possível concluir que a análise do Lean Manufacturing foi viável para a comparação das máquinas semiautomática e automática, pelo fato do mesmo identificar três desperdícios, superprodução, excesso de estoque e tempo e, com isso utilizar o poka yoke através de sensores, para reduzir os erros que fazem esses desperdícios acontecerem. E pelos dados coletados, não é propício continuar com a máquina semiautomática, já que a produtividade e a quantidade de colaboradores são inviáveis.

Esse estudo servirá de base para os futuros alunos e profissionais para conhecerem melhor outras fabricações de produtos, que mesmo contendo especialidades, podem ser analisados e averiguados de forma que comprovem como a automatização aumentou o processo produtivo e como podem ocorrer possíveis desperdícios durante uma produção.

<http://www.abepro.org.br/biblioteca/ENEGEP2002 _TR11_0553.pdf>. Acesso em: 17 set. 2015.

[3] Alves, J.D. Blocos pré-moldados de concreto. Goiânia: Editora da UEG, 2004

[4] Andrade. J. União Geral dos Trabalhadores - UGT; Sindicato dos Empregados NO Comércio de Belo Horizonte e Região Metropolitana. Em defesa da indústria e do emprego participa de ato conjunto com ABIMAQ e demais centrais. 2015. Disponível em: <http://www.secbhrm.org.br/noticias/noticias/view/e m-defesa-da-industria-e-do-emprego-ugt-participade-ato-conjunto-com-abimaq-e-demais-centrais > . Acesso em: 23 ago. 2015. 
[5] Appolinário. Fábio. Metodologia da ciência: filosofia e prática da pesquisa. São Paulo: Pioneira Thomson Learning, 2006.

[6] Barbosa, C.S. Resistência e deformabilidade de blocos vazados de concreto e suas correlações com as propriedades mecânicas do material constituinte. 2004. Dissertação (Mestrado) - Escola de Engenharia de São Carlos Universidade de São Paulo. São Paulo, 2004.

[7] Barnes, R. M. Estudo de Movimentos e Tempos. São Paulo: Edgard Blücher. 6eeㄹ. 1982.

[8] Besser. The concrete century. 2004. Disponível em:

[9] <http://www.besser.com/100years/concret ecentury.pdf\#search=\%22\%22block\%20machine\% 22\%20besser\%20history\%20pdf\%22>. Acesso em: 10 set. 2015

[10] Campos, Vicente Falconi. TQC: Controle de qualidade Total (no estilo japonês). $8^{\circ}$ ed. Nova Lima - MG: INDG Tecnologia e Serviços LTDA, 2004.

[11] Casado, Alberto; Valéria, Rubia; Flaviana, Claudia. Blocos de concreto para vedação: estudo da conformidade através de ensaios laboratoriais. Anais... Enegep 2008. Disponível em: <http://abepro.org.br/biblioteca/enegep2008_TN_S TO_073_519_12236.pdf $>$. Acesso em: 17 set. 2015.

[12] Corrêa, Henrique L.; Corrêa, Carlos A. Administração de produção e operações: manufatura e serviços: uma abordagem estratégica. 2. ed. São Paulo: Atlas, 2007.

[13] Deitz, S.M. Two correct definitions of "applied". The Behavior Analyst, N.G, p.105-106, 1983.

[14] De Melo, A. E. N. S. Aplicação do mapeamento de processo e da simulação no desenvolvimento de projetos de processos produtivos. Itajubá: UNIFEI, 2011.

[15] Duarte, R.B. Recomendações para o projeto e execução de edifícios de alvenaria estrutural. Associação Nacional da Indústria Cerâmica. Porto Alegre, p.79, 1999.

[16] Eduardo, Moresi. Metodologia da pesquisa. 2003. Disponível em: <http://ftp.unisc.br/portal/upload/com_arquivo/1370 886616.pdf>. Acesso em: 19 set. 2015.

[17] Esperidão, Márcia; Nogueira, Renato; Pelisson, Walternei. Gestão da qualidade total e suas ferramentas. Disponível em: $<$ https://www.inesul.edu.br/revista/arquivos/arqidvol_21_1348774929.pdf>. Acesso em: 01 set. 2015.

[18] Forti, Arnaldo. Uma breve história do cimento Portland. ABCP- Associação Brasileira de cimento Portland. Disponível em: $<$ http://www.abcp.org.br/conteudo/basico-sobre- cimento/historia/uma-breve-historia-do-cimentoportland> Acesso em: 20 set. 2015

[19] Francio. N. Evolução dos sistemas de produção e as organizações modernas. 2008. Disponível em: <http://sinop.unemat.br/projetos/ciclodepaletrasem csa/historico/2/03.pdf>. Acesso em: 05 set. 2015.

[20] Genexus. Humanware: a cara humana dos projetos. Disponível em: <http://www.genexus.com/imprensa/leernoticia/humanware-a-cara-humana-dosprojetos?pt>. Acesso em: 18 set. 2015.

[21] Gil, A. C. Como elaborar projetos de pesquisa. 3를 ed. São Paulo: Atlas, 1996

[22] Gil, Antonio Carlos. Métodos e técnicas de pesquisa social. São Paulo: Atlas, 1999

[23] Gil, Antonio Carlos. Métodos e técnicas de pesquisa social. 5. ed. São Paulo: Atlas, 2006.

[24] Gil, Antonio Carlos. Como elaborar projetos de pesquisa. 5. ed. São Paulo: Atlas, 2010.

[25] Givisiez, V. A administração e sua colaboração para as organizações do século XXI. Faculdade Casa do Estudante Aracruz. Espírito Santo. Disponível em: $<$ http://www.facefaculdade.com.br/arquivos/revista s/A_Administrao_Cientifica_e_sua_colaborao_para_ as_Organizaes_do_Sculo_XXI.pdf>. Acesso em: 13 set. 2015

[26] Godinho. M.; César. F. Manufatura enxuta: uma revisão que classifica e analisa os trabalhos apontando perspectivas de pesquisas futuras. $2004 . \quad$ Disponivel em: <http://www.scielo.br/scielo.php?pid=S0104530X2 $004000100002 \&$ script $=$ sci_arttext $>$. Acesso em: 05 set. 2015

[27] Gressler, Lori Alice. Introdução à pesquisa: projetos e relatórios. 2. Ed. São Paulo: Loyola, 2004.

[28] Ghinato, P. Elementos Fundamentais do Sistema Toyota de Produção. Produção e Competitividade: Aplicações e Inovações. Ed. Almeida \& Souza, Editora Universitária da UFPE, Recife, 2000.

[29] Gusmão, Sergio Luiz. Um modelo conceitual para integração do just in time com a teoria das restrições em pequenas e médias empresas industriais. Porto Alegre, 1998. Disponível em: http://www.lume.ufgs/bitstream/handle/10183/2053/ 000225193.pdf?sequence=1. Acesso em: 14 set. 2015

[30] Henrique, Luís. Abordagem para instalação de Poka Yoke em linhas de produção com deficientes auditivos no setor automotivo. $2010 . \quad$ Disponível em: <http://www.utfpr.edu.br/curitiba/estruturauniversitaria/diretorias/dirppg/programas/ppgem/ba nco- 
teses/dissertacoes/2010/SILVALuisHenriqueStocco da.pdf.> Acesso em: 11 set. 2015.

[31] Hoffmann, G. W. Blocos pré-moldados de concreto. Concreto Revista Técnica Ltda. Rio de Janeiro ano V, vol.7. 1941.

[32] Hunt, Daniel. Process mapping: how to reengineer your business processes. New York:John Wiley \& Sons, Inc., 1996.

[33] IMAI, M. Gemba Kaizen: estratégias e técnicas do Kaizen no piso de fábrica. São Paulo: IMAM, 1997.

[34] IMAI, Masaaki; Kaizen: a estratégia para o sucesso competitivo. 5. ed. São Paulo: IMAM, 1994.

[35] IMAI, Masaaki; Kaizen: estratégias para o sucesso competitivo. 6. ed. São Paulo: IMAM, 2005.

[36] Instituto de Engenharia Mecânica E Gestão Industrial - INEGI; Instituto de Apoio ÀS Pequenas e Médias Empresas - IAPMEI. Benchmarking nas empresas fornecedoras de serviços logísticos. Disponível em: $<$ http://www.iapmei.pt/resources/download/estudo_ sectorial_logistica.pdf>. Acesso em: 05 ago. 2015.

[37] Jordão, Sônia: Os 8S: uma extensão do programa 5S. Pós-graduação (Pós-graduação em produção e economia de energia) - Universidade Federal de Minas Gerais - UFMG. Disponível em: $<$ http://www.qualidadebrasil.com.br/artigo/qualidad e/os_8s_uma_extensao_do_programa_5s>. Acesso em: 12 set. 2015

[38] Jose, L. M. Melhoria da qualidade através de sistemas poka yoke. Disponível em: $<$ http://repositorio-

aberto.up.pt/bitstream/10216/59614/1/000141304.p df>. Acesso em 25 out. 2015.

[39] Juran, J.M.; Gryna, F. M. Controle da qualidade: métodos estatísticos clássicos aplicados à qualidade. 4 ed. São Paulo: Makron, v.6, 1993

[40] Lean Institute Brasil. Setup rápido. Disponível em: <http://www.lean.org.br/workshop/34/setuprapido.aspx>. Acesso em 15 set. 2015.

[41] Liker, Jeffrey k. O modelo Toyota: manual de aplicação. Porto Alegre: Bookman, 2007.

[42] Liker, J. K.; Meyer, D. Modelo Toyotamanual de aplicação: um guia prático para a imprementação dos 4Psda Toyota. Porto Alegre: Bookman, 2007.

[43] Luiz, Henrique. A História da gestão de produção e operações.2005. Disponível em: <https://bibliotecadigital.fgv.br/dspace/bitstream/ha ndle/10438/3202/P00259_1.pdf?sequence=1\&isAllo wed $=y>$. Acesso em: 14 set. 2015.

[44] Luiz, Sergio. Um modelo conceitual para integração do just-in-time com a teoria das restrições em pequenas e médias empresas industriais. Porto Alegre, 1998. Disponível em: <http://www.lume.ufgs/bitstream/handle/10183/205 3/000225193. pdf?sequence=1 $\mathrm{>}$. Acesso em: 14 set. 2015.

[45] Martins, J; Bicudo, M. A. V. A pesquisa qualitativa em psicologia: fundamentos e recursos básicos. São Paulo: Educ/Moares, 1989.

[46] Mattos, A. Estudo de caso: o lean manufacturing aplicado na Becton Dickinson. 2006. Disponível em: <http://www.ufjf.br/ep/files/2014/07/2006_3_Aline.p df>. Acesso em: 10 ago. 2015.

[47] Maximiano, Antonio C. Introdução à administração. São Paulo: Saraiva, 2007.

[48] Medeiros, J.S. Alvenaria estrutural não armada de blocos de concreto: produção de componentes e parâmetros de projeto. São Paulo, 1993. 449p. Dissertação (Mestrado) - Escola Politécnica, Universidade de São Paulo.

[49] Meirelles, Hely Lopes. Direito administrativo brasileiro. 33. ed. São Paulo: Revista dos Tribunais, 2007.

[50] Mello, A. E. N. S. Aplicação do mapeamento de processos e da simulação no

[51] desenvolvimento de projetos de processos produtivos. Dissertação de mestrado - Minas Gerais: Universidade Federal De Itajubá, 2008.

[52] Monden, Yasuhiro; Sistemas de redução de custos: custo-alvo e custo Kaizen. Porto Alegre: Bookman, 1999

[53] Moreira, D. A. Administração da Produção e Operações. 2 ed. São Paulo: Cengage Learning, 2008.

[54] Motta, Fernando, C. P. Teoria geral da administração: uma introdução. São Paulo: Pioneira Administração e Negócios, 2000.

[55] Oliveira Netto, Alvim Antônio de; Tavares, Wolmer Ricardo. Introdução à engenharia de produção. Florianópolis: Visual Books, 2006.

[56] Onho, Taiichi. O Sistema Toyota de Produção: além da produção em larga escala. Porto Alegre: Bookman, 1988

[57] Onho, Taiichi. O Sistema Toyota de Produção: além da produção em larga escala. Porto Alegre: Bookman, 1997.

[58] Ortiz, Chris. All-out Kaizen.IndustrialEngineer.Vol.38, Num. 4 - United States.2006. Disponível em: $<$ http://proquest.umi.com/pqdweb? did. $=1017577631 \& \mathrm{Fmt}=4 \&$ clientld $=65396 \& \mathrm{RQT}=3$ 09\&VName=PQD $>$. Acesso em: 01 set. 2015.

[59] Richiter. C. Alvenaria estrutural processo construtivo racionalizado. 2007. Disponível em: <http://www.ceramicapalmadeouro.com.br/downlo ads/richter2007.pdf. Acesso em: 14 ago. 2015. 
[60] Rother, M, Shook, J. Learning to see-value stream mapping to add value and eliminate Muda. Massachusetts: The Lean Enterprise Institute, 1998.

[61] Salvador Filho, J. A. A. Blocos de concreto para alvenaria em construções industrializadas. 2007. Tese (Doutorado) - Escola de Engenharia de São Carlos da Universidade de São Paulo, São Carlos, 2007

[62] Samora, Kwami. Metodologia para diagnóstico de problemas e fatores causadores sob o enfoque da informação - Matriz PCI. 2003. Disponível em: <http://www.saturno.unifei.edu.br/bim/0031164.pdf >. Acesso em: 17 set. 2015.

[63] Santos, Carlos Aparecido dos. Produção enxuta: uma proposta de método para a introdução em uma empresa multinacional instalada no Brasil. Curitiba, 2003. Disponível em: <http://dspace.c3sl.ufpr.br:8080/dspace/bitstream/ 1884/8776/1/dissertacao_008_Carlos\%20Aparecid o\%20dos\%20Santos.PDF>. Acesso em: 06 set. 2015 .

[64] Shah, R., \&Ward, P. T. Lean manufacturing: context, practice bundles, and performance. Journal of Operations Management, 2003

[65] Shingo, Shigeo. O sistema Toyota de Produção. 3. ed. Porto Alegre: Artes Médicas, Bookman, 1996.

[66] Shingo, Shigeo. O sistema Toyota de Produção: do ponto de vista da engenharia industrial. Cambridge: Productivity Press, RevisedEdition, 1989.

[67] Shingo, Shigeo. O sistema Toyota de produção do ponto de vista da engenharia de produção. 2 ed. Ed Porto Alegre: Bookman, 2007.

[68] Sloan, Jr., A. E. Meus anos com a General Motors. São Paulo. Negócio Editora. 1999.

[69] Silva, Lizandra; Arcoverde, Carla; Ferrari, Dalvio; Andres, Eugenio; Mauricio, Paulo. Aplicação do método Benchmarking enxuto em uma indústria de aditivos químicos e impermeabilizantes do segmento da construção civil - ENEGEP 2010. Disponível em: <http://www.abepro.org.br/biblioteca/enegep2010_ TN_STO_113_739_16614.pdf >. Acesso em 8 set. 2015.

[70] Slack, Nigel; Chambers, Stuart; Johnston, Robert.Administração da produção. 2. ed. São Paulo: Atlas 2002.
[71] Slack, Nigel; Chambers, Stuart; Johnston, Robert.Administração da produção. 2. ed. São Paulo: Atlas, 2007

[72] Spendolini, M. J. Benchmarking. São Paulo: Makron Books, 1992.

[73] Swales, J. M.; Feak, C. B. Academic writing for graduate students: essential tasks and skills. 2nd ed. Ann Arbor, Ml: The University of Michigan Press, 2004.

[74] Tachizawa, Takeshy; Scaico, Oswaldo. Organização flexível: qualidade na gestão por processos. São Paulo: Atlas, 1997.

[75] Tango, C.E.S. Blocos de concreto: dosagem, produção e controle de qualidade. 1 ed. São Paulo, Instituto de Pesquisas Tecnológicas IPT, v.1 1984

[76] Taylor, Frederick. Princípios de administração científica. 8. ed. São Paulo: Atlas 1990.

Disponível em:https://cesarmangolin.files.wordpress.com/2010 /02/taylor-principios-de-administracaocientifica.pdf>. Acesso em: 10 set. 2015

[77] Tedlow, R.S. 7 Homens e os impérios que construíram. São Paulo. Futura. 2002.

[78] Villela, C. S. S. Mapeamento de processo como ferramenta de reestruturação e aprendizado organizacional. 2000. Dissertação (Mestrado em Engenharia de Produção) - Programa de pósgraduação em engenharia de produção Universidade Federal de Santa Catarina - UFSC, Florianópolis, 2000. Disponível em: <https://repositorio.ufsc.br/bitstream/handle/123456 789/78638/171890. pdf?sequence=1>. Acesso em: 12 set. 2015 .

[79] Womack, J. P,; Jones, D. T.; Roos, D. A. A máquina que mudou o mundo. São Paulo: Campus, 1992.

[80] Womack, J.P.; Jones, D. T. A mentalidade enxuta nas empresas: elimine o desperdício e crie riquezas. 5. ed. Rio de Janeiro: Campus, 2004.

[81] YIN, Robert. Estudo de caso: planejamento e métodos. Porto Alegre: Bookman, 2001.

[82] X Seprosul, X Simpósio de Engenharia de Produção Sul-Americano. 2010. Duarte, E. Aplicação das ferramentas da qualidade no desenvolvimento do controle de produção em uma indústria moveleira. Disponível em: <http://www.fapam.edu.br/admin/monografiasnupe/ arquivos/9042015193155Ernane_Duarte_Coelho.pd f>. Acesso em: 24 out. 2015. 
APÊNDICE

Apêndice A: Estratificação dos dados pelo Kaizen

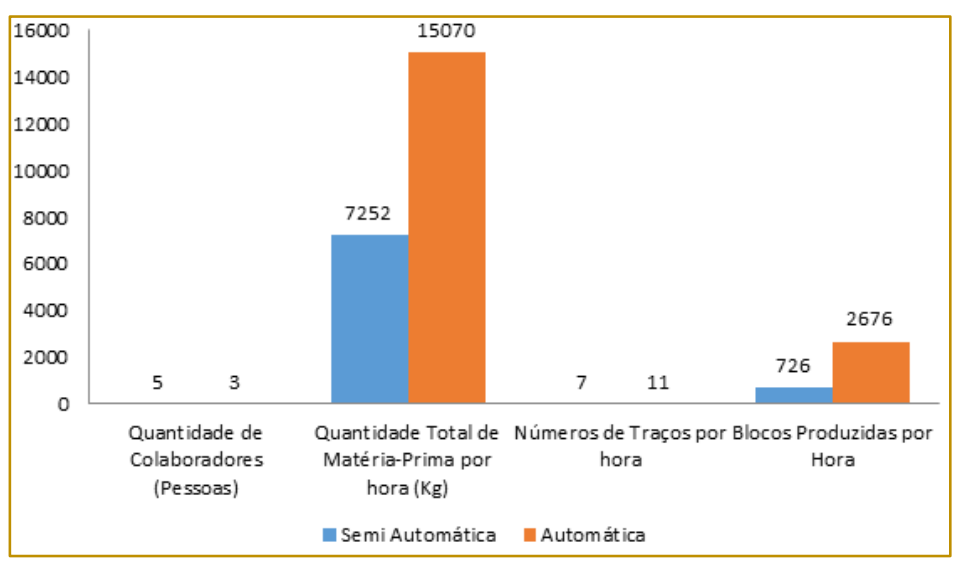

Fonte: Autoria dos pesquisadores, 2016.

\section{ANEXO}

Anexo A: Planilha 5S apresentada na empresa Alpha Ltda

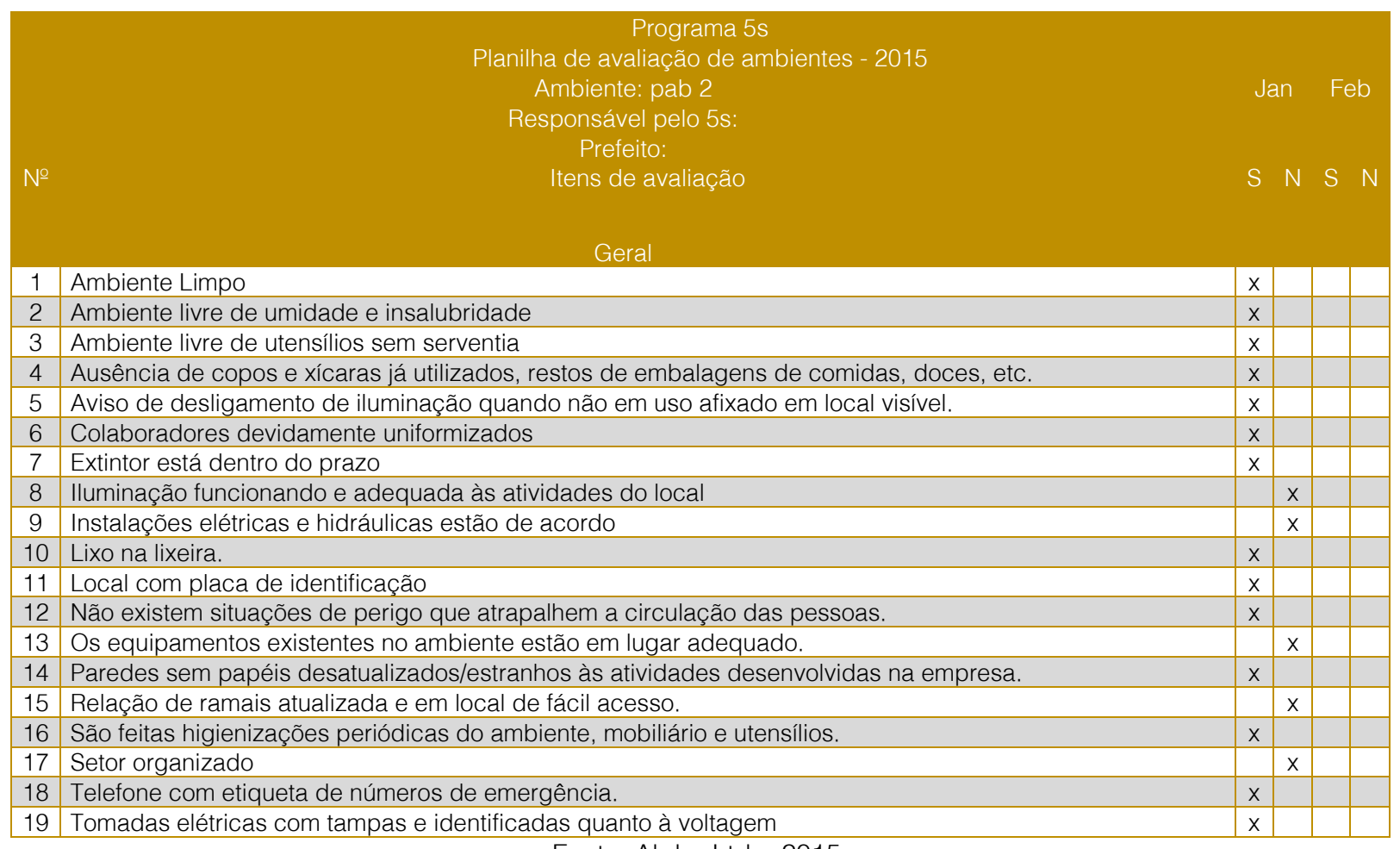

Fonte: Alpha Ltda, 2015. 


\section{Capítulo 18}

\section{ANÁLISE DA APLICAÇÃO DA FILOSOFIA LEAN MANUFACTURING EM INDÚSTRIA DE EMBALAGENS PLÁSTICAS DE PEQUENO PORTE}

\section{Luana Ferraz de Souza}

Alessandra Lopes Carvalho

Danielle Brey-Gil Faria

César Augusto Figueiredo Maciel

Resumo: Este trabalho analisa a aplicabilidade de ferramentas vinculadas a filosofia Lean Manufacturing com a finalidade de reduzir desperdícios e melhorar a capacidade produtiva. Primeiramente foi feita uma revisão bibliográfica sobre Lean Manufacturing para apresentação das ferramentas. Posteriormente foi realizado um estudo de caso descritivo a partir de análise qualitativa em uma indústria de embalagens plásticas, tendo como instrumentos de coleta de dados questionários, entrevistas e observações. Este estudo teve como proposta a sugestão de utilização das ferramentas do Lean Manufacturing que são de fácil aplicação e entendimento por parte dos funcionários e representam baixo custo para a empresa. Foi feito também um levantamento para se detectar quais ferramentas já estão sendo utilizadas e quais não se adéquam a realidade da empresa hoje em dia. A conclusão foi uma imediata implantação e aprimoramento de três das nove ferramentas apresentadas que se apresentaram mais viáveis atualmente.

Palavras-chave: Desperdício; Lean Manufacturing; Otimização. 


\section{INTRODUÇÃO}

A história da produção se inicia com produtos feitos artesanalmente. Esse sistema era de baixa produtividade, custo elevado e qualidade imprevisível (DENNIS, 2008).

No início do século XX, segundo Rodrigues (2014), o sistema artesanal deu lugar à produção em massa quando Henry fez surgir a ideia da linha de montagem e da produção padronizada.

De acordo com Rodrigues (2014), logo após a Segunda Guerra Mundial, o Japão necessitava reerguer suas organizações e torna-las produtivas novamente. O momento não era para implantação de novas mudanças e conceitos, então a atenção ficou voltada para a eliminação de desperdícios e divisão das tarefas.

O berço da aplicação desses novos conceitos foi a fábrica da Toyota. O foco no desperdício fez com que essa empresa buscasse uma nova maneira de organizar o sistema produtivo que inicialmente ficou conhecido como Sistema Toyota de Produção. Esse sistema ganhou novos conceitos e valores e serviu de base para o Sistema de Produção Enxuta ou Lean Manufacturing (RODRIGUES, 2014).

Este trabalho apresenta um estudo de caso feito em uma empresa de embalagens plásticas de Belo Horizonte abordando o sistema de produção lean.

De acordo com Werkema (2012, p.22), o Lean Manufacturing é "uma iniciativa que busca eliminar desperdícios, isto é, excluir o que não tem valor para o cliente e imprimir velocidade a empresa".

\section{REFERENCIAL TEORICO}

\subsection{LEAN MANUFACTURING}

Apesar de terem aprendido muito com os sistemas criados pelos americanos, os executivos da Toyota não se satisfizeram com o sistema de produção em massa. Sua cultura, sua economia, o foco continuo em eliminar desperdícios fizeram com que os japoneses buscassem outros meios de melhorar seu sistema produtivo. Mesmo diante da estagnação econômica do ocidente as empresas japonesas continuavam a crescer, o que chamou a atenção do mundo todo para o sistema que estava sento implantado, em especial, na Toyota (RODRIGUES, 2014).

Essa nova filosofia é chamada de Lean Thinking e segue um roteiro para maior entendimento do pensamento lean, (RODRIGUES, 2014).

Os princípios do lean thinking determinam, segundo Moreira (2015), que o valor é definido pelo cliente e não pela empresa. A empresa deve determinar o que é necessidade para o cliente e é essa necessidade que gera valor. O fluxo de valor seria separar os processos entre aqueles que de fato geram valor para a empresa, os que não geram, mas devem ser mantidos e aqueles que não geram valor e devem ser eliminados. O fluxo contínuo, que tem como objetivo eliminar as barreiras entre as organizações envolvidas tendo assim, uma melhor capacidade de se desenvolver, produzir e distribuir seus produtos rapidamente. Segundo os princípios da produção puxada, base do processo produtivo do Lean Manufacturing, o consumidor é quem puxa o fluxo, valorizando o produto e reduzindo os estoques. E por último a busca da perfeição, o aperfeiçoamento contínuo deve ser um objetivo constante de todos os envolvidos na cadeia de valor.

De acordo com Rodrigues (2014), existem muitas ferramentas que são utilizadas pelas empresas na busca da eliminação de desperdícios e impressão de velocidade aos processos.

\subsection{OS SETE DESPERDÍCIOS FUNDAMENTAIS}

Para Rodrigues (2014) o Lean Thinking tem como objetivo principal a eliminação de sete tipos de desperdícios - defeitos, superprodução, estoque, processamento, movimento, transporte e espera. Quando esses desperdícios são identificados, devemse tomar as medidas cabíveis o mais rápido possível antes que eles se tornem fontes de problemas ainda maiores para a organização. Silveira (2013) apresenta os grupos potenciais de ocorrência de desperdício:

a) Desperdício por defeitos: são produtos feitos fora das especificações dos clientes, gerando retrabalho ou refugo. O indicado é que se faça certo da primeira vez; 
b) Desperdício por superprodução: se produz mais do que a empresa é capaz de vender, gerando estoque adicional;

c) Desperdício por estoque: para evitar esse desperdício deve haver um bom planejamento de compras e a entrega imediata ao cliente assim que o produto fica pronto;

d) Desperdício por processamento: atividades desnecessárias ou superdimensionadas são desperdícios que gera custo para a empresa, mas não agregam valor ao produto;

e) Desperdício por movimento: esse desperdício atrasa o início dos trabalhos e o fluxo das atividades. Para reduzi-lo pode-se fazer uma reorganização simples no layout da fábrica;

f) Desperdício por transporte: uma maior proximidade entre clientes e fornecedores e postos de trabalho, ajudam a reduzir bastante o desperdício por transporte;

g) Desperdício por tempo de espera: evitar atrasos de todos os tipos elimina tempos longos de espera.

Desperdícios que não são vistos, dificilmente serão eliminados. Portanto, a empresa deve ficar atenta para visualizar todo e qualquer tipo de desperdício a fim de trabalhar nas causas e finalmente elimina-los.

\subsection{AS FERRAMENTAS DO LEAN MANUFACTURING \\ O sistema Lean passou a ter o Just in Time como uma filosofia de suporte.}

O Just in Time tende a nortear a organização para um menor lead time, reduzir custos, eliminar os desperdícios, aumentar a flexibilidade, dar confiabilidade ao sistema e, principalmente, possibilitar uma integração eficaz entre o ciclo de produção e o ciclo de consumo, fazendo com que a produção atenda plenamente o valor do cliente. (RODRIGUES, 2014, p.67).

De acordo com Corrêa e Gianesi (1993) o Just in time deve ser tomado como uma filosofia de trabalho, tendo como objetivos principais a qualidade, a redução de custos e a flexibilidade do processo.

Para Dennis (2008) Just in time significa produzir somente o necessário na quantidade necessária e na hora certa. Tudo o que é feito fora dessas especificações implicam em desperdícios.
Um programa que alimenta o Just In Time é o Kaizen, que significa melhoria contínua. Segundo Werkema (2012) é uma maneira de se alcançar melhorias rápidas para aprimorar total ou parcialmente o fluxo de valor. Quando é aplicado na empresa, uma equipe é formada para trabalhar em regime de dedicação total, mas a colaboração da gerência é de extrema importância. Pode ser aplicado em todos os setores da empresa sempre que se identificar fontes de desperdícios significativos.

Outro método que integra o Just in Time é o 5S. Segundo Umeda (1997) os 5S representam as inicias de palavras japonesas que em português significam separar, classificar, limpar, padronizar e manter, e são atividades destinadas e desenvolvidas por cada empregado e seu posto de trabalho.

Os 5Ss deixa tudo claro e previsível, a desordem é reduzida, os itens necessários estão sempre nos mesmos lugares e o trabalho fica mais fácil e rápido (SLACK, CHAMBERS JOHNSTON, 2009).

Além disso, de acordo com Rodrigues (2014), essa pratica também serve de base para outros trabalhos de qualidade, preparação da manutenção produtiva (TPM), troca rápida de ferramentas (TRF), e a dinâmica do Kanban.

A Troca Rápida de Ferramentas (TRF) é mais uma ferramenta que compõe o Just in Time. Para eliminar o tempo gasto com preparação, processamento e ajuste das peças nas máquinas foram desenvolvidos quatro passos práticos, que de acordo com TUBINO (2007) consistem em identificar e separar o setup interno (setup com máquina parada) do externo (setup com máquina operando); converter setup interno em externo; adicionar colaboradores na hora do setup para agilizar o processo e por último, o objetivo principal: eliminar o setup.

Ohno (1997) afirma que a Toyota reduziu o tempo de troca de ferramentas para menos de uma hora e em alguns casos pra quinze minutos, atividade que consumia de duas a três horas, o que exigiu muito treinamento no local de trabalho.

Outro método utilizado é o Kanban, que segundo Werkema (2012, p.57), é um dispositivo sinalizador utilizado nas indústrias que trabalham em sistema Just In Time: "O Kanban é usado para controlar um sistema puxado, isto é, um produto é fabricado ou um item é retirado somente quando um cartão 
Kanban assim o determinar". Neles devem conter informações como quantidade, tipo de transporte e armazenamento. Isso evita o excesso de produção e a espera por informações e mantém todos informados sobre as prioridades de produção.

Outra ferramenta que deriva naturalmente do Just In Time é a TPM, que segundo Slack et al. (2007) consiste em eliminar a variabilidade devido quebras não planejadas. Neste processo melhora-se a eficácia dos equipamentos, pois todos os funcionários são envolvidos e os operadores das máquinas são os maiores responsáveis por elas, além de realizarem pequenas manutenções e reparos frequentes. Esses operadores são devidamente treinados para isso o que compete maior habilidade em desempenhar suas funções.

O Just in Time é composto também pelo Jidoka, que segundo Rodrigues (2014), são dispositivos, muitas vezes simples, instalados nas máquinas para identificar defeitos nas peças que passassem por essas máquinas, implicando maior liberdade para o operador que poderia dessa forma, tomar conta de uma quantidade maior de máquinas.

O Poka-Yoke é mais um método utilizado no Just in Time. Para Werkema (2012) Poka-Yoke são dispositivos simples e de baixo custo instalados nas máquinas para se evitar ou avisar que um erro ocorreu e corrigi-lo no momento em que ocorre, evitando assim novos erros.

Silveira (2013) fala sobre o Heijunka, outra ferramenta do Just in Time. Trata-se de programa de nivelamento de volume e variedade de produção. Ele é aplicado para prevenir o excesso de lote, tipos de produtos e flutuações nos volumes dos produtos. Dessa forma haverá maior flexibilidade na linha de produção, redução do risco de produtos não vendidos, uso equilibrado de trabalhadores e máquinas e nivelamento na demanda. Mas para isso a empresa deve manter o setup baixo, trabalhar com operações padronizadas, a produção de itens e os estoques deve ser estabelecido e estar sempre atualizado.

O último programa tratado neste trabalho e que compõe o Just in Time é o Milk Run. Rodrigues (2014) explica que esse é um método eficaz de suprimento de materiais em uma linha de produção. Este programa apresenta vantagens como redução de custo de transporte, melhores condições para controlar o fluxo de estoque, além de poder ser controlado por um único operador logístico. Entretanto, para que isso funcione plenamente, é imprescindível que haja uma boa comunicação entre a organização e seus fornecedores e um bom plano para lidar com imprevistos alheios a indústria e aos fornecedores.

\section{METODOLOGIA}

A metodologia utilizada neste trabalho é um estudo de caso que utiliza uma análise qualitativa e de caráter descritivo com base na bibliografia apresentada anteriormente. Foi necessário compreender as várias fases do processo de fabricação das embalagens plásticas para então poder ser feitos apontamentos de melhorias para a empresa.

Para Bertucci (2008) estudo de caso é uma pesquisa que pretende conhecer uma empresa e responder como e por que ocorrem erros.

Foram feitas visitas à fábrica, entrevista com a engenheira responsável, observação direta e análise de alguns relatórios disponibilizados pela empresa.

Ainda segundo Bertucci (2008), a coleta documental pode combinar diversas alternativas de coleta de dados como entrevistas, documentos da empresa e observação direta por parte do pesquisador. A figura 1 apresenta o fluxograma que estruturou o trabalho realizado. 
Figura 1 - fluxograma com a estrutura do trabalho prático.

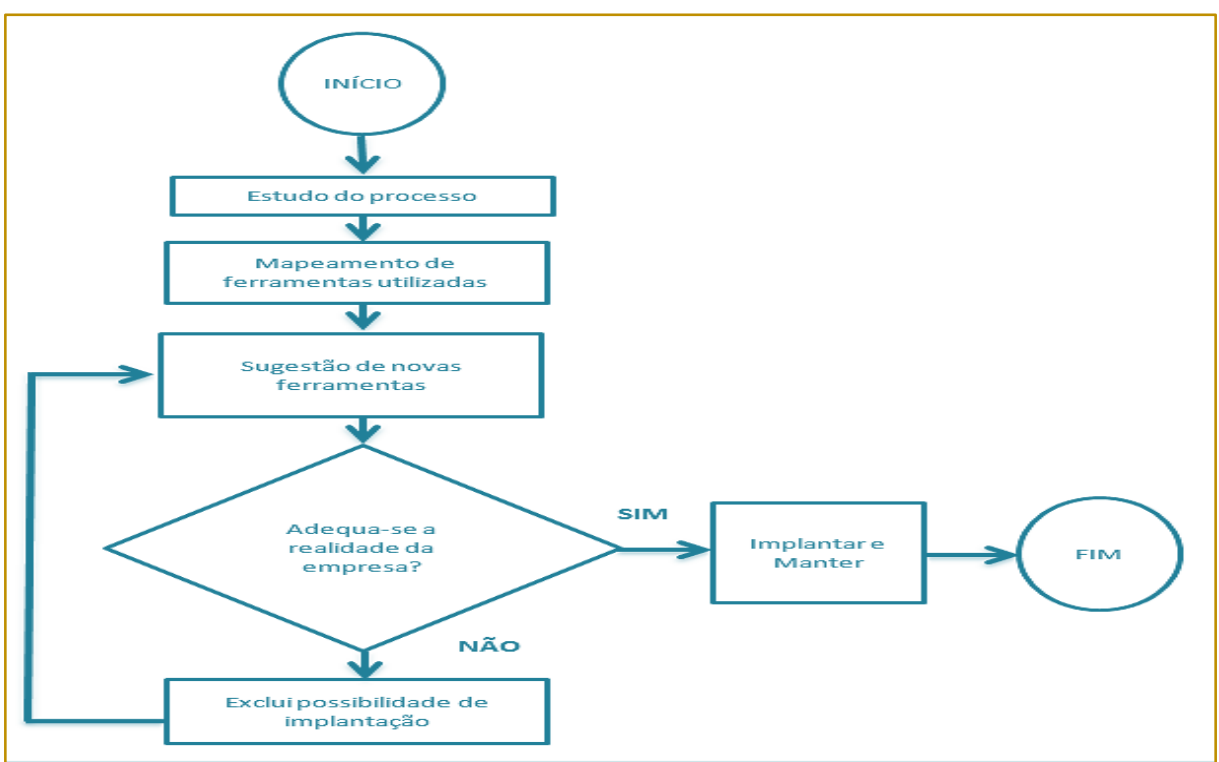

Fonte: Desenvolvido pelos autores

\section{DESENVOLVIMENTO}

\subsection{DESCRIÇÃO DO PROCESSO}

Serão descritas as atividades dos setores da linha de produção da empresa foco deste trabalho denominada Empresa Beta. O nome real da empresa foi omitido por motivo de sigilo industrial.

A empresa onde foi realizado o estudo de caso é uma tradicional fábrica e distribuidora de produtos plásticos de baixa densidade. A empresa produz sacos plásticos sob medida ou padronizados de acordo com as normas brasileiras. A linha de produção é composta pela fabricação de película, embalagens e sacos plásticos. A figura 2 ilustra o layout do fluxo produtivo que representa a ordem dos processos.

Figura 2 - Layout do fluxo produtivo.

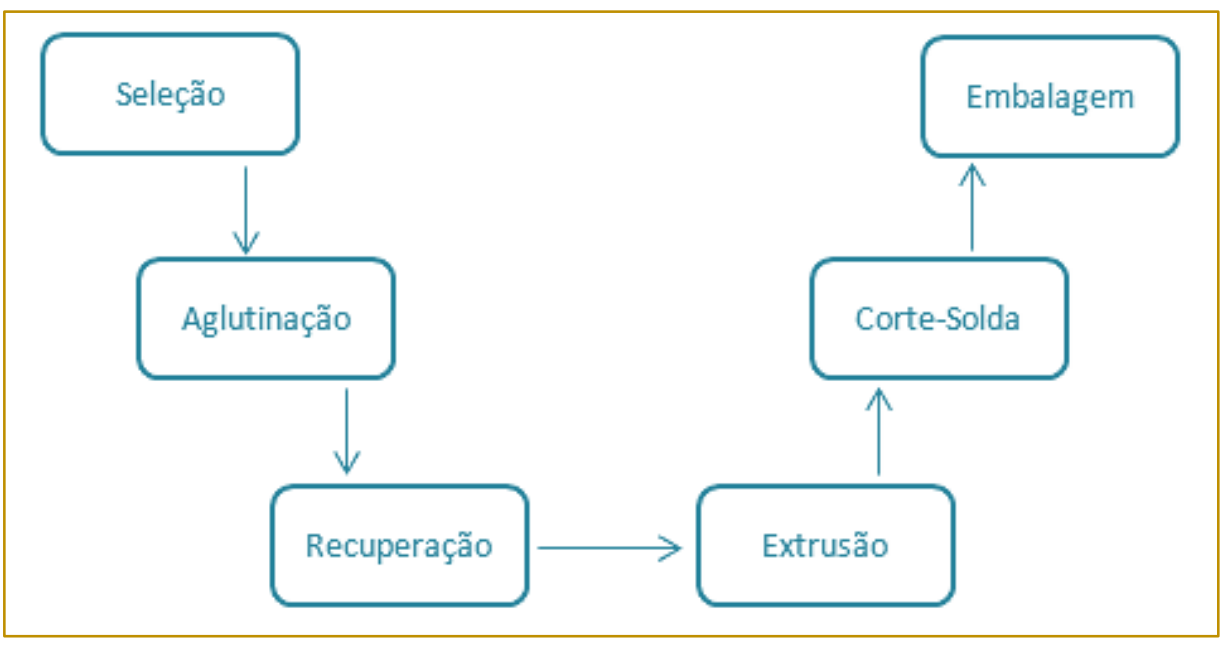

Fonte: Dados fornecidos pela empresa Beta 
Faria (2012) explica que a empresa adquire material virgem para fabricar os plásticos, mas grande parte da matéria prima vem de refugo de outras empresas e é reciclado para ser introduzido no processo. Esse material passa por processos de derretimento, trituração e extrusão, de onde sai em cores e espessuras variadas no formato cilíndrico e são finalmente enrolados em bobinas pra serem cortados, soldados e embalados de acordo com a especificação do cliente.

\subsection{COLETA DE DADOS}

As informações foram coletadas pessoalmente a partir de anotações feitas pelos autores em visitas à empresa, entrevista com a engenheira responsável e questionário aplicado aos funcionários da fábrica. Assim foi possível analisar se existiam os sete desperdícios citados no referencial teórico deste trabalho e identificar onde poderiam ser implantadas algumas das ferramentas do Lean Manufacturing capazes de resolver problemas identificados.

\subsection{CARACTERIZAÇÃO DOS PROBLEMAS}

Conforme estudos anteriores realizados por Faria (2012) nesta mesma empresa e observados novamente pelos autores, alguns setores apresentam gargalos. Podem ser citados a chegada (alimentação) do processo, o que causa grandes acúmulos de matéria prima vinda de refugo, e o cortesolda, onde há acumulo de materiais vindos do setor de extrusão. Já é sabido que estoques em excesso podem esconder problemas e visualmente deixarem a fábrica tumultuada.

Notou-se também a necessidade de um aprimoramento nos conceitos de 5S uma vez que medidas já haviem sido adotadas pela empresa e ainda persiste um certo grau de desorganização nos postos de trabalho. Um local de trabalho limpo e organizado traz mais disposição e senso de responsabilidade aos colaboradores, já que quem mantém limpo os setores são os próprios funcionários, tornando visíveis situações fora de padrão e assim podendo ser resolvidas mais rapidamente.

Outro problema observado pela pesquisadora foram as máquinas paradas no setor de Corte-Solda da fábrica. Isso afeta todo o setor, pois sobrecarrega as outras máquinas e causa gargalo.
A empresa reconhece ainda algumas falhas oriundas da falta de motivação dos funcionários, falta de interesse em reportar para seus superiores problemas ocorridos no chão de fábrica, desinteresse no trabalho em equipe e falta de responsabilidade com relação as Ordens de Produção que muitas vezes acarreta em retrabalho. Esses problemas são considerados muito graves, pois sem o interesse e colaboração dos funcionários os problemas observados pela pesquisadora se tornam difíceis de serem resolvidos, pois são totalmente dependentes de ações realizadas por eles para se chegar ás soluções.

Este trabalho foca nos seis processos de produção da indústria a fim de melhorar a linha produtiva com sugestões de implantação e utilização de algumas ferramentas do Lean Manufacturing.

\subsection{SUGESTÕES DE MELHORIAS}

O gargalo existente na alimentação do processo é um problema identificado já no início da fabricação dos plásticos. A ideia inicial seria a implantação do Milk Run para solucionar esse problema. Esse método poderia gerenciar e controlar o fluxo de materiais vindos dos fornecedores. Entretanto, a empresa Beta não poderá fazer muitas mudanças quanto a aquisição da matéria prima reciclável para não correr o risco de perder seu fornecedor. Para resolver esse impasse, então, foi sugerido que a empresa deixe 0 setor organizado fazendo delimitações entre os setores para que o material que alimentará o setor subsequente não ocupe o espaço fora das demarcações.

O nível de desorganização em alguns setores da fábrica ainda persiste. Novos treinamentos de $5 S$ devem ser realizados para a conscientização dos funcionários de que essa é uma prática de grande importância por trazer muitos benefícios. Essa é a base para melhorias. Deve-se sempre lembrar que tanto o 5S quanto qualquer outra ferramenta do Lean Manufacturing devem ser considerados cultura dentro da empresa, ou seja, devem se tornar hábitos e as ações não podem ocorrer somente nos dias dos treinamentos.

Para evitar o desperdício da movimentação desnecessária, quadros e prateleiras para guardar ferramentas utilizadas no dia a dia podem ser adotados. Delimitações como faixas amarelas desenhadas no chão para 
que todos saibam onde é seguro transitar e onde exatamente devem ficar os equipamentos e as máquinas é outra sugestão. Essa melhoria, em especial, precisa antes passar por uma reforma do piso da fábrica, pois este se encontra danificado de forma que pode vir até causar acidentes.

Não só as máquinas, mas os equipamentos e os setores devem ser alvo de limpeza. Devem-se descobrir as principais causas do problema de limpeza e trabalhar em cima disso para eliminar a origem da sujeira. Por exemplo, próximo a rosca sem fim foi encontrado material ao chão. O ideal é que o operador coloque-o diretamente em um recipiente para reciclagem, e não deixar essa providência para ser tomada depois.

Foi aplicado um questionário simples aos funcionários da fábrica com o intuito de saber qual o nível de engajamento de todos para com o 5S. No total foram aplicados 13 questionários. Constatou-se que 100\% desses funcionários consideravam importante manter o local de trabalho limpo e organizado, que o 5 S era importante e que o treinamento serviu para melhorar o trabalho de todos. Somente na última pergunta houve uma pequena queda nesse índice, mostrando que $8 \%$ dos funcionários que responderam ao questionário não consideram importante ter mais treinamentos sobre esse assunto. Esse número indica que já está no momento de ser realizado mais um treinamento $5 \mathrm{~S}$.

O 5S deve se tornar rotina na fábrica e para isso a empresa deve investir em treinamento, promoção e comunicação, por exemplo, quadros para que os funcionários preencham toda vez que for realizada limpeza no setor e premiações para quem se destacar.

O 5S naturalmente leva à Manutenção Produtiva Total (TPM), pois com as medidas de cuidados com as máquinas, cada funcionário será inevitavelmente treinado a fazer pequenas intervenções como lubrificação, pequenos ajustes, limpeza e inspeção em suas máquinas. São intervenções simples como essas que podem evitar grandes problemas como máquinas paradas esperando manutenção especializada trazendo maiores custos para a empresa.

Com a TPM eliminam-se as seis grandes perdas: avaria (perda total de função); atrasos nos ajustes; tempo de pequenas paradas; velocidade reduzida; defeitos de processamento e rendimento reduzido. O objetivo final da TPM é a meta zero de interrupções e parada total das máquinas por defeito ou quebra. Se todo o possível for feito para se manter as máquinas bem ajustadas as manutenções para prevenção poderão ser programadas sem que precise interromper a produção e sem que haja surpresas desagradáveis.

Foi aplicado um segundo questionário aos operadores de máquinas para saber se eles faziam pequenas intervenções em suas máquinas ou se verificam se estão precisando de algum tipo de conserto. Foram aplicados 9 desses questionários. Constatou-se que 67\% dos operadores já fizeram algum pequeno ajuste em suas máquinas e 8 funcionários que responderam ao questionário, confere sempre se é preciso algum ajuste mesmo antes de aparecer um defeito; $100 \%$ dos funcionários responderam que limpam suas máquinas, mas apenas 3 operadores lubrificam. Quando aparece algum tipo de problema no maquinário $50 \%$ dos questionados responderam que inicialmente tentam solucionar o problema sozinhos, a outra metade dos funcionários, se não conseguirem, solicitam o encarregado ou engenheiro responsável. A apuração desses dados revelou que ainda existe a necessidade de mostrar a alguns funcionários as simples intervenções que eles podem realizar em suas máquinas.

A tabela 1 a seguir pode auxiliar os operadores de máquinas da empresa Beta a controlar as inspeções feitas nas máquinas e a periodicidade que elas ocorrem. Essa tabela também serve para auxiliar a gerência a tomar ciência de qual o problema mais frequente e tornar prioridade de verificação na manutenção preventiva feita por uma equipe mais especializada. 
Tabela 1 - Folha De Verificação Tpm

\begin{tabular}{|c|c|c|c|c|c|c|c|}
\hline $\begin{array}{c}\text { Folha de verificação } \\
\text { TPM }\end{array}$ & 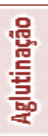 & 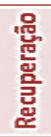 & $\begin{array}{l}\overrightarrow{0} \\
\text { 苞 }\end{array}$ & 雚 & 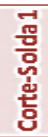 & 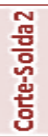 & 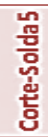 \\
\hline \multicolumn{8}{|l|}{$\begin{array}{l}\text { Ferramenta contém } \\
\text { sujeira/graxa/óleo }\end{array}$} \\
\hline \multicolumn{8}{|l|}{$\begin{array}{l}\text { Contém peças que não se } \\
\text { movem }\end{array}$} \\
\hline \multicolumn{8}{|l|}{ Sinal de desgaste } \\
\hline \multirow{2}{*}{\multicolumn{8}{|c|}{ Trincas ou quebras }} \\
\hline \multirow{2}{*}{\multicolumn{8}{|c|}{$\begin{array}{l}\text { Peças entupidas } \\
\text { Más condições de eixos }\end{array}$}} \\
\hline & & & & & & & \\
\hline \multicolumn{8}{|l|}{$\begin{array}{c}\text { Parafusos e porcas } \\
\text { frouxos ou em más } \\
\text { condições }\end{array}$} \\
\hline \multicolumn{8}{|l|}{$\begin{array}{l}\text { Falta de lubrificação de } \\
\text { ferramentas }\end{array}$} \\
\hline \multicolumn{8}{|l|}{ Aquecimento excessivo } \\
\hline \multicolumn{8}{|l|}{ Vibração excessiva } \\
\hline \multicolumn{8}{|l|}{$\begin{array}{l}\text { Más condições de fios/ } \\
\text { tomadas }\end{array}$} \\
\hline \multicolumn{8}{|l|}{$\begin{array}{l}\text { O usuário anterior deixou } \\
\text { a máquina em más } \\
\text { condições de uso }\end{array}$} \\
\hline \multicolumn{8}{|l|}{ Operador: } \\
\hline Observações: & & & & & & & \\
\hline
\end{tabular}

Fonte: Adaptade Dennis, 2008

Com isso a empresa poderá então calcular a disponibilidade das máquinas, a eficiência de desempenho e a eficácia de equipamentos, pois será capaz de obter resultados mais precisos e reais. Assim, futuramente os funcionários terão condições de medir pequenas paradas, tempo entre falhas (MTBF) e tempo médio de reparo (MTTR), pois saberão a importância desses números para a produtividade e saúde da empresa.
Para que esses grandes avanços aconteçam de fato na empresa Beta, é fundamental que os funcionários estejam cientes da importância das melhorias constantes.

As atividades de manutenção devem ser organizadas de acordo com o ciclo de vida do equipamento que geralmente segue a chamada curva da banheira, mostrada na figura 3.

Figura 3 - Curva da Banheira

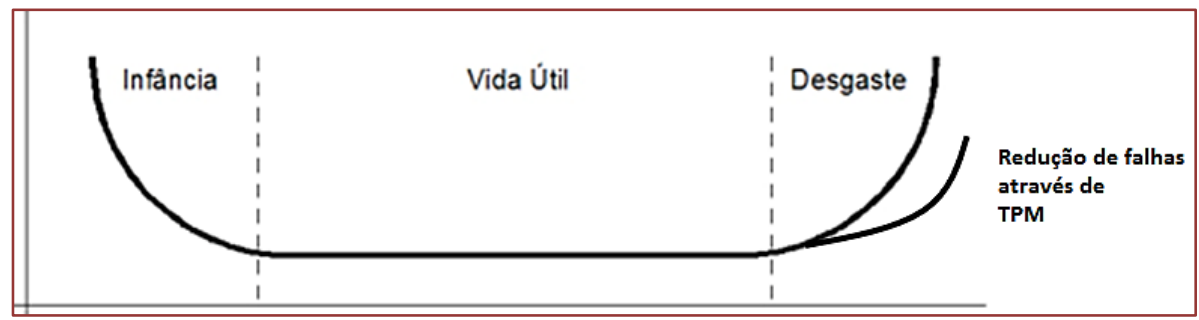

Fonte: Adaptado de Dennis 2008

Para cada etapa da vida do equipamento existem falhas, causas dessas falhas e medidas que devem ser tomadas em cada caso. Na fase de Infância do equipamento as falhas geralmente acontecem por erros de projetos. Na fase de Vida Útil as falhas acontecem por acaso, são erros operacionais e nesse caso que é mais importante a verificação das máquinas e rastreamento das falhas para se tomar medidas certas. Já na fase de Desgaste, fase de envelhecimento dos equipamentos, as falhas ocorrem justamente por desgaste das máquinas e a prevenção e a manutenção são as melhores soluções. Por isso se faz tão necessário nesse estudo de caso a utilização da ferramenta 
TPM, pois, em visita a empresa, um dos engenheiros da fábrica explicou que a empresa Beta conta com maquinário e equipamentos antigos, onde até mesmo os próprios funcionários, por vezes, encontram dificuldade em operá-las. Uma observação importante deve ser feita considerando que três das cinco máquinas corte-solda já estão na fase de velhice e já foi mostrado anteriormente que há um gargalo neste setor.

Quando as realizações de manutenções simples nas máquinas se transformarem em rotina para os funcionários, a empresa irá perceber o aumento de vida útil e a eficiência de equipamentos e aumento da competência dos operadores das máquinas.

A empresa não conta com tecnologia de ponta em todos os setores para informar que algo de errado está acontecendo. Por isso os funcionários do setor de aglutinação e recuperação tem que estar atentos o tempo todo para que o silo da máquina de aglutinação não se esvazie e o silo da máquina recuperadora não transborde. Eles precisam verificar o tempo todo a quantidade de material nessas máquinas que tem um processo relativamente acelerado. $\mathrm{Na}$ máquina recuperadora já foram implantadas "janelas" de acrílico para que se veja de longe se o silo está muito cheio. Na máquina de aglutinação uma solução seria a implantação de uma ferramenta Jidoka, podendo ser instalado um sensor que avise cada vez que o material chegar a um determinado nível. Dessa forma o operador pode se concentrar em outra atividade até que soe o alarme informando que a máquina precisa ser realimentada.

A adoção do Jidoka e a melhoria de $5 S$ e Manutenção Produtiva Total podem ser colocados em prática imediatamente, pois representam baixo custo para a empresa e podem significar ganho como a eliminação do desperdício de movimento no setor de recuperação de material, disciplina com relação a organização e maior responsabilidade e avanço no uso das máquinas da fábrica. Com relação as outras ferramentas Lean Manufacturing podemos dizer que a Poka-Yoke já é utilizada, por exemplo as "janelas" de acrílico instaladas no silo da máquina recuperadora. Um dispositivo Jidoka também já foi instalado entre a rosca sem fim e a recuperadora, trata-se de um alarme que soa cada vez que há irregularidade.

Foi possivel perceber que a empresa Beta já utiliza muitos conceitos tratados neste trabalho, ela só precisa aprimora-los e manter sua equipe sempre atualizada sobre a importância da colaboração de cada um para o sucesso da empresa para se tornar cada vez mais competitiva. A seguir é apresentada na tabela 2 quais ferramentas do Lean Manufacturing já são utilizadas, quais podem ser adotadas pela empresa e outras que poderão ser adotadas futuramente.

O Kaizen acontecerá de forma gradativa e natural a medida que os funcionários da empresa perceberem que uma melhoria nunca pode ser considerada definitiva. Já o TRF, Kanban e Heijunka precisarão esperar um pouco para serem colocados em prática já que necessitam de investimentos maiores e que o 5S e a Manutenção Produtiva Total estejam claros para todos os funcionários. Com o tempo a empresa Beta se tornará uma organização Just In Time adotando medidas simples e de baixo custo, contando com a colaboração de todos.

Tabela 2 - Ferramentas Adotadas

\begin{tabular}{|c|c|c|} 
Ferramentas e & $\begin{array}{c}\text { Conceitos que podem } \\
\text { ser aprimorados } \\
\text { imediatamente }\end{array}$ & $\begin{array}{c}\text { Ferramentas que } \\
\text { poderão ser adotadas }\end{array}$ \\
\hline $5 S$ & $5 S$ & Kaizen \\
\hline TPM & TPM & TRF \\
\hline Jidoka & Jidoka & Heijunkan \\
\hline Poka-Yoke & & \\
\hline Milk Run & \multicolumn{2}{c}{} \\
\hline \multicolumn{2}{|c|}{ Fonte: Desenvolvido pelos autores } \\
\hline
\end{tabular}




\section{CONCLUSÕES}

Manter uma empresa funcionando em pleno vapor e com baixo número de desperdícios é um desafio enorme para a organização objeto de estudo deste trabalho considerando não se dispunha de muitos recursos financeiros para implementação de ferramentas que exigiam investimentos altos. Foram sugeridos implantações e aperfeiçoamentos de ferramentas do Lean Manufacturing com o intuito de melhorar a produção, eliminar desperdícios e aumentar a responsabilidade dos funcionários com relação ao trabalho como um todo.

A melhoria dos conceitos de $5 \mathrm{~S}$ e Manutenção Produtiva Total são fundamentais já que estas são ferramentas que servem de base para

\section{REFERÊNCIAS}

[1] Bertucci, J. L.O. Metodologia básica para a elaboração de trabalhos de conclusão de curso (TCC): ênfase na elaboração de TCC de pósgraduação Lato Sensu. São Paulo: Atlas, 2008.

[2] Corrêa, H. L.; Gianese, I. G. N. Just in time, MRP II e OPT: um enfoque estratégico. 2. ed. São Paulo: Atlas,1993.

[3] Dennis, P. Produção lean simplificada: um guia para entender o sistema de produção mais poderoso do mundo. 2. ed. Porto Alegre: Bookman, 2008 .

[4] Faria, D. B. Modelagem e simulação da manufatura em uma indústria de embalagens plásticas. 61f. Monografia (Conclusão de curso) Graduação em Engenharia de Produção, Instituto Politécnico, Pontifícia Universidade Católica de Minas Gerais, Belo Horizonte, 2012.

[5] Moreira, F. Os princípios do lean thinking. (2010) Disponível em < https://www.portalgestao.com/item/6002-os-princ\%C3\%ADpios-

oleanthinking.html > Acesso em 10 de setembro/2015. sustentar toda a filosofia Lean. Após isso será possível aplicar ferramentas Jidoka que não exigem grandes gastos. Futuramente as outras ferramentas Lean poderão ser aplicadas de forma gradativa, lembrando sempre a importância do acompanhamento do desenvolvimento dos conceitos para que se tornem rotina na empresa.

A utilização do Lean Manufacturing se destaca por ser eficaz no aumento da competitividade da empresa, tem por finalidade a eliminação de desperdícios e o auxílio na melhoria contínua, é de rápido entendimento por parte dos funcionários e baixo custo para a empresa.

[6] Ohno, T. O sistema Toyota de produção: Além da produção em larga escala. Porto Alegre: Bookman, 1997.

[7] Rodrigues, M. V. Entendendo, aprendendo e desenvolvendo sistema dee produção Lean Manufacturing. Rio de Janeiro: Elsevier, Campus, 2014.

[8] Silveira, C. B. Sete desperdícios na produção. (2013). Disponível em < http://www.citisystems.com.br/7-desperdiciosproducao/ > Acesso em 16 de setembro/2015.

[9] Slack, N.; Chambers, S.; JOHNSTON, R. Administração da produção. 3. ed. São Paulo: Atlas, 2009.

[10] Tubino, D. F. Planejamento e controle da produção: teoria e prática. 2. ed. São Paulo: Atlas, 2009.

[11] Umeda, M. As sete chaves para o sucesso do 5S. Belo Horizonte: Fundação Cristiano Otoni, 1997.

[12] Werkema, M. C. C. Lean seis sigma: Introdução às ferramentas do Lean Manufacturing. 2. ed. Rio de Janeiro: Campus, 2012. 


\section{Gapítulo 19}

\section{CONCEITOS DO SISTEMA TOYOTA DE PRODUCÃO PROPOSTOS POR SHINGO E OHNO E SUA APLICABILIDADE ATUAL NAS ORGANIZAÇÕES}

\section{Ismael Cristofer Baierle}

Jones Luís Schaefer

Jaqueline de Moraes

Heloísa Pereira Burin

Johanna Dreher Thomas

Resumo: O objetivo deste trabalho é realizar uma revisão da literatura sobre os conceitos, métodos e ferramentas do Sistema Toyota de Produção (STP) propostos por Shigeo Shingo e Taiichi Ohno e comparar com pesquisas recentes, para saber como as organizações estão implementando o STP. Outra preocupação é verificar se os estudos realizados e publicados nos últimos anos ainda estão utilizando os princípios e conceitos idealizados por Shigeo Shingo e Taiichi Ohno integralmente e se eles ainda são referência principal nas pesquisas atuais. Inicialmente foi realizada uma revisão bibliográfica sobre os principais conceitos do STP e após um comparativo desses conceitos com a aplicabilidade na atualidade. Foram utilizadas para a pesquisa publicações dos últimos 5 anos por meio de consultas na base de dados Scopus. Os resultados indicam que o STP não é amplamente conhecido pelas organizações e mostram que existem barreiras culturais para implementação. 


\section{INTRODUÇÃO}

O Sistema Toyota de Produção (STP), juntamente com outras técnicas de gestão japonesas, tem sido implantado em muitas empresas nas últimas décadas como forma de reinventar sua forma de gestão e gerenciar as operações. Alvarez \& Antunes Jr. (2001) dizem que um dos primeiros modelos do STP foi apresentado no livro "O Sistema Toyota de Produção", de Yasuhiro Monden (1984), cuja versão em inglês é de janeiro de 1982. Sendo assim, entre as décadas de 1970 e 1980 as empresas americanas e europeias começaram a aprender uma nova lição industrial baseada Total Quality Control (TQC) e no STP de empresas japonesas como a Toyota. Diversos pesquisadores americanos tais como: Deming, Juran, Crosby, Feigenbaum e Ishikawa publicaram livros e artigos sobre a implementação do TQC, enquanto que autores japoneses tais como Shigeo Shingo, Taiichi Ohno e outros começaram a divulgar e teorizar as ferramentas e os princípios da filosofia do modelo de produção japonês, que passou a ser conhecido como Sistema Toyota de Produção.

Um dos primeiros modelos estruturados sobre - STP foi apresentado no livro "O Sistema Toyota de Produção", de Yasuhiro Monden (1984), cuja versão original em inglês data de janeiro de 1982. Posteriormente, outros autores trataram de interpretar e esquematizar o STP, tornando-o palatável para o público ocidental e disseminando os conceitos da produção enxuta, também conhecida como Lean Production. O termo Lean Production foi apresentado no livro "A máquina que mudou o mundo" de Womack e Jones (1992), o qual passou a ser amplamente disseminado na américa. Lean Production vem a ser uma prática que visa ajudar as empresas a identificar e eliminar desperdícios através da melhoria contínua (VERRIER, et al. 2014). O Lean Production é uma filosofia de gerenciamento, não só da produção, mas de toda a organização, que busca oferecer aos clientes exatamente o que eles desejam: produtos de alta qualidade, baixo custo e no momento em que solicitam (SHINGO, 1996).

Os conceitos, princípios e práticas propostos e utilizados no STP são amplamente reconhecidos como elementos constituintes de um modelo robusto de organização e gestão da produção. Dentre os princípios básicos de construção desse modelo, encontra-se o conceito de perdas (ANTUNES,
1998). Para os precursores, Shingo e Ohno, o objetivo mais importante do Sistema Toyota de Produção (STP) é justamente o aumento da eficiência através da eliminação total das perdas (OHNO, 1997; SHINGO,1996). O STP é bastante difundido e conhecido por empresas de todo o mundo, mas neste artigo o interesse é saber se ele realmente é conhecido amplamente, se a sua implementação é fácil e se não há nenhum desvio com relação aos conceitos propostos por Shingo e Ohno. De acordo com Alaya (2016), a precipitação para implementação e a falta de conhecimento de todos os princípios e conceitos resulta em uma implementação dispersa, que impede de colher efetivamente os benefícios da fabricação enxuta. Ainda com esse mesmo pensamento, Yadav, et al. (2017) também concluem que o conhecimento sobre o Lean Production é disperso e diversificado em relação à aplicação e implementação de ferramentas e conceitos, o que torna difícil para pesquisadores e profissionais obterem uma compreensão real deste tópico. Com base nisso, mesmo o STP sendo um programa com conceitos que visam a redução perdas e custos, melhora na produção, melhora na qualidade e aumento de lucratividade para as empresas, pode-se observar que o programa não é uma unanimidade nas organizações.

Esse é o objetivo deste trabalho, realizar uma revisão de literatura sobre os conceitos, métodos e ferramentas do STP para identificar e mostrar quais são as principais dificuldades encontradas para se aplicar os conceitos propostos por Shingo e Ohno e o porquê de existirem essas dificuldades.

Além desta introdução o artigo ainda é composto por uma fundamentação teórica, pela metodologia da pesquisa, pela seção de resultados e análise e por fim, a conclusão do artigo.

\section{FUNDAMENTAÇÃO TEÓRICA}

Nesta seção será apresentada uma breve revisão teórica sobre o Sistema Toyota de Produção e levantar alguns conceitos básicos que Shingo (1996) trata em seu livro. É muito importante entender esses conceitos, pois na secção de análise e resultados será realizado um comparativo dos conceitos implementados por Ohno e Shingo na fábrica de automóveis Toyota e como esses 
conceitos são vistos e implementados atualmente.

Nos últimos anos tem havido maiores esforços da comunidade empresarial para pesquisar e implementar STP. Segundo Antunes et al. (2008), os princípios básicos de construção do Sistema Toyota de são: i) Mecanismo da Função Produção; ii) o princípio do não custo; e iii) as perdas nos sistemas produtivos. No Mecanismo da Função Produção, Shingo (1996) define o sistema de produção como uma rede funcional de processos e operações. Para Ohno (1997), idealizador do STP, a base do Sistema Toyota de Produção é a eliminação total do desperdício, e, segundo ele, os pilares necessários à sustentação do sistema são: o Just-in-Time (OHNO, 1997; WOMACK, 2004, ) e a Autonomação ou Jidoka (OHNO, 1997; ALVAREZ e ANTUNES Jr., 2001; LIKER e MEIER, 2007). Para Hunter (2008) o STP é funcional e diferente de qualquer outro sistema pois utiliza menos de tudo quando comparado ao sistema comum de fabricação e, quando implementado, resulta na diminuição dos defeitos e no aumento da qualidade.

Para Shingo, o princípio mais importante é o princípio do não-custo, ou seja, é preciso eliminar todo e qualquer custo desnecessário ao sistema produtivo. Isso tanto é verdade, que o próprio Shingo em seu livro, afirma que o Sistema Toyota de Produção é o sistema mais adequado para produção em um período de crescimento econômico lento. Segundo Ohno (1997) e Shingo (1996) o STP é justamente o aumento da eficiência através da eliminação total das perdas. Outro conceito do STP é vislumbrar o lucro como função dos custos e do preço de venda determinado pelo mercado (SHINGO, 1996). É o Princípio da Subtração do Custo, como o descreve Shingo (1996), em que o preço de venda dos produtos não é mais dado pela equação "Custo + Lucro = Preço de Venda", mas substituída por "Preço - Custo = Lucro".

$\mathrm{Na}$ primeira equação, o preço de venda é definido pelos custos para se produzir determinado item somado ao lucro pretendido. Isso implica não haver necessidade de melhorias uma vez que todo o custo gerado pela ineficiência do sistema de manufatura é agregado ao valor do produto. A questão é que hoje, com a acirrada concorrência dos mercados consumidores, quem dita o preço não é mais o produto. O STP propõe então o princípio de que o lucro é, na verdade, o preço, determinado agora pelo mercado, menos o custo. Esta nova abordagem implica que, se uma empresa deseja manter uma determinada margem de lucro e, até mesmo, sobreviver no mercado, ela deve mover esforços implacáveis para cortar custos e, consequentemente, eliminar perdas. Ainda segundo Shingo (1996b), a subtração do custo é o conceito mais básico do Sistema Toyota de Produção, exigindo por vezes esforços extraordinários para a eliminação as perdas. Um dos principais objetivos do STP é chegar a "zero defeitos" encontrando e corrigindo erros o mais rápido possível no momento e local onde esses erros ocorrem (FURMAN e CAPLAN, 2007). Em um de seus livros, Shingo (1996), diz que para chegar a zero defeitos e conseguir a redução de perdas deve-se criar novos métodos para os processos, diminuindo custos e melhorando a qualidade dos produtos.

A inspeção é muito importante, pois objetiva a prevenção de defeitos e consequente perdas com peças defeituosas ou retrabalho. Redução de setup das máquinas também é considerada muito importante, e pela simples troca de parafusos de fixação por grampos, por exemplo, Shingo conseguia diminuir a troca de ferramentas de 2 horas para 2 ou 3 minutos. Essa diminuição causa um ganho de tempo muito grande, tempo esse que pode ser utilizado para atividade que agregue valor, ou seja, para a produção propriamente dita. Para evitar peças defeituosas, o conceito de autonomação ou Jidoka, um dos pilares do STP (DEKIER, 2012), que vêm da junção dos conceitos de automação + autonomia, garante a qualquer trabalhador parar toda a linha de produção ao detectar algum defeito. Isso faz com que não ocorram muitas peças com o mesmo defeito, evitando-se desperdícios e retrabalhos. Além de detectar - problema e parar a produção, qualquer funcionário pode e deve consertar ou corrigir a condição imediatamente, investigar a causa raiz e instalar uma contramedida.

De forma a traduzir a filosofia STP para o pensamento e culturas ocidentais foi criado o pensamento Lean que foi popularizado por pesquisadores americanos para descrever o STP (JADHAV, MANTHA e RANE, 2014). Portanto, o Lean tem suas origens no JIT (Just In Time), metodologia de produção concebida na fábrica de automóveis Toyota como sendo um sistema de produção perfeito (SCHONBERGER, 2007) que deu origem ao Sistema Toyota de Produção (STP). Mas esse 
conceito ainda é pouco difundido e conhecido nas indústrias ocidentais, pois segundo Pakdil e Leonard (2017), pode haver diferenças de cultura social, já que os sucessos na implementação inicial no Japão não foram seguidos pelo sucesso global. Não trabalhar com estoque ou reduzir os estoques ao menor nível possível dentro das empresas é outro grande princípio do Sistema Toyota de Produção. Segundo Shingo, é melhor deixar trabalhadores ociosos do que produzir em excesso, pois grandes estoques significam dinheiro parado, o que acaba influindo negativamente nas operações das empresas não sendo bom para os negócios. Ainda nessa linha, Kull et al. (2014), afirma que as práticas do STP bem sucedidas são mais que simplesmente implementar ferramentas e técnicas, é preciso também ocorrer uma mudança de pensamento, uma mudança de ordem cultural na empresa que planeja implantar os conceitos do STP e do Lean.

\section{METODOLOGIA DA PESQUISA}

Como forma de auxiliar e orientar o pesquisador foi utilizado neste artigo uma abordagem qualitativa simples, como forma de geração de conhecimento para o avanço da ciência. (PRODANOV e FREITAS, 2013). Segundo Gil (2010), a forma qualitativa visa traçar um caminho planejado para o atingimento da meta inicial proposta pelo autor. Gil (2007) ainda apresenta um esquema de classificação das fontes bibliográficas. Esse esquema pode ser adaptado para esta pesquisa, de maneira que as publicações analisadas foram divididas em dois tipos fundamentais: livros dos principais autores sobre um determinado tema e as publicações científicas publicadas em periódicos científicos.

De acordo com o exposto pode-se dividir esta pesquisa em duas etapas: a primeira através da leitura dos livros dos autores precursores do Sistema Toyota de Produção, Ohno, 1997 e Shingo, 1996 de forma a adquirir os conhecimentos prévios e necessários sobre os assuntos da pesquisa. E a segunda, realizada através de buscas por publicações recentes na base de dados Scopus (Elsevier) para um período de cinco anos (2013 - 2017) utilizando os termos de busca Lean Production e Toyota Production System. Foi selecionando o operador booleano "OR" para que pelo menos um dos dois termos de busca conste, e também foi utilizado o filtro de seleção para que os termos de busca constem no título, resumo ou palavras-chave dos artigos. Outro filtro utilizado a seleção de artigos provenientes da área de engenharia. As pesquisas na base de dados Scopus ocorreram no dia 29 de março de 2018.

De posse dos resultados pode-se, posteriormente, realizar uma análise quantitativa das publicações existentes e também verificar quais são os periódicos científicos que têm mais publicações relacionadas aos termos de busca utilizados.

\section{RESULTADOS E ANÁLISE}

No total, foram encontrados 486 artigos internacionais que contém os termos de busca "Lean Production" ou "Toyota Production System". Os artigos que foram classificados por ano para possibilitar uma análise quantitativa das publicações conforme Figura 1.

FIGURA 1 - Total de artigos publicados por ano.

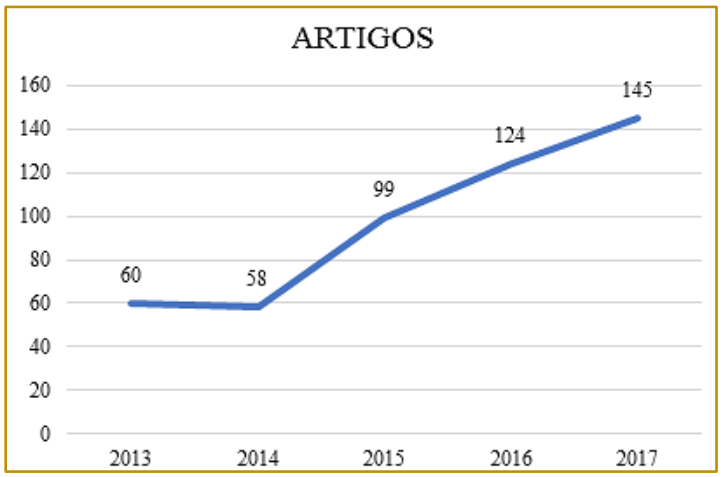

Fonte: Elaborado pelos autores de acordo com dados obtidos na base de dados Scopus (2018). 
A esses 486 artigos encontrados inicialmente foi aplicado um filtro pelas principais revistas e journals da área de engenharia, pois estes meios são os meios científicos que refletem e disponibilizam os estudos mais atuais e de maior qualidade na área. Desta forma foi elaborada a Figura 2 apresentada a seguir.

FIGURA 2: Publicações nas revistas de referência em Engenharia.

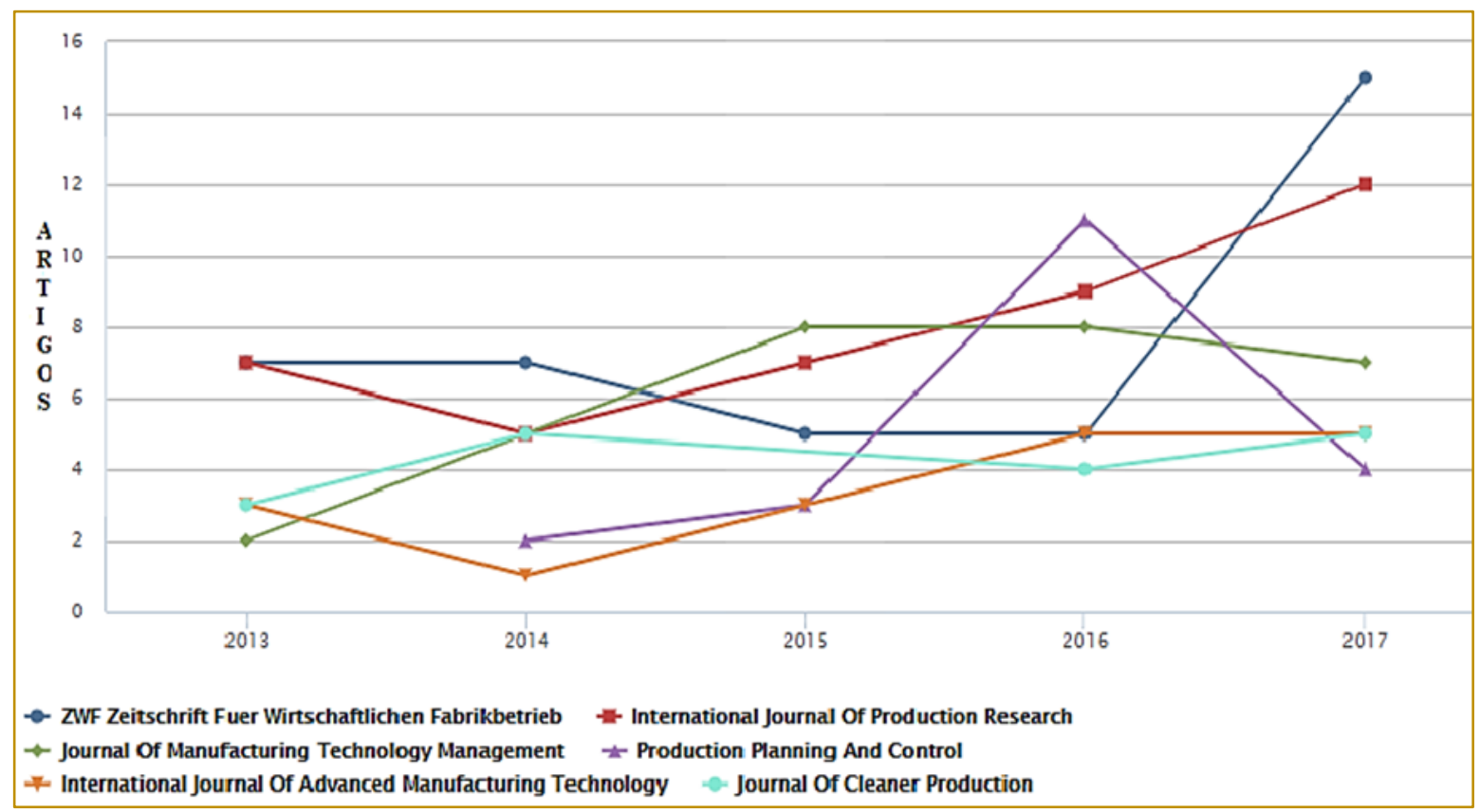

Fonte: Elaborado pelos autores de acordo com dados obtidos na base de dados Scopus (2018).

Através da análise dos gráficos de nossas pesquisas de artigos científicos em revistas e periódicos, podemos ver que nos últimos 5 anos o Lean Production e o Sistema Toyota de Produção continuam sendo alvos de estudos e publicações científicas, pois o número de artigos científicos sobre esses temas têm evoluído de uma forma considerável, o que nos indica que os conceitos do STP continuam sendo considerados, estudados e aplicados, influenciando de alguma maneira os estudos sobre melhorias nos processos de produção e eliminação de todos os tipos de desperdícios nas empresas.

Outro fato que ressalta a importância desses temas na atualidade é o alto fator de impacto JCR-2016 de alguns dos periódicos com mais publicações sobre os temas nos últimos 5 anos, como por exemplo (INCITES JOURNAL CITATIONS REPORTS, 2018): Production Planning and Control: 2,369; Journal of Cleaner Production: 5,715; International Journal of Production Research: 2,325; International Journal of Advanced Manufacturing Technology: 2,209.
Para Anholon e Sano (2016) muitas empresas realmente alcançaram resultados significativos nas últimas décadas adotando a filosofia de Lean Production, mas sua implementação ainda deixa margem para melhorias em diversos segmentos. Alguns processos ainda são críticos durante a implementação de projetos Lean e estes processos deveriam ser identificados e estruturados de forma a se garantir uma melhor performance na sua implementação e garantindo resultados ainda melhores. Netland (2016), sugere, neste mesmo sentido, de que a implementação do STP não deve ser generalizada, mas sim estudada de acordo com cada caso de modo a melhor atender os objetivos específicos de cada empresa. Algumas produções científicas enfatizam que a maioria das empresas que implementam programas baseados nos conceitos do STP e Lean Production não tiveram sucesso na execução dos seus objetivos (BORTOLOTTI, BOSCARI e DANESE, 2015). Para Crandall e Crandall (2011) um fator de insucesso de algumas empresas de não conseguirem implantar os conceitos Lean, é que elas buscam realizar essa implantação da mesma 
forma como se fossem implantar uma nova máquina no processo.

Um dos principais conceitos de Shingo é o de autonomia, onde todo e qualquer funcionário deve ter autoridade para parar o processo de produção ao constatar alguém problema. Porém esse conceito de autonomia encontra muitas barreiras e até um certo preconceito no mundo ocidental, pois não é difundido, e segundo Camara e Fuentes (2017), induz as empresas a realizar mudanças na organização no trabalho, algo que não é facilmente absorvido pelas empresas ocidentais. Chiarini (2015) fez uma comparação entre a Manufatura de Classe Mundial (WCM), o STP e a produção Lean através de um estudo no grupo Fiat. A Fiat lançou a WCM causando uma transformação radical nas diferentes funções atribuídas aos trabalhadores no processo de fabricação, com vistas a alcançar os objetivos do WCM (GARIBALDO, 2008). O modelo WCM da Fiat está rapidamente se tornando uma espécie de alternativa ao STP.

\section{CONCLUSÃO}

Pode-se concluir que Shingo e Ohno ainda são muito importantes quando se fala em Sistema Toyota de Produção pois seus conceitos, criados na segunda metade do século XX ainda são claramente aplicáveis na atualidade. Porém, percebe-se que alguns conceitos estão sendo desvirtuados, dando origem a outros tipos de sistemas de produção mistos e/ou híbridos que acabam por ter características de mais de um modelo

\section{REFERÊNCIAS}

[1] Alaya, L.B.F-B. VSM a powerful diagnostic and planning tool for a successful Lean implementation: a Tunisian case study of an auto parts manufacturing firm. Production Planning \& Control, v.27, n.7-8, p.563-578, 2016.

[2] Alvarez, R.dosR.; Antunes Jr., J.A.V. Takttime: conceitos e contextualização dentro do Sistema Toyota de Produção, Gestão \& Produção, v.8, n. 1, 2001

[3] Anholon, R.; SANO, A.T. Analysis of critical processes in the implementation of lean manufacturing projects using project management guidelines. International Journal Advanced Manufacturing Technology, v.84, n.9-12, p.22472256, 2016. de produção. Prova disso é o que nos diz Chiarini (2015), quando diz que a Fiat está criando um modelo alternativo ao STP, porém utilizando-o como ponto de partida. Ou seja, os conceitos de Shingo e Ohno não estão ultrapassados, apenas sofrem influência principalmente da cultura ocidental, sendo então aplicados de forma a adquirirem características ocidentais e também serem adaptados para funcionarem nas indústrias que operam em sistemas mais flexíveis do que os japoneses.

Um estudo de Bevilacqua, Ciarapica e Sanctis (2017), apresenta uma revisão da literatura de 83 estudos que tratam do grau de adoção de Lean Production em todo o mundo e os vínculos entre essas práticas e o desempenho da organização. Os resultados revelaram que a aplicação de práticas Lean ainda é fragmentado e desconsidera a ligação sistêmica entre os conceitos, que é essencial. 41 artigos obtiveram como resultados um efeito positivo com aplicação das práticas Lean. No entanto, cinco estudos indicaram que algumas práticas enxutas tiveram um efeito negativo. Isso nos evidencia que antes de implementar o STP é preciso conhecer a fundo todos os seus conceitos, e cada um desses conceitos deve ser aplicado dentro da realidade das empresas, pois para que o STP funcione, além de muito conhecimento, ele necessita do envolvimento de $100 \%$ das pessoas. Isso quer dizer que desde o funcionário do chão de fábrica até a gerência devem estar comprometidos com o programa, pois caso não esteja todo mundo engajado, o Lean não terá os efeitos positivos desejados quando da sua implantação.

[4] Antunes, J. et al. Sistemas de Produção: Conceitos e Práticas para Projeto e Gestão da Produção Enxuta. Porto Alegre: Bookman, 2008.

[5] Antunes Jr., José Antonio Valle. Em Direção a uma Teoria Geral do Processo na Administração da Produção; uma discussão sobre a possibilidade de unificação da teoria das restrições e da teoria que sustenta a construção dos sistemas de produção com estoque zero. Tese de Doutorado em Administração, Programa de PósGraduação em Administração, Universidade Federal do Rio Grande do Sul, Porto Alegre, 1998.

[6] Bevilacqua, M.; Ciarapica, F.E.; Sanctis, I. Lean practices implementation and their relationships with operational responsiveness and company performance: an Italian study. International Journal of Production Research, v.55, n.3, p.769-794, 2017. 
[7] Bortolotti, T.; Boscari, S.; Danese, P. Successful Lean Implementation: Organizational Culture and Soft Lean Practices. International Journal of Production Economics, v.160, p.182-201, 2015.

[8] Cámara, A.U.S.B.; Fuentes, J.M. Lean production, workforce development and operational performance. Management Decision, v.55, n.1, p.103-118, 2017.

[9] Crandall, R.E.; Crandall, W.E. Three Little Words: inventory reduction programs require alignment of technology, infrastructure and culture. Industrial Engineering, 2011.

[10] Dekier, L.K. The origins and evolution of Lean Management System. Journal of International Studies, v.5, n.1, p.46-51, 2012

[11] Furman, C.; Caplan, R. Applying the Toyota production system: Using a patient alert system to reduce error. Joint Commission Journal on Quality and Patient Safety, v.33, n.7, p.376-386, 2007.

[12] Garibaldo, F. A company in transition: Fiat Mirafiori of Turin. International Journal of Automotive Technology and Management, v.8, n.2, p.185-193, 2008.

[13] GIL, A.C. Como elaborar projetos de pesquisa. 4. ed.São Paulo: Atlas, 2007.

[14] Hunter, S.L. The Toyota production system applied to the upholstery furniture manufacturing industry. Materials and Manufacturing Processes, v.23, n.7, p.629-634, 2008

[15] Incites Journal Citations Reports. Consulta ao site. Disponível em: <https://jcr-incitesthomsonreuters.ez127.periodicos.capes.gov.br/JC RJournalHomeAction.action>. Acesso em: 29 mar. 2018.

[16] Jadhav, J.R.; Mantha, S.S.; RANE, S.B. Exploring barriers in lean implementation.
International Journal of Lean Six Sigma, v.5, n.2, p.122-148, 2014

[17] Kull, T.J.; Yan, T.; LIU, Z.; Wacker, J.G. The Moderation of Lean Manufacturing Effectiveness by Dimensions of National Culture: Testing Practice-culture Congruence Hypotheses. International Journal of Production Economics, v.153, p.1-12, 2014.

[18] Netland T.H. Critical success factors for implementing lean production: the effect of contingencies. International Journal of Production Research, v.54, n.3, p.2433-2448, 2016.

[19] Pakdil, F.; Leonard, K.M. Implementing and sustaining lean processes: the dilemma of societal culture effects, International Journal of Production Research, v.55, n.3, p.1700-1717, 2017.

[20] Prodanov, C.C.; Freitas, E.C. Metodologia do trabalho científico: métodos e técnicas da pesquisa e do trabalho acadêmico. 20 ed. Novo Hamburgo: Feevale, 2013.

[21] Schonberger, R.J. Japanese production management: An evolution-With mixed success. Journal of Operations Management, v.25, n.2, p.403-419, 2007

[22] Scopus. Pesquisa na base de dados. Disponível em: <www.scopus.com>. Acesso em 29 mar. 2018

[23] Shingo, S. O Sistema Toyota de Produção do ponto de vista da engenharia de produção. Editora Bookman, Porto Alegre, 1996

[24] Verrier, B.; ROSE, B.; Caillaud, E.; Remita, $\mathrm{H}$. Combining organizational performance with sustainable development issues: The Lean and Green project benchmarking repository. Journal of Cleaner Production, v.85, p.83-93, 2014.

[25] yadav, O.P.; Nepal, B.P.; Rahaman, M.M. e Lal, V. Lean Implementation and Organizational Transformation: A Literature Review, Engineering Management Journal, 2017. 


\section{Capítulo 20}

\section{LEAN SIX SIGMA METHOD AND ITS APPLICATION IN THE INDUSTRY 4.0}

\section{Amanda Duarte Feitosa}

\section{Laurent Muller}

\section{Francisca Jeanne Sidrim de Figueiredo}

\section{Thais Cadete da Silva}

Amanda da Silva Xavier

\section{Taynara Siebra Ribeiro}

Abstract: Currently many companies are looking for solutions to get the best competitive advantages. Increasingly, industries are looking for methodologies to improve their products to improve processes and reduce costs. With the method Lean Six Sigma it is possible to get these results. In addition, the development, incorporation and application of recent technological innovations have caused changes and prompted rapid expansion in technical studies. Several studies reveal that this is the beginning of the fourth industrial revolution called industry 4.0. The objective of this research is to show the implementation of the Lean Six Sigma method in the industry 4.0 and what are the advantages for companies. Research is basic and descriptive with a qualitative approach. This research conducted in the ENSGSI (École Nationale Supérieure en Génie des Systèmes et de l'Innovation) with the ERPI (Équipe de Recherche sur les Processus Innovatifs) in France. A bibliographic procedure was done in which several documents were found based on scientific articles that could show the evolution of the industry 4.0 and how we can exploit its technological potential with the lean six sigma methodology to favour the industries.

Keys words: Lean Six-Sigma, Industry 4.0, competitive advantages, Technology innovation, process improvement 


\section{INTRODUCTION}

Competition in the labour market and customer orientation force companies to have a competitive advantage, and in particular the investment in quality and satisfaction (ALVES, J.L.L. et al., 2016 ) In this way, the Lean Six Sigma method is very important to improve products, improve processes and reduce costs in companies. In addition, the industry is changing at a pace never seen before, driven by development and the use of increasingly sophisticated and agile technologies (COELHO, 2016). In this context, there is Industry 4.0 that is strategic for the advanced integration of control with Internet technology: communication between people, products and systems (REINER, 2014).

Germany is leading a transformation towards the fourth industrial revolution, based on innovation in manufacturing and services of cyber-physical systems (LEE et al., 2014). This new German term could be exploited by the Lean Six Sigma method and with this the industry could gain several advantages, such as more intelligent and productive products, continuous improvement in quality management and digital tools for ergonomic analysis. The lean six sigma method can take advantage of cyber physical systems by taking advantage of the data provided by sensors in contact with people and machines and thus increase the possibilities of improvement by the lean six sigma.

The industry's biggest challenge is to select relevant data and process it meaningfully. This activity requires technologically advanced systems, with real-time process capability. Getting knowledge opens horizons beyond imagination. Moreover, it could be a great engine for improving performance for the industry of the future (COELHO, 2016).

\section{LEAN-SIX SIGMA AND INDUSTRY 4.0}

\subsection{LEAN SIX SIGMA}

Today in the competitive environment, differentiating from the competition and achieving better performance is the rule for survival. Faced with this situation, eliminating waste, adopting advanced technology, developing new products, getting employee commitment and continuous improvement of production processes have become the basis of business development. In this context, companies wishing to win from the competition should strive to obtain efficient management of their resources and support their positions in the market, to carry out actions allowing the analysis of processes and the search for improvements (ANDRIETTA; MIGUEL, 2002).

Currently the many industries are looking for solutions to obtain the best competitive advantages. Thus, more and more companies are demanding methodologies allowing, improving their products, to improve the techniques and to reduce costs. Through Lean Management and Six Sigma integrated into the management and production processes, it is possible to obtain these results (TENERA; PINTO, 2014). The Lean Six Sigma has become a business model, a symbol of excellence, in order to eliminate waste and reduce defects and variations in processes (MUTHUKUMARAN et al., 2013). The Lean and Six Sigma enabled companies to get good results, for example, there is the DMAIC (Define, Measure, Analyze, Improve, Control) which is a cycle focused on finding solutions to problems. The DMAIC is one joint structure continuous improvement and efforts to reduce the production of defects (TENERA; PINTO, 2014).

The success that companies achieve with the use of six-sigma methodology is mainly due to the use of powerful tools applied in a specific situation and in appropriate manner, it allows to offer an important help to the improvement of the administrative systems and Manufacturing, quality management and process management. Among the tools most used are: Control charts for problem identification, regression, Failure Mode and Effect Analysis (FMEA), and for prioritizing and preventing problems, there are anti-error devices POKA-YOKE (ANDRIETTA; MIGUEL, 2002).

\subsection{INDUSTRY 4.0}

Today with this new concept industry 4.0 the industrial sector must become more dynamic, modern, digital and all this process more flexible with these products personable. Called the fourth industrial revolution, Industry 4.0 set up a network of companies, machines, products and people real time, according to Rosa (2017).

One industrial revolution is characterized by strong and extreme changes, caused by incorporation of technology, with duplication in the economic, social and political fields. There 
is a consensus on the existence of three industrial revolutions. The first was between 1760 and 1840, oriented by technology as the machines-steam and railways. The second took place between the end of the XIX century and begun in the XX century, centred on mass production and electricity innovation. The third, which began in the 1960s, broke with some paradigms through the development of semiconductors and technologies such as central computers, personal computers and later in the 1990s, the Internet. However, with an important development of some technologies of the third industrial revolution and the advent and incorporation of other technologies at the beginning of $\mathrm{XXI}$ century we arrive at the beginning of a fourth industrial revolution (TADEU; SANTOS, 2016). Germany is leading a transformation to fourth generation industrial revolution, based on manufacturing innovation and services from Cyber Physical Systems (LEE et al., 2014).

Figure 1- Industrial Revolution

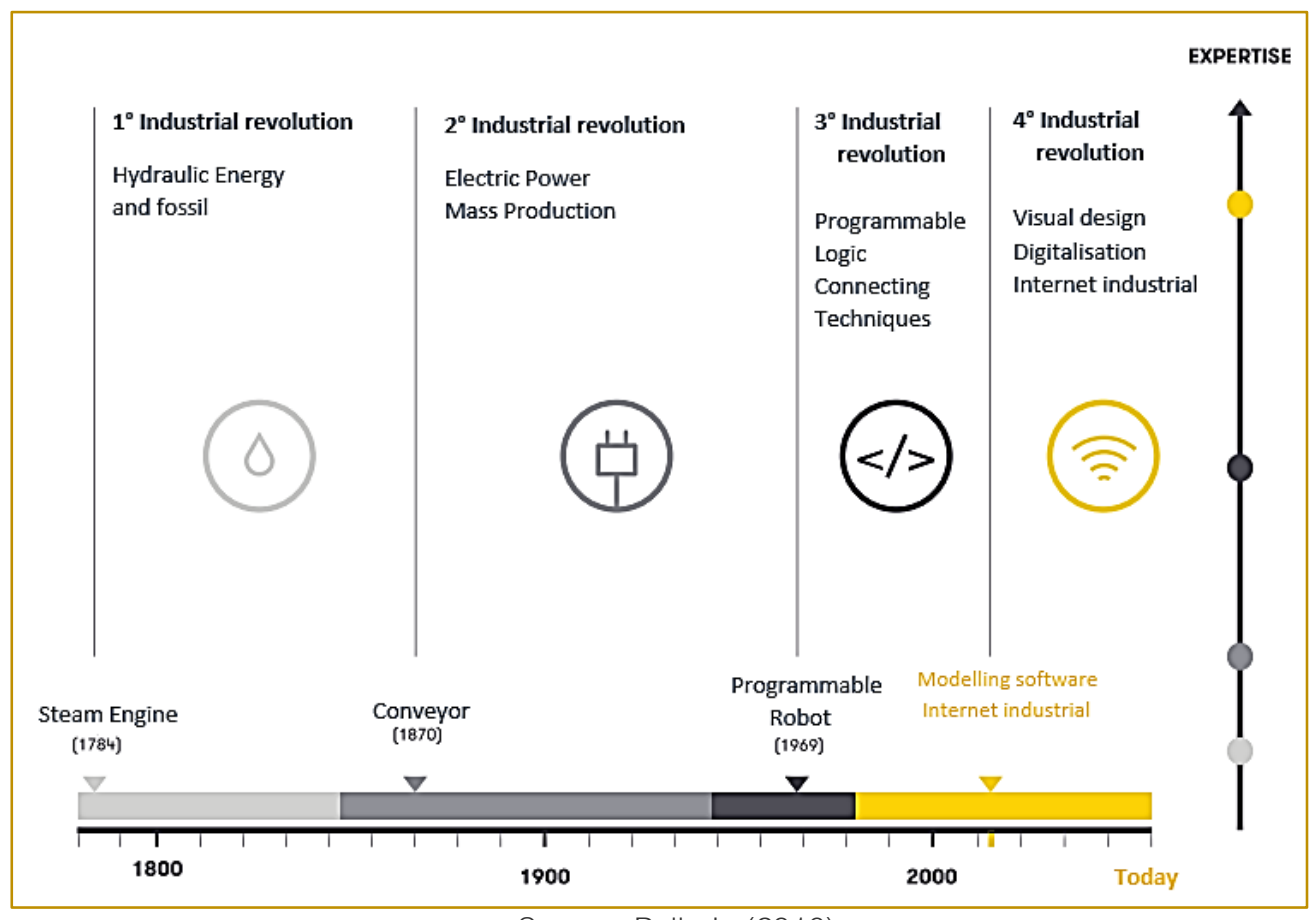

Source: Pellerin (2016)

In the third industrial revolution, the use of CLP's and robots led to a significant increase in automation of production. In the fourth industrial revolution industry 4.0 is an entrepreneurial network of machines, products and people in real time according to the Rosa (2017).

The industry 4.0 is an Internet integration with technology that establishes communication between people, products and the whole system (REINER, 2014). Industry 4.0 highly concentrated on continuous improvement in terms of efficiency, assurance, productivity of operations and especially in the return of investment. There are several facilitating technologies and trends available. The main ones in the smart industry are: internet of things, cyber-physical systems and Big- Data (COELHO, 2016).
The feasible approach of Industry 4.0 is to use the ability of cyber-physical systems to provide intelligence and communication to artificial technical systems that are called intelligent systems. These systems are a successor technology to mechatronic and adaptive systems. These characteristics enable communication mainly the integration of cyber-physical systems. In the industry 4.0 there are four basic approaches: cyberphysical systems; Internet technology; The components as information carriers and protection of knowledge (REINER, 2014). The Cyber-physical systems (CPS) is networks of autonomous entities that are composed of two parts: physical and digital. The systems integration (CPS) in industrial systems can offer great prospects for the agility and durability of these systems. The search field of 
CPS is important and covers many areas, such as intelligent manufacturing systems, industrial agent, system-oriented product, service-oriented architectures, cloud computing, large amounts of data, Production of the machine (M2M) (CARDIN et al., 2016). These systems can be understood as a consequent configuration of integrated systems, sensors and actuators with network access (REINER, 2014).

Figure 2 - Cyber-Physical Systems

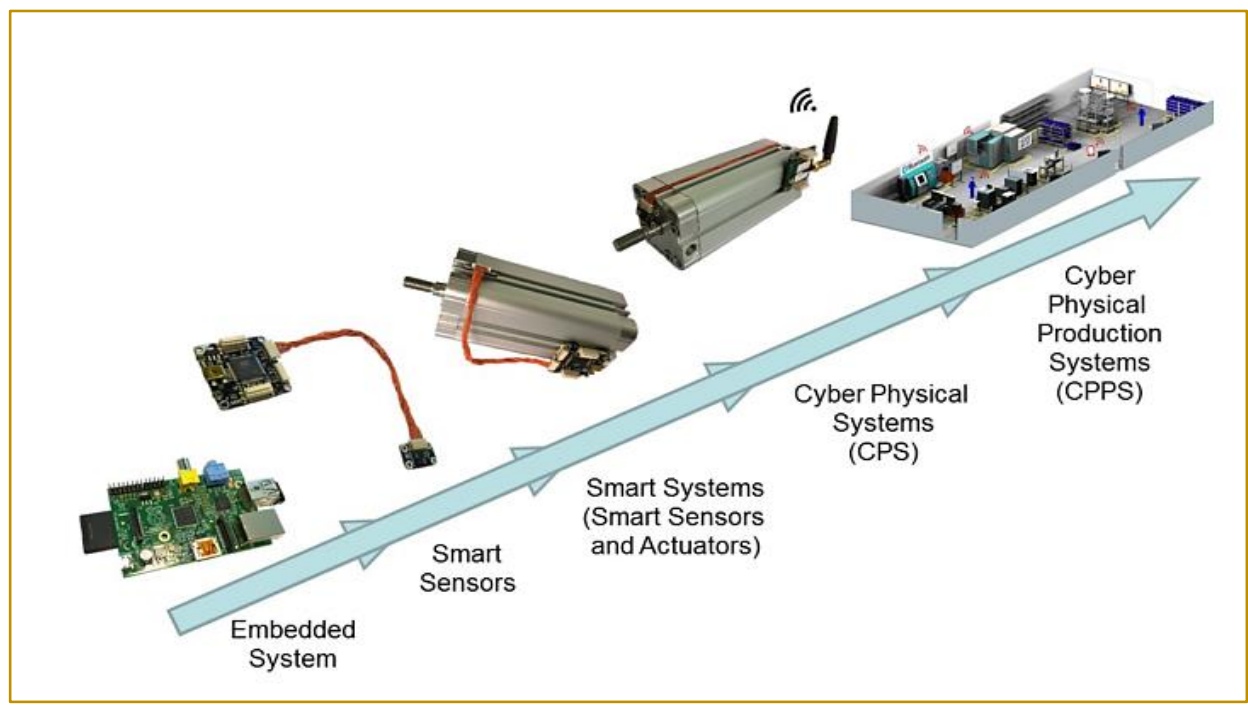

Source: Reiner (2014)

Figure 2 shows a configuration approach which allows the creation of cybernetic systems and its applications as cybernetic production systems.

The cybernetic systems approach allows objects to be identified, located and addressed. By considering the object of manufacture as a single piece, this technology opens up new avenues of innovation. The manufacture of objects becomes information carrier and the connected objects constitute a communication network. Industry 4.0 should really change the industry. One of the main changes is to develop process management, which in this case will be decentralized and connected. Strategy and process control become more flexible and adaptable. The main objective is to improve value-added processes and develop new management models to enhance industrial competitiveness (REINER, 2014).

With the aim of contributing to the implementation of a flexible, secure, easy to maintain system capable of evolving in its infrastructure, it is necessary to use cybernetic systems. With the new developments of an internet of things and the appearance of new detection technologies create, a unique network of information will connect strongly systems and human beings. With advanced analysis, the arrival of cloud computing and a cybernetic systems structure (CPS), the industry of the future can provide a vast information system that helps machines avoid potential performance problems (SCHMITT et al., 2014).

In the industry 4.0, parts are released from the stock and identified in the assembly line by a radio frequency chip (RFID), so all parts are integrated and identifiable in the manufacturing shop.

The impact of Industry 4.0 goes beyond simple digitization, undergoing a much more complex form of innovation. It is based on the combination of several technologies, which will force companies to rethink their ways of managing their processes that are positioned in the value chain, to think about the development of new products and to introduce them into the market, adjusting marketing and distribution activities. It should be noted that the changes would impact both sides of the supply chain, both in terms of customer needs and as business partners (COELHO, 2016).

The term internet of things (IOT) refers to physical and virtual objects linked to the internet. IOT was born at MIT (Massachusetts 
Institute of Technology) when in 1999 a research group developed a work in a radio frequency identification (RFID) area connected. Since then, this technology has been driven by the emergence and widespread use of ever smaller and costeffective sensors, developing mobile devices, wireless communication and cloud technologies. This new approach by internet of things (IOS), is the natural evolution of internet of things. Connectivity and the interaction of things can create high value added services for the customer, which is one of the strongest supporters of the industrial revolution, it opens up a world of opportunities and challenges (COELHO, 2016).

Today IoT is part of our everyday life. For example: check the production of the energy system, find the fastest way to go from point $A$ to point $B$ while considering traffic conditions, to control the production environment in real time, check the state of wear of our equipment and if necessary, we program or let the equipment itself plan its maintenance. Today we have a library with information (Big-Data) that we can consult at any time as soon as we need to make a decision or that we have a doubt about something or someone. Many "things" can use it to make "smart" decisions and by extrapolating, anticipate what we need (COELHO, 2016).

The Big-Data refers to large amounts of data that are network-related (IoT), which produces real-time data (COELHO, 2016). Several services such as social networks and smart ecommerce need to manage data on a large scale, which is a difficulty for a traditional database, in which case a different approach is required, with Big-Data, it is possible to build an architecture system with tools specifically designed to capture and analyze web-scale data (MARZ; WARREN, 2015).

\section{APPLICATION OF LEAN SIX-SIGMA ON INDUSTRY 4.0}

Currently several companies are looking for solutions to obtain the best competitive advantages. As a result, more and more companies are asking for methodologies to improve their products, improve processes and reduce costs. Through methodology such as Lean Six-Sigma the companies seek to optimize the production process (TENERA; PINTO, 2014). Today the term industry 4.0 is becoming more and more common for companies, mainly the concepts of connection of objects, cyber-physical systems, cloud computing, machine-to-machine and BigData. Since then, several positive points have emerged, for example: reducing costs, reducing waste and increasing the quality of products (BATISTA et al., 2017).

The Lean can optimize the speed and efficiency of waste reduction work and the Six Sigma is a continuous improvement plan that is intended to reduce variability (MUTHUKUMARAN et al., 2013). A combination of these new technologies with the lean six-sigma methodology can, if well integrated, improve the interaction of people and machines to benefit the overall performance of the company.

According to Pellerin (2016) today companies have an increasing amount of information, for example: their supply chain (variability of material costs, delivery time, supplier capacity, etc.); of the production floor; of their supply chain (for example: orders in preparation, energy, etc.); of their business environment. It is important to use all of these data effectively to increase business value. With Industry 4.0 the Lean Six Sigma will have a much larger amount of data to improve products / processes.

There are several possible combinations of industry 4.0 and Lean production, conforming Kolberg and Zühlke (2015) there are:

- Smart Operator: The smart operator can reduce the time from the absence of default until the fault notification. In addition, CPS teams with appropriate sensors recognize defaults and automatically activate actions to repair defaults in other CPS. With the smart operator, the employee gets information about the activities needed to manufacture in the time allotted. In addition, the computer systems receive the default and can display it in real time for the employees.

- $\quad$ Smart product: The smart product can contain information about Kanban and control the production processes. For example: Make a mapping to collect information about products and production chains automatically.

- Smart Machine: The CPS can be connected to processes and so avoid errors, but also send errors directly to the smart operator and inform other systems for possible repairs. As a result, production remains more flexible.

- Smart Planner: The Lean is often part of a planned production and traditional 
Kanban system keep a fixed cycle time and a fixed round trip time. The smart planner offers another way with a decentralized, dynamic production system and a workstation integrated into the CPS, thus making it possible to negotiate cycle times and automatically update the Kanban.

- Thus, with a conciliation of a digital technology and Lean system it is possible to offer a reduction of cost for the companies.

The impact of Industry 4.0 is not only a simple digitization, it is also a much more complex way of innovating through the combination of multiple technologies, forcing companies to rethink their business and processes, for example thinking, In the development of new products, their introduction into the market or adjusting the marketing and distribution actions in real time. (COELHO, 2016). The combination of modern paradigms of interaction and modulated software components will allow for increased flexibility and dynamism in the function as well as its effectiveness in application (SCHMITT et al., 2014).

According to Schwab (2016) there are four main expected changes in the industry overall:

- $\quad$ Change in customer expectations

- More intelligent and productive products

- New forms of collaboration and partnerships

- Transforming the business model into a digital model

The products and services are enhanced with the integration of digital capabilities, with the use of new, smarter materials, sensors capable of real-time monitoring, performance statistics and preventing deviations from normal operation, Correction of deviations before they turn into defects, in order to maximize its use, reduce costs and increase the realized value for the customer (COELHO, 2016).

With the implementation of innovative technologies, there is also the opportunity to take advantage of the digital environment to improve ergonomic analysis. Thus, this can contribute to continuous improvement in quality management and at the same time make work less painful and more productive (HOVANEC, 2017). Moreover, with the application of lean six-sigma in industry 4.0 there are other benefits, for example: a more innovative, competitive, efficient and attractive environment.

\section{METHODOLOGY}

According to Ganga (2012) this research present a descriptive case study. He states that the work can be a descriptive case study when it involves an examination to define a phenomenon or even differentiate it from another, or it can describe the characteristics of a population or establish relations between variables. Martins et al. (2014) state that a descriptive case study aims to describe the variables and their behaviours in a research, in addition it does not establish a cause and effect relation, it only describes in detail the reality as it is. With a very detailed description it is possible to help understand the problem under study.

The nature of the research is basic. According to Ganga (2012), research can be considered basic when it produces new knowledge, useful for the advancement of science without a practical application envisaged, it may involve universal truths and interests.

According to Ganga (2012) the approach of this research is qualitative. A work is qualitative when it has a great subjectivity, it is based on the use of qualitative methods, in which the researcher obtains information of the phenomenon with minute observations and collects evidence in that it makes possible to interpret the environment in which the problematic occurs. According to Cauchik (2010) the qualitative approach has the concern of obtaining information about the perspectives of individuals, interpreting the environment where the problem occurs.

In relation to the procedures, a bibliographical research was carried out. According to Ganga (2012) the bibliographical work seeks to clarify a problem based on theoretical references that have been published, such as scientific articles, books or encyclopedias. The present research used scientific articles from the Elsevier publishing house, dissertations and books that deal with the fourth industrial revolution.

This research was carried out at ENSGSI (École nationale supérieure en génie des systèmes et de l'innovation) with the ERPI (Équipe de Recherche sur les Processus Innovatifs) in France, in the city of Nancy at the Université de Lorraine, where it was performed in the Master MIDI (Master Design 
Global spécialité Management de l'innovation et Design industrie), in which I did the internship in the field of research, the proposed theme was: to explore the industry's 4.0 tools to improve existing processes with Lean Six Sigma. From this theme I have done a bibliographical work on this, and what are the competitive advantages for companies.

\section{CONCLUSION AND PERSPECTIVE}

The lean six-sigma (LSS) has been described as a business improvement methodology with the intention of improving business processes and results. This methodology is a combination of two philosophies, the Lean approach from the Toyota system, which became widely known in the years of 1982 . The Lean aims to improve the efficiency of an organization by reducing waste. The Six sigma is a continuous improvement plan that aims to reduce variability in products and processes. It was developed in the 1980 by Motorola in an attempt to improve quality, reducing variability in their manufacturing operation.

Today with the industry 4.0 the vision of production is built. The objective is to optimize value chains by setting up dynamic, autonomous and controlled production. The solutions of industry 4.0 combined with the lean six sigma philosophy would greatly increase the possibilities of analysis and hence improvements in the performance of companies. This is possible, because there are the cyber-physical systems (CPS), smart operators, smart products, smart machines and smart planners which give information that was not previously available to improve the Supply Chain. The aim is for the lean six sigma to work with industry 4.0 and thus cyberphysical systems (CPS), which can exchange data with actuator sensors, and CPS can

\section{REFERENCIES}

[1]. Alves, J.L.L., Xavier, A.S., SILVA, A.A., Albuquerque, R.M., Alencar, T.C. Seis sigma e sua aplicabilidade como ferramenta de qualidade em processos industriais. In: XXXIV Encontro nacional de engenharia de produção. João Pessoa/PB, 2016.

[2]. Andrietta, J.M., Miguel, P.A.C. A Importância do método seis sigma na gestão da qualidade analisada sob uma abordagem teórica. Rev. de ciências e tecnologia. v. 11, p. 91-98, n. 20, São Paulo. interact with humans and machines and allow easier work and one flexible production line. The proposal is to lead a change or evolution of the application of the Lean Six Sigma industry. To respond to the market, it is necessary to have a fast, flexible manufacturing process and a company capable of adapting its organization to be creative and to manufacture with quality. With the industry 4.0 workstations can be adaptable and updated with automation technology, in this way industry 4.0 has a agile manufacturing processes and able to reconfigure quickly.

In today's competitive environment companies face challenges with the need to quickly process very large amounts of information to improve productivity. In this context industry 4.0 will open up new opportunities for exponential growth in available information and possible communications and interactions. How can lean six sigma evolve to enable it to exploit this information potential (Big data) in the service of improving the overall performance of companies? This is the main question we ask in this research.

\section{ACKNOWLEDGMENTS}

I am very grateful to URCA (Universidade Regional do Cariri) for having encouraged me in the area of research. I would like to thank CAPES (Coordenação de Aperfeiçoamento de Pessoal de Nível Superior) for the opportunity to participate in the BRAFITEC project (Exchange Program between Brazil and France), in particular to ENSGSI (École Nationale Supérieure en Génie des Systèmes et de I'Innovation) and the group of research ERPI (Équipe de Recherche sur les Processus Innovatifs) for having accompanied me during the entire probationary period.

[3]. Batista, N.C., Melicio, R., Mendes, V.M.F. Services enabler architecture for smart grid and smart living services providers under industry 4.0. Energy and Buildings journal. v.141, p.16-27. Elsevier, 2017.

[4]. Cardin, O., Leitao, P., Thomas, A., Trentesaux, D. Cyber-physical systems for future industrial systems. IFAC World Congress. p. 15-17. Mar, 2016

[5]. Cauchick, P.A. et al. Metodologia de Pesquisa em Engenharia de Produção e Gestão de Operação. Rio de Janeiro: Elsevier, 2010. 
[6]. Coeho, Pedro Miguel Nogueira. Rumo à Industria 4.0. Dissertação (Mestrado). Fctuc, 2016.

[7]. Ganga, G.M.D. Trabalho de conclusão de curso (TCC) na Engenharia de Produção. São Paulo: Atlas, 2012.

[8]. Hovanec, M. Digital factory as a prerequisite for successful application in the area of ergonomics and human factor. Theoretical Issues in Ergonomics Science ISSN, v.18, p. 35-45. Taylor \& Francis, 2017

[9]. Kolberg, D., Zühlke D. Lean Automation enabled by Industry 4.0 Technologies. IFAC-Papers OnLine. v.28, p. 1870-1875. Elsevier, 2015.

[10]. Lee, J., Kao, H., Yang, S. Service innovation and smart analytics for Industry 4.0 and big data environment. The 6th CIRP Conference on Industrial Product-Service Systems, v.16, p.3-8. Elsevier, 2014.

[11]. Mars, N., Warren, J. Big Data: Principles and best practices of scalable real-time data systems. Manning Publications, 2015.

[12]. Martins, R.A., Mello, C.H.P, Turrione, J.B. Guia para elaboração de Monografia e TCC em Engenharia de Produção. São Paulo: Atlas, 2014.

[13]. Muthukumaran, G., Venkatachalapathy, V.S., Pajaniradja, K. Impact on integration of Lean Manufacturing and Six Sigma in various applications - a review. Journal of Mechanical and Civil Engineering. v.6, p.98-101, 2013.

[14]. Pellerin, R., Rivest, L., Danjou, C. Prendre part à la révolution manufacturière ?. CEFRIO. Nov, 2016.

[15]. Reiner, A. Industrie 4.0 - Advanced Engineering of Smart Products and Smart Production. Research Gate. Out 2014.

[16]. ROSA, P.V.T. Oportunidades de inserção profissional na indústria 4.0. in: Simpósio Internacional Indústria 4.0, Curitiba/PR. SENAI, 2017.

[17]. Schmitt, M., Loskyll, M., Zuehlke, D. Development of a Framework for Dynamic Function Deployment and Extension by Using Apps on Intelligent Field Devices. IFAC World Congress, v.19,p. 2611-2616. Aug, 2014

[18]. Schwab, K. The fouth Indústrial Revolution. United States. Crown Publishing Group, 2016.

[19]. Tadeu, Hugo Braga., SANTOS, Eduardo Stock dos. O que seria a Indústria 4.0?. Fundação Dom Cabral. Belo Horizonte, 25 jan. 2016.

[20]. Tenera, A., Pinto, L.C. A Lean Six Sigma (LSS) project management improvement model. Procedia - Social and Behavioral Sciences. v.119, p.912-920.

Elsevier,

2014. 


\section{Gapítulo 21}

\section{PROPOSTA DE REDUCÃO DE TEMPO DE SETUP EM MÁQUINAS DE TESTES DE DURABILIDADE EM UMA EMPRESA FORNECEDORA DE AUTOPECAS COM O USO DE CONCEITOS SMED E PADRONIZACÃO}

\section{Lucas Verzenhassi Toledo}

\section{Matheus de Moraes}

\section{Ivan Correr}

Resumo: Devido à concorrência atual, as organizações perseguem incansavelmente a otimização dos processos, com eliminação de desperdícios, redução de custos, aumento de produtividade e qualidade através de conceitos como: Lean Manufacturing, que visa reduzir os desperdícios; Conceitos do SMED, que visa a diminuição do tempo de setup; e Padronização, que visa normalizar, esquematizar e metodizar atividades. Neste contexto, o presente artigo visa apresentar uma proposta de melhoria para redução do tempo de setup das máquinas de testes de durabilidade em uma empresa fornecedora de autopeças, baseando-se nos conceitos da ferramenta SMED e métodos de padronização das atividades de setup. Para isso, foi utilizada a metodologia da pesquisa-ação, construindo hipóteses, coletando e analisando dados para a resolução do problema. Estima-se uma redução de 55\% do tempo médio das operações de setup e maior confiabilidade no processo com a padronização das atividades, evidenciando a importância dos conceitos propostos.

Palavras-chave: Setup, SMED, Padronização. 


\section{INTRODUÇÃO}

No cenário atual, com o aumento da competitividade, as organizações buscam aumentar a produtividade, diminuir custos, diminuir o ciclo de produção, atender as flutuações de damanda do mercado e introduzir novos produtos com agilidade. Através da manufatura enxuta ou Lean Manufacturing, é possível obter vantagens competitivas, com o máximo uso dos recursos disponíveis, produzindo diversos produtos com qualidade e lead time baixo, oferecendo flexibilidade e maior força para a competição mercadológica (CONCEIÇÃ̃O et al., 2009).

Uma das atividades que auxiliam o aumento da competitividade em função da redução do tempo de preparação do processo é sistema SMED (Single Minute Exchange of Dye) ou TRF (Troca Rápida de Ferramentas) proposto por Shingo (1985).

Conforme Palomino e Lucato (2016), o SMED mostra-se eficaz, com a ampliação da lucratividade, qualidade e produtividade. A redução de desperdícios e a diminuição do tempo da operação de Setup é fundamental para as organizações obterem competitividade e flexibilidade no cenário atual. Os resultados da implementação do SMED são alcançados por meio da padronização dos processos, com baixo investimento e retorno expressivo para a organização.

Em relação a padronização de processos, Campos (2013) define que esta é a base das atividades diárias e deve direcionar os meios (métodos) e os fins (metas e objetivos) para execução das atividades, e Costa et al. (2016) apresenta que a padronização reduz vários tipos de desperdícios, aumenta a quantidade de itens produzidos com qualidade e também possibilita maior domínio do processo produtivo.

A padronização de processos oferece suporte e melhoria contínua às execuções de atividades agregadoras de valor, baseadas em normalizações, esquematizações, sistematizações e vários métodos que controlam e adequam os resultados, desde que as orientações sejam claras e objetivas para a execução de cada tarefa (CAVANHA FILHO, 2006; TAYLOR, 2010).

Neste contexto, o presente artigo tem como objetivo apresentar uma proposta de melhoria para redução de tempo de Setup das máquinas de testes de durabilidade de uma empresa fornecedora de peças automotivas, baseando-se nos conceitos da ferramenta SMED com o uso de métodos de padronização de processos.

\section{REFERENCIAL TEÓRICO}

\subsection{LEAN MANUFACTURING}

O sistema de produção conhecido por Manufatura Enxuta ou Lean Manufacturing é um conjunto de ações, princípios e ferramentas que, quando aplicadas, visam a eliminação das causas raízes de baixa performance.

Iniciada na década de 1950 por dois japoneses chamados Eiji Toyoda e Taiichi Ohno, a Manufatura Enxuta também está contida no Sistema Toyota de Produção (TPS) (SUGAI; MCINTOSH; NOVASKI, 2007).

Para Shingo (1996), o princípio fundamental do TPS é a eliminação de desperdícios e estes são classificados em sete tipos, conforme abaixo (OHNO, 1997; RODRIGUES, 2014):

- Desperdícios por superprodução: produção em quantidades maiores que o necessário ou produzidas no momento errado, gerando estoques;

- Desperdícios por espera: Tempo de máquinas e mão-de-obra ociosas pelo processo ou por material;

- Desperdícios por transportes: Movimentações desnecessárias de peças, estoques, equipamentos, geralmente causado por layouts mal planejados;

- Desperdícios por processamentos: Superdimensionamento do processo ou tarefas desnecessárias;

- Desperdícios por estoques: Produtos acabados, semiacabados e matéria-prima com grandes volumes estocados no processo desnecessariamente;

- Desperdícios por movimentos desnecessários: Movimentação dos operadores na realização das atividades do processo, seja essa ocorrida por maquinário, layout e/ou ergonomia ineficientes;

- Desperdícios por produtos defeituosos: Produtos em não conformidade com as especificações, podendo provocar retrabalho ou o descarte dos mesmos. 
O Lean Manufacturing proporciona diversos benefícios para as organizações, focando na melhoria contínua através da redução dos desperdícios. As aplicações das ferramentas do Lean são eficazes com o trabalho padronizado já implementado, pois quando não há padronização, as melhorias não se perpetuam (VIEIRA et al., 2016).

Conforme Paiva e Bergiante (2016), o Lean Manufacturing é um pilar estratégico da empresa, pois essa ferramenta contribui para a sustentabilidade financeira.

O Lean Manufacturing possui diversas características, que podem ser verificadas a seguir (DUARTE et al., 2015):

- Estratégia de aumento de produtividade;

- Identificação das atividades que agregam valor e também a cadeia de valor de todo processo;

- Redução das quantidades de perdas de matéria-prima;

- Redução de custos de manutenção e;

- $\quad$ Proporciona padrões de qualidade.

Duarte et al. (2015) e Conceição et al. (2009), citam benefícios sucedidos do Lean Manufacturing e que estão descritos em seguida:

- Redução de desperdícios;

- Redução esforços necessários;

- $\quad$ Produzir grande família de produtos;

- Lead time baixo;

- Utilização eficiente dos recursos disponíveis;

- Aumento produtividade;

- Aumento qualidade;

- Diminuição de retrabalhos e;

- $\quad$ Flexibilização da manutenção.

Para visualização e definição das causas raízes, podem ser efetuados o diagrama de Ishikawa e os cinco porquês. Algumas ações podem ser tomadas para que os desperdícios anteriormente citados possam ser minimizados ou ainda eliminados e, exemplos dessas ações estão na união de maquinários de um mesmo processo a fim de eliminar transportes, utilização de lotes únicos de produção - One Piece Flow - com a finalidade de eliminar estoques em processo e também esperas, minimização de tempos de ciclos dos processos produtivos, adoção de inspeções diretamente na fonte para que sejam evitados processamentos de produtos defeituosos, implantação da ferramenta SMED, a fim de diminuir tempos de repostas com a diminuição dos tempos de Setup, dentre outros (SHINGO, 1996; LIKER, 2005; CARVALHO, 2010).

\subsection{SMED}

Setup é definido por Hirano (2009), como todas as preparações que devem ser feitas antes de um conjunto de operações serem iniciadas, ou seja, todas as etapas de preparações, parametrizações, montagens, referenciamentos, medições, correções, dentre outras diversas operações a serem realizadas antes de que o processo produtivo seja iniciado.

Os conceitos básicos do sistema SMED (Single Minute Exchange of Dye) ou TRF (Troca Rápida de Ferramentas) proposto por Shigeo Shingo (1985) em seus estudos, é o de todo e qualquer setup seja realizado em tempos com somente um dígito, ou seja, tempos inferiores a 10 minutos. Para isso, é necessário que as operações de preparação sejam divididas e classificadas em etapas internas ou externas à máquina, conforme publicado pelo mesmo autor no ano de 2000.

Shingo (2000) propõe em sua metodologia, com a finalidade de melhorar o processo de preparação dos maquinários, em um estágio preliminar, onde deve-se analisar e aferir as condições atuais do processo de setup. Em uma etapa posterior, deve-se separar os processos internos que são os que somente podem ser realizados com a máquina parada, dos processos externos que, contrariamente aos internos, podem ser realizados com a máquina em operação.

Ainda para o mesmo autor, a etapa subsequente consiste em transformar os processos de preparação internos em processos externos, pois assim, evita-se deixar a máquina ociosa para realização de processos de preparação e que não acrescentam valores ao produto final. A última etapa da implantação da metodologia SMED, consiste na etapa de melhoria contínua dos processos preparatórios visando sempre a redução dos tempos de setup e, consecutivamente, aumentando a disponibilidade do maquinário para novos 
setups e para a produção de outros produtos que se façam necessários.

O SMED é efetivo em reduzir o tempo de preparação e, assim, permite efetuar maiores quantidade de setups por obter maior disponibilidade e possibilidade de diversificações de produtos com pequenos lotes, com menores lead times, aumento da produtividade, maior obtenção de lucros e maior agilidade na resposta ao cliente (BASTOS; LOFFAGEN; CARDOSO, 2016; DIAS et al., 2016).

A técnica do SMED permite que os envolvidos possuam maior entendimento de todo o processo de preparação separando, compactando e transferindo atividades em internas ou externas, obtendo redução de tempo ocioso e proporcionando maior competitividade para as organizações (SILVA; ALSISI; COSTA, 2016; REIS; ALVES, 2010).

Com a aplicação do SMED, é possível realizar padronizações das atividades que não são de extrema criticidade ao processo, porém que também são fundamentais para a confiabilidade da qualidade do produto por meio de inspeções e maior agilidade na troca de produtos (GAZEL; SALLES; FEITOSA, 2014)

\subsection{PADRONIZAÇÃO}

De acordo com Cavanha Filho (2006), a padronização oferece suporte e melhoria contínua às execuções de atividades em operações agregadoras de valor, baseadas em normalizações, esquematizações, sistematizações e vários métodos que controlam e adequam os resultados.

Conforme Taylor (2010), é necessário detalhar o trabalho que será executado. Com a finalidade de instruir o executante da tarefa, podem ser utilizadas documentações escritas, desde que as orientações sejam claras e objetivas para a execução de cada tarefa.

A padronização é a base das atividades diárias e deve direcionar os meios (métodos) e os fins (metas e objetivos) para execução das atividades (CAMPOS, 2013).

A padronização reduz vários tipos de desperdícios, aumenta a quantidade de itens produzidos com qualidade e também possibilita a obtenção de maior domínio do processo produtivo (COSTA et al., 2016).
Conforme Ramon et al. (2016), a padronização motiva melhorias contínuas nas tarefas executadas. Devido à falta de padronização, não há visibilidade do processo de execução das tarefas, por consequência, obtém-se maior dificuldade em resolver os problemas na causa raiz e, consecutivamente, o faturamento pode ser reduzido.

A padronização dos processos diminui perdas as do tempo de produção e de produtos, contribui para a redução de desperdícios e aumenta a qualidade da produção. Para implementar a padronização, o investimento é mínimo, sendo necessário apenas realizar diversos ajustes no processo em análise (IONAK, 2016).

A padronização tem como objetivo diminuir as variações relacionadas às atividades e, assim, é possível reduzir o tempo da atividade e otimizar os movimentos necessários para sua realização (CAVANHA FILHO, 2006).

Campos (2013), cita ferramentas de apoio para padronizar o ambiente de trabalho, sendo elas:

- $\quad$ Fluxograma: Utilização do fluxograma com intuito de aumentar e maximizar a produtividade e qualidade, sendo que em todos os níveis da organização sejam estabelecidos quais os processos que estão sob responsabilidade de cada indivíduo ou departamento. O fluxograma também auxilia na confecção do mapeamento dos processos, evidenciando diversos processos. Também é importante que o fluxograma retrate a situação verdadeira do local;

- Definição de tarefas com prioridades: Determinar junto à equipe, quais são as atividades principais nas quais se deve focar para realizar as padronizações;

- Procedimentos operacionais padronizados: São procedimentos de operações e não do processo. É necessário que todos os operadores efetuem as atividades da mesma maneira e no mesmo fluxo.

Também podem ser citadas, as instruções de trabalho que contribuem para que os colaboradores sejam adequadamente treinados e também para que possuam autonomia e segurança nas atividades, possibilitando a padronização (VIEIRA et al., 2016). 
De acordo com Santanna et al. (2016), a falta de padronização é prejudicial nas organizações, pois causa produtos finais caros, obtenção de barreiras para aprendizados e a agilidade de disponibilidade do produto e de tomada de ações são reduzidas. Para que a padronização seja realizada, é possível utilizar ferramentas da qualidade, entre elas:

- Fluxogramas;

- Diagramas;

- $\quad 5 \mathrm{~W} 2 \mathrm{He}$;

- 5 por quês.

A implementação da padronização nos processos proporciona melhor qualificação e maior satisfação no trabalho para os colaboradores, gera estabilidade no processo e como consequência, diminui os níveis de refugo, controlando os custos relacionados a produtividade. Nota-se também que, para o sucesso da implementação da padronização, todos os funcionários devem estar motivados e a alta administração deve fornecer apoio para a implantação (TEIXEIRA, 2014).

\section{METODOLOGIA DO DESENVOLVIMENTO DA PESQUISA.}

O artigo refere-se a uma pesquisa ação, que é definido por Thiollent (2009) e Trip (2005) como a pesquisa sobre ações de problemas ou resoluções de problemas, onde o grupo de pesquisadores estão envolvidos diretamente à situação, sendo de modo participativo ou cooperativo. A pesquisa ação possui diversas, características, conforme Quadro 1 a seguir (GILBERTONI, et al., 2016):

Quadro 1: Principais características da pesquisa ação

\begin{tabular}{|ll|}
\hline \multicolumn{1}{c|}{ Caracteristicas } & \multicolumn{1}{c|}{ Descrição } \\
\hline Pesquisa e ação & $\begin{array}{l}\text { Contribuir para o conhecimento científico } \\
\text { Solucionar problemas e promover melhorias nas organizações }\end{array}$ \\
Teoria e prática & $\begin{array}{l}\text { Ambas devem ser conduzido simultaneamente } \\
\text { A teoria suporta as práticas produzidas }\end{array}$ \\
Participação dos pesquisadores & $\begin{array}{l}\text { Trabalham efetivamente para a resolução do problema } \\
\text { Facilita o diálogo e promove analises entre os participantes }\end{array}$ \\
& $\begin{array}{l}\text { Ciclo de auto-reflexão } \\
\text { Diagnósticos das situações } \\
\text { Processo ciclico }\end{array}$ \\
& Escrita dos desultados finais \\
\hline
\end{tabular}

Fonte: Adaptado de Gilbertoni, et al., 2016

O delineamento do presente trabalho foi adotado conforme Gil (2010) e Mello et al. (2012), destacado a seguir:

- Fase exploratória: Tem como objetivo determinar o ambiente de investigação, as expectativas e os auxílios que os interessados podem oferecer ao decorrer da pesquisa;

- Formulação do problema: Visa garantir a definição do problema com precisão;

- Construção de hipóteses: As hipóteses devem ser claras, sucinta, sem ambiguidade gramatical e que possibilita realizar verificações empíricas;

- Realização do seminário: Reúne os membros da equipe de pesquisadores e interessados no desenvolvimento da pesquisa, nessa etapa, a discussão e a aprovação nos seminários são as diretrizes da pesquisa-ação;

- Seleção da amostra: Após a limitação da pesquisa, é necessário determinar elementos que serão pesquisados sendo que, amostras intencionais são mais relevantes para os pesquisadores e participantes, sendo a mais adequada para a pesquisa-ação;

- Coleta de dados: A técnica aplicada para a coleta de dados são as observações dos pesquisadores e participantes;

- Análise e interpretação dos dados: A análise de dados deve ser realizada pelos pesquisadores e participantes, por meio dessa abordagem colaborativa, a análise dos 
participantes é fundamental, pois eles que convivem com aquele ambiente todos os dias;

- Elaboração plano de ação: Após a análise, deve ser elaborado um documentado de plano de ação, onde deve incluir os objetivos, quais tipos de mudanças necessárias, quais medidas e procedimentos podem contribuir com a situação, e também, determinar o controle e avaliação dos resultados;

- Divulgação de resultados: Os resultados podem ser expostos em simpósios, relatórios, conferências, dentre outros.

\subsection{PESQUISA-AÇÃO}

Esse trabalho tem como local de estudo um laboratório de testes experimentais de uma grande empresa localizada na cidade de Limeira, Estado de São Paulo. Neste laboratório, são testadas caixas de direção de veículos leves e pesados, sistemas de frenagem e também sistemas de segurança aos ocupantes, porém o foco inicial será dado ao departamento de testes de caixas de direção de veículos leves.

Os testes em caixas de direção do tipo pinhão-cremalheira - Rack and Pinion aplicadas à veículos leves, podem ser classificados como testes funcionais, estruturais, de durabilidade, dentre outros e podem ocorrer na validação de protótipos de novos produtos, validações/avaliações de novos fornecedores de componentes internos ou externos dos mecanismos de direção, testes periódicos chamados de Layout Inspection que visam a avaliação de características funcionais e estruturais de produtos em produção corrente e os testes também podem ocorrer de acordo com solicitações e demandas dos setores produtivos ou de engenharia.

Todos os testes realizados no laboratório seguem criteriosamente normas internas, coorporativas ou ainda normas de grandes montadoras de veículos que são clientes da empresa em estudo e, por se tratar de um produto que está diretamente ligado com a segurança e conforto dos ocupantes do veículo, os testes experimentais são de suma importância para a verificação e validação do funcionamento dos mecanismos de direção e, consecutivamente, do veículo final no qual será instalado.

Os testes de durabilidade ocorrem em máquinas de grande tecnologia embarcada e que contam com controladores, servoválvulas, atuadores lineares e rotacionais. Esses testes possuem por finalidade a simulação de condições mais severas do que as quais os veículos estão sujeitos durante toda a vida útil deste automóvel.

Esses testes de durabilidade ocorrem, conforme anteriormente citado, em acordo com normas e especificações e no fluxograma abaixo (Figura 1), pode-se visualizar a sequência lógica e simplificada destes testes.

Figura 1 - Fluxograma dos testes

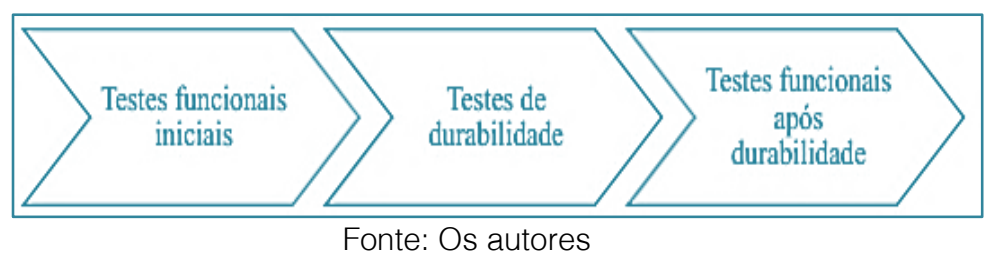

A fixação dos mecanismos de direção às máquinas de durabilidade ocorre de acordo com orientações veiculares e normativas, ou seja, os testes devem ser realizados com as caixas de direção fixadas de forma que sejam gerados ângulos iguais aos quando instalados no veículo de aplicação para qual tenha sido desenhado e projetado e, para tal correta fixação, são necessárias bases e dispositivos também desenvolvidos, avaliados e validados para o projeto. Essas bases são compostas por 04 componentes que são a base inferior, coluna, base superior de fixação e ainda por inserto e, a composição desses elementos irá resultar em uma altura final de fixação, sendo essa altura, fator determinante nos ângulos resultantes de fixação, conforme podemos observar na Figura 2: 
Figura 2 - Fixação da caixa de direção na máquina de testes

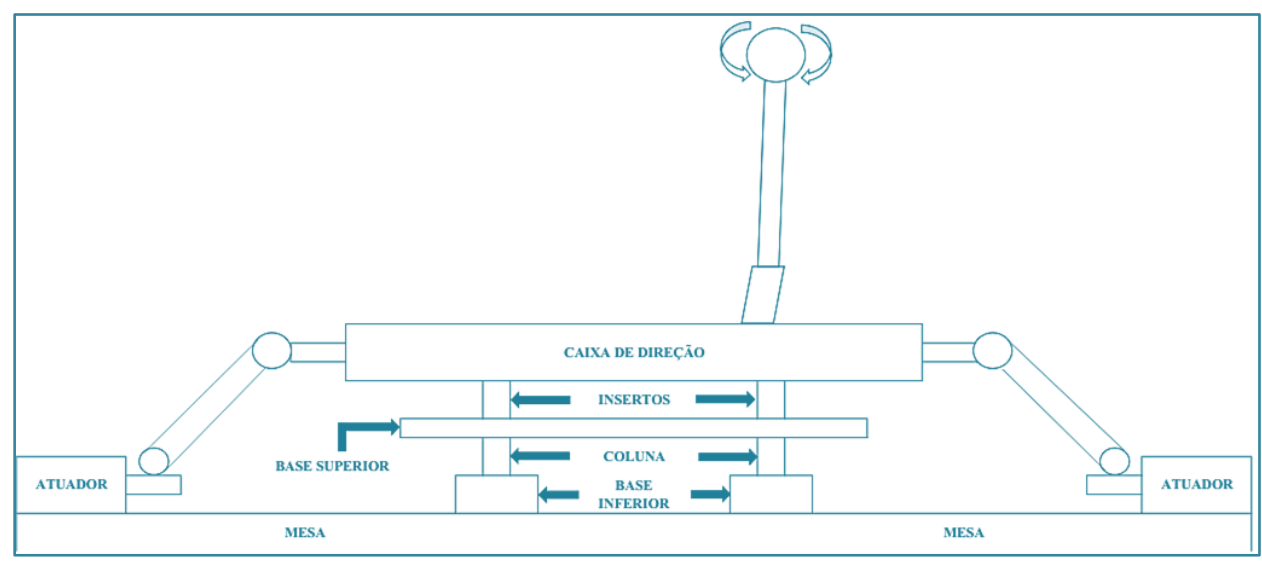

Fonte: Os autores

Conforme citado anteriormente, as alturas das bases de fixação dos mecanismos às máquinas de durabilidade são de suma importância e, devido à grande diversidade de produtos oferecidos e testados no laboratório, existem diversas composições e montagens possíveis de dispositivos de fixação, gerando em alguns casos, retrabalhos, desperdícios de tempo com medição e/ou seleção dos corretos componentes para montagem dos dispositivos, dentre outros. O tempo atual de execução de setups é de até aproximadamente 09 horas, devido à grande complexidade e exigência de detalhes e, também, muitas das vezes à montagem, medição e seleção dos componentes dos dispositivos e também, devido aos grandes números de retrabalhos executados.

Para a verificação dos motivos do tempo despendido na operação de setup, foi realizado entre os colaboradores do laboratório e o grupo de pesquisadores um diagrama de causa e efeito, onde foi abordada as possíveis causas raízes para o efeito, conforme pode ser observado na Figura 3:

Figura 3 - Causa e efeito para a operação de setup

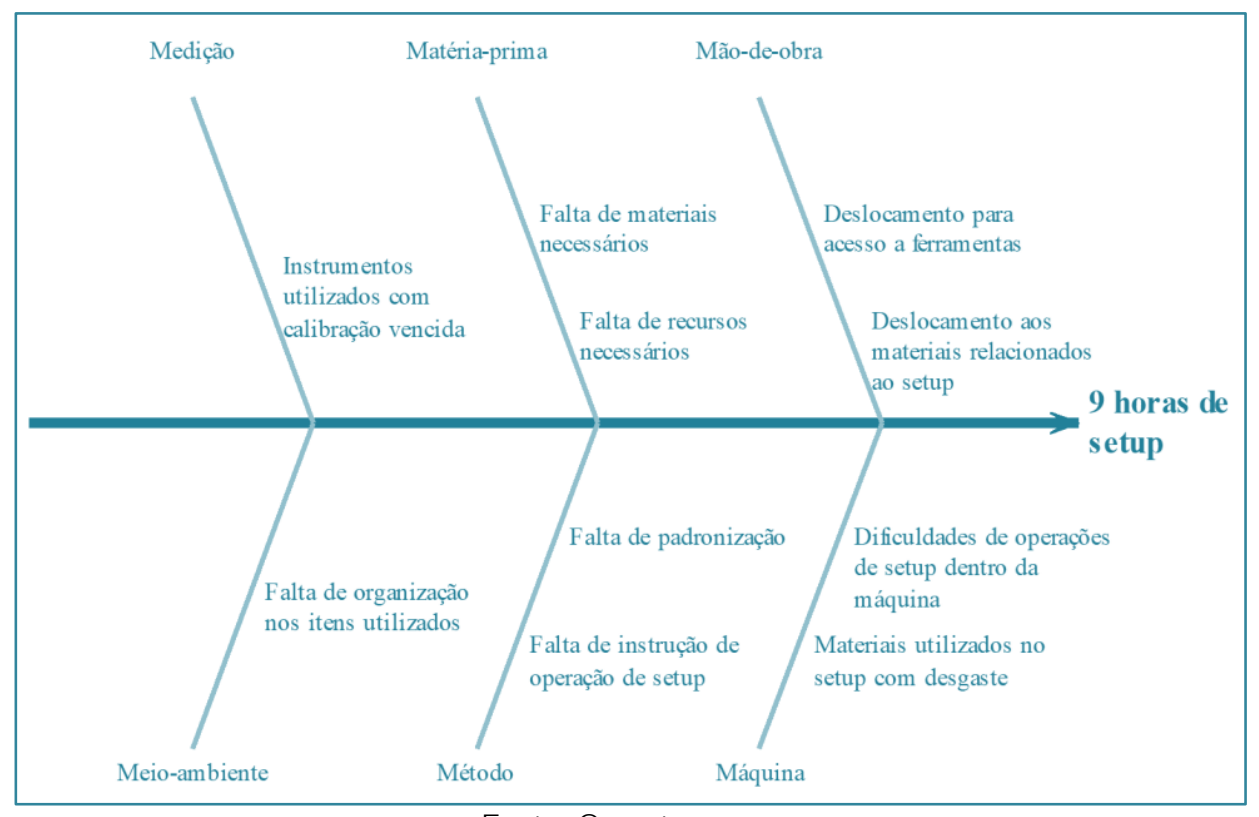

Fonte: Os autores 
Após o diagrama de causa e efeito ser efetuado, foram discutidas as causas levantadas através de um seminário, e foram alcançadas as seguintes descrições, conforme abaixo:

- Medição: Os instrumentos de medição utilizados na operação de setup possuem calibração validada, ou seja, os valores estão conforme especificação e a calibração está validada e no prazo correto;

- Matéria-prima: Os materiais necessários para efetuar a troca das bases estão disponíveis para uso;

- Meio ambiente: Os materiais necessitam de uma organização e identificação mais adequada;

- Mão-de-obra: Deslocamento desnecessário por retrabalhos da operação de setup,

- Máquina: O setup realizado internamente é dificultoso, sendo que, a montagem é realizada passo a passo;

- Método: Não há padronização de métodos entre os colaboradores do setor por falta de procedimento ou instrução de trabalho.
- Sendo assim, foi definido que, as diretrizes de análise, baseadas nos conceitos SMED e padronização, seriam:

- Verificar a possibilidade de transformar setup interno em externo;

- Melhorar a codificação e organização dos materiais;

- Propor instrução de trabalho, com o intuito de padronizar a operação, apresentando quais são os itens utilizados na operação e também como deve ser feita a atividade de setup, com a intenção de reduzir os retrabalhos utilizados.

Com a definição das amostras, foi possível levantar os dados das operações com as observações dos pesquisadores e dos participantes, sendo assim, verificou-se no dia-a-dia as atividades da operação e realizou-se as medições de tempo dessas atividades e, através das medições efetuadas, foi possível apresentar o tempo médio das operações de setup com os retrabalhos efetuados (Figura 4) e também um fluxograma do estado atual (Figura 5) das operações de setup:

Figura 4 - Tempo médio das atividades do setup com retrabalho (estado atual)

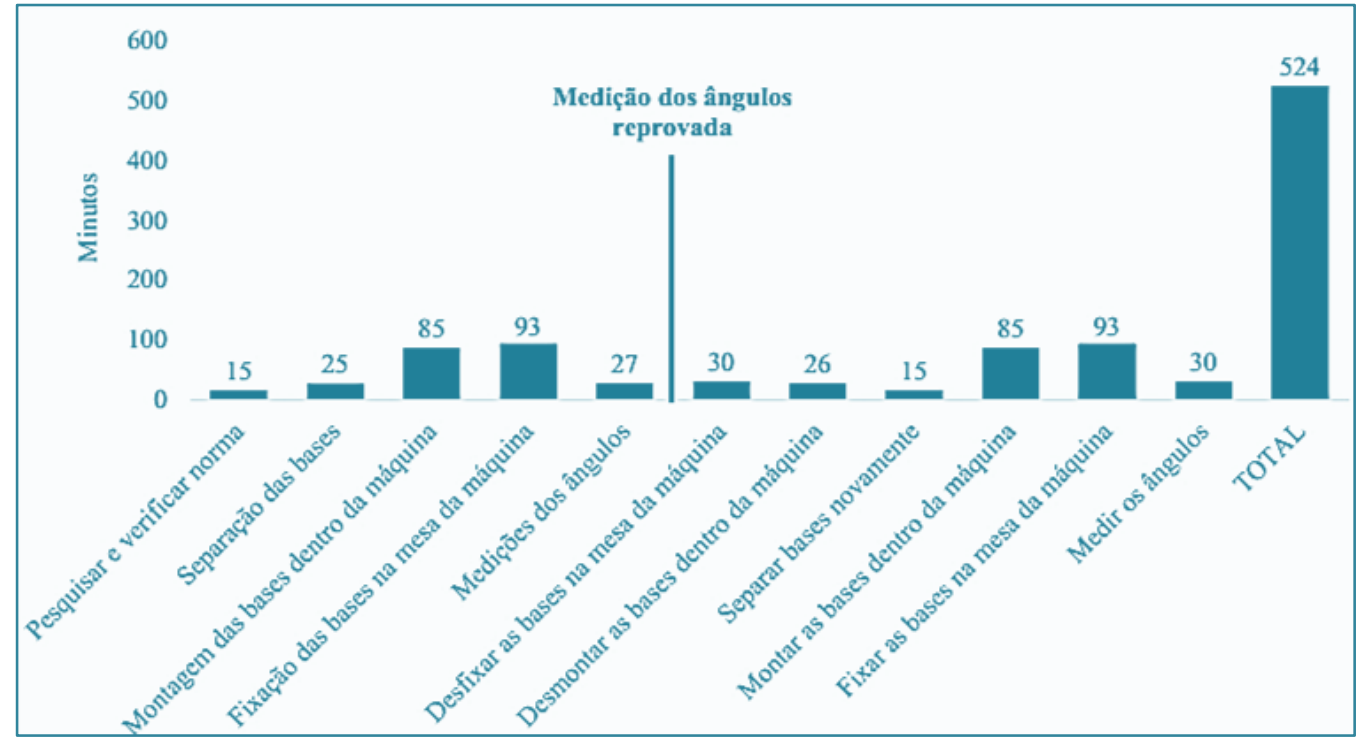

Fonte: Os autores 
Figura 5 - Fluxograma da operação de setup das máquinas de durabilidade (estado atual)

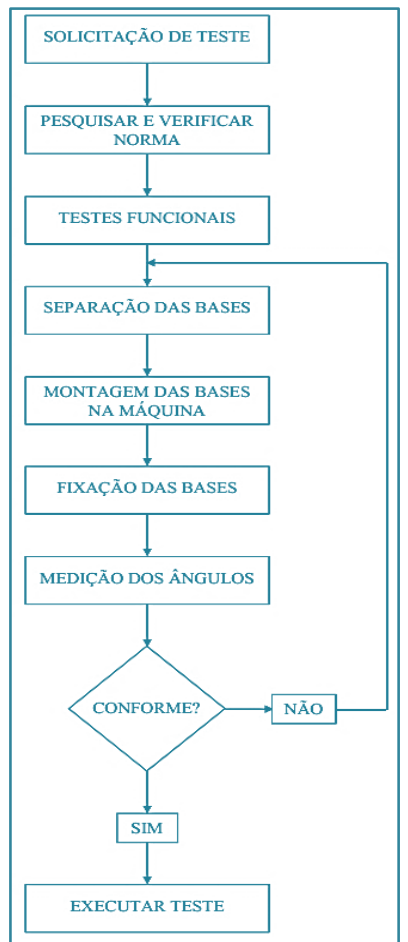

Fonte: Os autores

Uma vez que, ao ser citado no diagrama de causa e efeito (Figura 3), uma das possíveis causas da longa demora ao se efetuar os setups foi a falta de organização dos itens utilizados, especialmente os componentes das bases utilizadas para a fixação das caixas de direção e com a proposta de padronização abaixo citada, foi detectada a necessidade de identificação de todos os itens das bases, sejam eles colunas, insertos, bases inferiores ou superiores, e também um correto e lógico armazenamento desses componentes no armário no qual são guardados esses itens que não estão sendo utilizados para testes.

Essa identificação deverá ser realizada utilizando-se de ferramentas punção para escrita em aço e, nessa identificação, deve estar contido o número do dispositivo juntamente com sua medida de altura, para os insertos e colunas. Já a armazenagem desses itens no armário, deverá ser realizada de forma que sejam mantidos os itens de mesma codificação juntos (pares ou jogos) e também de forma em que os comprimentos dos insertos e colunas estejam em ordem crescente.

Com a identificação dos possíveis pontos de melhorias e também do maiores desperdícios durante o processo de preparação das máquinas de durabilidade, foi possível realizar a proposta de implementação de instruções de trabalho padronizadas, contendo as informações e itens necessários para a montagem das bases de testes, visando a extinção dos retrabalhos das montagens, conforme pode ser visto na descrição das atividades da operação setup (Quadro 2) e também nas folhas de verificações, conforme Figura 6, Figura 7 e Figura 8: 
Quadro 2: Instrução da operação setup

\begin{tabular}{ccc|}
\hline \hline $\mathbf{N}^{\circ}$ atividade & Atividades executadas \\
\hline 1 & Verificar solicitação e normas de testes; \\
2 & Verificar na IT quais serão os materiais utilizados; \\
3 & Separar os materiais de acordo com a IT; \\
4 & Posicionar as colunas sobre as bases inferiores, de modo que os furos fiquem centralizados; \\
5 & Fixar os 03 parafusos de cada coluna às bases inferiores; \\
6 & Posicionar os insertos centralizados nos alojamentos da base superior destinados ao mecanismo a ser testado; \\
7 & Fosicionar a base superior sobre a coluna, de modo que os furos fiquem centralizados; \\
8 & Fixar a base superior nas colunas, sendo 3 parafusos M10 por coluna; \\
9 & Fixar a caixa de direção aos insertos, sendo um parafuso M12 para cada inserto; \\
10 & Fixar os outers aos atuadores e células de carga, utilizando os parafusos do outers e porcas M12; \\
11 & Transportar o conjunto pré-montado até a máquina, posicionando centralizadamente a furação da base inferior \\
12 & aos furos da mesa; \\
13 & Fixar as bases inferiores na mesa com 04 parafusos 5/8". \\
14 & Finners à célula de carga, obedecendo as medidas descritas de sobra de rosca especificadas na IT; \\
15 & & Fixarafusos M8 por inserto; \\
\hline
\end{tabular}

Fonte: Os autores

Figura 6 - Folha de verificação para montagem de máquina de testes de durabilidade XS-014

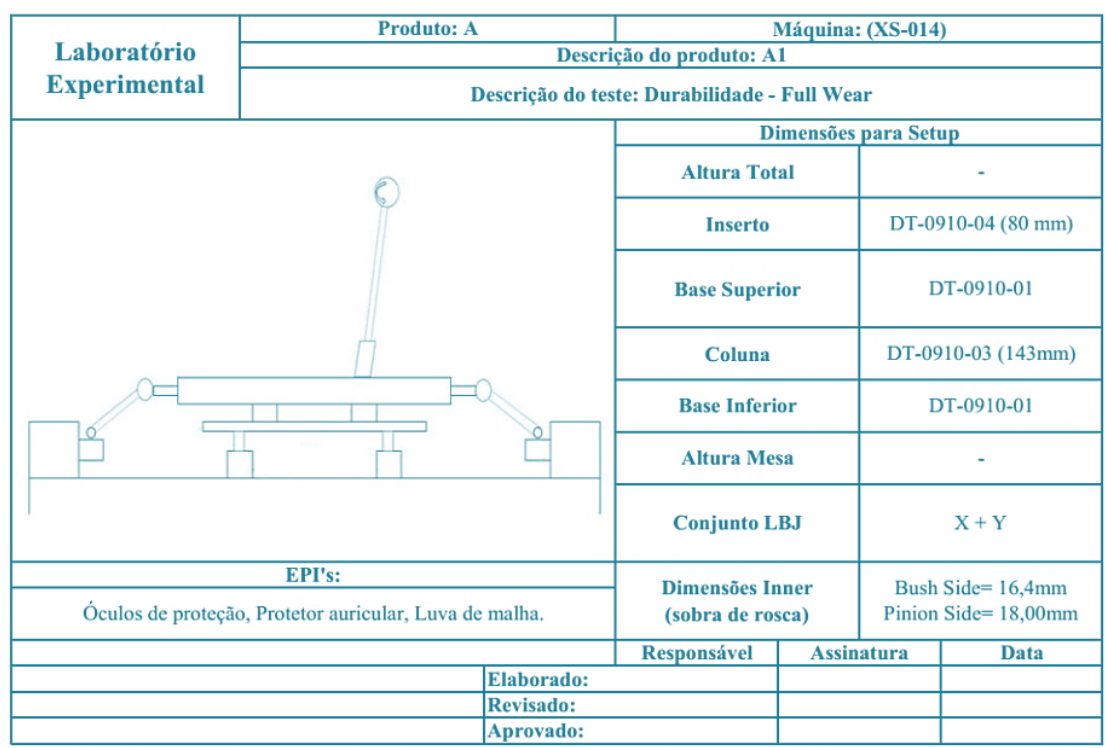

Fonte: Os autores 
Figura 7 - Folha de verificação para montagem de máquina de testes de durabilidade XS-015

\begin{tabular}{|c|c|c|c|c|c|}
\hline \multirow{3}{*}{$\begin{array}{l}\text { Laboratório } \\
\text { Experimental }\end{array}$} & Produto: A & \multicolumn{4}{|c|}{ Máquina: (XS-015) } \\
\hline & \multicolumn{5}{|c|}{ Descrição do produto: A1 } \\
\hline & \multicolumn{5}{|c|}{ Descrição do teste: Durabilidade - Full Wear } \\
\hline & & \multicolumn{4}{|c|}{ Dimensões para Setup } \\
\hline & & \multicolumn{2}{|c|}{ Altura Total } & \multicolumn{2}{|r|}{-} \\
\hline & & \multicolumn{2}{|c|}{ Inserto } & \multicolumn{2}{|c|}{ DT-0910-04A (51 mm) } \\
\hline & & \multicolumn{2}{|c|}{ Base Superior } & \multicolumn{2}{|c|}{ DT-0910-02 } \\
\hline & & \multicolumn{2}{|c|}{ Coluna } & \multicolumn{2}{|c|}{ DT-0899-01 (112 mm) } \\
\hline & & \multicolumn{2}{|c|}{ Base Inferior } & \multicolumn{2}{|c|}{ DT-0910-01 } \\
\hline & & \multicolumn{2}{|c|}{ Altura Mesa } & \multicolumn{2}{|r|}{$167 \mathrm{~mm}$} \\
\hline & & \multicolumn{2}{|c|}{ Conjunto LBJ } & \multicolumn{2}{|r|}{$X+Y$} \\
\hline \multirow{2}{*}{\multicolumn{2}{|c|}{ Óculos de proteção, Protetor auricular, Luva de malha. }} & \multirow{2}{*}{\multicolumn{2}{|c|}{$\begin{array}{l}\text { Dimensões Inner } \\
\text { (sobra de rosca) }\end{array}$}} & \multirow{2}{*}{\multicolumn{2}{|c|}{$\begin{array}{l}\text { Bush Side }=13,5 \mathrm{~mm} \\
\text { Pinion Side }=7,0 \mathrm{~mm}\end{array}$}} \\
\hline & & & & & \\
\hline \multicolumn{2}{|c|}{ Óculos de proteção, Protetor auricular, Luva de malha. } & Responsável & & tura & Data \\
\hline \multicolumn{3}{|c|}{ Elaborado: } & & & \\
\hline \multirow{2}{*}{\multicolumn{3}{|c|}{\begin{tabular}{|l} 
Revisado: \\
Aprovado:
\end{tabular}}} & & & \\
\hline & & & & & \\
\hline
\end{tabular}

Fonte: Os autores

Figura 8 - Folha de verificação para montagem de máquina de testes de durabilidade XS-023

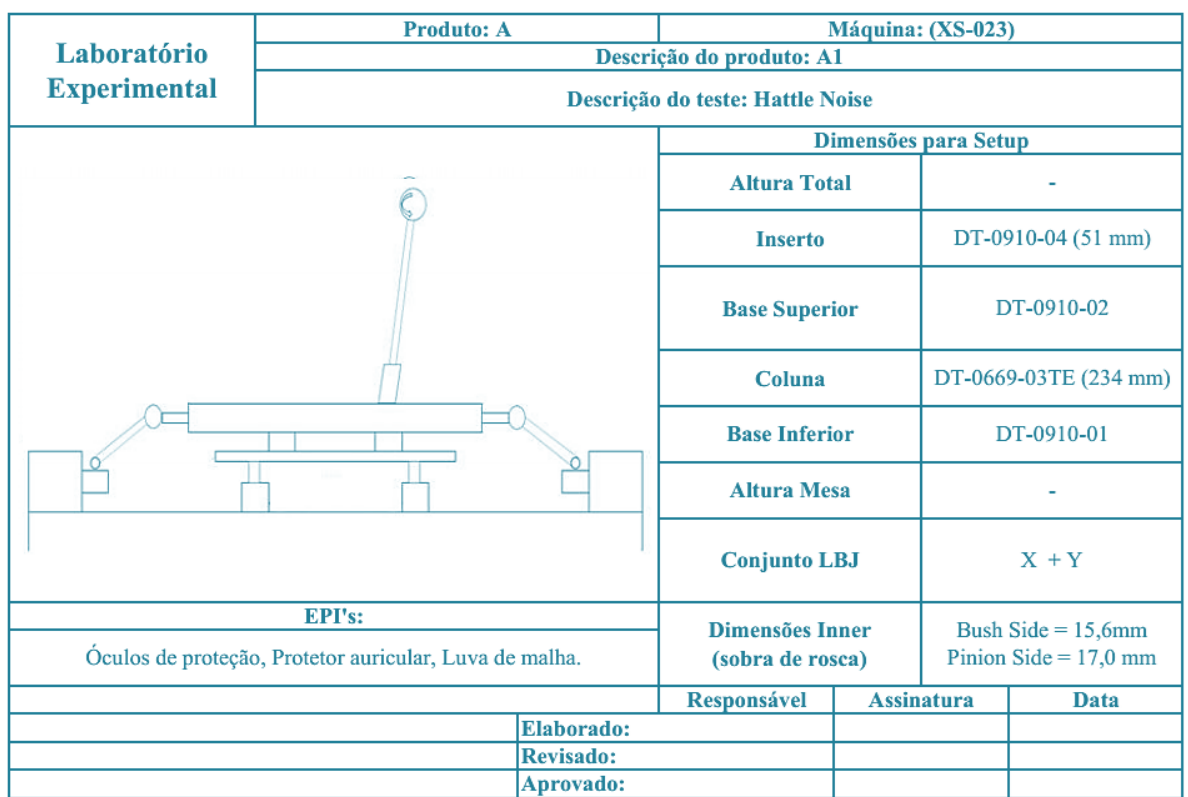

Fonte: Os autores

\section{ANÁLISE DOS RESULTADOS}

Com as propostas de melhorias apresentadas, espera-se que o tempo médio de preparação das máquinas de durabilidade passe de 524 minutos para 235 minutos, devido aos procedimentos, metodologia e padronização do processo de setup, atingindo assim, redução de aproximadamente $55 \%$, conforme apresentado na Figura 9 (Tempo médio de setup com as melhorias) e na Figura 10 (Fluxograma das atividades). 
Figura 9 - Tempo médio das atividades do setup sem retrabalho (estado futuro)

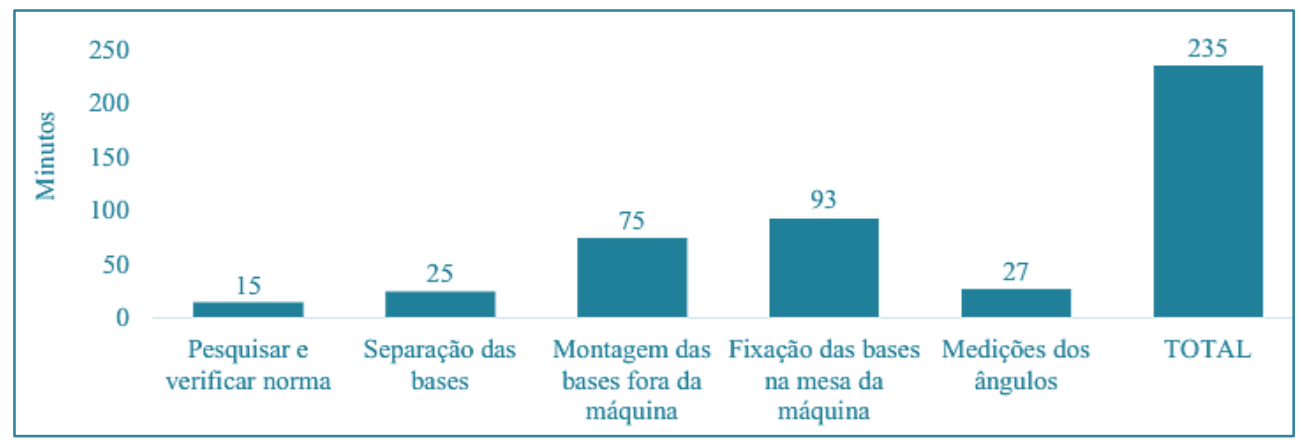

Fonte: Os autores

Figura 10 - Fluxograma da atividade setup (estado futuro)

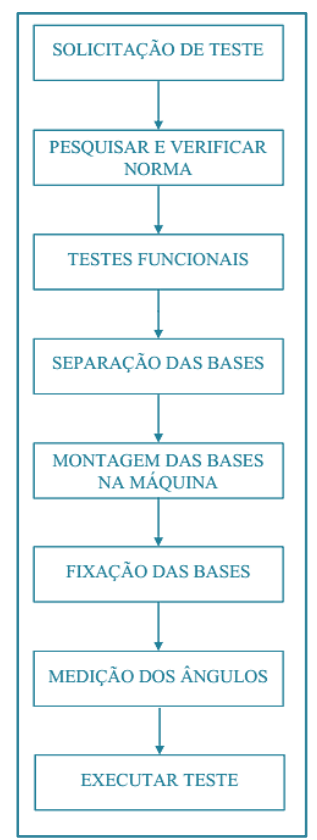

Fonte: Os autores

\section{CONSIDERAÇÕES FINAIS}

A pesquisa-ação desenvolvida teve como finalidade apresentar uma proposta de melhoria para redução do tempo de setup de máquinas de testes de durabilidade em uma empresa automotiva, utilizando como referência conceitos do SMED e também com o uso de conceitos da padronização de processos. Com isso, pôde-se concluir:

- Com o uso dos conceitos SMED e da padronização, foi possível efetuar instruções de trabalho e folhas de verificações conforme pode ser observado no Quadro 6 e nas Figuras 6, 7 e 8;

- Com a utilização das instruções de trabalho e com as folhas de verificações, estima-se uma redução de 55\% no tempo de setup conforme apresentado na Figura 9 e também um fluxo contínuo da execução da atividade, apresentado na Figura 10.

Como consequência, outros benefícios não abordados no presente trabalho podem ser gerados, tais como:

- Reduções de custos com redução de atividades não agregadoras de valor;

- Maior agilidade e menores tempos de resposta às necessidades de resultados de testes;

- Maior disponibilidade da máquina para a realização de testes;

- Aumento de flexibilidade;

- Maior conforto e confiança por parte dos funcionários do setor; 
- Dentre outros benefícios.

Sugere-se para pesquisas futuras, o estudo de propostas de implementação para redução

\section{REFERÊNCIAS}

[1] Bastos, André L. A. Smed e Redução do Tempo de Setup em um Processo Produtivo. In: VI Congresso Brasileiro de Engenharia de Produção. Paraná, 2016. p. 1-9.

[2] Campos, Vicente F. Gerenciamento da Rotina do Trabalho do Dia a Dia. 9 ed. Nova Lima: Falconi, 2013. 266p

[3] Carvalho, Marco T. Lean Manufacturing na Indústria de revestimentos de cortiça. Dissertação de Mestrado - Faculdade de Engenharia da Universidade do Porto, Portugal, 2010. 71p.

[4] Cavanha Filho, A.O. Estratégia de Compras. Rio de Janeiro: Editora Ciência Moderna, 2006. $104 p$.

[5] Conceição, Samuel $v$ et al. Desenvolvimento e implementação de uma metodologia para troca rápida de ferramentas em ambientes de manufatura contratada. Revista Gestão e Produção, São Carlos. v. 16, n.3, p.357369, jul-set. 2009.

[6] Costa, Luiz E. A et al. Procedimento Operacional Padrão: Estudo de caso no setor de recebimento de peças importadas de uma empresa montadora de veículos. In: XXXV| Encontro Nacional de Engenharia de Produção. Paraíba, 2016. p. 1-13.

[7] Dias, Edimar N. et al. Troca Rápida de Ferramentas (TRF): análise da literatura para identificação de oportunidade de pesquisa. In: VI Congresso Brasileiro de Engenharia de Produção. Paraná, 2016. p. 1-12

[8] Duarte, Alan R. S et al. Aplicação do Lean Manufacturing no setor de manutenção de subconjuntos de uma mineradora de grande porte. In: XXXV Encontro Nacional de Engenharia de Produção. Ceará, 2015. p. 1-13.

[9] Gazel, Welleson F; Salles, Jose A. A; Feitosa, Wesley H. Redução do tempo de Setup em uma linha de ingredientes sólidos de uma fábrica alimentícia do pim: Estudo de caso. In: XXXIV Encontro Nacional de Engenharia de Produção. Paraná, 2014. p. 15-26.

[10] Gil, Antônio C. Como elaborar projetos de pesquisa. 5. ed. São Paulo: Atlas, 2010. 210p.

[11] Gilbertoni, D. et al. The contribution of action research in the construction of scientific knowledge in Brazilian Production Engineering. Revista Production. v.26, n.2, p. 373-384, abr./jun. 2016 . de desperdícios em laboratórios metalógrafos e em laboratórios de metrologia que utilizam dos mesmos conceitos operacionais e de testes da presente pesquisa.

[12] Hirano, H. JIT Implementation Manual: The Complete Guide to Just-In-Time Manufacturing. Volume 02, CRC Press: 2009 216p.

[13] lonak, Raabe M. Benefícios da implementação do Trabalho Padronizado na Águia Sistemas de Armazenagem S/A. In: VI CONGRESSO BRASILEIRO DE ENGENHARIA DE PRODUÇÃO. Paraná, 2016. p. 1-9.

[14] Liker, Jeffrey K. O modelo Toyota: 14 princípios de gestão da maior fabricante do mundo. Porto Alegre: Bookman, 2005. 320p.

[15] Mello, Carlos H. P. Pesquisa-ação na engenharia de produção: proposta de estruturação para sua condução. Revista Produção. Brasil. v.22, n.1, p.1-13, jan./fev. 2012.

[16] Ohno, Taiichi. O sistema Toyota de Produção: Além da produção em larga escala. Tradução por Cristina Schumacher. Porto Alegre: Bookman, 1997. 152p.

[17] Paiva, Nathalia T; Bergiante, Nissia C. R. Aplicação de conceitos enxutos na manufatura: $A$ realidade Brasileira. In: XXXVI Encontro Nacional de Engenharia de Produção. Paraíba, 2016. p. 116.

[18] Palomino, Raoni; Lucato, Andre V. R. Implementação da metodologia SMED: Um estudo de caso em uma célula de produção do ramo automobilístico. In: XXXVI Encontro Nacional de Engenharia de Produção. Paraíba, 2016. p. 1-26.

[19] Ramon, Caio R et al. Padronização de Processos para Redução de Erros em uma Distribuidora: Um estudo de Caso. In: XXXV| Encontro Nacional de Engenharia de Produção. Paraíba, 2016. p. 1-15

[20] Reis, Mário E. P.; Alves, João M. Um método para o cálculo do benefício econômico e definição da estratégia em trabalhos de redução do tempo de Setup. Revista Gestão e Produção. São Carlos. v.17, n.3, p.579-588, 2010.

[21] Rodrigues, Marcus V. Entendendo, aprendendo e desenvolvendo, Sistema de Produção Lean Manufacturing. Rio de Janeiro: Elsevier, 2014. 168p.

[22] Santanna, Angelo M. O. Modelo de Padronização de Processos em uma Industria de Termoformagem. In: XXXVI Encontro Nacional de Engenharia de Produção. Paraíba, 2016. p. 1-13.

[23] Shingo, S. A Revolution in Manufacturing: The SMED System. Cambridge, MA: Productivity Press, 1985. 384p 
[24] Shingo, Shigeo. O Sistema Toyota de Produção: do ponto de vista da engenharia de produção. 2.ed. Porto Alegre: Bookman, 1996. $291 p$.

[25] SHINGO, Shigeo. O Sistema de Troca Rápida de Ferramentas. Porto Alegre: Bookman Editora, 2000. 327p

[26] Silva, Joao P. N; Alsisi, Rene B; Costa, Felipe $\mathrm{G}$. Aplicação da troca rápida de ferramentas em uma empresa de corte e dobra de aço. In: XXXVI Encontro Nacional de Engenharia de Produção. Paraíba, 2016. p. 1-13.

[27] Sugai, Miguel; Mcintosh, Richard I; Novaski, Olívio. Metodologia de Shigeo Shingo (SMED): análise crítica e estudo de caso. In: Revista Gestão e Produção. São Carlos. v. 14, n.2, p. 323-335, maio-ago. 2007
[28] Taylor, Frederick W. Princípios da Administração Científica. 8.ed. São Paulo: Atlas, 2010. 112p.

[29] Teixeira, Priscila C. et al. Padronização e melhoria de processos produtivos em empresas de panificação: estudo de múltiplos casos. In: Revista Production, v. 24, n.2, p. 311-321, Apr./June 2014.

[30] Thiollent, Michel. Metodologia da pesquisa-ação. São Paulo: Cortez, 2009. 132p.

[31] TRIP, D. Pesquisa-ação: uma introdução metodológica. In: Educação e Pesquisa. São Paulo, v.31, n.3, p. 443-466, Set./Dez. 2005.

[32] Vieira, Everton $L$ et al. Melhoria no layout de uma indústria metal mecânica utilizando ferramentas Lean Manufacturing. In: XXXVI Encontro Nacional de Engenharia de Produção. Paraíba, 2016. p. 1-21. 


\section{Gapítulo 22}

\section{APLICAÇÃO DE FERRAMENTAS DA MANUFATURA ENXUTA EM UMA FÁBRICA DE COLCHÕES: UM ESTUDO DE CASO}

\section{José Leodoro Sales Júnior \\ Mayanne Camara Serra \\ Ana Célia Silva Vieira \\ Alyson da Luz Pereira Rodrigues \\ Eduardo Mendonça Pinheiro \\ Eduardo Carvalho Dourado}

Resumo: A Manufatura Enxuta é um modo de produzir que visa, basicamente, maximizar o valor agregado através da redução de desperdícios e aplicação de determinadas ferramentas, dentre as quais estão o Mapeamento de Fluxo de Valor MFV, a Padronização do Trabalho e o 5S. Este artigo explana sobre o estudo de caso realizado em uma fábrica de colchões, localizada em São Luís - MA, onde foi realizado um diagnóstico com auxílio do MFV para identificar oportunidades de elevação de produtividade na linha de produção de cama box. Após intervenções por meio do Programa 5S e da Padronização do trabalho no setor de tapeçaria, que foi identificado como prioritário, os principais ganhos obtidos são representados pelo aumento do índice de produtividade e pela expressiva redução de movimentação. Com a realização do estudo de caso, notou-se que os efeitos positivos da aplicação de ferramentas da Manufatura Enxuta excedem o alcance das metas definidas, refletindo-se também em melhoria da qualidade de vida dos colaboradores e da satisfação dos clientes.

Palavras-chave: 5S. Manufatura Enxuta. Mapeamento de Fluxo de Valor. Padronização do Trabalho. 


\section{INTRODUÇÃO}

É importante que as empresas se reinventem constantemente, ou pelo menos atuem na melhoria de seus processos, visando satisfazer clientes cada vez mais conscientes de seu elevado poder de barganha e escolha diante de várias opções de empresas buscando sobreviver e crescer no mercado. Uma empresa que se reinventou há algumas décadas se trata da Toyota, que foi o berço da Manufatura Enxuta - uma forma de produzir buscando a eliminação de desperdícios e o aumento da produtividade, que são meios básicos de aumentar o valor agregado para o cliente final.

Com o desenvolvimento da produção enxuta, técnicas e ferramentas surgiram para facilitar ainda mais a sua implementação em um ambiente empresarial, principalmente quando se trata de sistemas produtivos fabris, pois o desafio de evitar erros e extinguir desperdícios se mostra ainda maior em um fluxo de produção já em funcionamento. Diante disso, entre as técnicas e ferramentas da Produção Enxuta que podem ser aplicadas, há o trabalho padronizado, a metodologia 5S e o Mapeamento de Fluxo de Valor.

Tendo em vista o contextualizado, este artigo aborda sobre a Produção Enxuta e o estudo de caso realizado em uma fábrica ludovicense de colchões, sendo que o estudo se desenvolveu sob o objetivo delineado de aplicar ferramentas da produção enxuta em uma fábrica de colchões buscando aumentar a produtividade de seu sistema produtivo.

\section{A MANUFATURA ENXUTA}

Também sob as denominações de Sistema Toyota de Produção - STP, Filosofia Lean, Lean manufacturing ou Produção enxuta (LÉLIS, 2014), a Manufatura Enxuta surgiu no Japão, mais especificamente na empresa Toyota no período Pós-Segunda Guerra Mundial. Tendo como expoentes o engenheiro Taiichi Ohno e o consultor Shineo Shingo, o sistema de produção em temática se desenvolveu ao longo das décadas, utilizando como objetivos primordiais o aumento da qualidade e satisfação de clientes, além da eliminação de perdas (ALBERTIN e PONTES, 2016; WOMACK e JONES, 2004).

Com base em Zorzo (2015), pode-se explanar que o contexto histórico da origem do STP é interessante devido ter sido incentivado por uma série de dificuldades que o Japão estava passando, financeiramente e industrialmente, após perder a guerra e precisava se reconstruir. Na época, o modelo que até então dominava o mercado era o Fordista, que gerava muito estoque e despendia muitos recursos para um ritmo de produção empurrada. Neste paradigma, o Japão não tinha como seguir modelo semelhante e, diante de suas baixas condições, foi criado um modelo de produção japonês baseado no combate aos desperdícios, intolerâncias a erros e minimização de estoques.

Com o tempo, Ohno identificou e categorizou as sete perdas que o Sistema Toyota de Produção visa eliminar, sendo elas: superprodução, transporte excessivo, processamento, produtos defeituosos, movimentações desnecessárias, espera e estoque. Sendo importante mencionar que, posteriormente, iniciou-se o discurso sobre um oitavo tipo de perda, que é aquela relacionada à não escuta das ideias dos colaboradores para melhorar os processos em que se inserem (ALBERTIN e PONTES, 2016; BIAGIO, 2015).

Geralmente os princípios enxutos são apresentados em cinco, sendo eles o valor, o fluxo de valor, o fluxo contínuo, a produção puxada e a perfeição. Entretanto, de forma mais detalhista, Liker (2005), após estudar o STP por 20 anos, elenca 14 princípios que melhor traduzem as práticas em prol da Filosofia Lean, que são (LAGE JÚNIOR, 2016): tomar decisões em uma filosofia de longo prazo; criar fluxo contínuo; puxar a produção; nivelar a produção; parar para resolver problemas - dispositivos poka-yoke; padronizar as atividades; usar controle visual; usar tecnologia confiável; desenvolver líderes; desenvolver pessoas e equipes; respeitar e ajudar parceiros; ver por si mesmo; tomar decisões por consenso; e aprender e melhorar sempre.

\section{TÉCNICAS E FERRAMENTAS ALIADAS AO LEAN MANUFACTURING}

Existem técnicas que podem ser aplicadas se voltando para a manufatura enxuta e que possuem um objetivo em comum, que é o de "[...] melhorar a sincronização do fluxo de entrega de produtos à demanda, com o mínimo de estoques possível, ou seja, da forma mais 'enxuta' possível" (ZORZO, 2015, p. 71). Dentre as citadas técnicas, Lage Júnior (2016) destaca como principais o Just- 
In-Time - JIT (produzir somente o necessário e quando necessário), a qualidade total, a melhoria contínua, a manutenção produtiva total, a padronização, entre outras.

Sob o enfoque do Lean Manufacturing, a padronização tende a minimizar as fontes de variabilidade dos processos, facilitando o seu controle e a manutenção da estabilidade. Desta forma, a padronização facilita a prática da melhoria contínua e permite que diferentes colaboradores possam executar determinadas tarefas sem variações significativas de resultados (ALBERTIN e PONTES, 2016).

Existem também as ferramentas da produção enxuta, que nada mais são do que soluções para alcance dos objetivos que a Filosofia Lean preconiza. Dentre as principais ferramentas, Lage Júnior (2016) apresenta o
Kanban, a Troca Rápida de Ferramentas TRF, o layout celular e o Mapeamento de Fluxo de Valor - MFV. Frente a essa variedade de ferramentas disponíveis, ressalta-se que, para esse estudo, será enfocado o 5S, o MFV e a Padronização do Trabalho.

No âmbito da produção enxuta, um método fundamental se trata da metodologia 5S, contribuindo para elevar a pontualidade, produtividade e qualidade nos processos, bem como promover a segurança para o ambiente laboral. A referida metodologia se originou no Japão e envolve a aplicação de cinco práticas de trabalho denominadas por cinco termos iniciados com a letra "S" (LÉLIS, 2014).

Pelo Quadro 1, Albertini e Pontes (2016) apresentam os significados das palavras japonesas referentes aos programas de 5S:

Quadro 1 - Significado das palavras japonesas do 5S

\begin{tabular}{|c|c|c|c|}
\hline Japonês & Português & Conceito (local de trabalho) & Objetivo (Local de trabalho) \\
\hline Seiri & $\begin{array}{l}\text { Senso de utilização } \\
\text { (descarte) }\end{array}$ & $\begin{array}{l}\text { Separar o que não é necessário } \\
\text { no dia a dia }\end{array}$ & $\begin{array}{l}\text { Deixar somente o que é necessário } \\
\text { para se trabalhar }\end{array}$ \\
\hline Seiton & $\begin{array}{l}\text { Senso de } \\
\text { organização } \\
\text { (arrumação) }\end{array}$ & $\begin{array}{l}\text { Organizar e identificar o local } \\
\text { de trabalho }\end{array}$ & Organização \\
\hline Seiso & Senso de limpeza & Limpar e cuidar & Manter limpo \\
\hline Seiketsu & $\begin{array}{l}\text { Senso de } \\
\text { padronização }\end{array}$ & $\begin{array}{l}\text { Criar procedimentos para } \\
\text { manter as rotinas }\end{array}$ & $\begin{array}{l}\text { Procedimentos para limpeza e } \\
\text { arrumação }\end{array}$ \\
\hline Shitsuke & Senso de disciplina & $\begin{array}{l}\text { Manter o programa com a } \\
\text { participação de todos }\end{array}$ & Melhorar continuamente \\
\hline
\end{tabular}

Fonte: Adaptado de Albertini e Pontes (2016)

Quanto aos sensos apresentados, Lage Júnior (2016) enfatiza que estes devem ser implantados de forma integrada e que, apesar de os três primeiros possuírem maior facilidade de implantação, são os dois últimos que sustentam efetivamente a ferramenta. 0 autor ainda destaca que são esses cinco sensos que possibilitam o desenvolvimento de um ambiente de trabalho com ordem, limpeza, padronização, produtividade, segurança e com colaboradores motivados.

\subsection{O MAPEAMENTO DE FLUXO DE VALOR - MFV}

O ponto de partida para a Filosofia enxuta que se desenvolveu a partir do sistema de produção da Toyota Motor Company é a definição de valor, sendo que quem define o valor não é a empresa, mas sim seus clientes. Fundamentando-se nisso, as atividades que agregam valor são todas aquelas que fazem parte do processo de transformação do produto de modo a gerar benefícios ao cliente. Sendo assim, quaisquer atividades que não atendam a essa definição, não agregam valor e, na produção enxuta, tudo o que não agrega valor ao produto é desperdício, se configurando como custos que devem ser eliminados (ALBERTIN e PONTES, 2016).

Corroborando com a interrelação entre manufatura enxuta e valor, Lean Enterprise Institute (2011 apud HEUSNER et al., 2015, p. 50) apresenta os cinco princípios da mentalidade enxuta recorrendo várias vezes aos termos "fluxo" e "valor":

- $\quad$ valor para o cliente é criado por meio de uma combinação de ações, algumas produzem valor e outras são necessárias devido ao processo que envolve a produção do produto;

- fluxo de valor concentra-se nas atividades características imprescindíveis para o projeto, para a produção e para 
oferecer um produto específico, da concepção até o lançamento;

- fluxo contínuo concede fluidez aos processos e atividades, o fluxo contínuo nada mais é que o cumprimento das tarefas através do fluxo de valor sem que ocorram interrupções;

- A produção puxada: sistema de produção na qual nada é produzido sem a sinalização da necessidade do cliente, reduz a necessidade de estoques e valoriza o produto;

- A perfeição busca incessantemente pelo aperfeiçoamento contínuo, ocorre através do melhoramento das atividades do fluxo de valor.

Portanto, o fluxo de valor abrange tudo o que é realizado desde a matéria-prima obtida até a entrega do produto ao cliente final, ou seja, armazenamento de material, deslocamentos, filas, setups, processamentos, inspeções, atividades de embalar, entre outras. $\mathrm{Na}$ análise do fluxo de valor de uma organização, é importante a identificação e separação dos processos que de fato resultam em valor para o cliente daqueles que não fornecem valor. Deste modo, devem ser maximizados os processos que geram valor, enquanto os demais devem ser minimizados, porém aqueles que não geram valor e ainda são desnecessários devem ser eliminados (ALBERTIN e PONTES, 2016; LAGE JÚNIOR, 2016).

Ferro (2005) destaca que a o fluxo de valor já foi abordado por Womack e Jones, na obra "Mentalidade Enxuta", como o pilar para a implementação do lean, contudo faltava uma ferramenta que pudesse ser empregada na análise da agregação de valor em sentido horizontal entre os processos. Por isso, era necessário o rompimento do paradigma tradicional da análise de departamentos ou funções de forma isolada.

Atualmente, para identificação das atividades que agregam valor ao fluxo da produção, há o Mapeamento do Fluxo de Valor - MFV, ou Value Stream Mapping - VSM, como importante recurso (LAGE JÚNIOR, 2016; LÉLIS, 2014). Diante das contribuições do MFV, Biagio (2015) aponta o fluxo de valor como o "coração" da manufatura enxuta e, por isso, é importante realizar o seu mapeamento.

Compilando a explicação de Lage Júnior (2016) quanto ao desenvolvimento do MFV, tem-se como primeiro passo a escolha de uma família de produtos similares quanto aos processos envolvidos; em seguida uma equipe deve ser formada sob a coordenação de um líder, que deverá ter contato tanto com os operacionais quanto com os níveis superiores da organização; já na implementação da ferramenta em si, desenhase o estado atual do processo, o estado futuro e, por fim, elabora-se um plano de melhorias com base nas análises realizadas.

De acordo com o que se depreende das abordagens de Bagio (2015) e Lage Júnior (2016), os desenhos para o Mapeamento do Fluxo de Valor podem ser feitos tanto computacionalmente, quanto manualmente, seguindo simbologia própria com itens que representam processos, fontes externas, caixas de informações, estoques, entregas, movimentações empurradas ou puxadas, operadores, entre outros fatores presentes em um fluxo de produção. Portanto, o MFV mostra-se como de fácil entendimento e aplicação diante da simplicidade em torno da sua metodologia, comprovando-se que se trata de uma importante ferramenta para melhoria de processos com a implementação da Manufatura Enxuta.

\section{METODOLOGIA}

Para o desenvolvimento deste trabalho, basicamente tem-se a realização de um levantamento bibliográfico a respeito da Manufatura Enxuta e aspectos correlacionados, principalmente quanto às suas ferramentas, para subsidiar um estudo de caso ocorrido em uma empresa real. $\mathrm{Na}$ referida empresa foram aplicadas ferramentas da Filosofia Lean, sendo elas o Mapeamento do Fluxo de Valor, a metodologia $5 S$ e a Padronização do trabalho.

A empresa estudada é de médio porte e se trata de uma fabricante de colchões e camas box, localizada em São Luís - MA e, portanto, possui dois layouts independentes para cada tipo de produto citado. O sistema de produção da empresa é do tipo misto e há um gerente de produção que direciona as atividades entre os líderes de cada setor. Ressalta-se que o estudo envolveu apenas o setor de produção de camas box e, mais especificamente, os processos posteriores à fabricação da espuma, ou seja, à montagem das camas.

O estudo realizado na empresa, no segundo 
semestre de 2016, formou-se por quatro etapas principais, sendo elas: a visita diagnóstico, o mapeamento do fluxo de valor em relação ao estado presente, a aplicação de ferramentas do Filosofia Lean e, por fim, a análise e documentação dos resultados. Deve-se enfatizar que todas as medidas necessárias para a melhoria do sistema produtivo analisado foram planejadas e definidas por meio de Plano de Ação formal apresentado à empresa.

Além do MFV para a etapa de diagnóstico, as ferramentas aplicadas também abrangeram o Programa 5S e a Padronização do Trabalho nas etapas relacionadas a intervenções no setor estudado. Quanto às essas ferramentas, são válidas as seguintes considerações:

- No software Visio, o layout foi desenhado e o MFV foi desenvolvido com base em dados obtidos a partir de observações diretas e entrevistas com colaboradores para o entendimento do sistema produtivo;

- Programa 5S foi implementado por meio de treinamentos com os colaboradores, visando principalmente a organização física dos espaços de trabalho; e

- Buscou-se padronizar o trabalho como forma de implementar e efetivar o fluxo contínuo que não existia antes do desenvolvimento deste estudo de caso.

\section{RESULTADOS E DISCUSSÕES}

\subsection{O MFV DO ESTADO PRESENTE}

Antes de tudo, é importante destacar que, quanto à produção de camas box, a empresa participante do estudo possui um sistema produtivo misto devido às duas formas de ter sua produção acionada. Uma dessas formas se trata do sistema puxado pela demanda já formalizada por pedidos, enquanto a outra se caracteriza pelas previsões de demanda conforme o setor de Planejamento e Controle da Produção - PCP.

Considerando a etapa de escolha de uma família de produtos para a realização do MFV, para o estudo foi escolhida a produção da chamada cama box uni spring molas, que tem elevada demanda. Para o referido produto, tem-se os seguintes processos: Montagem de Gabarito, Grampo, Montagem de Caixa, Bucha, Compensado, Tapeçaria, Grampo, Colagem, Costura e Inspeção/Embalagem. No estado inicial do sistema em estudo, tais processos se integravam da forma ilustrada pelo Mapeamento de Fluxo de Valor da Figura 1:

Figura 1 - MFV - Estado Presente

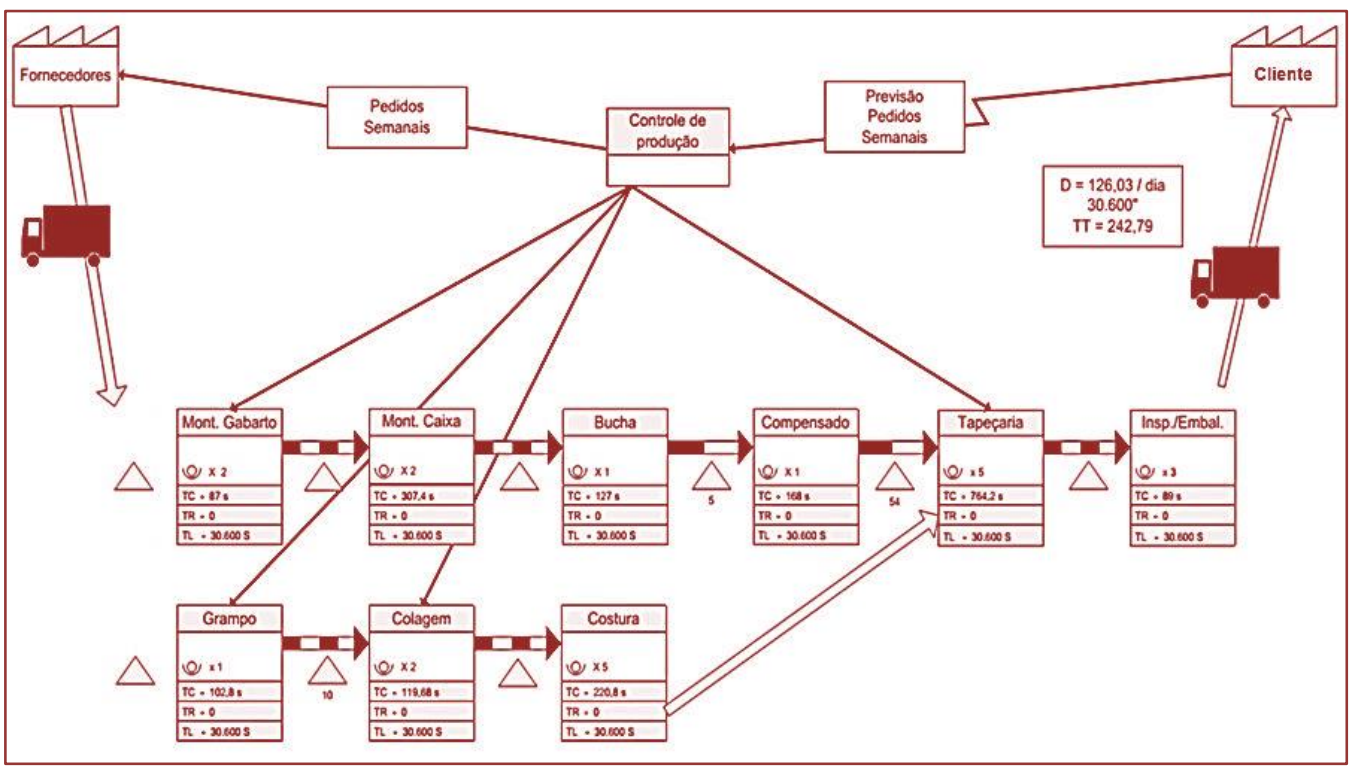

Fonte: Os autores 
No diagnóstico do estado presente do sistema produtivo da fábrica de colchões, foram percebidos como aspectos negativos a desordem e o distante posicionamento de recursos dos postos de trabalho, bem como a sua não regularidade de abastecimento, o que torna fácil indicar que o arranjo físico original não era favorável ao fluxo do processo, assim como o trabalho não seguia um padrão, e ainda existia o ponto crítico dos colaboradores não seguirem a ordem de produção estipulada pelo PCP.

Neste cenário, uma série de fatores facilmente representavam desperdícios de tempo, de produção desnecessária, de estoques intermediários, por movimentações, por transportes excessivos e por esperas - o que impactavam negativamente no produto final, refletindo principalmente o atraso na entrega.

Um ponto importante é que, durante o diagnóstico, identificou-se que as atividades da tapeçaria a indicavam como processo prioritário, principalmente devido ao seu tempo de ciclo ser o mais elevado e devido à possibilidade de obter maiores ganhos em produtividade. A tapeçaria se trata do "vestir" a cama e, embora o processo conte com cinco operadores para cada um "vestir" uma cama simultaneamente, com seu tempo de ciclo relevantemente alto em comparação aos outros, foi notado um alto estoque intermediário aguardando passar por este processo, refletindo-se em um expressivo gargalo no fluxo.

Então, o indicador de produtividade foi medido, resultando 126 unidades por dia e foi definido como meta a sua elevação para 151,2 unidades, ou seja, um aumento de $20 \%$, a partir do observado inicialmente no local em termos de melhorias imediatamente detectadas como possíveis. Paralelamente a movimentação inicial foi detectada como de 84 metros por unidade produzida e definida a meta de redução para $8,4 \mathrm{~m}$.

\subsection{O PROGRAMA 5S}

A partir da análise inicial, percebeu-se como latente a necessidade de organização do sistema produtivo da fábrica de colchões, principalmente devido à presença de materiais desnecessários nos postos de trabalho ou alocados longe destes, enquanto que itens essenciais como forro, TNT, pés e tampos para camas não estavam disponíveis regularmente para os colaboradores. Outro fator crítico era o não esvaziamento diário das lixeiras, gerando acumulo de resíduos e piora no aspecto de desorganização.

Portanto, além da explicação, treinamento e aplicação de todos os sensos da metodologia 5S, foi implementada a sugestão de confeccionar sacos de tecidos reaproveitados para o acondicionamento de cantos de camas e de disponibilizar cavaletes para 0 armazenamento de forros das molas.

De maneira geral, a aplicação do 5S promoveu uma expressiva melhoria visual, organizacional e operacional do setor de produção da empresa estudada, promovendo principalmente a redução de desperdícios. Nos estudos de Kohl, Silva e Souza (2015) também foram obtidos resultados qualitativos semelhantes com a aplicação do 5S em uma empresa do setor de pré-tratamento de resíduos de equipamentos eletroeletrônicos.

Em suma, as medidas tomadas na fábrica de colchões do estudo contribuíram para a facilitação da produção e na redução de movimentações dos funcionários refletindo-se desta forma em produtividade como preconizado por Falconi (2004) sobre o 5S ser uma forma de direcionar a empresa com ganhos efetivos de produtividade e não somente como um episódio isolado de limpeza.

\subsection{A PADRONIZAÇÃO DO TRABALHO}

Após análise das operações, estas foram redefinidas em termos de sequência e integradas em um layout de modo a propiciar ao máximo o caráter de repetitividade. Com isso, foi notável o aspecto de organização e "enxugamento" gerado pelo novo arranjo físico, que está representado pela Figura 2: 
Figura 2 - Layout resultante

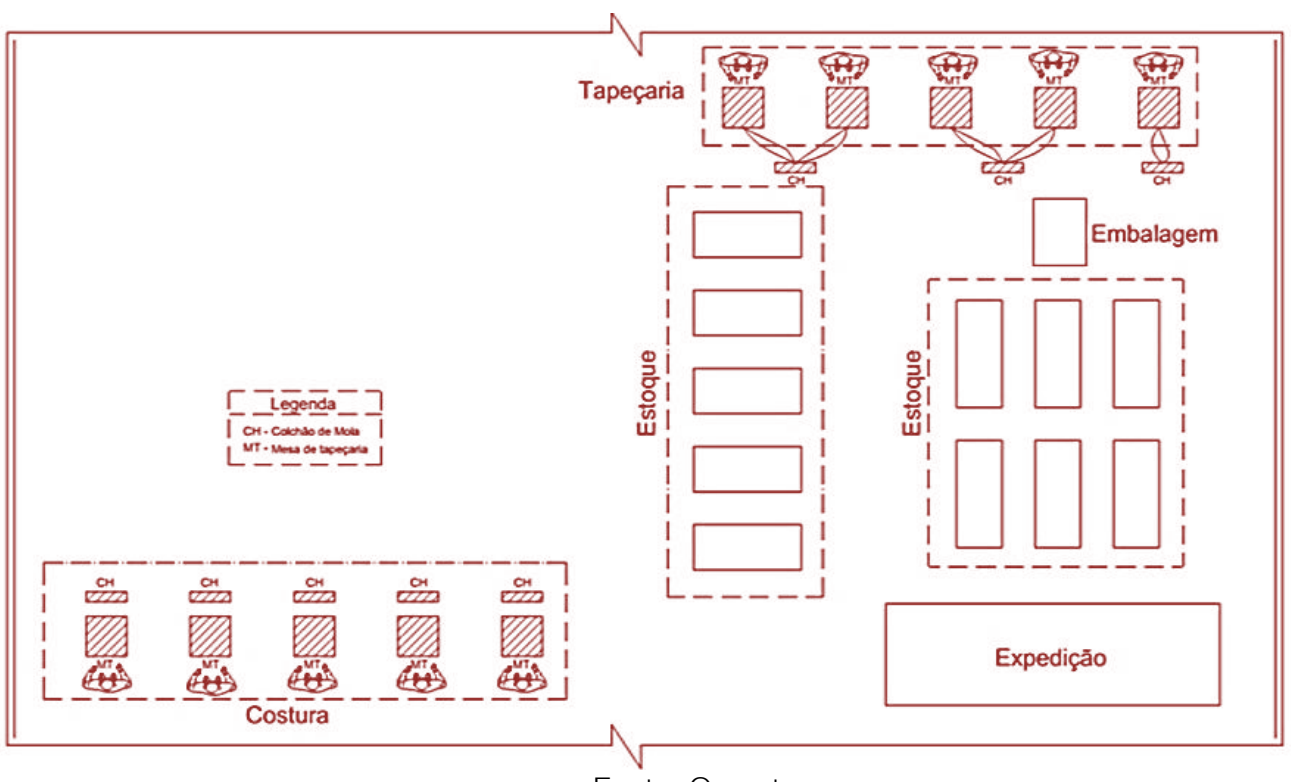

Fonte: Os autores

Aliado ao exposto, para combater ainda mais as atividades que não agregavam valor, os funcionários foram treinados para que elevassem o entendimento sistêmico do processo, seguissem a ordem de produção do PCP e, principalmente, de suas atividades específicas para reduzir desperdícios de movimentações, entre outros tipos de desperdícios e perdas que a Produção Enxuta visa combater.

Para corroborar com as contribuições almejadas pelos métodos aplicados, menciona-se novamente os estudos de Kohl, Silva e Souza (2015), em que se percebe que a padronização, bem como a melhoria do arranjo físico, relaciona-se com o senso de ordenação, pelo qual as autoras detectaram a redução dos desperdícios de espera, transporte excessivo e movimentação desnecessária. Outro trabalho que comprova a inter-relação entre a padronização do trabalho com o 5S buscando a produção sem perdas é o de Freitas et al. (2015), que realizaram estudo de caso em uma empresa de motores ferroviários.

Em complemento, houve a implantação efetiva da tarefa de abastecimento de materiais nos postos de trabalho na rotina do setor. Assim, também como forma de melhor aproveitar o líder, este ficou definido como responsável pelo referido abastecimento de recursos, podendo contar com ajuda de funcionários disponíveis sempre que necessário. E, ainda vale acrescentar que esse abastecimento passou a ser realizado com auxílio de um carrinho com o fito de maximizar a capacidade de acondicionamento de materiais e, ao mesmo tempo, minimizar os deslocamentos para transporte.

\subsection{ANÁLISE DOS RESULTADOS E GANHOS}

Além das já citadas melhorias em termos de organização e redução de desperdícios, as metas estipuladas foram atingidas. Desta forma, no setor de tapeçaria da fábrica de colchões, o índice de produtividade teve um ganho sobre a redução do tempo de 122 segundos por unidade produzida para 96 segundos por unidade produzida, o que equivale a um ganho de $20 \%$. Com isso, fica evidente que o tempo de agregação de valor foi elevado e gerada a margem para atuação em casos de contingências. Reis et al. (2016) em estudo de MFV em uma linha de produção de latas de bebidas alcançaram um aumento de efetividade em torno de $7 \%$ suprimindo os pontos fracos no processo. Elias et al. (2011) obtiveram ganhos de lead time de $66 \%$ na linha de produção de uma indústria de gesso.

Também foi notado o ganho no índice de movimentação, sendo este de $90 \%$ em virtude da redução de movimento de 84 metros por unidade produzida para 8,4 metros conforme meta definida inicialmente. Essa redução de movimentação, de certa forma, também indica o aumento da qualidade de vida dos trabalhadores no âmbito laboral, pois reduz o cansaço causado por deslocamentos 
excessivos, entre outras contribuições.

\section{CONCLUSÃO}

O trabalho obteve êxito em reduzir desperdícios e aumentar a produtividade na fábrica de colchões do estudo a partir de análise, identificação de pontos críticos e intervenção para implantação de melhorias por meio de ferramentas da produção enxuta. Vale destacar que os efeitos das melhorias são sentidos em vários contextos, desde a otimização de processos, satisfação dos clientes até a qualidade de vida dos colaboradores envolvidos no processo.

Pelos aspectos abordados e demonstrados por este estudo, comprova-se que são

\section{REFERÊNCIAS}

[1] Albertin, M. R.; Pontes; H. L. J. Gestão de processos e técnicas de produção enxuta. Curitiba: InterSaberes, 2016.

[2] Biagio, L. A. Como administrar a produção: + curso on-line. Baueri, SP: Manole, 2015 .

[3] Elias, S. J. B.; Oliveira, M. M.; TUBINO, D. F. Mapeamento do fluxo de valor: um estudo de caso em uma indústria de gesso. Revista ADMpg Gestão Estratégica, v. 4, n. 1, p. 2-10. 2011.

[4] Falconi, V. TQC - Controle Total da Qualidade no estilo japonês. 8 ed. Minas Gerais: INDG Tecnologia e Serviços Ltda, 2004.

[5] Ferro, J. R. A essência da ferramenta Mapeamento do Fluxo de Valor. 2005. Disponível em: <https://www.lean.org.br/artigos/61/a-essenciada-ferramenta-mapeamento-do-fluxo-devalor.aspx>. Acesso: abr. 2017.

[6] Freitas, A. S. et al. Análise da Implantação do Programa 5S em uma Empresa de Motores Ferroviários no Sul de Santa Catarina. In: XV Mostra de Iniciação Científica, Pós-Graduação, Pesquisa e Extensão, Universidade Caxias do Sul, 27 nov a 29 dez, 2015

[7] Heusner, R. et al. Aplicação da ferramenta mapeamento do fluxo de valor para identificação dos desperdícios do processo produtivo em uma empresa de reciclagem de plástico. Revista de facilmente factíveis o MFV, o Programa $5 \mathrm{~S}$ e a Padronização do Trabalho, proporcionando a implementação do lean manufacturing. Ademais, mostram-se que os ganhos são garantidos pela implementação desse modo de produzir reduzindo perdas e aumentando o valor agregado.

Quanto ao trabalho prático, visando a melhoria contínua, sugere-se como estudo futuro uma nova análise e intervenção na fábrica de colchões estudada. Mas também fica como sugestão o desenvolvimento de estudos semelhantes do âmbito da filosofia Lean, em empresas de diferentes ramos e portes, para que esta se dissemine nos meios acadêmicos e organizacionais.

Administração do Sul do Pará (REASP) - FESAR. v. 2, n. 3, p. 48-60, set./dez., 2015.

[8] Kohl, C. A.; Silva, C. S.; Souza, C. L. L. Programa 5 s e os desperdícios do Sistema Toyota de Produção aplicados em uma planta de prétratamento de REEE. In: VI Congresso Brasileiro de Gestão Ambiental. Porto Alegre - RS, 23-26 nov. 2015

[9] Lage Júnior, M. Mapeamento de processos de gestão empresarial. Curitiba: InterSaberes, 2016

[10] Lélis, E. C. Gestão da Produção. São Paulo: Pearson Education do Brasil, 2014.

[11] Liker, J. K. O modelo Toyota: 14 princípios de gestão do maior fabricante do mundo. Porto Alegre: Bookman, 2005.

[12] Womack, J. P.; Jones, D. T. A mentalidade enxuta nas empresas: Lean Thinking. Rio de Janeiro: Campus, 2004

[13] Reis, C. F.; Faria, M; Marciano, V. G. Aplicação do mapeamento do fluxo de valor (VSM) em uma linha de produção de latas para bebidas. Revista Científica da FAEX. 10ª edição, p. 116-134. 2016.

[14] Zorzo, A. Gestão de produtos e operações. São Paulo: Pearson Education do Brasil, 2015. 


\section{Gapítulo 23}

\section{LEAN CONSTRUCTION - PROPOSTAS DE INTRODUCCAO DA TECNICA EM DUAS EMPRESAS CONSTRUTORAS NA CIDADE DE MANAUS: CASE}

\section{Juliana Barbosa de Carvalho}

Samantha Coelho Pinheiro

Resumo: A demanda por melhorias no processo produtivo de empresas construtoras no Brasil é de grande importância. A escassez de aplicação de técnicas de gerenciamento na cidade de Manaus é um ponto que necessita de atenção para que se tenha um aprimoramento do gerenciamento de obras atualmente utilizado por grande parte das construtoras que desenvolvem atividades em Manaus. O presente estudo trata da avaliação do processo produtivo de duas empresas de Construção Civil na cidade de Manaus - AM, através da observação de seus processos produtivos sob a luz da técnica Lean Construction, com base em seus principais princípios. Objetivou-se realizar uma vistoria nos processos executivos das empresas visitadas e propor modificações na gestão atual, com base nos princípios da técnica que se mostraram falhos ou inexistentes durante a vistoria, elucidando-se as vantagens do uso da técnica como metodologia de gerenciamento de obras. Com base nas observações feitas durante a realização de visitas técnicas, através de registros fotográficos e também da aplicação, entre os gestores das obras, de um questionário elaborado com base nos princípios da técnica, obteve-se a base necessária para propor as melhorias nos processos produtivos. O resultado dessa pesquisa mostra que o uso intencional da técnica ainda é raro nessas empresas, tendo-se um leque de possibilidades de inserção intencional de seus princípios a fim de que a execução dos projetos seja mais satisfatória e eficaz para o processo produtivo. Finalmente, concluiu-se que há espaço para melhoria no processo de gestão destas empresas, sendo os problemas encontrados de solução alcançável dentro de um plano real de aplicação da técnica.

Palavras-chave: gerenciamento de obras, Lean Construction, processo produtivo, Construção Civil, vistoria. 


\section{INTRODUÇÃO}

A natureza da Construção Civil apresenta-se como um ambiente hostil para seus gestores. O controle e definição do escopo são as maiores dificuldades enfrentadas durante o processo produtivo, principalmente pela necessidade de grande velocidade de resposta e imprevisibilidade do tipo de produção, mostrando-se um processo desafiador para as metodologias de gestão.

Polito (2016) afirma que o desafio a se vencer é conseguir agregar valor e garantir o resultado em meio a tantas incertezas, o que exige profissionalismo, não dando margem ao empirismo ou à informalidade amadora com que se desenvolveu a atividade durante anos. Afirma ainda que o uso de práticas de gestão em obras é reconhecidamente atrasado no país. O conservadorismo do setor gera resultados insatisfatórios e ainda assim, a gestão tradicional permanece incontestada pela alta administração de diversas empresas do setor.

A inflexibilidade e previsibilidade das técnicas convencionais de gestão não se adequam à modernização da produção no setor de construção civil e este projeto objetiva mostrar a importância da atualização nessa área, voltando-se para métodos introdutórios da técnica Lean Construction em duas empresas construtoras localizadas na cidade de Manaus, visando a reestruturação da gestão de execução de atividades componentes de seus processos produtivos, sob a luz da técnica citada, identificando as áreas que necessitam de melhoria, através da observação sistemática do tipo de gestão da produção realizado atualmente nas construtoras e do resultado da ferramenta de pesquisa, neste caso, um questionário aplicado entre os gestores, evidenciando a facilidade de implementação desta técnica de gestão, que contribui e se adapta perfeitamente ao setor.

\section{REFERENCIAL TEÓRICO}

\subsection{A TÉCNICA LEAN CONSTRUCTION}

\subsubsection{CONCEITOS BÁSICOS}

A Lean Construction, baseada no Sistema Toyota de Produção e posteriormente agregando valores do Pensamento Enxuto de Womack e Jones (2004), prima pela mudança no processo produtivo convencional, provado, ao longo do tempo, ineficaz no sentido de identificação e eliminação de perdas desnecessárias no processo produtivo.

Koskela (1992) definiu Lean Construction como "nova filosofia de gestão de produção, originada do Sistema Toyota de Produção STP e adaptada para a construção civil". Seu estudo contém a avaliação da aplicabilidade deste sistema de produção, originalmente da indústria automobilística, no setor de construção civil, provado grande candidato à melhoria do processo produtivo, principalmente devido à sua expansão crescente e consequente maior competitividade de mercado.

\subsubsection{PRINCÍPIOS}

Koskela (1992) determinou e explicou os princípios básicos para execução para a implementação dessa técnica de gestão na construção civil, conforme Quadro 1 a seguir: 
Quadro 1. Princípios Lean Construction.

\begin{tabular}{|c|c|}
\hline Princípio & Significado \\
\hline $\begin{array}{l}\text { Redução das parcelas de } \\
\text { atividades que não agregam valor }\end{array}$ & $\begin{array}{l}\text { Resulta na diminuição das perdas, que é um dos principais problemas } \\
\text { no processo produtivo da construção civil e otimizando-o, este se } \\
\text { torna mais eficaz e simples dentro do fluxo. }\end{array}$ \\
\hline $\begin{array}{l}\text { Aumento do valor do produto } \\
\text { através da consideração } \\
\text { sistemática das necessidades do } \\
\text { cliente }\end{array}$ & $\begin{array}{l}\text { As exigências dos clientes devem sempre serem atendidas com } \\
\text { prioridade, agregando valor ao produto final e evitando retrabalhos } \\
\text { durante o processo. }\end{array}$ \\
\hline Redução da variabilidade & $\begin{array}{l}\text { O setor de construção civil apresenta grande variabilidade, sendo } \\
\text { esta a causa principal da lentidão no processo produtivo, e suas } \\
\text { causas podem ser os tipos de clientes, os materiais, o tempo de } \\
\text { execução de uma mesma atividade, entre outros. }\end{array}$ \\
\hline Redução do tempo de ciclo & $\begin{array}{l}\text { Relacionado à filosofia Just in Time (JIT) que, de forma reduzida, } \\
\text { significa que cada processo deverá ser abastecido no momento } \\
\text { correto, evitando-se assim, a geração de estoques. Fazendo-se isso, } \\
\text { obtém-se uma entrega mais rápida, além de gerar padronização na } \\
\text { execução dos processos, rapidez em sua gestão, e estimativas } \\
\text { precisas de demandas futuras, contribuindo para diminuir a } \\
\text { vulnerabilidade do sistema utilizado. }\end{array}$ \\
\hline $\begin{array}{l}\text { Simplificação através da redução } \\
\text { do número de passos ou partes }\end{array}$ & $\begin{array}{l}\text { Quanto menores forem os passos para executar determinada } \\
\text { atividade, menor a tendência de geração de fases de execução que } \\
\text { não agregam valor, e isso estende-se à complexidade da obra como } \\
\text { um todo, facilitando o andamento das atividades, aumentando a } \\
\text { eficácia e otimizando o processo produtivo. }\end{array}$ \\
\hline Princípio & Significado \\
\hline Aumento da flexibilidade de saída & $\begin{array}{l}\text { Capacidade de alterar o produto final sem gerar aumentos no } \\
\text { planejamento de forma considerada e sem prejudicar a empresa } \\
\text { contratada para realizar o serviço. }\end{array}$ \\
\hline $\begin{array}{l}\text { Aumento da transparência do } \\
\text { processo }\end{array}$ & $\begin{array}{l}\text { Todos têm acesso ao planejamento, sabendo definir as fases de } \\
\text { execução e as atividades subsequentes dependentes ou não das } \\
\text { anteriores, auxiliando o diagnóstico de erros durante o processo } \\
\text { produtivo. }\end{array}$ \\
\hline $\begin{array}{l}\text { Foco do controle no processo } \\
\text { global }\end{array}$ & $\begin{array}{l}\text { Esclarecer a determinação de responsabilidades pelos serviços e } \\
\text { pelos clientes, para manter o controle do processo. }\end{array}$ \\
\hline $\begin{array}{l}\text { Introdução de melhorias contínuas } \\
\text { no processo }\end{array}$ & $\begin{array}{l}\text { Gera aumento no valor da gestão de processos, integrando à JIT, } \\
\text { resultando num processo que objetiva a produção do melhor produto } \\
\text { tanto para o cliente quanto para quem o produz. }\end{array}$ \\
\hline Equilíbrio da melhoria de fluxo & $\begin{array}{l}\text { Melhorias alternadas em incrementação e participação dos } \\
\text { colaboradores, focadas em novas tecnologias e atividades de fluxo. }\end{array}$ \\
\hline Benchmarking & $\begin{array}{l}\text { Termo referente à técnica, amplamente utilizada nos Estados Unidos, } \\
\text { de aprender e utilizar métodos adotados por outras empresas do setor } \\
\text { que funcionaram no contexto geral, através de pesquisa de mercado } \\
\text { e visitas a outras empresas, não gerando, assim, investimentos } \\
\text { internos para obter as informações, e a partir do seu uso, reduz-se a } \\
\text { competitividade, por trazer os produtos para um mesmo padrão. }\end{array}$ \\
\hline
\end{tabular}

\subsection{PROCESSO PRODUTIVO CONVENCIONAL VERSUS MODELO LEAN}

Uma empresa preocupada com a gestão de seus projetos acaba por gerar, adaptar e conseguir implementar novas técnicas de planejamento de forma que seu produto final é superior ao da concorrência e produzido de

\section{forma mais rápida e simples.}

A falta de padronização das atividades é uma das causas de maior variabilidade no processo produtivo da construção civil. Utilizando a Lean Construction é possivel a redução do desperdício no processo produtivo e o planejamento de ações, 
aumentando a qualidade do produto colocado no mercado.

Hofstede (1978) definiu o Modelo Termostato como um padrão em que a performance da empresa é medida em função do controle dos processos de produção. A possível variabilidade entre o padrão e o valor medido é utilizado para corrigir o processo produtivo a fim de que o processo padrão possa ser atingido. Esse conceito é fundamental para as empresas que prezam pela melhoria na produção, e principalmente, as que intendem implantar a tecnologia Lean Construction em suas linhas de trabalho.

O processo de gestão convencional, de uma perspectiva da Lean Construction, se apoia num modelo defeituoso de projeto, onde o trabalho envolvido e seu controle não são interligados (KOSKELA et al., 2014). De maneira geral, o método convencional de gestão se baseia em gerenciar atividades isoladamente aplicando cronogramas centralizados para controlá-las utilizando medidas de saída, ou seja, falha no sentido de não gerenciar o projeto como um fluxo, onde atividades interdependentes exigem maior atenção, e deixa de lado a criação de valor, apontando seus esforços nas partes e não no todo.

\section{METODOLOGIA}

Realizou-se um estudo de caso a respeito de formas de aplicação da técnica Lean Construction em duas empresas construtoras na cidade de Manaus. As empresas foram selecionadas com base no tipo de serviço executado e a disponibilidade em receber as visitas técnicas necessárias à realização deste estudo. Este estudo foi dividido em três etapas:

Etapa 1: pesquisa teórica sobre a Lean Construction, abrangendo trabalhos já publicados, tanto em revistas quanto em congressos, a respeito do tema, em especial os de Koskela, que é o autor da adaptação da técnica Lean para a Construção Civil, observando os princípios, conceito, formas de aplicação e efeitos da técnica em questão no processo produtivo da construção civil;

Etapa 2: coleta de dados em duas empresas construtoras na cidade de Manaus, através da observação e acompanhamento da execução de algumas atividades durante o processo produtivo registrando fotograficamente, e, ao final do período de observação, a aplicação do questionário previamente elaborado entre os gestores das obras visitadas, buscando identificar as etapas do processo produtivo adotado que poderão ser otimizadas com a utilização da Lean Construction;

O questionário (Quadro 2) aplicado nesta fase é uma adaptação do questionário de Souza e Cabette (2014) e do checklist de Souza e Brandstetter (2010), acrescido de questões pertinentes observadas no estudo de Isatto et.al (2000), que abrangem de forma extensiva os detalhes a serem observados, através de respostas simples (sim ou não), a fim de facilitar sua aplicação em campo.

Etapa 3: consistiu na elaboração, para cada empresa, de uma lista de propostas de formas de utilização dos princípios da técnica Lean Construction que se observaram inaplicados ou deficientes durante a pesquisa de campo, com base nos dados coletados na etapa 2, elucidando as possíveis melhorias no processo produtivo a partir da utilização desta ferramenta de gerenciamento.

\section{RESULTADOS}

A aplicação do questionário apresentado no Quadro 2 a seguir, acrescido da observação in loco da execução das atividades pelas empresas estudadas, permitiram a observação dos detalhes executivos em que os princípios da técnica Lean Construction estão falhos ou inexistentes, abrindo a possibilidade de inserção destes para a melhoria do processo produtivo no setor de execução destas empresas. O questionário foi respondido na Empresa 1 (Figura 1) pelo estagiário que se encontrava na obra devido à dificuldade de contato com o engenheiro responsável por esta e, na Empresa 2 (Figura 2) por um dos engenheiros civis responsáveis pela obra. Em ambas as empresas o Quadro 1 foi apresentado previamente para um melhor entendimento por parte das empresas dos princípios que foram avaliados durante as visitas realizadas na etapa 2 da metodologia deste estudo. 
Figura 1. Amostra do questionário respondido pelo estagiário da Empresa 1.

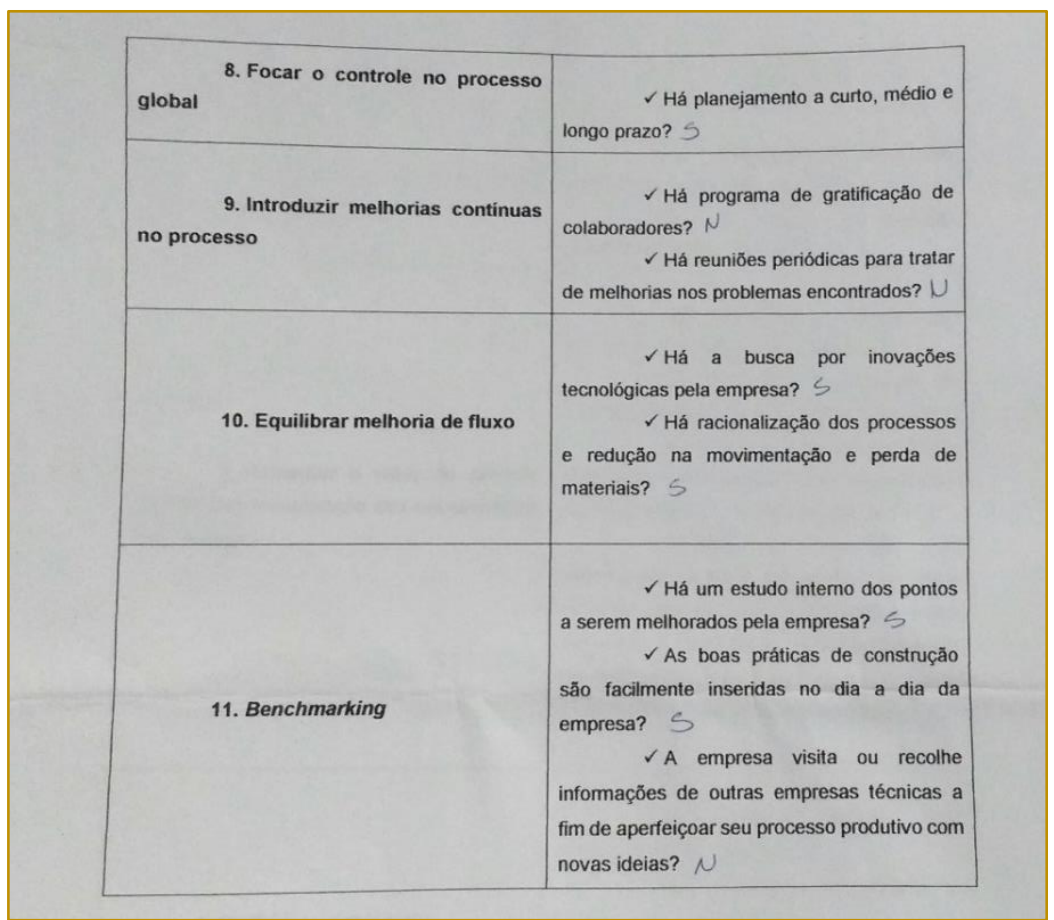

Figura 2. Amostra do questionário respondido pelo engenheiro da Empresa 2.

\begin{tabular}{|c|c|}
\hline 3. Reduzir variabilidade & 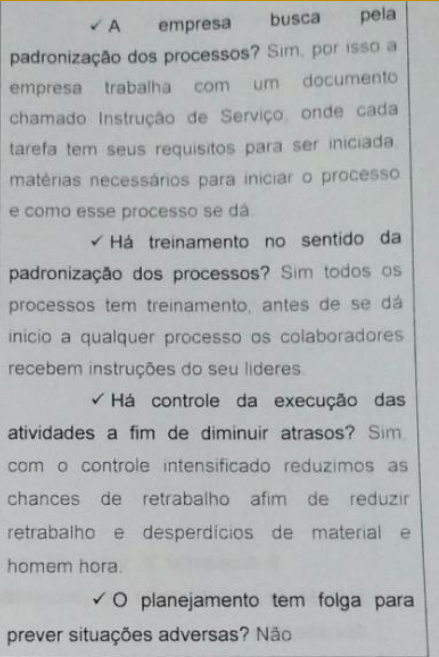 \\
\hline 4. Reduzir o tempo de ciclo & $\begin{array}{l}\text { } \checkmark \text { planejamento é feito de modo } \\
\text { que o minimo de atividades sejam } \\
\text { interdependentes (podendo ser executadas } \\
\text { em paralelo)? Sim, temos alguns casos que } \\
\text { antecipamos algumas atividades para } \\
\text { otimizar o tempo e melhor rendimento da } \\
\text { posterior. }\end{array}$ \\
\hline
\end{tabular}


Quadro 2. Ferramenta de pesquisa - questionário para gestores e respostas das empresas.

\begin{tabular}{|c|c|c|c|}
\hline Princípios & Questões & $\begin{array}{l}\text { Respostas } \\
\text { Emp. } 1\end{array}$ & Emp. 2 \\
\hline \multirow{2}{*}{$\begin{array}{l}\text { 1. Reduzir a parcela } \\
\text { de atividades que não } \\
\text { agregam valor }\end{array}$} & As atividades de fluxo são explicitadas da área de trabalho? & Sim & Sim \\
\hline & Há o controle e possível eliminação destas atividades? & Sim & Sim \\
\hline \multirow{4}{*}{$\begin{array}{l}\text { 2. Aumentar o valor } \\
\text { do produto através da } \\
\text { consideração } \quad \text { das } \\
\text { necessidades dos } \\
\text { clientes }\end{array}$} & Há pesquisa de mercado com possíveis compradores do produto? & Sim & Sim \\
\hline & $\begin{array}{l}\text { Há avaliações pós-ocupação de edificações feitas pela empresa já } \\
\text { entregues? }\end{array}$ & Sim & Sim \\
\hline & $\begin{array}{l}\text { Há a comunicação desses dados obtidos para os responsáveis da obra } \\
\text { durante as várias etapas do processo produtivo? }\end{array}$ & Sim & Sim \\
\hline & $\begin{array}{l}\text { Durante a execução de determinada atividade são levados em conta os } \\
\text { requisitos necessários nesta para que não prejudique a execução da } \\
\text { próxima atividade? (ex: tolerâncias dimensionais no concreto para a } \\
\text { execução de alvenaria e revestimento). }\end{array}$ & Sim & Sim \\
\hline \multirow{4}{*}{$\begin{array}{l}\text { 3. Reduzir } \\
\text { variabilidade }\end{array}$} & A empresa busca pela padronização dos processos? & Sim & Sim \\
\hline & Há treinamento no sentido da padronização dos processos? & Sim & Sim \\
\hline & Há controle da execução das atividades a fim de diminuir atrasos? & Sim & Sim \\
\hline & O planejamento tem folga para prever situações adversas? & Sim & Não \\
\hline \multirow{2}{*}{ Princípios } & & \multicolumn{2}{|c|}{ Respostas } \\
\hline & 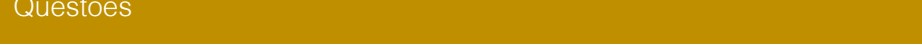 & Emp. 1 & Emp. 1 \\
\hline \multirow{3}{*}{$\begin{array}{l}\text { 4. Reduzir o tempo de } \\
\text { ciclo }\end{array}$} & $\begin{array}{l}\text { O planejamento é feito de modo que o mínimo de atividades seja } \\
\text { interdependente (podendo ser executadas em paralelo)? }\end{array}$ & Sim & Sim \\
\hline & O planejamento é feito considerando-se o tempo de ciclo? & Sim & Sim \\
\hline & $\begin{array}{l}\text { Há a possibilidade de se averiguar erros que podem ser evitados em } \\
\text { lotes subsequentes? }\end{array}$ & Sim & $\operatorname{Sim}$ \\
\hline \multirow{4}{*}{$\begin{array}{l}\text { 5. Simplificar através } \\
\text { da redução do } \\
\text { número de passos ou } \\
\text { partes }\end{array}$} & $\begin{array}{l}\text { A empresa utiliza elementos pré-fabricados para reduzir o número de } \\
\text { etapas de execução de determinado elemento? }\end{array}$ & Sim & Não \\
\hline & $\begin{array}{l}\text { Há treinamento polivalente de equipes (ao invés de um número maior } \\
\text { de equipes especializadas)? }\end{array}$ & Sim & Não \\
\hline & O planejamento procura agregar pequenas tarefas em maiores? & Sim & Não \\
\hline & $\begin{array}{l}\text { Há a organização dos materiais necessários à execução da atividade } \\
\text { de modo que se evite movimentações desnecessárias ou interrupções } \\
\text { na tarefa? }\end{array}$ & Sim & $\begin{array}{l}\text { Sim } \\
\text { (com } \\
\text { falhas) }\end{array}$ \\
\hline \multirow{2}{*}{$\begin{array}{l}\text { 6. Aumentar a } \\
\text { flexibilidade de saída }\end{array}$} & O projeto e a produção dão oportunidade para permitir flexibilidade? & Não & Não \\
\hline & $\begin{array}{l}\text { Existe equipe destinada a modificar o projeto de acordo com } \\
\text { solicitações do cliente? }\end{array}$ & Não & Não \\
\hline \multirow{4}{*}{$\begin{array}{l}\text { 7. Aumentar } \\
\text { transparência } \\
\text { processo }\end{array}$} & $\begin{array}{l}\text { Há a oportunidade do envolvimento da mão de obra no } \\
\text { desenvolvimento de melhorias? }\end{array}$ & Sim & $\operatorname{Sim}$ \\
\hline & $\begin{array}{l}\text { A empresa utiliza dispositivos visuais (placas, cartazes, sinalização } \\
\text { luminosa, demarcação de áreas) que disponibilizem informações } \\
\text { relevantes à gestão? }\end{array}$ & $\operatorname{Sim}$ & Sim \\
\hline & $\begin{array}{l}\text { Há indicadores de desempenho (nível de produtividade, número de } \\
\text { peças rejeitadas)? }\end{array}$ & Não & Sim \\
\hline & $\begin{array}{l}\text { A empresa usa programas de melhoria de organização e limpeza (por } \\
\text { exemplo, 5S)? }\end{array}$ & Não & Sim \\
\hline $\begin{array}{l}\text { 8. Focar o controle no } \\
\text { processo global }\end{array}$ & Há planejamento a curto, médio e longo prazo? & Sim & Sim \\
\hline \multirow{2}{*}{$\begin{array}{l}\text { 9. Introduzir melhorias } \\
\text { contínuas no } \\
\text { processo }\end{array}$} & Há programa de gratificação de colaboradores? & Não & Sim \\
\hline & $\begin{array}{l}\text { Há reuniões periódicas para tratar de melhorias nos problemas } \\
\text { encontrados? }\end{array}$ & Não & $\operatorname{Sim}$ \\
\hline \multirow{2}{*}{$\begin{array}{l}\text { 10. Equilibrar melhoria } \\
\text { de fluxo }\end{array}$} & Há a busca por inovações tecnológicas pela empresa? & Sim & Sim \\
\hline & $\begin{array}{l}\text { Há racionalização dos processos e redução na movimentação e perda } \\
\text { de materiais? }\end{array}$ & $\operatorname{Sim}$ & Sim \\
\hline \multirow{3}{*}{ 11. Benchmarking } & Há um estudo interno dos pontos a serem melhorados pela empresa? & Sim & Sim \\
\hline & $\begin{array}{l}\text { As boas práticas de construção são facilmente inseridas no dia a dia } \\
\text { da empresa? }\end{array}$ & Sim & Não \\
\hline & $\begin{array}{l}\text { A empresa visita ou recolhe informações de outras empresas técnicas a } \\
\text { fim de aperfeiçoar seu processo produtivo com novas ideias? }\end{array}$ & Não & $\operatorname{Sim}$ \\
\hline
\end{tabular}

Fonte: Adaptado de Souza e Cabette (2014), Souza e Brandstetter (2010) e Isatto et.al (2000).

Para comparar os processos produtivos e, sem identificar as empresas estudadas, conhecer suas características principais, elaborou-se o Quadro 3, baseado no trabalho de Barros Neto e Alves (2008), que contém, de forma resumida, os diversos aspectos das gestões atuais das empresas visitadas, para que se possa ter uma visão sistemática do que deve ser analisado em cada uma delas. 
Quadro 3. Comparativo entre gestões das empresas estudadas.

\begin{tabular}{|c|c|}
\hline \multicolumn{2}{|c|}{ Empresas Construtoras } \\
\hline \multicolumn{2}{|l|}{ Empresa 1} \\
\hline \multicolumn{2}{|c|}{ Em qual nicho do mercado a empresa atua? } \\
\hline Obra industrial/comercial/pública & $\begin{array}{c}\text { Incorporação imobiliária, edificação multi-familiar } \\
\text { residencial vertical }\end{array}$ \\
\hline \multicolumn{2}{|c|}{ Quais as dificuldades encontradas para a implantação? } \\
\hline $\begin{array}{l}\text { Realizar a fiscalização dos serviços executados } \\
\text { para controle do uso da técnica, abranger e } \\
\text { disseminar o conhecimento e a assimilação da } \\
\text { técnica pelos colaboradores da empresa e } \\
\text { prestadores de serviço. }\end{array}$ & $\begin{array}{l}\text { Participação ativa da alta direção no processo } \\
\text { produtivo, oferecimento de cursos e palestras } \\
\text { para incentivar o uso da técnica, mudando a } \\
\text { perspectiva dos colaboradores, além da } \\
\text { fiscalização do uso dos princípios na execução } \\
\text { das atividades. }\end{array}$ \\
\hline \multicolumn{2}{|c|}{ Quais os primeiros passos para a implantação da técnica? } \\
\hline $\begin{array}{l}\text { Informação e disseminação dos princípios da } \\
\text { técnica e suas formas de aplicação na parte } \\
\text { executiva do processo de produção, através de } \\
\text { palestras e cursos. }\end{array}$ & $\begin{array}{l}\text { Informação e disseminação dos princípios da } \\
\text { técnica e suas formas de aplicação na parte } \\
\text { executiva do processo de produção, através de } \\
\text { palestras e cursos. }\end{array}$ \\
\hline \multicolumn{2}{|l|}{ Como a filosofia Lean pode contribuir com a empresa? } \\
\hline $\begin{array}{l}\text { Redução do tempo de ciclo, redução da } \\
\text { variabilidade, eliminação de retrabalhos, } \\
\text { agilidade no processo produtivo, redução de } \\
\text { desperdícios (materiais e de tempo). }\end{array}$ & $\begin{array}{l}\text { Aumento da transparência do processo, foco no } \\
\text { controle do processo global, aumento da } \\
\text { flexibilidade de saída (inexistente no momento), } \\
\text { redução da variabilidade, redução do número de } \\
\text { passos por atividade, benchmarking. }\end{array}$ \\
\hline \multicolumn{2}{|c|}{ Onde se pretende chegar com a implantação da filosofia Lean? } \\
\hline $\begin{array}{l}\text { Tornar a técnica parte da filosofia da empresa, } \\
\text { integrando a construção enxuta na mentalidade } \\
\text { de todos os colaboradores, reduzindo etapas } \\
\text { desnecessárias (como retrabalho) e melhorando } \\
\text { o acompanhamento da execução dos serviços. }\end{array}$ & $\begin{array}{l}\text { Cumprir prazos de entrega de obras, não } \\
\text { ultrapassar o orçamento previsto para a obra em } \\
\text { questão e existir a possibilidade de flexibilidade } \\
\text { na execução dos serviços. }\end{array}$ \\
\hline
\end{tabular}

Fonte: Adaptado de Barros Neto e Alves (2008).

\subsection{EMPRESA 1}

\subsubsection{DESCRIÇÃO DA EMPRESA}

A Empresa 1 atua nas áreas industrial, comercial e também com obras públicas. É uma empresa que possui obras em todo o estado do Amazonas aplicando o mesmo princípio de gerenciamento em todas elas. A obra visitada trata-se de uma edificação pública. A Empresa 1 não possui certificação Lean (requisito para aplicação deste estudo) tampouco certificações de qualidade (série ISO 9000). A Figura 3, apresenta a hierarquia atualmente utilizada no gerenciamento das obras desta empresa.

Figura 3. Hierarquia atual - Empresa 1 - linearidade sugere dificuldade de controle.

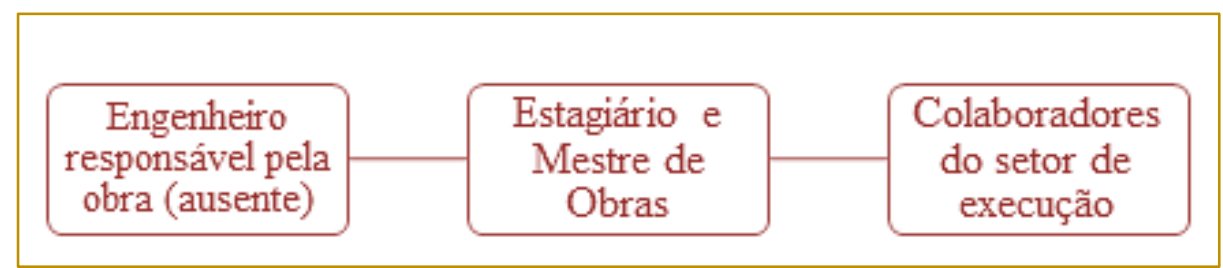




\subsubsection{PONTOS OBSERVADOS DE APLICAÇÃO DA TÉCNICA LEAN CONSTRUCTION}

Após a observação in $10 c o$ e a aplicação do questionário, que nesta empresa foi respondido pelo estagiário que estava presente na obra, foram identificados os seguintes pontos de aplicação da técnica na Empresa 1, apresentados de acordo com cada princípio avaliado inaplicado:

a) Redução da variabilidade: mediu-se o tempo de execução de uma mesma atividade (reboco de parede) em três execuções feitas por colaboradores diferentes e verificou-se que há variabilidade considerável (até 2 horas de diferença) na execução, de um colaborador para outro, tendo-se um tempo de execução não padronizado e algumas vezes superior ao necessário. Quando descontados os tempos de parada nos três casos analisados, ainda há uma diferença de tempo de aproximadamente 45 minutos entre uma atividade e outra, agora analisadas sob as mesmas condições, sem interrupções, tempo ainda considerado com grande variabilidade;

b) Aumento do valor do produto através da consideração sistemática das necessidades do cliente: um dos pilares da Lean Construction é evitar que exista o retrabalho. Nessa empresa, durante o acompanhamento da execução dos serviços, observou-se o retrabalho em dois pontos: durante a concretagem das vigas, não foi observado previamente o adensamento do concreto, o que gerou patologia nas vigas e, consequentemente, retrabalho para recuperálas (Figuras 4 e 5). O caso do banheiro (Figuras 6 e 7) não se verificou o nível antes da execução (que deveria ser $3 \mathrm{~cm}$ abaixo do nível da calçada do lado de fora deste) e assim, gerou-se retrabalho para rebaixar o nível do solo, consequentemente retrabalho para rebaixar as instalações hidráulicas e, ainda assim, o problema não foi completamente resolvido pela impossibilidade de rebaixar as vigas baldrames que existem nas imediações do banheiro;

Figura 4. Recapeamento de viga

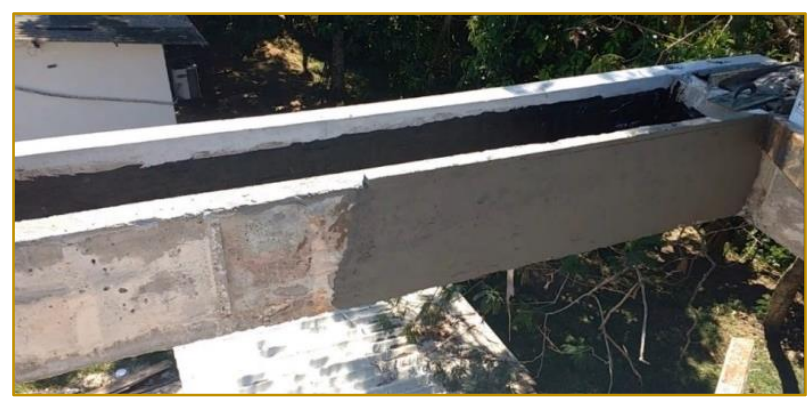

Figura 5. Visão inferior de uma viga com armadura exposta - patologia de concreto.

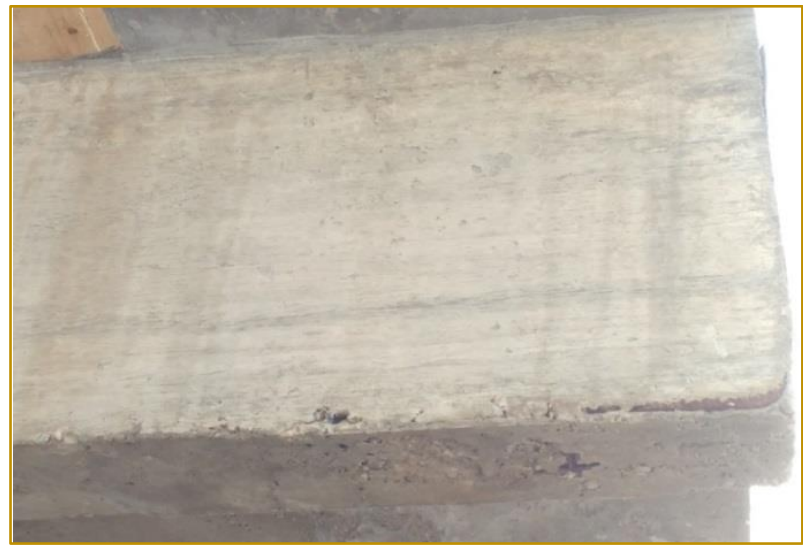


Figura 6. Rebaixamento no nível do solo no banheiro e viga baldrame.

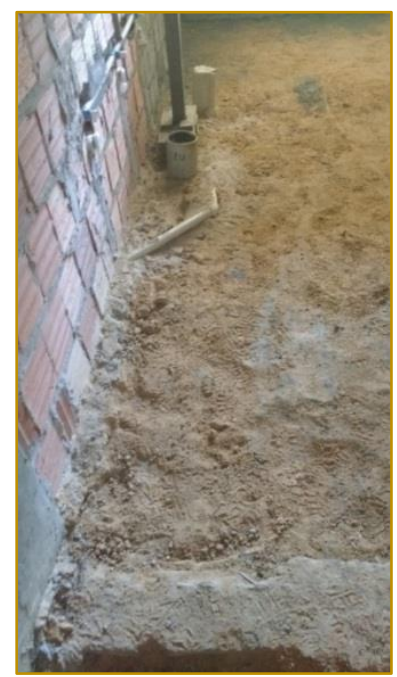

Figura 7. Rebaixamento das instalações hidráulicas.

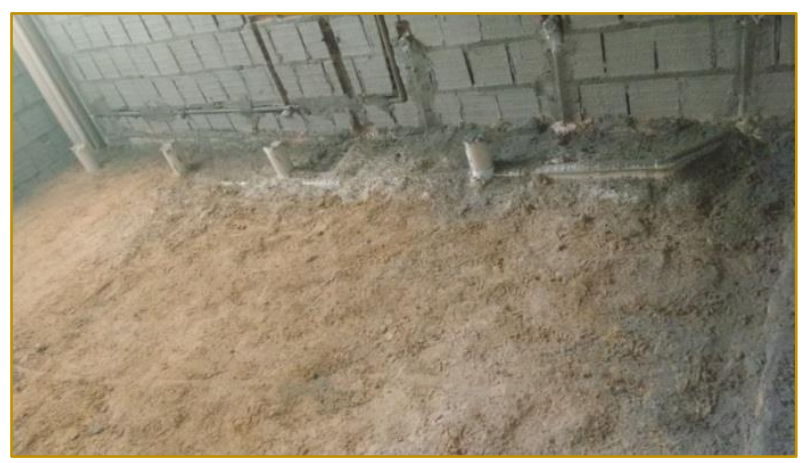

a) Redução do tempo de ciclo: o tempo de execução também varia em função de fatores externos à execução desta atividade. Como exemplo, pode-se citar que a produção de argamassa de diversos traços é feita utilizando-se apenas uma betoneira, mesmo existindo outra disponível (Figura 8), o que interrompe a produção de determinada atividade quando há necessidade de produção de mais argamassa para esta e a betoneira está ocupada com a produção de uma argamassa de outro traço para outro serviço;

Figura 8. Betoneira não utilizada.

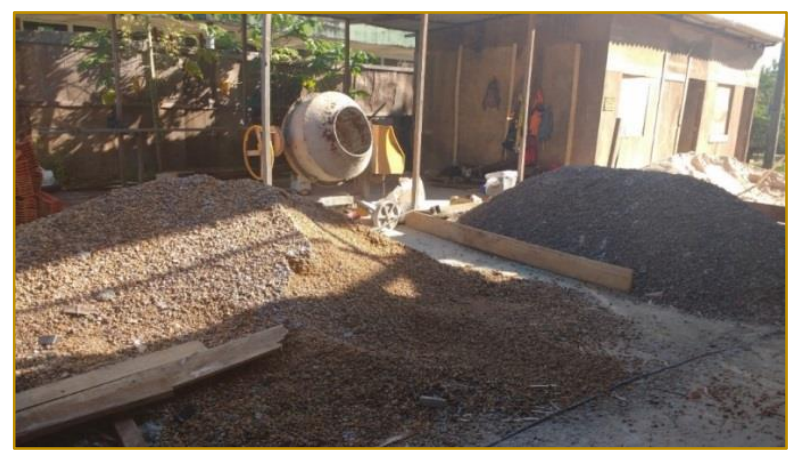


b) Foco no controle do processo global: a determinação de responsabilidades fica a desejar. Todos estão subordinados ao mestre de obras e ao estagiário presentes na obra, e estes respondem ao responsável pela obra, não havendo uma hierarquia que satisfaça o controle correto, pois o mestre de obras e o estagiário ficam com muitas responsabilidades acumuladas em diversos setores da obra (execução, administração, folha de ponto, diário de obra, recebimento e armazenamento de material, entre outras atribuições), não estando presentes o suficiente em cada etapa para evitar que situações adversas aconteçam, acabando por ter de encontrar soluções para resolvê-las ao invés de evitá-las;

c) Equilíbrio da melhoria de fluxo: a inovação tecnológica é de suma importância para todas as empresas existentes no país. Nesta, a disposição para inserção de novas técnicas de construção é reduzida, optando-se pela maneira convencional de executar as atividades. Observou-se também que, apesar de no questionário a pergunta relativa à participação dos colaboradores ter sido respondida de forma positiva, a participação destes é mínima, restrita ao serviço a ser executado, não havendo espaço para mudança através de suas sugestões;

d) Aumento da transparência do processo: não há controle apropriado de material. Não se tem o número de peças rejeitadas, apenas a contagem das peças entregues. Não há armazenamento adequado das peças entregues, observado na oxidação da cobertura metálica (Figura 9) antes mesmo desta ser instalada no edifício. Há dificuldade em distribuir informações sobre as etapas da obra aos colaboradores que ficam em campo. O plano de execução é conhecido somente pelo engenheiro responsável, pelo mestre de obras e pelo estagiário, não sendo passado o plano inteiro ao restante da equipe, Ihes sendo passadas apenas as atividades pertinentes ao dia em questão, dificultando uma visão global da obra, o que também contradiz a pergunta a respeito deste assunto, respondida de forma positiva no questionário;

Figura 9. Estrutura metálica da cobertura oxidada.

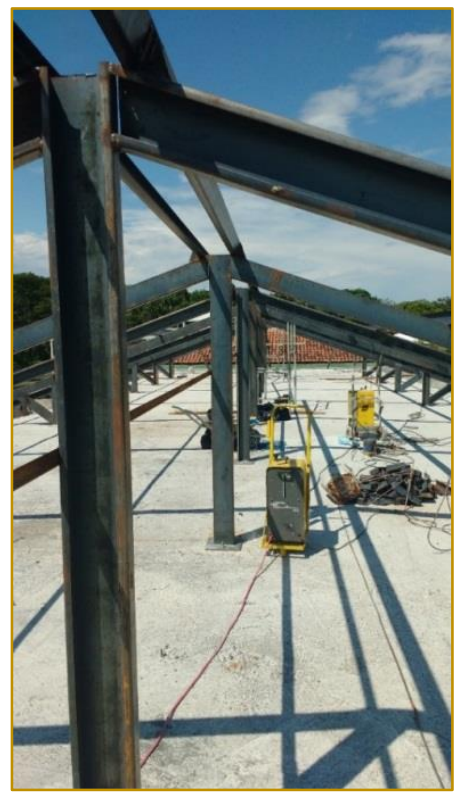

\subsubsection{PROPOSTAS PARA INSERÇÃO DA TÉCNICA LEAN CONSTRUCTION}

A partir dos pontos observados no item 4.1.2, propõe-se as seguintes mudanças no sistema de gestão para que seja possível a utilização dos princípios notados ausentes: a) Redução da variabilidade: garantir uma padronização das atividades desenvolvidas no setor de execução da obra da empresa através de treinamento multifuncional da equipe contratada, para que, além do trabalho ser desenvolvido de forma semelhante, haja uma rotatividade e possível 
substituição de equipes em outras atividades, descentralizando os serviços desenvolvidos por todas as equipes especializadas em um só serviço;

b) Aumento do valor do produto através da consideração sistemática das necessidades do cliente: evitar retrabalhos ao máximo. Isatto et. al. (2000) afirma que, com base nos padrões definidos pela empresa aliados ao planejamento e controle adequado da execução evita-se a incidência de retrabalhos. Para isso se faz necessária uma observação constante das etapas desenvolvidas e a presença do responsável pela fiscalização destas atividades, tanto atenção ao projeto antes deste ser executado quanto atenção à execução deste, para que, assim, evite-se ao máximo a perda de tempo, de material e de mão de obra em retrabalhos;

c) Redução do tempo de ciclo: recomenda-se o uso de todos os recursos disponíveis em campo, para que se possa aumentar o nível de produtividade e diminuir as interrupções durante a execução de um serviço, em função de outro;

d) Foco no controle do processo global: descentralizar as responsabilidades acumuladas pelo mestre de obras e pelo estagiário. A presença do engenheiro responsável pela obra em campo é de fundamental importância para que haja um "desmembramento" das funções acumuladas pelo mestre de obras e pelo estagiário. Os mesmos precisam serem capazes de cumprir metas reais e satisfatórias de acompanhamento e de fiscalização e isso só será possível com a determinação de responsabilidades que sejam possíveis de serem cumpridas. Portanto, é importante que a responsabilidade descentralize dos dois, havendo mais pessoas a quem se possa confiá-las;

e) Equilíbrio da melhoria de fluxo: a abertura para a inserção de novas técnicas é fundamental para a evolução de uma empresa no mercado construtivo. A descentralização das responsabilidades e a difusão do conhecimento sobre o projeto (citadas nos itens anteriores) aumentam a possibilidade de melhoria no fluxo de execução das atividades previstas;

f) Aumento da transparência do processo: a organização quanto ao material e armazenamento se mostra um ponto de importante foco para mudança. Com a organização, tem-se um controle de gastos, das necessidades da empresa, da qualidade do material que se utiliza e pode-se facilmente identificar as deficiências a serem melhoradas. O armazenamento ideal de materiais e seu correto manuseio permite que a qualidade dos mesmos não seja alterada até o momento de instalação, garantindo total resistência do material para o uso ao qual foi designado. Há também a necessidade da difusão do conhecimento sobre o projeto inteiro para com os colaboradores dos setores de execução. Assim, não sabendo somente sua parte diária, os colaboradores têm uma visão melhor do que é necessário fazer, podendo dar sugestões construtivas aos seus superiores, pois o conhecimento prático aliado ao conhecimento teórico gera resultados mais significantes em termos produtivos.

\subsection{EMPRESA 2}

\subsubsection{DESCRIÇÃO DA EMPRESA}

A Empresa 2 é uma incorporação imobiliária, especializada em edificações multi-familiares residenciais verticais, e possui uma equipe de trabalho maior que a Empresa 1. São obras de grande complexidade espalhadas pelo país. Em Manaus, a única obra desta empresa é a obra deste estudo. A Empresa 2 não possui certificação Lean (requisito para aplicação deste estudo), mas possui certificação de gestão da qualidade ISO 9001. A Figura 10 apresenta a hierarquia atualmente utilizada no gerenciamento das obras desta empresa. 
Figura 10. Hierarquia atual - Empresa 2 - concentração de responsabilidades e dificuldade de controle.

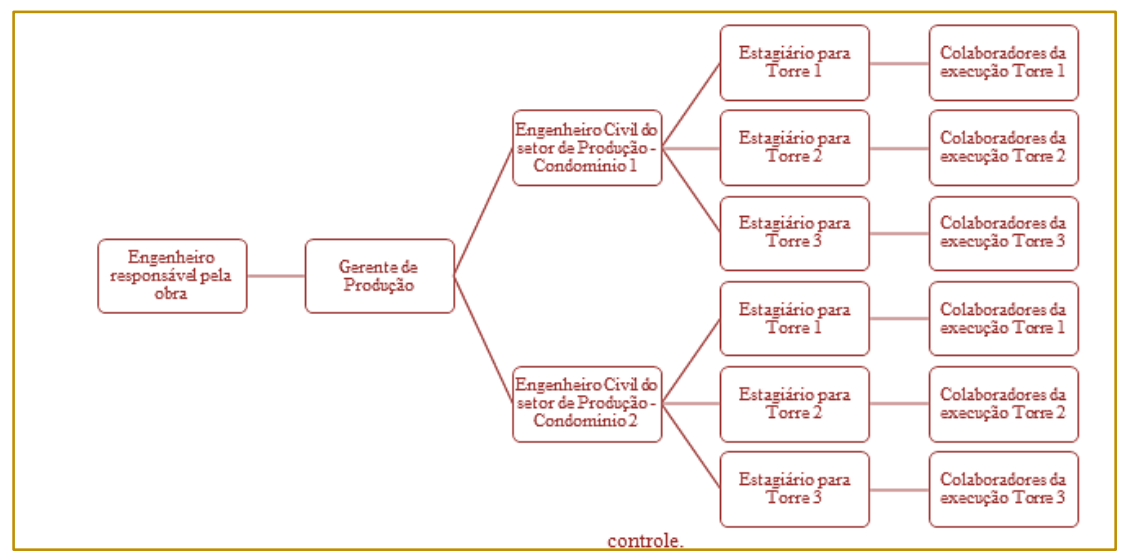

\subsubsection{PONTOS OBSERVADOS DE APLICAÇÃO DA TÉCNICA LEAN CONSTRUCTION}

Após a observação in loco e a aplicação do questionário, que nesta empresa foi respondido por um dos engenheiros responsáveis pela obra, foram identificados os seguintes pontos de aplicação da técnica na Empresa 2, apresentados de acordo com cada princípio avaliado inaplicado:

a) Aumento na transparência do processo: cada colaborador só tem acesso à sua parcela de atividades designadas para o dia. A hierarquia adotada na Empresa 2 impossibilita a difusão do conhecimento sobre o projeto nos diversos níveis de produção. Este conhecimento fica concentrado na alta gerência, constituída pelos engenheiros responsáveis pelas torres, porém não é de livre acesso aos estagiários que ficam responsáveis pelas torres, nem muito menos aos colaboradores da parte específica de execução (pedreiros, serventes, etc.), gerando inconvenientes de execução. Cada projeto (de instalações, de fôrmas, de paisagismo, etc.) é feito por uma empresa diferente. Há também o fato de que os projetos chegam na obra apenas para serem executados, sendo projetados por empresas diferentes sob o comando do cliente da obra, chegando de outra cidade. No momento de execução são detectados problemas de incompatibilidade de projetos. Quando isso acontece, os projetos são devolvidos para as empresas que os fizeram e revisados para que a execução seja possível. A Empresa 2 não tem autonomia para mudar nenhum aspecto dos projetos; b) Foco no controle do processo global: a designação de responsabilidades se dá até o nível dos estagiários (de engenheiro para mestre de obras e estagiários). Estes são os que ficam com maior constância acompanhando a execução das atividades, porém cada estagiário é responsável por uma torre de 20 pavimentos, não podendo, o mesmo, ter controle total das atividades desempenhadas pelos colaboradores no decorrer do dia;

c) Redução do tempo de ciclo: não há folga para administrar situações escusas ao planejado para execução. Quando isso ocorre, perde-se tempo no cronograma para resolver a situação;

d) Aumento da flexibilidade de saída: não há nesta empresa a possibilidade de modificação do projeto em função de solicitação de clientes. A flexibilidade de projeto e produção é inexistente;

e) Redução do número de passos ou partes: a organização dos materiais ainda é um tanto falha; não há agregação de tarefas menores em passos maiores; o planejamento tem uma data limite de entrega para a obra, mas o mesmo quase nunca é cumprido devido às paralisações que se fazem necessárias durante a execução, pela falta de folga no planejamento (mencionado anteriormente).

\subsubsection{PROPOSTAS PARA INSERÇÃO DA TÉCNICA LEAN CONSTRUCTION}

A partir dos pontos observados no item 4.2.2, propõe-se as seguintes mudanças no sistema de gestão para que seja possível a utilização dos princípios notados ausentes: 
a) Aumento na transparência do processo: sugere-se uma mudança hierárquica no pensamento da Empresa 2, difundindo o projeto e seus detalhes aos colaboradores de todos os níveis concernentes à execução das atividades, o que proporcionará melhoria no fluxo dos serviços. Também é perceptível a necessidade de maior autonomia aos engenheiros responsáveis pela execução da obra. Os mesmos têm a necessidade de serem capazes de fazer modificações nos projetos;

b) Foco no controle do processo global: é necessário que haja a presença mais constante dos engenheiros de produção (como são chamados na empresa os responsáveis pela execução das atividades), além dos estagiários responsáveis pelas torres, para que se possa conseguir um controle mais eficiente da execução;

c) Redução do tempo de ciclo: há a necessidade de, no cronograma da obra, inserir folgas entre as atividades em torno dos marcos construtivos da obra para que 0 aguardo de adaptações dos projetos não comprometa os prazos a serem cumpridos;

d) Aumento da flexibilidade de saída: a autonomia citada no item anterior se estende para este princípio também, focando agora na possibilidade de modificações do projeto em função da solicitação do cliente;

e) Redução do número de passos ou partes: a agregação de tarefas menores em atividades maiores gera uma economia de tempo, importantíssima para o cumprimento do cronograma previsto para a obra.

\subsection{AVALIAÇÃO DO GERENCIAMENTO DAS OBRAS}

Os resultados deste estudo de caso reafirmam que "os benefícios quanto à utilização de recursos e eliminação de desperdícios são evidentes por meio da implantação dos conceitos, métodos e ferramentas Lean Construction nos empreendimentos" (PEREIRA et. al., 2015, p.9). Há de se ressaltar que "qualquer aplicação isolada fica desprovida de significado, do ponto de vista do sistema. A força do sistema de uma 'empresa enxuta' está nas complexas relações entre todas estas possíveis ações" (PICCHI, 2001, p. 14).

Em termos de custos financeiros, ao analisarse o desperdício pelo tempo perdido nas atividades analisadas, e comparar com o valor de mão de obra do pedreiro, de acordo com a tabela do Sistema Nacional de Pesquisa de Custos e Índices da Construção Civil (SINAPI), mês de referência Outubro de 2016, para a localidade de Manaus, utilizando a planilha desonerada, para pedreiro (referência 4750), o preço da hora de serviço é $R \$ 10,34$.

Para a Empresa 1, verifica-se na Figura 11 os recursos financeiros perdidos pela falta de padronização e de controle da variabilidade.

Figura 11. Comparativo das execuções do reboco.

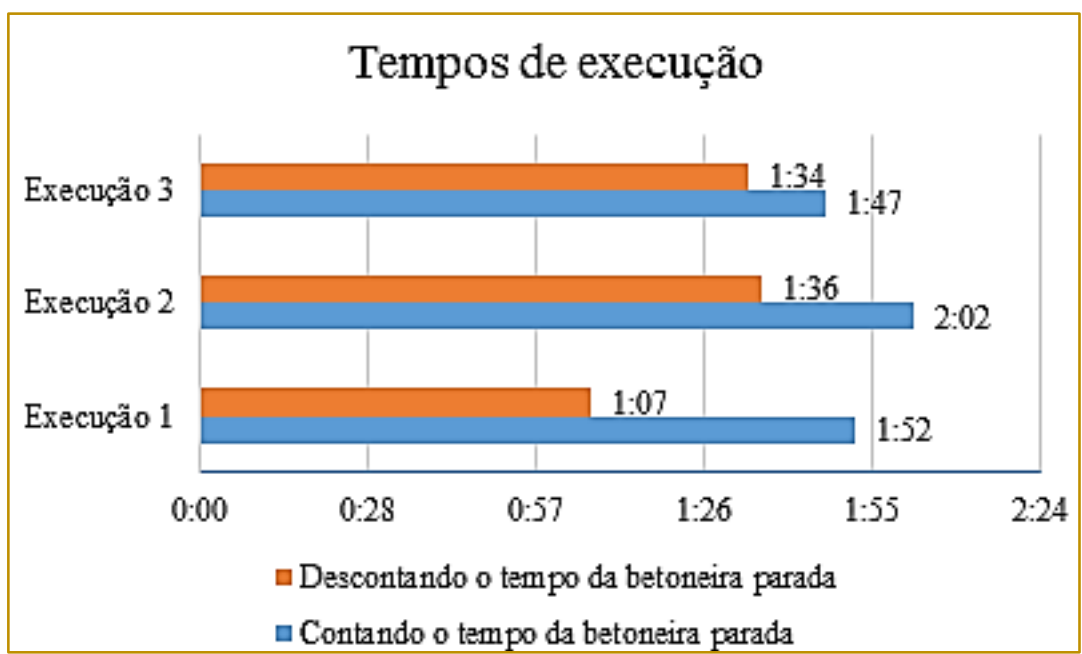


A Figura 11 mostra que das três execuções, o tempo máximo observado de intervalo é de aproximadamente 45 minutos, o que leva a uma fração de 0,75 de hora perdida, consumindo $\mathrm{R} \$ 7,75$ de mão de obra do pedreiro apenas em uma execução. É uma perda muito grande em termos de preços de mão de obra para a empresa, problema que pode ser evitado com a simples utilização das duas betoneiras em campo.

Utilizando a mesma tabela do SINAPI, agora para a Empresa 2, observando um período de duas semanas (tempo médio de retorno dos projetos, segundo engenheiro responsável) de parada na execução devido à devolução de projetos incompatíveis e seu tempo de retorno, considerando um pedreiro que trabalhe numa jornada de 44 horas semanais, tem-se uma perda de $\mathrm{R} \$ 909,22$ apenas com um funcionário, em função de não haver autonomia para mudanças nos projetos.

A maioria das falhas encontradas nas empresas estudadas, foram evidenciadas também nos trabalhos de Souza e Brandstetter (2010), na cidade de Goiânia/GO, e de Rodrigues et. al (2016), em São Luís/MA, cada qual com suas particularidades, mas que no todo deixam perceber que o processo produtivo da construção civil no Brasil é semelhante, tendo pontos que podem ser aprimorados com a introdução da técnica Lean Construction, além de deixar claro que a técnica é extremamente recomendada para o setor, tendo sua aplicabilidade no país comprovada por, entre outros, Marinho et. al. (2016), que analisa uma empresa que já pratica os princípios da técnica.

\section{REFERÊNCIAS}

[1] Barros Neto, José de Paula, Alves, Thaís da C. L. Análise Estratégica da Implementação da Filosofia Lean em Empresas Construtoras. Fortaleza: SIMPOI, 2008.

[2] Brasil. Caixa Econômica Federal. Sistema Nacional de Pesquisa de Custos e Índices da Construção Civil (SINAPI). Localidade: Manaus. Mês de referência: Out/2016. Disponível em: http://www.caixa.gov.br/ Downloads/sinapi-a-partirjul-2009-

am/SINAPI_ref_Insumos_Composicoes_AM_10201 6_Desonerado.zip Acesso em 10Dez2016.

[3] Hofstede, Geert. The poverty of management control philosophy. Academy of Management Review, pp. 450-61, July, 1978.

\section{CONSIDERAÇÕES FINAIS}

A partir da avaliação da gestão atual das empresas estudadas e de como os princípios da técnica Lean Construction podem ser aplicados, verifica-se que há a grande necessidade de melhoria nos processos produtivos observados.

Os resultados dos questionários aplicados apontam uniformidade de respostas em alguns princípios, o que sugere que as deficiências encontradas, em sua maioria, são nas mesmas áreas já em outros princípios há disparidade de respostas, mostrando que, mesmo não intencionalmente, acabam por aplicar alguns princípios, necessitando atenção à correta aplicação destes e à introdução dos que foram citados não praticados nos resultados deste estudo, para que, dessa forma, se tenha a real utilização da técnica Lean Construction no processo produtivo de cada empresa. As propostas apresentadas para introdução da técnica nas empresas visam uma forma prática e alcançável de melhoria gradativa do processo produtivo e, conforme os princípios forem sendo aplicados em cada setor, tem-se, ao final, um sistema de gestão eficaz a partir do uso desta técnica.

Assim, verifica-se que a aplicação da técnica é possível como nova metodologia de gerenciamento de obras das duas construtoras analisadas na cidade de Manaus. É necessário, para isso, que haja comprometimento e envolvimento da alta direção das empresas no setor de execução das atividades.

[4] Isatto, Eduardo L.; Formoso, Carlos T.; DE Cesare, Cláudia M.; hirota, Ercília H. \& ALVES, Thaís C.L. Lean Construction: Diretrizes e ferramentas para o controle de perdas na construção civil. Porto Alegre, SEBRAE/RS, 2000. Série SEBRAE Construção Civil, Vol. 5.

[5] Koskela, Lauri; Howell, Greg; Ballard, Glenn; Tommelein, Iris. Design and Construction: Building in Value, Chapter 14: The foundations of Lean Construction. Technical Report, Lean Construction Institute, 2014.

[6] KOSKELA, Lauri. Application of the new production philosophy to construction. Technical Report, Stanford University, 1992.

[7] Marinho, Joanderson de S.; Castro, Alan de O.; Marinho, Joalysson de S.; Lucas, Ruan 
Eduardo C.; Rique Junior, Jose Flavio. Análise da aplicação de princípios da construção enxuta em uma construtora de João Pessoa - PB. João Pessoa/PB: XXXVI Encontro Nacional de Engenharia de Produção, 2016.

[8] Pereira, Adriana M. BARCO, Clarissa F. Utiyama, Marcel H. R. Razzino, Carlos do A. Cintra, Paula F. Aplicação da Construção Enxuta (Lean Construction) na Construção Civil. Fortaleza/CE: XXXV Encontro Nacional de Engenharia de Produção, 2015.

[9] Picchi, Flavio A. Lean Thinking (mentalidade enxuta): avaliação sistemática do potencial de aplicação no setor de construção. (Pós-doutorado). Working paper. Center for Technology, Police and Industrial Development, Massachusetts Institute of Technology, Cambridge, MA. 2001.

[10] Polito, Rafael. Metodologias e boas práticas de gerenciamento de obras - PDCA e Gerenciamento de Projetos. Revista Téchne, edição 228, ano 24, março de 2016, Ed. Pini.
[11] Rodrigues, Alyson da L. P.; Moraes Filho, José R. S.; Silva Junior, Claudio Roberto; COSTA, Edilange M. da. Aplicabilidade do pensamento enxuto em uma indústria de construção civil. João Pessoa/PB: XXXVI Encontro Nacional de Engenharia de Produção, 2016.

[12] Souza, Beatriz C.; Cabette, Regina Elaine S. Gerenciamento da Construção Civil: Estudo da Aplicação da "Lean Construction" no Brasil: Revista de Gestão \& Tecnologia UNISAL, vol. 1, n 2, p. 21 26. ISSN 2358-3126.

[13] Souza, Leiliane S.; Brandstetter, Maria Carolina G. de O. Avaliação de Princípios da Lean Construction em Construtoras Goianas. São Carlos/SP: XXX Encontro Nacional de Engenharia de Produção, 2010.

[14] Womack, James P.; Jones, Daniel T. A Mentalidade Enxuta nas Empresas Lean Thinking: elimine o desperdício e crie riqueza. Tradução de Ana Beatriz Rodrigues e Priscilla Martins Celeste. Rio de Janeiro: Elsevier, 408p., 2004 


\section{Capítulo 24}

\section{PRINCÍPIOS DO LEAN APLICADOS NA CONTRATAÇÃO PÚBLICA}

Andréa de Freitas Avelar

Michele Tereza Marques Carvalho

Virley Souza Lemos

Resumo: Nos últimos cinco anos, foi empenhado, via contratação pública, o montante de $\mathrm{R} \$ 124.581 .524 .749,90$, distribuídos em 101.986 contratos, de acordo com o Sistema Integrado de Administração de Serviços Gerais - SIASG, do Governo Federal. Neste sentido, torna-se essencial que os gestores públicos possam contar com métodos, técnicas e ferramentas que os auxiliem em suas ações, possibilitando resultados mais eficazes, até porque é possível perceber que dentre vários setores que compõem o staff público o que tem merecido maior destaque é o setor de licitações de obras. Esta área tem passado por momento de instabilidade, gerado por licitações inadequadas Desta feita, tem-se como objetivo deste trabalho utilizar de forma convergente as teorias Lean Office e Lean Thinking como opção de melhoria das ações administrativas ligadas ao setor de obras públicas por meio da ferramenta MACE - Matriz de Contratação Enxuta - produto deste estudo - assim como a utilização dos passos estabelecidos na gestão de projetos do guia PMBOK@ para formar a matriz. Esta matriz traz em sua essência a sequência necessária às ações licitatórias embasadas nos processos, entradas, ferramentas e técnicas e as saídas esperadas em cada ato, para montagem eficaz do certame. Ao aplicar os passos metodológicos mencionados, foi possível observar que grande parte das dificuldades na composição de um processo licitatório se deve à falta de conhecimento dos solicitantes, assim como a carência de técnicas e ferramentas que possam auxiliar os servidores responsáveis pela montagem do certame.

Palavras-chave: Contratação Pública; Produção;Lean Office; Lean Thinking 


\section{INTRODUÇÃO}

De acordo com a Lei 8666(1993), "considerase contrato todo e qualquer ajuste entre órgãos ou entidades da Administração Pública e particulares, em que haja um acordo de vontades para a formação de vínculo e a estipulação de obrigações recíprocas, seja qual for a denominação utilizada". Lei esta que estabelece as "normas gerais sobre licitações e contratos administrativos pertinentes a obras, serviços, ..., no âmbito dos Poderes da União, dos Estados, do Distrito Federal e dos Municípios".

Em valores absolutos, e através de contratos firmados à luz da Lei 8666/93, nos últimos cinco anos, foi empenhado, via contratação pública, 0 montante de $\mathrm{R} \$$ 124.581.524.749,90, distribuídos em 101.986 contratos, de acordo com o Sistema Integrado de Administração de Serviços Gerais SIASG, do Governo Federal.

Nesse sentido, observa-se que o volume de recursos envolvidos em contratos públicos é altamente significante, provocando o contratante envidar esforços não somente no uso e gestão dos recursos, mas também e principalmente, no planejamento das contratações, uma vez que o custo do processo de cada contratação, de acordo com a pesquisa realizada pelo Instituto Negócios Públicos (2014), resulta no valor de $\mathrm{R} \$ 12.849,00$.

Constata-se, portanto, que somente no custeio do processo de contratação pública foram gastos $\mathrm{R} \$ 1.310 .418 .114,00$ nos últimos cinco anos, data feita, importante reconhecer que toda melhora que se possa aplicar para que o processo de contratação venha a ter maior eficácia tem grande representação junto aos cofres públicos.

No entanto, ainda se constata que o gestores destinam a maior parte de seus esforços na gestão dos contratos das obras públicas, desconsiderando que possíveis ocorrências podem ter advindo da ausência de instrumentos e ferramentas utilizadas nas fases de planejamento e elaboração desses contratos.

Fato observado com a constatação de grande número de licitações que não são concluídas com sucesso, uma vez que, de acordo com estudo realizado por Freitas e Carvalho (2017), 78\% da sua amostra de contratos de obras públicas não foram concluídos conforme previsto, ou seja, tiveram algum tipo de aditamento contratual.

.Por esta razão, os Tribunais de Contas e o Judiciário se veem abarrotados por longos processos, situação que deságua em diversos prejuízos à Administração Pública, seus servidores, fornecedores e à sociedade.

Grande parte das dificuldades na composição de um processo de contratação pública ou licitação se deve à falta de conhecimento dos solicitantes, assim como a carência de técnicas e ferramentas que possam auxiliar os servidores na montagem do certame (SOUZA e CARVALHO, 2016)

Deste modo e a partir da identificação da problemática, o presente trabalho objetiva abordar a filosofia Lean com base em duas linhas: a que trabalha o pensamento enxuto, conhecida como Lean Thinking, e a vertente da filosofia Lean que envolve estudos nas áreas administrativas ou de serviços, denominada Lean Office de forma a propor uma matriz de contratação enxuta associando ferramentas Lean e tarefas constituintes de um processo de contratação pública para ordenamento das atividades de forma a estabelecer um processo eficiente e eficaz de contratação, utilizando como ferramenta de apoio os preceitos do PMBOK (PMI,2013).

Cabe ressaltar, nesse momento, que o presente estudo trabalhou um recorte no processo licitatório de obras e limitou sua análise somente às fases internas do processo de licitação de obras públicas, ou seja, os processos analisados estariam compreendidos entre a solicitação do objeto até a publicação do edital correlato ao certame.

Quanto à validação, a pesquisa limitou-se a apresentar uma proposta de aplicação da matriz em processo de contratação de uma instituição pública de médio porte com atuação na educação de nível superior.

\section{REVISÃO BIBLIOGRÁFICA}

Segundo Rossetti e Gonçalves (2014), em seu estudo voltado as aspectos júridicos das licitações, afirmam que os processos de contratação pública compreendem um desafio maior ao gestor público, onde não está relacionado somente à escolha da proposta de melhor custo, mas também e sobretudo, na atenção especial à realização de um planejamento adequado que considere 
boas práticas de governança, custos de transação, normatização e principiologia que rege o Direito Público.

Reis (2014) afirma ainda que grande parte dos insucessos se dão por equívocos causados pela falta de planejamento, suporte técnico, capacitação e atualização dos profissionais.

Tapping e Shuker (2010) afirmam que 60\% a $80 \%$ de todos os custos envolvidos para satisfazer a demanda de um cliente, seja produto ou serviço, é uma função administrativa, ou seja, grande parte das ações ocorrem na administração, portanto pode ser dito que ocorrem nos escritórios das empresas.

Castro (2013) afirma que para uma gestão eficiente de contratos de obras públicas, é necessário o prévio conhecimento de mecanismos e instrumentos técnicos que possam antever ocorrências e analisar medidas para que não ocorram prejuízos para nenhuma das partes.

Para atingir resultados significativos e, assim, promover o desenvolvimento, o gestor público é desafiado a compor soluções planejadas, eficientes e eficazes. E planejamento, em matéria de contratação pública, não significa meramente considerar a necessidade $e, a$ partir dela, eleger a proposta de solução de menor preço. Pelo contrário, é necessário refletir o processo de contratação pública enquanto contexto complexo, marcado pela atuação de diversos setores e, em especial, da dependência de boas práticas de governança.

Desde a década de 40, os conceitos Lean na produção são conhecidos, de acordo com o Lean Institute Brasil (2015), no entanto, somente com a aplicação do Lean na produção Toyota em 1950, através das iniciativas de Eiiji Toyoda e Taiichi Ohno, que o conceito vem ganhar força e notoriedade, tornando o processo conhecido como Toyota Production System.

Mas é somente na década de 80 , através de uma apresentação do estudo dos alunos e docentes do Massachusetts Institute of Technology (MIT) realizado no chão de fábrica da Toyota, que contou com algumas anotações destacadas em um quadro negro, referente a montagem de um "carro padrão", onde tamanho e níveis de opcionais eram previamente determinados, deparam com as seguintes anotações: menor esforço humano, menos defeitos, menor espaço utilizado na fábrica, menor investimento de capital; algumas das fábricas mais eficientes eram também as menos automatizadas; menor tempo gasto e em um volume mais baixo por tipo de produto - em linhas de modelos mistos.

Ao observarem, as anotações viram que tinham escrito "menor", "menos", "menor", "menor" ou "mais baixo" ao lado de cada atributo.

Após esta definição, John F. Krafcik (1988) escreveu o seguinte artigo, "Triunmph of the Lean Production System" para a edição de outono da MIT Sloan Management Review, foi lançado em setembro, e o termo "Lean" foi lançado ao mundo.

Como foi possível observar o termo "Lean" surge mundialmente ao final da década de 80 em um projeto de pesquisa do Massachusetts Institute of Technology (MIT) sobre a indústria automobilística mundial, porém sua primeira concepção é trabalhada pelos engenheiros Taiichi Ohno e Shingeo Shingo, estes em meados de 1950, em período ainda de escassez de recursos materiais, financeiros e humanos, por conta da Segunda Guerra Mundial, propuseram um novo sistema de produção para a indústria automobilística da Toyota.

Segundo Souza e Carvalho (2016), como características básicas do Sistema Toyota de Produção tem-se: eliminação de desperdícios; Just-in-time; Kanban; Muda; Kaizen, produção flexível e fabricação com qualidade, onde o sistema é alicerçado principalmente nos métodos Just-in-time; Kanban; Muda; Kaisen.

Buscando divulgar o conhecimento a respeito deste sistema de produção japonês, os pesquisadores então definem o Lean thinking, que consiste na identificação, redução e eliminação das atividades que não agregam valor ao processo, ou seja, eliminar ou mitigar os desperdícios, baseando-se em cinco princípios Lean (Valor; Fluxo de valor; Fluxo contínuo; Produção puxada; Perfeição).

Cabe ressaltar, segundo trecho do livro Teoria Geral da Administração: da revolução urbana à revolução digital de Maximiano (2011), os dois princípios mais importantes do sistema Toyota são: eliminação de desperdícios e fabricação com qualidade. O princípio da eliminação de desperdício, aplicado primeiro à fábrica, fez nascer a produção enxuta (lean production), que consiste em fabricar com o 
máximo de economia de recursos. Porém o termo "Lean" tem sua primeira tentativa de adaptação às áreas administrativas em 1972, por Theodore Levvit.

Tyagia et al (2015) propuseram em seu estudo um conjunto de dez ferramentas e métodos enxutos para apoiar a melhoria e a eficiência do processo de criação do conhecimento voltado a definir estruturalmente um processo de criação e práticas no desenvolvimento de produtos.

Com o estudo, concluíram que somente a aplicação das ferramentas não é suficiente para a sustentação e utilização eficaz do conhecimento criado, para isso é necessário que a mentalidade Lean faça parte da cultura da organização.

Pillon et al (2015) tiveram como objetivo de estudo, aplicar o pensamento enxuto na gestão de processos da Educação a Distância (EaD) de uma Instituição de Ensino Superior.

Em suas conclusões notaram que as ferramentas do pensamento enxuto são de grande importância, de forma especial o mapeamento de fluxo de valor (VSM), por se tratar de uma representação das tarefas, fluxos de informações e material do processo atual, possibilitando assim a avaliação de melhorias futuras. Sendo as informações advindas do VSM juntamente com o mapa de processo institucional, pode-se ter indicações importantes para otimizar os processos e consequentemente buscar a melhor satisfação dos alunos da Instituição.

Costa et al (2014) apresentam uma compilação e avaliação com base em pesquisas empíricas sobre as métricas mais usadas pelos gerentes de projetos durante a gestão de desenvolvimento de produto, com a abordagem Lean. Ao finalizar o estudo relataram, dentre as contribuições de seu trabalho, a proposta de um novo quadro de categorias para as métricas utilizadas na visão Lean, ou seja, métricas ligadas ao valor e os benefícios das partes interessadas; objetivo do programa e seus requisitos; o produto resultante de processos e pessoas.

Autores como Thakkar (2014); e Hasle (2014), vão além da condição do uso do Lean Thinking na linha de produção como foco exclusivo nos processos. Para eles existe uma necessidade latente de estudos onde o Lean também possa ser voltado às pessoas envolvidas na produção.
Neste sentido, vale salientar Gallardo et al (2015) que realçam a "importância da equipe" no processo Lean, assim como Tyagia et al (2015) que se referem à cultura organizacional, onde afirmam que a mentalidade Lean deve fazer parte da cultura da organização ou somente "as ferramentas podem não ser suficientes para se chegar aos resultados esperados"

Diante de todas as inferências neste tópico, fica clara a importância do Lean Thinking para a melhoria dos setores produtivos, assim como fica claro a sua pouca utilização nos setores administrativos, ou seja, o Lean aplicado às empresas com o foco também nos recursos humanos.

Isso não significa o rebaixamento de seu uso na produção, mas sim que haja um complemento entre linha de produção e a mão de obra, seja ela na produção ou administração.

Esta possibilidade de fechar o ciclo, e ter os setores da produção e da administração contemplados, é algo proposto neste estudo. Mas além de estudos e pesquisas outro fator de extrema importância neste contexto, inclusive abordado por Akabane e Sinkunas (2014), é a capacidade dos líderes das empresas neste processo.

$E$ é baseando-se nos princípios que compõem o Lean Thinking que se objetiva buscar a melhoria dos processos e soluções para eliminar os desperdícios dos recursos nas licitações de obras públicas em suas fases preliminares. Desta feita, os princípios do Lean Thinking saem do ambiente industrializado, onde tem sua origem, e passam a ser aplicados nos processos licitatórios de obras públicas.

Surge, portanto, o Lean Office, ou escritório enxuto. Quando se fala em Lean Office, muitas vezes o pensamento é levado aos escritórios, e estes estão inseridos em todos os modelos e áreas de negócios: escritórios de planejamento e administração de obras, gerência de produção, coordenação, coordenação de cursos, laboratórios, secretarias e células de trabalho em organizações, empresas de consultoria, entre outras (GREEF et al, 2010).

Nas áreas definidas como administrativas, é comum encontrar processos desarticulados no qual as tarefas são individualizadas, ocorrendo atrasos e problemas de comunicação (NUNES e FACCIO, 2014). 
Após 2003, com a nova aplicação da metodologia Lean voltada aos setores administrativos, tem-se então o surgimento do Lean Office. Para se alcançar o Lean Office Tapping e Shuker (2010) propuzeram oito passos para estruturar esta nova aplicação Lean: i)comprometer-se com o lean; ii) escolher o fluxo de valor; iii) aprender sobre o lean; iv)mapear o estado atual; v) identificar as métricas lean; vi) mapear o estado futuro; vii) criar planos Kaizen; e viii) implementar planos Kaizen.

Para que isso ocorra, a mudança organizacional, motivada por uma mudança de mentalidade, deve ocorrer, nascendo no nível estratégico da organização e deve ser desdobrada e assimilada até o nível operacional (Evangelista et al, 2013), sendo incorporada à organização como uma nova cultura da empresa, uma nova forma de olhar e executar seus processos de modo geral e não somente na área fabril, sem ser um conceito imóvel, mas sim em constante movimento, promovendo melhorias de acordo com cada época ou cada situação (PAOLI et al, 2014).

Admite-se, em tempo, que o processo de contratação pública requer um ordenamento de tarefas e estas interligadas, ou correlacionadas entre si, onde se busca a conclusão de um trabalho, podendo ser denominado projeto, uma vez que tem início e fim definidos. De toda sorte, a gestão do projeto, com a conclusão atendendo aos limites de preço, prazo e qualidade pode ser definida, segundo o Project Management Institute - PMI (2013), como sucesso.

Em concordância com PMI (2013) o gerenciamento de projetos é a aplicação de conhecimento, habilidades, ferramentas e técnicas às atividades do projeto a fim de atender aos seus requisitos com sucesso. Sendo que o sucesso do projeto depende da definição e gerenciamento de seu escopo.

Para Aramayo et al (2013) a definição mais comum de sucesso em gerenciamento de projeto está relacionada ao cumprimento das seguintes restrições: i) Prazo; ii) Custo; e iii) Desempenho/Qualidade.

Porém alguns autores como Munns e Bjeirmi (1996), Lewis (2000), Cooke-Davies (2002),
IPMA (2006) e Kerzner (2010) relatam que a definição do escopo não garante o sucesso do projeto, uma vez que o sucesso no gerenciamento de projeto se faz necessário desde as primeiras ordens e cumprimento de metas pré-determinadas.

Espera-se, diante disso, que por meios princípios pertencentes ao Lean Office, se possa extrair soluções voltadas a melhoria dos processos e eliminar os desperdícios de recursos nas licitações de obras públicas, ainda em suas fases preliminares, através a propositura de uma matriz de tarefas e processos.

Com base no PMI (2013) o gerenciamento de projetos é realizado através da aplicação e integração apropriada dos processos agrupados logicamente, abrangendo os 5 grupos de processos: i) Iniciação; ii) Planejamento; iii) Execução; iv) Monitoramento e controle; e v) Encerramento.

Para tanto, gerenciar um projeto inclui: i) Identificação dos requisitos; ii) Adaptação às diferentes necessidades, preocupações e expectativas das partes interessadas à medida que o projeto é planejado e realizado; iii) Balanceamento das restrições conflitantes do projeto que incluem, mas não se limitam a: Escopo; Qualidade; Cronograma; Orçamento; Recursos; e Risco.

Desta feita, buscando melhorar os processos para a realização de licitação de obras públicas, utilizou-se a gestão de projeto como uma ferramenta auxiliar na simplificação e padronização dos atos licitatórios em suas fases preliminares.

Cabe salientar que a utilização do PMI, (2013) nesta pesquisa não tem como âmago fazer uso do seu objetivo principal de identificar um subconjunto do conjunto de conhecimentos em gerenciamento de projetos e sim buscar em seu conteúdo padrões que estabeleçam diretrizes para as ações intrínsecas aos processos pertencentes as fases iniciais das licitações de obras públicas, de forma a facilitar as atividades e melhor ordenar os processos.

Assim sendo, se propõe a fundamentação proposta na Figura 1. 
Figura 1 - Fundamentação proposta

\begin{tabular}{|c|c|c|c|c|}
\hline $\begin{array}{c}\text { Lean } \\
\text { Thinking }\end{array}$ & $\begin{array}{l}\text { Gestão de } \\
\text { Projetos }\end{array}$ & $\begin{array}{l}\text { Sistemas de } \\
\text { Engenharia }\end{array}$ & 믐 & $\begin{array}{c}\text { Facilitadores Lean para } \\
\text { Gestão de Programas de } \\
\text { engenharia }\end{array}$ \\
\hline
\end{tabular}

Fonte: Adaptado de Oehmen (2012)

\section{MÉTODO PROPOSTO}

Com o objetivo de proporcionar uma fundamentação teórica ao pesquisador, a revisão bibliográfica foi realizada durante todas as fases da pesquisa.

\subsubsection{FASE EXPLORATÓRIA}

Nesta etapa ocorreram os levantamentos exploratórios inicias por meio de referências bibliográficos e documentais.

Para análise da revisão, foi realizado levantamento de publicações científicas, disponibilizadas nas bases de dados eletrônicas da Coordenação de Aperfeiçoamento de Pessoas de Nível Superior - CAPES e do portal de pesquisa Google Acadêmico, tendo o primeiro como base de liberação de seus periódicos o servidor da Biblioteca do Campus Darci Ribeiro - UnB.

\subsubsection{ANÁLISE DO MATERIAL LEVANTADO: CLASSIFICAÇÃO, TIPIFICAÇÃO E COMPARAÇÃO}

Para análise dos dados selecionados, artigos, livros, teses, dissertações e páginas da rede mundial de computadores, foram considerados quanto ao seu conteúdo, sendo então extraídas informações específicas de cada um deles.

Para melhor utilização do material levantado, foi utilizado a escala de leitura, conforme demonstrado na Figura 2.

Figura 2 - Escala de leitura

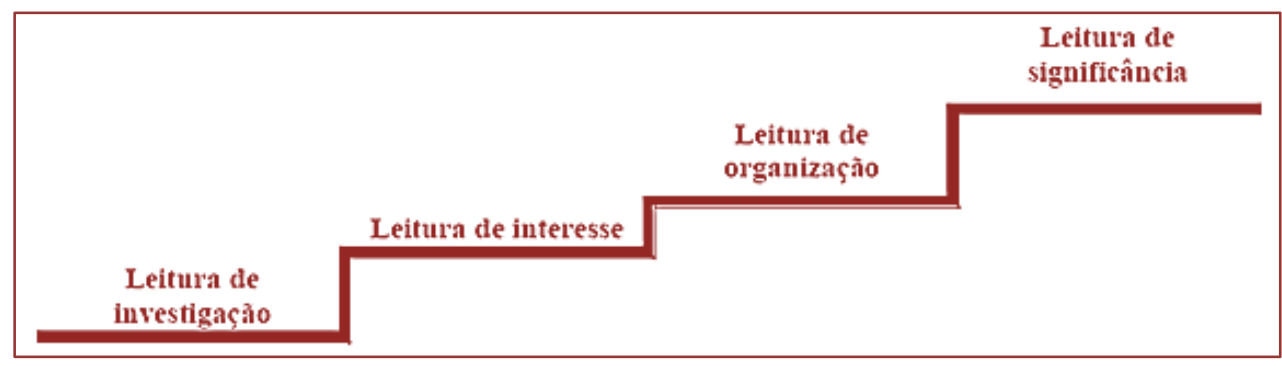

Fonte: Adaptado de Souza e Carvalho (2016)

Simplificando a explicação da escala de leitura, cada degrau faz com que se identifique o material de convergência com a necessidade da pesquisa de forma que se selecione apenas o material de completo interesse, resultante na seleção de "leitura de significância".

Após a primeira análise do total de mais de 60 artigos levantados, partiu-se para um estudo minucioso, tendo como objetivo separar apenas aqueles que estariam alinhados a temática da pesquisa e que proporcionassem, por meio desta análise, atingir o estado da arte para a pesquisa e a identificação de possíveis lacunas do conhecimento relacionados ao que já tenha sido estudado por outros pesquisadores.

Em posse destes dados, com 23 artigos selecionados, procurou-se condensá-los de forma convergente à necessidade de resposta que se esperava da nova ferramenta, ou seja, buscou-se junto ao material estudado pontos que iriam contribuir na construção de uma nova ferramenta que pudesse ser utilizada como instrumento de diagnóstico dos métodos e processos nos setores envolvidos, ligados a licitações de obras públicas, podendo assim revelar dados importantes para a melhoria das ações administrativas e de produção. 


\subsubsection{DESENVOLVIMENTO DA FERRAMENTA}

Para o desenvolvimento da ferramenta, propôs-se o refino dos resultados anteriores e cotejamento minucioso de todo o material já citado, destacando o diagnóstico dos setores envolvidos em processo de licitação pública. Com o uso destas informações juntamente com os cinco princípios do Lean Thinking, e os oito do Lean Office aliados às boas práticas de gerenciamento de projetos

Figura 3 - Principais pontos do Lean estabelecidas no PMBOK (PMI,2013) tem-se a construção de uma matriz gerencial.

\section{RESULTADOS E DISCUSSÃO}

Com base nos estudos bibliográficos, tem-se, conforme Figura 3, os principais pontos do Lean levantados pelos pesquisadores.

\begin{tabular}{|c|c|c|}
\hline ITEM & AUTOR & PONTOS OU ACOES LEVANTADADAS \\
\hline 1 & Pillon et al (2015) & $\begin{array}{ll}\text { - } & \text { Mapa de processos; } \\
\text { - } & \text { Otimização de procedimentos } \\
\text { - Satisfaçăo }\end{array}$ \\
\hline 2 & Freitas et al (2014) & $\begin{array}{ll} & \text { Modelo de avaliaçâo de qualidade } \\
\text { - } & \text { Cheklist } \\
\text { - } & \text { Avaliar dos processos internos } \\
\end{array}$ \\
\hline 3 & Leite e Barros Neto (2014) & $\begin{array}{ll}\text { - } & \text { Novas práticas e ferramentas planejamento } \\
\text { - } & \text { Controle } \\
\text { - } & \text { Aumento da qualidade } \\
\text { Prazos } \\
\text { - }\end{array}$ \\
\hline 4 & Kiste e Miyake (2014) & $\begin{array}{ll}\text { - } & \text { Competências operacionais } \\
\text { - } & \text { Revisào dos modelos }\end{array}$ \\
\hline 5 & Pedrào (2014) & $\begin{array}{ll}- & \text { Eliminar desperdicios } \\
\text { - } & \text { Flexibilidade da aplicaçāo lean }\end{array}$ \\
\hline 6 & $\begin{array}{l}\text { Akabane e SinKunas } \\
\text { (2014) }\end{array}$ & $\begin{array}{ll}-\quad & \text { Mudanças organizacionais } \\
\text { - } \quad \text { Cultura empresarial }\end{array}$ \\
\hline 7 & Thakkar (2014) & $\begin{array}{l}\text { - Abordagem do fator humano de forma nảo adequada } \\
\text { qualidade e tecnologia de processos } \\
\text { - } \quad \text { Esforgos inadequados } \\
\text { Insight pobres. }\end{array}$ \\
\hline 8 & Tyagia et al (2015) & 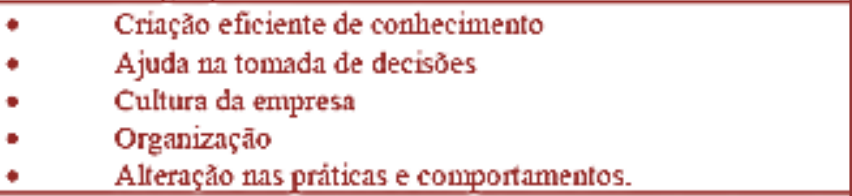 \\
\hline 9 & Lucato et al (2014) & $\begin{array}{l}\text { Práticas Lean năo são igualmente consideradas pelas } \\
\text { empresas. }\end{array}$ \\
\hline 10 & Dilantti (2014) & $\begin{array}{l}\text { Reduçāo de residuos } \\
\text { Desenvolvimento operacional }\end{array}$ \\
\hline 11 & Gallardo et al (2015) & $\begin{array}{l}\text { Ciclos de melhorias } \\
\text { Ganho de produtividade }\end{array}$ \\
\hline 12 & Fullerton et al (2014) & $\begin{array}{l}\text { - Informações mais relevantes } \\
\text { - Apoiar ao pessoal de operaçōes com a sua tomada de } \\
\text { decisão } \\
\text { Aumentar a performance estratégica nas operaçòes }\end{array}$ \\
\hline 13 & Costa (2014) & $\begin{array}{l}\text { Métricas } \\
\text { Gestāo de desenvolvimento de produtos com foco no valor } \\
\text { e beneficio. }\end{array}$ \\
\hline 14 & Hasle (2014) & $\begin{array}{l}\text { - } \\
\text { - } \quad \text { Gescontentamento de mudança } \\
\text { - } \quad \text { Pouco envolvimento das equipes } \\
\text { Descontentamento com os pré-requisitos técnicos na } \\
\text { implementação } \\
\text { Envolvimento importante para resultados positivos } \\
\text { - } \quad \text { Eficácia na gestão da mudança. }\end{array}$ \\
\hline
\end{tabular}


Continua...

\begin{tabular}{|c|c|c|}
\hline ITEM & AUTOR & PONTOS OU AÇÕES LEVANTADADAS \\
\hline 15 & Andersen et al (2014) & $\begin{array}{ll}- & \text { Identificar fatores } \\
\text { - } & \text { Facilitadores para a intervençăo Lean, envolvimento da } \\
\text { gestão } \\
\text { - } \quad \text { Cultura } \\
\text { - } \quad \text { Eormação } \\
\text { Equipe de trabalho } \\
\text { Envolvimento da equipe }\end{array}$ \\
\hline 16 & Stenger et al (2014) & $\begin{array}{l}\text { - } \quad \text { Pressão do trabalho sobrecarga de tarefas } \\
\text { Trabalho intensificado e em condição ergonômica } \\
\text { desfavorável. } \\
\text { - } \quad \text { Pressão por metas e qualidade - fator estressor } \\
\end{array}$ \\
\hline 17 & Silva et al (2015) & $\begin{array}{ll}- & \text { Insatisfação dos clientes; } \\
\text { - } & \text { Planos de ação } \\
& \text { Trabalhos padronizados; }\end{array}$ \\
\hline 18 & Rüttimann et al (2014) & $\begin{array}{ll} & \text { Incompreensão no uso do Lean } \\
\text { - } & \text { Alta expectativa } \\
\text { - } & \text { Ações não cumpridas } \\
\text { Diferenças de processos }\end{array}$ \\
\hline 19 & Nievwenhuis et al (2014) & $\begin{array}{ll} & \text { Escritórios verdes } \\
\text { - } & \text { Percepção mais positiva do ambiente de trabalho } \\
\text { - } & \text { Satisfação no local de traballo } \\
\text { - } & \text { Qualidade do ar } \\
\text { - } & \text { Aumcentração } \\
& \text { Aumento na produtividade }\end{array}$ \\
\hline 20 & Rossitti et al (2014) & $\begin{array}{l}\text { Melhoria nos processos administrativos; } \\
\text { - } \quad \text { Flexibilidade lean, } \\
\text { - } \quad \text { ean é adaptável a equipe e a empresa. }\end{array}$ \\
\hline 21 & Silva (2014) & $\begin{array}{l}\text { - Melhorias aos niveis de comunicação, } \\
\text { Produtividade, } \\
\text { Qualidade, } \\
\text { - Custos e desperdicios; } \\
\text { Resistência ao funcionamento Lean } \\
\text { Vícios de traballo; } \\
\text { - Impulsiona a melloria; } \\
\text { Os principais resultados estão relacionados com os } \\
\text { colaboradores. }\end{array}$ \\
\hline 22 & Paoli et al (2014) & Disseminação da cultura Lean \\
\hline 23 & Nunes e Faccio (2014) & $\begin{array}{l}\text { - } \quad \begin{array}{l}\text { Divergência entre as açðes de apoio e suporte } \\
\text { Os lideres de apoio têm dificuldade em atender o fluxo } \\
\text { de valor }\end{array} \\
\text { - } \quad \text { Pessoas não identificam aplicação das ferramentas Lean } \\
\text { Não combatem os desperdicios. }\end{array}$ \\
\hline
\end{tabular}

Fonte: As autoras (2018)

Ainda interessante observar as palavras ou ideias principais voltadas ao Lean nos artigos estudados, conforme Figura 4. 
Figura 4 - Palavras ou ideias principais do Lean

\begin{tabular}{|l|l|}
\multicolumn{1}{|c|}{ Lean Thinking } & \multicolumn{1}{c|}{ Lean Office } \\
\hline Valor & Comprometer-se com o Lean \\
\hline Fluxo de valor & Escolher o fluxo de valor \\
\hline Fluxo contínuo & Aprender sobre o Lean \\
\hline Produção puxada & Mapear o estado atual \\
\hline Perfeição & Identificar as métricas \\
\hline & Mapear o estado futuro \\
\hline & Criar planos Kaisen \\
\hline & Implementar planos Kaizen \\
\hline
\end{tabular}

Fonte: As autoras(2018)

Tem-se, portanto, a construção dos procedimentos licitatórios com base na filosofia Lean, denominada Matriz de
Contratação Enxuta - MACE, conforme Figura 5.

Figura 5 - MACE

\begin{tabular}{|c|c|c|c|c|c|c|}
\hline \multirow{2}{*}{ Item } & \multirow{2}{*}{ Procedimento } & \multirow{2}{*}{$\begin{array}{c}\text { Açōes } \\
\text { convergentes } \\
\text { a0 Lean }\end{array}$} & \multicolumn{4}{|c|}{ Gerenciamento segundo a guia PMBOK 8} \\
\hline & & & Processos & Entradas & $\begin{array}{c}\text { Ferramentas } \\
\text { técnicas } \\
\text { te }\end{array}$ & Saidas \\
\hline 1 & $\begin{array}{l}\text { Solicitação do } \\
\text { eliente - } \\
\text { necessidade } \\
\text { administrativa }\end{array}$ & $\begin{array}{l}\text { A abertura do } \\
\text { processo só } \\
\text { ocorrerá com a } \\
\text { solicitação do } \\
\text { cliente. Esta } \\
\text { solicitação terá } \\
\text { como base } \\
\text { principal as } \\
\text { justificativas } \\
\text { de uso do } \\
\text { produto por } \\
\text { parte do } \\
\text { cliente. }\end{array}$ & $\begin{array}{l}\text { Processos } \\
\text { de } \\
\text { iniciaçăo }\end{array}$ & Solicitaçāo do cliente & $\begin{array}{l}\text { Análise da } \\
\text { solicitaçāo }\end{array}$ & $\begin{array}{l}\text { Aprovaçăo } \\
\text { da } \\
\text { solicitação }\end{array}$ \\
\hline 2 & $\begin{array}{l}\text { Definiçåso do } \\
\text { objeto de forma } \\
\text { clara e precisa }\end{array}$ & $\begin{array}{l}\text { Valor - por } \\
\text { meio da } \\
\text { definiçăo do } \\
\text { objeto, o } \\
\text { cliente deve } \\
\text { manifestar sua } \\
\text { percepcão de } \\
\text { valor para com } \\
\text { o mesmo, de } \\
\text { forma clara c } \\
\text { objetiva. }\end{array}$ & $\begin{array}{l}\text { Processos } \\
\text { de } \\
\text { iniciação }\end{array}$ & $\begin{array}{c}\text { Solicitaçào do } \\
\text { Cliente; } \\
\text { Definiçăo do escopo; } \\
\text { Definição das partes } \\
\text { interessadas; } \\
\text { Definiçāo dos } \\
\text { membros da comissão } \\
\text { licitatónia; } \\
\text { Defunição do } \\
\text { presidente da } \\
\text { comissão licitatória. }\end{array}$ & $\begin{array}{c}\text { Análise da } \\
\text { solicitação; } \\
\text { Consulta a planilha } \\
\text { orçamentária } \\
\text { institucional; } \\
\text { Amuência do agente } \\
\text { financeiro e } \\
\text { ordenador de } \\
\text { despesas; } \\
\text { Expedição das } \\
\text { portarias }\end{array}$ & $\begin{array}{c}\text { Abertura } \\
\text { do } \\
\text { projeto }\end{array}$ \\
\hline
\end{tabular}


Continua...

\begin{tabular}{|c|c|c|c|c|c|c|}
\hline \multirow{2}{*}{ Item } & \multirow{2}{*}{ Procedimento } & \multirow{2}{*}{$\begin{array}{c}\text { Açōes } \\
\text { convergentes } \\
\text { ao Lean }\end{array}$} & \multicolumn{4}{|c|}{ Gerenciamento segundo o guia $\mathrm{PMBOK}^{8}$} \\
\hline & & & Processos & Entradas & $\begin{array}{c}\text { Ferramentas e } \\
\text { técnicas }\end{array}$ & Saidas \\
\hline 3 & $\begin{array}{l}\text { Apreciação do } \\
\text { Projeto Básico }\end{array}$ & $\begin{array}{l}\text { Mapear o } \\
\text { estado atual/ } \\
\text { identificar } \\
\text { métricas/ } \\
\text { Mapear o } \\
\text { estado futuro: } \\
\text { Melhorar o } \\
\text { fluxo de valor } \\
\text { ou de } \\
\text { processo, com } \\
\text { o intuito de } \\
\text { aumentar o } \\
\text { valor agregado } \\
\text { diminuindo } \\
\text { desperdicios }\end{array}$ & $\begin{array}{l}\text { Processos de } \\
\text { Planejamento }\end{array}$ & $\begin{array}{l}\text { Plantas detalhadas } \\
\text { de todos os niveis; } \\
\text { Memoriais } \\
\text { descritivos; } \\
\text { Cortes transversais } \\
\text { e longitudinais; } \\
\text { Elevaçoes de todas } \\
\text { as fachadas; } \\
\text { Perspectivas } \\
\text { externas e internas; } \\
\text { Estudo definitivo } \\
\text { do layout; } \\
\text { Projetos básicos e } \\
\text { memoriais } \\
\text { descritivos de } \\
\text { todas as instalações } \\
\text { prediais; } \\
\text { Estimativa } \\
\text { detallhada de custo }\end{array}$ & $\begin{array}{l}\text { Análise detalhada } \\
\text { das planithas, } \\
\text { memoriais, plantas } \\
\text { e planilhas; } \\
\text { Analise de risco } \\
\text { do Projeto Básico }\end{array}$ & $\begin{array}{l}\text { Parecer } \\
\text { técnico } \\
\text { sobre o } \\
\text { projeto } \\
\text { básico }\end{array}$ \\
\hline 4 & $\begin{array}{l}\text { Averiguação } \\
\text { das possiveis } \\
\text { soluções e } \\
\text { análise de suras } \\
\text { vantagens e } \\
\text { desvantagens }\end{array}$ & $\begin{array}{c}\text { Valor, Fluxo } \\
\text { de Valor - } \\
\text { Com base nas } \\
\text { definiçōes de } \\
\text { valor } \\
\text { estabelecida } \\
\text { pelo cliente } \\
\text { levanta-5e as } \\
\text { atividades que } \\
\text { serão } \\
\text { necessárias } \\
\text { para atingir o } \\
\text { objetivo } \\
\text { desejado. }\end{array}$ & $\begin{array}{l}\text { Processos de } \\
\text { planejamento. }\end{array}$ & $\begin{array}{l}\text { Escopo do projeto; } \\
\text { Riscos do projeto; }\end{array}$ & $\begin{array}{l}\text { Coleta de } \\
\text { informaçōes } \\
\text { contextualizando } \\
\text { com as exigências } \\
\text { da lei; mapear as } \\
\text { atividades do } \\
\text { projeto que } \\
\text { ocorrem dentro } \\
\text { dele com base no } \\
\text { fluxo de valor para } \\
\text { separação dos } \\
\text { processos; } \\
\text { considerar os } \\
\text { loops de feedback, } \\
\text { repetidos, para } \\
\text { análises } \\
\text { adicionais. }\end{array}$ & $\begin{array}{l}\text { EAP } \\
\text { Preliminar. }\end{array}$ \\
\hline 5 & $\begin{array}{l}\text { Avaliação das } \\
\text { diversas } \\
\text { soluçōes sob os } \\
\text { prismas da } \\
\text { legalidade e da } \\
\text { conveniència }\end{array}$ & $\begin{array}{l}\text { Fluxo de } \\
\text { Valor, Fluxo } \\
\text { Contínuo- } \\
\text { definir as } \\
\text { atividades que } \\
\text { realmente } \\
\text { contemple o } \\
\text { fluxo de valor, } \\
\text { deve ser } \\
\text { observado qual } \\
\text { a melhor } \\
\text { maneira de } \\
\text { executá-las } \\
\text { extraindo do } \\
\text { processo sua } \\
\text { melhor } \\
\text { sequência. }\end{array}$ & $\begin{array}{l}\text { Processos de } \\
\text { planejamento. }\end{array}$ & $\begin{array}{l}\text { Escopo do projeto; } \\
\text { Riscos do projeto; } \\
\text { EAP Preliminar }\end{array}$ & $\begin{array}{c}\text { Coleta de } \\
\text { informações } \\
\text { contextualizando } \\
\text { com as exigências } \\
\text { da lei: Definiçăo } \\
\text { dos custos do } \\
\text { projeto. }\end{array}$ & $\begin{array}{c}\text { EAP e } \\
\text { cronogramas. }\end{array}$ \\
\hline
\end{tabular}


Continua...

\begin{tabular}{|c|c|c|c|c|c|c|}
\hline \multirow{2}{*}{ Item } & \multirow{2}{*}{ Procedimento } & \multirow{2}{*}{$\begin{array}{c}\text { Ações } \\
\text { convergentes ao } \\
\text { Lean }\end{array}$} & \multicolumn{4}{|c|}{ Gerenciamento segundo o guia PMBOK $^{\text {ह }}$} \\
\hline & & & Processos & Entradas & $\begin{array}{c}\text { Ferramentas } \\
\text { e técnicas }\end{array}$ & Saídas \\
\hline 6 & $\begin{array}{c}\text { Escolha das } \\
\text { soluçōes a } \\
\text { serem adotadas; }\end{array}$ & $\begin{array}{c}\text { Fluxo de Valor- } \\
\text { observar as } \\
\text { soluçōes existentes } \\
\text { para se chegar ao } \\
\text { objetivo final do } \\
\text { projeto, observando } \\
\text { as atividades que } \\
\text { compõe cada uma } \\
\text { destas soluçōes, } \\
\text { sendo que para cada } \\
\text { uma delas devem- } \\
\text { se separar as } \\
\text { atividades que } \\
\text { efetivamente gerem } \\
\text { valor; aquelas que } \\
\text { não geram valor e } \\
\text { são importantes e as } \\
\text { que nảo agregam } \\
\text { valor, para que se } \\
\text { possa chegar à } \\
\text { escolha. }\end{array}$ & $\begin{array}{l}\text { Processos de } \\
\text { planejamento }\end{array}$ & $\begin{array}{c}\text { EAP e } \\
\text { cronogramas. }\end{array}$ & $\begin{array}{l}\text { Coleta de } \\
\text { informações } \\
\text { segundo as } \\
\text { exigências da } \\
\text { lei, consulta ao } \\
\text { corpo técnico. }\end{array}$ & $\begin{array}{l}\text { Declaraçào do } \\
\text { escopo do } \\
\text { projeto: } \\
\text { Processos } \\
\text { necessários para } \\
\text { gerenciar o } \\
\text { projeto }\end{array}$ \\
\hline 7 & $\begin{array}{l}\text { Verificação da } \\
\text { possibilidade } \\
\text { legais segundo } \\
\text { a Lei }\end{array}$ & & $\begin{array}{l}\text { Processos de } \\
\text { planejamento }\end{array}$ & $\begin{array}{l}\text { Declaraşão do } \\
\text { escopo do } \\
\text { projeto; } \\
\text { Processos } \\
\text { necessários } \\
\text { para gerenciar } \\
\text { o projeto; }\end{array}$ & $\begin{array}{c}\text { Levantamento } \\
\text { documental; } \\
\text { Definição da } \\
\text { EAP final; } \\
\text { Cronograma } \\
\text { fisico, final, do } \\
\text { projeto; }\end{array}$ & $\begin{array}{c}\text { Plano de } \\
\text { gerenciamento } \\
\text { do projeto }{ }^{54} \text {. }\end{array}$ \\
\hline 8 & $\begin{array}{l}\text { Definição da } \\
\text { modalidade } \\
\text { conforme lei } \\
\text { vigente }\end{array}$ & & $\begin{array}{l}\text { Processos de } \\
\text { planejamento }\end{array}$ & $\begin{array}{l}\text { Plano de } \\
\text { gerenciamento } \\
\text { do projeto }\end{array}$ & $\begin{array}{c}\text { Comparação } \\
\text { das } \\
\text { informaçð̃es } \\
\text { plano gerencial } \\
\text { com as } \\
\text { modalidades da } \\
\text { lei }\end{array}$ & $\begin{array}{l}\text { Definição da } \\
\text { modalidade } \\
\text { licitatória com } \\
\text { justificativa, } \\
\text { justificativa da } \\
\text { responsabilidade } \\
\text { de empenho } \\
\text { orçamentário e } \\
\text { financeiro }\end{array}$ \\
\hline 9 & $\begin{array}{l}\text { Composiçāo do } \\
\text { certame } \\
\text { conforme a lei }\end{array}$ & & $\begin{array}{l}\text { Processos de } \\
\text { execução. }\end{array}$ & $\begin{array}{l}\text { Processos de } \\
\text { planejamento; } \\
\text { Definição e } \\
\text { justificativas } \\
\text { do item } 8\end{array}$ & $\begin{array}{c}\text { Execução } \\
\text { formal, de } \\
\text { material } \\
\text { paramétrico, } \\
\text { segundo } \\
\text { legislação, para } \\
\text { composição do } \\
\text { edital. } \\
\text { Projeto básico; } \\
\text { Cotaçōes ou } \\
\text { orçamentos; } \\
\text { Consulta } \\
\text { funanceira, etc. }\end{array}$ & $\begin{array}{l}\text { Anteprojeto } \\
\text { (conjunto } \\
\text { preliminar das } \\
\text { diretrizes legais } \\
\text { do projeto) }\end{array}$ \\
\hline
\end{tabular}


Continua...

\begin{tabular}{|c|c|c|c|c|c|c|}
\hline \multirow{2}{*}{ Item } & \multirow{2}{*}{ Procedimento } & \multirow{2}{*}{$\begin{array}{c}\text { Açōes } \\
\text { convergent } \\
\text { es ao Lean }\end{array}$} & \multicolumn{4}{|c|}{ Gerenciamento segundo o guia $\mathrm{PMBOK}^{2}$} \\
\hline & & & Processos & Entradas & $\begin{array}{c}\text { Ferramentas e } \\
\text { técnicas }\end{array}$ & Saidas \\
\hline 10 & Minuta do edital & & $\begin{array}{c}\text { Processos de } \\
\text { execução. }\end{array}$ & Anteprojeto & $\begin{array}{c}\text { Minuta modelo } \\
\text { CGU }\end{array}$ & $\begin{array}{c}\text { Minuta do } \\
\text { edital }\end{array}$ \\
\hline 11 & $\begin{array}{l}\text { Elaboração da } \\
\text { minuta de } \\
\text { contrato. }\end{array}$ & & $\begin{array}{l}\text { Processos de } \\
\text { execução. }\end{array}$ & $\begin{array}{l}\text { Anteprojeto } \\
\text { Minuta do } \\
\text { edital }\end{array}$ & $\begin{array}{l}\text { Minuta modelo } \\
\text { CGU, } \\
\text { Formalização } \\
\text { escrita da peça, } \\
\text { ou seja, o } \\
\text { contrato } \\
\text { administrativo, } \\
\text { este deve } \\
\text { obedecer às } \\
\text { regras legais } \\
\text { imputadas pela } \\
\text { legislação. }\end{array}$ & $\begin{array}{l}\text { Minuta de } \\
\text { contrato }\end{array}$ \\
\hline 12 & Parecer jurídico & & $\begin{array}{l}\text { Processos de } \\
\text { monitoramento } \\
\text { e controle. }\end{array}$ & $\begin{array}{l}\text { Anteprojeto: } \\
\text { Minuta do } \\
\text { edital } \\
\text { Minuta de } \\
\text { contrato }\end{array}$ & & $\begin{array}{l}\text { Parecer } \\
\text { juridico }\end{array}$ \\
\hline 13 & $\begin{array}{c}\text { Desencadeament } \\
\text { o dos atos de } \\
\text { conclusão da fase } \\
\text { preparatória e, se } \\
\text { for o caso de } \\
\text { instauração das } \\
\text { etapas } \\
\text { subsequentes. }\end{array}$ & & $\begin{array}{l}\text { Processo de } \\
\text { encerramento }\end{array}$ & $\begin{array}{l}\text { Anteprojeto: } \\
\text { Minuta do } \\
\text { edital } \\
\text { Minuta de } \\
\text { contrato } \\
\text { Parecer juridico }\end{array}$ & $\begin{array}{l}\text { Verificaçāo do } \\
\text { parecer juridico } \\
\text { em caso de } \\
\text { observações } \\
\text { realizar as } \\
\text { alteraçōes ou } \\
\text { finalizar o } \\
\text { proces5o }\end{array}$ & $\begin{array}{c}\text { Anteprojeto } \\
\text { com ações } \\
\text { corretivas }\end{array}$ \\
\hline
\end{tabular}

Fonte: As autoras (2018)

\section{CONCLUSÕES}

Pode-se constatar que a filosofia Lean está distante da realidade do processo de contratação pública no Brasil e, mais ainda, nos escritórios administrativos de um modo geral, onde se percebe um alto grau de esforço destinado ao gerenciamento do processo produtivo, "tanto nos aspectos do controle da qualidade e produtividade, quanto nos da eficiência e da eficácia" (STENGER et al, 2014).e um certo grau de distração com relação aos procedimentos de contratação.

Desse modo, a mira voltada para o desenvolvimento do processo produtivo, tanto nos aspectos do controle da qualidade e produtividade, quanto nos da eficiência e da eficácia, a proposta desenvolvida ao longo deste estudo foi analisar as teorias Lean Office e Lean Thinking, assim como a utilização do guia $\mathrm{PMBOK} 囚$, para que por meio destes, fosse possível elaborar uma proposição quanto à utilização das teorias, como instrumento de diagnóstico, e do Guia $\mathrm{PMBOK} \otimes$, como suporte ao ordenamento do processo licitatório em uma instituição pública, podendo levar a mitigação de problemas e auxiliar os responsáveis pelas ações práticas e de gestão neste contexto.

Para se chegar a ferramenta mencionada, um longo e detalhado estudo foi realizado em vários materiais relacionados as temáticas Lean, gestão de projetos e legislação licitatória vigentes no Brasil.

Com o presente estudo, pode-se notar que as Instituições trabalham o Lean de forma fragmentada, assim como os estudiosos do assunto também o fazem, ou seja, trabalham os princípios e técnicas Lean separadamente, a filosofia e suas linhas são dividida entre ações para o setor administrativo ou para o setor de produção.

Neste momento cabe uma reflexão, toda linstituição tem produção, mesmo que isso aconteça em setores administrativos/escritórios, estes setores também são geradores de produtos e possuem uma linha de produção para se chegar a um determinado produto final, assim 
como as instituições que tem seu foco na produção, onde o produto final depende em "summa" de ações ligadas a processos tecnológicos ou de manufatura, também tem em sua estrutura setores administrativos/escritórios.

Outro fato constatado com a pesquisa, foi a falta de ações direcionadas, aos funcionários ou pessoas, envolvidas nos processos.

De uma forma geral, pode-se concluir que as ações Lean juntamente com as condições norteadoras do guia PMBOK®, implementadas nos setores de licitação de

\section{REFERÊNCIAS}

[1] AKABANE e SINKUNAS (2014). Uma revisão da literatura sobre fatores que apoiam a mudança organizacional voltada para o Lean Thinking. IX Workshop de pós-graduação e pesquisa do Centro Paula Souza.

[2] ANDERSEN et al (2014). Lean thinking in hospitals: in there a cure for the absence of evidence? A systematic review or reviews. BMJ Open.

[3] ANDREJANINI, F. (2015) Licitações e Contratos Administrativos, Belo Horizonte: Vesticon.

[4] ARAMAYO, S. (2013). A conceptual model for project management of exploration and production in the oil and gas industry: The case of a Brazilian company. International Journal of Project Management.

[5] AZEVEDO, C. E. F. et al (2013). A Estratégia de Triangulação: Objetivos, Possibilidades, Limitações e Proximidades com o Pragmatismo. EnEPQ, Brasília.

[6] AZHAR, S.; AHMAD, I.; SEIN, M.K. (2010). Action Research as a Proactive Research Method for Construction Engineering and Management. In: Journal of Construction Engineering and Management.

[7] BARBOSA, J. et al (2008). Análise das metodologias e técnicas de pesquisas adotadas nos estudos brasileiros sobre Balanced Scorecard: um estudo dos artigos publicados no período de 1999 a 2006. In J. Lopes, J. Francisco \& M. Pederneiras (Orgs.), Educação contábil: tópicos de ensino e pesquisa. São Paulo: Atlas.)

[8] BAZELEY, P. (2002). Issues in Mixing Qualitative and Quantitative Approaches to Research. Proceeding of International Conference Qualitative Research in Marketing and Management obras podem ser eficientes e eficazes no sentido de diminuir custos e aumentar o padrão de qualidade do processo de contratação pública

Desta feita, recomenda-se para estudos futuros, a aplicação da matriz MACE ora desenvolvida em uma instituição educacional de ensino superior de médio porte, com o estabelecimento e metas e registro das métricas alcançadas de forma a atestar a funcionalidade e os benefícios da matriz proposta com base na filosofia Lean.

[9] BERG, B. L. (2011) Qualitative Research Methods for Social Sciences. Editora Pearson Education, EUA

[10] BERNAL, J. D. (1969). Ciência na História. Lisboa : Livros Horizonte.

[11] BLAIKIE, N. W. H. (1991). A critique of the use of triangulation in social research. Quality \& Quantity

[12] BRASIL - Controladoria Geral da União CGU, (2013). 38 a Etapa do Programa de Fiscalização a partir de Sorteios Públicos, RELATÓRIO DE FISCALIZAÇÃO № 38034. Presidência da República, Controladoria Geral da União, Secretaria Federal de Controle Interno, Brasília.

[13] BRASIL. (2016) Ministério da Educação. Secretaria de Educação Profissional e Tecnológica. Educação, sociedade e trabalho: abordagem sociológica da educação / Ricardo Gonçalves Pacheco e Erasto Fortes Mendonça, - 4. ed. atualizada e revisada - Cuiabá: Universidade Federal de Mato Grosso / Rede e-Tec Brasil.

[14] BRYMAN, A. (2007). Barriers to Integranting Quantitative and Qualitative Research. Journal of Mixed Methods Research.

[15] CAMPBELL, D.T, \& FISKE, D. W. (1959) Convergent and discriminant validation by the multitrait-multimethod matrix. Psychological Bulletin.

[16] CHIAVENATO, I. (2014) Introdução Geral da Administração. Rio de Janeiro: Manole.

[17] CORNELIUS, D (2014). The PM role in a lean and agile world. Consultado em 11/04/2016. http://www.pmi.org/learning/pm-role-lean-agileworld-9350

[18] COSTA et al (2014). Toward a better comprehension of Lean metrics for research and product development management. R\&D Management. 
[19] EVANGELISTA et al (2013). Lean Office escritório enxuto: estudo da aplicabilidade do conceito em uma empresa de transporte. Revista Eletrônica Produção \& Engenharia.

[20] FLICK, U. (1992). Triangulation revisited: strategy of validation or alternative? Journal for the Theory of Social Behavior.

[21] FRANÇA, S.V.S (2013). Implementação de Ferramentas de Lean Manufacturing e Lean Office: indústria metálica, plástica e gabinetes de contabilidade. Dissertação de Mestrado pela Faculdade de Engenharia da Universidade do Porto, Portugal.

[22] FREITAS et al (2014). Lean thinking e lean project delivery system. XV Encontro Nacional de Tecnologia do Ambiente Construído.

[23] FULLERTON et al (2014). Lean manufacturing and firm performance: The incremental contribution of lean management accounting pratices. Journal of Operations Management.

[24] GALLARDO et al (2015). Productivity Gains in a Line Flow Precast Concrete Process after a Basic Stability Effort. Jornal Construction Engineer Management.

[25] GERHARDT, T. E. e SILVEIRA, D. T. (2009) Métodos de Pesquisa. Porto Alegre: Editora da UFRGS.

[26] Gil, A. C. (2002). Como elaborar projetos de pesquisa. 4. ed., São Paulo: Atlas.

[27] GODOY, A. S. (1995). Introdução à pesquisa qualitativa e suas possibilidades. Revista de Administração de empresas. São Paulo: RAE.

[28] GREEF et al (2010). Lean Office: operação, gerenciamento e tecnologias. São Paulo: Atlas.

[29] HASLE, P. (2014). Lean Production - An Evaluantion of the Possibilities for an Employee Supportive Lena Practice. Human Factors and Ergonomics in Manufacturing \& Service Industries.

[30] HUNTZINGER, J. (2015). The Roots of Lean Training Within Industry: The Origin of Japanese Management and Kaizen. www.twisummit.com Acesso em: 04 de setembro de 2015.

[31] HUSSEIN, A. (2009). The use of triangulation in Social Sciences Research: Can qualitative and quantitative methods be combined? Journal of Comparative Social Work.

[32] IKEDA, A. A. (2009) Reflections on Qualitative Research in Business. Revista de Gestão USP.

[33] INSTITUTO NEGÓCIOS PÚBLICOS (2014). http://www.negociospublicos.com.br/home/. Acesso em: 08 de junho de 2015.
[34] INTERNATIONAL

PROJECT MANAGEMENT ASSOCIATION - IPMA, (2006). ICB-IPMA competence baseline, version 3.0. consultado em 20/01/2014 http://ipma.ch/?s=icb

[35] JICK, T. D. (1979). Mixing qualitative and quantitative methods: triangulation in action. Administrative Science Quartely.

[36] JOHN F. Krafcik. (1988). Triunmph of the Lean Production System. Sloan Management Review, Massachsetts Institute of Technology: Fall Vol. 30

[37] JUSTEN FILHO, 2013. Comentários ao RDC. São Paulo: Dialética.

[38] KAUARK, F. S. et al (2010). Metodologia da pesquisa: Um guia prático. Itabuna: Via Litterarum.

[39] KERZNER, $\quad H ., \quad$ (2010). Project management: a systems approach to planning, scheduling, and controlling. John Wiley \& Sons, Inc., Hoboken.

[40] KHATIB, H. (2003). Economic Evaluation of Projects in the Electricity Supply Industry. The Institution of Engineering and Technology, London.

[41] KISTE e MIYAKE (2014). Um método para avaliação de competências operacionais de fornecedores segundo a abordagem do pensamento enxuto. SIMPOI.

[42] KONECKI, K. T. (2008). Triangulation and Dealing with the Realness of Qualitative Research. Qualitative Sociology Review.

[43] KOSKELA, L. (1992). Application of the new production philosophy to construction. CIFE Technical Report 72, CIFE, Stanford University, Stanford, CA.

[44] KOSKELA, L. (2000). An exploration towards a production theory and its application to construction. PhD thesis. VTT Publications 408. VTT, Technical Research Centre of Finland, Espoo.

[45] KRAFCIK, J. (1988). Triunmph of the Lean Production System. Sloan Management Review, V. 41.

[46] LACHER, R and BODAMER, R. (2009). The new reality of agile project management. Consultado em 11/04/2016. http://www.pmi.org/learning/new-reality-agile-pm6765

[47] LEAN ENTERPRESE INSTITUTE (2015). http://www.lean.org/WhatsLean/History.cfm. Acesso em: 27 de março de 2015.

[48] LEAN ENTERPRISE INSTITUTE (2011). Léxico Lean: glossário ilustrado para práticas do Pensamento Lean. São Paulo: Lean Institute Brasil

[49] LEAN INSTITUTE BRASIL - LIB, (2014). Lean Thinking (Mentalidade Enxuta). Consultado em 20/01/2014. 
[50] LEAN INSTITUTE BRASIL (2015). http://www.lean.org.br/. Acesso em: 27 de março de 2015

[51] LEITE e BARROS NETO (2014). Avaliação do processo de projeto em empreendimentos imobiliários. XV Encontro Nacional de Tecnologia do Ambiente Construído.

[52] LEWIS, J. P. (2000). The Project Manager's Desk Reference: A Comprehensive Guide to Project Planning, Scheduling, Evaluation, and Systems. McGraw-Hill, New York.

[53] LIKER J.K, KAISHA T.J.K.K. (2004). The Toyota way: 14 management principles from the world's greatest manufacturer. McGraw-Hill, New York.

[54] LLEDÓ, $\mathrm{P}$ and MERCAU, $\mathrm{R}$ (2008). Administración lean de proyectos eficiencia en la administración de proyectos: Managing lean projects efficiently in project management. Consultado em 11/04/2016. http://www.pmi.org/learning/managing-lean-basedprojects-efficiently-7087

[55] LUCATO et al (2014). Performance evaluation of lean manufacturing implementation in Brazil. International Journal of Productivityy and Performance Managemente.

[56] MACADAM, T (2009). Slashing Waste to Reduce Project Costs and Timelines. Project Management Institute. Consultado em 11/04/2016. http://www.pmi.org/learning/lean-projectmanagement-reduce-factors-6745

[57] MATTOS, ALDO DÓREA (2010). Planejamento e controle de obras. São Paulo: Pini.

[58] MAXIMINIANO, A (2011). Teoria geral da administração: da revolução urbana à revolução digital. São Paulo: Atlas.

[59] MAZZOCATO P. et al (2010). Lean thinking in healthcare: a realist review of the literature. Qual Saf Health Care.

[60] MESKENDAHL, S. (2010). The influence of business strategy on project portfolio management and its success a conceptual framework. International Journal of Project Management. Elsevier.

[61] MINAYO, M. C. S. (2010). Pesquisa social: teoria, método e criatividade. Rio de Janeiro: vozes.

[62] MINISTÉRIO DA EDUCAÇÃO (2016). Secretaria de Educação Profissional e Tecnológica. B823 Educação, sociedade e trabalho: abordagem sociológica da educação / Ricardo Gonçalves Pacheco e Erasto Fortes Mendonça, - 4. ed. atualizada e revisada - Cuiabá: Universidade Federal de Mato Grosso / Rede e-Tec Brasil, 2012. Consultado em 11/04/2016 http://portal.mec.gov.br/docman/fevereiro-2016pdf/33451-02-disciplinas-form-pedagogicacaderno-05-educacao-sociedade-trabalho-pdf/file
[63] MORAN-ELLIS, J et al (2006). Triangulation and integration: processes, claims and implications. Qualitative Research.

[64] MORSE, J. (1991). Approaches to qualitative-quantitative methodological triangulation. Nursing Research.

[65] MOUJIB, A (2007). Lean project management. Project Management Institute. Consultado em 11/04/2016. http://www.pmi.org/learning/lean-projectmanagement-7364

[66] MUNNS, A. K. E BJEIRMI, B. F. (1996). The role of project management in achieving project success. International Journal of Project Management.

[67] NICHOLAS, J. M., 2004. Project Management for Business and Engineering. Elsevier, Burlington.

[68] NICOLACI-DA-COSTA, A. M. (2007). The Field of Qualitative Research and the Underlying Discourse Unveiling Method (UDUM). Psicologia: Reflexão e Crítica.

[69] NIEUWENHUIS et al (2014). The Relative Benefits of Green Versus Lean Office Space: Three Field Experiments. Journal of Experimental Psychology.

[70] NUNES e FACCIO (2014). Avaliação fatores chave implementação Lean Office. Produção \& Produção.

[71] OEHMEN, J (2012). An overview of The guide to lean enablers for managing engineering programs. Project Management Institute. Consultado em 11/04/2016. http://www.pmi.org/learning/guide-lean-enablersmanaging-engineering-programs-6401

[72] PAOLI et al (2014). O conceito de Lean Office aplicado a um ambiente industrial com produção ETO - Engineer-to-Order. EXACTA, Sistema de Informação Científica - Rede de Revistas Cientificas de América Latina, Caribe, Espanha e Portugal.

[73] PEDRÃO, L. C. (2014). Gerenciamento de Projetos Lean; utilização otimizada de recursos garante sucesso na gestão de projetos. IBE FGV Campinas.

[74] PILLON et al (2015). Aplicabilidade do pensamento enxuto na gestão de processos da Educação a distância de uma instituição de ensino superior. Revista ESPACIOS.

[75] PMI (2013). Um Guia do conhecimento em Gerenciamento de Projetos (Guia PMBok®), Newton Square, Pennsylvania, EUA: PMI.5르ed.

[76] REIS, R. B (2014). Infográficos Informativos do Instituto Negócios Públicos. Curitiba: Compras Públicas.

[77] REZENDE (2011). O Regime Diferenciado de Contratação Pública: comentários à Lei $n^{\circ}$ 
12.462, de 2011. Núcleo de Estudos e Pesquisa do Senado. Brasília: Senado.

[78] RIBEIRO (2012). Regime Diferenciado de contratação: licitações para a Copa do Mundo e Olimpíadas. São Paulo: Atlas.

[79] ROSSITI, B. S. (2014). Melhoria de processo por meio do Lena Project Management: um estudo de caso. São Carlos: Universidade de São Paulo.

[80] RÜTTIMANN et al (2014). Leveraging Lena in the Office: Lean Office Needs a Novel and Differentiated Approach. Journal of Service an Management.

[81] THAKKAR (2014). Status of lean manufacturing practices in Indian industries and government initiatives. Jornal of Manufacturing Technology Management.

[82] SHENTON, A. K. (2004). Strategies for ensuring trustworthing in qualitative research projects. Education for Information.

[83] SILVA et al (2015). Lean office in health organization in the Brazilian Army. International Journal of Lena Six Sigma.

[84] SILVA, A. M. F. (2014). Aplicação de técnicas Lean Office nos serviços acadêmicos de uma universidade. Universidade do Minho, Portugal.

[85] SMITH, H. W. (1975) Strategies of Social Research: The Methodological Imagination. Englewood Cliffs, NJ: Prentice Hall.

[86] SODERLUND, J. et al (2011). Theoretical foundations of project management. The Oxford Handbook of Project Management. Oxford university press, New York.

[87] SOUZA, V. e CARVALHO, M. (2014) Princípios de Gestão na Execução de Empreendimentos Residenciais. Saarbrücken/Sarre - Alemanha; Editora: OmniScriptum GmbH \& Co.

[88] SOUZA, V. e CARVALHO, M. (2016) Lean Thinking: Proposta de Melhoria das Práticas de Gestão em Licitações de Obras Públicas Dissertação (doutorado) - Universidade Federal de Brasília (Unb) - Brasília. 2016.
[89] STENGER et al (2014). Lean production e riscos psicossociais: o caso de uma fusão multinacional de grupo metalmecânico no Brasil. Cad. Saúde Pública, Rio de Janeiro.

[90] SUNDBO, J. (2015). From service quality to experience - and back again? International Journal of Quality and Service Sciences.

[91] TAPPING e SHUKER (2010). Lean Office: gerenciamento de fluxo de valor para áreas administrativas - 8 passos para planejar, mapear e sustentar melhorias Lean nas áreas administrativas. São Paulo: Leopardo.

[92] TEIXEIRA, J. C et al (2012) Triangulação entre métodos na administração: gerando conversações paradigmáticas ou meras validações "convergentes"? Revista de Administração Pública.

[93] THIOLLENT, M. (1994). Metodologia da Pesquisa-ação. São Paulo: Cortez

[94] THOMAZ, E. (2001). Tecnologia, gerenciamento e qualidade na construção. São Paulo: Pini.

[95] TOMMELEIN, I.D. (1998). Pull-driven scheduling for pipe-spool installation: simulation of lean construction technique. ASCE Journal of Construction Engineering and Management.

[96] TYAGIA et al (2015). Lean tools and methods to support efficient knowledge creation. International Jornal of Information Management.

[97] WEBB, E.J. et al (1996) Unobtrusive Measures: Non-Reactive Research in the Social Sciences. Rand McNally, Chicago.

[98] WICKRAMASINGHE, N. et al (2014). Lean Principles for Healthcare. Lean Thinking for Healthcare. New York: Springer Science

[99] WOMACK e JONES (2004). A mentalidade enxuta nas empresas: elimine o desperdício e crie riquezas. Rio de Janeiro: Elsevier

[100] WOMACK et al (2004). A máquina que mudou o mundo: baseado no estudo do Massachusetts Institute of Technology sobre o futuro do automóvel. Rio de Janeiro: Elsevier. 


$$
\text { Alutary }
$$




\section{RENATA FERREIRA (ORGANIZADORA)}

Bacharel em estatística pela Universidade Federal de Minas Gerais. Atuou como consultora de gestão por mais de sete anos no Instituto de Desenvolvimento Gerencial (INDG, atualmente Falconi), trabalhando principalmente com gerenciamento da rotina, seis sigma, gestão da inovação. Desenvolveu sua carreira em empresas privadas do segmento logístico atuando como gestora de processos e projetos.

\section{ALESSANDRA LOPES CARVALHO}

Possui graduação em Engenharia Elétrica ( PUC Minas 1996), mestrado em Engenharia Elétrica com ênfase em Automação ( UFMG 1998) e doutorado em Engenharia Elétrica, linha de pesquisa Confiabilidade de Sistemas (UFMG, 2008). Integra o corpo docente da PUC MG ah dezoito anos. É membro do Núcleo Docente Estruturante do curso de Engenharia de Produção da PUC-MG onde leciona Engenharia da Qualidade, Controle Estatístico e Confiabilidade de Produtos e Processos.

\section{ALICE RODRIGUES ALIMEIDA}

Possui graduação em Letras Português e Respectivas Literaturas e MBA em Gerenciamento de projetos, pela Universidade La Salle - Canoas. Atua como educadora na rede Estadual de Ensino do rio Grande do Sul e é coordenadora do Escritório de Projetos da Universidade La Salle, possuindo experiências que se entrelaçam entre a gestão e a educação.

\section{ALYSON DA LUZ PEREIRA RODRIGUES}

Graduado em Engenheiro de Produção pela Faculdade Pitágoras (2017), Mestrando em Meio Ambiente pela Universidade CEUMA. Desenvolveu atividades de pesquisa nas áreas de Lean Manufacturing, Simulação a Eventos Discretos (SED), Gestão Ambiental, Bioenergia com produções científicas publicadas em periódicos nacionais e internacionais. É tutor no grupo de escrita de livros do UNICEUMA, membro da Liga Acadêmica de Meio Ambiente (UNICEUMA) e colaborador da Liga Acadêmica de Modelagem e Simulação (UNICEUMA). Atualmente trabalha com a utilização de materiais lignocelulósicos (biomassas) para a produção de bioenergia e/ou biocombustíveis.

\section{AMANDA DA SILVA XAVIER}

Mestranda pelo Programa de Pós-Graduação em Engenharia de Produção pela Universidade Federal de Pernambuco (UFPE) (2018). Graduada em Engenharia de Produção Mecânica pela Universidade Regional do Cariri (URCA) (2012-2017). Foi Bolsista/Pesquisadora de investigação sobre Crédito de Carbono na Região do Cariri/Ceará (2014-2016). Em sua atuação profissional foi Diretora de Projetos em EJEPRO Consultoria (2015-2016). Analista pleno na ENEL Distribuição Ceará. E analista de PCP na indústria IBK.

\section{AMANDA DUARTE FEITOSA}

Graduando em Engenharia de Produção Mecânica pela Universidade Regional do Cariri. Foi bolsista/pesquisadora de iniciação científica (2014-2015). Na parte profissional foi estagiária na empresa Singer do Brasil (2015-2016). Fez graduação sanduíche (2016-2017) na França pela ENSGSI (École nationale supérieure en génie des systèmes et de l'innovation), em que foi bolsista pelo programa BRAFITEC fornecido pela CAPES (Coordenação de Aperfeiçoamento de Pessoal de Nível Superior). Atualmente pesquisadora e bolsista da URCA (Universidade Regional do Cariri). 


\section{ANA CÉLIA SILVA VIEIRA}

Especialização em Nutrição e Controle de Qualidade pela Faculdade INTA de Sobral (2012). Graduação em Tecnologia de Alimentos pelo Instituto Centro de Ensino Tecnológico (2006) e experiência com Análises Microbiológicas e Físico - Química de Alimentos e Bebidas. Atua no SENAI-MA como Analista prestando assessoria e consultoria em empresas da área de Alimentos e Bebidas pelo Programa Alimentos Seguros. Consultora em Lean Manufacturing.

\section{ANDERSSON ALVES DA SILVA}

Mestrando pelo Programa de Pós-Graduação em Engenharia de Produção pela Universidade Federal de Pernambuco (UFPE). Graduado em Engenharia de Produção Mecânica pela Universidade Regional do Cariri (URCA) (2012-2017). Foi Coordenador Institucional na Voitto Treinamento e Desenvolvimento (2015); Bolsista de Extensão com o Projeto: Resíduos Sólidos e a Sustentabilidade do Planeta (2016); e Técnico em Modelagem Matemática (2015).

\section{ANDRÉ EDUARDO STAEDELE}

Educador de líderes e equipes em mudanças organizacionais, tendo expertise em estratégia, melhoria continua, processos, qualidade, inovação e performance, reunindo competências para atuar em áreas administrativas e produtivas de diversos segmentos de negócios. Possui vivência internacional, tendo auxiliado na implantação de jornadas lean em negócios do segmento agroindustrial da América do Norte. É certificado em lean management, six sigma black belt, e change management. É bacharel em administração de empresas, especialista em gestão da qualidade e mestrando em engenharia de processos.

\section{ANDRÉA DE FREITAS AVELAR}

Possui graduação em Engenharia Civil pela Universidade de Brasília (1995), MBA em Gestão de Projetos (2006), MBA em Gestão da Construção Civil e Negócios Imobiliários (2011) e Mestranda em Engenharia Civil com ênfase em Construção Civil (UNB). Tem experiência na área de Engenharia Civil, atuando principalmente nos seguintes temas: gestão de projetos, gestão da produção, engenharia de custos, análise de viabilidade financeira de empreendimentos para garantia de operações financeiras e avaliação imobiliária. Atualmente é coordenadora do curso de engenharia civil do Centro Universitário de Patos de Minas (UNIPAM) e sócia da Planejar Engenharia e Consultoria LTDA.

\section{ANNA LETICIA TEIXEIRA ROSA}

Graduanda em Engenharia de Produção, UNISAL. Estagiária de engenharia e gestão de ativos e Green Belt em Lean Six Sigma. Ama gestão da manutenção, produção e projetos.

\section{ARTHUR MARCON}

Mestre em Engenharia de Produção pelo Programa de Pós-Graduação em Engenharia de Produção da Universidade Federal do Rio Grande do Sul. Possui graduação em Administração. Atua nos campos de inovação, produção mais limpa, e produtos sustentáveis. Trabalhou como pesquisador-engenheiro convidado do G-SCOP - INP (França).

\section{BRUNA DONES GAYER}

Engenharia Civil pela Universidade Federal do Rio Grande do Sul (UFRGS) em 2016. Atualmente faz Mestrado em Engenharia de Produção pela Universidade Federal do Rio Grande do Sul (UFRGS). Sua pesquisa é baseada nas áreas de Lean Production e Sistemas Sócio-técnicos Complexos. 


\section{CAMILA FARIAS ARAÚJO}

Graduanda em Engenharia de Produção pela Universidade La Salle.

\section{CARLOS ANTÔNIO VINOTTI}

Coordenador de Gestão, Processo Produtivo e Inovação do Sistema FIESC - SENAI/SC Itajaí, Graduado em Administração pela Universidade do Vale do Itajaí - UNIVALI (1997), Especialização em Logística Empresarial pela Universidade do Vale do Itajaí - UNIVALI (2002), Especialização MBA em Gestão para Excelência - SENAI SC (2010), Especialização MBA Gestão de Instituições de Educação Profissional e Tecnologia - SENAI SC (2013), Mestrado em Engenharia de Produção pelo Centro Universitário SOCIESC (2017).

\section{CAROLINA DOS SANTOS NUNAN}

Professora Adjunta da Pontifícia Universidade Católica de Minas Gerais (PUC Minas) nas áreas de Logística, Produto e Qualidade. Atua na área de pesquisa em Geodemografia, Geoprocessamento e Mobilidade Urbana. É Doutora (2012) e Mestre (2006) em Tratamento da Informação Espacial (PUC Minas); Especialista em marketing (1999; PUC Minas) com aperfeiçoamento em Logística (2000, FGVSP); e graduada em Administração (1997; PUC Minas).

\section{CÉSAR AUGUSTO FIGUEIREDO MACIEL}

Graduado e mestre em Administração pela Universidade Federal de Minas Gerais. É professor da Pontifícia Universidade Católica de Minas Gerais desde 2001, tendo vasta experiência acadêmica nas seguintes disciplinas: Administração Mercadológica, Gestão da Inteligência de Mercado, Administração Estratégica, Teorias da Administração e Gestão de Operações.

\section{CLEBER HENRIQUE COTA}

Engenheiro de Produção, formado pela FEAMIG em 2016, atualmente cursando licenciatura em Matemática pela Estácio de Sá, formado também em Técnico Eletromecânica pelo CEFETMG EM 1999, Técnico em Ferramentaria em 1993 pelo SENAI-MG. Trabalhando atualmente no setor automotivo há 25 anos como Oficial de Ferramentaria, na construção de moldes para fabricação de blocos de motor, Cabeçotes e caixa de Câmbios.

\section{CLEGINALDO PEREIRA DE CARVALHO}

Pós-Doutorado em Engenharia de Produção pela UNESP (2018). Pós-Doutorado em Engenharia de Produção pela USP (2017). Doutor em Engenharia Mecânica pela UNESP (2002). Mestre em Engenharia Mecânica pela UNESP (1991). MBA Executivo pela Fundação Dom Cabral (2003)

\section{CRISTIANO ROOS}

É Professor do Departamento de Engenharia de Produção e Sistemas no Centro de Tecnologia da Universidade Federal de Santa Maria. É Engenheiro de Produção, Especialista em Engenharia de Produção pela Universidade Federal do Rio Grande do Sul, Mestre em Engenharia de Produção pela Universidade Federal de Santa Maria, e Doutor em Engenharia de Produção pela Universidade Federal de Santa Catarina. 


\section{DANIELLE BREY-GIL FARIA}

Mestranda em Engenharia de Produção pela UFMG na linha de pesquisa: Estudos Sociais do Trabalho, da Tecnologia e da Expertise (ESTTE). Especialização em Ergonomia: Projeto de Situações de Trabalho em curso (UFMG). Possui especialização em Gestão Estratégica de Logística (UNA, 2013) e graduação em Engenharia de Produção (PUC-Minas, 2012). Experiência na indústria manufatureira de filme plástico e na montadora do setor automobilístico. Interesse em processos de trabalho, ergonomia, gestão e desenvolvimento organizacional pela qualidade, saúde e eficiência.

\section{DIEGO FETTERMANN}

Doutor em Engenharia de Produção (PPGEP-UFRGS). Professor Adjunto junto ao Departamento de Engenharia de Produção e Sistemas (EPS) e Pós-graduação em Engenharia de Produção (PPGEP), ambos da UFSC. Co-Editor do Journal of Lean Systems. Líder do grupo de pesquisa do CNPq denominado Produtividade e Melhoria Contínua. Presidente do Instituto de Inovação e Gestão do Desenvolvimento de Produto na gestão 2018-2020. Experiência na área de desenvolvimento de novos produtos, atuando principalmente nos seguintes temas: gestão de projetos de produtos, desenvolvimento Lean, plataforma de produtos e Customização em Massa.

\section{EDSON PACHECO PALADINI}

Professor Titular do Departamento de Engenharia de Produção e Sistemas da Universidade Federal de Santa Catarina. Membro Titular da Academia Brasileira da Qualidade. Doutorado em Engenharia de Produção (UFSC, 1992), Mestrado em Engenharia de Sistemas (UFPb Campina Grande - 1979), Especialização em Administração da Produção (UFPb, 1981) e Graduação em Matemática (UFSC, 1975). Atua nas áreas de Engenharia, Gestão e Avaliação da Qualidade. É autor de diversos livros sobre temas inseridos em suas áreas de atuação e de artigos técnicos publicados em periódicos qualificados no país e no exterior. Integrou o Comitê de Avaliação dos Programas de Pós-graduação da CAPES na área das Engenharias III. Coordenador do Programa de Pós-graduação em Engenharia de Produção da UFSC (2002-2006). Autor dos textos: Gestão Estratégica da Qualidade (duas edições); Gestão da Qualidade: Teoria e Prática (sete edições); Avaliação Estratégica da Qualidade (duas edições); Qualidade Total na Prática (duas edições), entre outros.

\section{EDUARDO CARVALHO DOURADO}

Graduação em Ciências Econômicas pela Universidade Federal do Maranhão (2004). Especialização em Auditoria e Controladoria pela Universidade Gama Filho (2010). Atuação como professor pela Faculdade Pitágoras. Relação de Mercado pelo SENAI-MA. Tem experiência na área de Economia, com ênfase em Economia.

\section{EDUARDO DA SILVA FERNANDES}

Graduou em Engenharia Elétrica pela Universidade do Estado de Santa Catarina (UDESC) em 2016. Atualmente faz Mestrado em Engenharia de Produção pela Universidade Federal do Rio Grande do Sul (UFRGS). Sua pesquisa é baseada nas áreas de Análise de Risco e Controle Estatístico da Qualidade. 


\section{EDUARDO MENDONCA PINHEIRO}

Mestre em Agroecologia pela Universidade Estadual do Maranhão (UEMA, 2017). Especialista em Gestão Agroindustrial pela Universidade Federal de Lavras-MG (UFLA, 2006), Especialista em Engenharia de Produção pelo Centro Universitário Internacional (UNINTER, 2017). Graduado em Agronomia pela Universidade Estadual do Maranhão (UEMA, 2004), Licenciatura Plena pela Universidade do Sul de Santa Catarina (UNISUL, 2008). Inspetor Sanitário de Produtos de Origem Vegetal pela Secretaria Municipal de Agricultura, Pesca e Abastecimento de São Luís (SEMAPA). Professor substituto do Curso de Engenharia de Produção/Agronomia na Universidade Estadual do Maranhão. Professor dos cursos de Engenharias pela Faculdade Pitágoras/FAMA. Professor Conteudista e Pesquisador do Curso de Tecnologia de Alimentos pela UEMANET. Consultor pelo Programa Alimentos Seguros (PAS) pelo SENAI-MA.

\section{EMERSON RODRIGUES SABINO}

Formado em Engenharia de Produção Mecânica pela Universidade Regional do Cariri (2017) e atualmente bolsista pela CAPES no Programa de Pós-Graduação em Engenharia de Produção (PPGEP) da Universidade Federal de Pernambuco (UFPE). Sua atuação profissional se resume em estagiário na empresa Singer do Brasil com atividades voltadas principalmente ao acompanhamento e controle de indicadores de desempenho e o desenho industrial. $\mathrm{Na}$ empresa JOB Roupas Profissionais atuou como analista de PCP desenvolvendo atividades de programação, acompanhamento e controle dos setores produtivos da fábrica

\section{ÉRICO MARCON}

Mestrando no Departamento de Engenharia de Produção da Universidade Federal do Rio Grande do Sul. Ele é membro do Núcleo de Engenharia Organizacional (NEO) na mesma universidade. Sua pesquisa é focada em serviços digitais e sistemas produto-serviço habilitados por tecnologias da informação e comunicação.

\section{ÉRIKA CRISTINA RIBEIRO}

Graduanda em Engenharia de Produção pelo Centro Universitário Salesiano de São Paulo UNISAL (2018). Técnica em Controle Ambiental pela Escola Técnica Limassis - Fundação ROGE (2013). Interessa-se pelas áreas de Gestão da Produção e Finanças.

\section{FÁBIO SILVA ABREU}

Especialista em Engenharia de Segurança do Trabalho pela Universidade Cândido Mendes (2018), graduado em Engenharia de Produção com Ênfase em Gestão da Qualidade pela faculdade de Engenharia de Minas Gerais - FEAMIG (2016). Possui vasta experiência na indústria automobilística, atuando na área de Produção, Gestão de Materiais, Logística Interna, WCM - WORD CLASS MANUFACTURING e Engenharia Logística na Fiat Chrysler Automobilies. 


\section{FERNANDA ROLIM UEPCOSKI}

Graduada em Curso Superior de Tecnologia em Processos Gerenciais, Pós Graduanda em Gestão de Projetos e atualmente Analista de Projetos na Universidade La Salle. Experiência com Departamento Financeiro.

\section{FERNANDO ANTÔNIO FORCELLINI}

Graduado em Engenharia Mecânica, Mestre em Engenharia, e Doutor em Engenharia pela UFSC, pós-doutorado pela EESC/USP. Atualmente é Professor Titular no Departamento de Engenharia Mecânica da UFSC. Atua nos cursos de graduação em Engenharia Mecânica e Engenharia de Materiais e nos cursos de Pós-graduação em Engenharia Mecânica e Pósgraduação em Engenharia de Produção da UFSC. Interessa-se por desenvolvimento, modelagem, melhoria e gestão de processos, produtos e serviços.

\section{FERNANDO CESAR BRANDÃO}

Engenheiro de Produção pela Universidade de São Paulo. Experiência no exterior, com intercâmbio de graduação na Technische Universität Darmstadt (Alemanha). Fundador e ExVice-Presidente do Clube de Consultoria da Escola de Engenharia de Lorena (EEL-USP). Experiência em grandes empresas nacionais e multinacionais como Bosch, Ambev e Johnson \& Johnson.

\section{FRANCISCA JEANNE SIDRIM DE FIGUEIREDO}

Possui graduação em Desenho Industrial (UFCG - 1990), mestrado em Engenharia de Produção (UFPB -1998) e doutorado em CIÊNCIAS (UNESP - 2017). Atualmente é avaliadora voluntária da AEDB, Editora Abril e Associação Brasileira de Engenharia de Produção, professora Adjunta da Universidade Regional do Cariri, Coordenadora de desenvolvimento Territorial Sustetável do Geopark Araripe. Tem experiência na área de Administração, com ênfase em Gestão da Qualidade, atuando principalmente nos seguintes temas: processo, qualidade, métodos, seis sigma, desenvolvimento sustentável e produção segura.

\section{GABRIELA DA ROSA WITECK}

Mestra em Engenharia de Processos pela Universidade da Região de Joinville (2018). Bolsista PIBPG (2016-2018), e atuante na linha de pesquisa em gestão da inovação tecnológica. Bacharelada em Engenharia de Produção e Sistemas pela Universidade do Estado de Santa Catarina (2015). Bolsista em iniciação científica pelo CNPQ (2010-2011) no Projeto de Pesquisa intitulado: gestão da qualidade e produtividade. Além disso, possui 4 anos de experiência na indústria multinacional automotiva (BMW do Brasil), na área de Engenharia de Produção e Engenharia de Logística.

\section{GUILHERME BENITEZ}

Doutorando no Departamento de Engenharia de Produção da Universidade Federal do Rio Grande do Sul. Ele é membro do Núcleo de Engenharia Organizacional (NEO) na mesma universidade. Sua pesquisa é focada na criação de ecossistemas para a Indústria 4.0.

\section{GUILHERME LUZ TORTORELLA}

Professor Adjunto da Engenharia de Produção na Universidade Federal de Santa Catarina, realizou Pós-Doutoramento em Sistemas de Produção, Doutorado em Engenharia de Produção (2012), Mestrado em Sistemas de Produção (2005), Especialização em Gestão Empresarial na Escola de Administração (2007) e formado em Engenharia Mecânica (2003), 
todos estes na Universidade Federal do Rio Grande do Sul - UFRGS. Possui experiência na área de Sistemas de Produção e Sistemas de Qualidade, tendo lecionado nos programas de Pós-Graduação em Engenharia de Produção da UFRGS, ULBRA, PUCRS, UNOESC, FSG e ESADE como Professor convidado. Além disso, possui 12 anos de experiência na indústria automotiva com vivência internacional em capacitações em México, Inglaterra, EUA e Uruguai. Pertencente aos Laboratórios de Produtividade e Melhoria Contínua e de Simulação de Sistemas de Produção, e é líder do grupo de pesquisa do CNPq intitulado: Produtividade e Melhoria Contínua.

\section{GUILHERME MARANHÃO BARRETO PEREIRA}

Possui graduação em Engenharia de Produção pela Universidade do Sul de Santa Catarina (2010). Atualmente é Supervisor Produção da Votorantim Cimentos. Tem experiência na área de Engenharia Civil, com ênfase em Construção Civil.

\section{HELOÍSA PEREIRA BURIN}

Acadêmica do curso de Engenharia de Produção na Universidade de Santa Cruz do Sul (UNISC). Bolsista de iniciação científica PROBITI/FAPERGS (2018/2), atuou também como bolsista PIBITI/CNPq (2018/1) e bolsista PROBIC/FAPERGS (2017).

\section{HIASMIN AMARAL PINHEIRO}

Graduanda em Engenharia de Produção na Universidade La Salle - Unilasalle.

\section{ISMAEL CRISTOFER BAIERLE}

Professor em cursos de graduação tecnológica; cursos de qualificação profissional básica e aprendizagem industrial básica do SENAI - Departamento Regional do Rio Grande do Sul. É Engenheiro de Produção, Mestre em Sistemas e Processos Industriais pela Universidade de Santa Cruz do Sul, e Doutorando em Engenharia de Produção pela Universidade do Vale do Rio dos Sinos

\section{ISMAEL LUIZ DOS SANTOS}

Pesquisador em Sistema Lean do Núcleo de Inovação, Gestão e Processo Produtivo da Região Foz do Rio Itajaí/SC do Instituto SENAI de Tecnologia em Logística de Produção FIESC - SENAI/SC, Doutorando do curso de Pós-graduado em Administração (UNIVALI), Mestre em Administração (UNIVALI), MBA em Gestão Empresarial (GAMA FILHO), Pós-graduação em docência de ensino superior (AVANTIS) Graduado em Administração de Design (UNIVALI) Professor de graduação nos cursos de Administração / Ciências contábeis e pesquisar na área de estratégia no Varejo.

\section{IVAN CORRER}

Formado em Engenharia de Controle e Automação pela Universidade Metodista de Piracicaba (2004), Mestrado em Gerência da Produção pela Universidade Metodista de Piracicaba (2006), Doutorando em Gerência da Produção pela Universidade Metodista de Piracicaba (desde 2017). Atualmente é coordenador de P\&D da empresa GeoTecno Soluções em Automação para o setor industrial. Tem experiência na área de Engenharia de Produção , Engenharia de Controle e Automação e Gestão Empresarial, com ênfase em Automação da Manufatura, Gestão da Produção, Administração, atuando principalmente nos seguintes temas: P\&D de Novos Produtos, Controle de Processos, Controle da Produção, Sistemas de Monitoramento, Redução de tempos de Setup. 


\section{JAQUELINE DE MORAES}

Bolsista PROSUP/CAPES do Programa de Pós-Graduação em Sistemas e Processos Industriais, da Universidade de Santa Cruz do Sul (UNISC), graduada em Administração (UNISC, 2016). Atuou como bolsista PROBIC/FAPERGS (2016), bolsista PIBITI/CNPq (2015/2016) e bolsista PIBITI/CNPq (2012/2013).

\section{JOÃO CARLOS ESPÍNDOLA FERREIRA}

Professor Titular do Departamento de Engenharia Mecânica da Universidade Federal de Santa Catarina (UFSC). Possui Mestrado em Engenharia Mecânica (1986) pela PUC-Rio, e Doutorado em Engenharia Mecânica (1991) pela University of Manchester Institute of Science and Technology (UMIST), Reino Unido. Desenvolveu atividades de Pós-Doutorado em Engenharia Industrial e Manufatura na Pennsylvania State University, EUA (1999/2000). Possui experiência em sistemas integrados de manufatura, manufatura sustentável, manufatura enxuta, controle de sistemas de manufatura, gestão de informações sobre a qualidade de produtos e processos, simulação de sistemas de manufatura, programação da produção.

\section{JOHANNA DREHER THOMAS}

Acadêmica do curso de Engenharia de Produção e bolsista PUIC-IC da Universidade de Santa Cruz do Sul - UNISC. Foi bolsista Probex de Projeto de Extensão (abril/2017 a dezembro/2017) e bolsista Probae de Mecânica Geral (agosto/2016 a dezembro/2016).

\section{JONES LUÍS SCHAEFER}

É mestrando do Programa de Pós-Graduação Sistemas e Processos Industriais da UNISC. Integrante do projeto de pesquisa Tomada de decisão gerencial com enfoque multicritérios: fundamentos teóricos e utilização de prática corporativa. Dissertação em andamento sob o título Mensuração da Competitividade em Micro e Pequenas Empresas. Possui graduação em Engenharia de Produção pela Universidade de Santa Cruz do Sul (2006), tem formação como Técnico em Eletrotécnica.

\section{JORGE OKUMURA}

Consultor em Sistema Lean do Núcleo de Inovação, Gestão e Processo Produtivo da Região Foz do Rio Itajaí/SC do Instituto SENAI de Tecnologia em Logística de Produção FIESC SENAI/SC, Gestor Industrial, Pós-graduado em Engenharia de Produção (PUCPR), Graduado em Administração de Empresa/Processos Gerenciais e Técnico em Mecânica. Especialização e treinamento em "Toyota Production System - TPS" pela DENSO CO/Nagoya Japão (1981). Tem mais de 30 anos de atuação em Sistema Toyota de Produção (TPS) nas empresas multinacionais de peças automobilísticas e experiências nas áreas de gestão de processos, ambiente fabril, Lean System e controle operacional. Atualmente exerce função de consultoria para indústrias metalúrgicas, moveleiras, confecções, metal-mecânica, madeireira e outros das regiões de Santa Catarina.

\section{JOSÉ LEODORO SALES JÚNIOR}

Graduado em Tecnologia de Alimentos pela Universidade Estadual do Maranhão (2012) ; Especialista em Vigilância Sanitária dos Alimentos pela Universidade Estadual do Maranhão (2012); Licenciatura Plena pela Universidade do Sul de Santa Catarina (2011); Graduado em Técnicas de Alimentos dos Produtos Agropecuários pela Universidade Estadual do Maranhão (2008); Técnico agrícola Habilitado em Zootecnia pela Escola Agrotécnica Federal do Maranhão; Experiência na área de Ciência e Tecnologia de Alimentos, com ênfase em Ciência e Tecnologia de Alimentos. Atuou como Consultor no SENAI-MA pelo Programa Alimentos Seguros. 


\section{JULIANA BARBOSA DE CARVALHO}

Engenheira Civil pela Universidade do Estado do Amazonas - UEA. Pós-Graduanda em Gestão de Obras e Empreendimentos na Construção Civil

\section{JULIANA SAYURI KURUMOTO}

Doutora em Engenharia de Produção pela Universidade de São Paulo (EESC/USP). Bacharel em Administração pelo Centro Universitário Eurípides de Marília (UNIVEM), com mestrado em Engenharia de Produção pela Universidade de São Paulo (EESC/USP). Atualmente, está como docente do Departamento de Engenharia de Produção da Universidade Estadual de Maringá (UEM). Tem interesses pelas áreas de Gestão da Inovação, Gestão da Qualidade e Redes Colaborativas

\section{LAURENT MULLER}

Consultant specializing in Lean Management and Six Sigma and a part-time associate professor in Industrial Engineering at the ENSGSI-Ecole Nationale Supérieure en Génie des Systèmes et de l'Innovation (Engineering School). Graduated with a PhD in Industrial Engineering, he is a researcher in organizational innovation at the ERPI Laboratory (Research team on innovative processes) at the University of Lorraine, France.

\section{LAYRA GABRIELA GONCCALVES}

Graduanda em Engenharia de Produção na Universidade La Salle - Unilasalle.

\section{LUANA FERRAZ DE SOUZA}

Engenheira de produção formada na PUC Minas e pós graduanda em Gerenciamento de Projetos pela mesma instituição.

\section{LUCAS GONCALVES PAGNOSSIN}

É Engenheiro de Produção pela Universidade Federal de Santa Maria. É Gerente de Contas I na empresa Ecolab Química. Atuou como Estagiário e como Supervisor de Contas na empresa Ecolab Química. Participou como voluntário de Iniciação Científica na Universidade Federal de Santa Maria.

\section{LUCAS VERZENHASSI TOLEDO}

Engenheiro de Produção pelas Faculdades Integradas Einstein de Limeira - FIEL

\section{LUCIANA APARECIDA DE SOUZA}

Técnica em Administração de empresas 2009. Administradora pelo Centro universitário Salesiano de Lorena 2014. Estudante de Engenharia de Produção pelo Centro Universitário Salesiano de Lorena.

\section{MAICON SULIVAN DA CRUZ}

Graduado em Engenharia de Produção com Ênfase em Gestão da Qualidade pela faculdade de Engenharia de Minas Gerais - FEAMIG (2016). Possui vasta experiência na indústria automobilística, atuando na área de Produção, Logística Interna, WCM - WORD CLASS MANUFACTURING na Fiat Chrysler Automobilies. 


\section{MARCOS MALINVERNI PAGLIOSA}

É bacharel em Administração de Empresas pela Unifebe (2015) e Mestrando em Engenharia de Produção na Universidade Federal de Santa Catarina (UFSC). Especialista em processos de usinagem. Possui conhecimento nas áreas de engenharia mecânica, engenharia de manufatura com ênfase em processos de usinagem. Possui experiência de 18 anos na indústria metal mecânica automotiva, nas áreas de desenvolvimento e implantação de novos processos, estudo de viabilidade de novos negócios e identificação de oportunidades de melhorias em processos, produtos e nos setores da produção.

\section{MARIA APARECIDA FERNANDES ALMEIDA}

Graduada em Engenharia Industrial Elétrica, Mestre em Engenharia Elétrica (UFSC, 1997), Mestre em Ciência da Computação (UFSC, 1999), Doutora em Ciência da Computação (UFSC, 2002) e Doutora em Engenharia Elétrica (UFSC, 2011). Pesquisadora e professora do Departamento de Engenharia de Produção da Pontifícia Universidade Católica de Minas Gerais (PUC Minas). Suas principais áreas de atuação são Pesquisa Operacional, Simulação de Sistemas, Inteligência Artificial e Engenharia Biomédica.

\section{MARIA LUCIA MIYAKE OKUMURA}

Professora Pesquisadora e Pós-doutoranda (CNPq) do Programa de Pós-graduação em Engenharia de Produção e Sistemas da Pontifícia Universidade Católica do Paraná PPGEPS/PUCPR, Doutorado e Mestrado em Engenharia de Produção e Sistemas (Automação), graduada em Processos Gerenciais, Especialização em Educação Especial, Magistério Superior e Processos Pedagógicos. Atua nas áreas de Engenharia de Produção com ênfase em projetos e pesquisa de tecnologia\&inovação relacionados com Processo de Desenvolvimento de Produto orientado para Tecnologia Assistiva, Sustentabilidade e inclusão social. Membro do Núcleo de Pesquisa NPOTA (Tecnologia Assistiva) e Núcleo SEEDS (Desenvolvimento Sustentável) atribuindo os conceitos e métodos em desenvolvimento sustentável, ergonomia de processos, macroergonomia, Lean Systems / Lean HeathCare, Design Universal, Engenharia Simultânea, Design for Assistive Technology (DFAT), Responsabilidade Social Empresarial (RSE) e Sustentabilidade.

\section{MATHEUS DE MORAES}

Engenheiro de Produção pelas Faculdades Integradas Einstein de Limeira - FIEL

\section{MAYANNE CAMARA SERRA}

Graduada em Engenharia de Produção pela Universidade Estadual do Maranhão (2015) com Pós-Graduação em andamento em Higiene e Segurança do Trabalho pela UNYLEYA; técnica em Design de Produto (CEFET-MA/IFMA); com experiências profissionais em atividades administrativas e de produção; experiências acadêmicas em empresa júnior, produção de artigos, participação e organização de eventos; e titular de patente depositada no INPI.

\section{MICHELE TEREZA MARQUES CARVALHO}

Possui graduação em Engenharia Civil pela Universidade Católica de Goiás (2000), especialista em Planejamento Urbano e Ambiental pela Universidade Estadual de Goiás (2001) e mestrado em Engenharia Civil pela Universidade Federal de Goiás (2005). Doutoramento pela Universidade de Brasília (2009), sendo a área de pesquisa em construção civil com ênfase em sustentabilidade e habitação de interesse social. Tem experiência na área de Engenharia Civil, com ênfase em Construção Civil, atuando principalmente nos seguintes temas: reciclagem, gesso, tijolo de gesso, sustentabilidade, planejamento de grandes obras, Sistema de Gestão da Qualidade, Gestão Ambiental e Gestão de Projetos. 


\section{OSIRIS CANCIGLIERI JUNIOR}

Engenheiro Industrial Mecânico pela Escola de Engenharia Industrial de São José dos Campos (EEI), Mestre em Engenharia Mecânica pela Universidade Estadual de Campinas (DEF/DEM/UNICAMP) e PhD pela Universidade de Loughborough (Loughborough University UK). Coordenador do Programa de Pós-Graduação em Engenharia de Produção e Sistemas da Pontifícia Universidade Católica do Paraná (PPGEPS/PUCPR), Líder do Grupo de pesquisa "Concepção e Desenvolvimento de Produtos e Sistemas (CDPS)" e Professor Titular na Escola Politécnica da Pontifícia Universidade Católica do Paraná (PUCPR) no cursos de Engenharia de Produção e Controle e Automação (Mecatrônica). Foi Professor convidado nas Universidades de Loughborugh (UK) e Lorraine (França), possui mais de 30 anos de experiência em Engenharia de Projeto e Manufatura de Produtos, trabalhando na área Acadêmica e Industrial. Seu campo de pesquisa, nos últimos 20 anos, está focado em desenvolvimento de produto em um ambiente de engenharia simultânea com uma abordagem multidisciplinar, trabalhando sinergicamente com áreas como Medicina, Odontologia, Sustentabilidade, Logística, Negócios, entre outras, na busca de solução de problemas relativos a integração das necessidades e desejos dos consumidores no processo de desenvolvimento e manufatura de produtos.

\section{PAULA CAMILA DIAS PORTES}

Graduada em Engenharia de Produção pela Universidade de São Paulo. Experiência no exterior pelo Programa Ciências sem Fronteiras (CAPES), estudando na University of Arizona. Experiência em grandes empresas nacionais e multinacionais. Atualmente, atuando como analista de projetos.

\section{PAULA VASCONCELOS STOCCO}

Graduanda em Engenharia de Produção pela Universidade Estadual de Maringá (UEM).

\section{RAFAELLE DE OLIVEIRA ALMEIDA}

Graduada em Engenharia de Produção pela faculdade de Engenharia de Minas Gerais FEAMIG (2016). Atualmente trabalho no ramo de joias, no qual ajudo na confecção de peças em ouro.

\section{RENATA MANSUELO ALVES DOMINGOS}

Mestrado em andamento em Engenharia Civil na Universidade Federal de Santa Catarina na área de construção civil com enfoque em eficiência energética. Especialização em Segurança do Trabalho com Ênfase em Meio Ambiente e Sustentabilidade. Graduação em Engenharia Civil pela Universidade do Estado de Mato Grosso.

\section{RIANA AUXILIADORA NUNES BELARMINO}

Graduanda em Engenharia de Produção (UNISAL-2018).Green Belt em Lean Six Sigma.

\section{ROSANGELA DA ROSA DA SILVA}

É Engenheira de Produção pela Universidade Federal de Santa Maria. Participou durante dois anos como voluntária no Movimento LEO Clube, sendo secretária, vice-presidente e coordenadora distrital. Foi consultora e presidente da Projep Jr, empresa júnior de Engenharia de Produção UFSM e assessora de rede do NEJSM, Núcleo de Empresas Juniores de Santa Maria. É monitora de produção na empresa Aurora Alimentos. 


\section{SAMANTHA COELHO PINHEIRO}

Possui graduação em Engenharia Civil pela Universidade Federal do Amazonas (2006) e mestrado em Engenharia Civil pela Universidade Federal do Amazonas (2009). Concluiu o doutorado em Engenharia Civil pelo Instituto Alberto Luiz Coimbra de Pós-Graduação e Pesquisa em Engenharia da Universidade Federal do Rio de Janeiro (COPPE/UFRJ) em 2015. Foi Pesquisadora da COPPE, vinculada à Fundação COPPETEC, entre 2014 e 2015. Atualmente é professora adjunta na Universidade do Estado do Amazonas, onde coordenou o curso de Engenharia Civil (2016) e chefiou o Laboratório de Materiais e Estruturas (2016). Atua na área de Sistemas Construtivos não convencionais e Materiais de Construção, atuando principalmente nos seguintes temas: análise de adições mineriais para materiais cimentíceos com foco na caracterização físico-química, micro e nanoestrutural, dosagem e análise de pastas para poços de petróleo e análise de durabilidade de concretos.

\section{SIMONE FERIGOLO VENTURINI}

Graduanda em Engenharia de Produção pela Universidade La Salle

\section{TAÍS OLIVEIRA DA SILVA}

Graduanda em Engenharia de Produção pela Universidade La Salle

\section{TAÍS OLIVEIRA DA SILVA ALFONSO}

Graduanda em Engenharia de Produção na Universidade La Salle - Unilasalle. Atualmente também é Analista de Projetos na mesma Instituição.

\section{TAYLANA PICCININI SCOLARO}

Mestranda em Engenharia Civil pela Universidade Federal de Santa Catarina (UFSC), na área de Construção Civil com ênfase em Materiais de Construção. Possui graduação em Engenharia Civil pela Universidade Tecnológica Federal do Paraná (UTFPR), Campus Pato Branco.

\section{TAYNARA SIEBRA RIBEIRO}

Graduada em Administração de Empresas pelo Centro Universitário Leão Sampaio (UNILEÃO) (2010.2-2014,2). MBA em Docência do Ensino Superior pela Universidade Vale do Acaraú (2017-2018). Cursando MBA em Gestão de Processos pelo Centro Universitário Leonardo da Vince (UNIASSELVI) Com atuação profissional como estagiária no Centro Integração Empresa Escola (CIEE) (2010-2012); e estagiária no Itaú (2012-2014). Atualmente com Assistente Administrativo na ENEL Distribuição Ceará.

\section{THAYS LORRANNY DA SILVA JANUÁRIO}

Possui graduação em Tecnologia em Alimentos pela Faculdade de Tecnologia CENTEC (2012). Atualmente, Graduanda em Engenharia de Produção Mecânica pela Universidade Regional do Cariri (URCA). Tem experiência na área de Engenharia de Produção, com ênfase em Engenharia de Produção Mecânica.

\section{THIAS CADETE DA SILVA}

Graduada em Engenharia de Produção Mecânica pela Universidade Regional do Cariri (URCA) (2013-2017). Foi Bolsista no projeto de extensão PREVEST URCA como professora de matemática (2017-2017). Em sua atuação profissional trabalhou no acompanhamento de produção e PCP da empresa SD Calçados. 


\section{TIANA LEAL VICENTE}

Formanda em Bacharelado em Engenharia de Produção pela Pontifícia Universidade Católica de Minas Gerais (PUC Minas). Desde 2005 trabalha na Indústria Gráfica, atuando como técnica de pré-impressão e controle de produção. Desde 2014 trabalha como instrutora de ensino no SENAI MG lecionando as disciplinas Cálculo Aplicado, Gestão de Custos, Saúde e Segurança do Trabalho, Gerenciamento da Cor e Desenvolvimento de Embalagens Cartotécnicas em cursos técnicos. Também atua como consultora na área de Lean Manufacturing em programas na Federação das Indústrias do Estado de Minas Gerais (FIEMG).

\section{VIRLEY LEMOS DE SOUZA}

Doutor e Mestre em Construção Civil com ênfase em Gestão; Especialista em Gestão e Auditoria na Administração Pública, Hipnologo, Business Coaching e Mentor Building Management; Formações complementares em Analista DISC; Técnicas de Planejamento; Procedimentos de Trabalho; e Relações Humanas.Diretor representante do Project Management Institute (PMI) no Tocantins; Cofundador do Instituto de Coaches do Tocantins (ICT). Autor do Livro: Princípios de gestão na execução de empreendimentos residenciais. Ed NEA, Saarbrücken, Deutschland / Niemcy - Alemanha e PROFESSOR no Instituto Federal de Educação, Ciência e Tecnologia do Tocantins. Experiências em Gestão de Projetos, Análise de Risco e Métodos Lean.

\section{WAGNER PIETROBELLI BUENO}

Bacharel em Administração pela UFSM e Mestrado em Engenharia de Produção pela UFSM. Atualmente doutorando em Engenharia de Produção pela UFRGS no qual trabalha com linhas de pesquisas relacionadas a melhoria e gestão da qualidade e processos na área da saúde. Utilizando engenharia de resiliência, teoria da complexidade e segurança e cuidados do paciente, assim como, lean healthcare.

\section{WILSON LUIGI SILVA}

Graduação em Administração pelo Centro Universitário Newton Paiva (1999) e mestrado em Administração pelo Instituto Novos Horizontes de Ensino Superior e Pesquisa (2007). Atualmente é administrador - Carpini \& Silva Ltda, analista de sistemas da Behouse Soluções Tecnológicas em Informática Ltda, Diretor Comercial - Stark Soluções Tecnológicas Ltda, Coordenador e professor -SESI- Serviço Social da Indústria, Senac Minas - Serviço Nacional de Aprendizagem Comercial, professor UNIBH - Centro Universitário de Belo Horizonte, UMA Centro Universitário Uma - Pitágoras, FEAMIG - Faculdade de Engenharia de Minas Gerais e PUC Pontifícia Universidade Católica de Minas Gerais. Professor da comissão Assessora de Avaliação de área do ENADE. 


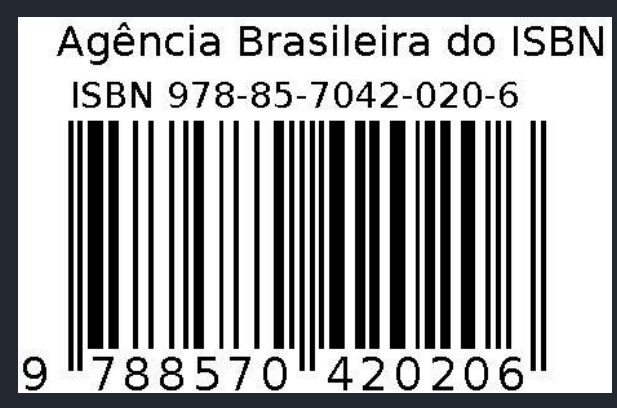

